\title{
Revista da FACULDADE DE DIREITO da Universidade Federal do Rio Grande do Sul
}

\author{
VOLUME $20-2001$
}

NOVA PROVA GRÁFICA E EDITORA

Rua Santos Dumont, 1186 - São Geraldo

Fone: (51) 3346-5454

www.novaprova.com.br 
Universidade Federal do Rio Grande do Sul

Professora Wrana Maria Panizzi - Reitora

Professor Carlos Ferraz Hennemann - Vice-Reitor

\section{Faculdade de Direito}

Plínio de Oliveira Corrêa - Diretor

Professor Sérgio José Porto - Vice-Diretor

Revista da Faculdade de Direito da Universidade Federal do Rio Grande do Sul

Professor Franz August Gernot Lippert - Diretor

\section{Conselho Editorial}

Prof. Almiro do Couto e Silva

Rep. Dis. Suplente Bruno Nubens Barbosa Miragem

Prof. Dr. Carlos Alberto Álvaro de Oliveira

Prof. Dr. Carlos Silveira Noronha

Prof. Dr. Cezar Saldanha Souza Junio

Profa. Dra. Cláudia Lima Marques

Prof. Dr. Cláudio Fortunato Michelon Jr.

Prof. Eduardo Kroeff Machado Carrion

Prof. Dr. Humberto Bergman Ávila

Prof. Dr. José Antônio Giusti Tavares

Prof. Dra Judith Hofmeister Martins Costa
Prof. Dr. Luís Afonso Heck

Prof. Dr. Luiz Fernando Barzotto

Rep. Discente Marcos de Campos Ludwig

Profa. Dra. Marília Morosini

Profa. Dra. Martha Lúcia Olivar Jimenez

Prof. Dr. Peter Walter Ashton

Prof. Dr. Raúl Enrique Rojo

Prof. Dr. Rui Portanova

Prof. Sérgio José Porto

Profa. Vera Maria Jacob de Fradera

\section{DADOS INTERNACIONAIS DE CATALOGAÇÃO NA PUBLICAÇÃO (CIP)}

Revista da Faculdade de Direito da Universidade Federal do Rio Grande do Sul. -

Vol. 20 - Porto Alegre: UFRGS. Out./2001 - Semestral - Continuação de: Revista

da Faculdade de Direito de Porto Alegre, publicada de 1949-1974

ISSN 0104-6594

1. Direito: Periódicos. I. Universidade Federal do Rio Grande do Sul

\section{Pede-se permuta \\ Piedese canje \\ We ask for exchange \\ On demande échange \\ Wir bitten um Austausch \\ Si richiede lo scambio}

\section{REVISTA DA FACULDADE \\ DE DIREITO DA UFRGS}

Endereço para correspondência:

Lippert e Cia. Advogado

Fone: (51) 3231-7988 - Fax: (51) 3231-7989

Av. Padre Cacique, 320 - $5^{\circ}$ andar - Bloco B

CEP 90810-240 - Porto Alegre/RS - Brasil

E-mail: biblio@lippert.com.br

Site: www.lippert.com.br
Omne jus ex facto natum,

sed ad hominem factum est.

Ruy Cirne Lima

\section{Agradecimento}

A Direção da Revista da Faculdade de Direito da Universidade Federal do Rio Grande do Sul agradece à bibliotecária Simone Augustinho Rocha por suas colaborações.
Rua Félix da Cunha, 751-Sala 402 - Moinhos Fone/Fax: (51) 3346-3995

$$
\text { CEP 90570-00 }
$$

E-mail: diartes@conex.com.br 


\section{Sumário}

\section{ARTIGOS}

Proteção contra produtos defeituosos: das origens ao Mercosul

Adalberto Pasqualotto

La posmodernidad jurídica los derechos de las personas bajo la linea de indigencia

los criterios de reciprocidad e igualdades razonables: documento de debate

Carlos A. Ghersi.

Mauro Cappelletti e o Direito processual brasileiro

Carlos Alberto Álvaro de Oliveira

Desembargador Carlos Thompson Flores: fundador da Faculdade de Direito

de Porto Alegre

Carlos Eduardo Thompson Flores Lenz....

A pesquisa em Direito: um testemunho sobre a pesquisa em grupo, o método

"Sprechstunde" e a iniciação científica na pós-modernidade

Cláudia Lima Marques.

Los desafios del derecho civil em el Mercosur

Claudia Schmidt Hott.

El convenio sobre los aspectos civiles de la sustracción internacional de

menores y su aplicacción en los tribunales alemanes

Christoph Benicke

Entre o "positivismo" e o "catolicismo": as dimensões do espaço jurídico no

Rio Grande do Sul.

Fabiano Engelmann

A aproximação das legislações: o caminho do Mercosul

Florisbal de Souza Del'Olmo

Construcción social del derecho: aproximaciones al debate del siglo XXI

Graciela Lovece.

A Conferência da Haia de Direito Internacional Privado

Gustavo Vieira da Costa Cerqueira

Pressupostos e diferenças de um direito dogmaticamente organizado

João Maurício Adeodato

O Novo Código Civil Brasileiro: em busca da "ética da situação"

Judith Martins-Costa

Repudiando Montesquieu? A Expansão e a Legitimidade da "Justiça Constitucional

Mauro Capelletti (Tradução de Fernando Sá)

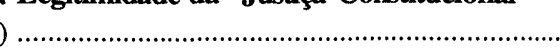

Da extinção da punibilidade pela união estável da vítima com terceiro

Ney Fayet Júnior .

La Justicia como instancia simbólica y la reconstruccion del sujeto de derecho

Raúl Enrique Rojo 


\title{
Proteção contra produtos defeituosos: das origens ao MERCOSUL
}

\author{
Adalberto Lasqualotto
}

\section{Introdução}

12 marginal inexorável da indústria. Com a expansão fabril, revelou-se a inadequação do direito então posto nos países em processo de industrialização para assegurar a reparação dos danos sofridos pelos usuários, destinatários naturais dos bens que saíam das fábricas. Eram países essencialmente liberais, com regimes de responsabilidade civil que exigiam a prova da culpa como requisito da indenização, prova a ser constituída em juízo pelo lesado. As dificuldades na feitura dessa prova, decorrentes em grande parte do desconhecimento do processo industrial e da crescente automação, que nublava a imputação do fato lesivo a um autor determinado, conduziram a linha evolutiva do direito para a superação de limites, com o fim de favorecer a reparação às vítimas.

Os expedientes de que os juristas lançaram mão apresentaram inicialmente dois vetores: a extensão das garantias contratuais e a criação de responsabilidades extracontratuais. No âmbito contratual, foi rompida a relatividade do contrato para alcançar o fabricante, com quem o lesado normalmente

não tinha vínculo, pois adquirira o produto causador do dano de um intermediário. As garantias contratuais por si eram, porém, insuficientes, porque são classicamente voltadas para assegurar a utilidade do produto nada provendo quanto à segurança do usuário. No âmbito extracontratual, a culpa opu nha-se como óbice para o alcance da indenização correspondente aos danos pessoais. A evolução consistiu em presumir a culpa do fabricante, com a instituição de uma responsabilidade de caráter delitual mais rígida do que $o$ ato ilícito comum.

A evolução dessa responsabilidade pode ser percebida no common law, de modo especial nos precedentes ingleses e norte-americanos, e nos países continentais europeus de tradição romana.

Com a formação da Comunidade Econômica Européia, os sistemas common law e civil law convergiram para uma normatividade básica, que se expressou na Diretiva que trata da matéria. Já então havia amadurecido a idéia de que a responsabilidade civil do fabricante de um produto defeituoso lhe deve ser imputada em razão do risco que ele cria para

" Mestre em Direito Civil pela UFRGS. Doutorando na mesma Universidade. Trabalho apresentado para aquisição dos créditos correspondentes à disciplina "Direito do Consumidor no Mercosul", sob a orientação da Prof " $\mathrm{Dr}^{\mathrm{a}}$ Cláudia Lima Marques. 
terceiros, não de culpa, e independentemente da existência de vínculo contratual direto com a vítima.

O Brasil, país que se adiantou na América do Sul em legislar de modo abrangente sobre defesa do consumidor, recepcionou essas influências no Código editado em 1990, sob inspiração constitucional. Com o processo de formação do Mercosul em andamento, os demais paises do bloco também editaram leis ao mesmo respeito, mas ainda está distante o ponto ideal de uma normativa comum, no molde europeu.

O presente trabalho volta-se, num primeiro plano, para o exame das origens da evolução do direito em matéria de proteção contra produtos defeituosos e, logo em seguida, para o panorama do Mercosul. Restringe-se aos defeitos que ameaçam a segurança e a integridade física dos consumidores, sem ingressar no trato da proteção dos interesses econômicos, versados no CDC sob a rubrica de vícios. Também não se detém na disciplina paralela que diz respeito ao defeito dos serviços.

\section{Responsabilidade Civil por produtos defeituosos: a for- mação de um Patrimônio Ju- rídico}

A historiografia da proteção jurídica contra produtos defeituosos registra a contribuição paralela das duas famílias de direito hegemônicas no mundo ocidental, que convergiram para a formação de uma cultura que se universalizou. No common law e no direito norte-americano, os precedentes que delinearam o perfil da responsabilidade civil dos fabricantes foram surgindo pari passu com o desenvolvimento indus trial. Na Europa continental, um grande labor doutrinário e também jurisprudencial foi vencendo as barreiras impostas pelo positivismo jurídico. A formação da Comunidade Européia propiciou a fusão dessas experiências, resultante na Diretiva de ${ }^{\circ}$ 374 , de 1985

A razão que gestou a evolução das idéias na Europa e nos Estados Unidos nos alvores do século $X X$ se fez presente em outros quadrantes do globo, por efeito da propagação da indústria. Esses países, em desenvolvimento econômico mais atrasado, se beneficiaram da inspiração do modelo existente, implantando por via legislativa o resultado final do apontado processo histórico- jurídico.

\subsection{Vias de Proteção Contra-tual e Delitual}

As tradicionais fontes romanas do direito, o contrato e o delito, alicerçaram os sistemas jurídicos ocidentais. Particularmente na família romano-germânico, a codificação deu rigidez a essa dualidade, vencida pela evidência da sua inadequação a novos tempos e pelo aporte de idéias mais consentâneas com as realidades emergentes de uma sociedade em franca evolução. Os sistemas de civil law e commom law culminaram em idênticas conclusões: a ultrapassagem dos efeitos dos contratos limitadamente às partes e a superação da culpa como fundamento delitual, imputando ao fabricante a responsabilidade de indenizar os danos causados por defeitos dos seus produtos com base em garantias implícitas e no risco inerente à sua circulação.
2.1.1. Modificações na eficácia dos contratos e Responsabilidade Delitual no Common Law e no Direito Norte-Americano

2.1.1.1. Direito inglês. No direito inglês, a responsabilidade civil por produtos defeituosos não é um tema autonômico. Um produto pode ser considerado defeituoso sob dois aspectos: materialmente perigoso (dangerously defective), quando pode fazer mal à saúde humana; e substandard product (ou merely substandard) quando, não sendo perigoso, frustra a expectativa do consumidor por não atender à qualidade esperada. ${ }^{1}$

São indenizáveis danos econômicos primários (primary economic loss), que têm natureza contratual e compreendem a perda pèla compra da coisa e os eventuais lucros cessantes se, por exemplo, o comprador era um comerciante que tinha intenção de revender o produto adquirido. Também podem ser indenizados danos indiretos (consequential damages), como dano à propriedade, se o produto danificou um bem do adquirente, e lucro cessante, se a periculosidade do produto afetou a saúde do adquirente, impedindo-o de trabalhar por algum tempo. Os danos indiretos são extracontratuais e se inscrevem no regime da responsabilidade por produtos defeituosos. ${ }^{2}$

O regime contratual é estrito. Se um homem compra para a sua mulher um ferro de passar e o produto, por defeito, causa dano a ela, a reparação não comporta uma demanda com base no contrato, porque a mulher é um terceiro em relação à compra e venda. Essa rigidez devese ao princípio privity of contract.
A não existência de contrato entre o fabricante e o consumidor foi obviada com a criação de cláusulas implícitas, que se fortaleceram em estatutos legais. O Sales of Goods Act, de 1893, dispôs que as mercadorias vendidas em gênero, seja a venda realizada pelo fabricante ou não, têm uma condição implícita de qualidade comercial (merchantable qualitiy). A mesma garantia foi estendida aos gêneros de abastecimento em 1973, no Supply of Goods Act, que definiu qualidade comercial como a aptidão para servir aos fins para os quais a mercadoria habitualmente é comprada. Segundo o mesmo estatuto, a garantia deve conservar-se, dentro de um limite razoável, se o comprador dá conhecimento ao vendedor de um uso especial que pretende fazer da mercadoria, diferente da sua função habitual, a menos que o comprador tenha desconsiderado a opinião contrária do vendedor. Esses statutes law derrogaram o princípio caveat emptor.

A responsabilidade extracontratual baseia-se em fatos típicos descritos como torts Não há uma cláusula geral de ilicitude. O tipo mais próximo do art. $159, \mathrm{CCB}$, é o tort of negligence. Nele se subsumem os casos de produtos defeituosos, mas também é aplicável o tort of breach of statutory duty, toda vez que a lei imponha um dever que deixa de ser observado. Um dever é exigível do fabricante quando tem previsão no Consumer Protection Act, de 1961 .

As normas penais desempenham um papel importante. Desde 1972 (Criminal Justice Act) os tribunais podem estipular de ofício uma indenização em favor da vítima do crime, que 
será posteriormente descontada da liquidação do dano, se houver ação indenizatória. Em alguns casos, que incluem os de produtos defeituosos, a vítima pode demandar a reparação pelo dano sofrido com base em strict liability do fabricante, pelo simples descumprimento do dever contido na norma penal, sem necessidade de debater a culpa e independentemente da existência de processo criminal, com base no Criminal Law Act, de 1967.

Alguns precedentes judiciais que se tornaram célebres mostram a marcha das idéias na definição da responsabilidade civil do fabricante no direito inglês.

No caso Winterbottom $v$. Wright (1843), um cocheiro sofreu acidente com a carruagem que dirigia. Apesar de haver defeito de produção, o pedido de indenização foi julgado improcedente porque fora formulado contra o produtor, com quem a vítima não tinha vínculo contratual. Prevaleceu o princípio privity of contract,${ }^{3}$ que foi superado à medida que os tribunais passaram a distinguir things dangerous "per se" de things dangereous because of negligent construction.

Essa diferença ficou assinalada no caso Longmeid v. Holliday (1851). Uma lâmpada defeituosa explodiu, causando queimaduras na esposa do comprador. $O$ tribunal negou a indenização porque uma lâmpada não constitui $a$ thing dangereous in itself. $\mathrm{O}$ argumento, todavia, abriu caminho para uma mudança de orientação, que culminou no caso McAlister (ou Donoghue) v. Stevenson (1932), conhecido como Snail's case. Duas senhoras se encontraram num café, onde uma delas pediu uma ginger beer. Depois de ingerir parte da bebida, a vítima notou no fundo da garrafa os restos de um ca-

${ }^{3} \mathrm{O}$ caso Winterbotton permaneceu durante muitos anos como uma espinha na garganta, expressão de W. Prosser apud BARROS LEÃES, L. G. P. de. A Responsabilidade do Fabricante pelo fato do produto. São Paulo:
Saraiva, 1987. p. 44.

${ }^{4}$ SPENCER, J. Op. cit. p. 123-124.

${ }^{5}$ BARROS LEÃES, L. G. P. de. Op. cit. p. 39

Revista da Faculdade de Direito da UFRGS, v. 20, Outubro/2001 cance da responsabilidade do fabricante. Em seu voto, Lord Atkin afirmou que "o fabricante que vende seus produtos prevendo que eles chegarão ao consumidor definitivo no mesmo estado em que saíram da fábrica, sem possibilidade de exame intermediário, e verificando-se que a falta de cuidados razoáveis na prepara- ção e na apresentação dos produtos ocasionará um dano à vida ou à propriedade do consumidor, assume frente a ele um dever legal de adotar tais cuidados". ${ }^{6}$ A responsabilidade especial do fabricante está ligada ao consumo do produto. Se a mercadoria é destinada a um agente econômico intermediário a regra não é a mesma, aplicando-se preceitos comuns. A diferença de regime ficou assinalada no caso Holmes v. Ashford (1950), que tratava de um produto experimental.?

A inversão do ônus da prova veio no caso Grant v. New Australian Knitting Mills (1936). Um cidadão adquiriu um par de calças de lã, em cujo estágio inicial de produção entrava sulfito. Essa substância química permaneceu na calça mesmo após as primeiras lavagens e causou no adquirente uma grave dermatite, acompanhada de fortes dores e inabilitação para o trabalho por mais de um ano. A corte que decidiu o caso em favor do adquirente resolveu que era dispensável a prova da culpa específica de uma pessoa ou em que estágio da produção o defeito fora incorporado. A negligência decorre de uma presunção de existência de defeito, em conexão com todas as circunstâncias conhecidas, presunção que prevalece mesmo que o fabricante possa produzir prova em contrário. A corte fez aplicação da regra res ipsa loquitur, ${ }^{8}$ que considera como prova suficiente de culpa a falta de explicação do fabricante quando a coisa é produzida sob a sua vigilância ou de seus prepostos e verifica-se um evento danoso que não poderia desenrolar-se de

${ }^{6}$ Tradução livre da versão de GRUBER-MAGITOT, S. L'action du consummateur contre le fabricant d'um objet affecté par um vice cachê. Paris: Presses Universitaires de France, 1978. p. 89.

7 Conforme GRUBER-MAGITOT, S. Op. et loc. cit.

${ }^{8}$ Regra que fora definida no caso Scott v. London \& Saint Katherine Docks Co. (1865) 3 H. \& C. 596, apud SPENCER, J. Op. cit. p. 125

- A inversão do ônus da prova constitui uma prova absoluta de culpa, provando-se a negligência por meio das circunstâncias conhecidas. Daí porque a sede da responsabilidade por produtos defeituosos é o tort of negigence. 9 HENDERSON JR., J. A.; TWERSKI, A. D. Closing the american products liability frontier: the rejection of liability without defect. New York University Law Review, v. 66, n. 5, p. 1263-1331, Nov. 91 ordinário se no processo de fabricação tivesse havido a diligência devida. ${ }^{*}$ A prova de que o produto defeituoso é um fato excepcional, que discrepa de toda a normalidade da produção, não exonera o fabricante, pois a sua responsa-

2.1.1.2. Direito norte-americano. Nos Estados Unidos, o surto industrial subseqüente à Guerra Civil propiciou o começo da proteção aos checialmente invertendo ônus da prova para a inferência de negligência, bem como derrubaram barreiras contratuais, com de garantias. $^{9}$

A regra da relatividade do contrato fo quebrada pela primeira vez no caso Thomas $v$. Winchester (1852). Um veneno foi vendido como dadão chamado Thomas. Depois de ingerir poção, a mulher do adquirente passou mal e obteve reparação de danos do laboratório Winchester, fornecedor da farmácia, que etiquetara o produto erroneamente. $\mathrm{O}$ dever de produto inerentemente perigoso à saúde não se extinguiu frente ao farmacêutico, adquirente imediato de um produto destinado a uso por terceiros desavisados.

Em 1916, foi registrado o caso MacPherson v. Buick Motor Co. Tendo adquibilidade tem natureza de garantia. prejudicados por produtos defeituosos. As cortes norte-americanas construíram uma base cuidado do laboratório ao colocar no mercado 
rido um automóvel da marca Buick, MacPherson sofreu graves lesões em acidente causado por uma roda que se partiu por defeito de fabricação. O lesado propôs a ação indenizatória contra o fabricante, e não contra o vendedor. A pretensão foi acolhida pelo tribunal, que prescindiu da privity in contract e imputou um dever de diligência (duty of care) a quem fabrica qualquer produto capaz de colocar em perigo a vida ou a integridade física de outrem, quando feito negligentemente. $O$ dever de cuidado instituído no caso Thomas v. Winchester generalizou-se, tornando o fabricante responsável frente ao usuário final, se provada a negligência na fabricação e a periculosidade do produto.

A partir do caso MacPherson, o direito norte-americano formulou três diretrizes básicas para a responsabilidade civil do fabricante: a) em presença de um vínculo contratual, o fabricante responde nos amplos termos da obrigação de garantia (warranty); b) se o lesado é um terceiro sem vínculo contratual, é imputado um dever de cuidado (duty of care) ao fabricante, que passa a responder por negligência (negligence); c) a negligência, no entanto, tem que ser demonstrada pelo lesado, tornando-se freqüentemente uma prova diabólica. Daí a aplicação da regra res ipsa loquitur (a coisa fala por si mesma), um instrumento processual de inversão do ônus da prova. ${ }^{10}$

Uma nova perspectiva somente surgiu com o caso Henningsen v. Bloomfield Motors Inc., ${ }^{11}$ julgado em 1960 na Suprema Corte de New Jersey, que proclamou a responsabilidade solidária entre o fabricante de um automóvel e o seu revendedor, com base em implied warranty, uma garantia implícita no contrato de compra e venda. Os argumentos básicos foram que, numa sociedade de massa, as garantias de

${ }^{10}$ BARROS LEÃES, L. G. P.de. Op. cit. p. 45.

${ }^{11}$ Heningsen v. Bloomfield Motors Inc., 32 N.J. 358, 161 A.2d 69 (1960), apud WHITE, J. J.; SUMMERS, R. S Uniform Commercial Code. $3^{\mathrm{d}}$ ed. St. Paul, Minn.: West Publishing, 1988.

Revista da Faculdade de Direito da UFRGS, v. 20, Outubro/2001 vel pelo dano físico desse modo causado ao consumidor, ao usuário ou às suas coisas, se: a) o vendedor desenvolve atividade de venda do produto; b) é razoável esperar-se que o produto chegue ao usuário ou consumidor nas mesmas condições em que é posto à venda. 2) A regra anterior se aplica ainda que: a) o vendedor tenha empregado toda diligência possível na fabricação e na venda do produto; b) o usuário ou o consumidor não tenha adquirido o produto diretamente do vendedor nem tenha mantido com ele relação contratual".

A venda em questão é feita pelo fabricante ao comerciante no momento da colocação do produto no mercado. O fabricante assume uma responsabilidade especial, porque desperta no público a confiança de que a compra do produto poderá atender a uma necessidade. A responsabilidade é objetiva, sem excluir, todavia, a possibilidade de ser invocada a culpa. Examina-se a relação de causa e efeito entre a imperfeição técnica do produto e o dano sofrido pelo usuário, desde que o defeito não seja imputável aos revendedores intermediários nem a comportamento negligente do lesado. Vigora o mesmo regime para todos os integrantes da cadeia de distribuição, compreendendo quem quer que tenha feito publicidade ou aposto sua etiqueta na embalagem ou por qualquer meio beneficiado-se de divulgação que tenha despertado no consumidor uma justificável confiança. A condição perigosa deve existir no momento da entrega do produto à circulação e ser desconhecida pelo consumidor. A regra não se aplica aos vendedores não profissionais. $O$ ônus da indenização deve ser considerado um custo de produção, contra o qual o fabricante pode assegurar-se. ${ }^{12}$
Uma strict liability só é imposta por uma Corte norte-americana ao fabricante após um juízo preliminar sobre o dever de diligência, matéria exclusivamente de direito. Strict liability significa que quem causa um acidente é responsável pelos danos sofridos pela vítima, ainda que não fosse possível evitá-lo mediante a devida diligência. ${ }^{13} \mathrm{O}$ dever de diligência é exigível em alguns contratos, como compra e venda, locação, licenciamento de produtos etc. São levadas em conta razões de política de direito, como se a ré é uma empresa com finalidade de lucro, se ela pode compensar-se das perdas por meio de seguros ou aumentando o preço das mercadorias, qual é a frequiência de acidentes com seus produtos. Também é avaliado se era o produtor ou o usuário quem tinha melhores condições de prevenir o acidente. $O$ tribunal verifica aspectos relativos ao produto, aos seus possíveis defeitos, ao nexo de causalidade, ao dano e ao comportamento da vítima ou de terceiros. São pertinentes indagações do tipo: a apresentação do produto e seu uso normal induziam a uma expectativa de segurança? Qual era o uso normal do produto? O produto era defeituoso? Que espécie de defeito portava? Que risco o produto oferecia? O risco era superável mediante uso diligente? Existe produto concorrente mais seguro? O produto é socialmente útil, apesar de inseguro? Sua fabricação obedece às normas regulamentares? Ao ser lançado no mercado, o produto era considerado perigoso? As condições de insegurança apresentadas pelo produto foram essenciais para a produção do dano? Que danos resultaram: a pessoas, à coisa ou os danos foram econômicos? Houve culpa exclusiva ou concorrente da vítima ou de terceiros? Ainda ou${ }^{12}$ Conforme ALPA, G.. Una postilla sui modelli della "lettura" della circolazione di prodotti difettosi nell'esperienza
nord-americana. In ALPA, G.; BESSONE, M. (a cura di). Danno da Prodotti e responsabilitá dell'impresa. nord-americana. In ALPA, G.; BESSO
Milano: Giuffrè, 1980. p. 100-101.

${ }^{13}$ POSNER, Richard A. Economic analysis of law. $4^{\text {th }}$ ed. Boston: Litte, Brown and Company, 1992: 175 
tras questões são decididas no mesmo juízo, como a responsabilidade do comerciante, a extensão da proteção aos circunstantes e a inclusão ou não de riscos do desenvolvimento. ${ }^{14}$ Dessa forma, os tribunais assumem lugar importante na definição da política do direito nessa questão.

Razões dessa ordem apareceram em 1944, no caso Escola v. Coca-Cola Bottling Co. of Fresno, julgado pela Suprema Corte da Califórnia, que proclamou: "Ainda que a empresa não seja culpada, razões de ordem pública impõem que se impute a responsabilidade pela difusão de produtos defeituosos porque o empreendedor tem a oportunidade de reduzir os custos a que é exposta a vida e a integridade física dos consumidores em razão dos produtos defeituosos que circulam no mercado. (...) $O$ custo de uma lesão e das suas consequiências pode resultar excessivamente gravoso para o consumidor atingido, e em vão, porque o risco pode ser assegurado pelo produtor e distribuído entre o público como custo das operações econômicas empresariais." 15

2.1.2. Superação da Culpa e Extensão das Garantias Contratuais no Direito Continental Europeu

O desenvolvimento de um capítulo particular da responsabilidade civil para tratar dos produtos defeituosos é um mérito do direito norte-americano. A expressão "responsabilidade pelo fato dos produtos" foi traduzida da fórmula product liability. A partir dos anos 1960 uma série de acidentes graves ocorridos na Europa com produtos alimentares, cosméticos,

aparelhos domésticos, despertou os especialistas e os desviou dos preceitos tradicionais do contrato e do delito. ${ }^{16}$

A necessidade de uma proteção mais eqüitativa aos usuários provocou a inventiva de expedientes técnicos para sobrepujar as barreiras da responsabilidade civil comum.

2.1.2.1. Direito francês. $O$ direito francês, que ao contrário do direito inglês dispõe da noção de vício oculto, no art. 1.641, do Código Civil, utilizou-se dessa disciplina para impor ao fabricante obrigações de cunho contratual frente ao consumidor, diretamente. Segundo aquela disposição do Code Napoleón, o vendedor garante a coisa vendida contra defeitos ocultos sendo reputados tais os que tornam a coisa imprópria ao uso a que ela se destina, ou diminuam de tal modo a sua utilidade que o vendedor não a teria adquirido, ou teria pago menor preço, se tivesse conhecido os defeitos. $\mathrm{O}$ art 1.641 foi combinado com o art. 1.135, segundo o qual as convenções não obrigam apenas pelo que nelas se exprime, como também pelas consequiências derivadas da eqüidade, dos usos ou da lei, conforme a natureza da obrigação. Assim, ao colocar um produto no mercado, o fabricante tem uma obrigação principal, que é a entrega da mercadoria, e uma acessória, consistente na isenção de vícios. A jurisprudência francesa tem por definido que o vendedor profissional age de má fé ao vender um produto com vício, ou porque, em razão de sua profissão deveria conhecê-lo, ou porque, pelo mesmo motivo, não poderia ignorá-lo. Tal presunção assume caráter absoluto (iuris et de iure),

\footnotetext{
${ }^{14}$ Conforme VERTí, Dominick. Profili... Op. cit., passim.

${ }^{15}$ Apud ALPA, G. Una postilla.... Op. cit., pp p. 94.

${ }^{16}$ VINEY, G. La responsabilité du fait des produits en droit français. Revue International de Droit Comparé, Paris, v. 11, n. especial, p. 567-596
}

o que equivale a uma obrigação de garantia. ${ }^{17}$ A ação contratual, que é própria do adquirente, também pode ser fundada em culpa, quando há má conservação do produto ou falha nas informações de uso.

A importância do vice caché na jurisprudência francesa deve-se provavelmente à constatação objetiva do defeito da coisa, tendo havido decisões que por tal fundamento proveram a segurança do usuário. ${ }^{18}$

O fabricante responde diretamente frente aos consumidores, pela via extracontratual: a) quando for culpado, por fato próprio, pela existência de defeito do produto causador do dano; b) quando o dano decorre de um acidente causado por produto defeituoso (fato da coisa) que estava sob a sua guarda; c) quando o dano é causado pela conduta de um preposto.

A base da responsabilidade delitual do fabricante no direito francês repousa sobre os artigos 1.382 e 1.383, do Código Civil, que estabelecem a obrigação de reparar o dano a quem comete um fato culposo. ${ }^{19}$ Para transpor a prova da culpa, foi estabelecida uma presunção, reproduzindo-se o mecanismo da responsabilidade contratual por vício oculto, ou seja, o fabricante não pode ignorar o vício do seu próprio produto, presumindo-se a sua culpa. Para fundamentar a presunção, é lembrado o princípio spondet peritiam artis, segundo o qual deve responder pela sua arte aquele que se compromete a fazer alguma coisa com a habilidade própria a um profissional. A simples existência de um defeito seria então suficiente para res- ponsabilizar o fabricante, porque revelaria de plano duas espécies de culpa: desconhecer o defeito e colocar no mercado um produto defeituoso. O princípio citado, ao fim e ao cabo, é símile ao res ipsa loquitur. Com a presunção de culpa, a responsabilidade delitual do fabricante pode apoiar-se nos mencionados artigos 1.382 e 1.383 , cabendo à vítima provar apenas a existência do vício. A presunção de culpa é absoluta, mas é franqueada ao fabricante a prova de causa estranha para livrar-se da reparação.

A jurisprudência nessa matéria não é expressiva, exceto por dois acórdãos. O primeiro impõe ao fabricante o dever de se manter atualizado no seu ramo de atividade. Nesse caso, cuidava-se de lesões físicas causadas por uma loção capilar, sendo demandados pela indenização o fabricante e o cabeleireiro que fez a aplicação. O tribunal fundamentou a condenação do fabricante numa publicação médica que tachara de perigoso um produto químico componente da fórmula da loção, o que o fabricante, “em razão de sua atividade, não podia e não devia ignorar". Novamente trata-se de aplicação do princípio spondet peritiam artis, ensejando a aplicação da máxima de que "o fabricante não pode nem deve ignorar os vícios da coisa". ${ }^{20} \mathrm{O}$ segundo acórdão cassa uma apelação porque o proprietário de um automóvel que demandava indenização contra o fabricante não provou nenhuma culpa contra o réu. Ocorrera um acidente por defeito do sistema de freios. O fundamento da cassação foi que esse defeito constituiria em si mesmo uma base culposa para a condenação. Portanto, a culpa

${ }^{17}$ Nesse sentido, GRUBER-MAGITOT, LAAction... Op. cit., pp. 36-37. Para CRÉPEAU, Paul-André (L'Intensité de l'Obligation Juridique ou des Obligations de Diligence, de Résultat et de Garantie.Québec: Yvon de 1908: 12 insirando-se em Mazeaud e Tunc), a origacão de gantia tem maior intensidade do que a de

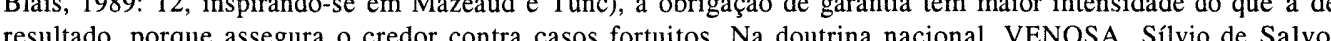
. Direito Civil: Teoria Geral das ( ${ }^{18}$ VINEY, G. La responsabilité...,Op. cit. P. 570

${ }^{19}$ Art. 1.382: quem quer que, por culpa sua, cause a outrem um prejuízo, fica obrigado a repará-lo. Art. 1.383: cada um é responsável pelos prejuizos que causa, não somente por culpa, mas também por negligência ou imprudência. ${ }^{20}$ GRUBER-MAGITOT, L'Action...”. Op. cit., p. 96. 
estaria na simples incorporação ao automóvel de peças defeituosas, o que é quase dizer que o fabricante deveria conhecer o vício da peça. Tal afirmação, que não é feita, seria o reconhecimento explícito da presunção de culpa, que resta, portanto, velada. ${ }^{21}$

No segundo fundamento, o fabricante responde pelo fato da coisa que estava sob a sua guarda. A responsabilidade por fato da coisa, no direito francês, que tem base no art. 1.384, do Código Civil, é fundada sobre a guarda e não depende de culpa, oferecendo grande vantagem à vítima, a quem bastará demonstrar que o dano adveio da coisa em custódia. Tratase de uma "presunção de responsabilidade", ou "responsabilidade de pleno direito", não de uma responsabilidade por culpa presumida. ${ }^{22}$ No entanto, como raramente a guarda de um produto defeituoso permanece com o fabricante, a doutrina inovou a teoria da guarda, desmembrando a clássica unidade de uso, direção e controle em duas concepções distintas e independentes: guarda da estrutura e guarda do comportamento (uso). O proprietário de um objeto é guardião do seu uso (guardião de comportamento) e só responderá pelo dano eventualmente causado se agir com culpa própria Sendo o vício oculto um defeito estrutural da coisa, o fabricante permanece como guardião da estrutura, respondendo pelos danos daí resultantes, a menos que o defeito tivesse sido descoberto ou que à coisa se tivesse imprimido

${ }^{21} I d .$, ib., pp. 96-97.

${ }^{22}$ Conforme GRUBER-MAGITOT, citando literalmente duas decisões da Corte de Cassação. L'Action..., Op. cit., p. 99; uma responsabilidade particularmente pesada, porque prescinde da prova culpa e mesmo do defeito ${ }^{23}$ Conforme GRUBER-MAGITOT, S. L'Action.... Op. cit., pp. 100-101.

${ }^{24}$ Apud CALVÃO DA SILVA, J. da. Responsabilidade civil do produtor. Coimbra: Almedina, 1990. p. 418.Em outra decisão, de 16/1/91, a Corte de Cassação decretou a responsabilidade do fabricante de um poste, como guarda da estrutura, pelo incêndio e queda sobre um prédio, causando também o incêndio do mesmo (captada na Internet). ${ }^{25}$ MALINVAUD, Philippe. I vizi redibitore e il loro ruolo nella vita moderna. In ALPAe BESSONE (a cura di). Danno da Prodotti. Op. cit. pp. 261-262.

${ }^{26}$ CALVÃO DA SILVA, J.da. Op. cit., p. 419. O autor menciona em nota a adesão de Starck e de Mazeaud/Tunc à tese da solidariedade dos dois guardiões.

${ }^{27}$ Pelo sim, os irmãos MAZEAUD; pelo não, STARK, apud GRUBER-MAGITOT, S. Op. cit. p. 104.

Revista da Faculdade de Direito da UFRGS, v. 20, Outubro/2001 feituosos e o favorecimento às empresas. $\mathrm{O}$ Código Civil, por exemplo, responsabiliza o proprietário, o usufrutuário, o aderente com pacto de reserva de domínio e o condutor por danos causados a terceiros por vícios de construção do veículo (art. 2.054). ${ }^{28}$ A figura das relações contratuais de fato não teve muito êxito como fundamento da responsabilidade do fabricante, uma vez que não existe contato pré-negocial com o consumidor e o argumento da mediatização da publicidade era inservível quando o produto não era anunciado ou já tivesse cessado a campanha publicitária. Foi lembrado o art. 1.337, do CC, que obriga as partes, durante as tratativas e na formação do contrato, a comportar-se segundo a boa-fé - considerado inaplicável, contudo, porque se volta para relações pré-contratuais. Nem mesmo os deveres de informação e de fabricação diligente, deduzidos da boa-fé, fizeram carreira, porque pertencem à fase de execução do contrato, não à da tratativa. A tutela do consumidor foi considerada mais apropriada com base no art. 1.494, segunda parte, do CC: "o vendedor deve ainda ressarcir ao comprador os danos derivados dos vícios da coisa". A ausência de qualquer referência à culpa na dicção legal deu lugar à sustentação de uma responsabilidade objetiva, posição contestada pelos partidários de uma interpretação sistemática. Segundo a doutrina dominante, os danos compreendiam as lesões pessoais do comprador ou de terceiro e o prejuízo da coisa. O ressarcimento devia ser perseguido junto ao vendedor (comerciante), o qual buscaria regresso com o fabricante. Ficava em aberto se o dano ao consumidor era indireto, uma vez que o art. 1.323 só assegura indeniza-

ção de dano direto. ${ }^{29}$ Outra construção doutrinária e jurisprudencial serviu-se do art. 2.043 , $\mathrm{CC}$, segundo o qual, "qualquer fato doloso ou culposo que causa a outrem um dano injusto obriga a quem cometeu o fato indenizar o dano". Sob o texto foi incluída a proteção inclusive ao bystander. Mesmo o dano imprevisível deve ser indenizado, desde que faça parte do risco típico da empresa. Esse regime, desamparado de previsão legislativa, onerou a empresa para evitar que o dano fosse suportado pelo consumidor. A culpa não é encarada como fundamento único da responsabilidade civil, aludindo-se também a uma "culpa objetiva", a presunção de culpa e o risco. ${ }^{30}$

Entendem alguns que a empresa deve responder pelo fato do produto com base na culpa somente se o dano é causado por defeito de projeto, tornando-se objetiva a responsabilidade se o defeito é de construção, controle ou informação. ${ }^{31}$ Outros preferem aplicar o critério da culpa para os danos evitáveis, como estímulo à empresa no aperfeiçoamento dos produtos, deixando o critério objetivo para os danos inevitáveis. ${ }^{32}$

A jurisprudência italiana seguiu duas orientações: a) o empreendedor é obrigado desenvolver a sua atividade adequando a estrutura da empresa ao desenvolvimento da técnica, de modo a prevenir qualquer dano a terceiro, ainda que as medidas que deva adotar não sejam próprias do seu ramo industrial; b) o empreendedor deve tomar as medidas exigíveis segundo a boa-fé. Nessas orientações, a boafé assume uma significação ambígua. De um lado, é brandida pelo consumidor para funda-

${ }^{28}$ Profili della responsabilitá del produttore nell'esperienza italiana". In ALPA e BESSONE (a cura di). Danno da Prodotti. Op. cit, p. 11-38 [18]

${ }^{29}$ BESSONE, Profili .... Op. cit., p. 32-36.

${ }^{30}$ Idem, ib., pp. 21-24.

${ }^{31}$ Assim CARNEVALI, apud BESSONE, Profilli... Op. cit., p. 26

${ }^{32}$ Conforme GHIDINI, apud BESSONE, Op. loc. cit.

Revista da Faculdade de Direito da UFRGS, v. 20, Outubro/2001 
mentar um regime de responsabilidade mais rigoroso para o fabricante. O consumidor adquire um produto animado pela expectativa da sua utilidade, imaginando a isenção de qualque defeito. A boa-fé estabelece uma conexão direta e imediata entre a confiança despertada pelo fabricante e a crença do consumidor na plausibilidade da promessa - uma boa-fé com carga subjetiva. Com a manifestação do defeito, o fabricante também apela para a boa-fé como argumento de inexigibilidade de outra conduta, pretendendo um abrandamento da sua responsabilidade, em vista da impossibilidade concreta de ter evitado o dano. ${ }^{33}$ Este último argumento só é aceitável na inexistência de regra de responsabilidade objetiva.

2.1.2.3. Direito alemão. Na Alemanha, a responsabilidade do fabricante por produtos defeituosos, tradicionalmente, podia ter natureza contratual ou extracontratual, ambas com base na culpa. A responsabilidade contratual tinha por fundamento uma lesão positiva do contrato. No entanto, se o fabricante fornecesse uma garantia do produto, não era necessária a prova da culpa. Em muitos casos, a jurisprudência considerava certas garantias implícitas. ${ }^{34}$ Mais adiante, sob influência da Comunidade Européia, prevaleceu a fundamentação extracontratual. A culpa, no entanto, mantinha sua posição. A doutrina germânica, quase à unanimidade, considerava temerária uma responsabilidade com base no risco da empresa, posição que em grande medida se justificava pelo fato de que, embora fosse dominante a aceitação de uma responsabilidade objetiva mesmo sem previsão legislativa, a inversão do ônus da prova pelos tribunais já tinha proporcionado uma considerável extensão do regime de responsabilidade. ${ }^{35}$ Assim: o ônus da prova contra o patrão era agravado, exigindo a demonstração de cuidado na escolha e vigilância do empregado; foi considerado presumido o defeito da organização (com base no § 831, BGB) como causa do defeito do produto, pois uma suficiente articulação de meios de segurança e controles certamente o teria evitado. Por outro lado, foram criadas facilidades para o consumidor. A prova dos defeitos de construção era considerada suficiente mediante meros indícios e para o nexo causal bastava uma aparência de prova. A pretensão indenizatória de natureza contratual protegia, além do adquirente, os seus familiares, hóspedes e dependentes. A via extracontratual abriu-se a qualquer lesado, inclusive os bystanders, prevalecendo mesmo em acidentes com máquinas industriais. ${ }^{36}$

A decisão que marcou a predominância do fundamento extracontratual na responsabilidade civil do fabricante foi tomada pelo Bundesgerichtshof em 1968, que assentou a predominância do $\S 823$, alínea 1 , do BGB, com inversão do ônus da prova da culpa. ${ }^{*} \mathrm{O}$ fundamento da responsabilidade do fabricante é a violação de uma obrigação de prevenção de perigo. Coerentemente com essa visão, a juris-

${ }^{33}$ BESSONE, Mario.Profili della responsabilità del produttore nell'esperienza italiana. In ALPA e BESSONE Danno da Prodotti...”. Op. cit., p. 25

${ }^{34}$ MARSCHALL VON BIEBERSTEIN, W. La responsabilità da prodotti nel diritto tedesco. In ALPA e BESSONE (a cura di). Danno da Prodotti..., Op. cit., pp. 165-185, passim.

${ }^{35}$ ARATO, Marco. La dottrina tedesca e la direttiva proggetuale della CEE. In ALPA e BESSONE (a cura di). Danno da Prodotti..”. Op. cit., p. 185-189.

${ }^{36}$ MARSCHAL VON BIERBENSTEIN, La responsabilità... Op. cit., p. 174-182.

* "\$ 82.3. Dever de ressarcimento de danos. 1. Aquele que dolosa ou culposamente lesa injustamente a vida, o corpo a sá́de a liberdade, a propriedade ou qualquer direito de outra pessoa, fica obrigado frente a ela a ressarcir o dano que causou".

Revista da Faculdade de Direito da UFRGS, v. 20, Outubro/2001 prudência alemã, apesar de rejeitar categoricamente a responsabilidade por risco do desenvolvimento - exceto no setor de medicamentos -, impõe ao fabricante um dever de acompanhar o produto mesmo depois de sua comercialização, advertindo o público sobre a descoberta ulterior de um risco desconhecido. Todavia, a lei que adaptou a diretiva não positivou a regra pretoriana, abrindo flanco à crítica de favorecimento à indústria. ${ }^{37}$

2.2. Fontes Alternativas da Responsabilidade Civil e o Advento da Diretiva Européia

O terreno tradicional da responsabilidade civil foi modificando-se no compasso da crescente importância assumida pelos acidentes com produtos defeituosos. Verificou-se uma convergência dos regimes contratual e delitual, sendo alguns de seus sintomas principais: a ineficácia das cláusulas limitativas de responsabilidade, que eram aceitáveis nos contratos em razão da autonomia da vontade; a assimilação da culpa profissional à culpa grave, implicando considerar o defeito um ato intencional em razão da paridade da culpa grave com o dolo; a assimilação do vendedor profissional a vendedor de má fé em face de um vício oculto; e principalmente o conteúdo das obrigações em matéria de segurança, que resguarda contra os usos e riscos dos produtos tanto o adquirente quanto terceiros. ${ }^{38}$

A confluência dos regimes clássicos do contrato e do delito leva à formulação de uma terceira fonte de responsabilidade civil, que pressupõe uma interação social que não se concretiza num contrato nem ingresse no terreno ilícito do delito.
A pavimentação dessa terceira via da responsabilidade civil fundamenta-se em deveres de proteção da integridade alheia, impondo um modo de agir que evite prejuízos ao parceiro relacional. A idéia motriz é uma solidariedade que deve permear o contato social, toda vez que ele se intensifica, indo além da vida de relação anônima ou eventual. Os deveres de proteção não se vinculam nem ao contrato nem ao delito. Eles constituem "a juridificação de uma moral da interação". ${ }^{39}$ A responsabilidade civil adviria da violação de um comportamento singular, exigível no quadro de uma relação concreta. A sua justificação é a legitimidade do interesse de conservação dos próprios bens, peculiar a qualquer um

Para a fundamentação jurídica dessa responsabilidade concorrem várias doutrinas, que têm em comum a justificativa de uma fonte de responsabilidade civil autônoma em relação àquelas clássicas do contrato e do ato ilícito.

\subsubsection{Em busca de uma Terceira Via da Res-} ponsabilidade Civil

As mais expressivas teorias alternativas ao contrato e ao delito como fontes de responsabilidade civil são a do contato social e a da proteção à confiança, que ao fim e ao cabo apresentam aspectos de complementaridade. Ambas constituem idéias que fundamentam deveres sem origem em vínculos jurídicos previamente estabelecidos, como os contratos, ou na contrariedade a condutas estipuladas em lei, como os atos ilícitos. Esses deveres surgem dos usos do tráfico e se revelam no campo sociológico, entrando no mundo jurídico por motivo de sua repercussão econômica.
${ }^{37}$ SCHWENZER, Ingeborg. L'adaptation de la directive communautaire du 25 juillet 1985 sur la responsabilité du fait des produits défectueux en Allemagne Fedérale. Revue Internationale de Droit Comparé. Paris: n. 1. 43. ano, p. 57-74, jan.mars 1991).

${ }^{38}$ Nesse sentido, comentando sobre o direito francês, VINEY G., La responsabilité.... Op. cit., P. 580-584.

${ }^{39}$ TEUBNER, apud FRADA, Manuel A. Carneiro da. Contrato e Deveres de Proteção. Coimbra, 1994: 266. 
A contribuição dessas teorias foi importante para superar a rigidez dos esquemas tradicionais do direito, comprometidos com os conceitos hegemônicos de contrato e delito. Mas não lograram consolidar uma posição indisputável. De um lado, ressuscitam as idéias romanas de quase-contrato e quase-delito. De outro lado, comportamentos concludentes podem substituir declarações de vontade na formação de vínculos contratuais, ficando dentro da teoria do negócio jurídico as situações que as teorias alternativas se propõem a explicar. Por fim, há que se evitar confusão com a boa-fé.

\subsubsection{Contato social, confiança e deveres de} proteção. O que se chama de contato social é o momento fático em que os indivíduos passam de uma convivência impessoal, diluída no anonimato, para uma situação particular, que adquire significado jurídico. Na convivência anônima a integridade de cada um está protegida pela regra nenimen leadere. No contato social passa a existir um relacionamento particular, em que alguém fica exposto à atuação ou influência de outrem, sem que necessariamente o passo seguinte seja a celebração de um negócio jurídico ou que ocorra um ato ilícito. Essa proximidade exige uma conduta especialmente cuidadosa por parte de quem possa eventualmente prejudicar o patrimônio jurídico alheio.Há un incremento de perigo por um lado e um acréscimo de responsabilidade pelo outro. O eventua dano sofrido por uma das partes durante esse contato social é indenizável, e o fundamento jurídico da obrigação de fazê-lo é a confiança.

"A confiança exprime a situação em que uma pessoa adere, em termos de atividade ou de crença, a certas representações, passadas presentes ou futuras, que tenha por efetivas". 40 Como está presente de modo geral no relacionamento humano (o pedestre atropelado confiava que o motorista respeitasse as regras de trânsito), a confiança deve ser o elemento determinante da conduta do lesado para poder fundamentar uma responsabilidade autônoma. Por conseguinte, somente uma concepção psicológica do princípio da confiança o legitima, pois uma conceituação normativa o confundiria com o dever geral de não infringir danos (regra neminen leadere), fundamento do ato ilícito. Sempre será necessário avaliar a subjetividade do lesado para saber se ele podia confi$\mathrm{ar}^{41}$ Portanto, fórmulas como "confiança digna de proteção jurídica" e "legítimas expectativas" não valem por si mesmas, necessitando invariavelmente de preenchimento fático. A confiança serve muitas vezes para limitar, outras para concretizar o contato social. ${ }^{42}$

A confiança "constitui, por excelência, uma ponte entre as boas-fés objetiva e subjetiva", como expressou Menezes COR$\mathrm{DEIRO}^{43}$, salientando que "a aproximação entre confiança e boa fé constitui um passo da Ciência Jurídica que não mais se pode irrealismo metodológico de compor litígios

${ }^{40}$ MENEZES CORDEIRO, Antonio Manuel da Rocha e. Da Boa Fé no Direito Civil. Coimbra: Almedina, 1984, II: 1234

${ }^{41}$ V. CARNEIRO DA FRADA, M. A., Contrato e Deveres de Proteção. Op. cit., p.252-253.

${ }^{42}$ Assim Dölle, Esser-Schmitdt, Thiele e Heinrich Stoll, apud FRADA. Op. cit., p. 249.

${ }^{43}$ Da boa fé.... Op. cit., v. II, p. 1238.

Revista da Faculdade de Direito da UFRGS, v. 20, Outubro/2001

com metadiscursos. ${ }^{44} \mathrm{~A}$ confiança tem raízes éticas que lhe conferem um conteúdo material a ser comunicado à boa fé. Ela é um fator de redução da complexidade social, na medida em que leva o fiduciante a descartar muitas das inúmeras eventualidades capazes de desencadear comportamentos humanos. O direito produz o mesmo efeito de redutor da complexidade, sendo uma fonte primordial de confiança. Numa sociedade dominada pela impessoalidade, o teor de confiança existente num contrato resulta mais da inserção do negócio em canais jurídicos pré-determinados do que de expectativas recíprocas de comportamento. A confiança gerada pelo direito decorre da previsibilidade proporcionada pela ordem jurídica. ${ }^{45}$ Enquanto as garantias legais infundem confiança ao cidadão, a falta de efetividade da lei constitui quebra da promessa.

A confiança se expressa no ordenamento jurídico por meio de disposições legais específicas ou de proteções genéricas albergadas em conceitos indeterminados. A primeira espécie reflete situações de boa-fé subjetiva e a segunda, de boa-fé objetiva. São exemplos de disposições legais específicas, inspiradoras de proteção em razão de confiança proveniente de boa-fé subjetiva: os efeitos, perante contraentes de boa-fé, do mandato aparente (art. 1.321, CC), mesmo que a lei não refira, de modo expresso, a boa-fé (a validade dos atos praticados pelo herdeiro excluído - art. 1.600, CC) ${ }^{46}$ As proteções de caráter genérico são

${ }^{44}$ Idem, ib., v. II, p. 1241

${ }^{45}$ Conforme CORDEIRO. Op. cit., v. II, p. 1243.

${ }^{46}$ Muitas disposições legais semelhantes são creditadas na literatura jurídica nacional à teoria da aparência, tal como o pagamento feito de boa-fé ao credor aparente (art. 935, CC) - e.g., RÁO, Vicente. Ato Jurídico. $3^{\text {a }}$ ed. São Paulo: Revista dos Tribunais, 1994. p. 205. Em casos como o exemplificado a confiança não integra necessariamente a aparência, como fica mais evidente na proteção ao possuidor de boa-fé (art. 510, CC), em que não existe um fiduciante. A eventual assimetria entre confiança e aparência foi gizada por Menezes CORDEIRO (Da Boa Fé... Op. cit. v. II, p. 1234). Contudo, para CANARIS, a aparência é tipicamente uma causa de responsabilidade pela confiança, do mesmo modo que alguns imperativos ético-jurídicos, declarações e intromissões lesivas. Apud FRADA, Manuel A. Carneiro da. Contrato e Deveres de Proteção, cit., 250

${ }^{47}$ V. CORDEIRO (Da Boa Fé... Op. cit. v. II, p. 1244).

${ }^{48}$ Idem, ib., v. II, p. 1247-1248.

${ }^{49}$ Apud João Calvão da SILVA, Responsabilidade civil do produtor, cit., p. 342, nota 5.

(x).

Revista da Faculdade de Direito da UFRGS, v. 20, Outubro/2001 relativas à boa-fé objetiva, exigindo uma conduta capaz de legitimar uma posição jurídica, tal na suppressio e na surrectio. ${ }^{47}$ Segundo MENEZES CORDEIRO, fora das disposições egais específicas, a confiança deve ser motivo de proteção jurídica quando houver atuação

A factualidade da violação dos deveres e proteção não pode ser confundida com o u regime. A violação ocorre em situações de zam em condutas exigíveis ou proibidas, mas a inexistência de um acordo prévio afasta o regicomo a imputação por fato de terceiro. que os deveres de proteção, que antecedem e sobrevivem ao contrato, formam uma relação vontade. A relac̃ão de confiança, por conseguinte, pode estabelecer-se entre fabricante e ao passo que a relação de prestação somente forma entre os elos da cadeia produtiva. ${ }^{49}$

A necessidade de proteção da integridade levou à combinação de regras de natureza delitual com o regime jurídico próprio dos con位os. Não fosse assim, seria imprópria a

Revista da Faculdade de Direiro da UFRGS, w 20 . Outubro/2001 
tratos, uma situação híbrida, que ensejou as denominações contort ${ }^{50}$ e Sonderdelikte. ${ }^{51} \mathrm{Po}$ rém, diferentemente do contrato, não há acordo negocial como base da responsabilidade; e, dis tintamente do delito, o ponto de partida não é violação pura e simples de uma regra de abstenção de conduta por parte do lesante, mas a aquiescência do lesado a uma possibilidade de interferência do lesante que o lesado confia que não ocorrerá. Na relação obrigacional emergente, situa-se no pólo credor (de credere, confiar) aquele que confia, cuja conduta fiduciante portadora de eficácia jurígena; no pólo devedor, o fiduciário, cujos deveres de proteção são a contrapartida de sua autonomia negocial, no exercício da qual opta por tornar-se guardião de bens alheios no transcurso relacional que consulta o seu interesse..$^{52}$

Em conclusão: existem deveres no contato social, fora do contrato e aquém do delito. O princípio que lhes infunde juridicidade é a confiança. A violação de tais deveres, dirigi dos à proteção alheia, implica a obrigação de reparar os danos. O critério de aferição dessa responsabilidade é a boa-fé. Vista objetivamente, a boa-fé é uma exigência de conduta ética leal, que se impõe ao lesante. De outro lado, ela será a medida de aferição do comportamento do lesado, de acordo com a sua representação subjetiva da realidade, autorizada pelos fatos que lhe era possível conhecer e por sua verossimilhança.

2.2.1.2. Boa-fé e incremento das pretensões contratuais. A difusão do princípio da boa-fé expandiu o conteúdo das obrigações contratuais, internalizando nos acordos de vontade situações que antes só eram cobertas no regime extracontratual. Ficou assim diminuída a importância da barreira representada pela regra non cumul, que não permitia a veiculação de pretensão delitual ante um incumprimento contratual, ainda que a via compulsória - no caso, a do contrato - trouxesse inconvenientes, tais como prazos prescricionais mais reduzidos e exclusão de alguns danos da possibilidade de reparação. A regra non cumul foi adotada, por exemplo, na França, e também no Brasil, em vista da disciplina separada que o Código Civil dedica às obrigações contratuais e às provenientes de delito. Já outros sistemas, como o germânico, admitiram uma facultas alternativa, permitindo que o lesado escolhesse a via de sua conveniência. ${ }^{53}$ No direito inglês, depois que o princípio formulado no caso Donoghue v. Stevenson (1932), de que os fabricantes respondem por danos causados por seus produtos aos consumidores se generalizou pela sua repetição numa série de outros julgados, a via da ação delitual foi aberta também aos contratantes. $O$ fatalismo da alternativa, contrato ou delito, foi colocado em xeque com o debate sobre os atos existenciais, que ganhou importância com a estandardização do tráfego. Nos atos existenciais, a vontade não é condição de eficácia. Portanto, o regime a eles aplicá-

${ }^{50}$ Contração de contract com tort (delito civil no common law), termo cunhado por GILMORE. Apud FRADA. Contrato e Deveres de Proteção, cit., p. 263.

${ }^{51}$ Delito especial, assim definido por GERT BRÜGGEMEIER. Apud FRADA. Op. cit., p. 264. FRADA acaba aderindo ao quase-contrato como figura apta a representar essa terceira via de responsabilidade, diferente do contrato e do delito (Op. cit., p. 272).

${ }^{52}$ No mesmo sentido, FRADA. Op. cit., p. 272.

${ }^{53}$ Nesse sentido, WEITNAUER, H. Remarques sur l'évolution de la responsabilité civile délictuelle en droit allemand. Revue International de Droit Comparé, Paris: n. 19, 1967, p. 810.

Revista da Faculdade de Direito da UFRGS, v. 20, Outubro/2001 vel não pode ser o contratual, porque, à míngua de manifestações válidas, o juiz não teria substrato para decidir sobre o conteúdo das obrigações. De delito, evidentemente, também não se trata. A solução de melhor alvitre é considerar os atos existenciais, atos materiais. No plano processual, a pretensão é veiculada no pedido e fundamenta-se nos fatos a que o mesmo se reporta, encontrando plena ressonância no art. 282, III, do Código de Processo Civil, que consagra o princípio da substanciação da causa de pedir. ${ }^{54}$

2.1.3. Refluxo às fontes tradicionais. Não colhem unanimidade, porém, as teorias unitárias de responsabilidade civil. Parte ponderáve da doutrina adapta a teoria clássica das fontes ao tráfico de massa. A formação dos vínculos contratuais bipolariza-se em declarações de vontade e comportamentos concludentes. Nos contratos de massa, conjugam-se uma oferta uma conduta. A confiança, nesse caso, não é o pressuposto de fato que origina uma responsabilidade in contrahendo, mas o nexo causal da obrigação de indenizar o interesse negativo. ${ }^{55}$ Dispõe nesse sentido o § 307, do Código Civil alemão, impondo àquele que conclui um contrato conhecendo com exclusividade ou deven- do conhecer a impossibilidade da prestação, a obrigação de indenizar a parte lesada que confiou na validade do negócio.

2.2.2. A Consolidação da Responsabilidade

A evolução da matéria da responsabilidade do fabricante no direito europeu, que por caminhos diversos chegou a idênticas soluções nos sistemas do common law e do civil law, convergiu para o concurso dos regimes contratual e extracontratual, com o fim de assegurar maior proteção às vítimas. Foi essa a solução consagrada na Diretiva 85/374, da Comunidade Econômica Européia, que promoveu uma unificação das responsabilidades contratual e extracontratual, tornando sem interesse a vinculação do dano a um regime ou outro. ${ }^{56}$

A Diretiva em referência harmonizou o direito europeu aplicável a produtos defeituosos e representou uma culminância legislativa, desdobrada para o direito interno dos países membros, depois que os tribunais, sensíveis à necessidade de propiciar um patamar de proteção efetiva aos consumidores, lograram atrair para o mesmo esforço o legislador. ${ }^{57}$ Civil do Fabricante na Diretiva 85/374/CEE

${ }^{54}$ Sobre os temas da regra non cumul e da facultas alternativa, bem como sobre atos existenciais, foi importante a contribuição do Prof. Clóvis do Couto e SILVA, em várias passagens de sua obra, tais como: Principes fondamentauxde la responsabilité civile em droit brésilien et comparé. Trabalho inédito, no acervo da Faculdade de Direito da UFRGS; Para uma história dos conceitos no direito civil e no direito processual civil. Boletim da Faculdade de Direito. Coimbra: v. LVIII, 1982, p. 311-372.

${ }^{55}$ FLUME, W. El negocio jurídico. Madrid: Fundación Cultural del Notariado, 1998. p. 166, t. 2.

${ }^{56}$ Assim CALVÃO DA SILVA J., segundo quem, "a querer catalogar-se na antiga dicotomia a responsabilidade (...), ela não pode deixar de ser havida como extracontratual, já que é independente de qualquer relação contratual entre o produtor e o lesado", acrescentando que "a summa divisio é antiga e continua a existir, concorde-se ou não"
(Responsabilidade civil... Op. cit., pp. 478-9). Sendo assim, a proclamada unificação de regimes é especial, não derruindo os alicerces da ancestral construção aquiliana. Também não tem trânsito a doutrina da confiança, de Canaris, por ele mesmo denominada de terceira pista ("dritte Spur") da responsabilidade civil. CALVÃO DA SILVA a considera artificial, por decompor uma relação obrigacional em duas (relação de confiança e relação de prestação). $\mathrm{O}$ autor português cita decisão do Supremo Tribunal alemão, que rejeita a teoria de Canaris, por suprimir os limites existentes entre os domínios contratual e extracontratual (Op. cit., p. 343). Parece-nos que a doutrina de Canaris ou qualquer outra "terceira pista", com a denominação que se lhe possa dar (contato social, conduta social típica, atos existenciais, relações contratuais fáticas etc.) tem o mérito de revelar uma área de responsabilidade intermediária, extracontrato e extradelito, autônoma em relação a ambos. A delimitação desse território não exclui a unificação dos dois regimes, porque em ambos vigoram regras híbridas. A questão a discutir é se é só um ou se são dois territórios.

s7 VINEY, G. La responsabilité.... op. cit, p. 569.

Revista da Faculdade de Direito da UFRGS, v. 20, Outubro/2001 

tado membro ou a transposição incorreta da gura na aplicação dos Regulamentos. Por con-
2.2.. A eficácia das Diretivas na Comunidade Européia. Conforme o Tratado de Roma, diretiva, decisão do Conselho da Europa, "vincula o Estado membro destinatário quanto ao resultado a alcançar, deixando, no entanto, às instâncias nacionais a competência quanto à forma e aos meios" (art. 189, $3^{\text {a }}$ parte).

A harmonização como efeito de uma diretiva pode ocorrer pelo implemento legislativo no plano interno de cada Estado membro, adaptando ao seu ordenamento jurídico o regime proposto, ou por aplicação direta da diretiva.

A Diretiva 85/374 concedeu aos Estados membros o prazo de três anos para a implementação dos atos legais visando a sua transposição para o direito interno. Alguns países excederam o prazo. ${ }^{58} \mathrm{~A}$ omissão de um Esdiretiva pode ser suprida pelo chamado efeito direto, consagrado pelo tribunal comunitário no caso Becker-Finanzamt Münster-Innenstad de 1982. Contudo, o efeito direto, no caso de uma diretiva, opera apenas no sentido vertical, impondo-se aos Estados membros, mas não ao particulares. O efeito direto integral só se confiseguinte, um particular pode invocar contra um Estado membro a aplicação de uma disposição direta $\mathrm{e}$ incondicional da diretiva, mas não obterá o mesmo efeito contra outro particular. ${ }^{59} \mathrm{~A}$

fundamentação do efeito direto é a doutrina do stoppel, corolário da boa-fé, segundo a qual, no caso em questão, um Estado não poderia negar direitos decorrentes da aplicação da diretiva, opondo o seu próprio incumprimento da obrigação de internalizá-la. ${ }^{60}$

Tendo em conta o efeito vinculativo das diretivas, o Tribunal de Justiça das Comunidades Européias decidiu, no caso Von Colson e Kamann, julgado em 10 de abril de 1984 , que as jurisdições nacionais devem interpretar o direito interno à luz do texto e da finalidade da diretiva. ${ }^{61}$

Outro mecanismo de harmonização do direito europeu é o reenvio prejudicial. $\mathrm{O}$ art. 177 do Tratado de Roma prevê essa figura, que faculta aos órgãos jurisdicionais dos Estados membros requerer um pronunciamento prévio do Tribunal de Justiça comunitário quando a decisão da causa implicar uma interpretação do Tratado ou de atos emanados das instituições comunitárias, tais como as diretivas. Através do reenvio prejudicial é assegurada uniformidade de interpretação do direito comunitário.

2.2.2.2. Bases do regime de responsabilidade na Diretiva 85/374/CEE. A Diretiva 85/374 dispõe que o produtor será responsável pelos danos causados por defeitos dos seus produtos, ${ }^{62}$ podendo ser responsabilizado também o im-

${ }^{58}$ Cumpriram o prazo Grécia, Grã-Bretanha e Itália (Decreto 224, de 24/5/88). Atrasaram-se Portugal (Decreto 383/89, de 6 de novembro) Alemanha (a já mencionada Lei de Responsabilidade pelo Fato de Produtos Defeituosos, Produkthaftungsgesetz, de 15/12/89) e Espanha (Lei 22/1994, de 6 julho).

${ }^{59}$ Apud Calvão da SILVA, "Responsabilidade...”, Op. cit. p. 460.

${ }^{60}$ Tal a decisão do tribunal comunitário na "Sentença Ratti", apud GARAU, Guillermo Alcover, La

${ }^{61}$ Apud Calvão da SILVA. Responsabilidade... Op. cit. p. 454.

62 "Art. $1^{\circ}$. O produtor é responsável pelo dano causado por um defeito do seu produto". Note-se a extensão do conceito de produtor, que aparece no art. $3^{\circ}, 1$ : "O termo 'produtor' designa o fabricante de um produto acabado, o produtor de uma matéria-prima ou o fabricante de uma parte componente, e qualquer pessoa que se apresente como produtor pela aposição sobre o produto do seu nome, marca ou qualquer outro sinal distintivo".

Revista da Faculdade de Direito da UFRGS, v. 20, Outubro/2001 Responsabilidad Civil del Fabricante. Madrid: Civitas, 1990. p. 45. portador ${ }^{63}$ Não sendo o produtor identificado, poderá responder pela indenização qualquer fornecedor, livrando-se, no entanto, se indicar ao lesado a identidade do produtor "num prazo razoável". ${ }^{64}$

A Diretiva, conforme consiga a exposição de motivos, aplica-se somente a bens móveis produzidos industrialmente, ${ }^{65}$ excluídos produtos agrícolas e da caça, a menos que tenham passado por processo industrial de transformação.

Tem o prejudicado o ônus de provar o

Nada é aludido com relação ao fator de imputação, entendendo-se prescindível a culpa, mesmo porque, segundo a exposição de motivos, "unicamente o critério da responsabilidade objetiva permite resolver o problema, tão próprio de uma época de crescente tecnicismo como a nossa, da justa repartição dos riscos inerentes à produção técnica moderna". Também são incluídos os importadores (art. $3^{\circ}, 2$ ) Havendo duas ou mais pessoas causadoras do mesmo dano, haverá solidariedade entre elas (art. $4^{\circ}$ ).

Não há preocupação dogmática em enquadrar a responsabilidade dos sujeitos passivos no campo contratual ou extracontratual. Ao dano, o defeito e o nexo causal. ${ }^{66}$ contrário, iguala-os, ao tornar responsável qualquer distribuidor colocado na cadeia de fornecimento nos casos em que o produtor, compreendido nos termos já explicitados, não puder ser identificado (art. $3^{\circ}, 3$ ). Também institui a solidariedade pela reparação entre todos os que concorreram para o dano $\left(\operatorname{art.~} 5^{\circ}\right)$.

\section{Responsabilidade Civil do Fabricante no Quadro do Mercosul}

A eviolução das idéias nos sistemas common law e continental europeu, bem como a posterior harmonização comunitária do regime de responsabilidade civil do produtor, por meio da Diretiva 85/374/CEE, influenciaram diretamente a disciplina legal da mesma matéria nos países do Mercosul. O primeiro país a seguir o modelo foi o Brasil.

\subsection{O Código Brasileiro como Paradigma}

A preocupação internacional com a proteção ao consumidor coincidiu com o momento histórico da abertura política no Brasil e a instalação de uma Assembléia Constituinte. É bem nítida a linha cronológica que revela o nexo das influências políticas que fizeram com que o cons-
${ }^{63}$ “Art. $3^{\circ}$, 2. Sem prejuízo da responsabilidade do produtor, qualquer pessoa que importe um produto na Comunidade tendo em vista uma venda, locação, locação financeira ou qualquer outra forma de distribuição no âmbito de sua actividade comercial, será considerada como produtor do mesmo, na acepção da presente directiva, e responsável nos mesmos termos que o produtor".

${ }^{64}$ "Art. $3^{\circ}, 3$. Quando não puder ser identificado o produtor do produto, cada fornecedor será considerado como produtor, salvo se indicar ao lesado, num prazo razoável, a identidade do produtor ou daquele que lhe forneceu o produto. O mesmo se aplica no caso de um produto importado, se este produto não indicar o nome do importador referido no $\mathrm{n}^{\circ} 2$, mesmo se for indicado o nome do produtor". A denúncia do fabricante pelo fornecedor imediato em "prazo razoável" de certo não é boa inspiração, permitindo interpretações no sentido de uma cadeia de

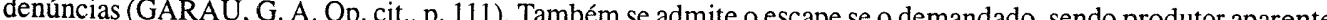
provar que o defeito é da matéria-prima ou de uma peça incorporada (BERCOVITZ, Alberto y BERCOVITZ Rodrigo Estúdios Juridicos sobre Proteción de los Consumidors Madid: TeChos, 1987. p. 267 Rodrigo. Estúdios Jurídicos sobre Protección de los Consumidores. Madrid: Tecnos, 1987. p. 267, interpretando 0 art. $3^{\circ}$, da Diretiva).

${ }^{65}$ "Art. $2^{\circ}$. Para efeitos do disposto na presente directiva, entende-se por 'produto' qualquer bem móvel, mesmo se incorporado noutro bem móvel ou imóvel. A palavra 'produto' designa igualmente a electricidade"

66 "Art. $4^{\circ}$. Cabe ao lesado a prova do dano, do defeito e do nexo causal entre o defeito e o dano". 
tituinte brasileiro implantasse em dois importantes sítios constitucionais a defesa do consumidor.

A necessidade de cooperação internacional na reconstrução da Europa no pós-guerra e a natural expansão dos mercados no regime capitalista ditou a conveniência da criação de organismos internacionais voltados para a conjugação de esforços e políticas com objetivos comuns.

A primeira organização a surgir foi a OECE (Organização Européia de Cooperação Econômica), fundada em 1948, pelos países aceitantes da oferta de ajuda norte-americana através do Plano Marshall.

Em 1968, a OECE foi sucedida pela OCDE Organização de Cooperação e Desenvolvimento Econômico), integrada pelos países europeus signatários da primeira convenção, mais os Estados Unidos e o Canadá, em virtude dos interesses comerciais comuns. Mais tarde associaram-se o Japão, a Austrália e a Nova Zelândia.

Foi nesse quadro que se desenvolveu a idéia de uma proteção sistemática ao consumidor, através da implementação de políticas que levassem em conta a sua situação de vulnerabilidade no mercado.

Em 1969 a OCDE criou a Comissão para a Política dos Consumidores, cujo trabalhou culminou em 1973 com a divulgação da Carta do Consumidor, através de Resolução do Conselho da Europa. Essa Carta lançou os direitos básicos dos consumidores, que receberam consagração universal na Resolução 39/248, de 10 de abril de 1985, da Organização das Nações Unidas. Logo três anos depois, foi promulgada a Constituição brasileira.

A defesa do consumidor é dever do Estado e direito subjetivo público de todo cidadão brasileiro, porque inserida no título das

garantias fundamentais, no capítulo dos direitos individuais e coletivos (art. $5^{\circ}$, inciso XXXII). Por outro lado, é um dos princípios que estrutura a ordem econômica, fator de moderação da livre iniciativa (art. 170, inciso V, CF).

Cumprindo disposição transitória (art. 48, do ADCT), o legislador ordinário elaborou a Lei $n^{\circ} 8.078$, de 11/9/90, que deu forma ao Código de Defesa do Consumidor.

\subsubsection{A Regência dos Princípios}

O Código de Defesa do Consumidor é uma conjugação de princípios, articulados por cláusulas gerais e conceitos jurídicos indeterminados, dando ao aplicador a possibilidade de subsumir nas disposições legais a inacabável diversidade de situações fáticas que se passa no âmbito abstrato de transações que faz a mediação de interesses e necessidades com os bens e serviços aptos ao seu atendimento: o mercado.

Para uma conveniente mediação, não é bastante uma lei como obra posta e definitiva A dinâmica do mercado exige atenção permanente. Por isso, a proteção ao consumidor é objeto de uma política nacional continuada, que tem como pressuposto a vulnerabilidade do consumidor (art. $4^{\circ}, \mathrm{I}, \mathrm{CDC}$ ).

Vulnerabilidade é exposição a um risco. Os consumidores são naturalmente vulneráveis, porque são heterogêneos e pouco coesos. Raramente se associam para defender coletivamente os seus interesses. Já os fornecedores são corporativos, mesmo quando atuam autonomamente (os profissionais liberais, por exemplo), sendo que na maioria das vezes a organização é imposta pela racionalidade e até pela lei (as sociedades comerciais). Daí a existência de uma "debilidade estrutural" no mercado em detrimento dos consumidores. ${ }^{67}$

${ }^{67}$ LORENZETTI, R. L. Fundamentos do Direito Privado. São Paulo: Revista dos Tribunais, 1998. p. 141. Revista da Faculdade de Direito da UFRGS, v. 20, Outubro/200I
Segundo Cláudia LIMA MARQUES, existem três tipos de vulnerabilidade: a técnica, a jurídica e a fática. ${ }^{68} \mathrm{Na}$ vulnerabilidade técnica, o consumidor é passível de engano porque não possui conhecimentos específicos sobre o objeto do consumo. Na vulnerabilidade jurídica, o consumidor sujeita-se especialmente às cláusulas abusivas dos contratos de adesão. $\mathrm{Na}$ vulnerabilidade fática, o consumidor pode ser vítima de abusos do poder econômico, como acontece no domínio de mercados através de monopólios, oligopólios ou cartéis.

Cumpre ao direito compensar a vulnerabilidade dos consumidores, através de mecanismos jurídicos de equilíbrio das desigualdades materiais. Assim: o juiz pode inverter o ônus da prova como meio de facilitar a defesa de direitos do consumidor (art. $8^{\circ}$, VIII); o juï deve interpretar os contratos de maneira mais favorável ao consumidor (art. 47); nos contratos realizados fora dos estabelecimentos comerciais, o consumidor tem direito de desistência imotivada (art. 49); os contratos só obrigarão os consumidores se lhes for dado conhecimento prévio do seu conteúdo e estiverem redigidos de modo compreensível (artigos 46 e 54, 8 $2^{\circ}$ ); as cláusulas consideradas abusivas são nulas de pleno direito, mas não invalidam o contrato, que deve ser preservado como meio de assegurar o atendimento das necessidades e interesses dos consumidores (art. 51 e parágrafo $2^{\circ}$ ); nos contratos de adesão, o direito de resolução é alternativa do consumidor (art. 54, $\S 2^{\circ}$ ); a defesa dos interesses e direitos dos consumidores pode ser realizada em juízo individual ou coletivamente (artigos 81 e 82) etc.

De um lado, mecanismos compensatóri-

os servem para atenuar a vulnerabilidade do mais fraco. De outro lado, ao mais forte são carregados deveres pré-contratuais e póscontratuais. $\mathrm{O}$ fabricante tem o dever de informar sobre os riscos e usos dos seus produtos (artigos $8^{\circ}$ e $9^{\circ}$ ) e deve assegurar a oferta de componentes e peças de reposição por tempo razoável, mesmo depois de cassada a produção (art. 32 e parágrafo único). A obrigação do fornecedor não depende, porém, de contrato, nascendo já da oferta (art. 30), que é suficiente para armar o consumidor de pretensão ao cumprimento forçado (art. 35, I).

As normas protetivas não devem instaurar, contudo, um espírito de antagonismo entre fornecedores e consumidores, que em verdade são pólos reciprocamente dependentes. A política nacional das relações de consumo visa a harmonia e o equilíbrio dos interesses em causa, procurando compatibilizar a proteção legal com o desenvolvimento econômico e tecnológico, tal como propõe o art. $4^{\circ}$, inciso III, do CDC. A relação de consumo, independentemente da existência de contrato, é uma totalidade, que convoca entre fornecedores consumidores uma ordem de cooperação, ${ }^{69}$ cuja base é a boa-fé.

A boa-fé, neste caso, é uma mediação entre princípios tensionais e estruturais da or dem econômica, quais sejam, a livre iniciativa e a defesa do consumidor (art. 170, incisos IV e V, $\mathrm{CF}$ ). A ordem ẹconômica se sobrepõe à autonomia privada, refreando o poder econômico, ao mesmo tempo em que ultrapassa a simples defesa do débil, olhando ao interesse social privilegiando a coletividade de consumidores. ${ }^{70}$ Retomando a idéia de LORENZETTI, a boa-fé

${ }^{68}$ LIMA MARQUES, C. Contratos no Código de Defesa do Consumidor. $3^{a}$ ed. São Paulo: Revista dos Tribunais, 1999. p. 147.

${ }^{69} \mathrm{O}$ conceito de totalidade obrigacional, vem exposto na valiosa introdução d' A Obrigação como Processo, de Clóvis do COUTO E SILVA (São Paulo: Bushatsky, 1976).

${ }^{70}$ AGUIAR JÚNIOR, R. R. A boa-fé na relação de consumo. Direito do Consumidor, São Paulo, v. 14, p. 21 ss. 
concilia os fatores estruturais do mercado, ainda que em eventual detrimento de interesses conjunturais. Daí o pertinente exemplo dos consórcios para aquisição de bens duráveis mencionado por Ruy Rosado de AGUIAR. A devolução das prestações pagas ao desistente só deve ser feita no final do plano, para não prejudicar os demais consorciados. ${ }^{7}$

\subsubsection{Produção e Responsabiliadade}

A atividade industrial não constitui um fator autônomo de responsabilidade. ${ }^{72}$ Ela é socialmente útil e necessária ao desenvolvimento econômico. A razão de ser da responsabilidade do fabricante está no defeito dos produtos. ${ }^{73}$ É impossível uma produção isenta de defeito, dada a falibilidade humana. $\mathrm{O}$ risco assumido pelo produtor é a eventualidade do defeito, ainda que involuntário. A responsabilidade industrial funda-se, portanto, num risco - risco que não está para o dano, mas para o defeito. O dano conseqüência que nem sempre se materializa. $O$ defeito constitui ameaça geral. O dano é prejuízo particular trazido à vítima pelo acidente. Havendo defeito sem dano, o bem jurídico em causa é a segurança dos consumidores e como conseqüência o produto deve ser retirado do mercado. É uma fase de prevenção. ${ }^{74} \mathrm{Se}$ ocorrer o dano terá que haver a reparação, desde que se constate o defeito.

3.1.2.1. Condiç̃es da responsabilidade civil do fabricante. O dano provém do chamado fato do produto.

Fato do produto é o acidente, acontecimento em cuja avaliação jurídica não se levam em conta fatores de voluntariedade ou previsibilidade. O evento danoso é considerado a partir da sua própria realidade e visto como um elemento de injustiça para a vítima. $\mathrm{Na}$ sociedade industrial tais acidentes são, lamentavelmente, inevitáveis. Por mais aperfeiçoados que se tornem os processos produtivos, jamais conseguirão reduzir a zero o risco de defeitos. Não se pode, porém, condicionar a reparação dos prejuízos à identificação de um culpado. A divisão do trabalho e a automação industrial concorreram para tornar os agentes humanos da produção praticamente anônimos. Dessa sorte, na disciplina dessa matéria o direito não olha mais para a ação dos homens ${ }^{75}$ e sim para o fato das coisas. Não há mais lugar para a culpa como fator de imputação da obrigação reparatória. Sucedeu-a o risco que o fabricante cria para terceiros ao colocar em circulação produtos defectíveis. O risco socialmente suportável é limitado ao que é inerente à utilização normal do produto, sendo alocado ao fabricante o perigo agregado por imperfeição do processo industrial.

O defeito é a relação causal entre o acidente (fato) e o resultado lesivo. É presumido o

${ }^{11}$ Op. cit., p. 22

${ }^{72}$ Nesse sentido uma conclusão das XV Jornadas Nacionales de Derecho Civil, de Mar del Plata (Argentina), 26 28 out. 95 , comissão n. 2, sobre Responsabilidade Civil pela Atividade Industrial, com presidência de Atílio Alterini e Roberto López Cabana, coordenação de Ricardo Lorenzetti e Silvia Tanzi. In Derecho Del Consumidor. Buenos Aires: Juris, n. 7, 1996. p. 123.

${ }^{73}$ A jurisprudência norte-americana, depois "flertar" nos anos 80 com uma responsabilidade do fabricante sem defeito do produto, refluiu para o sistema do defeito. HENDERSON JR. e TWERSKI, op. cit., p. 1271

${ }^{74}$ JOERGES, C. (Le 'Consumer Product Safety Act' americain et sa mise en oeuvre par la 'Consumer Product Safety Comiscion. Revue Internationale de Droit Comparé, n. 1,40. année, p. 7-37, jan.-mars 1988) critica a ausência de regras voltadas à prevenção dos danos na Europa, em contraste com os Estados Unidos.

a ausência de regras voltadas à prevenção dos danos na Europa, em contraste con
${ }^{75}$ Código Civil. "Art. 159. Aquele que, por ação ou omissão voluntária...". defeito, uma vez que incumbe ao fornecedo provar a sua inexistência (art. 12, parágrafo $3^{\circ}$, II, do CDC). Dado que o fabricante não pode colocar em circulação produtos inseguros (art. $8^{\circ}$ ), a ocorrência de um dano autoriza a presunção.

A pedra de toque da responsabilidade civil do fabricante é o defeito do produto, seja para prevenir, seja para reparar. O dano é pressuposto da indenização, não da responsabilidade. Pode haver responsabilidade sem dano, sendo obrigação retirar o produto defeituoso do mercado para afastar o perigo.

A política de prevenção de acidentes no CDC resume-se a um controle de comercialização e pós-comercialização, resolvendo-se basicamente num dever de informar positivado a partir da boafé. A inspiração do legislador nacional certamente foi o Consumer Product Safety Act, de 1972, que estabelece um amplo controle sobre a qualidade dos produtos, inclusive com um banco de dados sobre a ocorrência de acidentes, que serve para o desenvolvimento de novos mecanismos de segurança. ${ }^{76}$

Os fabricantes devem informar os consumidores sobre os usos normais e os riscos que dos seus produtos. Um produto não deve expor ninguém a risco maior do que o normal e previsível, de acordo com a sua natureza e modo de fruição. Têm os fornecedores um dever de segurança frente aos consumidores. Não é aceitável mais do que a periculosidade inerente ao bem, sem risco adicionado no processo produtivo (periculosidade adquirida). ${ }^{77} \mathrm{O}$ art. $8^{\circ}, \mathrm{CDC}$, ao dispor nesse sentido, exibe a matriz do fator de imputação da responsabilidade civil do for- necedor por produtos defeituosos.

A informação deve acompanhar os produtos industriais e ser prestada de modo mais ostensivo ou menos, conforme o grau de periculosidade.

O fabricante deve controlar o processo industrial, incumbindo-lhe conhecer todas as inovações pertinentes e manter o produto tecnologicamente atualizado em matéria de segurança. Se a periculosidade só é percebida depois que o produto está em circulação, as autoridades e os consumidores devem ser prontamente comunicados, e feita a substituição do bem ou dos componentes defeituosos. A obediência a tal regra vulgarizou o recall.

O plano da prevenção procura resguardar a segurança dos consumidores, sendo precisamente este o bem jurídico tutelado. Já no plano da reparação, trata-se de proteger a integridade física e psíquica dos consumidores.

Todavia, não se haveria de negar indenização ao bystander que sofresse prejuízo apenas econômico em conseqüência de um acidente de consumo. ${ }^{78}$ Imagine-se um automóvel estacionado próximo a um posto de gasolina, atingido pela explosão de uma das bombas de abastecimento. Caracterizando-se o acidente de consumo, não seria razoável remeter o proprietário às regras da responsabilidade civil comum, discriminando-o dentre as vítimas, apesar de não estar explicitada essa situação na lei brasileira. A Diretiva da Comunidade Européia manda indenizar a morte ou lesões corporais e os danos causados a uma coisa ou a destruição de uma coisa $\left(\operatorname{art} .9^{\circ}\right) .79$

${ }^{76}$ JOERGES, C. Ob. cit.

${ }^{77}$ Things dangerous "per se" (ou things inherently dangerous) e things dangerous because of negligent construction, distinguidas no direito inglês e no direito norte-americano. Cf. supra.

${ }^{78}$ Danos indiretos (consequential damages) do direito inglês. Cf. supra (A-I).

${ }^{79}$ STIGLITZ, G (El derecho del consumidor en Argentina y en el Mercosur. La Lei, Buenos Aires, 19 mayo 1995 , p. 1-5) classifica os danos ao consumidor em intrínsecos (sofridos apenas no próprio produto adquirido) extrínsecos (sofrido pelo consumidor em sua pessoa ou em seus outros bens). 
A responsabilidade civil do fabricante não se funda mais em culpa pelo dano da vítima, mas no risco de que o produto tenha defeito e cause dano a alguém. A lei imputa-lhe o risco, mas não em sentido integral ou absoluto, porque não o relaciona com o só fabricar o produto, mas sim com a existência de defeito.

Três situações a lei admite em que não é devida indenização, ainda que o consumido algum dano sofra: a) se o fornecedor demandado não colocou em circulação o produto causador do dano (v.g., se o produto é falsificado); b) se o produto não é portador de defeito, sendo provavelmente outra a causa do dano; c) se houve culpa exclusiva da vítima ou de terceiro. As três situações referem-se ao nexo causal, inclusive a terceira, onde a palavra culpa está em lugar de "fato".

A segunda excludente não deixa dúvida sobre ser o defeito nexo causal da responsabilidade do fornecedor pelo fato do produto. $\mathrm{O}$ dano terá havido em razão do produto, mas sem que se constate defeito. Vale lembrar que defeito é déficit de segurança. Poderá haver, por exemplo, uso inadequado do produto, sem defeito de informação. Imagine-se automedicação de paciente portador de contraindicação especificamente advertida na bula.

$\mathrm{Na}$ terceira excludente, para que o fornecedor se livre, o fato do consumidor ou de terceiro deve ser exclusivo, sem coexistência

${ }^{80}$ Aceitando: MARINS, J. (Responsabilidade da empresa pelo fato do produto. São Paulo: Revista do ${ }^{80}$ Aceitando: MARINS, J. (Responsabilidade da empresa pelo fato do produto. São Paulo: Revista dos
Tribunais, 1993), que considera juridicamente irrelevantes os defeitos decorrentes de culpa exclusiva da vítima ou de terceiro, caso fortuito, força maior, riscos do desenvolvimento eça do plo fato do produto no direito

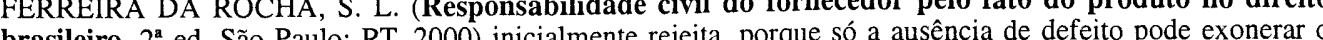
brasileiro. 2 ad. Sa Paus defricante, mas admite que caso fortio brasileiro de defesa do

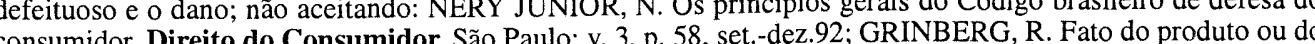

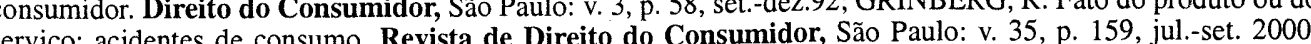
LIMA LOPES, J. R. (Responsabilidade civil do fabricante e a defesa do consumidor. São Paulo: RT, 1992 situa a responsabilidade civil do fabricante na dialética do capitalismo (op. cit., p. 151), justificando-se a situa a responsabilidade civil do fabricante na dialetica io cável a falha no processo produtivo, restando ao fabricante a única alternativa de provar a inexistência do defeito (op. cit., p. 76).

${ }^{81}$ LORENZETTI, R. L. Fundamentos do Direito Privado. São Paulo: Revista dos Tribunais, 1998. p. 226.

Revista da Faculdade de Direito da UFRGS, v. 20, Outubro/2001
De um lado, o fabricante tem melhores condições de suportar os danos causados aos consumidores, porque pode prevenir o desembolso da indenização, repartindo previamente esses custos e agregando-os ao preço do produto. Assim fica excluída a necessidade de levar em conta a culpa pela existência do defeito como fator de imputação da obrigação de indenizar. O fabricante responde pelo risco do defeito e danos eventuais. Também pode transferir esse risco contratando um seguro de responsabilidade civil, cujo prêmio será considerado um custo financeiro da produção.

De outro lado, a inadvertida circulação de produtos defeituosos pode realizar o lucro do fabricante. Nem todos os produtos defeituosos causam danos aos consumidores e nem sempre os lesados reclamam as correspondentes indenizações. É justo, pois, que os fabricantes indenizem os consumidores sempre que os defeitos dos seus produtos lhes causarem dano, sem possibilidade que invoquem como eximente qualquer fator causal incluído no espectro do risco da produção. Isso exclui, de plano, o caso fortuito, concebido como "um impedimento relacionado com a pessoa do devedor ou com a sua empresa", sendo aceitável apenas a idéia de força maior, um "caso fortuito externo". ${ }^{82}$

O mesmo pode ser dito quanto aos riscos do desenvolvimento, provavelmente com maior razão ainda, posto que certos riscos são assumidos de modo consciente pelo fabricante. Basta pensar nas controvérsias a respeito

de possíveis malefícios decorrentes de produtos alimentares transgênicos e da radiação dos telefones celulares e dos fornos de microondas. Nada obstante, ignorando eventuais efeitos perversos, as empresas desenvolvem as suas atividades face à inexistência de proibições, com fundamento na liberdade econômica. É evidente que, comprovando-se no futuro algum malefício, terão que arcar com as indenizações correspondentes, porque arrostaram o risco da existência de defeito.

Na Diretiva européia os riscos do desenvolvimento são causa de exclusão da responsabilidade do produtor ${ }^{83}$, mas foi ressalvada a derrogação da regra pelos estados membros.$^{84} \mathrm{~A}$ ressalva foi introduzida por instância da França, cuja jurisprudência não exclui a responsabilidade do fabricante em caso de vício oculto que afete a utilidade do produto, apesar de não ser igualmente protegida a segurança do consumidor ${ }^{85} \mathrm{Na}$ transposição da diretiva, apenas Luxemburgo e Finlândia derrogaram completamente a excludente no seu direito interno. A Espanha excepcionou o regime comunitário apenas para medicamentos, alimentos e produtos alimentícios de consumo humano. A lei alemã de 15/12/89 manteve-se fiel à diretiva, mas lei especial de 20/6/90, com modificações de 1933 e 1994, não acata a excludente para produtos transgênicos. O Reino Unido introduziu regime mais liberal do que a diretiva, admitindo a exclusão de responsabilidade do produtor cujos conhecimentos científicos e técnicos não

${ }^{82}$ ALVIM, A. Da inexecução das obrigações e suas conseqüências. São Paulo: Saraiva, 1949. p. 290. 83 “Art. $7^{\circ}$. O produtor não é responsável nos termos da presente directiva se provar: (...) e) Que o estado dos conhecimentos científicos e técnicos no momento da colocação circulação do produto pelo produtor não permitiu detectar a existência do defeito".

84 “Art. $15^{\circ}$. Qualquer Estado-membro pode: (...) b) Em derrogação da alínea "e" do artigo $7^{\circ}$, manter ou (...) prever na sua legislação que o produtor é responsável, mesmo se este provar que o estado dos conhecimentos científicos e técnicos no momento da colocação do produto em circulação não lhe permitia detectar a existência do defeito".

${ }^{85}$ VINEY, G. La responsabilité..., op. cit., p. 590, que exemplifica a restrição jurisprudencial com decisão da Corte de Cassação, datada de 8/4/86, que desestimou caso de infecção provocada pela combinação de dois medicamentos.

Revista da Faculdade de Direito da UFRGS, v. 20, Outubro/2001 
permitisse ao fabricante de um produto análogo detectar o defeito do produto no momento do seu lançamento no mercado. A Comissão das Comunidades Européias interpretou a norma britânica, integrada ao Consumer Protection $A c t$, como contrária à diretiva, por incluir um elemento de subjetividade, ou seja, os conhecimentos de outro produtor supostamente diligente. ${ }^{86}$ A Corte de Justiça das Comunidades Européias pronunciou-se sobre a questão em 29/5/97, decidindo que "um produtor somente se liberará da responsabilidade pelo fato dos seus produtos defeituosos se o estado dos conhecimentos científicos e técnicos no momento da colocação dos produtos no mercado não lhe permitissem descobrir a existência do defeito", recaindo a carga da prova exoneratória sobre o próprio produtor

3.1.2.2. Devedor da indenização. $O$ legislador brasileiro optou por nomear os sujeitos passivos da obrigação de indenizar os danos decorrentes de defeitos: o fabricante (de manufaturas acabadas ou de componentes), o produtor (de alimentos, in natura ou industrializados; de medicamentos), o construtor (de obras civis) e o importador (de quaisquer produtos). A responsabilidade é imputada a quem coloca o produto no mercado. ${ }^{87} \mathrm{~A}$ responsabilidade dos fabricantes de peças componentes está expressa no art. 25, parágrafo $2^{\circ}$. Subsidiariamente também responsável o comerciante. Trata-se de imposição da lógica, pois o comerciante, geralmente, não tem o controle do produto, que recebe acabado, repassando-o no mesmo estado ao consumidor.

${ }^{86}$ GARCÍA RUBIO, M. P. Los riesgos de desarrollo en la responsabilidad por daños causados por productos defectuosos: su impacto en el derecho español. Revista de Direito do Consumidor, São Paulo: v. 30, p. 66-84, abr.-jun. 99.

${ }^{87}$ BENJAmin, A. (Comentários ao Código de Proteção ao Consumidor. OLIVEIRA, J. (coord.). São Paulo: Saraiva, 1991. p. 56) classifica os fornecedores, nesse caso, em responsáveis reais (fabricante, produtor e construtor), presumido (importador) e aparente (comerciante).

${ }^{88} \mathrm{~V}$., adiante, parte II-B.

Revista da Faculdade de Direito da UFRGS, v. 20, Outubro/2001

O comerciante só será demandado se os responsáveis principais não puderem ser identificados ou se o produto não contiver a identificação clara do fornecedor primário. Falta menção expressa, na lei brasileira, ao fabricante aparente. É comum que redes de varejo ofereçam diversificada linha de produtos com sua própria marca, como se fabricantes fossem. Em vervarejista, por um terceiro que permanece oculto. Nesses casos, o comerciante poderá ser responsabilizado, pois o fabricante age como seu preposto $^{88}$, sem prejuízo de eventual ação contra este, em razão da solidariedade estabelecida no art. $7^{\circ}$, parágrafo único.

O comerciante também será responsabilizado quando não conservar adequadamente produtos perecíveis.

Por comerciante não se compreenderá tãosomente o último elo da cadeia de fornecimento - 0 varejista - mas toda a cadeia de intermediários, incluindo, pois, atacadistas e distribuidores.

\subsection{Os Parceiros do Mercosul}

Ainda não há normas comunitárias de proteção ao consumidor no Mercosul, permanecendo em vigor a Resolução 126/94, do Grupo Mercado Comum, dispondo que cada Estado parte aplique a sua legislação nacional enquanto não seja aprovado um regulamento comum. Os esforços nesse sentido fracassaram e as dificuldades atuais do Mercosul pela heterogeneidade de políticas econômicas dos países que o integram deixam em compasso de espera a continuidade dos trabalhos. dade, o produto é fabricado, a pedido da rede

3.2.1. Convergências da Legislação Interna dos Países Membros do Mercosul sobre Produtos Defeituosos

A lei argentina (Lei 24.240, sancionada em 22/9/93 e publicada definitivamente em $15 / 10 / 93$ ) dedica o segundo capítulo do primeiro dos seus três títulos à informação do consumidor e proteção de sua saúde, impondo a todos que produzam, importem, distribuam ou comercializem coisas o dever de prestar, com objetividade, informação verdadeira, detalhada, eficaz e suficiente sobre suas características essenciais. Os produtos, utilizados em condições normais ou previsíveis, não podem apresentar perigo para a saúde ou a integridade física dos consumidores, instituindo uma obrigação de segurança para os fabricantes. Se o produto envolve riscos de uso devem ser observiadas as normas estabelecidas ou as razoáveis para garantia da segurança dos consumidores.

Essas disposições voltam-se para a prevenção de danos. A reparação é prevista no art. 40, com redação modificada pela Lei 24.999 , de 1998. São obrigados a indenizar os danos o produtor, o fabricante, o importador, o distribuidor, o fornecedor, o vendedor e quem quer tenha aposto sua marca ao produto (produtor ou fabricante aparente). São todos devedores solidários, sendo permitida, porém, a prova de causa estranha à atuação do demandado. O transportador responderá pelos danos causados pelo seu serviço. A lei é omissa quanto ao fator de imputação da responsabilidade, mas a jurisprudência do Código Civil nessa matéria, relativa à aplicação do art. 1.113, com a redação da Lei 17.711, de 1968, é compatível com a imputação objetiva. O dono ou guardião é responsável pelo fato causado por vício ou risco inerente à coisa, podendo livrar-se somente se houver culpa exclusiva da vítima ou de um ter-

ceiro por quem não deva responder, incumbindo-lhe o ônus da prova. ${ }^{89}$

A falta de uma lista de direitos básicos na lei ordinária foi suprida pela reforma, em 1994 da Constituição nacional da Argentina, que passou a prever, no seu art. 42 , o direito dos consumidores e usuários de bens e de serviços à proteção da sua saúde, segurança e interesses econômicos, dentre outros.

A lei uruguaia (Lei $\mathrm{n}^{\circ} 17.189$, promulgada em setembro de 1999 para entrar em vigor nove meses depois) compreende quinze capítulos, dedicando o segundo aos direitos básicos do consumidor, o terceiro à proteção da saúde e segurança e o décimo terceiro à responsabilidade por danos.

Os direitos básicos compreendem, dentre outros, a proteção da vida, da saúde, da saú de e da segurança contra os riscos causados pelas práticas no fornecimento de produtos e serviços considerados perigosos ou nocivos.

Os riscos normais devem ser prevenidos pela observância das normas estabelecidas ou conforme as que forem razoáveis, na esteira da fórmula argentina. No fornecimento de produtos perigosos deve haver informação clara e visível sobre a periculosidade ou nocividade. Em caráter excepcional e fundamentadamente, a administração pode proibir a colocação no mercado de produtos de alto risco. Indo além do marco lei argentino, a lei uruguaia prevê o recall dos produtos cuja periculosidade seja detectada após a sua introdução no mercado.

A responsabilidade pela reparação de danos é remetida ao regime geral do Código Civil. Em regra análoga ao CDC brasileiro, são devedores da indenização o fabricante ou o importador, só respondendo o comerciante quando aqueles não puderem ser identificados ou

${ }^{89}$ ALTERINI, A. A. Responsabilidad civil. 3. ed. Buenos Aires; Abeledo Perrot, 1992. p. 115-121. No mesmo sentido, STIGLITZ, G, que menciona decisões pretorianas sob a Lei 24.240 aplicando regime de responsabilidade objetiva ao fabricante (Modificaciones..., ob. cit.). 
quando este não conservar adequadamente o produto ou alterar suas condições originais. $\mathrm{O}$ dano é caracterizado como fato ilícito e limitado às suas conseqüências diretas e imediatas, de ordem patrimonial ou extrapatrimonial. midor e do Usuário (Lei 1.334) é de 1998 e está disposta em quinze capítulos, sendo o segundo de direitos básicos e o sétimo de proteção à saúde e segurança. vida, da saúde e da segurança começa pelo dever de informar sobre a periculosidade ou nocividade dos produtos e serviços, sendo previsto o recall para os riscos conhecidos com posteridade ao lançamento no mercado. A le silencia quanto ao regime da responsabilidade dos fornecedores na reparação de danos.

\subsubsection{Entraves à criação de uma Lei Supranacional de Defesa do Consumidor} mes no Mercosul encontra o óbice estrutura da ausência de uma verdadeira supranacionalidade no processo de integração, uma vez que o Tratado de Assunção (1991) não transfere competências dos países soberanos para órgãos comunitários, havendo mesmo empecilhos constitucionais a serem previamente removidos, inclusive no Brasil. Nada obstante, há organismos que cuidam da formulação de regras para setores específicos, como é o caso do Comitê Técnico $\mathrm{n}^{\circ}$ 7, da Comissão de Comércio, criada pelo Protocolo de Ouro Preto (1994), que complementou o Tratado de Assunção. O CT 7 dedica-se à defesa do consumidor. É
No Paraguai, a Lei de Defesa do Consu-

A efetividade do direito à proteção da

A introdução de regras jurídicas unifor-

questionável, porém, a sua legitimidade, porquanto os seus integrantes, em verdade, são delegados do Poder Executivo dos países membros, pois a Comissão de Comércio é vinculada ao Grupo Mercado Comum, órgão executivo do Mercosul, integrado por representantes dos respectivos governos. Os direitos do consumidor, sendo direitos humanos de terceira geração e estando previstos como direitos fundamentais na Constituição (de Argentina e Brasil), só poderiam ser regulados através de tratados internacionais e não por decisão interna de órgãos subalternos do Mercosul, por falta da competência legislativa supranacional..$^{90}$

Apesar de tudo, em 1997 foi elaborado um projeto de Protocolo Comum de Defesa do Consumidor, no âmbito do CT 7, cuja aprovação implicaria a derrogação de 26 normas do Código brasileiro, em verdadeiro retrocesso para um pretenso nivelamento das diferentes leis nacionais. O projeto só não restou aprovado por desistência de última hora do governo brasileiro, a instâncias das entidades envolvidas com a política e os direitos do consumidor

$\mathrm{O}$ que realmente atenderia o interesse dos consumidores no Mercosul seria a harmonização das legislações existentes, com a criação de patamares básicos de proteção, sem prejuízo de níveis mais altos estabelecidos in ternamente em cada país membro. A proteção básica não poderia ficar abaixo do padrão internacional, haja vista o patrimônio universal que ao longo do tempo foi formando-se na jurisprudência dos países industrializados.

A harmonização deve preocupar-se particularmente com a compatibilidade dos princí

${ }^{90}$ LIMA MARQUES, C. Regulamento comum de defesa do consumidor do Mercosul: primeiras observações sobre - Mercosul como legislador da proteção do consumidor. Direito do Consumidor, São Paulo, n. 22-23, p. 79 103, jul.-dez. 97. Direitodo Consmidor, São Paulo, n.32, p. 16-44, out.-dez. 99. no plano nacional. ${ }^{91}$

${ }^{91}$ LIMA MARQUES, C. Direitos do consumidor no Mercosul: algumas sugestões frente ao impasse. Revista de

Revista da Faculdade de Direito da UFRGS, v. 20, Outubro/2001 pios e não tanto com a coincidência das regras. Todas as leis têm um conjunto de direitos básicos (no caso da Argentina, presente na Constituição), que inclui: proteção da vida, da saúde e da segurança, com responsabilidade pela repacia de culpa; garantia absoluta contra vícios que afetem a utilidade dos produtos e serviços, com vedação de exonerações contratuais; proteção contratual, especialmente nos contratos de adesão e contra práticas abusivas; proteção contra abusos da publicidade; vinculação obrigacional da oferta e garantias de cumprimento; tutela coletiva de direitos. Também existem mecanismos comuns de facilitação da defesa dos direitos do consumidor, como a inversão do ônus da prova; a interpretação mais favorável ao consumidor das normas das relações de consumo; a hierarquia indisponível das regras protetivas, porque pertencentes à ordem pública; a não taxatividade dos direitos dispostos nas leis e a sua integração por outros direitos, derivados de fontes diversificadas.

Todavia, não é suficiente a existência de textos legislativos satisfatórios. As leis podem ser importadas, mas não a sua implementação, anota Gabriel STIGLITZ, apontando como causas das deficiências de aplicação dos sistemas de proteção ao consumidor na América do Sul o desinteresse dos governos e o insignificante papel atribuído à questão no processo de integração do Mercosul. ${ }^{92}$

A incongruência de alguns vetos impostos a artigos do Código brasileiro e da lei argentina ${ }^{93}$ denunciam a subordinação dos governos a forças que só encontram explicação coerente na pressão a que se submetem quando se trata de disciplinar as atividades econômicas. ${ }^{94}$ Freqüentemente também sobressai o pouco apreço que nutrem pelos avanços legislativos, vendo-os mais como discurso político-e, portanto, conforme a sua prática, a qualquer momento revogável - do que como marco regulatório. Repetiu-se recentemente no Brasil a tragicomédia da derrogação de uma lei geral frente a um fato circunstancial, quando imperial medida "provisória" procurou afastar a aplicação do Código de Defesa do Consumidor nas eventuais decisões judiciais que versassem sobre a crise de energia elétrica.

O desinteresse dos governos ainda é lamentavelmente testemunhado no Brasil pelo descaso com que as administrações tratam os consumidores. É pequena a proporção de municípios que contam com um Procon, encontrando-se entre os omissos capitais importantes como Porto Alegre, não obstante os três mandatos consecutivos de governos de esquerda que coincidem com o decênio de vigência do Código de Defesa do Consumidor. Infelizmente, não é o único exemplo expressivo. ração de danos, independentemente da existên-

${ }^{92}$ STIGLITZ, G. El derecho del consumidor en Argentina y en el Mercosur. La Lei, Buenos Aires, 19 mayo 1995 p. 1-5.

${ }^{93} \mathrm{Na}$ Argentina, o Presidente da República vetou a redação original do artigo 40, da Lei 24.240, que dispunha sobre a responsabilidade objetiva dos fornecedores, apesar de haver projeto do Executivo em tramitação legislativa introduzindo regime mais rigoroso; o argumento do veto foi que o regime previsto era excessivamente gravoso para os produtores argentinos e mais severo do que o instituído no Código brasileiro, ignorando o conteúdo do art. 12, CDC (LOPEZ CABANA, R. M. Responsabilidade civil por la actividad industrial. Temas de derecho privado. Buenos Aires, n. 7, p. 18-23, 1995.

${ }^{94}$ No mesmo tom, STIGLITZ, G. Modificaciones a la Lei argentina de defensa del consumidor y su influencia en el Mercosur. Direito do Consumidor, São Paulo, n. 29, p. 9-20, jan.-mar. 99. 


\section{Conclusão}

A proteção contra produtos defeituosos é uma conquista universal do direito. Essa conquista é colocada à prova nos blocos econômicos. Em alianças fortes, como a União Européia, verifica-se uma integração de regimes jurídicos, com nivelação do regulamento comunitário acima dos patamares médios pré-existentes. Todavia, nos blocos mais fracos, como - Mercosul, a tentativa de harmonização das regras jurídicas embute o risco de um retrocesso para os países membros que lograram maio avanço legislativo interno. A nivelação pode ser feita por baixo, com a derrogação de leis e aviltamento da jurisprudência inovadora, garantidoras de uma proteção mais efetiva. A contínua concentração do poder econômico e a expansão transfronteiras dos mercados tornam mais do que nunca necessária a vigência de um regime jurídico favorável aos consumidores.

Os elementos em tensão nesse embate são, de um lado, os interesses dos consumidores e, de outro, as forças econômicas. Como estas são determinantes na formação dos blocos econômicos, elas tendem a prevalecer freqüentemente conseguem a adesão de governos dependentes de investimentos. Nessa con- tingência, os consumidores dependem, no plano do direito, da racionalidade jurídica, e no plano sociológico, de suas próprias iniciativas. A racionalidade jurídica pode oferecer resistência a mudanças legislativas oportunistas fazendo prevalecer os marcos avançados, especialmente se eles já estão fincados em território constitucional, como é o caso brasileiro. A defesa do consumidor, no Brasil, é direito subjetivo público de todo cidadão frente ao Estado, integrando o elenco dos direitos fundamentais (art. $5^{\circ}$, inciso XXXII), e princípio estrutural da ordem econômica (art. 170, inciso V,CF)

Os consumidores, por sua vez, devem organizar-se em associações, habilitando-se à defesa própria de seus interesses no plano coletivo, único nível em que se torna viável o enfrentamento do poder econômico no entrechoque de interesses que caracteriza o mercado. Essa providência, além de estimulante do ponto de vista do exercício dos direitos de cidadania, tornaria o consumidor menos dependente das iniciativas de órgãos oficias, tais como o Ministério Público e os Procons, revertendo o paternalismo em autonomia.

\section{La Posmodernidad juridica los derechos de las personas bajo la linea de indigencia los criterios de reciprocidad e igualdades razonables: documento de debate}

\author{
Carlos A. Ghersi
}

\section{Introducción}

17 xiste una concepción de equidad y justicia que se reclama constantemente para los incluidos, sin embargo, pareciera que no se aplica para aquellos que los propios gobiernos con la misma Constitución, no los consideran (para los marginados y excluidos) por no tener un rol sustancial en la sociedad, a pesar que poseen los mismos ideales y utopías reales.

En este sentido consideramos a estas personas como proscriptos o personas lastradas por condiciones desfavorables ${ }^{1}$, que por esta misma razón no pueden alcanzar el status de incluidos (algunos generacionalmente) y sobre los que pretendemos establecer las condiciones

mínimas que debieran poseer por el solo hecho de ser humanoides.

En realidad estas personas proscriptas o lastradas se encuentran especialmente afectadas por la injusticia de decisiones políticas, que debieran mantener la armonía de intereses y que sin embargo privilegian un sector minoritario de la sociedad, causando así la marginación y la pobreza denigrante ${ }^{2}$.

En este sentido de condiciones mínimas, sostenemos que básicamente deben considerar la posibilidad real de aplicar dos nuevos criterios que debieran asumir la calidad de principios generales del derecho: la reciprocidad $\mathrm{y}$ las igualdades razonables.

1. El término personas lastradas lo adopté y lo hice de John Rowls ( El derecho de Gentes Ed Paidos. Barcelona 2001 ) y que normalmente en la sociedad argentina se los atribuyó a marginados y desocupados, como procesos diferentes y de fragmentación interna de la comunidad. La marginación se constituye a partir de una cuestión social (aspecto sociológico ) como proceso de desintegración de pertenencia y denigración, en cambio la desocupación
(aspecto económico ) hace al proceso del sistema producción / consumo y la función económica del trabajo, ( sin duda que en general se presentan conjuntamente, pero insistimos no son conceptualmente sinónimos )

${ }^{2}$ Consult. Nochteef, Hugo y otros. La Economía argentina a fin de siglo: fragmentación presente y desarrollo ausente. Ed Flacso - EUDEBA . Bs As 1998.;

Filmus, Daniel. Los noventa. Politica, Sociedad y cultura en América Latina y Argentina de fin de siglo. Ed Flacso - EUDEBA, Bs As 1999.

Revista da Faculdade de Direito da UFRGS, v. 20, Outubro/2001 
II. Los nuevos principios generales del derecho: la reciprocidad y las igualdades razonables desigualdad que implicó marginación de pobres, nuevos pobres y desocupados, con migraciones hacia las ciudades principales o co - geográfico de las fronteras urbanas y conurbanas, que posibilitaba hasta la década de los ochenta, que estas personas se instalaran (villas o pueblos jóvenes) buscando porvenir y desarrollo social (especialmente generacional) es decir se quebró la función de equilibrio entre posibilidad (como expectativa) y la económicos reales).

Esto fue una negligencia o fracaso del poder político (regular las migraciones con desarrollo regionales que posibiliten el asentamiento poblacional o reubicación socioeconómica organizada), lo que significa una gran cuestión moral pendiente para la primer decena del siglo XXI.

El segundo criterio que nos interesa enunciar en esta cuestión es el de igualdades razonables.

Un pueblo que presenta desigualdades profundas que constituyan para la niñez y claves dentro del territorio. ${ }^{6}$

Esto tornó inviable el espacio histórirazonabilidad (potencialidad de medios decisiones de política económica una intolerable

${ }^{3}$ Van Boernud, Bert. Derecho, relato y realidad. pag 135 y sgtes. Ed Tecnos . Madrid . 1997.

${ }^{4}$ Denominamos reivindicativas a las sociedades como la Argentina que pose un marco normativo rico en posesión de derechos, pero no en posibilidad real de ejercicio de los mismos, un ejemplo típico de la década de los cincuenta fue el art. 14 bis de la Reforma Constitucional de 1957 y en muchos aspectos la de 1994.

${ }^{5}$ Funes, Robert, Manuel La lucha de clases en el siglo XXI. Visión política de la crisis económica de nuestro tiempo. pag 55. Ed ESIC. Madrid . 1997.

${ }^{6} \mathrm{Hay}$ dos diferencias con las migraciones anteriores ( especialmente durante las décadas cuarenta y cincuenta ). La primera, es que las migraciones internas se consolidaban en torno de la ciudades, especialmente la Capital Federal y el Conurbano, porque allí estaban radicadas las fábricas, es decir se agrupaban en torno a la fuente de trabajo (pequeñas, medianas y grandes industrias) principalmente durante el período de la sustitución de importaciones 1940 / 1960. y que lograron consolidar ciudades e individualmente situaciones de progreso y ascenso socil La y de los pá y de los parses latinoamericanos limitrofes o cercanos ( peruanos, uruguayos, bolivianos, chilenos, expulsados de sus propios países por las crisis económicas o políticas ) que ocuparon puestos de trabajo manuales o de escasa calificación profesional, vendedores ambulantes o simplemente mendigaje, que constituyen la legión de pobres, nuevos pobres, marginados y desocupados y que no albergan posibilidades reales bajo las condiciones económicas actuales de inclusión social y mucho menos ascenso o progreso económico.

Revista da Faculdade de Direito da UFRGS, v. 20, Outubro/2001 la juventud un proceso a-histórico (función involutiva de la raza humana en generaciones sucesivas) es una sociedad de desiguales irrazonables morales y éticamente; es decir, frente a situaciones de derecho absolutamente simétricas (posición inicial de todos en la Constitución Nacional que comprueba que es simplemente un velo formal) se oculta la realidad de los no iguales o proceso de desapropiación de la calidad y dignidad humana. (esto es el desentendimiento de la convivencia pacífica y quienes son expulsados devuelven la irracionalidad con violencia, que obviamente es mas irracionalidad, que conlleva a la espiral de la inseguridad).

La sociedad con estas desigualdades jurídico - económicas es impracticable e impide establecer condiciones razonablemente justas, para generar tendencias de equilibrio socia (pluralismo razonable) con diversidad, pero simultaneamente con dignidad (discernir los límites posibles en una sociedad de clases) donde la apropiación de derechos sea razonablemente distributiva, democrática y equitativamente justa, (concepción realista 0 de utopía real ) de bienes jurídicos primarios para toda la sociedad, de tal forma de consolidar la distribución efectiva de la libertad ${ }^{8}$ y la posibilidad de apropiación de la justicia.

Entonces hoy debiera haber una estructura básica de la sociedad garantista, de tal forma que los derechos fundamentales (utopía realista) guarden relación con la conducta de la sociedad como deber histórico y que ello además posea estabilidad, como

${ }^{7}$ Consult. Ghersi, Sebastián. El Estado penal Neoliberal . Rev Facualdade de Direito da UFRGS. Porto Alegre. 2001.

${ }^{8}$ Sen Amartya. Inequality Rexamined. Ed Harvard University Press. Cambrige. 1992.

${ }^{9}$ Consult. De Filippo, Armando y Franco,Rolando. Que modelo de integración regional puede contribuir a un desarrollo con equidad ? Rev, Socialis No 3. Ed Flacso - Homo Sapiens. Rosario. 2001

${ }^{10}$ Hay una segunda posición que en países desarrollados se consolidó el denominado "derecho al desarrollo desigual", lo que Adam Smith indicaba como la posibilidad de ascenso social y los mas técnicos denominan meritocracia personas.

${ }^{11}$ Rowls, John . El derecho de gentes. pag 57. "sin un proceso psicológico como este que llamaré aprendizaje moral, la idea del derecho como utopía real carece de un elemento esencial ". Ed Paidos. Barcelona. 2001. modus operandi de razonable tolerancia y

Esto no es ni mas ni menos, que (sociedad de clases con culturización y desarrollo de la lógica de la inteligencia, como factor tecnológico) para el acceso a la categoría de elementos económicos (jurídicamente existentes) ${ }^{10}$

\section{La concepción de una sociedad razonablemente justa y la lealtad al derecho}

Es el derecho una herramienta de consolidación de la justicia y por lo tanto es eminentemente moral y ético, y también es trucción de la sociedad deben consolidar por miedo a la sanción emanada principalmente e la normología jurídica Kelseniana).

Que es la lealtad al derecho?

Es la respuesta razonable de las personas ando sus intereses fundamentales, prometidos en la Constitución Nacional y los Tratados Internacionales como ambiciones propias y socialmente consideradas, tengan motivos suficientes para respetarlo y evitar su desobediencia. ${ }^{11}$ los procesos de culturización o 
Esa lealtad al derecho dependen mas de los gobiernos (no del Estado y la Nación) que de las propias personas gobernadas, pues cuando sus necesidades e intereses son satisfechos, consolidan la memoria histórica y la cultura del comportamiento razonable ${ }^{12}$; pero cuando operan la marginación y la exclusión (desempleo en el sistema económico) de grandes sectores de la sociedad aparece la resistencia en toda su extensión (desde dejar de pagar los impuestos ${ }^{13}$; corrupciones menores, hasta la invaloración de la propia vida y entonces ya nada significa un valor sustentable y la sociedad se torna inviable para todos (los excluidos y los incluidos). ${ }^{14}$

La seguridad jurídica, depende en gran medida de la lealtad al derecho, pues las personas asumen esta conducta cuando están convencidos de que el derecho es una institución cooperativa en términos de equidad económica y jurídica, lo cual, resulta crucial para el manejo del derecho como regulación moral. ${ }^{15}$

Un gobierno no puede actuar contra las personas que representa, porque entonces se cuestiona su legitimidad (no su legalidad) que es una cuestión mas profunda y como consecuencia se pierde la lealtad al derecho como dinámica social y solo funciona como posición individual (cuestiones diametralmente diferentes).
Los derechos fundamentales básicos son de naturaleza moral (a la vez y antes que jurídicos) y están institucionalizados, sin embargo ello no basta, deben ser apropiados por las personas en forma equitativa y justa ${ }^{16}$ donde el Estado no es un mero espectador, sino actor principal de conducta concurrente y debe hacerlo como razón de Estado. ${ }^{17}$

Entonces la lealtad al derecho se consolida con la reciprocidad en la apropiación de los derechos y la preocupación del Estado por evitar el criterio de dominación sectorial o minoritario en el gobierno, de esta forma se propende a una sociedad razonablemente justa y viable.

\section{Restricciones apropiadas para la regulación estructural básica de una de una sociedad sustentable}

El método de construcción social ${ }^{18}$, debe especificar condiciones justas de regulación ,de tal forma que el Estado, la Nación restricciones de apropiación de derechos, que los ciudadanos gozan en su posición inicial . y los Gobiernos consideren los mismos como

${ }^{12}$ Consult. Weingarten, Celia La Confianza en el sistema Jurídico. Ed Cuyo. Mendoza 2001.

${ }^{13}$ Rowls, John. Justicia como equidad. Materiales para una teoría de la justicia. pag 90. Ed Tecnos. Madrid . 1986. ${ }^{14}$ Gilpin,Robert. War and change in world politics. pag 7. La naturaleza fundamental de las relaciones no ha cambiado... continúan siendo permanentemente lucha por la riqueza y el poder.. ( traducción propia del autor de este trabajo no literal ) Ed Cambrige University Press, Cambrige. 1981

${ }^{15}$ Rowls, John . El derecho de gentes. pag 38. "Presumir la existencia de un Estado, en el cual un pueblo se organiza en el orden interno con instituciones de justicia básica no constituye un prejuzgamiento alguno sobre estas cuestiones, el tema es que funcionen "Ed Paidos. Barcelona . 2001

${ }^{16}$ Rowls, John. Justicia como equidad. Materiales para una teoría de la justicia. Pag 137. Ed Tecnos.Madrid .1986. ${ }^{17}$ Consult. Calderon, Fernando. Derechos humanos, ciudadanía y desarrollo humano. Rev. Socialis N. ${ }^{\circ} 1$. pag 75. Ed Flacso. Rosario. 1999.

${ }^{18}$ Lovece, Graciela. La construcción social del derecho. Derecho Privado del MERCOSUR pag 63. Ed Facultad de Ciencias Jurídicas Del Salvador. Junio 2001.

Revista da Faculdade de Direito da UFRGS, v. 20, Outubro/2001
Las condiciones de relaciones con intereses básicos y derechos fundamentales, implican simetría inicial real (no meramente formal como Alberdi y Velez Sarfield de igualdad, de los no iguales) de bienes jurídico económicos primarios que satisfacen las necesidades básicas (educación; justicia; seguridad; salud y empleo) como posición inicial sustentable. ${ }^{19}$

Aquellas condiciones básicas iniciales o de primer nivel, se presentan como racionales, pues son los derechos mínimos disponibles en una sociedad democrática que los hacen ser posibles, como recurso de convivencia en paz (elementos básicos de cooperación entre Estado, Nación, Gobiernos y Administrados o Ciudadanos en sus relaciones múltiples)

Esa razonable y justa distribución de intereses y derechos fundamentales es necesaria sostenerla como reivindicación legítima de la totalidad de personas y desde la responsabilidad de objetivos del Estado que hacen a la identidad de los gobiernos democráticos (que se dicen y son democráticos)

El bienestar económico - jurídico de las personas administradas - ciudadanos, es fundante y de conciencia compartida como logro histórico - cultural que determinan el principio de la igualdad social real inicial, en una comunidad.

Esta disponibilidad de los derechos básicos entonces es la condición razonable como se construye la justicia en sociedades democráticas reales.

\section{Los gobiernos tienen la obligación de asistencia y cons- truir condicionesfavorables para la disponibilidad de derechos de los excluidos}

La Constitución como carta fundamental de derechos y garantías, no puede ser la base para generar actos de gobierno de unos a expensas de otros y construir con ello excluidos sociales, pues esto es grave y constituye para los marginados el derecho de resistencia civil ${ }^{20}$ para obligar al Estado a cubrir las necesidades básicas insatisfechas (medios económicos).

La función de la propiedad común ${ }^{2}$ en cualquiera de sus formas implica prioritariamente mantener cubiertas las necesidades básicas y los derechos fundamentales de las personas, especialmente marginados coyunturales (hoy estructurales). ${ }^{22}$

Esto significa que al menos las personas excluidas tienen derecho de exigencia, calificado por el deber social de asistencia y cooperación que no permite al Estado excusar su reponsabilidad, pues es la frontera moral de su representación.

${ }^{19} \mathrm{El}$ segundo nivel es donde la democracia liberal permite las denominadas desigualdades propias del sistema, es decir, las relaciones entre personas que llevan a niveles de sustentabilidad diferenciadas en la cultura, economía, etc.

${ }^{20}$ Palomino, Rafael. Las objeciones de consciencias. pag 21. Ed Montecorvo. SA . Madrid. 1994.

${ }^{21}$ Rowls, John. El derecho de gentes. pag 53. "El pueblo de una democracia constitucional, no tiene como pueble liberal, una doctrina general del bien , mientras que los ciudadanos de una sociedad liberal si tienen tales concepciones y para atender a sus necesidades como individuos se empela la idea de bines primarios "Ed Paidos. Barcelona. 2001

${ }^{22}$ Villarreal , Juan. La exclusión social. pag. 181. Ed . Norma. Bs As 1996.

Revista da Faculdade de Direito da UFRGS, v. 20, Outubro/200 
El principio distributivo de justicia (equidad) significa que las personas de una comunidad democrática tengan asegurados los bienes sociales, económicos y jurídicos primarios, esto impide el privilegio utilitarista del beneficio de unos a costa de otros.

El principio de autodefensa frente al Estado plantea la cooperación y asistencia mutua, para asegurar a aquellos bienes primarios y esto no es renunciable, (desde lo legal) ni resignable (desde lo legítimo).

Estos bienes primarios básicos, no están sujetos a la ley del mercado y además el Estado debe impedir (función de legitimación) que hombres mas prósperos o sus representantes en el gobierno, intenten monopolizar los términos de intercambio en base a la debilidad o ignorancia de otras personas, logrando que el primer nivel sea distributivo (no competitivo). ${ }^{23}$

\section{El derecho de resistencia}

Las personas incluidas exigen de las personas excluidas un comportamiento que adolece de una falencia estructural y apotégmica: pretender que la conducta de aquellos asuman el rol de incluidos y resignen sus derechos mas elementales; y si así no lo hicieren, se les aplicaran las sanciones mas diversas, penales, contravencionales, etc.

Esta falta de respeto por el otro sin duda genera mas animaversión en los excluidos y devuelven mas violencia a aquella agresión moral y ética de los incluidos y su gobierno y por consiguiente se desestabiliza la paz social.
Esta negativa de los gobiernos a considerar a los excluidos del sistema económico y a los marginados del sistema social, es quitarles su pertenencia a la raza humana, pues carecen de los mas elementales derechos: supervivencia y dignidad.

La forma entonces de estas personas de asumir un rol sustancial en la sociedad, es el derecho de resistencia que posee jerarquía constitucional.

\section{Que es el derecho a la resistencia?}

El derecho a disentir con determinadas acciones de gobierno, cuando se ha llegado al límite de la tolerancia, donde precisamente está en juego la supervivencia humana, los disidentes, personas decentes, deciden expresar que modifican la vida ciudadana de los incluidos (cortes de ruta; apagones; cacerolazos; cierres de comercio, etc.) a favor de preservar su vida, la de su grupo familiar y llamar la atención de los incluidos que no se

Estos espacios significativos de autodeterminación y expresión de los excluidos y marginados (incluso se manifiestan con carácter federal) son de naturaleza moral pues hace a la dignidad, honor y orgullo de considerarse personas con derechos fundamentales básicos. familia y la cooperación para los de su clase, lo podemos considerar hasta una expresión de patriotismo y solidaridad moderada ${ }^{24}$, pues guarda coherencia con la igualdad de trato que los incluidos se deparan a si mismos en su consideración de decencia y pertenencia a la Patria. su participación por medio de actos o hechos interesan por el problema.

El debido respeto que reclaman para sí, su

${ }^{23}$ El nivel competitivo propio de las sociedades de las sociedades capitalistas es de segundo nivel, donde necesariamente surgirán desigualdades entre personas porque los términos de intercambio de este segundo nivel así lo propician.

${ }^{24}$ Rowls, John El derecho de gentes. pag 75 . Ed Paidos. Barcelona. 2001.

Revista da Faculdade de Direito da UFRGS, v. 20, Outubro/2001
Esto es nada menos que el principio de congruencia, pues reclaman la justa igualdad y el debido respeto a la dignidad humana.

Si los gobernantes dicen pertenecer y asegurar la democracia constitucional como forma superior de supervivencia en paz, deben aceptar que la forma de expresar la disidencia, puede ser la resistencia, que no es mas que el primero de los derechos que posee el hombre constitucionalizado (hombre jurídicamente socializado para convivir en comunidad). resistencia?

Cuál es la extensión del derecho de

Los marginados y excluidos son en su conjunto personas afectadas por condiciones desfavorables, pero que son dignos de pertenecer a la sociedad y que en determinado momento histórico (como el actual) no son tutelados por las autoridades constituídas y por los incluidos (específicamente por aquellos que los consideran jerárquicamente inferiores, en una clara actitud discriminatoria)

Frente a esta situación actúan movidos por una razón fundante y concreta, recuperar su posición original (igualdad de intereses y derecho básicos de convivencia). Se asocian bajo distintas formas, para operar el derecho de resistencia, no persiguen fines de agresividad o toma del poder y ejercen su derecho a la disidencia para afianzar sus legítimas metas.

Tratan de influenciar de la forma mas amplia posible de alterar la vida independiente de los incluidos (verbigracia desplazamientos) y es en consecuencia la manera mínima de expresión de su conducta reivindicativa y que es compatible constitucionalmente (entre los contradictorios del derecho a la supervivencia y el derecho al desplazamiento momentáneo).

El sistema jurídico establece un orden

jerárquico de principios, garantías y derechos de acuerdo con las necesidades y justicia de una sociedad de personas, comenzando por el derecho a la vida y la supervivencia digna de lo contrario el sistema económico se adueña de las personas y la sociedad y genera coercitividades hacia las personas conforme a las reglas del mercado (se reemplaza la idea de convivencia pacífica por la de supervivencia del mas fuerte) aparece entonces la inseguridad expandida (la seguridad económica es imprescindible para la supervivencia humana como derecho fundamental). ${ }^{25}$

En el respeto de esos derechos básicos son parte del derecho de propiedad como economía de supervivencia y el Estado liberal de tradición occidental debe ser responsable y capaz de asegurarlos a toda la población (derecho moralmente justo) y si el gobierno se desentiende, aquellos pueden emprender acciones con la creencia sincera y razonable que su acción está asentada en la resistencia (y no en la rebelión) para recuperar su derecho a la vida con dignidad.

Esta formulación social "asociacionista espontánea" de marginados y excluidos, trata mediante la resistencia de vincularse (o revincularse) al sistema social y requerir la cooperación de los gobiernos y la atención de los incluidos para restaurar la igualdad de dignidad ante Dios y la sociedad.

La agresión inicial se manifestó hacia ellos en la manera de exclusión o marginación y se hace creer a los incluidos que aquellos "son la causa" (vagabundos; etnias; rateros; personas a-sociales, etc.) que hace consolidar un rechazo a los actos de resistencia, de tal forma de "hacer verlos" como agresores y no como agredidos primitivos, que es diametralmente diferente.

${ }^{25}$ Shue, Henry. Basic rigths substance afluence and U.S. foring policy. pag 23. Ed Princiton University Press. Princeton. 1980. 
Es importante advertir sobre esta dialéctica de las palabras e investigar el origen de los problemas entonces los actos de resistencia son respuestas a la agresividad y no las causas.

Entonces es tolerable el derecho a la resistencia dentro del sistema jurídico?

$\mathrm{Si}$, lo intolerable sería que asumieran un rol agresivo saqueando masiva mente.

La fuerza intuitiva de la resistencia, aparece entonces como razonable frente a los sectores sociales incluidos, buscando la no exclusión o el cese de la misma y ello tiene doble finalidad: lo primero, llamar la atención a los incluidos para que sean parte del problema y no se aíslen (evitando la polarización incluidos - excluidos) y en segundo lugar, advertir sobre la expansión de la exclusión y la marginación como metodología del sistema económico (por aquello que decía Bertol Brech ... no sea que los excluídos de mañana sean los incluidos de hoy ....)

Entonces está afectado el propósito común y debe considerarse la posibilidad de que las restricciones (actos de resistencia) de los derechos de los incluidos, es una forma de establecer prioridades: el derecho a la vida y la supervivencia digna es el primero de los derechos y es inalienable y los otros derechos como la movilidad o la circulación o la molestia por la mendicidad, etc. son de segundo orden.

\section{Conclusiones}

La utopía realista, es aquella con justicia basada en la equidad económica y jurídica que consolida la paz democrática entre las personas y permite entonces una lealtad al derecho (no se necesita recurrir al agravamiento

penal de los delitos, salvo la corrupción sobre dineros públicos).

La utopía real se consolida como un sentimiento de justicia, con garantía de intereses $\mathrm{y}$ derechos fundamentales en su plenitud para todos, como hecho cultural o aprendizaje moral constante, que justifica al Estado y la Nación frente a las personas, ciudadanos o administrados.

En cambio, el gobierno (como situación temporal) es solo un intercambio de disputas por poder, entre la miseria intolerable y la poderosa riqueza que obliga constantemente a revisar y reformular políticas económicas; un gobierno no es entonces la expresión democrática de un Estado o de una Nación, pues no constituye para el pueblo y las personas la representación, sino coloca los límites de la asimetría en mínimamente la cobertura de las necesidades básicas que hacen a la dignidad del ser humano. ${ }^{26}$

En definitiva ,lo que hace un gobierno legal y que lo legitima, es el respeto por la libertad e integridad del ser humano, y que su preocupación prioritaria debe ser (pero no suficiente) establecer las disponibilidad de medios para un uso razonable de la riqueza (como PBI) donde la equidad en la distribución consolida la lealtad al derecho, base de un Estado democrático.

Entonces los principios de reciprocidad y de igualdades razonables, son la base de las democracias posmodernas (la posmodernidad de 2 do estadío, como contratendencia $)^{27}$ y que legitima a todo gobierno, de tal forma que una comunidad con intereses y derechos fundamentales de ler nivel simétricos, generará en las personas lealtad al derecho y se construirá una paz duradera con justicia social.

${ }^{26}$ Aron, Raymond. Peace and war. pag 162. "es la denominada paz por satisfacción diferente ..o paz del poder "Ed Garden Doubledy. 1966.

${ }^{27}$ Consult. Ghersi, Carlos Posmodernidad Jurídica . Ed Gowa. Bs As .2001

Revista da Faculdade de Direito da UFRGS, v. 20, Outubro/2001

\section{Mauro Cappelletti e o Direito Processual Brasileiro*}

\author{
Carlos Alberto Alvaro de Oliveira
}

Professor da Faculdade de Direito da Universidade Federal do Rio Grande do Sul Membro da Associação Internacional de Direito Processual
1) amplos poderes na apreciação dos atos praticados tanto pelo executivo quanto pelo legislativo. Embora durante o período colonial e mesmo no tempo do império, tenha o direito brasileiro se alinhado ao sistema dúplice, adotando o contencioso administrativo, já com a primeira Constituição Republicana, datada de 1891, introduziu-se o sistema uno. A Constituição de 1946 foi ainda mais incisiva, consagrando no $\S 1^{\circ}$ do art. 146 a apreciação pelo Poder Judiciário de qualquer lesão a direito individual. Atualmente, simples percorrer da Constituição Federal de 1988 evidencia a ampli- tude do controle jurisdicional da administração. Todos os atos dos entes públicos estão sujeitos a serem revisados pelo Poder Judiciário, seja pela Justiça Estadual, seja pela Justiça Federal, conforme o caso. Além disso, na esteira da tradição republicana, o art. $5^{\circ}$, inciso XXXV, deixa bem claro que "a lei não excluirá da apreciação do Poder Judiciário lesão ou ameaça a direito". Mais ainda: o cidadão brasileiro tem a seu dispor writs constitucionais semelhantes aos do sistema do commom law, tais como o mandado de segurança ${ }^{1}$, o habeas corpus ${ }^{2}$, e agora o habeas data ${ }^{3}$, sem falar no mandado de injunção $0^{4}$, remédio sem similar no direito comparado.
- Trabalho destinado ao volume de estudos em homenagem a Mauro Cappelletti, a ser editado pela Associação Internacional de Direito Processual.

${ }^{1}$ Constituição Federal, art. $5^{\circ}$, inciso LXIX: "conceder-se-á mandado de segurança para proteger direito líquido e certo, não amparado por habeas corpus ou habeas data, quando o responsável pela ilegalidade ou abuso de poder for autoridade pública ou agente de pessoa jurídica no exercício de atribuições do Poder Público." Trata-se de processo sumário documental, de largo emprego na experiência jurídica brasileira, e que tem preferência no julgamento em relação aos demais feitos, permitindo inclusive a concessão de liminar, se relevantes os fundamentos do pedido e houver risco de ser ineficaz a medida se concedida a final.

Constituição Federal, art. $5^{\circ}$, inciso LXVIII: "conceder-se-á habeas corpus sempre que alguém sofrer ou se acha ameaçado de sofrer violência ou coação em sua liberdade de locomoção, por ilegalidade ou abuso de poder."

${ }^{3}$ Constituição Federal, art. $5^{\circ}$, inciso LXXII: "conceder-se-á habeas data: a) para assegurar o conhecimento de informações relativas à pessoa do impetrante, constantes de registros ou bancos de dados de entidades governamentais ou de caráter público; $b$ ) para a retificação de dados, quando não se prefira faze-lo por processo sigiloso, judicial ou administrativo."

${ }^{4}$ Constituição Federal, art. $5^{\circ}$, inciso LXXI: "conceder-se-á mandado de injunção sempre que a falta de norma regulamentadora se torne inviável o exercicio dos direitos e liberdades constitucionais e das prerrogativas inerentes à nacionalidade, à soberania e à cidadania." O Supremo Tribunal Federal tem sido extremamente cauteloso na aplicação dessa norma, apenas mandando notificar a autoridade para que supra a falta de regulamentação, tratando a questão como inconstitucionalidade por omissão, regulada no art. $103, \S 2^{\circ}$, da Constituição Federal, pois considera que o mandado de injunção não é o sucedâneo constitucional das funções político-jurídicas atribuídas aos
órgão estatais inadimplentes, devendo ser observado o princípio constitucional da divisão funcional dos poderes. Todaviatis inadimplentes, devendo ser observado o princípio constituciciol da divisão funcional dos poderes. intimação da instituição parlamentar, tem se assegurado aos impetrantes do writ a possibilidade de ajuizarem as acões de seu interesse tendo-se como suprida a falta de norma (assim, $\mathrm{v} g$, no julgamento do Mandado de Injunção 248-DF, relator o Ministro Celso de Mello, Tribunal Pleno, 22.11.1991, RTJ, 139/712).

Revista da Faculdade de Direito da UFRGS, v. 20, Outubro/2001 
Segundo a doutrina e o próprio sistema constitucional, inexiste qualquer obstácul ao exame do excesso de poder pelo Judiciário. Também se mostra possível a desconstituição dos atos da administração pelo Poder Judiciário, assim como não se limita a possibilidade de revisão judicial de ato praticado pela administração, seja qual for a autoridade responsável.

No plano substancial, a Constituição em vigor cunhou como princípio fundamental proteção de valores supra-individuais, como a cidadania, a dignidade da pessoa humana, os valores sociais do trabalho e da livre iniciativa proclamando o desiderato de uma sociedade livre, justa e solidária, com promoção do bem de todos, sem discriminação de qualquer espécie (arts. $1^{\circ}$, incisos II, III e IV, e $3^{\circ}$, incisos I e IV), limitando ao mesmo tempo o uso da propriedade à sua função social (art. $5^{\circ}$, inciso XXIII), valores que, naturalmente impõem limites a abusos das mais varias espécies. Diversas hipóteses integram a categoria dos direitos coletivo na nova ordem constitucional, podendo se apontados como exemplos o direito ao meio ambiente ecologicamente equilibrado (art. 225 , caput), admitida a obrigação de reparação de danos a ele causados (art. $225, \S 3^{\circ}$ ); o respeito ao pleno desenvolvimento das funções sociai da cidade, com garantia do bem-estar de seu habitantes (art. 182); a responsabilidade civi objetiva por danos nucleares (art. 21, inciso XXIII, c) e a preservação da continuidade e da unidade histórico-cultural do ambiente urbano (art. 18, $4^{\circ}$ ). Vale ressaltar, ainda, ter o art. 170, V, elevado a "defesa do consumidor" à condição de princípio da ordem econômica, atribuindo à União, aos Estados e ao Distrito Federal competência para legislar de forma concorrente sobre responsabilidade por dano ao consumidor (art. 24, inciso VIII)

Dentro dessas coordenadas, a legislação infraconstitucional há muito tempo vem investindo o juiz brasileiro de poder para a prática de autênticos atos de império, por meio de ordens e mandados dirigidos à autoridade pública e a pessoas e entes privados, concebendo ações para defesa de interesses coletivos ou difusos, estabelecendo coisa julgada erga omnes ou ultra parte da sentenças nas demandas de natureza social ou política ${ }^{5}$, ou criando tutelas sumárias autônomas ${ }^{6}$.

2. O esboço das diretrizes públicas e sociais que de longa data informam o processo civil brasileiro mostra-se importante pois permite aquilatar a verdadeira dimensão da grande influência exercida no Brasil pela obra de Mauro Cappelletti, cuja elaboração doutrinária exibe como ponto de consistência uma concepção fenomenológica, inspirada por uma visão crítica da situação concreta e voltada a um projeto de solução e assim de reforma, com reflexo no plano prático.

Ao longo de quase trinta e cinco anos, Mauro Cappelletti preocupou-se essencialmente com temas fundamentais, como o princípio da oralidade, as garantias constitucionais do processo e sua dimensão social, o acesso à justiça seja por meio da participação, seja pela proteção dos chamados interesses difusos, as vias

5 Só para citar os diplomas legais mais importantes, podem ser referidas: a) a Lei ${ }^{\circ} 1.533$, de 31 de dezembro de 1951, relativa ao mandado de segurança, b) a Lei $\mathrm{n}^{\circ} 4.717$, de 29 de junho de 1965 , a respeito da ação popular; $\mathrm{c}$ a Lei $n^{\circ} 7.437$, de 24 de julho de 1985, reguladora da açăo civil pública; d) a Lei no 8.078 , de 11.9.1990, que institu Federal, alargou o campo da ação popular, que passou a proteger, além de direitos de natureza estritamente pública também direitos difusos, como o meio ambiente e o patrimônio histórico e cultural. De sua vez, o art. 129 , inciso III, atribui status constitucional à ação civil pública, veículo fundamental para a proteção de interesses e direitos difusos e coletivos.

6 Assim, por exemplo, a Lei $n^{\circ} 5.478$, de 25 de jutho de 1968 , que regula a ação de alimentos no âmbito do direito de família.

Revista da Faculdade de Direito da UFRGS, v. 20, Outubro/2001

alternativas de tutela e a justiça coexistencial, baseada em formas de conciliação, o papel do juiz e sua responsabilização, sem descartar é claro a questão da ideologia ${ }^{7}$.

Prega ele que a oralidade constitui um instrumento importante não só para resolver o problema da excessiva demora dos processos, mas também para melhorar a qualidade da Justiça civil, ressaltando sua importância principalmente no que diz respeito à realização da prova e a formação da convicção do juiz, daí a importância do testemunho da própria parte. É dessa época a esplêndida Tese de Cátedra, $L a$ Testimonianza della Parte nel Sistema dell'Oralità (Contributo alla Teoria della Utilizzazione Probatória del Sapare delle Parti nel Processo Civile), Milano, Giuffrè, 1962, a que se seguiu Procédure Orale et Procédure Écrite, Milano-New York, Giuffrè-Oceana, $1971^{8}$

No campo das garantias constitucionais do processo, exalta a necessidade de independência da magistratura diante do poder po- lítico, mas não se esquece de advertir que não se pode confundir imparcialidade com passividade. Daí a distinção entre "principio dispositivo em sentido substancial ou próprio" e "princípio dispositivo em sentido processual ou impróprio" e o destaque dado à garantia do $d u e$ process of law, acrescentando às garantias constitucionais formais as garantias sociais, aos direitos humanos de primeira geração os de segunda geração, que se destinam a tornar os direitos efetivos e acessíveis a todos, ao invés de se projetarem como simples figuração para parte menos favorecida. Nessa linha, o relatório geral da Conference of the International Association of Legal Science, realizado em 1971: Fundamental Guarentees of the Parties in $\mathrm{Ci}$ vil Proceedings ${ }^{10}$ e inúmeros outros trabalhos ${ }^{11}$.

Um outro domínio importante das investigações realizadas por Mauro Cappelletti diz respeito à consciência da dimensão social do processo, por ele denominada de revolução copérnica, porque rompe com a impostação tra-

É o que resulta da leitura da conferência por ele pronunciada no $1^{\circ}$ Congresso Brasileiro de Direito Processual Civil, realizado em Curitiba, Brasil, em maio de 1994, em que procura fazer o que denominou de "árduo exame de concemporaneas sua atividade profssional. Ver Problemas de Reforma do Processo Civil nas Sociedades Editora, 1994, p. 9-30.

${ }^{8}$ Relatório geral apresentado ao VIII Congresso Internacional de Direito Comparado, organizado pela Academia Internacional de Direito Comparado, realizado em Pescara entre 25 de agosto e 5 de setembro de 1970 . Sobre 0 tema, entre outros, ver também: Interrogatorio della parte e principii fondamentali del processo civile nell Europa comunista, Rivista di Diritto Processuale, XIV(1959):39-59; Efficacia di prove illegittimamente ammesse e comportamento della parte, Rivista di Diritto Civile, VII-I(1961):556-575, Giuramento, in Enciclopedia Forense, vol. III, Milano, Vallardi, 1958, Il giuramento della parte nel processo litisconsortile, Rivista Trimestrale di Diritto e Procedura Civile, IX-4(1955):1151-1195, Valore attuale del principio di oralità, relatório apresentado no II Congresso Latino-americano de Direito Processual (Cidade do México, fevereiro de 1960), Giur. It., CXIIIV(1960):89-95. Ainda no volume Giustizia e società, Milano, edizioni di Comunità, 1977: L'oralità nel process civile italiano: ideale contro realtà, p. 130-144

${ }^{9}$ Cf. Iniziative Probatorie del Giudice e Basi Pregiuridiche della Struttura del Processo, Rivista di Diritto Processuale, XXII(1967):407-428.

${ }^{10}$ In Fundamental Guarantees of the Parties in Civil Litigation, editores Mauro Cappelletti e Denis Tallon, Milano-New York, Giuffrè-Oceana, 1973, p. 661-773.

${ }^{11}$ A começar por La prejudizialità costituzionale nel processo civile, Milano, Giuffrè, 1957, seguindo-se: Il controllo giudiziario di costituzionalità delle leggi nel diritto comparato, settima ristampa, Milano, Giuffrè, 1978, Diritto di azione e di difesa e funzione concretizzatrice della giurisprudenza costituzionale (art. 24 Costituzione e "due process of law clause"), Giur. Cost., VI(1961):1284-1292, Il significato del controllo giudiziario di costituzionalità delle legge nel mondo contemporâneo, Rivista di Diritto Processuale, XXIII(1968):483-500, Il ricorso costituzionale nel sistema delle impugnazioni, Rivista Trimestrale di Diritto e Procedura Civile,
XXII(1968):1056-1061.

Revista da Faculdade de Direito da UFRGS, v. 20, Outubro/2001 
dicional, deixando o processualista de concentrar sua atenção sobre o direito como norma, para atentar para sua efetividade no mundo real e passar a examiná-lo pelo ângulo visual dos usuários dos serviços processuais ${ }^{12}$. Pode-se dizer que o tema desde cedo foi objeto de suas atenções porque data de 1962 o justamente célebre ensaio sobre a ideologia no direito processual ${ }^{13}$.

Insere-se também aí a problemática do acesso à Justiça, com seus questionamentos sobre o valor excessivo das despesas do processo e a demora na entrega da prestação jurisdicional, os poderes assistenciais do juiz e a proteção dos chamados interesses difusos, típicos de uma sociedade de massas ${ }^{14}$

Igualmente se enquadra nesse panorama a questão do emprego de técnicas processuais diferenciadas para tornar a Justiça mais acessível a todos: a simplificação dos procedimentos e a criação de vias alternativas, seja por meio do incentivo a formas de conciliação (Justiça coexistencial ${ }^{15}$ ), seja por meio da institui- ção de juizados especiais para as pequenas causas (small claims courts)

Outro aspecto constantemente enfocado na obra de Mauro Cappelleti concerne, como não podia deixar de ser, ao papel do juiz no processo. Sublinha ele a atividade essencialmente criadora do órgão judicial, destacando a intensificação dos poderes discricionários do magistrado no processo civil moderno e a politização no exercício de suas funções, a reclamar a necessidade do exame de sua responsabilização, tanto jurídica quanto social $^{16}$.

3. No Brasil, sua obra foi amplamente difundida e continua sendo estudada e citada, sem contar a marcante influência de sua presença em inúmeros encontros e congressos, em que proferiu palestras e conferências.

Já em 1969, a Revista de Jurisprudência do Tribunal de Justiça do Rio Grande do Sul publicava tradução de Athos Gusmão Carneiro do ensaio seminal Ideologie nel diritto processuale $^{17}$. Posteriormente, o editor Sérgio
${ }^{12}$ Cf. Cappelletti, O processo civil contemporâneo, cit., p. 15. A respeito, os ensaios Libertà individuale e giustizia sociale nel processo civile italiano e Aspetti sociali e politici della procedura civile (Riforme e tendenz volutive nellËurpa occidentale e orientale), in Giustizia e Società, cit., p. 23-47 e 48-105.

${ }_{13}^{13}$ Cappelletti, Ideologie nel diritto processuale, Rivista Trimestrale di Diritto e Procedura Civile, XVI(1962):193291.

${ }_{14}$ Assim, o extraordinário The Florence Acess-to-Justice Project, de que resultou Acess to Justice, A World Survey, editado por Mauro Cappelletti e Bryant Garth, Milano, Giuffrè, 1978, no qual se insere o relatório geral dos editores, Acess to Justice: The Worldwide Movement to Make Rights Effective. A General Report, vol. I, livro I, p. 5-124, com suas três "ondas": a assistência judiciária aos pobres, a representação dos interesses difusos e uma concepção mais ampla e renovada do acesso a Justiça. Com a mesma inquietação, o relatorio geral do ${ }^{\circ}$ Congresso da International Academy of Comparative Law, Terã, 27 de setembro a 4 de outubro de 1974, The Role of the Ministère Public, the Prokuratura, and the Attorney General in Civil Litigation - With a Glance at Other Form of Representantion of Public and Group Interests in Civil Proceedings, in Mauro Cappelletti e J. A. Jolowicz, New York, Giuffrè-Oceana, 1975, p. 13-153. Ver ainda: Il processo como fenomeno sociale di massa, Il Ponte, XXV(1969):1234-1240, La giustizia è uguale per tutti?, Resistenza, XXIII-6(giugno 1969):8, Povertà e giustizia, Foro Italiano, 91-V(1968):114-119.

${ }^{15}$ Como adverte Cappelletti, O processo civil contemporâneo, cit., p. 21, trata-se de uma Justiça que leva em a situação de tensão: "O Kampf ums Recht deve dart lugar ao Kampf um die Billigkeit, ou seja, à luta pela equaidade, por uma solução justa e aceitável para todos os contendores.

${ }^{16}$ Como frutos dessa linha de pesquisa podem ser citados: The 'Mighty Problem'of Judicial Review, 53 S. Calif. L. Rev. 409(1980), The Law-Making Power of the Judges and its Limits, 8 Monash Univ. L. Rev. 15(1981), Giudici Milano, Giuffré, 1988

17. A Ideologia no Processo Civil, in Revista de Jurisprudência do Tribunal de Justiça do Rio Grande do Sul,
$13(1969): 2-17$ Revista da Faculdade de Direito da UFRGS, v. 20, Outubro/2001
Antonio Fabris, que tanto vem contribuindo para a divulgação dos clássicos estrangeiros entre nós, lançava a tradução brasileira de $I l$ controllo giudiziario di costituzionalità delle leggi nel diritto comparato, Acess to Justice: The Worldwide Movement to Make Rights Effective. A General Report; Giudici Irresponsabili? e Giudici Legislatori? ${ }^{18}$

Não se revelaria difícil gizar a sua presença na obra dos principais processualistas brasileiros, pois repetidamente citadas e comentadas suas idéias fundamentais. Só deixo de levar a cabo o inventário por medo de alguma omissão, sempre desagradável, principalmente porque é grande a difusão e aceitação de sua doutrina, amplamente recepcionado o novo modo de ver o direito processual que seus escritos inspiram.

Sobretudo, revela-se facilmente detectável a influência da elaboração doutrinária desenvolvida por Mauro Cappelletti em três diplomas legislativos da maior importância para a defesa dos direitos dos cidadãos, dizendo respeito a temas tão importantes quanto os interesses difusos, os juizados especiais e o direito dos consumidores, e que lhe eram tão caros, como mencionado anteriormente.

Com grande força, as idéias de Cappelletti foram decisivas para a introdução dos juizados especiais de pequenas causas (Lei $\mathrm{n}^{\circ} 7.244$, de 7.11.1984), que depois passaram a se denominar tão somente juizados especiais (Lei ${ }^{\circ} 9.099$, de 26.9.1995), pois todo o sistema

18 A saber: O controle Judicial de Constitucionalidade das Leis no Direito Comparado, Porto Alegre 1984 tradução de Aroldo Plínio Gonçalves e revisão de José Carlos Barbosa Moreira, Acesso à Justiça, Porto Alegre, de Carlos Alberto Alvaro de Oliveira, e Juízes Legisladores?, Porto Alegre, 1993, tradução e revisão de Carlos Alberto Alvaro de Oliveira. Este último é dedicado pelo autor a José Carlos Barbosa Moreira e Sérgio Bermudes, tendo registrado sugestivamente que, graças a esses amigos, tinha a fortuna de sentir-se "em casa neste grande e maravilhoso país: o Brasil."

${ }^{19}$ Cândido Rangel Dinamarco, Princípios e Critérios no Processo das Pequenas Causas, in Juizado Especial de Pequenas Causas, coletânea de ensaios coordenada por Kazuo Watanabe, São Paulo, RT, 1985, p. 110. Aliás, quase todos os trabalhos constantes do livro apontam à contribuição inestimável de Mauro Cappelletti.

${ }^{20}$ Dedicado a Liebman, o ensaio foi originariamente publicado em Temas de Direito Processual São Paulo, Saraiva 1977 p. 110-123, e depois nos Studi in onore di Enrico Tullio Liebman, vol. IV, Milano, Giuffrè, 1979, p. $2673-2692$. é baseado pela facilitação do acesso à justiça, eformalização e simplificação do processo, ina da paridade de armas somar a participação da comunidade, por meio

Cândido Rangel Dinamarco, um dos autores do anteprojeto que veio a redundar na trat alargamento da via de acesso ao Poder Judiciário e registra ${ }^{19}$ que "Essa preocupação vem aflorando ultimamente no trabalho de juristas pra monumental conduzida por Mauro do com a colaboração de estudiosos das mais do com a colaboração de estud
diferentes nacionalidades".

Outro diploma legal importante do di作 7.347 de 24.7.1985, que disciplina a ação civil pública meio ambiente, ao consumidor, a bens e direitos de valor artístico, estético, histórico, turístico e paisagístico, assim como a qualquer outro

列 popular do Direito Brasileiro como instrumento de tutela jurisdicional dos chamados interesses difusos ${ }^{20}$, pois foi a partir deste ensaio 
que a doutrina brasileira começou a se preocupar com o tema. Já ali constavam diversas referências às idéias e à obra de Mauro Cappelletti, cuja influência é confirmada por Ada Pellegrini Grinover $^{21}$, autora juntamente com Cândido Rangel Dinamarco, Kazuo Watanabe e Waldemar Mariz de Oliveira Jr. do anteprojeto da Lei.

Não por acaso, três processualistas ilustres, autores, juntamente com outros juristas, do anteprojeto que resultou no Código Brasileiro de Defesa do Consumidor (Lei n ${ }^{\circ} 8.078$, de 11 de setembro de 1990), Ada Pellegrini Grinover, Kazuo Watanabe e Nelson Nery Júnior, têm grande intimidade com a obra de Mauro Cappelletti, sendo clara a influência deste em várias regulações desse verdadeiro monumento legislativo. Nos seus comentários ao Código prestam eles o devido reconhecimento, principalmente no que concerne às ações coletivas ali estatuídas ${ }^{22}$. Diz Ada Pellegrini Grinover, com expressa menção à obra de Cappelletti, que justamente por se tratar de defesa dos direitos do consumidor, a preocupação do legislador nesse passo é com a efetividade dessa proteção e com a facilitação de seu acesso à justiça ${ }^{23}$. Assim também Kazuo Watanabe ao ressaltar, citando também Cappelletti, a manifesta intenção do legislador brasileiro de incrementar a instrumentalidade substancial e a maior efetividade do processo e adequá-lo à nova realidade socioeconômica que estamos vivendo, marcada profundamente pela economia de massa ${ }^{24}$
4. Qualquer reflexão moderna sobre o processo há de levar em conta suas conexões internas e externas. Não basta tão somente o estudo da técnica, simples meio para atingir-se determinado resultado, porquanto o processo como fenômeno cultural se conforma em razão dos valores imperantes em determinada sociedade, das suas idéias, utopias, estratégias de poder, fatores sociais, econômicos e políticos Portanto, sempre se revela necessário atentar aos liames com a realidade social externa: a mais grave miopia de que pode padecer o processualista é ver o processo como medida de todas as coisas. Nenhuma tentativa de controlar o arbítrio estatal e de forma concomitante estabelecer padrões que permitam ao processo alcançar suas finalidades últimas em tempo razoável e ainda colaborar para a justiça do provimento judicial poderá frutificar, se não se atentar às vertentes políticas, culturais e axiológicas dos fatores condicionantes e determinantes de sua estruturação e organização ${ }^{25}$.

Mauro Cappelletti foi o grande inspirador e paladino em nossa época dessa ótica mais humana e realista de sentir e pensar o fenômeno processual. Sua visão sociológica do processo, herdada de Piero Calamandrei, a vivência compartilhada do civil law e do common law, a aptidão de seu refinado espírito para as vicissitudes da pós-modernidade, fizeram com que se tornasse um observador privilegiado dos grandes conflitos de valor do século XX e principalmente um renovador insuperável dos estudos do direito processual.

${ }^{21}$ Cf. Novas tendências na Tutela Jurisdicional dos Interesses Difusos, in O Processo em sua Unidade - II, Rio de Janeiro, Forense, 1984, p. 88-121. Como é aí informado, p. 116, o anteprojeto foi, inicialmente, apresentado no I Congresso Nacional de Direito Processual, realizado em Porto Alegre, de 11 a 16 de julho de 1983 , onde fo cões sobre o tema, sugerindo, além de modificaç̃os formais, a previsão do controle da medida liminar nas acões civis inibitórias. Após as manifestações favoráveis dos Professores Galeno Lacerda, Calmon de Passos e Ovídio Baptista da Silva, foi aprovado por aclamação.

${ }^{22}$ Ver Ada Pellegrini Grinover et allia, Código Brasileiro de Defesa do Consumidor Comentado pelos Autores do Anteprojeto, $6^{\mathrm{a}}$. ed., Rio de Janeiro, Forense Universitária, 1999, passim.

${ }^{23}$ Ada Pellegrini Grinover, Código Comentado, cit., p. 701.

${ }^{24}$ Kazuo Watanabe, Código Comentado, cit., p. 706.

${ }^{25}$ Maior desenvolvimento dessas idéias em Carlos Alberto Alvaro de Oliveira, Do Formalismo no Processo Civil São Paulo, Saraiva, 1997, passim.

\title{
Desembargador Carlos Thompson Flores: fundador da Faculdade de Direito de Porto Alegre
}

\author{
Dr. Carlos Eduardo Thompson Flores Lenz \\ Desembargador Federal do Tribunal Regional Federal da $4{ }^{a}$ Região
} Salão Nobre da Faculdade de Direito da Universidade Federal do Rio Grande do Sul, a propósito das Comemorações do Centenário da fundação daquela Faculdade de Direito.

É para mim honra inexcedível comparecer a esta Faculdade de Direito com o objetivo de proferir palestra sobre a vida e a obra do Desembargador CARLOS THOMPSON FLO RES, Fundador e primeiro Diretor da Faculdade de Direito de Porto Alegre, hoje integrante da Universidade Federal do Rio Grande do Sul.

Atendo, pois, com emoção, à honra do convite que recebi dos eminentes professores EDUARDO CARRION e PLINIO DE OLIVEIRA CORRÊA, respectivamente, Diretor e ViceDiretor da Faculdade de Direito, para colaborar nas comemorações do centenário da fundação desta notável instituição de ensino jurídico. Cuidarei de não desmerecê-lo, neste momento, não somente pela nobreza da missão recebida, como pela validade de seu significado no mundo emocional em que se insere o pretexto altíssimo desta comemoração. A todos, o meu agradecimento pela oportunidade que me deram de exaltar a memória de seu fundador, personalidade de grande relevo na história da Política e da Magistratura do nosso Estado no Império e primórdios da República.
O nome do Desembargador CARLOS THOMPSON FLORES foi pronunciado, reverentemente, vezes incontáveis, sob as variadas facetas de sua impressionante e encantadora personalidade, como atestam os seus contemporâneos, por ocasião das comemorações de sucessivas datas significativas da vida desta Casa do Direito. Os ecos de tantos louvores ainda persistem. Hoje mesmo, a Faculdade de Direito de Porto Alegre lhe dedicou um dia de reverência, à memória daquele que foi o seu principal fundador e primeiro Diretor.

Não será por demais repetir e enaltecer o descortino da geração da Independência do Brasil ao perceber que a novel Nação não necessitava unicamente de novas leis, mas, sobretudo, de uma consciência jurídica própria, a qual somente poderia se concretizar com a fundação de Faculdades de Direito vinculadas às nossas tradições.

A respeito, precioso o depoimento de CLOVIS BEVILAQUA, em sua consagrada História da Faculdade de Direito do Recife, verbis:

"Remontam aos tempos coloniais as aspirações brasileiras por possuírem, dentro do país, estabelecimentos de ensino superior, onde pudessem desenvolver as suas faculdades naturais, em harmonia com a cultura do tempo. Os 
inconfidentes mineiros, no fim do século décimo oitavo cogitaram de dotar a pátria livre com uma Universidade." 1

A necessidade, então geralmente sentida, de se criarem no Brasil Faculdades de Direito teve o seu arauto na pessoa de JOSÉ FELICIANO FERNANDES PINHEIRO, o Visconde de São Leopoldo, consoante se constata do discurso que proferiu quando da sessão de 14 de junho da Constituinte de 1823, oportunidade em que afirmou o eminente homem público brasileiro, verbis

"Proponho que, no Império do Brasil se crie, quanto antes, uma universidade pelo menos, para assento da qual parece dever se preferida a cidade de $S$. paulo, pelas vantagens naturais, e razões de conveniência geral. Que, na faculdade de Direito civil, que será sem dúvida, uma das que comporá a nova universidade, em vez de multiplicadas cadeiras de Direito romano, se substituam duas, uma de Direito público constitucional, outra de economia política." 2

Com a posterior dissolução da Assem bléia Constituinte pelo Imperador Dom Pedro I restaram inúteis os seus esforços em prol das Faculdades de Direito, o que somente veio a efetivar-se quando a Assembléia Geral votou Pedro I sancionou a Carta de Lei de 11 de agosto de 1827 , o diploma criador das Faculdades Jurídicas do Brasil.

Surgiram, assim, logo em 1827, os dois grandes centros jurídicos do País: um ao norte, em Olinda, posteriormente transferido para $\mathrm{Re}-$ cife; outro, em São Paulo. Ambos iriam se converter nos dois pólos em torno dos quais, no decorrer de várias décadas, a intelectualidade

brasileira pôde traçar a elipse da nossa cultura.

Instalava-se, portanto, em nossa incipiente Nação o culto ao Direito, que tão profundamente marcara a civilização romana, conforme magistralmente expõe RUDOLF VON JHERING, em obra clássica, verbis:

"On connaît suffisamment l'inclination qu'eurent de tous temps les Romains pour le droit, bien différents en cela du peuple grec, et la place éminente qu'il occupait dans leur vie. Le droit et l'État étaient pour les Romains ce que furent la religion pour le peuple hébreu, l'art pour le peuple grec: un objet d'orgueil national vis-à-vis de tous les peuples étrangers, la supériorité dont ils étaient le plus certains, l'aimant de l'ambition et de la force. (...) L'attraction qu'exerçait le droit sur les Romains ne provenait pas de la satisfaction $q u$ 'il procurait à l'intelligence et au sens juridique. Le droit était pour eux plus qu'une simple source de jouissances et de satisfactions intellectuelles, il était pour eux un objet d'ennoblissement moral. (...) Ce respect du droit, la soumission spontanée du Romain aux dispositions du droit, l'amour du peuple pour la justice, son aversion pour les violations $d u$ droit, le sentiment de sécurité que le droit inspirait à Rome, la confiance en son triomphe, en un mot, le sentiment sain, énergique et viril de la légalité, voilà ce qui exaltait l'orgueil du Romain." ${ }^{3}$

Nesse contexto insere-se o nosso homenageado, CARLOS THOMPSON FLORES, bem como o ambiente político e cultural que originou a Faculdade Livre de Direito de Porto Alegre, fundada a 10 de fevereiro de 1900, durante o Governo de BORGES DE MEDEIROS, sendo instalada a 03 de maio do mesmo ano, no

${ }^{1}$ In História da Faculdade de Direito do Recife, $2^{\mathrm{a}}$ ed., Instituto Nacional do Livro, 1977, p. 11. 2 In Anais do Parlamento Brasileiro, Assembléia Constituinte, II, p. 63.

${ }^{3}$ In L'Esprit Du Droit Romain, tradução de O. de Meulenaere, $3^{\mathrm{a}}$ ed., Forni Editore, Bologna, t. I, pp. 324/5.

Revista da Faculdade de Direito da UFRGS, v. 20, Outubro/2001 prédio da Escola Normal do Estado, tendo como o seu primeiro Diretor o Desembargador CARLOS THOMPSONFLORES.

Foi esta a sétima Faculdade de Direito a ser implantada no País. Dessas, duas eram oficiais, como as de Recife e São Paulo. As quatro outras eram livres, localizadas duas no Rio de Janeiro, uma na Bahia e outra em Minas Gerais.

As Faculdades Livres, à época, eram autônomas e desvinculadas da tutela oficial, sendo constituídas por meio de associação de professores e patrimônio determinado, presente, portanto, a inspiração positivista de AUGUSTO COMTE que prega a criação dos estabelecimentos de ensino livres, "independentes da vexatória tutela oficial, fora da es tufa de subvenções orçamentárias que, além de ilegítimas, são humilhantes".

Em conferência que proferiu na Faculdade de Filosofia da Universidade Federal do Rio Grande do Sul, intitulada "O Direito no Rio Grande do Sul", o saudoso Professor SALGADO MARTINS registrou a importância da fundação da Faculdade de Direito de Porto Alegre para o desenvolvimento dos estudos jurídicos em nosso Estado, verbis:

"Além da instauração do novo regime, com todas as consequências e implicações no campo do direito positivo, deve ser apontada outra causa de grande influência do fomento desses estudos: a fundação da Faculdade Livre de Direito de Porto Alegre, no dia 17 de fevereiro de 1900 . No di em que for escrita a memória da primeira Faculdade rio-grandense de Direito, há de ser salientado o papel que lhe coube não só no aprimoramento da cultura jurídica como na penetração dessa cultura em áreas sociais até então inteiramente alheias a esse interesse, e ainda no preparo das nossas melhores elites dirigentes, a partir da República. Para se compreeender sob que signos e influências culturais se iniciou o ensino e o estudo sistematizado do Direito, no Rio Grande do Sul, é necessário atentar para São Paulo e Recife, onde se situavam os dois grandes centros de cultura jurídica e dos quais provinham os jovens rio-grandenses que se consagraram à fundação da República, no Rio Grande do Sul. E não só os jovens, mas também os mestres, eram filhos espirituais de uma ou outra Academia......)

Ora, as matrizes próximas da cultura jurídica rio-grandense estão, sem dúvida, nesssas, duas nobres e ilustres Academias.

THOMPSON FLORES, PLÍNIO DE CASTRO CASADO, JAMES DARCY, PLÍNIO ALVIM, LEONARDO MACEDÔNIA FRANCO E SOUZA, NORMÉLIO ROSA, JOAQUIM RIBEIRO, PACHECO PRATES, naturais do Rio Grande do Sul, vinham de São Paulo.

ANDRÉ DA ROCHA, MELCKISEDECK CARDOSO, RIBEIRO DANTAS, VALENTIM DO MONTE, filhos de Estados do Norte, haviam se diplomado na Faculdade de Recife e traziam no espírito e no coração a presença dominadora de TOBIAS BARRETO.

Dentro dessas coordenadas derivadas do meio, do passado histórico, das circunstâncias politicas e sociais, dos fatores culturais a que vimos aludindo, começa a se constituir, no Rio Grande do Sul, a literatura jurídica, exprimindo, ainda que de modo incipiente, o trabalho de elaboração doutrinária, de determinação dos principios fundamentais, ou de simples exegese das leis." 4

${ }^{4}$ In JOSÉ SALGADO MARTINS, O Direito no Rio Grande do Sul, conferência publicada pela Gráfica da Universidade Federal do Rio Grande do Sul, Porto Alegre, 1961. 
O Desembargador CARLOS THOMPSON FLORES descendia de antiga e ilustre família do Rio Grande do Sul que, segundo reza a tradição, originou-se do casamento do Dr. LUIZDA SILVA FLORES, médico humanitário e prestigioso político do Império, com Dona MARIA DA GLÓRIA THOMPSON, filha do Capitão de Fragata da esquadra inglesa JAYME THOMPSON. ${ }^{5}$

Nascido em Porto Alegre, a 04 de junho de 1843, estudou os preparatórios nesta Capital, cursando a Faculdade de Direito de São Paulo, onde colou grau a 27 de novembro de 1865. Depois de formado, retornou à Província, onde ocupou os cargos de Promotor Público, Juiz de Direito, Deputado Provincial, de 1871 a 1876, tendo exercido a Presidência da Assembléia Legislativa, e Presidente da Província do Rio Grande do Sul na situação liberal de 1878 a 1885. Com o advento da República, fo Desembargador do Superior Tribunal de Justiça do Estado, onde foi eleito por seus pares Vice-Presidente da Corte, estando no exercício da Presidência por várias oportunidades, Procurador-Geral do Estado e Deputado Estadual à Constituinte de 1891, onde teve destacada atuação. Paralelamente, desenvolveu intensa atividade como jornalista, colaborando ativamente na "Reforma".

Por ocasião do seu falecimento, era Desembargador do Superior Tribunal de Justiça, no exercício do cargo de Procurador-Geral do Estado, Catedrático da cadeira de Legislação Comparada de Direito Privado, que inaugurou e regeu durante o ano letivo de 1904, e Diretor da Faculdade de Direito de Porto Alegre.

O Desembargador THOMPSON FLORES foi casado com D. LUÍSA ELVIRA FERNANDES DOS REIS, filha do Marechal de Campo SALUSTIANO JERONIMO DOS REIS, o Barão de Camaquam, destacado militar do Império brasileiro.

LA BRUYÈRE, conhecido moralista francês, afirmou, com inteiro acerto, que não se deve julgar os homens como um quadro, ou uma figura, através de uma única e primeira vista: há uma intimidade e uma alma que é preciso aprofundar. $^{6}$

Magistrado por cerca de quarenta anos, CARLOS THOMPSON FLORES honrou a toga e deu-lhe majestade e o brilho que não era difícil vaticinar.

A marca de sua personalidade ímpar ele a deixa estampada na memória dos que o viram à frente das mais importantes funções nos três Poderes do Estado, no Império e na República, sendo notado pelos traços característicos de sua enorme e atraente personalidade - a inteligência vivacíssima, que se revelava nas conversas e debates, pelo raciocínio extraordinário, rápido, sutil e cintilante, auxiliado por memória invejável, aliada a sólidos conhecimentos dos diferentes ramos do Direito, e a ampla cultura humanística.

Autêntico magistrado, dedicado como poucos ao cumprimento de sua apostolar missão, seguiu à risca os ensinamentos de D'AGUESSEAU, notável Juiz de França: "Pouvoir tout pour la justice, et ne pouvoir rien pour soi-même, c'est l'honorable mais pénible condition du magistrat".?
A sua preocupação com as questões do ensino já se manifestara quando de sua atuação como parlamentar na Assembléia Legislativa, no Império, conforme se observa março de 1873, verbis:

"Obedecendo à rigorosa obrigação de atender os votos, às aspirações da opinião pública, as conveniências morais e do progresso intelectual de meus comprovincianos, eu veme faltam as disposições naturais, (muitos não apoiados) servindo o soberano interesse da grande política - a educação popular - a que voto profundo amor, tratar do transcendente assunto da instruçâo pública, que reclama hoje mais do que nunca a nossa solicitude, os nos sos desvelos, que insta pela mais severa atenção". (Apoiados) ${ }^{8}$

Com a proclamação da República, foi escolhido Desembargador do Superior Tribunal de Justiça do Estado, cargo que exerceu com extraordinária competência até os seus últimos dias de vida.

Em razão de sua larga experiência na vida pública, notadamente por ter governado o Rio Grande do Sul, a sua palavra era sempre ouvida com o maior acatamento nos assuntos mais delicados da alta administração do Estado, constituindo, tal deferência, uma justa e merecida homenagem que the prestavam JÚLIO DE CASTILHOS B BORGES DE MEDEIROS, amigos seus, que o tinham no mais elevado conceito.

A Faculdade de Direito de Porto Alegre nasceu sob a égide do Poder Judiciário, tendo sido decisiva a colaboração do Desembargado JAMES FRANCO, Presidente do Superior Trido discurso que proferiu na sessão de 13 de nho, Sr. Presidente, a esta tribuna, para a qual

bunal de Justiça desde 1894, que franqueou a sua sala de atividade funcional para os contatos com as personalidades do mundo jurídico no Estado, com os quais o ilustre Desembargador THOMPSON FLORES aflorara a iniciativa da instituição da novel Faculdade de Direito, em autêntica ação coordenadora dos esforços em prol desse desiderato.

Impende reconhecer-se, também, a cooperação inestimável dos Doutores JÚLIO DE CASTILHOS E ANTONIO AUGUSTOBORGES DE MEDEIROS ao animar a iniciativa do Desembargador THOMPSON FLORES, inclusive no auxílio material, ao ceder as salas da Escola Normal do Estado para que ali se pudessem realizar as reuniões mais numerosas, onde se verificaram os debates para a criação do novo instituto superior do ensino.

Esse aspecto foi realçado pelo neto do nosso homenageado, o eminente Ministro CARLOS THOMPSONFLORES, ex-Presidente do Supremo Tribunal Federal, em seu discurso proferido no Plenário da Suprema Corte na sessão comemorativa do centenário de PLÍNIO CASADO, verbis:

"De há muito ansiavam os riograndenses pela criação de sua Faculdade de Direito, a exemplo de Recife e São Paulo.

De aguda sensibilidade política, apercebeu-a Júlio de Castilhos.

Dessa missão incumbiu ao então Procurador-Geral Desembargador Carlos Thompson Flores, do Superior Tribunal do Estado, o qual, na busca de valores, inseriu no rol dos mestres, Plínio Casado.

E foi de seus lábios que o Rio Grande ouviu a primeira lição de Direito, na novel Faculdade, aos 4 de maio do ano de 1900 sobre Direito Público e Constitucional." 9

${ }^{8}$ In Anais da Assembléia Legislativa da Província de São Pedro do Sul, Porto Alegre, 1873, Apêndice, II parte, p. 13. ${ }^{9}$ In Discurso do Min. THOMPSON FLORES, in Sessão Comemorativa do Centenário do Nascimento do Ministro PLÍNIO CASADO.

Revista da Faculdade de Direito da UFRGS, v. 20, Outubro/2001 
No mesmo sentido, é o magistério de ANDRÉ BRAGA, em alentado estudo acerca da História da Faculdade de Direito de Porto Alegre, verbis:

"Se a inspiração foi de Júlio de Castilhos que emprestou o máximo apoio à criação da Faculdade e que, segundo alguns, teria mandado - o que era muito do seu feito político, organizar mais este instituto de ensino superior; se amparo moral e material teve de parte do Presidente Borges de Medeiros a mais ampla cobertura; se sob a égide do Tribunal de Justiça do Estado, encontrou a Faculdade na pessoa do Des. James Franco um vibrante estusiasta, animando os colaboradores e presidindo reuniões preparatórias, é imperioso, todavia, que se diga que notável mérito em todos os passos alcançou a personalidade invulgar do Des. Thompson Flores que soube coordenar como líder inconteste o empreendimento, com visivel demonstração de criatividade. Àqueles que de outras gerações perlustraram esta Casa há de se indagar da significação altamente cívica do busto do $1^{\circ}$ Diretor. Desembargador Carlos Thompson Flores, sotoposto na escadaria central, ao pé do vitral Iustitia, a simbolizar a vigilância diuturna, qual sacerdote da justiça, na observância fiel dos princípios doutrinários para fazer do estudante um apóstolo do bem, em mensagem permanente de fé e convicção na aplicação do direito como regramento da conduta humana.

Emergindo do plano judiciário para a política de princípios para a institucionalização do Estado, depois de ter sido Presidente em exercício da Província, legislador constituinte luminar de 91, juiz integro e culto, vai então decidir sobre providências que transcendem o plano das relações individuais na medida em que nelas se envolve um interesse social da comunidade rio-grandense, a exi-

gir-lhe outra forma de reflexão, porque implica na formação humana, estranha à doutrina $e$ ao poder de limitar, mas que exige obviamente a linguagem do senso comum na perquirição das franquias e no respeito à individualidade do mestre e do aluno.

Pela primeira vez, iria coordenar a for mação de uma nova estrutura na tessitura social, a de dar formação jurídica à mocidade conformada aos princípios republicanos. Embora de exuberante inteligência, mas nunca arrebatado, o venerando magistrado exercita proeminente influência política com a fortuna de ser dotado de espírito de concórdia e ponderação, como asseverava a imprensa contemporânea, porque lhe cabia um papel singular na organizaação institucional do Estado e a quem se deve assinalados e relevantíssimos serviços.

Maior distinção entre os seus pares é a de ter sido, portanto, escolhido para dirigir os destinos do terceiro estabelecimento de ensino superior da Capital, a primeira escola de ensino jurídico do Estado, com tanto maior responsabilidade que era consabido ser o instituto indispensável à fixação e aprimoramento das instituições republicanas, ansiosamente esperado pela mocidade rio-grandense afe $i$ ta a uma vida libertária e de convicções políticas definidas." 10

No dia 10 de fevereiro de 1900 acorreram as mais proeminentes personalidades do Estado para ouvir a declaração do Desembargador THOMPSON FLORES, na sala do Atheneu Riograndense, de que estava fundada a Faculdade Livre de Direito de Porto Alegre.

Logo após, em 24 de fevereiro do mesmo ano, na sala de sessões do Superior Tribunal de Justiça do Estado, procedia-se à eleição do primeiro Diretor da Faculdade de Direito, cuja escolha recaiu, por unanimidade de votos, na pessoa do Desembargador CARLOS THOMPSONFLORES

É o que consta da Ata de Instalação e $1^{\mathrm{a}}$ Congregação da Faculdade Livre de Direito de Porto Alegre, verbis:

"Aos vinte e quatro dias do mez de fevereiro de 1900 , reunidos ás duas horas da tarde, na sala de sessões do Superior Tribunal do Estado os Srs. Desembargadores Carlos Thompson Flôres e Epaminondas Brasileiro Ferreira, Dr. Antonio Fausto Neves de Souza, Francisco de Paula Azevedo e Souza, Manoel Pacheco Prates, Timotheo Pereira da Rosa, Antonio Marinho Loureiro Chaves, Leonardo Macedonia Franco e Souza, Marçal Pereira d Escobar, José Joaquim de Andrade Neves Neto Normelio Rosa, Antonio Nunes Gomes Pereira Sebastião Leão, Ricardo Pereira Machado, Joaquim Antonio Ribeiro, Plínio Alvim, Germano Hasslocher, Plínio de Castro Casado, Arthu Pinto da Rocha e James Darcy - foi acclamado Presidente o Dr. Antonio Fausto Neves de Souza o qual declarou achar-se, desde então, installada a Faculdade Livre de Direito de Porto Alegre congratulando-se com os seus collegas presentes por esse magno acontecimento e declarando, em seguida que ia-se proceder á eleição para Director. Esta, por unanimidade de votos, recahiu na pessôa do Sr. Desembargador Carlos Thompson Flôres. O Sr. Director comovidamente agradeceu a investidura que nessa hora recebia dos seus collegas. Passando a funciona a Congregação, sob a presidencia do Director, votou os estatutos, approvando-os como sua lei organica, e de acordo com elles o Sr. Directo escolheu o Desembargador Epaminondas Brasileiro Ferreira para substituil-o, como ViceDirector em seus impedimentos, nomeou Secretario o Dr. James Darcy e Thesoureiro o Dr. Manoel Pacheco Prates. Logo após a Congregação elegeu para constituirem as commissões de Constas: aos Drs. Francisco de Paula Azevedo e Souza, Marçal Pereira de Escobar e Germano Hasslocher; de Revista: os Drs. Sebastião Leão, Plinio de Castro Casado e Arthur Pinto da Rocha; Scientífica: Drs. Timotheo Pereira da Rosa, Plinio Alvim e Joaquim Ribeiro; e ainda para a Comissão de Patrimônio da Faculdade: Drs. Possidonio Mancio da Cunha Junior, José Joaquim de Andrade Neves Neto e Normelio Rosa. O Sr. Director fez sciente á Congregação que convocal-a-ia, mais tarde, para que providenciasse acerca da installação solemne da Faculdade, em dia que seria opportunamente marcado. $\mathrm{E}$ como nada mais houvesse a tratar, o Sr. Director deu por terminados os trabalhos, e encerrada a $1^{\mathrm{a}}$ sessão da Congregação da Faculdade Livre de Direito".

No dia 10 de novembro de 1904, poucos dias antes da colação de grau dos primeiros bacharéis em Direito pela Faculdade de Direito de Porto Alegre, falecia subitamente o Desembargador THOMPSON FLORES, sob a constrangedora tristeza da sociedade de nosso Estado, como atesta o largo noticiário da imprensa da Capital no dia seguinte ao seu sepultamento, o maior daquela época.

Tombava a coluna mestra da Faculdade de Direito, o ilustre e incansável paladino a quem esta Casa do Direito deve a sua existência.

OPresidente do Estado, Dr. BORGES DE MEDEIROS, juntamente com todos os seus auxiliares, o Intendente JOSÉ MONTAURY e os Diretores dos estabelecimentos de ensino superior, além do Presidente da Assembléia Legislativa, Dr. CARLOS BARBOSA, e outras ilustres autoridades, participaram de todos os atos fúnebres, o que estava a demonstrar o apreço e alto conceito que desfrutava Desembargador THOMPSON FLORES perante a sociedade do Rio Grande do Sul.

A personalidade do Desembargador 
THOMPSON FLORES é das que o tempo não pode apagar. Magistrado e homem público íntegro, de dignidade e cultura por todos reconhecida, sua vida, sem qualquer sombra de dúvida, foi a exaltação à liberdade e à inteligência, bem podendo ser seus os versos de SHAKESPEARE dos conjuradores romanos, na peça política Julio Cesar, verbis:

"Ni la tour de pierre, ni les murailles de bronze travaillé, ni le cachot privé d'air, ni les liens de fer massif, ne peuvent enchaîner la force de l'âme; mais la vie fatiguée de ces entraves terrestres ne manque jamais du pouvoir de s'en affranchir". "1

O seu nome serviu de garantia para reunir ao seu redor as melhores inteligências da Ciência do Direito de seu tempo, aglutinados pelo nobre ideal de fundar a Faculdade de Direito de Porto Alegre, marcando com a sua vigorosa personalidade o modelo de estabelecimento de ensino jurídico dos mais notáveis do País.

Em todos os cargos e missões que exerceu, nunca deixou de ser jurista. Mas, para o Desembargador CARLOS THOMPSON FLORES, o papel do jurista jamais se esgotou na esclarecida interpretação e aplicação do Direi to. Ele se completava com a função pedagógica, concorrendo para o aperfeiçoamento humano.

O privilégio de transmitir ensinamentos não só através dos seus votos e acórdãos, mas também no contato direto com os alunos, contribuindo por afeição ao nobre ofício para o aprendizado de várias gerações, evidencia o ideal do saber à serviço da mocidade, quando, num verdadeiro apostolado, repartia com os

${ }^{11}$ In Oeuvres Complètes de Shakespeare, traduction de M. Guizot, neuvième édition, Paris, t. 2, p. 26. ${ }^{12}$ In MARCO FABIO QUINTILIANO, Istituzione Oratoria, traduzione e note di Orazio Frilli, Zanichelli Editore, Bologna, 1984, Libri X-XI-XII, p. 259, I, 25.

${ }^{13}$ In BOSSUET - Oeuvres Choisies, treizième édition, Librairie A. Hatier, Paris, 1941, p. 650.

Revista da Faculdade de Direito da UFRGS, v. 20, Outubro/2001

seus alunos não só a lição do saber jurídico, mas a própria lição da vida, tão enriquecida na sua longa caminhada. Assim, entregava-se ao magistério de espírito e coração. Um mestre, na acepção exata do termo.

Nada mais adequado para destacar a personalidade do Desembargador CARLOS THOMPSON FLORES do que lembrar o conhecido trecho da Institutio Oratoria, de QUINTILIANO, o maior preceptor da Antiguidade e notável Retórico de Roma, quando definiu o seu magistério, emitindo conceitos válidos até o dia de hoje, verbis:

"Infatti noi non diamo una qualunque educazione forense, nè formiamo un mercenario che metta la sua voce in vendita, nè (per addolcire l'espressione) un difensore utile nei processi, che insomma comunemente si chiama causidico, ma un uomo che si elevi per la tempra dell' ingegno e che abbia la mente ricolma di vaste e belle conoscenze, un uomo concesso in dono alla terra, tale quale l'antichità non ne ha mai veduto un eguale, un uomo unico, perfetto in tutto, ammirevole per i suoi sentimenti e per come li esprime". ${ }^{12}$

Vestem-no sem folgas as palavras com que o clérigo de Clérembault, em 02 de junho de 1704, se exprimiu acerca de BOSSUET, por ocasião da morte do célebre pensador francês, verbis:

"Ce grand personnage était un de ces hommes rares et supérieurs qui sont quelquefois au monde pour lui faire seulement sentir jusqu'où peut être porté le mérite sublime, sans laisser presque l'espérance de leur pouvoir trouver des successeurs." 13
Realmente, a vida só se completa com a morte. No entanto, só a morte dá a dimensão integral de uma vida.

O Desembargador THOMPSON FLORES foi um homem e um juiz severo e intransigente no culto do dever, inflexível consigo mesmo. Nunca soube cortejar. Nunca soube pedir. O magistrado, com efeito, não pede jamais. Espoliado ou ameaçado em seu direito, resiste com altivez, exigindo o cumprimento da lei. Mas não pede, não se curva. Ao contrário, sempre soube renunciar às coisas vãs e ilusórias da vida.

No Superior Tribunal do Estado, o insigne jurista ratificou o alto conceito que desfrutava na Província. Permaneceu nesta Corte cerca de treze anos, período suficiente para deixar a marca de sua sólida formação jurídica, revelada no exercício da judicatura, pois sentira, desde o primeiro instante, o desafio cultural e humano que representava a multiplicidade e a complexidade das questões decididas pelo Tri bunal, atento, sempre, à advertência de FRANCIS BACON aos juízes no sentido de que a sua missão constitui "a wise use and application of laws". ${ }^{14}$ Quem reunir os votos que proferiu, notadamente no terreno do Direito Privado, terá uma antologia de lições esplêndidas.

Um exemplo basta para atestar a verdade da asserção. Modelo de síntese e precisão, esta passagem do voto que emitiu no julgamento da apelação cível n ${ }^{\circ} 204$, versando causa de anulação de casamento por motivo de coação, verbis:

"O Juiz a quo julgou dar-se o caso previsto e arguido no procedimento do juiz districtal que presidiu o casamento, tendo

${ }^{14}$ In The Essays, Penguin Books, 1985, p. 225

${ }^{15}$ In Decisões do Superior Tribunal - ano 1896, p. 257

Revista da Faculdade de Direito da UFRGS, v. 20, Outubro/200 colligido da instrucção feita ameaça de processo por crime de defloramento, dando causa ao consentimento do autor Marcellino Brum n'esse acto.

Considerando, porém, que tal apreciação é desacertada, ainda não attendida a duvida da prova que devêra ser " muito plena e liquidissima" em vista do theor do instrumento da celebração do casamento, e da não se tratando da falta de consentimento quimavult, vult, $e$ sim de determinado vicio d'elle, o mesmo, a coacção, não se entende existir na hypothese, qual a devida intervenção da autoridade com competencia tutelar sobre a miseravel offendida, para o fim da reparação legal (art. 276, § único, do Codigo Penal), que se operou; Considerando que nem a voz de prisão, circumstancia allegada, está sufficientemente verificada, como qualquer mal, ou perigo "consideravel e presente" a poder amedrontar irresistivelmente o autor apellado para a sua determinação de csar-se; não sendo elle pessoa rustica a ponto de desconhcer as garantias legaes, nem de animo tão timido, como por sua parte se inculca, attenta a qualificação resultante dos autos; $e$ sob similhantes respeitos deve ser consultada a doutrina e bem assim a legislação comparada (Pothier, "Obrigações", ann. Corrêa Telles, Part $1^{a}$, numeros 21 a 26; Rogrou aos artigos 1.111 a 1.112, "Cod. Napol"; Giarelli - ao art. 1.112, Cod. Civil Ital.; Dias Ferreira - ao art 663, "Cod. Civ. Port."; e Coelho da Rocha, "Dir. Civ." \$\$ 102 e 736)". 15

Problemas de Direito Público iriam ocupar, por largo tempo, a atenção de THOMPSON FLORES. Num momento em que as obras fundamentais nessa especialidade ainda não haviam sido dadas à lume, o estudo da matéria consconveniencia da solidez d'este acto, - pois que, 
titucional conduzia, inevitavelmente, à análise da doutrina estrangeira, trabalho que o eminente magistrado levou a termo com lucidez e prudência.

Exemplo disto está na posição por ele assumida relativamente ao cuidado e à cautela do Juiz ao reconhecer a insconstitucionalidade das leis, a evidenciar insuspeitados conhecimentos do direito constitucional americano, verbis:

"Considerando que a attribuição, ou funcção jurisdiccional, objecto da excepção n'este processo, é por sua natureza restricta, devendo ser attendida nos termos rigorosos da declaração legal (art. $8^{\circ}$ da Cit. L. n. 10, $v b$. manifestamente), e de accôrdo com a doutrina, calcada sobre a jurisprudencia do systhema constitucional americano, que adverte ao juiz que a constitucionalidade da lei é presumida, que só cumpre-lhe declarar um acto inconstitucional, quando elle clara e evidentemente viola a Constituição, devendo, em caso de duvida, ser em favor do Poder Legislativo, e que o assumpto é extremamente delicado, é para ser tratado com reluctancia e hesitação para não subverter-se a necessaria e legitima co-ordenação dos departamentos do poder publico, e não se desprestigiar o regimen republicano, que deve ser verdadeiramente o governo da lei. (Tim. Walker, Introd. To American Law. Part. $2^{a}$ Secç. 27, pg. 73, not. B; Cooley, Const. Limit., cap. $7^{\circ}$, pgs. 193, 195 e 216)." 16

Outro caso a merecer destaque foi a questão da competência da Justiça do Estado para o julgamento de ação de indenização ajuizada contra empresa estrangeira, tópico raramente versado em nosso direito naquela época, verbis:

${ }^{16}$ In Op. Cit., p. 30

${ }^{17}$ In Op. Cit., p. 105

Revista da Faculdade de Direito da UFRGS, v. 20, Outubro/2001 “a) A qualidade allegada de ser extrangeira a Ré, attenta a natureza da acção para pagamento de divida de serviços, restituição de retenções de quantias, e indemnisação de prejuizos, perdas e damnos, tudo decorrente de actos administrativos da mesma companhia, excipiente, não limita a jurisdicção comum local em virtude do nosso regimen constitucional federativo mais liberal do que o das constituições norte-americana e argentina, perante o qual por esse motivo a especie seria da competencia da justiça federal;

b) A acção não interessa ao Fisco $\mathrm{Na}$ cional, não perdendo a Ré pelo facto do privilegio e garantia de juros não tendo na hypothese o Fisco a minima intervenção, quer como assistente, que como oppoente, como bem se conhece da informação prestada pelo engenheiro representante daquelle Governo, ut a fl. 99. Condemnão a aggravante nas custas." 17

Esse registro, como um perfil, contém apenas alguns índices representativos da escala de sua atividade judicante, impossível de se condensar, nesta oportunidade, quer pelo número das manifestações, quer pela diversidade das proposições.

Impressionava, sobremaneira, o que dele diziam os seus contemporâneos, não só os seus eminentes Colegas do Superior Tribunal do Estado, como todos aqueles que o conheceram e privaram de seu convívio humano e acolhedor, da integridade do seu caráter.

Parafraseando MACHADO DE ASSIS, os qualificativos estão já tão gastos que dizer que um homem é virtuoso, parece que não é dizer nada. Mas, em realidade, quantos merecem rigorosamente esta qualificação tão simples e tão curta? $O$ grande assombra, o glorioso ilumina, o intrépido arrebata; o virtuoso não produz nenhum desses efeitos. Contudo, em sua ação e no seu modo de proceder há uma grandeza, há uma glória, há uma intrepidez em ser simplesmente virtuoso, sem aparato, nem interesse, nem cálculo.

\section{Virtus est omnium bonorum maximum}

O conhecido historiador romano SAUSTIO escreveu, em certa oportunidade, que "l'éclat de la richesse et de la beauté est fragile et passager, la vertu seule demeure glorieuse et immortelle". ${ }^{18}$

Poderia falar, ainda, muito mais, de senvolvendo cada parágrafo do que acabo de dizer, referindo-me às diversas fases da vida e às múltiplas atividades do talentoso jurista que foi o Desembargador CARLOS THOMPSON FLORES

Creio, porém, que basta. Repetindo RENAN, os fatos consumados dizem mais do que todas as individuações biográficas.

Em um de seus famosos Diálogos De Brevitate Vitae -, SÊNECA exproba o brocardo "vitam brevem esse, longam artem". Na sua concepção, a vida nos proporciona tempo de sobejo, nós é que o perdemos demasiado ("nous n'avons pas peu de temps, nous en avons beaucoup de perdu"). ${ }^{19}$ Desconheço se o Desembargador CARLOS THOMPSON FLORES, em algum momento de sua vida, teria lido essas páginas do filósofo romano. Se não as leu, seguiu-as, contudo, por intuição. Viveu como bom ecônomo do tempo. Por ocasião do seu falecimento, após mais de quarenta anos de magníficos serviços prestados ao seu país, e toda uma existência votada ao magistério e às letras jurídicas, aureolado pelo prestígio e admiração que soube granjear de toda a sociedade de sua época, CARLOS THOMPSON FLORES deixou para os pósteros o exemplo de uma vida de progressão contínua, mercê de trabalho incansável, legando a seus descendentes um nome respeitado e venerado, por suas virtudes cívicas e privadas.

${ }^{18}$ In SALLUSTE, Conjuration de Catilina, texte établi par B. Ornstein et traduit par J. Roman, Société d'édition "Les Belles Lettres", Paris, 1924, p. 1.

${ }^{19}$ In SÉNÈQUE, Dialogues, texte établi et traduit par A. Bourgery, Société d'édition "Les Belles Lettres", Paris, 1923 , t. II, pp. $47 / 8$. 


\title{
A pesquisa em Direito: \\ Um testemunho sobre a pesquisa em grupo, o método "Sprechstunde" e a iniciação científica na pós-modernidade ${ }^{1}$
}

\author{
Cláudia Lima Marques
}

Doutora em Direito (Heidelberg), Mestre em Direito (Tübingen), Especialista em Integração Européia (Saarbrücken), Alemanha, Prof. Adjunto da Faculdade de Direito da Universidade Federal do Rio Grande do Sul, Depto. de Direito Público e Filosofia do Direito.

“...any viable education theory has to begin with a language that links schooling to democratic public life, that defines teachers as engaged intellectuals and border crossers, and develops forms of pedagogy that incorporate difference, plurality, and the language of the everyday as central to the production and legitimation of learning....Postmodern educational criticism offers the opportunity for a discursive practice, works in the interest of mankind... acknowledging difference as the basis for a public philosophy that rejects totalizing theories that view the Other as a deficit, and providing the basis for raising questions the dominant culture finds too dangerous to raise."(ARANOWITZ/GIROUX,Postmodern Education-Politics, Culture \& Social Criticism, University of MinnesotaPress, Mineapolis, 1993, p. 187e 188).

\section{Introdução}

12 inquietude, a curiosidade, o interesse pelo novo são características normais de quem está a aprender, de quem está desenvolvendo e acumulando conhecimentos, como os alunos de Direito de qualquer Universidade brasileira. Penso ser possivel direcionar e utilizar esta força de inquietude e de dúvida para a pesquisa científica, para a beleza da descoberta e da explicação da realidade, para o prazer de construir o pensamento, de desenvolver o raciocínio crítico, dedutivo ou indutivo, o prazer de desco-

brir a solução de um caso ou um problema da vida, para reconstruir o respeito e a admiração pelas descobertas e caminhos dos juristas que nos antecederam, para conhecer e acompanhar as novas descobertas e os novos caminhos dos juristas de hoje, para desenvolver uma visão própria da realidade, para admirar e descortinar a lógica - racional ou sentimental- das atuais soluções jurídicas para os velhos e novos conflitos e problemas de nossa sociedade.

${ }^{1}$ Trabalho apresentado no IX Encontro Nacional do CONPEDI -Conselho Nacional de Pesquisa e Pós-Graduação em Direito, PUC-RIO, no dia 19 de setembro (GTR4-Cooperação Interinstitucional e Programa Simon Bolívar) e discutido no dia 20 de setembro (GTEl-Direito Internacional e Integração regional: os efeitos da globalização). A autora gostaria de agradecer (e homenagear) ao Prof. Michael R. Will e ao Programa DAAD/CAPES pelo apoio recebido durante meu aprendizado na Alemanha. 
Pesquisar é pensar, refletir, ler, discutir, perguntar, criticar, descobrir, enfim, é buscar uma visão, uma explicação, uma idéia, uma solução para as perguntas e problemas que nos movimentam e interessam; é construir, formar e organizar um pensamento (próprio ou não); é alcançar um resultado que apazigúe ou que confirme a inquietude inicial.

Se pesquisar em Direito é algo tão simples e hermenêutico, quase natural e intrínseco a nossa ciência, porque é tratado como algo tão complexo, egoístico e exclusivo de poucos? As explicações são muitas, de jogos de poder, ${ }^{2}$ à influência do positivismo e do empirismo em nosso pensamento científico. ${ }^{3}$ Parece-me útil, pois neste IX Encontro Nacional do CONPED -Conselho Nacional de Pesquisa em Direito, refletir sobre esta pergunta e, analisar as respos-

tas atuais com uma visão pós-moderna. ${ }^{4}$ Quem sabe, assim poderei contribuir um pouco para uma - a meu ver, ainda necessária - reconstrução e redirecionamento de nossos próprios preconceitos em relação à pesquisa em Direito e pesquisa realizada em nossas Faculdades de Direito.

Neste sentido, gostaria de dividir minhas reflexões em duas partes. A primeira analisando a pesquisa em Direito na Universidade e as dificuldades de pesquisar hoje em Direito, conscientes da crise da pós-modernidade. ${ }^{5}$ A realidade é que, na Universidade e nas outras ciências, considera-se pouco a pesquisa realizada em Direito. Mister, pois, refletir o porquê deste preconceito contra a pesquisa jurídica, miste defender a pluralidade de métodos em pesquisa, ${ }^{6}$ especialmente em tempos pós-mo-

${ }^{2}$ Assim TRINDADE, Hélgio, Universidade, Ciência e Poder, in Universidade em ruinas, 2ed., Ed. Vozes, 2000 p. 14 a 21 .

${ }^{3}$ Assim ensina SAMAJA, Juan, Aportes de la metodologia a la refexión epistemológica, in in La posciencia-El conocimento científico en las postrimerías de la modernidad, Esther Díaz (Editora), Ed. Biblos, Buenos Aires, 2000 , p. 151

${ }^{2}$ Esta análise pós-moderna é uma homenagem ao mestre orientador de Doutorado, Prof. Dr. Dr.h.c. Erik Jayme, da Universidade de Heidelberg, que em seu brilhante curso de Haia lançou sua teoria dos reflexos da pós-modernidade no direito. Veja JAYME, Erik, Identité culturelle et intégration: Le droit internationale privé postmoderne in: Recueil des Cours de l' Académie de Droit International de la Haye, 1995, II, pg. 36 e seg.

${ }^{5}$ Sobre os reflexos da atual pós-modernidade, na pesquisa e na ciência do Direito, veja meu artigo A crise científica do Direito na pós-modernidade e seus reflexos na pesquisa, in Cidadania e Justiça-Revista da AMB, ano 3, n. 6 (1999), p. 237 e seg (republicado na Revista Arquivos do Ministério da Justiça) e no livro de Anais da Conferência , Rumos da Pesquisa-Múltiplas Trajetórias, Organizadoras Maria da Graca KRIEGER e Marininha Aranha ROCHA, Porto Alegre: Pró-Reitoria de Pesquisa/Ed.UFRGS, 1998, p. 95 a 108.

${ }^{6}$ Inspiro-me neste trabalho no livro de ARANOWITZe GIROUX (ARANOWITZ, Stanley e GIROUX, Henry A., Postmoder Education - Politics, Culture \& Social Criticism, University of Minnesota Press, Mineapolis, 1993) que demonstra como os paradigmas pós-modernos, como o pluralismo e o fim das metanarrativas absolutas e universais para todas as ciências (como por exemplo, o fim da tradicional metarrativa da necessidade do uso de métodos empíricos para uma pesquisa ser considerada "cientifica"), pode e deve ser usada para discutir a crise na educação e os nossos métodos universitários atuais: "Regardless of whether critics see postmodemism as pastiche, parody, or serious cultural criticism, the postmodern temperament arises from the exaustion of the still prevalling intellectual and artistic knowledge and the crisis of the institutions charged with their production and transmission - the schools. The "nihilism" of postmodem discourse does not signify ist rejection of ethir politisc, and power only its refissal to accept the givens of public and private morality and the judgements arising from the Of cour, a Of course, we gofurher in this book and arge that crilcal postmodemism provides a political and pedagogical basis no only for challenging current forms of academic hegemony but also for deconstructing conservative forms of postmodernism in which social life merely made over to accommodate expanding fields of information in which reality collapses into the proliferation of images. At its bests, a critical postmodernism signals the possibility for not only rethinking the issue of educational reform but also creating a pedagogical discourse that deepens the most radical impulses and social practices of democracy itself." (ARANOWITZ, Stanley e GIROUX, Henry A., Postmodern Education - Politics, Culture \& Socia Criticism, University of Minnesota Press, Mineapolis, 1993, p. 187).

Revista da Faculdade de Direito da UFRGS, v. 20, Outubro/2001 dernos, ${ }^{7}$ mister construir em atitude afirmativa ${ }^{8}$ recusando-se a sermos nós, juristas-pesquisadores, mais um instrumento de exclusão de preconceito em relação aos nossos colegas, das Universidades e das Instituições da sociedade, ${ }^{9}$ pesquisadores em Direito (Parte I). A segunda parte será dedicada aos problemas e dificuldades de se "ensinar a pesquisar em $\mathrm{Di}$ reito". Em nossa realidade acadêmica, a pesquisa extraclasse de estudantes, a pesquisa de iniciação científica, sem finalidade de nota ou para trabalhos de conclusão, é ainda muito pouco realizada no país. Como tive a sorte e o privilégio de ter sido pesquisadora-junior da Universidade de Saarlandes, do Instituto Max-Planck, na Alemanha e do Instituto Suíço de Direito Comparado, e, como desde minha entrada na Universidade Federal do Rio Grande do Sul, há 10 anos, tenho trabalhado em iniciação científica e pesquisa em grupo, penso poder contribuir à discussão com um testemunho. Quero

relatar aqui um pouco a forma, o método, as dificuldades e os resultados deste trabalho de pesquisa em grupo na Faculdade de Direito da UFRGS. Este testemunho tem como finalidade não só abrir a metodologia que desenvolvi para ensinar a pesquisar e que denominei "Sprechstunde", mas principalmente, como se trata de um caminho misto, altamente influenciado pelos métodos alemães e nãoconvencionais no Brasil, de ajudar a refletir sobre a necessária abertura de espírito em relação aos esforços dos colegas em iniciação científica e em ensino da pesquisa. Talvez, assim, possamos refletir um pouco sobre o normal "egoísmo" dos professorespesquisadores e do "fechamento" da redoma da pesquisa. ${ }^{10}$ Talvez, assim, possamos iniciar uma contratendência, de trabalho mais cooperativo, interdisciplinar, em grupo, respeitoso das diferenças e da pluralidade atual, em uma espécie de "criticismo educacional pós-moderno"11

${ }^{7}$ Defendo a idéia que a crise da pós-modernidade no Direito advém também da modificação dos bens economicamente relevantes, que na idade média eram os bens imóveis, na idade moderna, o bem móvel material e que na idade atual seria o bem móvel imaterial ou o desmaterializado "fazer" dos serviços, do soft ware, da comunicação, do lazer, da segurança, da educação, da saúde, do crédito. Se só este bens imateriais e fazeres que são a riqueza atual, os contratos que autorizam e regulam a transferência destas "riquezas" na sociedade também têm de mudar, evoluir do modelo de dar da compra e venda para modelos novos de serviços e dares complexos, adaptando-se a este desafio desmaterializante "pós-moderno". Veja nosso livro, Contratos, p.. 89 e seg. Os sociólogos preferem estudar o fenêmeno na mudança dos meios de produção: pré-industrial, industrial e pós-industrial ou inform o fentron inform o fentis Manuel, The rise of the network society, vol. I, The Inform Massachusetts, 1996/1999, p. 14 e seg.

${ }^{8}$ Segundo ROSENAU, Pauline Marie, Post-modernism and the social sciences, Princeton Univ. Press, Princenton, 1992, p. 117. Na classificação de ROSENAU, p. 53, seriam "skeptical" pós-modernos, para contraponto aos "affirmative" pós-modernos (ROSENAU p. 57), estes últimos clamam por reconstrução e utilização de parte das metanarrativas da modernidade, como a posição defendida neste artigo.

${ }^{9}$ Mister frisar que a pesquisa em Direito näao está restrita às Faculdades e Universidades, ao contrário, após minha experiência em Institutos de pesquisa na Alemanha e Suíça e no Brasilcon-Instituto Brasileiro de Política e Direito do Consumidor, considero que no futuro a pesquisa, também no Brasil, se fará tanto nas universidades como nas organizações e Instituições do Terceiro Setor.

${ }^{10}$ Defendi o pluralismo na pesquisa escrevi no trabalho "A crise", p. 95 e seg.

${ }^{11} \mathrm{~A}$ expressão "Postmodern educational criticism" é um tanto incongruente, pois a crítica é típica da modernidade, mas esta expressão foi usada por ARANOVITZ/GIROUX, p. 188, para descrever sua teoria de reconstrução da educação, de forma democrática, plural e crítica em plena pós-modernidade: "Postmodern educational criticism points to need for constructing a critical discourse to both constitute and reorder the ideological broader parameters of a radical democracy"

Revista da Faculdade de Direito da UFRGS, v. 20, Outubro/2001 
também em Direito. ${ }^{12}$

compreensão da realidade e fundamentação do conhecimento, um modo empírico: "El pensamento científico abandonó la incuestiona-

\section{A pesquisa em Direito na Universidade}

Como ensina Pádua, em "um sentido amplo, pesquisa é toda atividade voltada para a solução de problemas, como atividade de busca, indagação, investigação, inquirição da realidade, é a atividade que vai nos permitir, no âmbito da ciência, elaborar um conhecimento, ou um conjunto de conhecimentos, que nos auxilie na compreensão desta realidade e nos oriente em nossas ações."13

Durante os séculos XVI e XVII assentaram-se as bases epistemológicas e metodológicas do saber científico moderno, ${ }^{14}$ no qual Galileu Galilei, Isaac Newton e Johannes Kepler são considerados precursores, e que resultou na constituição de um modo novo de pensamento medieval para opornele la legitimidad y la fuerza de los hechos empíricos. La razón vinculada con la experiencia permitió el conocimiento de los fenómenos físicos natureales. La observación, la experimentación y la medición fueron las metodologías fundamentales que facilitaron esta fructifera relación entre teorías y hechos." 15

Os êxitos alcançado nas ciência exatas permitiram aos pensadores do século XVII transferir esta visão "científica" para as análises dos fenômenos sociais, forçando as ciências sociais e aplicadas, ${ }^{16}$ como o Direito, para ter "validade" e alcan çar a "verdade", a utilizar estes métodos. ${ }^{17}$ Estava aberta a crise do método de pesquisa em Direito.

${ }^{12}$ Para alguns, esta é uma tarefa muito difícil, que exige uma volta ao pensamento epitesmologico. Assim o mestre argentino Carlos Alberto Ghersi (GHERSI, Carlos Alberto, Tercera Via-Âmbito Jurídico, Ed. Gowa, 2000), considera que a pósmodernidade construiu um perigoso subjetivismo jurídico e uma metodologia abstrata de ensino, que abstrai da realidade e quivition como um fim em si mesmo (p. 44), a destruir a própria validade e função social do Direito (p. 45). Prega o autor uma contratendência (p. 33), que "el derecho debe enseñarse como fenómeno social complejo" e com recurso às outras ciências pois "definir la frontera de una ciencia, es limitar la investigación, es no permitir la consubstanciación o entrecruzamento de los saberes, lo social es un todo inescindible, pues apunta a la humanidad en comunidade, parcializada en Estados o globalizada en un solo mundo"(p. 33 e 34) e conclui: "Pensamos que a partir de involucrar el derecho con los saberes que están en lo social, mostramos aspectos de las normas que las sumergen en un mundo de contradicciones y de causalismos; la contextuación enfrenta así a la abstracción individualista, es la

${ }^{13}$ Assim define pesquisa, PÁDUA, Elisabeth Matallo Marchesini de, Metodologia da pesquisa- Abordagem teórico-prática, Ed. Papirus, 2.ed, Campinas, 1997, p. 29

${ }^{14}$ Assim ensina Trindade, op. cit., p. 14

${ }^{15}$ LUQUE, Susana de, El objeto de estudio en las ciencias sociales, in La posciencia-El conocimento científico en las postrimerías de la modernidad, Esther Díaz (Editora), Ed. Biblos, Buenos Aires, 2000, p. 223. corriente de reacción o su contratendencia."(p. 37).

${ }^{16}$ Sobre o tema das especificidades das áreas das ciências e a cada vez maior distinção entre "ciência básica" e "ciência aplicada", veja síntese do congresso,REGNER, Anna Carolina K. P. , O fazer cientifico: as especificidades das áreas e uma nova agenda para a ciência, in Rumos da Pesquisa-Múltiplas Trajetórias, Organizadoras Maria da Graça KRIEGER e Marininha Aranha ROCHA, Porto Alegre: Pró-Reitoria de Pesquisa/Ed.UFRGS, 1998, p. 273.

${ }^{17}$ Assim LUQUE, La posciencia, p. 223: "Los éxitos alcanzados en el ámbito de las ciencias físicas impulsionaron a los pensadores del siglo XVII a trasladar la mirada científica hacia dos fenómenos sociales... [las ciencias sociales] sólo alcanzarían la verdad en la emedidad en que siguieran el modelo de la físico-matemática..."

Revista da Faculdade de Direito da UFRGS, v. 20, Outubro/2001

A) Dificuldades da pesquisa em Direito e do diálogo Universitário em tempos pós-modernos

O termo "método", usado no contexto da pesquisa científica, tem um duplo significado: a) pode evocar os procedimentos para obter um conhecimento, para descobri-lo, para conhecê-lo, para investigá-lo e b) pode evocar os procedimentos para "validar" ou "justificar" um conhecimento, uma assertiva, um resultado que já se sabe. ${ }^{18}$

A dificuldade básica da pesquisa em Direito é seu método, apesar de ser polêmico também seu resultado. ${ }^{19}$ Efetivamente, em Direito, é polêmico tanto o método de pesquisa (método de investigación) ${ }^{20}$ em si, quanto o método de validação da pesquisa jurídica (método de justificación) ${ }^{21}$ A primeira crise foi de seu método de validação. Nos séculos XIX e $\mathrm{XX}$, o Wienerkreis, o Círculo de Viena com Carnap $^{22}$ e o fundador da sociologia empírica e do método positivista, Auguste Comte, ${ }^{23}$ acabaram por defender, contra toda metafísica e especulação, que somente o que se podia explicar positivamente e empiricamente teria valida-

de científica. Isto teve enorme repercussão na Filosofia, na Religião e no Direito. Inicialmenteo Direito não mudou seus métodos de pesquisa, de procura, de investigação e de "descoberta" dos conhecimentos, continuou utilizando o método hermenêutico (dogmático e dedutivo) ${ }^{24}$ típico desde os estudos dos livros romanos na Idade Média, o que resultou em uma grande crise de validação (ou de justificação) para a pesquisa em Direito, ajudando no triunfo do método positivista, único considerado "científico" à época. ${ }^{25}$

\section{O método hermenêutico e o menosprezo pela pesquisa em Direito: a falta de validação ou justificação dos métodos qualita- tivos}

Por muito tempo, os pensadores menosprezaram a importância e mesmo a possibilidade de se pesquisar em Direito. ${ }^{26}$ Sem querem repetir esta discussão estéril (e hoje felizmente

${ }^{18}$ Assim ensina SAMAJA, Juan, Aportes de la metodologia a la refexión epistemologica, in in La posciencia-El conocimento científico en las postrimerías de la modernidad, Esther Díaz (Editora), Ed. Biblos, Buenos Aires, 2000, p. 151.

${ }^{19}$ Os hoje denominados produtos da pesquisa em Direito são incialmente os mesmos das outras ciências: livros, artigos, estudos, relatórios, palestras, conferências etc. Mas também os resultam indiretamente da pesquisa em Direito o próprio "objeto" ou Direito, uma lei, um Tratado, uma doutrina nova, um parecer opinativo ou consultivo, um trabalho forense, uma decisão de líder. Estes são normalmente desconsiderados como produtos da ciência, pois fáticos-jurídicos.

${ }^{20}$ Segundo ensina GIANELLA, p. 78: "[Los métodos de investigación]... están dirigidos al incremento del conocimiento, a conocer neuvos hechos, propriedades, relaciones y regularidades.” (GIANELLA, Alicia E., Introduccion a la epistemologia y la metodologia de la ciencia, Ed. da la Universidad Nacional de la Plata, La Plata, 1995, p.78).

${ }^{21}$ Segundo ensina GIANELLA, op. cit., p. 78: "[Los métodos de validación o justificación] tiene por función ejercer una espécie de "control de calidad" de los conocimientos, evaluar las hipótesis y teorías desde los fundamentos que ofrecen."

${ }_{22}^{2}$ Assim ensina SAMAJA, op. cit., p. 152.

${ }^{23}$ Assim ensina SAMAJA, op. cit., p. 152.

${ }^{24}$ Assim as palavras clássicas de Reinhold Zippelius: "Der Gegenstand bestimmt die Methode", ZIPPELIUS, Reinhold, Juristische Methodenlehre, 5. Aufl., Beck, München, 1990, p. 1

${ }^{25}$ PÁDUA, op. cit., p. 31

${ }^{26}$ Veja sobre o tema as reflexões de ZITSCHER, Harriet Christiane, Como pesquisar?, in Revista da Faculdade de Direito da UFRGS, vol. 17(1999), p. 103 e seg., que distingue entre pesquisa conceitual/dogmática e pesquisa empírica, também no Direito. 
quase superada), ${ }^{27}$ gostaria apenas de destacar que esta visão é típica da mono-metodologia da idade moderna e não mais condiz com o pluralismo de métodos ${ }^{28}$ da idade atual ou pósmoderna. ${ }^{29}$

Como ensina Pádua: "Até meados do século $X X$, considerou-se como científico o conhecimento produzido a partir das bases estabelecidas pelo método positivista, apoiado na experimentação, mensuração e controle rigoroso dos dados (fatos), tanto nas ciências naturais como nas ciências humanas. Associou-se a idéia de cientificidade à pesquisa experimental e quantitativa, cuja objetividade seria garantida pelos instrumentos e técnicas de mensuração e pela neutralidade do próprio pesquisador frente à investigação da realidade. Com o desenvolvimento das investigações nas ciências humanas, as chamadas pesquisas qualitativas procuraram consolidar procedimentos que pudessem superar os limites das análises meramente quantitativas. A partir de pressupostos estabelecidos pelo método dialético, e também apoiadas em bases fenomenológicas, pode-se dizer que as pesquisas qualitativas têm se preocupado com o significado dos fenômenos e processos sociais, levando em consideração as motivações, crenças, valores, representações sociais, que permeiam a rede de relações sociais. Como estes aspectos não são passiveis de mesuração e controle, nos moldes da ciência dominante, sua cientificidade tem sido freqüentemente questionada." 30

Relembre-se, porém, que na Idade Média, o método científico era exclusivamente hermenêutico. Quando surgiram as primeiras Universidades, a hermenêutica é a ciência por excelência, ciência da compreensão e da interpretação dos textos, das escrituras e das leis. As três primeiras Faculdades organizadas foram justamente de Teologia (Filosofia), Direito e Medicina. ${ }^{31}$

O Direito, Teologia e Filosofia constroem seus conhecimentos, sua ciência, seu saber de forma hermenêutica. É historicamente, pois, recente considerar-se científico apenas o método empírico, da reação de Galilei até a formulação do empirismo por Locke e outros. Como vimos anteriormente, é somente nos séculos XIX e XX que chegarão os pensadores a considerar o método empírico, mais afeito às ciências exatas e ciências outras do que ao Direito, como o único científico, em uma visão perfeccionista típica das crenças universais e absolutas da idade moderna. ${ }^{32} \mathrm{O}$ método hermenêutico e tradicional do Direito causa espécie, é considerado problemático, não científico ou não-válido. É preciso fugir deste método, separar-se, é preciso medir, comparar, preparar estudos empíricos e quantitativos sobre a realidade, para que a pesquisa em Direito seja científica.

Passa-se a menosprezar a forma de produção do conhecimento jurídico até então existente, menosprezam-se os juristas e doutrinadores desta época, como não-científicos. Força-se o Direito a mudar, a usar métodos outros e com exclusividade, como se a comple-

${ }^{27}$ Assim, bastante pós-moderna, REGNER, op. cit., p. 274.

${ }^{28}$ Sobre pluralismo de métodos, como reflexo nessário dos tempos atuais, veja JAYME, Curso, p. 36 e seg.

${ }^{29}$ Veja uma bela defesa do pluralismo, in SILVA, Tomaz Tadeu, A produção social da identidade e da diferença, in Identidade e Diferença, Coord. SILVA, Tomaz Tadeu, Ed. Vozes, São Paulo, 2000, p. 73. Veja também excepcional sobre pluralismo no Direito, FRIEDMAN, Lawrence, The Republic of Choice, Cambridge, Harvard University Press, 1994, p. 11 e seg. Como explica Vattimo em sua introdução, " $O$ pós de pós-moderno indica, com efeito, uma despedida da modernidade...", veja VATTIMO, Gianni, o fim da modernidade- niilismo e hermenêutica na cultura pós-moderna, São Paulo, Martins Fontes, 1996, p. VII.

${ }^{30}$ PÁDUA, op.cit., p. 31.

${ }^{31}$ Veja sobre a universidade medieval, TRINDADE, op. cit., p. 12

${ }^{32}$ PÁDUA, op. cit., p. 31.

Revista da Faculdade de Direito da UFRGS, v. 20, Outubro/2001 xa realidade social pudesse ser compreendida e captada apenas pelos métodos empírico e de pesquisas quantitativas.

Em nossas Universidades ainda hoje encontramos alguns que pensam que o caráter científico (da pesquisa) depende do uso de métodos empíricos. Criticam os juristas e seus métodos, criticam sua falta de dedicação à pesquisa, à Universidade, sua baixa produção "científica", sua preocupação com a prática, sua falta de profissionalismo. ${ }^{33}$ Mal ou bem este menosprezo estrutural pelo método hermenêutico usado no Direito contribuiu para o isolamento (e fechamento) do pensamento, do discurso e das atividades científicas dos juristas nas Universidades. Se nos séculos XVIII e XIX, o Direito era ciência de destaque e os juristas consistiam na elite pensante daquelas sociedades, no século XX, a partir da década de 60, com a reforma das universidades e com um novo "cientifismo-neutro" imposto as Faculdades de Direito, esta posição científica de destaque, modificou-se, isolando ainda mais nossos predecessores. As Faculdades de Di- reito passaram a valorar e a elaborar seu pensamento científico de forma distinta das demais ciências sociais, ${ }^{34}$ em uma independência de "descompreensão" e falta de diálogo. A pesquisa era individual, por interesse próprio dos docentes ${ }^{35}$ ou comercial das editoras, ${ }^{36} \mathrm{sem}$ chegar aos alunos e muito menos aos colegas de outras áreas. ${ }^{37}$

A avaliação da produção científica oriunda das Faculdades, porém, veio da Universidade, utilizando seus métodos, seus critérios, seu empirismo, suas perguntas ao trabalho realizado pelos juristas, poucas vezes foi este classificado de científico. Chegamos ao ponto de documentos oriundos da universidade considerarem que não havia "pesquisa científica" nas Faculdades de Direito, apesar da representativa produção intelectual, especialmente livros de grande repercussão lá realizados. ${ }^{38}$ Importantes eram estátisticas de "impacto", a repercussão abstrata dos veículos utilizados para publicação nacional e internacional e não as citações ou a repercussão, prática que nossos mestres conseguiram nos Tribunais, na
${ }^{33}$ Efetivamente, TRINDADE, p. 12 comprova que o "profissionalismo" na universidade está intimamente ligado à pesquisa e à dedicação acadêmica, desde o século XVIII: "Com a criação das academias científicas, intensificase a profissionalização das ciências, fato que vai permitir sua inserção nas universidades através da pesquisa. Até o século XVII, o cientista não tem um papel especializado na sociedade, mas a partir dai desencadeia-se uma mudança profunda no sistema de valores e normas universitárias, reconhecendo-se, não sem conflitos, a mudança profunda no sistema de valores e normas universitarias, reconhecentade de uma atividade relacionada com as ciências em geral" (p. 12)
legitidade

${ }_{34}$ Assim OLIVEIRA, Luciano e ADEODATO, João Maurício, O Estado da Arte da pesquisa jurídica e sócio${ }^{34}$ Assim OLIVEIRA, Luciano e ADEODATO, João Maurício, O Estado da Arte da pesquisa juridica e sócio-
jurídica no Brasil, Ed. CJF/CEJ, Brasília, 1996, p. 11: "Há um notório descompasso entre a pesquisa jurídica e o estágio atual" nas outras ciências.

${ }^{35}$ Bastante críticos, OLIVEIRA/ADEODATO, p. 12, usam a expressão “ quase diletante” para descrever a pesquisa das Faculdades de Direito desta época.

${ }^{36}$ Não se pode desconhece o fato do mercado editorial de livros jurídicos estar muito ligado aos nomes da academia. Veja no Brasil, a tradição em publicações dos professores, por exemplo, da Faculdade Largo de São Francisco da USP.

Francisco da USP.
${ }^{37}$ OLIVEIRA/ADEODATO, p. 11, comprovam que a pesquisa jurídica está quase toda concentrada nas Univer${ }^{37}$ OLIVEIRA/ADEODATO, p. 11, comprovam que a pesquisa jurídica está quase toda concentrada nas Univer-
sidades Públicas, mas que o "debate sobre a pesquisa e o ensino jurídico no Brasil remonta a San Thiago Dantas e Ridades Públicas, mas

${ }^{38}$ Surpreende o número de publicações dos professores da Faculdade de Direito de 1904 a 1975, levantadas no livro de nosso falecido professor SANTOS, João Pedro, A Faculdade de Direito de Porto Alegre- Subsídios para sua História, Ed. Síntese, Porto Alegre, p. 189 a 277 e p. 341 a 370.

de Kuhn e a evolução da epistemologia, veja em português, BOMBASSARO, Luiz Carlos, Ciência e Mudança conceitual- Notas sobre Epitesmologia e História da Ciência, Edipucrs, Porto Alegre, 1995, p. 61 e seg. 
sociedade, nas leis que ajudaram a realizar, nas Constituições e na jurisprudência em geral. ${ }^{39}$ Chegamos a ponto de considerar não-cientistas, os grandes autores e doutrinadores do $\mathrm{Di}$ reito do início deste século. ${ }^{40}$

A incorreção desta lógica de exclusão da produção jurídica da Universidade repousa principalmente em sua visão metodológica reduzida. Um exemplo pode esclarecer: os médicos, geralmente, também dedicam pouco tempo à Universidade, praticam e realizam suas técnicas na sociedade, modificam a realidade e aplicam sua ciência em prol da coletividade. Nunca ninguém, porém, acusaria estes brilhantes professores e práticos da medicina de não-científicos. E porque não? Simplesmente por que Medicina, ao contrário do Direito e da Teologia, sempre utilizou o método empírico. Fáci acusar um hermenêuta de "a-científico", dificílimo acusar um médico, que usa quase que exclusivamente os métodos empíricos, de não científico. Observem, pois, como cala fundo este preconceito, pré-concebido mito de uma só metodologia científica para a pesquisa. Se a

dedicação de nossos predecessores foi pouca à Universidade e à pesquisa então considerada científica, também foi grande a falta de compreensão quanto as especificidades de nossa ciência e métodos tradicionais.

Bem, hoje, nós juristas, superamos os preconceitos, o sentimento de vergonha de nosso próprio método, repensamos nosso papel na Universidade, envidamos esforços pelo pluralismo de pensamento e multiplicação da pesquisa jurídica, aceitamos e utilizamos muitos métodos e discursamos sobre a pesquisa quase de iguais para iguais com as outras ciência sociais. ${ }^{41} \mathrm{O}$ pluralismo de métodos, de abordagens, de procedimentos na pesquisa jurídica é uma realidade. ${ }^{42}$ As pesquisas qualitativas de hoje não usam apenas o método hermenêutico, o comparatista e o histórico, mas há também a análise jurisprudencial qualitativa ou discursiva, o estudo das diferenças no Direito Comparado Pós-moderno, ${ }^{43}$ sem falar no crescente uso das pesquisas quantitativas no Direito, como o estudo de casos, ${ }^{44}$ como a aná-

${ }^{39}$ Como ensina LOPES, José Reinaldo de Lima, Direito e Transformação Social, Belo Horizonte, Ed. Nova Alvorada, 1997, p. 77, tanto o Direito faz parte da cultura, quanto possui sua própria cultura e reflexos típicos na sociedade: "...o sistema jurídico é constituído de uma "cultura". São as atitudes que fazem do sistema um todo. uma unidade, e que determinam o lugar dos aparelhos e das normas na sociedade globalmente considerada. A cultura jurídica engloba tanto as atitudes, hábitos e treinamento dos profissionais quanto do cidadão comum." Tal linha de pensamento possui tradição no Brasil, através da escola de Recife e a influência do „culturalismo jurídico" de Tobias Barreto, sobre o tema veja o nosso Artigo, Cem anos de BGB e o Código Civil Brasileiro, in: Revista dos Tribunaus vol. 741, p. $21 \mathrm{e} \mathrm{seg}$

${ }^{40}$ Sobre a intolerância científica como forma de manutenção de paradigmas, veja KUHN, Thomas, Die Struktur wissenschaftlicher Revolutionen, Suhrkamp, Frankfurt, 1996, p. 38 e seg, sobre o neo-radicalismo, como resposmodernismo, Raza o modermismo, Razao e Religião, Institu Plaget, Lisboa, 1922, p. 70 e seg. O autor denomina esta última vertente neo-ortodoxa de "uina de Kuhn e a evolução da epistemologia, veja em português, BOMBASSARO, Luiz Carlos, Ciência e Mudança conceitual- Notas sobre Epitesmologia e História da Ciência, Edipucrs, Porto Alegre, 1995, p. 61 e seg.

${ }^{41}$ Veja Zitscher, Como pesquisar?, p. 104 a 107.

${ }^{42}$ Veja bom exemplo deste pluralismo no recente livro de VENTURA, Deisi, Monografia Jurídica- uma visão prática, Ed. Livraria dos Advogados, Porto Alegre, 2000, p. 76 a 78.

${ }^{43}$ Veja sobre o tema JAYME, Erik, Visões para uma teoria pós-moderna do Direito Comparado, in Revista dos Tribunais nr. 759 , janeiro 1999 , p.24 a 40

${ }^{44}$ Veja sobre o tema ARAÚJO, Nádia, Formação do jurista pesquisador: Pressupostos e requisitos. Técnicas de pesquisa e ensino na pós-graduação, in Revista Direito, Estado e Sociedade, nr. 14, jan./julho. 1999, PUC/RJ, p. 23 a 37.

Revista da Faculdade de Direito da UFRGS, v. 20, Outubro/2001 lise jurisprudencial ${ }^{45}$ e a pesquisa de campo, em suas mais variadas formas. ${ }^{46}$ Geralmente, hoje optamos por uma combinação de método de investigação. Com a consolidação da pósgraduação no país, a produção científica no Direito aumentou fortemente, ${ }^{47}$ assim como o profissionalismo do professor-pesquisador. $\mathrm{O}$ que parecia um avanço calmo e certo, porém, sofre com a perda de modelo com a crise social da pósmodernidade. ${ }^{48}$ É necessário continuar a construir. ${ }^{49}$

\section{Crise da pós-modernidade: "desconstrução" do Direito e novo acirramento metodológico}

Efetivamente, veio a crise da pósmodernidade, ${ }^{50}$ as incertezas e o caos atingiram todas as ciências. ${ }^{51}$ Por ironia do destino, foi justamente a ciência do Direito uma das que mais se descontruiu com a crise da pós-

${ }^{45} \mathrm{Bom}$ exemplo é a pesquisa quantitativa e qualitativa de jurisprudência gaúcha sobre seguro-saúde e o CDC realizada pelo Grupo de Pesquisa CNPq "Mercosul e Direito do Consumidor", coord. Claudia Lima Marques e Harriet C. Zitscher, conjuntamente com estudantes, cujo Relatório foi publicado na Revista Direito do Consumidor (São Paulo), vol. 29, jan/mar 1999, p. 88 a 105.

${ }^{46}$ Bom exemplo de pesquisa de campo é fornecido por RIZZATTO NUNES, Luiz Antônio, Manual da Monografia Jurídica, 2. ed., Ed. Saraiva, São Paulo, 1999, p. 22.

${ }^{47}$ Veja sobre o tema, trazendo lista das monografias publicadas no país de 1980 a 1995, LEITE, Eduardo de Oliveira, A monografia jurídica, Ed. Revista dos Tribunais, 3. ed., 1997, p. 288 e seg.

${ }^{48}$ Assim MINDA, Garry, Postmodern Legal Movements- Law and Jurisprudence at Century's end, New York University Press, New York, 1995, p. 247 e, conclusão, p. 249: "Academic trends in legal scholarship do not occur in a vaccum, nor are law schools and legal scholars autonomous. To understand what has been going on in contemporary legal theory, one must look to what has been going on at the university... an intellectual and cultural revolution is now under way at American Universities... The crisis of representation, known as postmodernism, has reached the legal academy and it is represented by a new form of postmodern jurisprudence" Veja como ZIMA, Peter, Moderne/Postmoderne, UTB, Francke, Tübingen, 1997, p. 61, identifica nos movimentos neo-liberais conservadores e economicistas (de direita) um dos braços da pós-modernidade. Assim também MINDA p. 83, identifica o movimento conservador de "direita" da análise econômica do Direito como pósmoderno.

${ }^{49}$ Assim também, para todas as ciências sociais, conclui REGNER, p. 276

${ }^{50} \mathrm{Assim}$ manifestou-se ROSENAU, 1992, p. 124: "Legal theory is an arena where post-modern views of epistemology and method have created one of the most serious intellectual crises, questioning the very legitimacy of judicial systems and the integrity of legal studies."

${ }^{51}$ Como antes escrevi, A crise, p. 99: "A realidade denominada pós-moderna (LYOTARD, 1994, p. 13) é a realidade da pós-industrialização, do pós-fordismo, da tópica, do ceticismo quanto às ciências, quanto ao positivismo (HABERMAS, 1992, p. 35); época do caos, da multiciplicidade de culturas e formas, do Direito à diferença, da "euforia do individualismo e do mercado",(GHERSI, p. 27) da globalização e da volta ao tribal. É a realidade da substituič̃o do Estado pelas empresas particulares, de privatizações, do né-liberalismo, de terceirizações, de comuica do Ea , $1994, \mathrm{p} .13)$, de ceticismo sobre 0 geral, de um individualismo necessário, da coexistência de muitas meta-narrativas simultâneas e contraditórias, da perina dos vares modernos, esculpidos pela revolução burguesa e substituídos por uma ética meramente discursiva e argumentativa, de legitimação pela linguagem, pelo consenso momentâneo e não mais pela lógica, pela razão ou somente pelos valores que apresenta (KAUFMANN, 1994, p. 224 ). É uma época de vazio, de individualismo nas soluções (LIPOVETSKY, 1996, p. 7) e de insegurança jurídica, onde as antinomias são inevitáveis e a de-regulamentação do sistema convive com um pluralismo de fontes legislativas e uma forte internacionalidade (JAYME, 1995, p. 36) das relações. É a condição pós-moderna que, com a pós-industrialização e a globalização das economias, ja atinge América Latina e tem reflexos importantes na ciência do Direito. É a crise do Estado do Bem-Estar Social." a América Latina e tem reflexos importantes na ciência do Direito. É a crise do Estado do Bem-Estar Social."

Revista da Faculdade de Direito da UFRGS, v. 20, Outubro/2001 
modernidade, mas uma das últimas a se dar conta sobre os efeitos desta crise em sua ciência, talvez por seu isolamento ainda existente. Como ensina Rosenau, conhecer o fenômeno da pósmodernidade e seus efeitos nas ciências sociais é o melhor caminho para superar seu efeito destruidor: "Postmodernism haunts social science today. In a number of respects, some plausible and some preposterous, post-modern approaches dispute the underlying assumptions of mainstream social science and ist research product over the last three decades. The challenges post-modernism poses seem endless. It rejects epistemological assumptions, refites methodological conventions, resists knowledge claims, obscures all versions of truth, and dismisse policy recommendations. If social scientits are to meet this challenge and take advantage of what post-modernism has to offer without becoming casualities of it excesses, then an adequate understanding of the challenge is essential." 52

Sobre o tema já escrevi de forma crítica e ativista que: "Se o desafio do passado era ver a pesquisa em Direito reconhecida como tal na Universidade, o desafio do presente é superar a crise da pós-modernidade, de forma reconstruir uma razão para a pesquisa jurídica e viabilizar um avançar do Direito no futuro.A reação necessária é, pois, de uma pes

quisa renovada, ao mesmo tempo científica e jurídica, plural e tolerante, como se está tentando fazer na Faculdade de Direito da UFRGS,$^{53}$ apesar das dificuldades. Pesquisa renovada esta que, consciente da crise pósmoderna, possa responder à crescente disputa vazia de formas, métodos e linhas de pensamento, que ameaçam hoje devastar as nossas Faculdades, reduzindo-as em um misto de radicalismo, intolerância e passividade científica no final de século. Pesquisa esta que demonstre que a ciência do Direito ainda possui um valor em si mesmo, que o Direito ainda pode e deve dar respostas aos problemas do homem em sociedade e não só pesquisar sobre seu método, sua ideologia, seu discurso, seus atores, suas relações de poder, isto é, que a ciência do Direito ainda está legitimada a procurar o justo e o eqüitativo, apesar da sua atual e profunda crise de fundamentos.

... Neste sentido, como Rosenau, mister alertar que ao quebrar sua legitimidade como ciência de conduta, a crise pós-modernidade levou a uma desconstrução dos fundamentos do Direito tão profunda que nenhuma teoria ou linha de pensamento mais seria absolutamente válida e a pesquisa teria ficado "sem objeto". ${ }^{54}$ O foco o ponto de concentração seria qualquer outro objeto que não o Direito,

\section{${ }^{52}$ ROSENAU, p. 3.}

${ }^{53}$ Destaque-se que no livro da Pesquisa UFRGS de 1988 a 1992, a Faculdade de Direito aparece com 41 professores, autores de livros e artigos, no Brasil e exterior, denotando que mais da metade dos professores 80 professores da instituição e $70 \%$ dos professores ativos de sala de aula fazem pesquisa e submetem-se à crítica através de publicacões. No livro da Pesquisa UFRGS de 1993 a 1994, este número aumenta para 51 professores-auto $67 \%$ do $67 \%$ dos professores oficialmente ligados à instituição e quase $90 \%$ dos 62 professores ativos de sala de aula fazem pesquisa individual e publicam. Desde 1988, já chegam a seis os grupos de pesquisa oficialmente reconhecidos pelo CNPq. Dois são os nossos pesquisadores A1, contamos com um Mestrado cientificamente muito ativo, assim como multiplicam-se os trabalhos de iniciação científica de acadêmicos orientados por professores de nossa casa; de 3 trabalhos no I Salão para os 32 trabalhos inscritos em 1998, assim como dois prêmios Jovem Pesquisador e vários destaques e menções honrosas nesses dez anos de Salão. Este aumento quantitativo é acompanhado por uma crescente preocupação com a formação acadêmica dos professores, Doutores e Mestres, sensibilizados todos para a pesquisa científica.

${ }^{54}$ Assim ROSENAU, 1992, p. 50

Revista da Faculdade de Direito da UFRGS, v. 20, Outubro/2001 dos sentimentos, do discurso, à literatura ou à economia. ${ }^{55}$ Rejeitada a verdade jurídica, aberto o sistema do Direito, deslegitimado o Direi to e suas instituições, cria-se assim um vazio científico e uma desconfortante igualdade $\mathrm{ci}$ entífica dos discursos, todos iguais ${ }^{56}$ uma vez que todos sem base e subjetivados ou flexibilizados ${ }^{57}$ há uma grande dificuldade para os estudantes e professores identificarem e avaliarem a qualidade das pesquisas e suas contribuições à sociedade e ao Direito.

Esta crise da pós-modernidade é, en verdade, uma mudança na maneira de pensar o Direito a resultar um certo apatismo imobilismo em relação às novidades por part da maioria, combinado com um certo radicalismo por parte de minorias, face aos novos desafios da sociedade pós-moderna. É uma desconcertante crise de ideais e de valores, entre pluralismo e radicalismo de verdades, que tem grande influência no Direito e na pesquisa deste final de século. Como ensina Rosenau, ${ }^{58}$ o vazio e a insegurança nas ciências sociais são grandes: "Post-modernists reduce social science knowledge to the status of stories.. Post-modern methodology is postpositivist or anti-positivist. As substitutes for the 'scientific method', the affirmatives (postmodernists) look to feelings, personal experience, empathy, emotion, intuition, subjective judgment, imagination, as well as diverse forms of creativity and play."

...Como ensina Rosenau ${ }^{59}$, esta fragmentação e desconstrução não pode ser aceita totalmente, uma reação deve existir. Em outras palavras, para evitar o atual vazio do estudo do discurso é necessário um revival do sério estudo da filosofia do Direito. Para combater o vazio das formas metodológicas, é necessário revisitar a especificidade do conhecimento jurídico, ${ }^{60}$ aceitar as bases do Direito como procura do justo e valorizar mesmo seus métodos tradicionais e específicos. ${ }^{61}$ Para combater a guerrilha metodológica, é necessário defender o pluralismo de pesquisas e a tolerância científica, única forma de evitar que os radicais "antimodernos" acabem excluindo vários cientistas que poderiam dar alguma contribuição à criação de um Direito adaptado ao novo milênio. Em outras palavras, há que se superar a visão que o Direito em si, sua metodologia e seu discurso ou a economia seria o único objeto de pesquisa válido. Há que se defender a pesquisa em Direito como contribuição à ciência do Direito, contribuição à procura do justo e da solução dos problemas individuais e sociais atuais, não importando a sua linha de pensamento, se alternativa desdogmatizante, se tradicional ou se conservadora neo-liberal." 62
${ }^{55}$ Veja ROSENAU,1992, p.50 a 52: "Post-modernists in almost every field of the social sciences have been experimenting with a subjectless approach in their inquiries... Rejecting the subject permits them to shift the focus of the inquiry elsewhere..."

${ }^{56}$ ROSENAU,1992, p.77 e p. 89.

${ }^{57} \mathrm{FACHIN}$, Luiz Edson e CARNEIRO, Maria Francisca, Aspectos da avaliação institucional dos programas de pós-graduação em Direito: instrumentos e concepçóes, in Revista de Informação Legislativa, Brasília, ano 35, nr. 137, jan/mar 1998, p. 205.

${ }^{58}$ ROSENAU,1992, p. 91 e p.117.

${ }^{59}$ ROSENAU, 1992, p. 124.

${ }^{60} \mathrm{FACHIN/CARNEIRO,} \mathrm{p.} 205$.

${ }^{61}$ LARENZ, Karl, Methodenlehre der Rechtswissenschaft, 6.Aufl., Springer, Berlin, 1991,p. 6.

${ }^{62}$ Extratos de nosso artigo, "A Crise, p. 96 a 101

Revista da Faculdade de Direito da UFRGS, v. 20, Outubro/2001 
Parece-me, efetivamente, se vamos ser pós-modernos, sejamos pelo menos conscientes de nosso papel na evolução da ciência do Direito, sejamos ao menos pós-modernos afirmativos. ${ }^{63}$ É o momento do revival pós-moderno, plural e tolerannte, dos Direitos humanos refletir-se na própria academia e na liberdade científica de cada um, como forma de construção de uma teoria não-discriminatória e efetiva de harmonia social, teoria de inclusão científica para o Direito no novo século. Repito: O desafio neste início de século não é mais a simples inclusão da pesquisa jurídica nas ciências sociais, mas o seu desenvolvimento como efetiva contribuição à sociedade ${ }^{64} \mathrm{e}$ à Justiça , não ao cientificismo e à burocracia.

\section{II - Ensinando a pesquisar: $O$ Grupo de Pesquisa CNPq "Mercosul e Direito do Con- sumidor" e o desenvolvimen- to da metodologia de ensino da pesquisa "Sprechstunde"}

\section{A. Metodologia de pesquisa em grupo "Sprechstunde"}

Desenvolvi uma metodologia para ensinar a pesquisar e parar pesquisar em grupo, compilando influências alemãs e brasileiras, $o$ resultado final é mais uma experiência do que um caminho, um método, mas de qualquer maneira quero agora compartilhar este modelo de erros e acertos. Como antes observei, fui monitora na Faculdade de Direito da UFRGS, e ainda aluna pude colaborar com uma pesquisa quantitativa realizada pelo Prof. Dr. Michael R.

${ }^{63}$ ROSENAU, 1992, p. 57.

${ }^{64} \mathrm{GELLNER}$, Ernest, Pós-modernismo, Razão e Religião, Instituto Piaget, Lisboa , 1992, p. 60.

Revista da Faculdade de Direito da UFRGS, v. 20, Outubro/2001
Will, professor da Universidade de Saarbrücken, durante os seus seis meses de estadia em Porto Alegre. Estas duas experiências confirmaram minha vocação para ser professora e para continuar na pesquisa. A convite do Professor Will fui para a Alemanha, realizei um Mestrado e uma especialização e ainda tive a sorte e honra de ter sido sua pesquisadora-assistente por seis meses na Universidade de Saarlandes, assim como pesquisadora contratada por 3 meses no Instituto Max-Planck, de Freiburg im Breisgau, trabalhando com o Professor Hühnerfeld, além de ser colaboradora científica por três meses no Instituto Suíço de Direito Comparado, em Lausanne, trabalhando com o Professor Alfred von Overbeck. Ao retornar para o Brasil, queria compartilhar estes ensinamentos. Procurei basear-me nos modelos europeus que observei, adaptando-os à nossa realidade e necessidade.

A solidão da pesquisa, da elaboração dos trabalhos é inevitável. Aprendi, porém, que é possível crescer em conjunto, observando e compartilhando os trabalhos prévios de elaboração das produções científicas com os grandes mestres. Observei que de um talentoso "aprendiz" de pesquisa se pode fazer um brihante sucessor, e que vários aprendizes motivados mantém e renovam importantes escolas do pensamento. Efetivamente, eu própria aprendi muito com a precisão, rigorismo e sinceridade intelectual destes grandes professores-pesquisadores e fundar um grupo de pesquisa foi a maneira que encontrei para multiplicar estes ensinamentos. Desde minha entrada na Universidade Federal do Rio Grande do Sul, há 10 anos, tenho trabalhado em iniciação científica e pesquisa em grupo. Ao desenvolver uma metodologia própria para ensinar a pesquisar nomeie em sua homenagem, face à acessibilidade e à grandeza de meus mestres europeus: "Sprechstunde".

\section{Compilando influências ale- mãs e brasileiras para formar a "Sprechstunde"}

A monitoria é uma boa experiência para quem quer ser professor, mas a pesquisa é uma boa experiência para qualquer futuro profissional do Direito. A pesquisa é um elemento diferenciador, tão ou mais importante hoje, quando tantos estudam Direito e apenas passam nas Faculdades, como números à procura de um diploma autorizador do exercício de uma profissão. Saber pesquisar é um instrumento de criação de competência em Direito, é um caminho para a excelência e a especialização cada vez mais procuradas no mercado, é uma base a mais para a formação própria, a suṕrir falhas eventuais nos curricula das Faculdades ou os limites dos nossos próprios mestres e de nossas bibliotecas. Saber pesquisar é uma maneira para enfrentar qualquer desafio novo em Direito e a vida dos profissionais é uma constante renovação destes desafios.

Particularmente, considero que a pesquisa foi meu caminho de destaque e de excelência. Quando o professor Michael Will me convidou para com ele levantar e pesquisar todos os casos de adoção internacional em Porto Alegre nos últimos 5 anos, poderia ter dito "não", mas aceitei e isto me descortinou o mundo do Direito. Não há pesquisa em Direito Internacional, porém, sem conhecimento de línguas estrangeiras e neste caso, fui escolhida inicialmente por esta aptidão. ${ }^{65}$ Então no quarto ano da Faculdade tive o prazer de acompanhar o mestre de Saarbrücken, desde a elaboração das fichas de casos e formulários, das fichas de leituras e bibliográficas, até o fotocopiar de todas as fontes e os processos. Observei seu rigor e preciosismo, sua preocupação com os erros,

com a exatidão e exaustão das fontes. Esta primeira pesquisa com casos foi uma experiência impar, que muito me ajudou no futuro, especialmente na escolha de meus temas de Mestrado e Doutorado. Nada melhor para descortinar as perguntas importantes, do que saber o que acontece na prática e quais as falhas o nosso sistema legal ainda possui. Esta pesquisa ajudou-me muito também quando dos trabalhos de elaboração e crítica do Estatuto da Criança e do Adolescente, quando trabalhava na Consultoria Jurídica do Ministério da Justiça. Por ironia do destino, justamente a evolução e a mudança da lei brasileira de 1990 acabou por deixar inédito o trabalho resultado desta pesquisa. De outro lado, esta pesquisa quantitativa e qualitativa ajudou-me decivamente a abrir meus horizontes também para a interdiciplinariedade, pois tive a oportunidade de trabalhar durante um ano com as assistentes sociais e psicológas do então Juizado de Menores. ${ }^{66}$

Já na Alemanha, fui contratada como pesquisadora-junior no Instituto Max-Planck de Freiburg junto ao Prof. Dr. Peter Hühnerfeld. O Instituto, que consiste em uma maravilhosa $\mathrm{Bi}$ blioteca, realiza estudos para o governo alemão e pude participar de dois destes trabalhos de pesquisa, transformados mais tardes em livros, um sobre o aborto e a condição da mulher no Brasil e outro sobre a proteção do meio ambiente no Brasil. Aprendi que o simples levantamento bibliográfico e fichamento das obras já é um momento de grande crescimento para o aluno. Aprender a resumir, a criticar as obras por sua relevância, sua organização, suas notas ou pela origem de suas principais teses, é um valioso exercício, que poupa o tempo do pesquisador sênior (ainda mais em um Brasil que tudo se publica) e enriquece em muito, solidificando, os conhecimentos do pesquisador-júnior. Des-

${ }^{65}$ Assim também ARAÚJO, p. 29

${ }^{66}$ Minhas homenagens à assistente social Sylvia Nabinger, que realizou com os mesmos casos a pesquisa de seu doutorado na Faculdade de Direito de Lyon, França, por seu aopoio e modelo.

Revista da Faculdade de Direito da UFRGS, v. 20, Outubro/2001 
taque-se a sinceridade intelectual deste mestres alemães. Foi muito positivo poder observálos e ajudá-los a elaborar suas notas de rodapé, seu minucioso re-exame das fontes e organização lógica do pensamento. Os pesquisadoresjunior nada escrevem, mas tudo acompanham, e este acompanhar, inclusive em Congressos e em discussões de grupos de pesquisadores, são momentos de grande crescimento. Outro fator a destacar é a liberdade no trabalho de pesquisa, organizado nas horas (inclusive nos finais de semana) e espaços livres e "inspirados" do pesquisador-júnior. Há controle de tarefas, não de horas ou dedicação, que aparecem claras nos resultados concretos do levantamento.

Em Tübingen, tive o prazer de acompanhar o Professor Dr. Wolfgang Knutt Nörr em muitas de suas "Sprechstunden". Chamou-me muita a atenção como este grande historiador do Direito estava lá, todas as semanas, na mesma hora, a nossa disposição, junto com seus assistentes, para aconselhar e tirar dúvidas, para guiar-nos e repassar-nos literatura e tarefas como se isto fosse parte de uma missão. $O$ acesso ao professor-orientador é um fator de segurança. O contato com o mestre, o poder participar das reuniões de Cátedra e observar suas discussões e trabalhos com os assessores, enriquece o aluno. Outra boa experiência na Faculdade de Direito de Tübingen foi ter participado dos "Doktorseminaren", seminários onde os doutorandos expõem suas pesquisas para se submeter às críticas dos professores $\mathrm{e}$ assistentes. A mistura entre ambos, da graduação e da pós-graduação, agradou-me muito. ${ }^{67}$

Já mestre fui contratada para ser colaboradora científica do Instituto Suíço de Direito Comparado em Lausanne, podendo escrever um artigo (Prêmio van Calker), mas tendo que escrever pareceres de Direito Internacional
Privado junto ao Prof. Alfred von Overbeck. Instituto conta, ao total, com cerca de 10 colaboradores, que se reúnem regularmente com o professor coordenador, este e os colaboradores de todos os continentes escrevem juntos os livros do Instituto. Cada colaborador ou pesquisador tem seu tema individual, afeito a sua origem, sua língua materna, sistema jurídico ou religião, e assim todos trabalham com uma finalidade comum, mas individualmente e com pleme muito frutífero, pois estimula a cooperação e o trabalho em grupo, na convergência do objetivo comum, mas valoriza as individualidades e as origens diferentes (contávamos, por exemplo, em 1987, com especialistas sobre os sistemas socialistas, sobre China e Japão, sobre os países muçulmanos, sobre Israel, sobre Austrália e Oceania, sobre o sistema da common reito suíço e direitos da América-Latina).

Ao retornar para o Brasil, em 1988 após, em 1990, ao passar no concurso da Faculdade de Direito da UFRGS, procurei organizar algo semelhante, adaptado as nossas circunstâncias e contextos. Não posso porém deixar de mencionar a enorme influência que os anos de Doutorado, passados no Instituto de Direito Estrangeiro e Direito Internacional Privado da Universidade de Heidelberg, sob a coordenação do Prof. Dr. Dr. h. c. multi Erik Jayme, exerceram em mim. Neste Instituto, observei a preparação das reuniões de redação da Revista IPRAx, onde todos os 26 pesquisadores (seniores e juniores) do Instituto colaboram com material, traduções e artigos. Observei como organizavam em conjunto os congressos - as tradicionais festas de final de semestre- e seminários, como cooperam para cumprir com as tarefas distribuídas pelos 3 professores Diretores, como compartilham o conhecimento com seus "sucessores", sempre na procura da excena liberdade de opinião. Este método pareceulaw, sobre o direito alemão, direito francês, di-

${ }^{67}$ Assim também o testemunho de GUERRA, Willis,Critérios de avaliação e reconhecimento dos cursos de pósgraduação em Direito, Cad. Pós-Grad. Dir. UFPA, Belém, Ed. Especial, out.1999, p. 79

$\frac{\text { graduação em Direito, Cad. Pós-Grad. Dir. UFPA, Belém, Ed. Especial }}{\text { Revista da Faculdade de Direito da UFRGS, v. } 20 \text {, Outubro/2001 }}$ lência e da camaradagem. A organização de um Instituto como o de Heidelberg (que também é uma das mais excepcionais Bibliotecas que conheci) é o ideal de qualquer pesquisador.

Se o resultado final parece-se um pouco com tudo - e não é idêntico a nada que conheci -, resolvi nomear a metodologia com uma expressão alemã, justamente na esperança que fosse algo sólido e frutuoso, como o que observei. Queria bem marcar as influências que sofri: "Hora de aconselhamento", "hora da conversa", "hora de encontro" são algumas possíveis traduções desta expressão alemã que está na porta de cada professor, em cada Faculdade de Direito: "Sprechstunde".

A metodologia de ensino da pesquisa é simples. Repousa sobre três pilares básicos: a) liberdade acadêmica, b) uso positivo do interesse, das tarefas e dos erros, c) Aprender pesquisa, pesquisando e observando.

A liberdade acadêmica está retratada no grupo em dois aspectos: na liberdade do pesquisador-senior em escolher o assunto das pesquisas guarda-chuva e na liberdade de escolha dos temas individuais pelos pesquisadoresjuniores. $\mathrm{O}$ pesquisador-lider determina livremente o tema da pesquisa guarda-chuva, a depender de seu interesse ou necessidade momentânea, ele determina também as tarefas que deverão ser cumpridas pelos pesquisadores juniores e seus prazos, explicando-as. Receber uma tarefa é sinal de confiança no potencial do aluno. Quem pode participar naquela semana, manifesta-se e pede para colaborar, quem não

\section{O resultado final: a "Sprechstunde"}

pode cala ou manifesta o motivo porque não pode participar. Assim valoriza-se a tarefa e o grupo desenvolve uma dinâmica própria de ajuda àqueles que receberam uma tarefa e não podem a cumprir sozinhos. A reunião é toda conduzida pelo líder, que determina a ordem de temas a ser discutidos. Quando as reuniões semanais terminam, o líder coloca-se à disposição dos pesquisadores juniores para tratar de suas pesquisas individuais e aconselhá-los em suas dificuldades. ${ }^{68}$

O método usado distingüe-se de outros grupos de pesquisa por nunca impor leituras obrigatórias, referenciais teóricos ou discutir textos previamente lidos em conjunto. $\mathrm{O}$ crescimento do aluno de iniciação científica é fomentado individualmente, pela dinâmica de cooperação do grupo, pela reincidência das tarefas, nunca por condução do pensamento. Leituras dirigidas, reflexões coordenadas e em grupo dirigem e manipulam o interesse dos alunos, nivelando-os e igualando-os no pensamento O método "Sprechstunde" se assenta justamente na manutenção das diferenças e tendências individuais. Leituras são recomendadas individualmente e nunca discutidas em grupo. Naturalmente, porém, os participantes do grupo acabam por ler a produção intelectual dos professores que participam do grupo, por curiosidade e interesse, não, por imposição. O ritmo de leituras de cada um, o despertar de seus interesses próprios (mais filosóficos, mais ligados à prática, ao direito comparado etc.) é um dos objetivos do método.

A iniciação científica, nas pesquisas guarda-chuva, dá-se por observação, por construção própria e imitação, não é conduzida, nem o método é discutido ou revelado para os alunos, sendo a tarefa de condução metodológica
${ }^{68}$ Como ensina Jeniffer GORE,p. 12, citando Foucault, por vezes ser menos democrático, dar forma e dirigir a conduta dos indivíduos em formação pode ser positivo, pois "nesse sentido, é estruturar o campo possível de ação dos outros".,(GORE, Jeniffer, Foucault e Educação: fascinantes desafios, in SILVA, Tomaz Tadeu, O Sujeito da

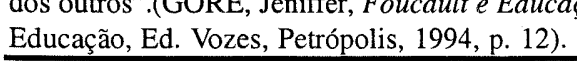

Revista da Faculdade de Direito da UFRGS, v. 20, Outubro/2001 
apenas do líder do grupo. Não há qualquer leitura metodológica indicada, nem qualquer discussão sobre o método entre aluno de iniciação científica e o professor-pesquisador, as leituras metodológicas nascem da necessidade sentida pelo aluno, que é então orientado.

A liberdade acadêmica do aluno se manifesta na escolha de seu tem a individual. Cada aluno, que participar das pesquisas guarda-chuva e das reuniões do grupo, deve escolher um tema, um aspecto, dentre os três tópicos possíveis: "Direito do Consumidor", "Mercosul", "Pós-modernidade jurídica". Cada aluno passa a pesquisar um tema individual, por ele livremente determinado, de acordo com a sua curiosidade, seu interesse e vocação individual. ${ }^{6}$ Neste tema ele prepara um pequeno trabalho oral de 10 a 20 minutos para ser apresentado nos Congressos Acadêmicos do Brasilcon (Instituto Brasileiro de Política e Direito do Consumidor), em caso de intercâmbio internacional (como aconteceu nos anos de 1996, 97, 98 e 99 com congressos acadêmicos organizados na Argentina e no Paraguai) e, especialmente, nos Salões de Iniciação Científica da UFRGS. Os salões de iniciação científica realizam-se há 12 anos na UFRGS, sempre em setembro. Há também o Salão preparatório da Faculdade de Direito da UFRGS, que se realiza, há quatro anos, sempre em agosto, organizado pela Comissão de Pesquisa da Faculdade (que atualmente coordeno) e o Centro Acadêmico André da Rocha. Este foi o pioneiro salão de uma unidade da UFRGS e tem como finalidade divulgar e

mapear a pesquisa na Faculdade, assim como treinar e desinibir os alunos para a apresentação principal na Universidade.

Há liberdade de determinação do tempo de dedicação à pesquisa, pois o importante é a realização da tarefa, não quando e como o aluno a cumprirá. Observei no Instituto Max-Planck que a determinação própria do tempo é uma excelente medida de disciplina e de adaptação. Cada um tem um ritmo para trabalhar e a pesquisa muitas vezes necessita de inspiração ou atenção redobrada. Poder pesquisar apenas uma hora por dia ou 5 horas corridas ou 2 noites na semana, vai depender de cada um e de suas tendências. Parece-me que não deve haver horários obrigatórios para a pesquisa ou para a presença do pesquisador na Universidade. A liberdade é também manifestada na presença não obrigatória nas reuniões do grupo. As reuniões e o contato mais íntimo com os professores-orientadores e mestrandos é um oferecimento. Se o aluno pode e quer aproveitar do oferecimento, excelente, se não, poderá mesmo assim pesquisar.

Especialmente com alunos que trabalham durante a graduação, dois caminhos são possíveis: ou os alunos mantém a comunicação por e-mail e participam das demais atividades do grupo (seminários, encontros, congressos) ou os alunos combinam com seus chefes poder participar de algumas reuniões. Muitos pesquisadores voluntários não tem bolsas de pesquisa, justamente pois fazem estágios ou já são

${ }^{69} \mathrm{Como}$ exemplo podemos observar a diversidade de temas escolhidos pelos alunos mais adiantados (pesquisadores-seniôres) este ano de 2000 nos Salóes de Iniciação Científica da UFRGS e da Faculdade de Direito: 1. Aspectos da Harma Publicidade Abusiva: sua regulamentação no Mercosul - Daniela Correa Jacques, 3. Serviços públicos essenciais e o princípio da continuidade: tutela do consumidor versus Estado-Fornecedor - Fernanda Girardi, 4. As várias nuances do dever de informar no Código de Defesa do Consumidor - Fernanda Nunes Barbosa, 5. Medicamentos genéricos: a liberdade de escolha do consumidor - Laura Ederich, 6. Cláusulas abusivas na Argentina e no Brasil Guillermo Campbell (UFRGS/Univ. de Cordoba, Argentina), 7. Fundamentos da proteção dos direitos da personalidade: a evolução da tutela do direito de imagem na jurisprudência do Tribunal de Justiça do Rio Grande do Sul ( 1984 a 2000) - Bruno Nunes Barbosa Miragem; 8. Internet e Direito - Antonia Espíndola Longoni Klee 9. Garantia globalizada: Análise de um possível leading case - Rafael Garcia; 10. Limitação de juros nos cartões de crédito- Odiléa Oliveira de Almeida Simão.

Revista da Faculdade de Direito da UFRGS, v. 20, Outubro/2001 concursados nos Tribunais. Como as reuniões do grupo são entre $12 \mathrm{~h} 30 \mathrm{~min}$ e 14 horas, quase todos que fazem estágios podem participar. A combinação entre prática e ensino da pesquisa em grupo tem sido muito exitosa, tanto que vários juizes do Rio Grande do Sul hoje dão preferência (ou convidam) os pesquisadores do nosso grupo para assessores, vários escritórios e grandes empresas de Porto Alegre e São Paulo nos telefonam pedindo "pesquisadores" do últimos anos e as cartas de recomendação do grupo têm aberto várias portas profissionais assim como permitido vantagens comparativa ao se concorrer por bolsas de estudo. O grupo oferece também pequenas aulas sobre metodologia da pesquisa, que são dadas pelos mestrandos e professores visitantes DAAD/ CAPES.

O uso positivo do interesse, das tarefa e dos erros, é uma tentativa de respeitar as individualidades e permitir que cada um desenvolva-se no seu ritmo e conforme suas inclinações temáticas (linguísticas e ideológicas). Todos os pesquisadores falam pelo menos uma língua estrangeira e entendem espanhol, que é considerada língua de trabalho no Rio Grande do Sul. $\mathrm{O}$ grupo facilita o acesso dos pesquisadores aos cursos de línguas, através do pedido de bolsas (principalmente de alemão) e recebe a colaboração constante do Instituto Goethe e do DAAD. ${ }^{70}$ As tarefas são valorizadas através da explicação de sua função: o aluno sabe então da importância do levantamento que vai fazer para a pesquisa guarda-chuva do professor ou do grupo, sabe se está procurando uma nota de rodapé ou uma recente crítica publicada da posição defendida do professor, de forma a demonstrar ao aluno como ele está colaborando com o pesquisador-senior. Os erros são critrutiva, mas a demonstrar a valorização do trabalho do aluno, pois se o erro persistir, o trabalho principal pode ser comprometido. Por exemplo, se o aluno fotocopia uma fonte e não indica a Revista da qual retirou o artigo, ou esquece de fotocopiar uma página, o erro será identificado pelo orientador, que pedirá para o aluno corrigir, explicando que assim a fonte está incompleta e não pode ser citada, o que a inutiliza. No Brasil, há certo receio em criticar e mostrar os erros, mas isto pode levar a uma repetição negativa. Na Alemanha, criticar é sinônimo de respeito e seriedade pelo trabalho alheio e próprio, leva ao crescimento, a melhoria. Errar é natural, e é um indício que o aluno se esforçou, está ativo, atuando, pesquisando. Só erra, quem faz. Quem erra, porque está iniciando e se desenvolvendo (em pesquisa), merece saber como acertar na próxima.$^{71}$

Mais do que funcional, o grupo deve servir para convívio. A aprendizagem passa pelo convívio. É o que distingue a escola da Universidade, que é fórum e lugar de convívio. Do modelo do hiwi alemão aprendi a beleza e prazer de conhecer e conviver mais intimamente com os grandes mestres. O grupo de pesquisa é uma maneira de conviver com o professor orientador, mas principalmente de encontrar, acompanhar e ajudar, durante sua estada na cidade, os professores convidados de fora. $\mathrm{Co}$ nhecer um importante professor estrangeiro, um professor de uma outra Universidade, um doutorando, um pesquisador associado é também o descortinar de novos horizontes, novos interesses, novos temas, nova bibliografia, novas idéias, é sobretudo , importante motivação modelo para se continuar a pesquisar, a querer saber sempre mais, a acompanhar este mundo

${ }^{70} \mathrm{Em} 2000$, receberam as bolsas de curta do duração DAAD para cursos de verão em alemão, na Universidade de Heidelberg e Freiburg, Rafael Garcia e Aline Jackisch.

${ }^{71}$ Veja sobre análise do erro (Fehleranalyse) na aprendizagem, EDMONDSON, Willis e HOUSE, Juliane, Einfïhrung in die Sprachlehrforschung, Ed. Francke, Tübingen, 1993, p. 205: "Fehler sind aus dieser Sichtweise also durchaus etwas natürliches, nämlich Indizien dafür, dass der Lerner sich aktiv mit [dem Objekt] auseinandersetzt."

Revista da Faculdade de Direito da UFRGS, v. 20, Outubro/2001 
que passa a estar ao alcance. Receber a tarefa de acompanhar, de ser o "Angel" do mestre visitante , pode determinar o lugar onde o estudante fará seu futuro mestrado e doutorado, pode mudar a perspectiva de vida do pesquisador-júnior. O convívio também deve se fazer no próprio grupo, por isso aprendi em Heidelberg que é preciso encontrar-se em outros momentos e tempos do que apenas na Universidade, especialmente em festas e comemorações.

O terceiro pilar é a prática da pesquisa: aprender, pesquisando. Se o Grupo de Pesquisa funciona como grupo de apoio e levantamento de fontes para os pesquisadores seniors e ao líder, ajudando na elaboração de seus trabalhos, produções científicas e acadêmicas, especialmente para preparar artigos de doutrina, livros, pesquisas quantitativas de jurisprudência, levantar novos leading cases, nova bibliografia e acompanhar a rapidez das modificações legislativas. O Grupo funciona, principalmente, como um laboratório de iniciação científica para os alunos, que assessoram as pesquisas principais (exceção feita à redação dos trabalhos, que é exclusiva dos pesquisadores-seniors), ${ }^{72}$ que levantam o material, discutem a sua relevância, precisão, orientação e atualidade, lêem e elaboram fichas de leituras individuais (do material selecionado como importante pelos pesquisadores seniors), observam as técnicas de delimitação, de precisão, de clareza, de sinceridade intelectual e de reflexão usadas pelos pesquisadores seniores, assim como passam a dominar os instrumentos técnicos da pesquisa (fichas de leituras, fichas de bibliografia, desenvolvimento de fichas de análise de casos, etc.) e instrumentos materiais (domínio dos acervos das Bibliote-

${ }^{72}$ Ao não permitir que os pesquisadores juniores elaborem qualquer texto, nem que ajudem nas pesquisas de Mestrado e Doutorado dos outros pesquisadores seniores, evita-se qualquer tipo de exploração de idéias e textos dos pesquisadores juniores e mantém-se a sinceridade intelectual de trabalhos exigida pelo modelo alemão, permitindo a sua participaçäo somente em algumas atividades básicas e que acompanhem os resultados e observem os métodos de cada pesquisador senior.

Revista da Faculdade de Direito da UFRGS, v. 20, Outubro/2001 e Direito do Consumidor", já com 9 anos de existência prática em Direito Internacional e Direito Comparado.

\section{Evolução e Estrutura atual do Grupo de Pesquisa CNPq "Mercosul e Direito do Con- sumidor"/UFRGS}

O Grupo de Pesquisa CNPq "Mercosul e Direito do Consumidor", que fundei e tenho a honra de liderar, completa agora 11 anos de experiência. Iniciou-se em fins de 1990, com alunos da minha primeira turma de Direito Internacional Privado na Faculdade de Direito da UFRGS, então formandos, com o mesmo método proposto, mas não frutificou. Comó na época era apenas Mestre e Especialista em Direito Comunitário Europeu, fazíamos parte do Grupo de Pesquisa sobre Mercosul liderado pela Profa Dra. Martha Olivar no PPGD da UFRGS, com um sub-projeto intitulado "Mercosul: Realidade Jurídica?", dentro da linha de pesquisa do PPGD/UFRGS "Integração como tarefa para ciência do Direito". Visava o grupo pesquisar apenas os temas momentosos de Direito Internacional Privado ${ }^{73}$ e do nascente Mercosul. ${ }^{74}$ nacionais, através da análise comparativa, da produção em conjunto e na diversidade atual; 2. A vocação intrínseca e estrutural do Direito Internacional, como matéria, e da pesquisa realizada neste campo do conhecimento refletir, desenvolver e ser instrumento da integração regional.

Como forma de unir e organizar estes dois temas usarei minha experiência como líder e fundadora do Grupo de Pesquisa CNPq "Mercosul

${ }^{73}$ Este projeto de Pesquisa, na linha de pesquisa "Integração como tarefa para a ciência do Direito" e teve três fases intituladas: 1991/92- Fase I: Contratos Interhacionais e Mercosul/Circulação de bens, $1992 / 93$-Fase II:Contratos Internacionais e Mercosul/Circulação de pessoas; 1993/94- Fase III: Proteção do Consumidor no Mercosul.

${ }^{74}$ Este projeto de Pesquisa intitulado "Integração do Cone Sul - Realidade Jurídica ?" teve apenas duas fases: 1991Fase I - Mercosul - Aspectos Jurídicos; 1992-1994- Fase II- Mercosul- Realidade Jurídica.

${ }^{75} \mathrm{Os}$ trabalhos individuais apresentados em 1992 tinham como temas: 1. Mercosul e Harmonização: Política de Transportes (Ana Inês Algotarta Latorre); 2. Mercosul - Realidade Jurídica (Luiz Carlos Hagmann); 3. O Contrato de Transporte Internacional de Cargas no contexto da integração Latinoamericana (Sabina Cavalli); 4. O papel do projeto de Código de Conduta da ONU sobre transferência de tecnologia nos países em desenvolvimento (Elaine Ramos da Silva).

${ }^{76}$ Os trabalhos individuais de pesquisa apresentados no Salão de Iniciação Científica da UFRGS, em 1993, tinham

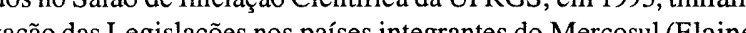
Ras Silva); 2. Respection Ramos no Mercosul (Fabiana d'Andrea Ramos); 4. Direito Internacional Privado - O casamento e as novas uniões (Ana Inês Latorre); 5. Relações de Sucessão no Mercosul (Sabina Cavalli). 
Em 1994, em virtude da saída dos quin- até março de 1996, o grupo ficou sob a coordeto-anistas, resolvi reformular novamente os projetos direcionando-os apenas para a pesquisa em temas envolvendo o Mercosul e o Direito do consumidor interno, de forma a permitir que alunos dos primeiros anos participassem do grupo. Novamente fomos premiados e o grupo renovou-se, ${ }^{77}$ mas como retornei para a Alemanha em fins de 1994 e lá escrevi meu Doutorado nação da Profa. Dra. Martha Olivar.

Com o meu Doutorado em $1996,{ }^{78}$ resolvi formalizar o Grupo e minha posição de pestrutura e o nome atual "Mercosul e Direito do Consumidor". Desde então o Grupo tem sido muito ativo e de 1996 a $2001^{79}$ recebeu mais 25 prêmios de pesquisa de iniciação científiquisador líder junto ao CNPq, dando-lhe a es-

${ }^{n}$ Os trabalhos individuais de pesquisa apresentados no Salão de Iniciação Científica da UFRGS, em 1994, tinham como títulos:1. A informática e o Direito à Privacidade (Angela Dumerque); 2. Direito de Arrependimento no Código de Defesa do Consumidor (Clarissa Costa de Lima); 3. A nova concepção de oferta e clausulas abusivas no CDC (Elaine Ramos da Silva), 4. Os contratos de adesão e as cláusulas abusivas sob a perspectiva do CDC (Ana Letícia Fialho); 5. O sistema de solução de controvérsias no Mercosul (Pedro Montenegro); 6. O dever de informar e a publicidade no CDC (Fabiana D'Andrea Ramos).

${ }^{78}$ Os trabalhos individuais de pesquisa, apresentados no Salão de Iniciação Científica da UFRGS, em 1996, tinham como títulos: 1. O direito da Concorrência no Mercosul (Pedro Montenegro); 2.Mercosul: Arcabouço jurídico e políticas universitárias (Fabio Morosini); 3.Meio ambiente e consumidor (Ana Letícia Fialho); 4. Importância do de Lima); 6. A responsabilidade civil por dano ambiental (Jesus Tupã Silveira Gomes).

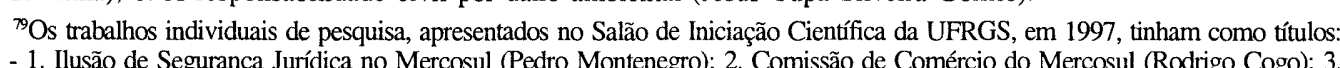
- 1. Ilusão de Segurança Jurídica no Mercosul (Pedro Montenegro); 2. Comissão de Comércio do Mercosul (Rodrigo Cogo); 3. Contratos à distância e a proteção do consumidor (Ariane Freitas); 5. Quantificação do dano moral: determinaç̃o de critérios (Patrícia Peressutti); 6. O conceito de consumidor no CDC (Fernanda Barbosa); 7. Contratos de Seguro-Saúde e o Código de Defesa do Consumidor (Alberto Franco); 8. Direito do consumidor de serviços médicos (Giovanna Maciel); 9. Reconhecimento de Paternidade: Um estudo paralelo entre Brasil e Argentina (Fábio Costa Morosini). Os trabalhos individuais de pesquisa apresentados no Salão de Iniciação Científica da UFRGS, em 1998, tinham como títulos: 1. A publicidade enganosa e abusiva no CDC e suas tendências (Aline Jackisch); 2. Consumo sustentável e o Direito do Consumidor (Bárbara Garcia); 3. Novo regime das incorporaçoes imobiliárias e o CDC (Fernanda Barbosa); 4. A responsabilidade civil no CDC pelo fato do produto e pelo vício do produto (Fabiano Menck); 5. O atual direito do consumidor de serviços no Brasil (Giovana Maciel) 6. O consumidor equiparado. reflexos nos serviços bancários (Fábio Morosini); 7. Contratos à distância e perspectivas de harmonizaçã̃o pesquise (Apresentados no Saño de Inicicoñ Científica Comércio no Mercosul (Rodrigo Cogo). Os trabalhos individuais de de pesquisa apresentados no Salão de Iniciação Científica da UFRGS, em 2000, tinham como títulos: 1 . A spectos da Harmonização do Direito Societário na União Européia: Um exemplo para o Mercosul (Lucas Faria Annes); 2. Publicidade Abusiva: sua regulamentação no Mercosul (Daniela Correa Jacques) 3. Serviços públicos essenciais e o princípio da continuidade: tutela do consumidor versus Estado-Fornecedor (Fernanda Girardi) 4 . As várias nuances do dever de informar no Código de Defesa do Consumidor (Fernanda Nunes Barbosa) 5. Medicamentos genéricos: a liberdade de escolha do consumidor (Laura Ederich) 6. Cláusulas abusivas na Argentina e no Brasil - Guillermo Campbell (UFRGS/Univ. de Cordoba, Argentina); 7. Fundamentos da proteção dos direitos da personalidade: a evolução da tutela do direito de imagem na jurisprudência do Tribuna de Justiça do Rio Grande do Sul (1984 a 2000) (Bruno Nunes Barbosa Miragem); 8. Garantia globalizada: Análise de um possível leading- case (Rafael Garcia); 9. Limitação de juros nos cartões de crédito (Odiléa Oliveira de Almeida Simão). Os trabalhos individuais de pesquisa que serão apresentados no XIII Salāo de Iniciação Científica da UFRGS, que ocorrerá entre os dias 03 e 07 de dezembro próximo, têm como títulos: 1. A Homologação de Sentenças Arbitrais Estrangeiras pelo Supremo Tribunal d'Azevedo); 3. A Proteção dos Consumidores nos Contratos Eletrônicos (Antonia Espíndola Lon Longi Klee); 4 . Alimentos Transgênicos: Ética, Consumo e Meio Ambiente (Laura Oliveira Ederich); 5. Aspectos Jurídicos do "Recall"); e sua Introduç̃o no Direito Brasileiro (Lucas Faria Annes); 6. Análise Crítica do Caso Colgate/Kolynos (Lúcia Carvalhal Sica); 7 . Aspectos Jurídicos da Proteção aos Programas de Computador com Código-Fonte Aberto no Brasil (Maitê de Souza Schmitz); 8.0 Código de Defesa do Consumidor enquanto Lei de Função Social (Marilia Zanchet); 9 . Os Contratos de Previdência Privada e o Código de Defesa do Consumidor (Odiléa Oliveira de Almeida Simão); 10. O Uso da Internet para a Aquisição de Bens e Serviços: alternativa segura? (Rafael Barreto Garcia); 11. Posição Imutâvel do Superior Tribunal de Justiça: A Questão da Importação de Merluzas (Rafael Pellegrini Ribeiro); 12. Comparação Principiologica entre a Affirmative Action e o Código de Defesa do Consumidor (Ricardo Medeiros de Castro); 13. Responsabilidade do Transportador Aéreo por Extravio de Bagagem (Tatiana de Campos Aranovich); 14. O Cartel de Preços e a Defesa do Consumidor (Thales Gonçalves Dell Giustina); 15. As linhas gerais da responsabilidade pelo fato do serviço no CDC e sua recep̧̧ão ou não pelo Tribunal de Justiça a de do Sul - (Thomaz Francisco Silveira de Araújo Santos) ca ${ }^{80}$ incluindo, na área de Ciências Sociais com o trabalho individual: "Comunicação Aplicadas, novamente o PRÊMIO JOVEM de Massa: implicações legais das PESQUISADOR UFRGS, em $1999,{ }^{81} \mathrm{com}$ o trabalho do Pesquisador e Bolsista FAPERGS Fábio Costa Morosini, que mereceu o prêmio máximo do Salão da UFRGS tecnologias emergentes".

O Grupo de Pesquisa $\mathrm{CNPq}$ "Mercosul e Direito do Consumidor", atualmente congrega 12 alunos de graduação

${ }^{80}$ Os prêmios recebidos pelos integrantes do Grupo, em iniciação científica, foram: 1. Pesquisadora PROPESPUFRGS Patrícia Peressutti, DESTAQUE no XI Salão de Iniciação Científica UFRGS e CNPq, Seção III, 1997 2. Pesquisadora FAPERGS Giovana Maciel (PUC), DESTAQUE no IX Salão de Iniciação Científica UFRGS e CNPq, Seção III, 1997 . 3. Pesquisador CNPq/UFRGS Pedro Montenegro- 2. PREMMIO no I Salão de Iniciação Científica da Faculdade de Direito/UFRGS, Bolsa de estudo do Mestrado em Direito/UFRGS para 1998. 4. Pesquisadora CNPq/
UFRGS, Bárbara S. Garcia, DESTAQUE no I Salão de Iniciação Científica do Direito, Faculdade de Direito UFRGS, UFRGS, Bárbara S. Garcia, DESTAQUE no I Salão de Iniciação Científica do Direito, Faculdade de Direito UFRGS,
1998 .5. Pesquisadora CNPq/UFRGS, Ariane Cunha Freitas, DESTAQUE no I Salão de Iniciação Científica do 1998 . 5. Pesquisadora CNPq/UFRGS, Ariane Cunha Freitas, DESTAQUUE no I Salão de Iniciação Cientifica do
Direito, Faculdade de Direito UFRGS, 1998. 6. Pesquisador voluntário Fabiano Menck, UFRGS, DESTAQUE no X Salão de Iniciação Científica UFRGS e CNPq, Ciências Sociais Aplicadas, 1998 . 7. Pesquisadora voluntária Cláudia Travi Pitta Pinheiro - 2. PRÊMIO no III Salão de Iniciação Científica da Faculdade de Direito/UFRGS, 1999, Bolsa de estudo do Mestrado em Direito/UFRGS para 2000. 8. Pesquisadora CNPq/PIBIC Aline Jackisch, Co-orientador o Prof. Sérgio José Porto, DESTAQUE no III Salão de Iniciação Científica do Direito, Faculdade de Direito UFRGS, 1999. 9. Pesquisadora CNPq/PIBIC Laura Oliveira Ederich, DESTAQUE no III Salão de Iniciação Científica do Direito, Faculdade de Direito UFRGS, 1999.10. Pesquisadora PROPESQ/UFRGS Rosaura Macagnan Viau, DESTAQUE no III Salão de Iniciação Científica do Direito, Faculdade de Direito UFRGS, 1999.11. Pesquisador PROPESQ/UFRGS Bruno Nunes Barbosa Miragem, DESTAQUE no III Salão de Iniciação Científica do Direito, Faculdade de Direito UFRGS, 1999. 12. Pesquisadora voluntária Odiléia Oliveira de Almeida Simão,
DESTAQUE no III Salão de Iniciação Científica do Direito, Faculdade de Direito UFRGS, 1999. 13. Pesquisador DESTAQUE no III Salão de Iniciação Científica do Direito, Faculdade de Direito UFRGS, 1999. 13. Pesquisador Fociais Aplicadas, 1999 .14. Pesquisadora voluntária Fernanda Nunes Barbosa (PUC), DESTAQUE no XI Salão de Iniciação Científica UFRGS e CNPq, Ciências Sociais Aplicadas, 1999. 15. Pesquisador CNPq/PIBIC Aline Jackisch, Co-orientador o Prof. Sérgio José Porto, DESTAQUE no XI Salão de Iniciação Científica UFRGS e CNPq Ciências Sociais Aplicadas, 1999. 16. Pesquisador FAPERGS Fábio Costa Morosini (PUC), PRÊMIO JOVEM PESQUISADOR do XI Salão de Iniciação Científica UFRGS e CNPq, Ciências Sociais Aplicadas, 1999. 17. Pesquisadora voluntária, ex-CNPq/PIBIC, Laura Oliveira Ederich, DESTAQUE no IV Salão de Iniciação Científica do Direito, Faculdade de Direito UFRGS, 2000. 18. Pesquisador PROPESQ/UFRGS, Bruno Miragem, DESTA QUE no IV Salão de Iniciação Científica do Direito, Faculdade de Direito UFRGS, 2000.19. Pesquisadora voluntária, Daniela Jacques, DESTAQUE no IV Salão de Iniciação Científica do Direito, Faculdade de Direito UFRGS, 2000. 20. Pesquisadora voluntária, Fernanda Giradi, DESTAQUE no IV Salão de Iniciação Científica do Direito,
Faculdade de Direito UFRGS, 2000. 21. Pesquisador CNPq/UFRGS, Rafael Garcia, DESTAQUE no IV Salão de Iniciação Científica do Direito, Faculdade de Direito UFRGS, 2000. 22. Pesquisadora voluntária, Antônia Klee, DESTAQUE no IV Salão de lniciaça Científica do Direito, Faculdade de Direito UFRGS, 2000. 23. Pesquisadora CNPq, Ciências Sociais Aplicadas, 2000 .24. Pesquisador PROPESQ/UFRGS, Bruno Miragem, DESTAQUE no XII Salão de Iniciação Científica UFRGS e CNPq, Ciências Sociais Aplicadas, 2000 . 25. Pesquisador CNPq/UFRGS, Rafael Garcia, DESTAQUE no XII Salão de Iniciação Científica UFRGS e CNPq, Ciências Sociais Aplicadas, 2000 . Em 2001 rectemos dois destaques internacionais: primeiro lugar no Brasil na Eliminatoria nacional realizada $\mathrm{n}$ UFSC do Philip C. Jessup International Law Moot Court Competition/2001, participação em Washington, D.C. Estados Unidos, com Professores Cláudio Moretti e Manoel André da Rocha), e estudantes do grupo: Ana Gerdau de Borja ; Thomaz Francisco Silveira de Araújo Santos Maitê de Souza Schmitz, Ricardo Medeiros de Castro. Prêmio de Melhor Delegado, representando o Canadá, no Comitê de Direitos Humanos, no IV Americas Model United Nations (AMUN), realizado em Brasília, D.F, entre 14 e 19 de julho de 2001 para Thomaz Francisco de Araújo Santos.

${ }^{81}$ Os trabalhos individuais de pesquisa apresentados no Salão de Iniciação Científica da UFRGS, em 1999, tinham como títulos: 1. A cláusula de indexação no contrato de leasing e o consumidor- Laura Oliveira Ederich; 2. A garantia como pós-venda no direito do consumidor- Rafael B. Garcia; 3. O prazo de carência nos contratos de incorporação imobiliária - Fernanda Nunes Barbosa; 4. A prestação de serviços educacionais à luz do direito do consumidor - Carina Bonzanini da Silva; 5. O Bug do milênio e seus reflexos para o consumidor - Roberto Silva da Rocha; 6. Multipropriedade - Rosaura Macagnan Viau; 7. A problemática dos serviços prestados através das linhas
0900 - Odiléia Oliveira de Almeida Simão; 8. O Plano Nacional de Desestatização e o consumidor - Bruno Nunes 0900 - Odiléia Oliveira de Almeida Simão; 8. O Plano Nacional de Desestatização e o consumidor - Bruno Nunes
Barbosa Miragem; 9. A agência estadual de regulação dos serviços públicos delegados do Rio Grande do Sul -
AGERGS e o consumidor - Cláudia Travi Pitta Pinheiro;10. As sociedades comerciais no Mercosul - Simone Stabel Daudt. 11. Comunicação de Massa: implicações legais das tecnologias emergentes - Fábio Costa Morosini.

Revista da Faculdade de Direito da UFRGS, v. 20, Outubro/2001 
da Faculdade de Direito da UFRGS, ${ }^{82} 3$ alunos da Faculdade de Direito da PUC/RS, ${ }^{83}$ uma aluna estrangeira (convênio) ${ }^{84}$, seis mestrandos do PPGD/UFRGS,${ }^{85}$ que realizam na co-orientação do grupo, como parte de sua "atividade docente", um doutorando, que oriento e uma economista, especialista em regulação, e na co-orientação, contamos até o mês de janeiro de 2001, com um jovem professor alemão, o docente de longa duração DAAD/CAPES ${ }^{86}$ lotado na Faculdade de Direito da UFRGS e com professores convidados estrangeiros ${ }^{87}$ por curto período, assim como com professores brasileiros e mestrandos de outras instituições, ${ }^{88} \mathrm{e}$
${ }^{82}$ Atualmente fazem parte do grupo, que se reúne sempre as terças feiras na sala de aula da Biblioteca Depositária da Organização das Nações Unidas (ONU), na Faculdade de Direito da Universidade Federal do Rio Grande do Sul, os seguintes alunos: Ana Gerdau de Borja, Ana Rispoli d'Azevedo, Antonia Espíndola Longoni Klee, Laura os seguintes alunos: Ana Gerdau de Borja, Ana Rispoli d'Azevedo, Antonia Espíndola Longoni Klee, Laura
Oliveira Ederich, Lucas Faria Annes, Lúcia Carvalhal Sica, Maitê de Souza Schmitz, Marília Zanchet, Odiléa Oliveira Ederich, Lucas Faria Annes, Lúcia Carvalhal Sica, Maitê de Souza Schmitz, Marilia Zanchet, Odiléa de Campos Aranovich, Thales Gonçalves Della Giustina e Thomaz Francisco Silveira de Araújo Santos.

${ }^{83}$ Ana Rispoli d'Azevedo, Lúcia Carvalhal Sica e Tatiana de Campos Aranovich, Faculdade de Direito da Pontifícia Universidade Católica, PUC/RS, Porto Alegre.

${ }^{84} \mathrm{Já}$ participaram do grupo os seguintes alunos estrangeiros: No ano letivo de 1996, o aluno alemão Christian Schindler, aluno então matriculado na Universidade de Heidelberg, Alemanha, hoje assistente do Prof. Dr. Erik Jayme, no Instituto de Direito Estrangeiro e Direito Internacional Privado da Univ. de Heidelberg, justamente por seu conhecimento do Direito brasileiro. O Doutorando Schindler, que recebeu na época crédito educativo do governo alemão para sua estada na UFRGS, é o secretário da Associação de Juristas Luso-Alemã da Univ. de Heidelberg e coordenou a ida de alunos do grupo para a Alemanha, como o mestrado de Fabiana D'Andrea Ramos na Universidade de Heidelberg, e os cursos de verão en Garcia e Aline Jackisch. No ano de 2000, por dois meses, duas alunas da Universidade conveniada de Santa Fé (Argentina). Este Intercâmbio de estudantes da graduação da Faculdade de Direito da Universidad Nacional del Litoral, Argentina, por dois meses na Faculdade de Direito da UFRGS, para assistir aulas e pesquisar sobre Direito do Consumidor, em maio/junho 2000, foi uma experiência muito positiva para o grupo e foi financiando pela UNL, que deu prêmios de pesquisa às duas estudantes, e esperamos que se repita em 2001. Atualmente, temos acompanhado a estada de Helene Heyd, aluna de Relações Internacionais da Universidade de Berlim, Alemanha.

${ }^{85}$ Atualmente Fernanda Nunes Barbosa, Daniela Correa Jacques, Michele Costa da Silveira, Bruno Nubens Barbosa Miragem, Cristiano Heineck Schmidt e José Salvador Cabral Marks., PPGD/UFRGS.

${ }^{86}$ Até o mês de janeiro do ano de 2001 tivemos o acompanhamento e orientação do Dr. Ulrich Wehner, professor convidado UFRGS, DAAD/CAPES, oriundo da Universidade de Colônia, Alemanha e indicado pela Universidade de Heidelberg, conveniada com a UFRGS, mas antes contamos por 2 anos com o acompanhamento da Dra. Harriet Christiane Zitscher, do Instituto Max-Planck em Hamburgo (Alemanha), professora convidada UFRGS/ DAAD/CAPES, nesta cátedra alemã na Faculdade de Direito de 1998 a 1999.

${ }^{87}$ Entre junho e outubro de 2000 tivemos a colaboração do pesquisador do Centre de Droit de la Consommation da Universidade Católica de Louvain-la-Neuve, Bélgica, o Mestre alemão Jens Karsten, enviado pelo Prof. Dr. Thierry Bourgoignie para pesquisar sobre a proteção do consumidor no Mercosul. Tentamos enviar nossos mestrandos para o mesmo intercâmbio no Centre, mas não obtivemos financiamento. O Intercâmbio de Mestrandos do Grupo de Pesquisa CNPq "Mercosul e Direito do Consumidor"/UFRGS com pesquisadores do Centre de Droit de La Consommation da Universidade de Louvain-la-Neuve, Bélgica, em estágios de pesquisa de 4 meses, iniciouse com a vinda do Me. Jens Karsten.

${ }^{88}$ Os hoje jovens professores das Faculdades de Direito de Porto Alegre, os hoje mestrandos e especializandos,que tem sua origem como pesquisadores do grupo, costumam acompanhar as reuniões do grupo e colaborar na orientação dos mais jovens em seus temas de especialização, assim hoje colaborarm com o Grupo as professoras Fabiana D'Andrea Ramos (PUC/RS), Elaine Ramos da Silva (UFSM/RS), Sandra Lima Alves (CEUB/Brasilía), Sabina Cavalli (Católica/CE). Assim também colaboram os especializandos: Fabiano Mencke, Roberto Silva, Gustavo Aguiar, Alberto Franco, os mestrandos Cláudia Pitta Pinheiro (UFRGS) e Evelena Boenning (UFRGS) e o doutorando Fábio Costa Morosini, University of Texas, Austin.

Revista da Faculdade de Direito da UFRGS, v. 20, Outubro/2001 com 2 colegas professoras da Faculdade de Direito da UFRGS. ${ }^{89}$

\section{Relações institucionais, inter-institucionais e com a sociedade}

A UFRGS mantêm vários convênios, ${ }^{90}$ a Faculdade de Direito ${ }^{91}$ também, mas o grupo mantém contatos próprios e menos formais, além destes já formalizados, especialmente com o Instituto Brasileiro de Política e Direito do Consumidor (São Paulo), algumas cátedras da UBA da Universidade de Rosário e de Santa Fé (Argentina), com a UROU de Montevidéu, com o Centre de Droit de la Consommation, na Bélgica, com o Instituto de Direito Internacional Privado da Universidade de Heidelberg, mais recentemente com a Universidade de Bremen na Alemanha, com o Centre de Recherches Européeennes da Université de Rennes I, na
França, com o Center of Comparative Law da Universidade de Baltimore, com o Texas International Law Jornal da Universidade do Texas-Austin, USA.

O Grupo de Pesquisa participa ativamene do Departamento Acadêmico do Brasilcon, Instituto Brasileiro de Política e Direito do Consumidor, uma organização não-governamental de caráter científico, criada pelos autores do Código de Defesa do Consumidor para estudar a eficácia desta lei e controlar a sua manutenção no mercado brasileiro. A colaboração com Brasilcon se concretiza de várias formas. Em primeiro lugar, através de publicações, trabalho que foi iniciado com a organização do congresso e após do livro que coordeno "Estudos sobre a proteção do Consumidor no Brasil e no Mercosul", publicado em 1994 pela Editora Livraria dos Advogados, de Porto Alegre.

Especialmente, depois volta de meu doutorado, o grupo passou a realizar traduções do francês, ${ }^{92}$ alemão ${ }^{93}$, inglês ${ }^{94}$ e espanhol ${ }^{95}$ para

${ }^{89} \mathrm{As} \mathrm{colegas} \mathrm{que} \mathrm{colaboram} \mathrm{nas} \mathrm{publicações} \mathrm{coletivas} \mathrm{do} \mathrm{grupo,} \mathrm{na} \mathrm{organização} \mathrm{de} \mathrm{congressos} \mathrm{e} \mathrm{eventos} \mathrm{do} \mathrm{grupo}$ o grupo em suas viagens ao exterior sao as colegas Martha Olivar Gimenez (UFRGS-PPGD e PUC/RS). bolsista pelo Prof. Me. Sérgio José Porto (UFRGS).

${ }^{\circ} \mathrm{O}$ grupo utilizou os convênio da UFRGS até agora com a Universidade de Heidelberg, Tübingen, Kiel na Alemanha, UBAArgentina, Universidad Nacional de Córdobae Universidad Nacional del Litoral, na Argentina, Universidade de Baltimore, nos EUA, Universidad Nacional de Assunción, Paraguai, e Universidad da República, Uruguai.

${ }^{91}$ A Faculdade de Direito e o PPGD possuem convênios com a Universidade de Münster, Alemanha, Universidade de Paris I (Panthéon- Sorbonne), Universidad Nacional de Rosário, Argentiña e USP, São Paulo.

${ }^{92}$ Assim os artigos de Alfred von Overbeck (Instituto Suiço de Direito Comparado), "Eleição de Foro segundo a nova lei suíça sobre Direito Internacional Privado de 18 de dezembro de 1987", in Revista da Faculdade de Direito da UFRGS, vo. 12,1996, p. 7 a 18 e artigo do Prof. Bernard Dutoit.

${ }^{93}$ Tradução do artigo de Michael R. Will (Instituto Europa, Saarbücken), A experiência de harmonização das legislações na Europa-Harmonização Autônoma?, executada por Elaine Ramós da Silva e publicada na Revista da Faculdade de Direito da UFRGS, vol. 13, 1997, p. 207-234. e tradução executada pela líder do grupo do capítulo do livro de Eike von HIPPEL, "Verbraucherschutz" e publicada na Revista Direito do Consumidor, São Paulo, vol. 1,pg. 7 a 15:"A proteção do consumidor-comprador" e também a tradução de artigo do alemão para o português do Prof. Dr. Dr. h.c. Erik Jayme, com 31 pgs., publicada na Revista dos Tribunais nr. 759, janeiro 1999, p.24 a 40, sobre o tema:"Visões para uma teoria pós-moderna do Direito Comparado".

${ }_{94}$ Tradução do artigo de J.H.A. van Loon, do inglês para o português, "Os Aspectos Legais da Adoção internaci"Tradução do artigo de J.H.A. van árion, da Associação de Direito Internacional", publicada no livro : -Homenagem à Carlos Henrique de Carvalho, Ed.Revistas dos Tribunais, São Paulo, 1995, pg. 241ss

${ }^{95}$ Veja tradução executada pela lider do grupo, para o português de artigo em espanhol do Prof. Rúben S. Stiglitz (Universidad de Buenos Aires), publicado na Revista Direito do Consumidor, São Paulo, vol. 13, jan/março 1995,

pg. 5 a 11, com o título: "Aspectos Modernos do Contrato e da Responsabilidade Civil" 
o português e publicar na Revista do Basilcon (Revista Direito do Consumidor) e também na Revista da Faculdade de Direito UFRGS. Também organizamos e publicamos colaborações em espanhol de nossos "correspondentes estrangeiros", ${ }^{96}$ especialmente nossos professores visitantes argentinos. ${ }^{97}$ Quanto à editoração de Revistas Jurídicas, inicialmente, de 1992 a 1998, ajudamos o Herman Benjamin, presidente e fundador do Brasilcon, ${ }^{98}$ na editoração da Revista Direito do Consumidor. Ao assumir a editoração da Revista, em 1998, criamos uma onde continuamos a publicar, em espanhol, trabalho pioneiro e inovador de Antônio seção especial para doutrina internacional,

${ }^{96}$ Assim publicamos os trabalhos dos jovens professores e pesquisadores estrangeiros que se correspondem com o grupo, Diego Fernandez Arroyo, argentino, professor na Univ. de Autonoma Madri (Sobre la existência de una família jurídica latinoamericana, in Revista da Faculdade de Direito da UFRGS, vo. 12, 1996, p. 93 a 110), Gilles Cistac, francês, Diretor da Univ. de Maputo, Monçambique (Poder Legislativo e Poder regulador na Constituição Moçambicana de 30 de novembro de 1990, in Revista da Faculdade de Direito da UFRGS, vo. 12, 1996, p. 148-160), Christoph Benicke, alemão, assitente na Universidade de Heidelberg ( La convención sobre los derechos del niño de las naciones unidas y la reforma del derecho de custodia y de visita en Alemania, , in Revista da Faculdade de Direito da UFRGS, vo. 13, 1997, p. 5170), Erasmo Marcos Ramos, brasileiro, mestrando na Universidade de Heidelberg, Alemanha (A influência do BGB na parte geral do novo Código Civil português, in Revista da Faculdade de Direito da UFRGS, vol. 15,1998 , p. 75-98).

${ }^{97}$ Veja os artigos de Carlos Alberto Ghersi (UBA) publicados na Revista da Faculdade de Direito da UFRGS (La contracción entre la reformulación de la categoria juridica del daño resarcible y ele acceso al daño resacible en el final del siglo XX, in vol. 11,1996, p. 24-39 e Posmodernidad juridica- el analisis contextual del Derecho como contracorriente a la abstracción juridica, in vol. 15, 1998, p. 21-32) e na Revista Direito do Consumi Direito da UFR (La descodificación y fractura del Decho Civil, in vol.11,1996, Contractuales, in Revista da Faculdade de Direito da UFRGS, vo. 16, 1999, p. 161-202) e na Revista Direito do Consumidor e apresentação do livro de Lorenzetti publicado pela Editora Revista dos Tribunais (Fundamentos do Direito Privado), Maria Blanca Noodt Taquela (UBA), publicado na Revista da Faculdade de Direito da UFRGS, vol. 15, 1998, p. 181-192, Atílio Alterini (UBA), Informe sobre la Responsabilidad Civil en el Proyecto de codigo Civil de 1998,vol. 17, 1999, p. 3 e seg. e os publicados na Revista Direito do Consumidor.

${ }^{98}$ Assim foram publicados de nossos correspondentes, por inicativa do Dr. Benjamin, na Revista Direito do Consumidor (RT, São Paulo), os seguintes trabalhos: Gabriel Stiglitz "O direito contratual e a proteção jurídica do consumidor". RDC n. 01, p. 184-199, "O Direito do Consumidor e as práticas abusivas Realidade e perspectivas na Argentina" RDC n.03, set/dez 1992, p. 27-35 e "Las acciones colectivas en proteccion del consumidor"RDC n. 15, jul/set 1995, p. 20-27. Rúben S. Stiglitz “Aspectos modernos do contrato e da responsabilidade civil" RDC n. 13, ja/mar 1995, p. 5-11. Ricardo Luiz Lorenzeti "Analisis crítico de la autonomia privada co "Clterini "Os contratos de consumo e as cláusulas abusivas", in RDC n. 15, jul/set 1995, p. 5-19 e "Control de la publicidad y comercialización"RDC n. 12, out/dez 1994, p. 12-16; Roberto M. López Cabana "Ecología y consumo" RDC n. 12, p. 25-28 e, após, 1994: Gabriel A. Stiglitz - Danõ moral individual y colectivo, medioambiente consumidor y dañosidad coletiva, RDC n.19- jul./set. 1996, p. 68/76, Atilio Aníbal Alterini - Bases para armar la teoría general del contrato em el derecho moderno,RDC n.19- jul./set. 1996, p. 7/24; Rubén S. Stiglitz - Seguro contra la responsabilidad civil. Control estatal de las condiciones generales de la poliza- estado actual en los paises del mercosul, RDC n.20- out./dez. y cont dectual y contractual de información. El deber de conseso, RDC n.22- abr/Jun. 1997, p. 9/25; Carlos Alberto Ghersi- Los profesionales y la posmodernidad- los abogados, RDC n.23/24- jun./dez. 1997, p. 9/18. os trabalhos de nossos correspondentes. ${ }^{99}$ A pesquisadora líder é correspondente in ternacional da Revista argentina, "Revista de Responsabilidad civil y seguros", cujo Diretor é o Prof. Atílio Alterni, publicado por La Ley, Buenos Aires e da revista belgo/inglesa Consumer Law Jornal, que tem como editores gerais Thierry Bourgoignie (Univ. de Louvainla-Neuve) e Geraint Howells (Univ. of Sheffield), publicada pelo Centre de Droit de la Consommation-CDC..$^{100}$

Outro exemplo de colaboração com o Brasilcon foi a elaboração e a publicação do relatório de pesquisa exaustiva sobre segurosaúde realizado pelo grupo no TJ/RS da entrada em vigor do CDC até a elaboração da lei de seguro-saúde, de 1996 a 1998. Este relatório foi publicado na Revista do Instituto (Revista Direito do Consumidor/RT ${ }^{101}$ e no livro do Instituto "Saúde e Responsabilidade" em 1998 e fazia parte de uma pesquisa do Brasilcon sobre a jurisprudência brasileira em seguros e planos de saúde, coordenada nacionalmente pelo Prof. Dr. José Reinaldo de Lima Lopes (USP). Tive a oportunidade de coordenar a pesquisa no Rio Grande do Sul e Paraná, realizada no Rio Grande do Sul com a ajuda da Docente convidada alemã, Dra. Harriet Zitscher e contando no Paraná com a contribuição no levantamento dos casos da acadêmica da PUC/PR, Caroline Araújo, também co-autora do relatório do Grupo.

O Grupo fornece jurisprudência atualizada para a Revista do Instituto, Revista Direito do Consumidor, que atualmente coordeno, revista especializada considerada a $3^{a}$ Revistä mais vendida pela Editora $\mathrm{Re}$ vista dos Tribunais e editada em São Paulo. Da mesma forma, a professora alemã Dra. Harriet Zitscher publicou pelo Brasilcon, com apresentação minha, seu livro "Metodologia do ensino com casos práticos- Exemplos do Direito do Consumidor" 102 , inaugurando uma nova linha de publicações do Brasilcon/MG.

${ }^{99}$ Assim foram publicados, na Revista Direito do Consumidor, os trabalhos de nossos correspondentes da Argentina: Gabriel Stiglitz- Modificaciones a la ley argentina de defesa del consumidor y su influencia en e mercosur, RDC n.29- jan./mar. 1999, p. 9/20; Carlos Alberto Ghersi- La caracterización de los servicio professionales de a a acia. El poder cultural y la desigualdad en la formación contractual. RDC n.25-jan./ma 1998 p. 9/18 e Consumo sustentable y medio ambiente, RDC n.31- jul./set. 1999, p. 97/103; Medida anticipativa 1998, p . Prevencion de agromiti- Redes Contractuales: sistemica del contrato, Revista n 33- jan/mar. 2000, p. 51/77; Ricter RC n.28- out./dez 1998, p. 22/58, Esquema de una Alterini- Tendencias en la contratación moderna, RDC n.31- jul./set. 1999, p. 104/114 e Roberto M. Lopez Cabaña- Defesa jurídica de los más débiles, RDC n.28- out./dez. 1998, p. 7/21.

100 Veja Informações sobre jurisprudência e legislação brasileira, artigos de Claudia Lima Marques, no "Consumer Law Jol" (CDC Puricar leasing Law Jorna" (CDC Publications, Belgica), vol. 7 (1999), p. contracts- Repayment indexed in dollars -Currency devaluation - Court apples proper code" "Brazil - New healph insurance law", no vol.8 (2000), com Gabriel Stiglitz: "New Consumer Protection Laws in Mercosur" e a aparecer: "The cigarette industry have the burden of proving that nicotine is not addictive to consumers".

${ }^{101}$ Relatório de Pesquisa quantitativa e qualitativa de jurisprudência gaúcha sobre seguro-saúde e o CDC, realizada " Claudia Lima Marques e Harriet C. pelo Gro dis Zitscher, conjuntamente com estudantes, publicado na Revista Direito do Consumidor (São Paulo), vol. 29,
mar 1999, p. 88 a 105:"Relatório BRASILCON sobre seguro-saúde no TJRS, de 1991 até maio de 1998"

mar 1999, p. 88 a 105:"Relatório BRASILCON sobre seguro-saúde no TJRS, de 1991 ate maio de 1998 "
${ }^{102}$ Livro de Bolso, "Metodologia do ensino com casos práticos- Exemplos do Direito do Consumidor" Ed. Del Rey, Belo Horizonte, 1999. Apresentação de Cláudia Lima Marques, p. 1 a 19.

Revista da Faculdade de Direito da UFRGS, v. 20, Outubro/2001 
Em matéria de relações interdisciplinares e interinstitucionais, mister destacar que o grupo possui uma interface muito importante com o Juizado de Pequenas Causas da Faculdad de Direito da UFRGS, uma vez que geralmente mestrando em estágio docente do Grupo coordena tal posto do Juizado ou lá realiza suas pesquisas de Mestrado em Direito do Consumidor com a FEE-Fundação de Economia e Estatística do Estado do Rio Grande do Sul, uma vez que contamos com um economista da FEE acompanhando e orientado os trabalhos sobre regulação, agências reguladoras e outros trabalhos voltados para o estudo do impacto da desestatizações frente as consumidores e com a AGERGS, uma vez que vários egressados do grupo trabalham e assessoram a Agência Reguladora do Estado do Rio Grande do Sul.

Na UFRGS, o grupo mantém contatos com o CEDEP, Centro e Biblioteca especializa da em Integração e seu curso de Especialização Interdisciplinar "Mercosul e Integração" (IFCH/
UFRGS), coordenados pela Profa. Dra. Maria Suzana Arrosa Soares, uma vez que os alunos de iniciação científica lá realizam suas pesquisas e todos os professores envolvidos no grupo, ministram aulas neste curso, ${ }^{103}$ assim como com o Curso de Especialização da Faculdade de Direito da UFRGS “O Novo Direito Internacional". ${ }^{104} \mathrm{O}$ grupo também coopera com o projeto TERMISUL, na elaboração de um dicionário de termos do Direito Ambiental Internacional, coordenado pela Profa. Dra. Maria da Graça Krieger. ${ }^{105}$

Em matéria de relações internacionais, ${ }_{1} 106$ o grupo mantém contato com a Universidade de Buenos Aires, com a cátedra da Carlos Alberto Ghersi (Direito Civil: Obrigações e Contratos), sendo que vários alunos do grupo puderam participar de Congressos na Argentina em 1993, 1994, 1997 e 1998, os professores do grupo são convidados anualmente a palestrar na Argentina e os professores da cátedra no Brasil. Da colaboração destes dois grupo nas-

${ }^{103}$ São professores do Curso, além da autora, as professoras Vera Fradera, Martha Olivar e Fabiana Ramos, além do professor convidado DAAD/CAPES, Ulrich Wehner.

${ }^{104}$ São professores do Curso do Departamento, além da autora, que o coordena junto com o Prof. Manoel André da Rocha, as professoras Vera Fradera, Martha Olivar e Fabiana Ramos, além do professor convidado DAAD CAPES, Ulrich Wehner.

${ }^{105}$ Cooperaram com o Projeto os alunos Fábio Morosini e Fernanda Barbosa, além da líder do grupo.

${ }^{106}$ Como conclama FERNADEZ ARROYO, Diego, Propuestas para la enseñanza y la investigación del Derecho Internacional Privado en América Latina, no livro "Jornadas de Derecho Internacional', Ed. OEA/Sec. de Asuntos Jurídicos, 2000, p. 93 a 112, há que se criar um "jurista americano abierto al mundo",p. 96 e especialmente frisar os estudos e pesquisas na "integración latinoamericana", p. 97.

Revista da Faculdade de Direito da UFRGS, v. 20, Outubro/200

ceram várias publicações conjuntas, na Argentina ${ }^{107}$ e no Brasil. ${ }^{108}$ Assim também mantêm o grupo colaboração com a cátedra do Prof. Ricardo Lorenzetti, da UBA e Prof. Gabriel Stiglitz, univ. de La Plata, com a Univ. de Rosário e Univ. Nacional del Litoral, Santa Fé.

\section{Conclusão}

Como se observa, é possível realizar pesquisa em grupo, frutífera e séria, em Direito. O método aqui retratado é apenas um, muitos outros podem ser desenvolvidos e aperfeiçoados pelos colegas interessados em pesquisa.
A pesquisa em Direito internacional é um caminho aberto para o trabalho conjunto de criação e evolução do pensamento e da doutrina Latino-americana. A colaboração com a sociedade civil organizada não possui apenas o caminho da extensão, também pode ocorrer através da pesquisa acadêmica e publicações direcionadas para a solução dos problemas regionais ou setoriais. A Universidade Brasileira evoluiu muito no que concerne a pesquisa de iniciação científica e este tem se mostrando um caminho positivo para alunos e professores-pesquisadores também no Direito. Esperamos que este testemunho possa motivar e ajudar.

${ }^{107}$ Em 1993 veja capítulo de Livro publicado na Argentina, "MERCOSUL - Perspectivas desde el Derecho Privado", Carlos Alberto Ghersi(Director), Editorial Universidad, Buenos Aires, 1993, p. 167 a 209: Cap.VIII"Tranferencia de Tecnología" e 1996 - Parte Brasileira do Capítulo IX do Livro coletivo publicado na Argentina, MERCOSUR - Perspectivas desde el derecho privado - Segunda Parte", org Ghersi, Carlos Alberto, Editorial Universidad, Buenos Aires, 196, tradç̧ão para o espanhol de Carlos Alberto Chersi, pg. 199 a 226. Cap.IX-"Los derechos del consumidor. Una visión comparativa entre el Brasil y la Argentina. A) El Código Brasileño de Defensa del Consumidor y el Mercosur" e em 2000 , capítulo de Livro publicado na Argentina, "Los Nuevos Daños- Soluciones modernas de reparación", vol. 2, Carlos Alberto Ghersi (Director), Editorial Hammurabi, Buenos Aires, 2000, traduzido para o espanhol, pg. 69 a 105: Cap.IV-"Contratos de Time-Sharing en Brasil y la protección de los consumidores: critica al Derecho Civil en tiempos posmodernos".

${ }^{108}$ Assim foram publicado os artigos dos Assistentes da Cátedra de Carlos Alberto Ghersi, Manuel Cunha Rodriguez (El Sistema de Franchising y la tutela de los consumidores y usuários en el derecho argentino, in Revista da Faculdade de Direito da UFRGS, vo. 13, 1997, p. 147-172), Graciela Lovece (El tiempo compartido, , in Revista da Faculdade de Direito da UFRGS, vo. 13, 1997, p. 131-146), Eduardo Barbier (La tutela del cliente bancario desde la ley de defensa del consumidor en el derecho argentino, , in Revista da Faculdade de Direito da UFRGS, vo. 13, 1997, p. 99-116), Célia Weingarten (Estado de la doctrina y jurisprudencia en la responsabilidade medica, in Revista da Faculdade de Direito da UFRGS, vo. 13, 1997, p. 39-50). 


\title{
Los Desafios del Derecho Civil en el Mercosur
}

\author{
Claudia Schmidt $\mathcal{H}_{\text {ott }}$
}

Profesora de Derecho Civil, Facultad de Derecho, Universidad de Chile

\section{CONGRESO NACIONAL Y VII LATINOAMERICANODEDERECHOPRIVADOEN HOMENAJE AL PROFESOR, DOCTOR ROBERTO MANUEL LÓPEZ CABANA}

Facultad de Derecho, Universidad de Buenos Aires, 7, 8 y 9 de junio del 2001

\section{Privatización del ius civile}

$1 F_{1}$ erecho Civil o Derecho del civis (ciudadano) o Derecho de la cívitas (ciudad), y más específicamente el Derecho del ciudadano romano no fue un Derecho esencialmente Privado, sino que, como es sabido, dentro de concepto ius civile, además del Derecho Romano se incluían temas que hoy cabrían dentro del Derecho Procesal, Penal o Administrativo. Señala Carlos Martínez de Aguirre y Aldaz que el Derecho Civil "en determinados momentos del proceso de su formación histórica fue más aún que sólo Derecho Privado". ${ }^{1}$ El proceso privatizador del Derecho Civil lo encontramos a lo largo de la Edad Media, como consecuencia de la desaparición de las estructuras sociopolíticas propias del imperio romano, que constituían el presupuesto necesario para la aplicación de los textos del Corpus Iuris. ${ }^{2}$ En consecuencia, la denominación "Derecho Civil" desde este punto de vista resulta más histórica que dogmática.
Sin embargo, teniendo en cuenta su contenido, es el Derecho privado general y común, toda vez que se ocupa de la persona, y por ende de la familia, y del patrimonio, dando lugar a subramas, como lo son los Derechos Reales que junto al Derecho de Familia, importan el presupueto esencial del Derecho Sucesorio; el Derecho Obligacional que junto a los Derechos Reales, constituyen el estudio del patrimonio; el Derecho General de los Contratos y muy especialmente el Derecho de Daños que se proyecta tanto en el campo del Derecho Privado Patrimonial como Extrapatrimonial. Diremos por el momento, porque a ello nos abocaremos más adelante, que las ramas del Derecho Civil son transversales dentro del Derecho Privado y dentro del Derecho Público, ramas estas últimas cuyas fronteras cada día se desdibujan más. Así por ejemplo, el penalista debe conocer desde y hasta cuando se extiende la vida del ser humano, qué se entiende por propiedad y cuales son sus limitaciones inmanentes y no inmanentes, qué son los títulos de mera tenencia, quées el parentesco y cuáles son sus parámetros de medición, etc.

'MARTINEZ DE AGUIRRE Y ALDAZ, El Derecho Civil a finales del Siglo XX, Editorial Tecnos S.A., Madrid 1991, pág. 17.

2 Díez-Picazo, El Sentido Histórico del Derecho Civil, RGLJ, 1959-2, pp. 621 y ss. 
II. La codificación del derecho privado en el siglo XIX

Algunas de las palabras del codificador chileno perfectamente podrían constituir hoy, las palabras del mensaje o moción de un nuevo Código Civil. Señalaba don ANDRÉS BELLOLÓPEZ:" "Muchos pueblos modernos más civilizados han sentido la necesidad de codificar sus leyes. Se puede decir que ésta es una necesidad periódica de las sociedades. Por completo y perfecto que se suponga un cuerpo de legislación, la mudanza de costumbres, el progreso mismo de la civilización, las vicisitudes políticas, la inmigración de ideas nuevas, precursora de nuevas instituciones, los descubrimientos científicos y sus aplicaciones a las artes y a la vida práctica, los abusos que introduce la mala $f e$, fecunda de arbitrios para eludir las precauciones legales, provocan sin cesar providencias, que se acumulan a las anteriores, interpretándolas, adicionándolas, modificándolas, derogándolas, hasta que por fin se hace necesario refundir esta masa confusa de elementos diversos, incoherentes $y$ contradictorios, dándoles consistencia y armonía y poniéndoles en relación con las formas vivientes del orden social." Sin embargo, cuando uno recorre el Mensaje de nuestro

codificador, va palpando cómo se han alejado muchos de sus principios fundamentes a los nuevos principios que han de informar un Código Civil del siglo XXI, porque tal como dijo Bello" "LA CODIFICACIÓN ES UNA NECESIDAD PERIÓDICA DE LAS SOCIEDADES."

Inicia el proceso codificador el Código Napoleónico de $1804{ }^{5}$ que ejerció gran influencia en otros códigos pertenecientes al grupo occidental de sistema legal, como lo fueron los de Bélgica, Luxemburgo, República Dominicana, Italia de 1865, España de 1889 , Portugal de 1867 y desde luego en el ámbito latinoamericano, los Códigos de Bolivia promulgado el 2 de abril de 1831, que rigiera 145 años, de Uruguay promulgado el 23 de enero de 1868, de Paraguay adoptado por leyes de 1876 y 1889 , y el vuestro, en que el ilustre jurisconsulto Dalmacio Vélez Sarsfield al remitirlo al Ministerio de Justicia el 21 de junio de $1865,{ }^{6}$ manifestó que para su trabajo se sirvió, principalmente entre otros códigos, del Código de Chile, que a su juicio, aventajaba a los códigos europeos. ${ }^{7}{ }^{8}$ Sin embargo, debo señalar, que hoy nuestro Código Civil demuestra un retraso de al menos 30 años dentro del contexto latinoamericano. Así por ejemplo, en e ámbito del Derecho de las Personas no consi-

${ }^{3}$ Mensaje del Ejecutivo al Congreso porponiendo la aprobación del Código Civil, Santiago de Chile, noviembre 22 de 1855.

${ }^{4}$ Don Andrés Bello López llegó a Chile en 1829 y se le concedió la nacionalidad chilena por gracia del Congreso Nacional en 1832, fue Senador de la República y primer rector de la Universidad de Chile, falleció en Santiago a los 84 años de edad. Fue jurista, poeta, filólogo e internacionalista, más no fue abogado, pues dada la muerte de su padre, debió abandonar sus estudios de Derecho a los 20 años para sostener a su madre y siete hermanos menores.

${ }^{5}$ Sin perjuicio que le anteceden el Código austríaco de 1811 y del Código Civil prusiano de 1874.

${ }^{6}$ Promulgado el 25 de septiembre de 1869 por Ley $\mathrm{N}^{\circ} 340$ y con vigencia desde el $1^{\circ}$ de enero de 1871 .

${ }^{7}$ Por su parte siguieron al Código Civil chileno los Códigos de Ecuador y Colombia y también, aunque en parte menos considerable el Código Civil del Uruguay de 23 de enero de 1868.

${ }^{8}$ Vodanovic Antonio H., Derecho Civil, Parte Preliminar y Parte General, Explicaciones basadas en las versiones de clases de los profesores de la Universidad de Chile Arturo Alessandri R. y Manuel Somarriva U., Quinta Edición, Ediar Conosur Ltda., Santiago de Chile, 1990.

Revista da Faculdade de Direito da UFRGS, v. 20, Outubro/2001

dera tales, a la criatura por nacer, cuestión que ya entonces criticaba Vélez Sarsfield ${ }^{9}$ y, establece que son absolutamente incapaces los sordomudos que no pueden darse a entender por escrito; en el ámbito del Derecho de Familia, contempla un sistema económico patrimonial antidemocrático en el cual, la mujer casada bajo el régimen legal y supletorio de sociedad conyugal, si bien tiene la propiedad de sus bienes, le está vedado su uso, goce, administración y disposición y, no contempla un ejercicio compartido de la autoridad parental tratándose de progenitores que viven juntos; en el ámbito del Derecho Patrimonial, entre tantas falencias, aún no da cabida a la revisión o resolución de los contratos por excesiva onerosidad sobreviniente, ${ }^{10}$ no contempla normas sobre cláusulas abusivas dentro de los contratos de adhesión, a los cuales, ni siquiera se refiere, salvo por alguna norma en materia de interpretación contractual; ${ }^{11} \mathrm{y}$, contempla la lesión con aplicación restringida (sólo 7 casos) y con un carácter estrictamente objetivo.

\section{El derecho civil: derecho privado y general}

El Derecho Privado no se agota en e Derecho Civil, pues dentro del Derecho Privado coexisten los Derechos Privados Especiales que nacen como una respuesta de regulación para relaciones jurídicas privadas entre personas no consideradas en cuanto tales, sino que por determinadas calificaciones, como por ejemplo, la de comerciante, trabajador, consumidor, niño y adolescente, etc. dando lugar a estatutos jurídicos diferenciados, fundados en principios particulares, pero que en caso alguno importan el alejamiento de la columna vertebral del Derecho Privado General y Común, pues antes de ser comerciante, trabajador, consumidor, niño o pariente, se es persona, pues como señala CARLOS FERNANDEZ SESSAREGO “la persona debe ser considerada como fin en sí misma y no como medio. Es por ello que jurídicamente no existe un interés superior al de la protección de la persona en cuanto protagonista del Derecho». ${ }^{12}$ Se formulan así el Derecho Comercial, el Derecho Bancario, el Derecho del Niño y/o Adolescente, el Derecho Ambiental, el Derecho del Consumidor, el Derecho Aeronáutico, el Derecho Indígena, el Derecho Registral, el Derecho Informático, etc. Sin embargo, estos Derechos Privados especiales destinados a personas que se encuentran en una determinada situación jurídica, no se apartan en lo medular del Derecho Privado General Es más, algunos de ellos, como el Derecho Mercantil, vuelven a formar parte del Código de Derecho Privado General, y en este aspecto, puede hablarse de la comercialización del Derecho Privado

${ }^{9}$ En relación al art. 63 del Código Civil argentino, señalaba Vélez Sarsfield: Las personas por nacer no son ción al art. 63 del Código Civil a re habría sujeto que personas futuras, pues ya existen en el 74 ć́digo Civil chileno, sén el cul la personalidadjurídica comienza representar. Agregaba criticando el art. 74 del Codigo Civil chileno, según el cúl, la perso pen con el nacimiento, porqué si lo que aún no han nacido no so personas, porque las leyes penales castigan el aborto premeditado y porqué no se puede ejecutar una pena en una mujer embarazada?

${ }^{10}$ Sin perjuicio que en la actualidad se encuentra para primer trámite constitucional dentro de la Comisión de Constitución. Legislación y Justicia de la Cámara de Diputados, un proyecto de Ley que permite la revisión judicial de los contratos civiles y mercantiles. Boletín No 309-07.

11 Ver art. 1566 del Código Civil chileno.

12 Derecho y Persona, Lima 1990, pág. 103. Citado por ALTERINI, ATILIO A. y LOPEZ CABANA, ROBERTO M., en

Cuestiones de Responsabilidad Civil en el Derecho de Familia, Derecho de Daños, La Ley, Buenos Aires 1992, pág. 241. 
Patrimonial. ${ }^{13}$ En este contexto, vuestra experiencia es notable. Señala el Doctor Atilio A. Alterini que, "en Argentina se intentó una y otra vez reformar los Códigos del Derecho Privado, con la idea básica de unificarlos y de modernizarlos bajo la forma del denominado Derecho Privado, o Derecho Privado Patrimonial" ${ }^{14}$ y dentro de ese contexto se enmarca el proyecto de Código Civil de 1998 que cuenta con 2532 artículos. Esta idea unificadora del Derecho Privado Patrimonial se consagra en el Código Italiano de 1942, que se agrupa dentro de los códigos civiles modernos y también en el Código Civil peruano de 1984 que comienza el inicio de la unificación de las reglas del Derecho Civil y del Derecho Comercial, especialmente en materia de actos jurídicos, obligaciones y contratos civiles y mercantiles. ${ }^{15}{ }^{16}$ Pero tal como señala el doctor Alterini, para determinar si la unificación es posible es necesario constatar si se han incorporado al Código Civil los principios propios de los contratos comerciales, como por ejemplo, la fuerza jurídica de los usos. En consecuencia, en mi opinión los países de la región pueden encontrarse en diferente grado de madurez sobre el particular. Sin embargo, creo que han de volver al Código Civil, como cuerpo normativo que representa la columna vertebral del Derecho

Privado, muchos de los Derechos Privados especializados. Por de pronto postulo a una unificación parcial del Derecho Civil y Comercial en lo atingente al Derecho de Obligaciones y al Derecho Contractual, unificación que se impone frente al proceso de globalización e internacionalización. Pero así como postulo a esta unificación, también me asiste el convencimiento que el Derecho Privado General, esto es el Derecho Civil dentro de un proceso recodificador, no puede abandonar el Derecho de Familia y sus problemas emergentes, como tampoco, el Derecho de las Personas desde la perspectiva del respeto de sus derechos humanos o derechos de la personalidad. Es así como puede apreciarse que algunos países han separado de la recodificación civil el Derecho de Familia a través de un Código de Familia como en el caso de Bolivia. ${ }^{17}$ En este mismo sentido, si bien la característica actual del Derecho a la Niñez es su codificación, como ha sucedido en Bolivia, Brasil, Colombia, Costa Rica, Ecuador, El Salvador Guatemala, Paraguay, Perú, Uruguay, Venezuela, siendo los más recientes los de Bolivia de 1992, Brasil de 1990, Colombia de 1989, Ecuador de 1992, Perú de 2000 y República Dominicana de 1994, ella está destinada a mi juicio a abordar el desarrollo legislativo de los

${ }_{13}$ Véase "La Comercialización del Derecho Civil" de LÓPEZ CABANA, ROBERTO M., en Revista de Responsabilidad Civil y Seguros dirigida por Atilio A. Alterini, Año III No I, Enero - Febrero, 2001, La Ley, Buenos Aires, Argentina.

${ }^{14}$ ALTERINI, ATILIO A., El Código Civil del Siglo XXI (Perú y Argentina), Coordinadores: Atilio A. Alterini, Carlos Alberto Soto y Jorge Muñiz Ziches, Primera Edición, págs. 38-39, Ediciones Jurídicas, Lima, Perú, 2000 ${ }^{15} \mathrm{El}$ art. 2112 del Código Civil de 1984 derogó cinco contratos contenidos en el Código de Comercio: compraventa, permuta, mutuo, depósito y fianza mercantil.

${ }^{16}$ Señala MUÑIZ ZICHES, Jorge en ob. cit. en nota 14 que: Esta idea unificadora tiene importantes antecedentes legislativos. El Código de las Obligaciones Suizo de 1881, el Código Civil Italiano de 1942 que comprende material

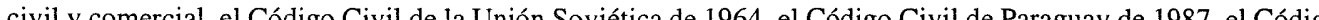
Civil Cuba de 1988, el Código Civil Hérigo Civil Cubano de 1988, écódigo Civilde Holanda de 1992, eód Códgo Civil Civilde Par de Vietnam de 1995, el Código Civil de la Federación Rusa de 1994, el Código UNICO en los Civil y Comercial de China de 1987.

${ }^{17}$ Código de Familia aprobado por Decreto Ley No 10.426 de 23 de agosto de 1972 que consta de un Título Preliminar y de Cuatro Libros, relativos al matrimonio, la filiación, la autoridad de los padres y los procedimientos, vigente desde el 26 de agosto de 1977.

Revista da Faculdade de Direito da UFRGS, v. 20, Outubro/2001 derechos fundamentales de los niños, pero los efectos jurídicos por ejemplo derivados de la filiación determinada, como la relación filial debiera particularizarse en un Código Civil moderno acogiendo la integralidad del Derecho Privado y en consecuencia, su unificación. ${ }^{18}$ En todo caso, debe tenerse presente que en general, la Convención sobre los Derechos del Niño tiene jerarquía constitucional a nivel regional. En efecto, vuestra Constitución reformada en 1994 establece en su art. $75 \mathrm{~N}^{\circ} 22$ que tiene jerarquía constitucional la Convención sobre los Derechos del Niño. No con esta misma claridad, pero sí en opinión de la doctrina mayoritaria, los tratados internacionales sobre derechos humanos tienen en nuestra carta fundamental jerarquía constitucional. En efecto, el art. 5 inciso $2^{\circ}$ de la Constitución Política de la República reformada el año 1989 estatuye: “ $E l$ ejercicio de la soberanía reconoce como limitación el respeto a los derechos esenciales que emanan de la naturaleza humana. Es deber de los órganos del Estado respetar y promover tales derechos, garantizados por esta Constitución, así como por los tratados internacionales ratificados por Chile y que se encuentren vigentes." Por su parte, en la Constitución de la República Federativa de Brasil de 1988, que ya ha tenido 22 enmiendas constitucionales en 1999, los tratados internacionales aprobados por el Congreso tienen la misma jerarquía de las normas constitucionales. En cambio la Constitución Nacional del Paraguay de 1992 le asigna a esto tratados un valor supralegal pero

infraconstitucional, dados los términos de sus art. 137 y $141 .{ }^{19}$

\section{La recodificación del dere- cho privado: un imperativo impostergable}

Se señala en el Acta de Arequipa que la "codificación es el método más adecuado para la expresión del Derecho Privado, como lo demuestra el yasto movimiento codificador" $y$ "Que la armonización en sectores relevantes del Derecho Privado es posible en América Latina por la pertenencia a la familia romanogermánica, lo que constituye un indudable factor de identidad cultural". ${ }^{20}$ En este contexto, la recodificación del Derecho Privado se nos impone como un imperativo dada la desintegración de él en diversos Derechos Privados Especiales y en atención a las leyes civiles satelitales o extracodiciales. La proliferación de estas leyes civiles especiales en nuestro país se hizo sentir ya desde el siglo XIX, cuestión que se va planteando por las falencias de los primeros códigos en diversas materias y por las nuevas realidades que se nos van presentando y que el legislador no puede ignorar. Tal vez, la proliferación de estas leyes extracodiciales se deba al hecho de que es más fácil la dictación de una ley especial, que la modificación del Código Civil, pero ha llegado el momento de recodificar y ello, muy especial-

${ }^{18}$ En este sentido puede citarse el Código del Menor de Bolivia

19 Art. 137: La ley suprema de la República es la Constitución. Ésta, los tratados, convenios y acuerdos internacionas a ley

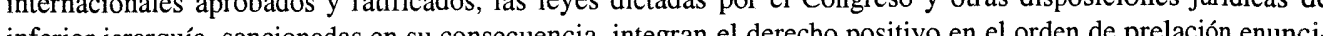
infe. Quention ado. Quienquiera queitentecalón, incurrirá en los delitos que se tipificarán y penarán en la ley. Carecen de validez todas las disposiciones y los actos de autoridad opuestos a lo establecido en esta Constitución.

${ }^{20}$ Consultada en Revista de Derecho Comparado, $\mathrm{N}^{\circ} 1$, "La Reforma de la Codificación Civil en América Latina" por JULIO CÉSAR RIVERA, Rubinzal - Culzoni Editores, Buenos Aires, 2000, págs. 176-177. 
mente con miras a la certeza jurídica. Así en nuestro país lo que es común en los países latinoamericanos, encontramos en su apéndice algunas de estas leyes especiales, otras, figuran en los apéndices de otros cuerpos normativos, pero que también integran el Derecho Privado. Dentro de las primeras podemos anotar cronológicamente entre las más importantes, las siguientes: Ley de Matrimonio Civil de 1884, ${ }^{21}$ Ley $\mathrm{N}^{\circ} 4.808$ sobre Registro Civil de 1930, Ley $\mathrm{N}^{\circ} 17.344$ que Autoriza el cambio de Nombres y Apellidos de 1970; Ley $\mathrm{N}^{\circ} 17.336$ sobre Propiedad Intelectual de 1970; Decreto Ley $N^{\circ}$ 993 sobre Arrendamiento de Predios Rústicos de 1975; Decreto Ley No 2.695 sobre Regularización de la Posesión de la Pequeña Propiedad Raíz de 1979; Ley No 18.010 sobre Operaciones de Crédito de Dinero de 1981; Ley $\mathrm{N}^{\circ} 18.101$ sobre Arrendamiento de Predios Urbanos de 1982; Ley N ${ }^{\circ} 18.112$ sobre Prenda sin Desplazamiento de 1982; Ley No 18.302 sobre Seguridad Nuclear de 1984; Ley No 19.039 sobre Privilegios Industriales y Protección de los Derechos de la Propiedad Industrial de 1991; Ley $N^{\circ} 19.281$ sobre Arrendamiento de Viviendas con Promesa de Venta de 1993; y Ley $\mathrm{N}^{\mathrm{o}} 19.537$ sobre Copropiedad Inmobiliaria de 1997. Otro tanto ha ocurrido con nuestro Código de Comercio que comenzara a regir el $1^{\circ} \mathrm{de}$ enero de 1867 y del cual, queda poco por no decir nada. Así por ejemplo, su Libro IV relativo a la quiebra fue derogado por una Ley especial de Quiebras en el año 1929, después sustituida por la actual Ley $\mathrm{N}^{\circ} 18.175$ de 1982 . Por otra parte encuentra normativa extracodicial el Derecho Bancario, el Derecho Marítimo, los Efectos de Comercio y Valores, las Garantías, la Libre Competencia, etc. En su apéndice encon-

tramos además, la Ley N 19.496 sobre Protección de los Derechos de los Consumidores de 1997

Aparte de esta descodificación enfrentamos la problemática de las sucesivas leyes modificatorias del Código Civil originario dictadas al menos en nuestro país en materia de Derecho de Familia, pues en lo que respecta a Derecho Patrimonial, las modificaciones han sido prácticamente nulas. Como hemos señalado en otra parte de esta presentación, aún no encuentran cabida entre nosotros instituciones tales como la regularización de las cláusulas abusivas, la incorporación de la revisión judicial de los contratos por excesiva onerosidad sobreviniente, la lesión mixta o subjetiva con aplicación general, por señalar algunas. En lo que respecta al Derecho de Familia, el proceso modificador comienza a partir del año 1925 y se paraliza en 1952 para reiniciarse en 1989, y concluir recientemente en 1998 con la instauración de un nuevo estatuto filiativo que a mi juicio, ha dado lugar a una derogación orgánica que recogiendo los principios de igualdad, identidad biológica e interés superior del niño, establece un régimen de libre investigación de la paternidad o maternidad, con la admisibilidad de todos los medios probatorios, y muy especialmente del peritaje biológico de ADN. Sin embargo, entre las materias de Derecho de Familia, muy especialmente en lo que respecta al sistema económico del matrimonio y la autoridad parental o relación filial, la reforma no ha sido integral, de tal manera que hoy nos enfrentamos a un Código parchado y desarmónico, que establece discriminaciones no sólo en razón del sexo, sino que también en lo que respecta a la posición social, específicamente en materia ali-

${ }^{21}$ Sin perjuicio que en la actualidad se tramita una Nueva Ley de Matrimonio Civil (Boletín $\mathrm{N}^{\circ} 1759-18$ ) que aparte de regular las condiciones generales de la celebración del matrimonio, estatuye dentro de la disolución de matrimonio, el divorcio vincular, aparte desde luego de la muerte y la nulidad de éste y la separación de los cónyuges, proyecto al cual, su Excelencia el Presidente de la República le ha dado urgencia, pues como es sabido, el divorcio a la chilena importa un jucio simulado de nulidad matrimonial por incompetencia del Oficial de Registro Civil, y constime el único pás dento Registro Civil, y constituye el unico pais dentro del sistema legal occidental que no contempla el divorcio con disolución de vínculo.

Revista da Faculdade de Direito da UFRGS, v. 20, Outubro/2001 mentaria. Nuestra esperanza ante esta problemática es que en sede judicial, se invoquen y se apliquen los tratados internacionales de derechos humanos, muy especialmente, la Convención sobre Eliminación de todas las Formas de Discriminación contra la Mujer, la Convención de los Derechos del Niño, los Pactos Gemelos y el Pacto de San José de Costa Rica, todos de jerarquía constitucional. Sin embargo, hasta la fecha, siendo manifiesta la inconstitucionalidad del Código Civil, no existe jurisprudencia en la materia.

\section{La constitucionalización de derecho privado o privatiza- ción del derecho constitucional}

Los primeros reconocimiento expresos de los derechos humanos a través de la Carta Magna de 1215, la Declaración de la Independencia Americana de 1776 y 1 Declaración de los derechos del Hombre y de Ciudadano de 1789 se fundaron en la necesidad de proteger a las personas de los excesos de poder. Con los procesos de reforma constitucional gestados durante el siglo pasado se van incorporando a las cartas fundamentales el reconocimiento de los derechos de 1 personalidad, considerados éstos no sólo desde una perspectiva Estado - Individuo, sino que también, de individuos entre sí, surgiendo una Privatización del Derecho Constitucional. Por su parte, los códigos civiles del siglo XIX enfocaron su preocupación fundamentalmente en el área del Derecho Patrimonial, preocupándose del Derecho de las Personas muy incidentalmente, no sólo en cuanto a espacio físico que se les dedica, sino que

${ }^{22}$ DIEZ - PICAZO, LUIS, Lecciones de Derecho Civil I, Parte General, Universidad de Valencia, Facultad de Derecho, Madrid 1967, pág. 327.

${ }^{23}$ Art. 5 también en consideración a la sustancia de las materias tratadas. Así, en los códigos civiles tradicionales interesa la persona sólo incidentalmente a propósito de relaciones jurídicas patrimoniales y se regulan instituciones tales como el estado civil, el domicilio y la capacidad. Frente a esta realidad, van apareciendo los códigos civiles modernos que centrados en el principio según el cual, la persona es el eje fundamental de la preocupación del Derecho, comienzan a regular los derechos de la personalidad, y allí podríamos hablar entonces de la Constitucionalización del Derecho Privado. Sin embargo, es necesario destacar que "la concepción tradicional española, tan favorable a la defensa de todas las manifestaciones de la personalidad nos transmite el principio jurídico de que es ilícito todo ataque o vejación a la persona", y en este sentido, señala DIEZ trato), 1936 (cosas prescriptibles), 865 ( legados), 1116 (condiciones imposibles) y 762 (incapacidad sucesoria) colocan a la persona fuera del trafico jurídico" ${ }^{22}$, principio que sin lugar a dudas encuentra asidero en los códigos civiles del siglo XIX. Pero ya con un reconocimiento explícito de los derechos de la personalidad, más allá de los clásicamente denominados "atributos de la personalidad", es atingente nombrar el Código Civil italiano de 1942, el que en su Libro I "De las personas y de la Familia", Título I, "De las personas físicas", prohibe los actos de disposición del propio cuerpo cuando ocasionasen una disminución permanente de la integridad física o cuando de otra manera sean contrarios a la ley, al orden público o a las buenas costumbres. ${ }^{23}$ Por otra parte, se consagra el derecho al nombre (arts. $6,7,8$ y 9) y se castiga el abuso de la imagen ajena de una persona o de sus padres, cónyuge o hijos en cuanto se haya expuesto o publicado PICAZO, "los artículos 1271 (objeto del con- 
fuera de los casos en que la exposición o la publicación es permitida por la ley, o, con perjuicio para el decoro o la reputación de la persona misma o de los parientes señalados. ${ }^{24}$ Así también, el Código Civil de Portugal de 1977 en su Libro I "Parte General", Título II, Sección II intitulada "Derechos de la personalidad" dispone en forma general, que la ley protege a los individuos contra cualquier ofensa ilícita o amenaza de ofensa a su personalidad física o moral y agrega, que independientemente de la responsabilidad civil a que haya lugar, la persona puede requerir las providencias adecuadas a las circunstancias del caso, con el fin de evitar la consumación de la amenaza o atenuar los efectos de la ya producida. ${ }^{25}$ Ya en forma más específica, reconoce el derecho al nombre y al seudónimo, la privacidad de la correspondencia, el derecho a la imagen y a la intimidad de la vida privada.

En el plano latinoamericano, es de resaltar el Código Civil peruano de 1984 que reconoce entre otros derechos humanos, el de no-discriminación entre varón y mujer, la intimidad personal y familiar, la imagen y voz, el secreto y la reserva de las comunicaciones y el deber y derecho al nombre. ${ }^{26}$ Dentro del proceso de recodificación y modificación de los códigos civiles latinoamericanos es importante destacar en este sentido, las enmiendas propuestas al Libro I del Código Civil peruano por la Comisión de Reforma entre las que puede mencionarse, el tratamiento jurídico del conce-

bido a través de una enmienda didáctica, la capacidad de goce entendida como connatural al ser humano sin que se admitan excepciones; la incorporación de los derechos a la identidad y a la salud; la libertad de someterse a tratamiento médico quirúrgico, la restricción de la capacidad de ejercicio con el fin de humanizar la institución, y muy especialmente el principio de una protección preventiva, integral y unitaria del ser humano. ${ }^{27}$ En este mismo contexto y citando al doctor JULIO CÉSAR RIVERA, vuestro proyecto de Código Civil de 1998, a la luz de la constitucionalización y supranacionalización del derecho general de la personalidad, incluye dentro de la temática la capacidad de derecho, la capacidad de ejercicio, tópico en el cual, acertadamente se estatuye que la interdicción por causas psíquicas no impone una incapacidad necesariamente absoluta, la mayoría de edad a los 18 años siguiendo de esta manera las legislaciones de Brasil, Paraguay, Uruguay y la de Chile que la establece el año 1993 por Ley $\mathrm{N}^{\circ} 19.221$; el discernimiento, el domicilio, y muy especialmente la protección de la personalidad, distinguiendo al efecto entre los derechos de la personalidad espiritual y los derechos a la personalidad física, reconociéndose entre los primeros a la intimidad personal o familiar, honor y reputación, el derecho a la identidad y el derecho a la imagen. Entre los derechos de la personalidad física, se reconoce el derecho a la vida e integridad física desde el momento mismo de la concepción, la regulación de los actos de disposición del propio cuerpo; la prohibición de las prácticas eugenésicas y el tratamiento de la disposición del cadáver. ${ }^{28}$

A modo de conclusión, podemos afirmar certeramente que dentro del proceso recodificador y como una consecuencia de la Constitucionalización del Derecho Privado o Privatización del Derecho Constitucional, como asímismo, de la internacionalización de Derecho Privado hemos arribado a la HUMANIZACION DEL DERECHOPRIVADO.

Considerando que los países que integran el mercosur ya como socios o asociados pertenecen a la familia de derecho romano - germánico, y que por otra parte, comparten una tradición histórica y cultural común, sin perjuicio de las singulares diferenciaciones de cada uno, la integración dentro de la región ha de materializarse no solamente en el área de lo económico, sino que además y en la medida de los esfuerzos y acuerdos que se logren al respecto, en los principios que han de fundamentar el derecho privado del siglo $x x i$ en el deseo de llegar a un derecho privado comunitario. en este sentido, constituye un ejemplo a seguir, los planteamientos y principios que a este respecto se señalan en el acta de arequipa de 1999.

\section{${ }^{24}$ Art. 10}

${ }^{25}$ Art. 70. Es este artículo que informa en gran medida el anteproyecto elaborado por la Comisión de Reformas Legales integrada en esa oportunidad por las profesoras (es) Solange Doyharcabal C., Claudia Schmidt H. y Francisco Merino S. de la Universidad Gabriela Mistral sobre "Protección a los Derechos de la Personalidad" publicado en la Revista Temas de Derecho, Volumen VI No 2 de Julio-Diciembre de 1991.

${ }^{26}$ Libro I "De las Personas", Sección Primera, "De las Personas Naturales" arts. 1 y ss.

${ }^{27}$ Ver FERNÁNDEZ SESSAREGO, CARLOS, Derecho de las Personas, Enmiendas propuestas al Libro Primero del Código Civil sobre el Derecho del concebido y de las personas naturales con breve Referencia al Proyecto de Código Civil de la República Argentina de 1998, en: El Código Civil del Siglo XXI, ob. Cit. en nota 14 pág. 181 y ss.

${ }^{28}$ Ver El Código Civil del Siglo XXI, Tomo II, ob. cit. en nota 14 págs. 993 y ss. 


\title{
El Convenio sobre los aspectos civiles de la sustracción internacional de menores y su aplicación en los tribunales alemanes*
}

\section{Introducción}

\author{
Dr. Christoph Benicke
}

Universidad de Heidelberg, Alemania

1. La problemática de la sustracción internacional de menores

1 describir el acto en que un padre traslada el

propio hijo del país de la residencia habitual a otro país en fraccionando un derecho de

"Este es la versión escrita y ampliada de una conferencia dada el 10 de abril de 1997 en la Universidad Federal de Rio Grande de Sul.

Literatura citada en forma abreviata: Aguilar Benítez de Lugo et al., Lecciones de derecho civil internaMadrid 1995, art. 9, apartado 6, p. 282; Baer, Legal Kidnapping,ZRP 1990, p. 209; von Bar. Internationales Privatrecht, Besonderer Teil, Muenchen 1991; Boehmer, Die 14. Haager Konferenz ueber internationales Privatrecht 1980, RabelsZ 46 (1982), p. 642; Bruch, Erfahrungen mit dem Haager Uebereinkommen ueber die zivilrechtlichen Aspekte internationaler Kindesentfuehrung, FamRZ 1993, p. 745; Gonzalez Campos et al. Derecho internacional privado. Parte especial, 5a ed. Madrid 1993; Jayme, Kulturelle Identitaet und Kindeswoh im internationalen Kindschaftsrecht, IPRax 1996, p. 237; Jorzik, Das neue zivilrechtliche Kindesentfuehrungsrecht, Bielefeld 1995; Kropholler, Kommentar zum Hager Uebereinkommen ueber die Zustaendigkeit der Behoerden und das anzuwendende Recht auf dem Gebiet des Schutzes von Mindejaehrigen vom S.10.1961 en Staudinger Privatrecht, $a$ ed. Tuebingen 1994: Kropholler. Kindesentfuehrung und Grundrechte Stellungnahme des Max Planck-Instituts fuer Auslaendisches und Internationales Privatrecht, Rabels Zeiltschrift 60 (1996), p. 485; Mansel, Neues internationales Sorgerecht, NJW 1990, p. $2176 \mathrm{~s}$. Matscher La valeur internationale des jugements relatifs à la garde des enfants, Institut de Droit international, Annuaire, Vol. 66. Tome I, Travaux préparatoiresParis 1995; Pérez-Vera, Informe explicativo del convenio sobre los aspectos civiles de la sustracción internacional de menores de la Haya de 1980, citado según la traducción alemana en Drucksachen des Deutschen Bundestages 11/ 5314, p. 38; Pérez-Vera, El "menor" en los Convenios de la Conferencia de La Haya de Derecho Internacional Privado, Revista Espanola de Derecho Internacional Privado XLV 1993, p. 101; Pirrung, Kommentar zum Haager Uebereinkommen ueber die zivilrechtlichen Aspekte internationaler Kindesentfuehrungen, en Staudinger Kommentar zum Buergerlichen Gesetzbuch, 13. ed., Berlin 1994 (Staudinger/Pirrung); Shapira, Private International Law Aspects of Child Custody and Child Kidnapping Cases, en Collected Courses of The Hague ueber die zivilrechtlichen Aspekte internationaler Kindesentfuehrung vom 25.10.1980 en Muenchener Kommentar zum Buererlichen Cesetzbuch. Eraenzungsand, 2 a ed. Muenchen 1992; Silbermamn, Hague Convention on International Child Abduction: A Brief Overview and Case Law Analysis, Family Law Quarterly 1994 p. Sturm, Neue Abkommen zm Schutz entfuehrter Kinder, en Festschrift fuer Heinrich Nagel, Muenster 1987, 457; Young, The Hague Convention on Child Abduction in the Courts of England and Wales, IPRax 1996, p. 221. Abreviaciones: AG: Amtsgericht (tribunal de primer instancia); BGB: Buergerliches Gesetzbuch (código civil alemán); BVerfG: Bundesverfassungsgericht (Corte constitucional de la RFA); OLG: Oberlandesgericht (Corte de segunda instancia); Revistas: FamRZ: Zeitschrift fuer das gesamte Familienrecht, IPRax. Zeitschrift fuer Internationales Privat- und Verfahrensrecht, NJW: Neue Juristische Wochenschrif, RabelsZ: Rabels Zeitschrif fuer auslaendisches und internationales Privatrecht; ZRP: Zeitschrift fuer Rechtspolitik. 
custodia del otro padre ${ }^{1}$. La sustracción conocida bajo el termino ingles de "lega kidnapping", es un fenómeno frecuente en la actualidad debido a la intensificación de los flujos migratorios, al alto número de matrimonios mixtos y a la reducción de trámites para pasar por las fronteras ${ }^{2}$

Como las existentes normas de derecho interno y de convenios en la materia de protección de menores se mostraron ineficaces para impedir las sustracciones, varios convenios especiales fueron elaborados ${ }^{3}$. E convenio que tuvo el mayor exito en cuanto las ratificaciones y a su aplicación en la practica, es el Convenio sobre los aspectos civiles de la sustracción internacional de menores, elaborado por la conferencia de La Haya de derecho internacional privado ${ }^{4}$. Este convenio fue promulgado en la Haya el 25 de octubre de 1980.

Para una mejor comprensión del convenio, de sus reglas y su estructura, el estudio tiene que comenzar por la interrogante ¿Cuál es el problema que el convenio quiere solucionar? El contexto de la problemática a la cual el convenio quiere responder es la siguiente: Cuando un matrimonio falla surge, en muchos casos una controversia sobre el derecho de custodia de los hijos comunes. La atribución de la custodia se demuestra conflictuosa por las consecuencias que trae. A un lado la atribución de la custodia tiene efectos

${ }^{1}$ Pérez-Vera, N. 12 ss.

${ }^{2}$ Aguilar Benítez de Lugo et al., p. 78 .

3 Sturm, p. 460 s.; Alvarez González, p. 283; Convenio europeo relativo al reconocimiento y ejecución de decisiones en materia de custodia de menores, así como al restablecimiento de dicha custodia, hecho en Luxemburgo
el 20 de mayo de 1980; Convenio sobre los aspectos civiles de la sustracción internacional de menores, hecho en La Haya el 25 de octubre de 1980; Convención interamericana sobre secuestro internacional de menores, de 15 de julio de 1989; además existen convenios bilaterales; ver Boggiano, Curso de derecho internacional privado, Buenos Aires 1993, p. 420 s. para el convenio sobre protección internacional de menores entre la República Argentina y la República Orientla del Uruguay del 31 de julio de 1981; ver Jayme, IPRax 1996, 241 sobre los convenios entre Belgica y Marueco y entre Francia y Algeria.

${ }^{4}$ Matscher, p. 476.

${ }^{5}$ En derecho alemán el padre con el cual el hijo vive cumple su obligación alimenticia por procurar al hijo alojamiento y comida, mientras el otro padre tiene que prestar los alimentos en dinero, $§ 1612$ BGB. Además el hecho de cuidar un hijo joven da el derecho de pedir alimentos propios al ex-cónyuge, \& 1570 BGB
Así la atribución de la custodia es decide más radical cual de los padres puede mantener una relación personal con sus hijos. Se anade la diferencia de culturas: El hijo se cria con otro idioma y otra cultura que los del padre que no obtuvo la custodia. Estas consecuencias más radicales llevan a que los padres luchan tan arduo para obtener la custodia.

Un elemento decisivo en esta lucha es la sustracción del hijo al otro padre. Es opinión común de que la sustracción y la separación brusca de su ambiente al cual el menor está acostumbrado produce efectos negativos. Además la sustracción consiste en una infraccion de las leyes y se usa como medio para privar al otro padre de sus derechos legítimos y tiene como consecuencia el separar al menor enteramente del otro padre.

El convenio de la Haya sobre los aspectos civiles de la sustracción internacional fue concebido con el objetivo de crear mecanismos idóneos para impedir la sustracción ${ }^{6}$. Con el aumento de los números de matrimonios mixtos ${ }^{7}$ y por la tasa alta de divorcios ${ }^{8}$ en matrimonios nacionales como internacionales la sustracción de menores por un padre fue percebido como un problema frecuente y grave. Las reglas existentes fallaron al dar una solución justa e impedir las sustracciones.

El sistema del convenio solo se puede comprender ante la situación jurídica que existía sin el convenio o fuera del ámbito de aplicación del convenio. Para saber cómo se puede impedir que las sustracciones se hagan, hay que analizar las causas. Un padre sustrae al menor

${ }^{6}$ Pérez-Vera, N. 16.

7 . Jahrbuch 1996 fuer die Bundesrepublik Deutschland, p. 72.

${ }^{8}$ En Alemania fueron concluidos en total 440.244 matrimonios en el año 1994; en el mismo año fueron divorciados 166.052 matrimonios, Statistisches Jahrbuch 1996 fuer die Bundesrepublik Deutschland. 9 Ver $\underline{\text { Sturm, p. }} 461$. solamente si la sustracción le sirve como medio para obtener la custodia a su favor ${ }^{9}$. Hay que estudiar entonces por cuáles causas y de qué manera el padre puede obtener su objetivo utilizando la sustracción como medio.

Antes de entrar en este estudio quiero describir tres constelaciones típicas. Estas sirven para ejemplificar los diferentes aspectos de la problemática.

El primer caso típico es el siguiente: Los padres del menor están divorciados. El derecho de custodia fue atribuido por ejemplo a la madre brasileña que vive con el hijo en Brasil. E padre alemán tiene el derecho de visita. Aprovechándose de una visita del menor el padre se lo lleva para Alemania, donde él está viviendo. El caso se caracteriza por los hechos: Existe un arreglo judicial del derecho de custodia. El derecho de custodia fue atribuido a un padre solo. El otro padre lesiona este derecho al sustraer el menor, llevándolo al país de su residencia. Este caso puede ser nombrado como clásico.

El segundo caso típico es que los padres están todavía casados. La madre es, por ejemplo, alemana y el padre es norteamericano. El domicilio familiar está en los Estados Unidos. Por consecuencia de disputas matrimoniales la pareja se separa. Antes de que se tomará una decisión jurídica en cuanto al arreglo de la custodia, la madre regresa a Alemania llevándose a los hijos. Las características en este caso son: No existe un reglamento

\section{Casos tipícos}


judicial y que por consequencia ambos cónyuges tienen el derecho de custodia en común. Un padre se lleva el hijo a otro país antes de que una decisión en cuanto al derecho de custodia pueda tomarse en el país de la residencia habitual de la familia.

El tercer caso típico es este: Madre alemana y padre australiano viven en Australia. Los padres estan divorciados. El derecho de custodia fue atribuido a los dos padres en común. Bien que la madre está encargada de la custodia cotidiana del hijo. Por consecuencia el hijo está viviendo con la madre. El derecho de custodia del padre consiste especialmente en el derecho de visita regular y en la participación en decisiones fundamentales, como por ejemplo un cambio de la residencia habitual al extranjero. La madre deja Australia llevándose al hijo para regresar a Alemania sin el consentimiento del padre. Las características de este caso son: La existencia de un reglamento judicial de la custodia. La persona encargada del cuidado cotidiano se lleva el menor a otro país. Al otro padre fue atribuido no sólo un derecho de visita, pero también una mayor participación en la educación del menor.

\section{La problemática jurídica sin el convenio}

La situación fuera del ámbito de aplicación del convenio puede ser caracterizada generalmente como defectuosa en el sentido de que la sustracción sirve como medio eficaz para obtener el derecho de custodia y excluir al otro padre ${ }^{10}$

${ }^{10}$ Jorzik, p. 19

${ }^{11}$ von Bar, N. 335

${ }^{12}$ Staudinger/Kropholler N. 128
Para que la sustracción sirva como medio de obtener el derecho de custodia hay dos condiciones: Primera condición es que los tribunales del estado en el cual el menor fue trasladado pueden adquerir competencia para decidir sobre el derecho de custodia. Segunda condición es que transcurre un cierto lapso de tiempo antes de que un tribunal tome una decisión sobre el reparto del derecho de custodia. Cuanto más tiempo el menor permanece en la nueva residencia tanto más se integra. Esta integración del menor sirve como argumento al tomar una decisión en favor de que el menor permanezca también en el futuro en el mismo ambiente ${ }^{11}$.

\section{Competencia en el país de la nueva residencia}

Para seguir con el análisis hay que determinar cuales son las condiciones que acreditan la competencia a los tribunales del estado al cual fue trasladado el menor.

La competencia internacional en materia de custodia de menors es reglada en Alemania en primer lugar por el convenio sobre la competencia de las autoridades y la ley aplicable en materia de protección de menores hecho en la Haya en 1961. Según el art. 1 de este convenio son competentes los tribunales del estado de residencia habitual del menor. Crucial es entonces la cuestión bajo cuales condiciones el menor adquiere una nueva residencia habitual en el país al cual fue trasladado.

La residencia habitual se encuentra en el lugar donde la persona tiene el centro efectivo de su vida ${ }^{12}$. Una nueva residencia habitual se adquiere cuando la nueva residencia se ha convertido en el centro efectivo de la vida. Si una persona se desplaza con la intención de establecerse por largo plazo, el nuevo lugar se convierte inmediatamente en la nueva residencia habitual ${ }^{13}$. En el caso que un menor de edad se desplaza a otro lugar, sólo adquiere una nueva residencia habitual en seguida en este lugar, si la persona encargada de su custodia está de acuerdo con el cambio de residencia. Esto se debe a que sin el acuerdo del custor la permanencia no está asegurada en el momento de llegar. El menor adquiere una nueva residencia habitual a pesar de la oposición de custodiante a partir del momento que el lugar donde se encuentra se ha convertido en el centro efectivo de su vida. Se considera que 1 integración necesaria para esta suposición se realiza por lo general en un plazo de seis me$\operatorname{ses}^{14}$.

Así podemos concluir que despues de un plazo de seis meses, que el menor se encuentra en un país los tribunales de este país son competentes para dictar la custodia. Y los tribunales del país de la antigua residencia habitual perdieron la competencia ${ }^{15}$.

\section{Influencia de la sustracción en los criterios para la decisión sobre el derecho de custodia}

La sustracción puede producir efectos en cuanto a la decisión sobre el derecho de custodia que están a favor del sustractor. El

${ }^{3}$ Staudinger/Kropholler N. 130, 131

${ }^{14}$ Staudinger/Kropholler N. 132.

${ }^{15}$ Además segun el art. 9 del convenio sobre competencia de las autoridades y la ley aplicable en materia de protección de menores las autoridades de todo Estado en cuyo territorio se encuentre el menor pueden adoptar las medidias necesarias de protección en casos de urgencia; fuera del ámbito de aplicación de este convenio la competencia está fundada sea también por la residencia habitual sea por la nacionalidad del menor. Como el menor tiene por lo general las nacionalidades de ambos padres, los tribunales del Estado de orígen del padre sustractor son competentes por este factor.

von Bar, N. 335; Baer, p. 210

${ }^{17}$ Boehmer, p. 645; Kropholler, p. 353; Baer, p. 210; para España González Campos et al., N.55 s. 
nados en las calles de Sao Paolo. Y el juez brasileno piensa talvéz en la frialdad de la sociedad alemana y la falta de cariño y atención que el niño puede recibir.

Estas observaciones se pueden resumi de la siguiente manera: Los tribunales del país en el cual el padre sustractor ha llevado el menor se vuelven competentes para el asunto de custodia en la práctica por el sólo hecho que transcurrió un lapso de seis meses. Cuanto más tiempo el menor se encuentra en este país tanto más probable se hace que por el aparente bienestar del menor el tribunal atribuye la custodia al sustractor para que el menor no sufra un nuevo cambio de ambiente.

\section{El convenio en general}

\section{El origen}

El convenio fue elaborado por la Conferencia de La Haya del Derecho internacional privado. La sesión XIII. en el año 1976 inició los trabajos que se concluyeron en la sesión XIV en octubre del año 1980 por la formulación final y las primeras signaturas ${ }^{18}$

En el mismo año el consejo de Europa adoptó un convenio sobre la misma materia: Es el convenio Europeo relativo al reconocimiento y ejecución de decisiones en materia de custodia de menores así como al restablecimiento de dicha custodia, hecho en Luxemburgo el 20 de mayo de 1980.

${ }^{18}$ Shapira, p. 189 ss.; $\underline{\text { Boehmer, }}$ p. 643

${ }^{19}$ Boehmer, p. 646

${ }^{20}$ Matscher, 476; Pérez-Vera, Revista Española de Derecho Internacional Privado XLV 1993, p. 109; $\underline{\text { Bruch }}$, p. 745 y Silbermann, p. 16 con estadisticas sobre la aplicación en los Estados Unidos.

${ }^{21}$ La Convención interamericana sobre secuestro internacional de menores, de 15 de julio de 1989, se inspira en el convenio de La Haya aunque con ciertos particularismos regionales, ver Samtleben. Neue Interamerikanische el convenio de La Haya aunque con ciertos particularismos regionales, ver Samtleben, Neue Interamerikanische ${ }_{22}$ Staudinger/Pirrung, N. 633.

Revista da Faculdade de Direito da UFRGS, v. 20, Outubro/200I de Europa tiene efectos positivos sobre todo en cuanto al reconocimiento y a la ejecución de sentencias extranjeras de derecho de visita ${ }^{23}$.

En lo siguiente quiero presentar el reglamento del convenio de La Haya. A continuación voy a presentar unas decisiones recientes de tribunales alemanes con el fin de discutir unos problemas de la aplicación del convenio más en detalle.

3. Ambito de aplicación personal y territorial del convenio

Según el art. 4, el convenio se aplica sólo a menores de menos de 16 años de edad. $\mathrm{E}$ convenio vuelve a ser inaplicable cuando e menor cumple los 16 años durante e procedimiento de restitución ${ }^{24}$. La razon por 1 limitación de la aplicación del convenio a menores de menos de 16 años es la consideración de que para la adjudicación de la custodia de un mayor de 16 años es decisiva la voluntad del menor y que el no puede ser forzado a acepta un cambio de residencia de un padre al otro ${ }^{25}$ Como este límite de edad está fijado formalmente, el convenio no se aplica en casos de custodia de un hijo de más de 16 años que es incapacitado y por consecuencia no puede tomar una decisón propia con cual padre quiere residir ${ }^{26}$ Territorialmente el convenio se aplica, si un menor tenía su residencia habitual en un paí miembro y se encuentra después de la sustracción en otro país miembro del convenio.

\section{Mecanismos del convenio}

El objetivo del convenio es de asegurar el regreso inmediato del menor, para así restau-

${ }^{23}$ Pirrung, Sorgerechts- und Adoptionsuebereinkommen der Haager Konferenz und des Europarats, RabelsZ 57 (1993), 124, 141 .

${ }^{24}$ Staudinger/Pirrung, N. 648

${ }^{25}$ Pérez-Vera, N. 77.

${ }^{26}$ Staudinger/Pirrung, N. 648

${ }^{27}$ Ver Pérez-Vera, Revista Española de Derecho Internacional Privado XLV 1993, p. 108. ${ }^{28} \underline{\text { Siehr, N. }} 62$. rar la situación anterior a la sustracción. Por el retorno inmediato del menor el convenio intenta de que el sustractor no pueda influenciar en su favor, los hechos decisivos para la atribución de la custodia por una decisión judicial.

El fin del convenio es en este aspecto a un lado la restauración de la situación anterior en el caso concreto. Además tiene el objetivo de producir efectos preventivos: Viendo que la sustracción no sirve como medio de influenciar la atribución de la custodia, el interés de usarlo desaparecerá. Como una sustracción siempre es capaz de producir daños para el menor, el objetivo del convenio, de impedir de una manera preventiva las sustracciones, es primordial ${ }^{27}$.

Los mecanismos del convenio para lo-

En art. 12 el convenio constata el derecho de pedir la restitución del menor. Este derecho está resforzado por una cooperación estrecha de las autoridades centrales que los paises miembros tienen que instalar. Además, el art. 16 prohibe a las autoridades competentes del esado de la residencia actual del menor, de tomar una decisión sobre la cuestión de fondo de los derechos de custodia desde el momento que están informados de un traslado o retención ilícitos. Esta regla tiene como fin, que la decisión de restitución no sea impedida por una decisión que atribuye el derecho de custodia al sustractor ${ }^{28}$. El convenio tiene como fin, que el derecho de custódia del estado de la residencia habitual del menor antes de la sustracción, se respete. Y si una nueva decisión sobre la custodia se hace necesaria, ésta tiene que grar estos fines son los siguientes: 
hacerse en este mismo estado. El convenio no tiene como objeto generar la cuestión de fondo de los derechos de custodia ni la cuestión de reconocimiento del derecho de custodia establecido por la ley o por decisión judicial. El reglamento sólo visa la restauración de la situación que existía antes de la sustracción ${ }^{29}$.

\section{La restitución}

El núcleo del convenio es el art. 12 que contiene el derecho de pedir, que la autoridad competente en el estado donde se halle el menor ordene la restitución inmediata del menor. En cuanto a las condiciones, para que la restitución se ordene, el convenio hace la diferencia si un período inferior o mayor a un año ha transcurrido desde el momento en que se produjo la sustracción y la fecha de la iniciación del procedimiento de restitución.

\section{Traslado o retención ilícitos}

Condición común es que el menor ha sido trasladado o retenido ilícitamente en el sentido previsto en el artículo 3.

\section{El art. 3 dice :}

El traslado o la retención de un menor se considera ilícitos:

a) Cuando se hayan producido con infracción de un derecho de custodia atribuido, separada o conjuntamente, a una persona, a una institución o a cualquier otro organismo, con arreglo al Derecho vigente en el Estado en el cual el menor tenía su residencia habitual inmediatamente antes de su traslado o retención; y

\footnotetext{
${ }^{29}$ Sturm, p. 468; Kropholler, p. 355

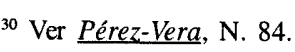

${ }^{31}$ Silbermann, p. 17.
}

b) Cuando este derecho se ejercía en forma efetiva, separada o conjuntamente, en el momento del traslado o de la retención, o se habría ejercido de no haberse producido dicho traslado o retención.

\section{a) Derecho de custodia}

Primer elemento es, que existía un derecho de custodía. Este puede ser atribuido a los dos padres, a otras personas o a una institución estatal o privada. Por razones de simplificar trataré en lo siguiente solo el caso más frecuente, que un padre lesiona el derecho de custodia del otro padre.

El caso está incluido, que los padres están casados y el derecho de custodia les está atribuido a los dos en común por la ley. Está protegido también el derecho de custodia atribuido por vía judicial a uno o a los dos padres después de la separación o del divorcio ${ }^{30}$.

El art. 5 define la noción de derecho de custodia como el derecho relativo al cuidado de la persona menor y, en particular, el de decidir sobre su lugar de residencia. La noción de custodia en el convenio es autónomo y no tiene que corresponder a nociones parecidas en los diferentes ordenes jurídicos nacionales ${ }^{31}$.

\section{b) La ley aplicable para determinar el derecho de custodia}

La ley aplicable para determinar si un derecho de custodia existía, es la ley del estado de la residencia habitual del menor. Según el art. 14, ésto vale también para las decisiones judiciales o administrativas, sin que éstas tengan que ser reconocidas en el Estado requerido.
Para la constatación, si un derecho de custodia existía, el juez del estado requerido en carga del caso tiene que apreciar la existencia de un derecho de custodia como haría un juez en el país de la residencia habitual del menor. Las reglas normales del derecho internaciona privado o las reglas sobre el reconocimiento de laudos extranjeros no se aplican en la rama de convenio.

El convenio no tiene como objeto directo el reconocimiento de decisiones sobre la custodia. Como el tribunal del estado requerido tiene que apreciar la existencia de un derecho de custodia como se hace en el estado de la residencia habitual del menor, una decisión sobre la custodia dictada en este estado antes de la sustracción es determinante para el procedimiento de la restitución ${ }^{32}$.

\section{c) Infracción}

Para que el traslado o la retención sean ilícitos, el traslado o la retención tienen que haberse producido con infracción de un derecho de custodia.

Una infracción significa, que el ejercicio del derecho de custodia fue obstaculizado por el acto de traslado o de retención. Sea que le impide a la otra persona el ejercer la totalidad o una parte del derecho de custodia. Esto equivale también para el caso, en que el derecho de custodia está atribuido a los dos padres en común. Al excluir al otro padre del ejercicio de derecho de custodia, el padre que se lleva el menor lesiona este derecho de custodia ${ }^{33}$

${ }^{32}$ Bruch, p. 746.

${ }^{33}$ Staudinger/Pirrung, N. 645

${ }^{34}$ Silbermann, p. 20; Staudinger/Pirrung, N. 691; Young, p. 222

${ }_{35}^{35}$ Staudinger/Pirrung, N. 643

${ }^{36}$ House of Lords (England) In re J. (a minor) (Abduction: Custody Rights)[1990] 3 W.L.R. 492, citado según Bruch, p. 746.

${ }^{37}$ Young, p. 222 y el caso Re B (A Minor) (Abductio) [1994] 2 FLR 249.
El art. 15 constata que la autoridad en cargo de un procedimiento de restitución puede exigir que el demandante obtenga de las autoridades del estado de residencia habitual del menor, una decisión o una certificación que acrediten que el traslado o retención del menor era ilícito. No queda claro si tal decisión o certificación tiene un caracter vinculante para la autoridad que decide sobre la restitución. A un lado un caracter vinculante promoviera una decisión rápida sobre la restitución. Al otro lado hay que diferenciar entre la descripción del derecho que tenia el padre según el orden jurídico del estado de la residencia habitual del menor y su clasificación según las reglas del convenio. Esta última decisión incumbra a la autoridad competente para dictar sobre la restitución ${ }^{34}$.

El derecho de custodia tiene que haber sido existente en el momento del traslado ${ }^{35}$. El convenio no se aplica en principio cuando el padre encargado de la custodia deja el estado de la residencia habitual y solo después una

Los casos se han monstrados problemáticos, cuando los padres vivían en una unión de hecho y ejercían la custodia en común y por la ley la custodia estaba solamente atribuida a la madre. Cuando los padres se separan y la madre se lleva al hijo, se plantea la cuestión si la del padre en el sentido del art. $3^{37}$.

El texto literal del art. 3 habla expresamente de la infracción de un derecho de custodia. Tomando en cuenta el objetivo del decisión transfiere la custodia al otro padre ${ }^{36}$. madre lesiona un derecho de custodia por lado 
convenio, de protejer al menor de no perder un padre por un acto unilateral del otro padre y de no permitir a un padre de utilisar la sustracción como medio de privar al otro padre de la custodia, un concepto amplio del derecho de custodia parece más adecuado. Si en el estado de la residencia habitual existe la posibilidad, que la custodia sea atribuida al padre del hijo extramatrimonial después de la separación de los padres a pesar de que éste no ha tenido un derecho formal de custodia. El caso equivale en todo aspecto de los objetivos del convenio al caso que los padres tenían formalmente und derecho de custodia en común.

Si el padre del hijo extramatrimonial no puede obtener un derecho de custodia, el solo hecho de que éste ha ejercido la custodia en la práctica, no es suficiente para la protección por el convenio. Bien que el interés del menor puede exigir la continuación de la relación con el padre, la misma ley del estado de la residencia habitual no sirve como base legal para la custodia del padre.

\section{d) Ejercicio efectivo del derecho de custodia}

El traslado o la retención solo son ilícitos, cuando el derecho de custodia que fue violado se ejercía de forma efectiva en el momento del traslado o de la retención (art. 3 lit. b, 13 lit

a). El convenio tiene la intención de proteger un derecho actualmente ejercido y no un derecho, que existe sólo de manera formal. Un tribunal alemán negó la restitución por falta de ejercicio efectivo del derecho de custodia en un caso, que el padre no había intentado du-

${ }^{38}$ Kammergericht Berlin 13.12.1995, FamRZ 1996, 691

${ }^{39}$ Ver sobre los problemas que se plantean en este sentido Staudinger/Pirrung, N. 682 y las decisiones ingleses Toportadas por Young, p. 222

${ }^{40}$ Mansel, 2177.

${ }^{41}$ Silbermann, p. 25.

Revista da Faculdade de Direito da UFRGS, v. 20, Outubro/2001 rante dos años entrar en contacto con su hija de 4 años de edad ${ }^{38}$.

\section{e) Consentimiento o aceptación del traslado}

No existe la obligación de dictar la restitución, si la persona a cargo de la cusodia había consentido o posteriormente aceptado el traslado o la retención (art. 13 lit. a) ${ }^{39}$.

\section{Excepciones de la obligación de restitución}

El convenio hace la diferencia en cuanto a las excepciones de la restitución del menor según el tiempo transcurrido entre el momento, que se produjo el traslado o la retención del menor y la iniciación del procedimiento ante la autoridad judicial o administrativa. Cuando este período es menos de un año la restitución del menor puede ser negada sólo por causas extremamente graves ${ }^{40}$. El éxito del convenio depende esencialmente en que las excepciones sean interpretadas de una manera restringida ${ }^{41}$. El efecto preventivo sólo se puede realizar, si la sustracción no favorece el sustractor.

\section{a) Riesgo de peligro}

Cuando la solicitud de restitución se ha iniciado dentro del plazo de un año sólo puede ser negada, si la persona que se opone a la restitución demuestra que "Existe un grave riesgo de que la restitución del menor lo exponga a un peligro físico, psíquico o de cualquier otra manera ponga al menor en una situación intolerable" (art. 13).

\section{(1) Grado del riesgo}

Por el fin del convenio de impedir la sustracción ilegal de los menores, el grado de riesgo para un peligro físico o psíquico tiene que ser muy alto. Los inconvientes, que resultan de cada traslado de un menor de un estado a otro con los cambios inherentes en cuanto al idioma y al ambiente cultural, no justifican la negación de la restitución. Si no, la sustracción siempre tendría éxito. La prevención general que el convenio tiene como objetivo, no se podría realizar. El convenio da preferencia al interés general de los menores, que consiste en la prevención de las sustracciones. Por este motivo el convenio acepta que el menor en un caso concreto tiene que sufrir el inconveniente de un cambio reiterado ${ }^{42}$.

Como excepción, fue reconocido e peligro actual no sólo hipotético, de que el menor fuera maltratado de obra en el país, en el cual la restitución se efectuará, sea por el mismo padre o la misma madre o por una tercera persona, por ejemplo, la nueva pareja de un padre $^{43}$.

La otra alternativa del art. 13 lit. b es e riesgo, que la restitución ponga al menor de cualquier otra manera en una situación intolerable. Esta excepción tiene el sentido de una clausula general para impedir una violación

${ }^{42}$ Pérez-Vera, No. 34; Siehr, N. 46; Staudinger/Pirrung, N. 683; Bruch, p. 751; Jayme, IPRax 1995, 118; Kropholler, RabelsZ 60 (1996), p. 490; Klein, IPRax 1997, 106, 109; BVerfG, 15.2.1996, FamRZ 1996, p. 405; por la oposicón de los menor); OLG Hamburg 16.1.1996, FamRZ 1996, 685. Court of A ppeal (England) casos citas

${ }^{43}$ AG Charlottenburg 7.10.1992, citado por Staudinger/Pirrung, N. 683.

${ }^{44}$ BVerfG 15.8.1996, NJW 1996, 3145; OLG Nuernberg 13.9.1993, IPRax 1995, 118; ver también las decisiones citadas por Bruch, p. 751; por Silbermann, p. 28 s. y por Young, p. 224.

${ }^{45}$ Bruch, p. 752; Staudinger/Pirrung, N. 635

${ }^{46}$ P.v.P. High Court of Justice (Manchester Fam. Div.) 19.9.1989 citado por Bruch, p. 751; decisiones de tribunales ingleses reportados por Young, p. 224; Kropholler, RabelsZ 60 (1996), 491 ss, con resumen de la jurisprudencia en Suiza, Estados Unidos, Inglaterra y Francia.

${ }^{47}$ Navaro v. Bullock, Calif. Superior Ct., Placer County, N. 86481 (1.9.1989) citado por Bruch, p. 753

Revista da Faculdade de Direito da UFRGS, v. 20, Outubro/200 de los intereses fundamentales del menor. Pareú ámo se aplica en la práctica. Tiene excepción por peligro físico o psíquico.

En el caso, que el menor fue sustraido por la persona que estaba primeramente los padres están todavía casados y la madre que cuidaba al hijo, deja el hogar llevándose al paca edad. (a) enordenaron la restitución con la convicción de - la madre se va a deplazar junto con el metribunales aplazaron el procedimiento para dar posibilidad de procurar condiciones adecuadas, para que la madre pudiera regresar con el mede un nuevo cambio fue causado primordialmente por la sustracción ilícita, efectuda por la misma madre ${ }^{47}$ madre. Esto vale sobre todo en casos de niños 
Por lo general esta actitud flexible me parece muy adecuada para realizar el fin del convenio. De esta manera se puede excluir el riesgo para el menor y realizar la restitución. La limitación de las excepciones de dictar la restitución es decisiva para el éxito del convenio.

\section{(3) Carga de prueba}

El convenio dispone, que la restitución solo se pueda negar, cuando el padre que se opone a la restitución, demuestra la existencia de una de las mencionadas excepciones a la restitución. La prueba está a cargo del padre, que se opone a la restitución. El tribunal no tiene que abrir investigaciones de oficio ${ }^{48}$. Puras aserciones del sustractor sobre peligros existentes no pueden ser suficientes para obligar al tribunal de entrar en investigaciones. Sino el fin del convenio de asegurar la restitución en corto tiempo podría ser impedido por el sustractor. El sustractor tiene que mostrar pruebas concretas y concluyentes ${ }^{49} . \mathrm{El}$ art. 13 par. 3 establece, que al examinar un posible peligro para el menor, el tribunal tendrá en cuenta la información que la autoridad central u otra autoridad competente del lugar de residencia habitual del menor proporcione sobre la situación social del menor.

La decisión sobre la restitución resulta ser una tarea muy difícil y compleja para el tribunal. Debido a que existe la contrariedad entre el fin preventivo del convenio y la protección del menor en el caso específico.

\section{b) Oposición del menor al dictar la restitución}

En el art. 13 el convenio reconoce también la oposición del menor como causa para

${ }^{48}$ Mansel, 2177.

${ }^{49}$ Kropholler, RabelsZ 60 (1996), 497.

${ }^{50}$ Boehmer, 650.

${ }^{51}$ OLG Celle 20.10.1994, FamRZ 1995, 955.

${ }^{52}$ Casos citados por Bruch, p. 753.

Revista da Faculdade de Direito da UFRGS, v. 20, Outubro/200I negar la restitución. La oposición se toma en cuenta, cuando el menor haya alcanzado una edad y un grado de madurez en que resulta apropiado tener en cuenta sus opiniones. El sentido de esta regla es, que el menor tiene el derecho que su propia voluntad sea respetada. $\mathrm{El}$ menor no es objeto del procedimineto. $\mathrm{El}$ convenio tiene por fin primordial el bienestar de los menores. La madurez del menor es el punto esencial. Ella se puede considerar únicamente en el caso específico.

El convenio determina la edad apropiada para tomar en cuenta la opinión del menor com condición acumulativa. No se fijó una edad mínima absoluta. Como consecuencia, todo depende de la madurez del menor en el caso específico. Por lo general, siempre se va a tomar en cuent la oposición de un menor con 14 o más años ${ }^{50}$

Pero muchas decisiones han respetado la voluntad de niños mucho más jóvenes. Por ejemplo tribunales alemanes han acepatado la voluntad de dos hermanos con 7 y 9 años $^{51}$, en otro caso la oposición de una niña con 7 años o hasta la oposición contra la restitución de 2 hermanos con 5 y 6 años ${ }^{52}$. La opinión del menor es también un factor para apreciar si la restitución causa un daño psíquico al menor.

El problema, que se plantea en este aspecto, es la influencia que tiene el sustractor en la opinión del niño. A un lado, es importante respetar la opinión del menor, ya que él tiene propios derechos y no puede ser tratado como el objeto de los intereses y derechos de los padres. Al mismo tiempo, el convenio perdería su eficacia, si el sustractor podría manipular la situación en su favor utilizando su influencia en la opinión del menor
Además, la oposición del menor de vivir con el otro padre, no justifica la negación de la restitución, argumantación errona que se encuentra en varias decisiones. La opinión de menor, con cual padre quiere vivir, tiene que se tomado en cuenta en el procedimiento sobre la custodia $^{53}$. La restitución no significa necesariamente que el menor sea entregado al otro padre. La restitución tiene como objetivo a hacer posible que el procedimiento sobre la cuestión de fondo se lleva a cabo en el estado de la residencia habitual del menor antes de la sustracción.

\section{c) Cláusula de ordre public}

El art. 20 constata que la restitución podrá denegarse cuando no lo permitan los principios fundamentales del estado requerido en materia de protección de los derechos humanos y de las libertades fundamentales. Esta cláusula de ordre public es formulada de una manera más estrecha que usual ${ }^{54}$. Al lado de art. 13, esta norma tiene un ámbito de aplicación muy restringido. No se conoce un caso en el cual el art. 20 justificó la negación de la restitución ${ }^{55}$.

\section{La restitución después de un lapso de un año}

En el caso, de que los procedimiento para la restitución se hubieran iniciado después de la expiración del plazo de un año desde e momento de la sustracción, el tribunal siempre puede ordenar la restitución. Pero según el art.

${ }^{53}$ Bruch, p. 753, nota 60; Silbermann, p. $30 \mathrm{~s}$

${ }^{54}$ Mansel, 2177; Shapira, p. 197 s.

${ }_{55}$ Staudinger/Pirrung, N. 698.

${ }^{56}$ Re N (Minors Abduction [1991] 1 FLR 413, citado por Young, p. 222

57 Ver la argumentación de OLG Bamberg 18.7.1994, FamRZ 1995, 305; para una interpretación restringida de la noción ,integrado“ Siehr, N. 44.

${ }^{58}$ OLG Bamberg 18.7.1994, FamRZ 1995, 305.

${ }^{59} \underline{\text { Jorzik, }}$ p. 51.
12 par. 3, el tribunal puede negar la restitución en este caso si queda demostrado que el menor ha quedado integrado en su nuevo ambiente. Esta disposición abre la posibilidad de reclamar la integración del menor en el ámbito de la nueva residencia.

Tribunales ingleses se han mostrados restringidos en aceptar esta excepción de la restitución. A un lado, un menor de poca edad depende primordialmente de la relación con el padre que le está cuidando. La integración de la madre sustractor no fue tomado como suficien-

Si se trata de menores de más edad que van al jardin de la infancia o a la escuela, la integración en el ambiente de la nueva residencia es la regla ${ }^{57}$. Así la observancia del plazo de un año es decisiva. La restitución que e solicita dentro de un año tiene una alta posibilidad de ser dictada. Mientras que una solicitud después de este lapso tiene poca chance de ser atribuida. Para que el procedimiento se pueda iniciar en este plazo, la ayuda que las autoridades centrales pueden prestar son de suma importancia. Decisivo para este lapso no es la recepción de la solicitud de autoridad competente para dictar sobre la restitución ${ }^{58}$

\section{El procedimiento}

El procedimiento para lograr la restitución es muy flexible y se caracteriza por la ayuda de las autoridades centrales ${ }^{59}$. La persona o la organización, que tenía un derecho te para suponer la integración del hijo ${ }^{56}$. restitución en la autoridad central, pero en la 
de custodia que fue lesionado por la sustracción, puede solicitar la iniciación de los trámites de restitución. Esta solicitud puede se dirigida a la autoridad central del estado de 1 residencia habitual del menor (art. 8). Esta autoridad central transmitirá la demanda a la autoridad central del estado, en el cual se supone que el menor se encuentra (art. 9).

La autoridad central del estado dond se encuentre el menor, adoptará o hará que se adopten todas las medidas adecuadas encaminadas para conseguir la restitución voluntaria del menor o a facilitar una solución amigable (art. 10, 7 lit. c). Si una solución voluntaria no se consigue, la autoridad centra incoará o facilitará la apertura de un procedimiento judicial (o administrativo) para conseguir la restitución del menor (art. 7 lit. f). En este caso concederá o facilitará la obtención de asistencia judicial y jurídica (art. 7 lit. g).

El demandante no está excluido de dirigirse directamente a la autoridad central de estado, donde se encuentra el menor o de iniciar directamente el procedimiento de restitució por la autoridad judicial o administrativa competente en el estado de la residencia acutal de menor (art. 29). En la práctica, la vía de 1 solicitud mediante la autoridad central del estado de la residencia habitual del menor es lo más efectivo. La autoridad central acumula con 1 práctica experiencia. Se establece una costumbre de contactos directos y personales con las demás autoridades centrales. De gran ayuda es también la mediación de las autoridades centrales para disminuir los obstáculos de llevar un proceso en otro país. Antes, muchos intentos de demandantes fallaron por el consumo de tiempo que causan la búsqueda de asistencia judicial y otras dificultades de un proceso en un país extranjero.
La colaboración y la ayuda de las autoridades centrales son los puntos claves para que el procedimiento de la restitución se pueda iniciar y llevar a cabo en un lapso de tiempo corto. La brevedad del procedimiento es esencial para la realización del objetivo del convenio: Cuanto más tarde el procedimiento y por esto cuanto más el menor se quede en la nueva residencia, tanto más causas pueden ser invocadas contra una restitución.

El convenio no prescribe un cierto procedimiento para el proceso de restitución delante la autoridad judicial o administrativa. El art. 11 constata solamente que las autoridades judiciales (o administrativas) actuarán con urgencia en los procedimientos para la restitución de los menores. Cada estado contractante tiene que determinar que procedimiento se aplica. El procedimiento tiene que permitir, que la decisión de restitución se pueda llevar a cabo dentro un plazo corto. El plazo de seis semanas del art. 11 par. 2 puede servir como norma. El art. 11 par. 2 determina que el demandante y la autoridad central del estado requerido tienen el derecho de pedir una declaración sobre las razones de la demora, si una decisión no se hubiera tomado dentro de seis semanas a partir de la fecha de la iniciación de los procedimientos.

En Alemania son competentes para decidir sobre la demanda de restitución los departamentos especiales encargados de asuntos de derecho de familia en los tribunales de la primera instancia. Las sentencias de este tribunal pueden ser apeladas delante del tribunal regional superior por el recurso imediato en un plazo de dos semanas ${ }^{60}$

60 §§ 6, 8 Ausfuehrungsgesetz, $\S \S 22,28$ Gesetz ueber die Angelegenheiten der freiwilligen Gerichtsbarkeit (FGG) en caso de divergencias de cuestiones de derecho entre diferentes tribunales superiores regionales la corte federal suprema decidará del caso por presentación del tribunal superior regional.

Revista da Faculdade de Direito da UFRGS, v. 20, Outubro/2001

\section{Recientes decisiones de tribunales alemanes}

Después de haber mostrado la problemática a la cual responde el convenio y las soluciones previstas por éste (la restitución rápi da bajo pocas condiciones y la colaboración internacional por medio de autoridades centrales) quiero ejemplificar unos problemas, analizando dos casos recientes que fueron decididos por la corte constitucional de Alemania en una manera casí opuesta.

\section{Primera decisión de la Corte Constitucio- nal}

En la primera decisión, la Corte Constitucional tenía que solucionar el siguiente caso $^{61}$ :

El marido, norteamericano, y la esposa, lemana, vivían juntos en Utah en los Estados Unidos. El hijo común nació en el año 1989. En el año 1994 los cónyuges se divorciaron. El derecho de custodia fue atribuido a la madre. Al padre fue atribuido el derecho de contacto permanente y seguido y el derecho de ser consultado de cuando se quiera cambiar la residencia en los Estados Unidos de un estado a otro. En caso de cambio de vivienda en el mismo estado existía la obligación de los excónyuges de informar al otro. La madre tuvo el derecho de llevarse al menor para Alemania en el tiempo de vacaciones de verano. Al final del año 1994 la madre salió de los E.U. junto con su hijo para domiciliarse en Alemania. El padre obtuvo la decisión de un tribunal en los E.U. que le atribuyó a él solo el derecho de custodia. El mismo tribunal constató por una decisión que los derechos del padre que le habían sido

${ }^{61}$ BVerfG 15.8.1996 (3. Kammer des Zweiten Senats), IPRax 1997, 124 = NJW 1996, 3145; caso y decisión Dents), IPRax 1997, $123=$ FamRZ 1996, 405

${ }^{62}$ BVerfG 17.3.1995 (1. Kammer des 1. Senats), IPRax 1997, 121 = FamRZ 1995, 663 atribuidos antes del traslado del menor, tienen que ser calificados como el derecho de custodia en el sentido de los art. 3 y 5 del convenio de la Haya. Por la solicitud del padre el tribunal alemán de primera instancia ordenó la restitución de menor. La decisión fue mantenida en la segunda instancia y el recurso a la Corte Constitucional quedó sin éxito.

El punto de salida es la observación de la Corte constitucional que la protección del menor contra la sustracción plantea cuestiones que toquen los intereses y derechos fundamentales del menor y de ambos padres. E interés del menor siempre es prescindible al de los padres. El fin del convenio es que la restitución se efectue lo más rápido posible. Este fin está orientado hacía el bienestar de menor. El bienestar en un sentido general demanda la restitución para desanimar a los padres de cometer sustracciones. El traslado causado por la restitución es inconveniente para e menor, pero está justificado por los efectos preventivos que tiene. De esa forma, futuras tendencias de sustracciones se deciminan. La protección de los niños en general reclama este efecto preventivo. El fin del convenio justifica una aplicación estrecha de las excepciones de la restitución. Los intereses del menor en juego en el caso concreto son protegidos en una manera suficiente por el art. 13 del convenio.

\section{Segunda decisión de la Corte Constitucio-}

Lo que la Corte Constitucional no toma en cuenta en esta decisión son los intereses de la madre, de no regresar a los Estados Unidos. Estos intereses fueron más importantes en otra decisión de la Corte Constitucional, tomada por otra cámara ${ }^{62}$. 
Los hechos de este caso son muy parecidos al recién mencionado. Se trataba también de una pareja mixta: El esposo norteamericano, la esposa alemana. La pareja se había casado en el año 1988 y vivían en los Estados Unidos. En febrero del año 1993 nació la hija común. En junio del mismo año, el padre dejó el hogar. Desde este tiempo los cónyuges vivían separados. El padre siguió viendo a la hija. En relación con las negociaciones sobre el reglamento de las consecuencias de la separación y de un divorcio, el padre ofreció a la madre ventajas financieras en el caso que se quedará con la hija en los Estados Unidos.

La madre dejó los E.U. antes de que una decisión sobre la custodia fuera tomada llevándose a la hija y se instaló en la casa de sus padres. El padre obtuvo en los Estado Unidos una certificación de que el traslado lesionó el derecho de custodia del padre. El padre no tenía la intención de obtener el derecho de guarda. Más bien quería, que el derecho de custodia se les atribuyera a los dos padres, mientras que la guarda cotidiana se le atribuyera a la madre. Por consecuencia de tal reglamento la madre tendría que permanecer y criar la hija en los Estados Unidos.

El tribunal de primer instancia negó la restitución con el argumento, de que el padre no ejercía efectivamente el derecho de custodia en el momento de que la madre dejó los Estados Unidos. El tribunal superior regional ordenó la restitución, argumentando que lo inconveniente de un regreso para la niña se puede evitar por la compaña de la madre.

La Corte Constitucional federal, a la cual la madre recurrió en nombre propio y en nombre de la hija, decidió en el procedimiento provisional que la restitución no se efectuara ${ }^{63}$ La restitución podría lesionar el derecho funda-

mental de la niña al respeto de su derecho de la personalidad. La separación de un niño de poca edad de la madre que la estaba cuidando hasta el momento es muy probable de causar daños severos. La Corte Constitucional constata, que en cuanto a la posibilidad de que este daño puede evitarse por la compaña de la madre había que tomar en cuenta las razones que la madre puede invocar en contra de un regreso.

\section{Analisis de las decisiones}

Las dos deciciones se contradicen en alto grado. Hay que analizar que solución favorce el convenio.

\section{a) Caso clásico}

Para ésto, es importante ver que estos casos no son los casos clásicos, que el convenio visaba. El caso clásico es que el padre que no tiene el derecho de custodia quita el hijo al otro padre que lo estaba cuidando ${ }^{64}$. En este caso no hay problema en cuanto a la infracción de un derecho de custodia y en que la restitución se realice con la entrega del menor al padre que lo estaba cuidando antes de la sustracción.

Todavía el segundo caso típico que fue descrito arriba, no causa problemas en la aplicación del convenio. Es el caso, que un padre se lleva a los hijos antes de que una decisión sobre el derecho de custodia haya sido tomada. El derecho de custodia que fue lesionado existía en pleno derecho. La restitución significa un regreso provisional del padre y del hijo para que se puedan efectuar los tramites de divorcio y de atribución de derecho de custodia.

La problemática que existe en este caso ya se mencionó. Si era por ejemplo la madre que

“3 La decisión final fue tomada de una cámara del segundo senato, BVerg 10.10.1997, IPRax 1997, 123; esta decisión rechazó el recurso de la madre con la consecuencia que la restitución se podía efectuar. 64 González Campos et al., N.55 se llevó a un hijo de poca edad, la restitución podría cometer un grave daño si el hijo no fuera acompanado de la madre. Pero fue mostrado arriba que los tribunales han encontrado medidas para hacer posible que la madre regrese temporalmente con el hijo. Es muy importante ver que según el convenio la restitución no puede ser negado con el argumento que e derecho de custodia se atribuyera con certeza a la madre que sustrajó el menor. El objetivo preventivo del convenio exige que la decisión sobre la atribución del derecho de custodia se tome en el estado de la residencia habitual del meno antes del traslado.

\section{b) Particularidad de los dos casos}

Los dos casos de las decisiones mencionados se caracterizan por un aspecto adicional. La atribución del derecho de custodia se ha hecho o se iba a hacer de la manera que la madre tiene la guarda actual y cotidiana del menor, mientras los dos padres tienen el derecho de custodia en común. Este derecho de custodia consiste por parte del padre en el derecho de visita resforzado por el hecho de que la madre puede tomar ciertas deciciones, como especialmente el cambio de residencia a un otro estado, sólo con el consentimiento de este padre.

La primera cuestión que se plantea es, si el derecho del padre puede ser calificado como un derecho de custodia, en el sentido de convenio. Sólo la infracción a un derecho de custodia da camino a una restitución. Si el otro padre tenía solamente un derecho de visita, e padre no puede oponerse a un cambio de residencia. El convenio no proteje el interés del padre, que solamente tiene un derecho de visita, de vivir cerca de su hijo. El derecho de visita no está protegido contra el obstáculo de ejecerlo

${ }^{65}$ Pérez-Vera, N. 65; Young, p. 222

${ }^{66}$ En este sentido dictaron la mayoría de los tribunales como reportado por Silberman, p. 17 s. (por ejemplo Court 66 En este sentido dictaron la mayoría de los tribunales como reportado
of Appeal in England [1989] 1 FLR 403 (C.A.) y por Young, p. 222 .

${ }^{67}$ Bruch, p. 752; Young, p. 222. sobre una larga distancia ${ }^{65}$. La dicción literal del convenio es bien claro en cuanto a esta cuestión. El art. 5 lit. a determina, que para los efectos del convenio, el derecho de custodia comprenderá el derecho relativo al cuidado de la persona del menor y, en particular el de deci-

Pero parece que a pesar de esta definición, los redactores no tenían consciencia de los problemas que surgen por este tipo de distribución del derecho de custodia ${ }^{67}$. Considerando un derecho que no contiene el cuidado de la vida cotidiana pero el derecho de participar en la decisión sobre la residencia del menor como derecho de custodia en el sentido de la convención causa problemas en dos aspectos.

A un lado se plantea la cuestión de que manera la restitución se efectua en un caso, que, por ejemplo la madre que tiene el derecho de guarda sustrajó el menor. La restitución no se puede realizar sin problemas por la entrega al padre. El derecho de éste no contiene la guarda cotidiana. Además en caso de niños de poca edad el bienestar del menor exige la continuación del cuidado por la misma persona, es decir en muchos casos la permanencia con la madre.

En este sentido se hace claro que el derecho de custodia del padre consiste en tal caso en realidad sólo en un derecho de visita reforzado. En la mayoría de los casos los tribunales pueden encrontrar una solución. Ya fue mencionado la posibilidad del tribunal de hacer entender al demandante que la restitución sólo se puede dictar si éste procura las condiciones adecuadas para que la madre pueda regresar con el menor.

Por ésto, las observaciones del tribunal superior de Berlin eran erróneas, cuando pensaba que la restitución no se podía dictar dir sobre su lugar de residencia ${ }^{66}$ 
porque la madre que sustrajo tenía el derecho de guarda cotidiana y que por consecuencia no se podía entregar el menor al padre ${ }^{68}$. El tribunal no prestó atención de que la restitución no significa necesariamente la entrega del meno al otro padre. La restitución visa a reestablece la situación que existía antes de la sustracción. Lo importante es por consecuencia que el menor toma de nuevo residencia en el país del cua fue sustraído. Se encuentran con frecuencia decisiones que ordenan la restitución y hacen entender a la madre, que debe regresar con e hijo, sobre todo por haber sido ella la causante de la situación al sustraer al menor. El hecho de que el otro padre no quiere o no puede se encargado del cuidado cotidiano no impide la restitución, cuando la madre puede regresar con el menor.

Esta observación lleva a la segunda problemática: De qué manera el tribunal tiene que tomar en cuenta los argumentos de la madre que no quiere regresar por sus propios intereses? Los intereses de la madre de no regresar tienen que tomarse en cuenta para apreciar, si existe el peligro de un daño que la restitución podría ocasionar. Si la situación de la madre es que no puede acompañar al menor los efectos de la separación en consecuencia de la restitución pueden causar la negación de la restitución. Un tribunal alemán de prime instancia negó la restitución por el peligro de un daño grave para el menor porque no veí posible que la madre que había sustraido al menor regresara a Australia. La madre se había casado otra vez y tenía un bébé recien nacido en el nuevo matrimonio ${ }^{69}$

En casos que el regreso sea posible, la tendencia de ordenar la restitución obliga a la madre de hecho, de regresar con su hijo al país

de la residencia anterior. Los intereses de la madre de no volver a vivir en el país, no necesitan ser tomados en cuenta para la decisión de la restitución. La idea de la decisión sobre la restitución, es que reestablece solamente la situación anterior de la sustracción y no tiene efectos sobre la decisión final sobre el reparto de la custodia. Estos intereses de la madre tienen que ser tomados en cuenta en el procedimiento sobre el reparto de la custodia que se va a llevar a cabo en el estado de la residencia anterior.

En la realidad, la separación total de la decisión sobre la restitución según el convenio y la siguiente decisión sobre el fondo de la custodia, solo se va a realizar, si el tribunal que decide sobre la restitución tiene la convicción que el tribunal que decide sobre la custodia en fondo, no tomará una decisión parcial en favor del padre nacional del mismo estado. Este problema se pone especialmente en tal caso que a la madre fue atribuido el derecho de custodia y la guarda cotidiana, pero con la restricción de que no puede salir del estado de la residencia habitual de la familia sin el consentimiento del excónyuge.

La restitución del menor significa que la madre tiene que regresar con el menor al país de la residencia habitual antes de la sustracción. Si en este país la decisión sobre el derecho de custodia es matenido de la misma manera, la madre queda obligada de permanecer en este país.

Esto puede ser justificado con el interés del menor de permanecer en el mismo país, donde él se crío hasta el momento de la sustracción. Además se reconoce el interes del menor de mantener relaciones estrechas con los dos pa-

${ }^{68}$ Kammergericht Berlin 13.12.1995, FamRZ 1996, 691, 693.

${ }^{69}$ AG Weilburg 22.6.1994, FamRZ 1995, 242; untribunal ingles negó la restitución por peligro de un daño para el hijo porque la madre padecía de depressiones que se hubieran agravados (Re G (Abduction:Psychological Harm)
[1995] 1 FLR 64, reportado por Young, p. 224.

Revista da Faculdade de Direito da UFRGS, v. 20, Outubro/2001 dres. Lo que es más fácil, viviendo cerca el uno del otro. Al otro lado me parece que hay que considerar también los intereses de la madre de regresar al país de orígen después de que su matrimonio falló

La decisión de la Corte Superior de Connectitut en los Estados Unidos me parece muy remarcable, ya que tomó una decisión en contra de la madre nacional de los Estados Uni$\operatorname{dos}^{70}:$ El tribunal dijo:

"El deseo de la madre de vivir en los Estados Unidos lejos del esposo, es la caus de esta tragedia. Ella escogió el enamorarse, casarse y tener hijos en España. Ahora tiene que enfrentarse a las consecuencias de esta decisión. La corte no puede dar su consentimiento de que una persona sustrae así a sus hijos del país de la residencia de ellos."

En estos casos, la decisión tiene que tomar en cuenta todos estos diferentes aspectos: la edad del menor y su integración en el ambiente de la residencia habitual, el carácter de la relación del menor con el otro padre etc. Para la decisión sobre la restitución del menor, todos estos aspectos formalmente no tienen ninguna importancia.

Según la estructura del convenio la decisión de la restitución no afectará la cuestión de fondo de derecho de custodia. Pero hay que tomar en cuenta, que esta separación total de las dos deciciones significa que el estado de refugio niega toda competencia propia y da la prioridad al estado de la residencia habitual anterior para la cuestión de fondo. En la práctica esta distribución de competencia sólo funciona, si los tribunales encargados de dictar la restitución, tienen la confianza de que en el estado al cual se efectuará la restitución, las decisones se tomarán de una manera imparcia en cuanto a las preferencias nacionales y según

Esto significa que los intereses de madre de no seguir viviendo en el estado de la antigua residencia habitual, no se pueden tomar en cuenta en si mismo según la estructura del convenio. Estos intereses tienen que ser apreciadas en el procedimiento que decide sobre el derecho de custodia o en un procedimiento que permite a la madre de cambiar la residencia habitual sin el consentimiento del padre. Estos procedimientos tienen que llevarse a cabo en el estado de la antigua residencia habitual del menor.

\section{Conclusiones}

Concluyendo se puede constatar. Para que el convenio logre su objetivo, es necesario que la sustracción no tenga efecto positivo para el sustractor. Para ésto, es esencial que la restitución se efectue lo más rápido posible y que no se pueden presentar causas contra la restitución que fueron producidas por la misma sustracción. La cooperación y la ayuda que prestan las autoridades centrales son de enorme imporancia para que los trámites de la restitución se puedan llevar a cabo en un plazo corto. La otra condición esencial consiste en que el tribunal, que decide sobre la restitución, limita su decisión estrictamente a este asunto. Tiene que abstenerse de tomar una decisión sobre el reparto de la custodia. Todas las deliberaciones en cuanto a qué padre la custodia debería ser atribuida tienen que ser excluidas del procedimiento de la restitución. La elitución tiene que ser limitada a la restauración de la situación anterior de la sustracción. Si esta limitación se respeta, son muy pocos los casos en los que la restitución puede ser negada.

${ }^{70}$ No. FA91-0392232S, 1991 Conn. Super. Ct. LEXIS 2215 (Sept. 27, 1991) citado por Silberman, 26. ${ }^{11}$ Silbermann, p. 34; Jayme, IPRax 1995, p. 118 
Mediante la restitución el tribunal entrega toda competencia de nuevo a los tribunales en el estado de la residencia habitual del menor antes de la sustracción. Esta entrega de competencia y esta autolimitación sólo se realizan, si el tribunal, que decide sobre la restitución, tiene la confianza de que la decisión de fondo so- bre la custodia se dicte con imparcialidad en cuanto a las nacionalidades y si los criterios para la decisión son parecidos en los dos estados. Por ésto la cooperación, que el mecanismo del convenio exige, sólo puede funcionar si las concepiones en cuanto al derecho de custodia son parecidas en los países contractantes.

\title{
Entre o "positivismo" "catolicismo": \\ As dimensões do espaço jurídico no Rio Grande do Sul
}

\author{
Fabiano Engelmann \\ Bacharel em Direito UFRGS \\ Mestre em Ciência Política UFRGS \\ Doutorando em Ciência Política UFRGS
}

\section{7} apresenta parte dos resultado corpo docente da Faculdade de Direito de Porto Alegre/UFRGS concernentes a condicionantes sociais de sua formação intelectual e as conseqüências desta formação na estruturação do espaço jurídico sul-riograndense. ${ }^{1} \mathrm{O}$ universo empírico do objeto centrou-se nos docentes que atuaram entre as décadas de 40 e 70 e que podem ser identificados com uma geração que teve ampla participação na definição do universo intelectual no estado.

A definição de um espaço ${ }^{2}$ jurídico no Rio Grande do Sul pode ser entendida em duas dimensões. Na primeira, ocorre a edição de leis que normatizam as profissões jurídicas na década de 30 inserindo-se no processo de corporativização presente no projeto políticoinstitucional do Estado Novo. Esta dimensão comporta paralelamente o crescimento do capital associativo entre os bacharéis originando as associações profissionais (tais como a $\mathrm{OAB}$ / RS) paços de celebração social e gestão do capital de relações sociais entre os profissionais do direito.

Numa segunda dimensão, pode-se acentuar o aumento da produção intelectual na área jurídica objetivada na edição de obras de doutrina e no aparecimento de um grupo de bacharéis sul-rio-grandenses que se associa a uma tradição do "pensamento jurídico gaúcho".

${ }^{1}$ A íntegra da investigação referida pode ser encontrada na dissertação de Mestrado intitulada "A Formação da Elite Jurídica no Rio Grande do Sul" que foi objeto da arguição dos professores Hélgio Trindade, Loiva Otero Felix e Enno D. Liedeke em março de 2001, tendo sido desenvolvida sob a orientação do Prof. Odaci L. Coradini. Os resultados apresentados foram selecionados a partir do segundo capítulo da mesma.

${ }^{2}$ As referências conceituais utilizadas na presente investigação estão ligadas principalmente ao aporte teórico desenvolvido na bibliografia francesa contemporânea acerca da sociologia de elites políticas e culturais, particularmente as pesquisas realizadas por Pierre Bourdieu, Monique de Saint Martin, Yves Dezalay e Cristophe Charle. A explicitação das referências teóricas e metodológicas, bem como, da problemática envolvendo sua aplicação ao caso específico, podem ser encontradas em Engelmann(1999). 
Esta produção intelectual pode ser lida como expressão de um espaço mental possíve dos bacharéis no período analisado conformado a partir de suas características sociais comuns que permitem a reunião de um conjunto de trajetórias individuais num grupo sociologicamente bastante homogêneo.

Os agentes no processo de definição deste espaço serão os alunos formados na $\mathrm{Fa}$ culdade de Direito de Porto Alegre entre 1914 e 1924 que já podem ser identificados na disputa entre duas tradições intelectuais em conflito. Uma geração ligada ao positivismo ${ }^{3}$ e ao PRR (Partido Republicando Rio-Grandense), herdeira dos padrões de inserção dos bacharéis da segunda metade do Império brasileiro (ver estudos de Pang \& Sechiringer (1972), Barreto (1978), Barman\&Barman (1976), Adorno (1988) que estrutura a fundação da Faculdade. Um do expoentes desta geração é Manuel André da Rocha, simultaneamente Diretor da Faculdade (1904-1936), chefe político do PRR e Presidente do Superior Tribunal do Estado (1921-1935) Este período é caracterizado pela total indissociação entre a "vida política" e a "vida jurídica". O título de bacharel em direito configura-se como um dos trunfos que contribuía para a legitimação da posição social de elite detida de "antemão" por aqueles que se inseriam nas lutas políticas que ocorriam então na província sul-riograndense. Entre outros capitais que legitimavam a posição social dos bacharéis estava o pertencimento à famílias de estancieiros, militares de alta-patente ou mesmo bacharéis em direito ${ }^{4}$
A esta "geração positivista" oriunda da Faculdade de Direito do Largo de São Francisco (São Paulo) e da Academia e Recife, opõese uma segunda geração, gestada já nos estudos pré-universitários nos Colégios Nossa Senhora da Conceição de São Leopoldo e no Colégio Anchieta e na própria Faculdade de Porto Alegre; a "geração dos católicos". 5 Neste contexto, o espaço jurídico de atuação presente no exercício da advocacia como atividade exclusiva, no ministério público e na magistratura; que se define institucionalmente entre as décadas de 40 e 70 não pode ser lido no sentido da constituição de um "campo jurídico autônomo". Mas antes, como um processo de reconversão da elite política que se constitui a partir da Faculdade de Direito. Esta se origina no âmbito intelectual num espaço de lutas delimitado, entre o catolicismo e o positivismo. Da mesma forma, as lutas neste "âmbito intelectual" não pode ser compreendidas fora das relações sociais e políticas ao mesmo tempo constituintes e constituídas neste espaço de lutas que não se esgota no aparente "debate intelectual"

\section{A dimensão "profissional" do espaço jurídico no Rio Grande do Sul}

No caso da advocacia, o Instituto dos Advogados do Rio Grande do Sul (IARGS) fundado em 1926, vai ser a pedra de toque para a
${ }^{3}$ Entende-se por "ligação ao positivismo" no caso analisado, as relações estabelecidas entre os acadêmicos e "Entende-se por "ligação ao positivismo" no caso analisado, as relaçôes estabelecidas entre os acadêmicos Logo, se trata de filiações fundadas em redes políticas, antes de filosóficas. "Sobre a influência do "positivismo"

Logo, se trata de filiações fundadas em redes políticas, antes de filosóficas. 'Sobre a
na política gaúcha neste período ver Love (1975), Pinto (1986) e Soares (1998)

${ }^{4}$ Ver a respeito das origens sociais e capitais mobilizados pela chamada "geração de 1907" expressão amostral das lutas políticas no âmbito da Faculdade de Direito no início do século, os trabalhos de Love (op cit) e Grijó (1988).

${ }^{5}$ A expressão "geração dos católicos" é utilizada por Trindade (1982) que analisou a estratégia da Igreja Católica em investir no ensino secundário visando a formação de elites. A homonegeneização intelectual desta geração ocorria principalmente através do ensino secundário centrado na escola Nossa Senhora Conceição de São Leopoldo (até 1911) e, posteriormente, no Colégio Anchieta.

Revista da Faculdade de Direito da UFRGS, v. 20, Outubro/200I organização da seccional gaúcha da Ordem dos Advogados do Rio Grande do Sul (OAB/RS) que será fundada em 1932 e terá como pano de fundo a disputa entre os "rábulas" (advogados sem diplomas") e os advogados bacharéis em direito $^{6}$. Este Instituto é fundado nos mesmos moldes do Instituto dos Advogados Brasileiros $(\mathrm{IAB})^{7}$, criado em 1842. O IARGS, assim como o IAB, vai ter preocupações ligadas aos atributos da profissão de advogado, com a finalidade de se constituírem em centros de estudos do direito e celebração entre seus pares visando conservar o capital simbólico ligado ao exercício da advocacia como atividade.

O propósito de celebração social e cultural entre os sócios do Instituto fica mais explícito na análise dos aspectos concernentes à sua fundação e a de seus fundadores. Embora não acumulasse a função de centro político como o IAB no período imperial, sua fundação vai ser protagonizada por um conjunto de advogados que se destacaram nas primeiras décadas do século vinte. Neste grupo de notáveis enquadram-se Camilo de Almeida Martin Costa, Armando Dias de Azevedo que atuaram politicamente juntos, formaram-se na mesma turma, "eram amigos" e constam como fundadores tanto do Instituto dos Advogados, como da Ordem dos Advogados do Brasil. Ambos passam pelo Colégio Anchieta, e formam-se a mesma época na Faculdade de Direito estando, conforme se depreende de suas trajetórias, associados à "geração dos católicos".

As relações amizade entre os sócio são cultivadas em diversas esferas de atuação. Em discurso proferido por Joaquim Tibúrcio de Azevedo, em homenagem ao primeiro presidente do IARGS, Leonardo Macedônia Franco e Sou$z a$, este faz questão de destacar a sua "intensa

${ }^{6}$ Maiores detalhes sobre esta disputa envolvendo as prerrogativas do exercício da advocacia encontra-se na publicação comemorativa dos 60 anos do IARGS, editada em 1986

${ }^{7}$ Sobre a formação do IAB ver IAB história dos 150 anos(1993)

Revista da Faculdade de Direito da UFRGS, v. 20, Outubro/200 e antiga amizade" com o Presidente que transparece ligações que vão se estabelecendo ao longo da trajetória pré-universitária, universitária, de exercício da advocacia e também na direção da Faculdade de Direito: "Sou amigo íntimo de Macedônia desde os tempos colegiais até hoje, sempre em convivência efetiva. Companheiros durante o curso de preparatórios no Instituto Brasileiro existente então nesta capital, dirigido pelo grande Apolinário Porto Alegre, colegas de ano, companheiros de casa e de estudos durante todo o ciclo acadêmico na acreditada Faculdade de Direito de São Paulo, onde recebemos em 1891. Abrimos banca de advocacia nesta Capital, há muito mais de trinta anos, ora defendíamos as mesmas causas, ora terçávamos armas em campos opostos, onde alternávamos vitórias e derrotas, sempre, porém amigos íntimos. Somos colegas de Congregação em nossa Faculdade de Direito, tendo ele acumulado as funções de cátedra com as de 1986). protagonizada principalmente pela geração de advogados que atua politicamente detendo mandatos parlamentares e exercendo simultaneamente a adocacia além do magistério na Faculdade de Porto Alegre. Este fenômeno demonstra que a atividade de advogado nasce como uma aposta do segmento dentre os detentores do título de bacharel, que possuía maior capital de relações sociais reconvertido concomitantemente na atividade política e na atividade de representação de interesses através da adocacia. A atividade de disputa de votos e a "clientela" necessária para andamento de uma banca de advocacia confundem-se, neste caso.

A ligação com a Faculdade de Direito e Instituto também é evidenciada pois tem-se secretário, durante mais de vinte anos (IARGS

A fundação do Instituto dos Advogados é 
do grupo de 16 advogados que constam como fundadores do IARGS/OAB, sete que são formados pela Faculdade de Porto Alegre e seis não-formados pela Faculdade de Porto Alegre que são professores da mesma. As primeiras reuniões do Instituto, inclusive, ocorrem nas dependências da Faculdade de Direito. Esta proximidade reforça a hipótese de que a Faculdade de Direito de Porto Alegre se constitui no pólo propulsor e articulador principal da elite jurídica gaúcha.

No concernente à carreira de promotor Público, a fundação da Associação do Ministério Público do Rio Grande do Sul (AMPRGS) em 1941 vai ser uma das expressões do processo de maior institucionalização da carreira. Terá, entre seus fundadores, figuras "menos notáveis" do que os fundadores do IARGS. Surgirá num momento em que a carreira de promotor público tradicionalmente ligada aos chefes de província e se constituindo em percurso inicial dos bacharéis recém-formados, assumirá progressivamente um papel específico dentro da divisão do trabalho nos meios jurídicos.

A Constituição de 1934 conferia aos estados a competência para a organização do Poder Judiciário e do Ministério Público locais, e fazia referências às garantias dos promotores que confundiam-se com às dos juízes. A luta dos promotores estará pautada pela busca das garantias outorgadas aos juízes e por sua autonomia em relação a estes que também terão maior prestígio enquanto carreira jurídica.

A referida Constituição, assim como a de 1946, trataram o Ministério Público como entidade autônoma em relação ao Poder Judiciário e também em relação ao Executivo. No Rio Grande do Sul, D'Avila(1974) ${ }^{8}$ vai destacar a figura de Abdon de Mello que idealizou o "pro-

jeto de reorganização" do Ministério Público no Rio Grande do Sul”, segundo o autor:

"O acento principal daquele projeto de Abdon de Mello, mostrando o seu pioneirism no aperfeiçoamento local da instituição, podia ser flagrado em três pontos de extraordinária importância: a) a pretensão de separar as funções de advogado dos interesses do Poder Público ou, melhor, de mandatário do Executivo, daquelas características institucionais, a de órgãos de pura e simples representação da sociedade e da lei; b) a idéia de carreira estrutural do Ministério Público, a iniciar-se na primeira entrância, com acessos regulares e gradativo até a Subprocuradoria que era então o último grau previsto; c) o instituto das correições no Ministério Público como fórmula para garanti o aperfeiçoamento funcional...." (D'Ávila, p.115)

Este projeto tinha por objetivo garanti a autonomia dos promotores frente aos chefe políticos locais ligados ao Executivo, e, também; frente aos "chefes" do Poder Judiciário tendo por pano de fundo a diferenciação do Ministério Público como instituição autônoma Abdon de Mello submete seu projeto ao exame das direções das Faculdades de Direito de Porto Alegre e de Pelotas (da qual fora aluno) o que segue uma tendência da época, pois sendo estas Faculdades pólo de reunião da elite jurídica à época servia para legitimar, impulsionar politicamente tais projetos.

A figura de Abdon de Mello também aparece consagrada como fundador da Associação do Ministério Público, além de publicar um livro contando a história da instituição em 1943 também vai organizar a Revista do Ministério Público em 1941. Mesmo tendo atingido relativa autonomia em relação aos outros poderes, conforme originariamente pretendido, o

${ }^{8}$ Floriano Maya D’Ávila publicou artigo reconstituindo o histórico da institucionalização do Ministério Público no Estado intitulado "O Ministério Público no Rio Grande do Sul", artigo inserto na coletânea organizada po Lenine Nequete em 1974, "O Poder Judiciário no Rio Grande do Sul "

Revista da Faculdade de Direito da UFRGS, v. 20, Outubro/2001
Ministério Público constitui-se tardiamente como um "poder de estado", prestígio que o judiciário, com sua progressiva institucionalização, vai atingir já no início do século. A atividade dos promotores também não vai chegar a atingir o mesmo capital simbólico acumulado pelos magistrados que terão no Judiciário um espaço definido socialmente.

O caso da construção da "profissão de magistrado" já vai redundar em maior complexidade, pois se tratavam os magistrados já, desde o Império de um segmento de elite nos meios jurídicos principalmente pela constituição do Tribunal de Relação e, posteriormente, Tribunal de Justiça ${ }^{9}$. Mesmo que, nas décadas de 10 e 20, a autonomia em relação ao "mundo político" fosse praticamente inexistente, a magistratura diferenciava-se mais enquanto carreira do que a promotoria.

Também na Constituição de 1934 é normatizada a carreira de magistrado. Os critérios de investidura adotados estabelecerão os critérios de antiguiidade e merecimento para promoção na carreira. A investidura nos juízos de $1^{\circ}$ grau será por concurso e nos graus superiores por critérios de antigüidade e merecimento e com o $5^{\circ}$ constitucional destinado a promotores e a advogados. A introdução de tais mecanismos visava modificar a antiga investidura no cargo por nomeação discricionária do Presidente da província pois este critério envolvia o comprometimento dos magistrados com o governo local.

Quanto ao aspecto associativo, a As sociação dos Juízes do Rio Grande do Sul

${ }^{9}$ Sobre a História do Poder Judiciário no Rio Grande do Sul, incluindo o período imperial ver a publicação do projeto memória do Judiciário organizada por Loiva O Félix Grijó(1999)

${ }^{10}$ A formação do "espírito de magistrado" envolvendo desde as origens sociais, familiares, a passagem pela faculdade de direito, formas de comportamento e percepção da realidade, são reforçadas nas "escolas preparatócotivas de fechamento da porta para a entrada na magistratura que tem a escola no curso preparatório uma forma de transformar esta "aprendizagem prática" que leva a formação do "espírito do magistrado" em um "saber formalizado', conforme Boigeol(1989) e Bancaud(1989).

Revista da Faculdade de Direito da UFRGS, v. 20, Outubro/2001

(AJURIS) fundada em 1944, vai se constitui como uma espécie de braço "político" do Poder Judiciário sem, entretanto, assumir uma teresses corporativos dos juízes, de suas garantias institucionais e, consequentemente, reservar-se um papel que o Tribunal de Justiça, "neutro" não explicitamente assumir. Posteriormendos através da Escola Superior da Magistratura que será fundada em 1979. Esta escola manurso "preparatorio para a carreira de magistrado"10 que se constituirá em uma porta e entrada para a magistratura inzes diferem das empreendidas pelo Instidos advogados, sendo que, no caso da blico, tratava-se de constituir uma profissão ercada de garantias institucionais. No caso da vocacia, o acesso ao exercício profissional dava a partir do capital de relações sociais detido pelos advogados, indispensável para o sucesso de uma banca de advocacia.

Estas breves considerações evidentemente não dão conta da complexidade que enas diferentretanto, ajudam a compreender hierarquização que opõe carreiras que se difecolar enquanto certificado de competências técnicas como a magistratura e o ministério público a atividades jurídicas como a advocacia e o 
magistério no âmbito das faculdades de direito que dependem fundamentalmente do capital de relações sociais detido pelo bacharel.

\section{A dimensão intelectual do espaço jurídico no Rio Gran- de do Sul}

O "pensamento jurídico gaúcho", se identifica nas características semelhantes que uniram os que "escreveram sobre direito" ou principalmente, "falaram sobre o direito" no estado do Rio Grande do Sul. Esta união, entretanto, não se dá apenas no âmbito do conhecimento técnico jurídico, mas é fruto de percursos comuns que compreendem os bacharéis envolvidos açambarcando, inclusive, uma certa homogeneização na sua formação intelectua antes de seu ingresso na Faculdade de Direito.

A produção deste conjunto de conhecimentos tendo por centro o direito, parte de esquemas de percepção e apreciação da realidade bastante próximos, onde misturam-se as variáveis referentes às origens sociais comuns, à formação intelectual e o tipo de relação que se estabelecem na apropriação e reprodução do conhecimento filosófico, literário e das tecnologia institucionais que os agentes vão trazer de suas leituras, via de regra, pautadas pela assistematicidade e pelo autodidatismo filosófico. Este será um traço importante na reconversão dos professores da Faculdade de Direito em direção à formação de juristas, o que também diferencia o caso do Rio Grande do Sul do modelo das academias imperiais que não se constituíam em pólos de produção intelectual.

Os autores pertencentes ao meio jurídi-

co que procuraram historicizar a produção jurídica no Rio Grande do Sul como Martins (1974) e Araújo (1996), invariavelmente ressaltam a influência das academias de Recife e São Paulo, o "pendor para o direito público"e a "oralidade" como basilares do "pensamento jurídico gaúcho". Segundo Martins (1974):

"Para se compreender sob que signos e influências culturais se iniciou o ensino e o estudo sistematizado do Direito no Rio Grande do Sul, é necessário atentar para São Paulo e Reci$\mathrm{fe}$, onde se situavam os dois grande centros de cultura jurídica e dos quais provinham os jovens rio-grandenses que se consagravam a fundação da República, no Rio Grande do Sul. E não só os jovens, mas também os mestres, eram filhos espirituais de uma ou de outra academia"(Martins, op. cit. p. 147)

Também é proclamado por Martins $(1974)^{11}$ o "pendor para o direito público". O primeiro livro de direito público escrito por autor gaúcho, segundo Martins, teria sido publicado ainda antes do surgimento da Faculdade de Direito em 1881, editado no Rio de Janeiro versando sobre a República Federal e assinado por Joaquim Francisco de Assis Brasil. No prefácio do livro mencionado lê-se:

"Quanto às fontes de inspiração para este trabalho, quase posso afirmar que outra não tive que não fosse a minha própria meditação sobre o que tenho observado em nosso e em alheios países. Tinha sem dúvida uma larga leitura anterior dos mais eminentes espíritos que trataram esta e análogas matérias - dos Montesquieu, dos Blackstone, dos De Tockeville, dos Story, dos Kent (sic), dos Macaulay, dos Freeman, dos Laboulaye, dos Bryce, dos Dupriez, sem contar os três

"Martins vai destacar ainda no campo do direito público: Alcides Cruz, professor a Faculdade, publica em 1910, Noções de direito administrativo brasileiro. No império, apenas aparecera o Direito Administrativo de Antônio Joaquim Ribas e, após a República, o Tratado da Ciência da Administração e Direito Administrativo, de Augusto Olímpio Viveiros de Castro, ao qual, acentua Martins, faltava o cunho didático(grifo meu).

Revista da Faculdade de Direito da UFRGS, v. 20, Outubro/2001 venerandos apóstolos do Federalista - Hamilton, Madison e Jay; mas enquanto escrevi, não abri livro, a não ser exceção raríssima. $O$ pouco que cito é ordinariamente de memória"(Assis, JF, 1896 apud Marins (1974, p. 150)

A passagem demonstra não somente a importação de conceitos estrangeiros para o desenho institucional brasileiro, mas também, o tratamento eclético, e assistemático dos mesmos, na sua apropriação, bastante características da importação das doutrinas jurídicas de uma forma retórica e literária. No início do século, vão predominar, segundo Martins (op. cit), as "obras de cunho didático". A edição não representa a produção de textos jurídicos, mas a compilação estimulada por um decreto federal que obrigava os professores à produção destes compêndios como o "Tratado de Ciềncia da Administração e Direito Administrativo" de Alcides Cruz, destinado aos seus alunos, prosseguindo até 1917 obras de comentário sobre códigos, traduções e compilações, ligadas a lições proferidas em sala de aula.

No período posterior à 1930 vai ocorrer a ampliação da produção jurídica no Rio Grande do Sul, ${ }^{12}$ sendo destacado a obra de Darcy Azambuja: "A Racionalização da Democracia" publicada em 1933: Nesta conjuntura é possível visualizar a estreita associação entre estas "teorias do estado" e os rumos políticos impressos ao governo federal com a ascensão de Vargas e seu grupo ao poder central. Referindo-se ao autor assinala Martins (op. cit)

"Racionalização do governo parlamen-

tar, os direitos sociais e a sua racionalização, regime representativo, a racionalização do regime representativo, a representação profissional e os conselhos técnicos, a dualidade de câmaras e, por fim, a crise da democracia e a função do poder executivo, são capítulos em que o brilhante constitucionalista expõe, discute e assenta conclusões de admirável equilíbrio quanto às transformações que se operam no estado moderno." (Martins, op. cit , 155)

Neste aumento da "produção jurídica" posterior a 1930 no Rio Grande do Sul, interessa notar que permanecem as mesmas formas de se relacionar-com o conhecimento, o que permite a consagração como "intelectual" até daqueles que aparentemente não produziram nada escrito: ilustrando aquilo que é conhecido como tradição nos meios jurídicos do sul: "a oralidade":

"Há brilhantíssimos espíritos, na história da cultura e do direito rio-grandense, que não vazaram o seu pensamento em livro. Comunicaram-no apenas pela imprensa ou pelas revistas especializadas, ou na cátedra universitária, ou nas rodas de amigos e no encanto da palestra íntima." (grifo meu) (Martins, op. cit p. 156).

No interior da faculdade, a disciplina de filosofia do direito vai ser o espaço em que se pode detectar as oposições que vão se estabelecer entre o positivismo e o catolicismo, e onde vai ocorrer, mais claramente, os debates reproduzindo no campo "filosófico" as lutas políticas. James Darcy que rege a disciplina de 1900

${ }^{12} \mathrm{O}$ autor refere além de Darcy Azambuja, Borges da Rosa, Maurício Cardoso, Pedro Vergara, Borges de Medeiros, Armando Fay de Azevedo, Ruy Cirne Lima, João Bonumá, Fanor Butler Maciel, Eloy José da Rocha , Elpídio Ferreira Paes, João Leitão de Abreu, Lourenço Mário Prunes, Clóvis Veríssimo do Couto e Silva, Hernani Estrella Eduardo Ruiz Caravantes, Darcy Pinto, Edgar Luiz Schneider, Mozart Victor Russomano, Dario de Bittecourt, Érico Maciel Filho, Dámasio Rocha, Waldemar do Couto e Silva, Gilda Maciel Corrêa Meyer Russomano, Breno Brandão Fischer, Alcides Mendonça Lima, Galeno Vellinho de Lacerda, Francisco Machado Vila, Paulo Barbosa Lessa, Paulino Jacques, Justino Vasconcellos, Homero Prates, Walmor Franke, Gervásio Luz, Armida Bergamin Miotto, João Didonet Neto, Lenine Nequete, Angelito Aiquel, Hugolino Uflacker, Osvaldo Optiz Rosah Russomano, Armando Dias de Azevedo, Antônio José Fabrício Leiria, sendo os que publicaram livros. (idem p. 156)

Revista da Faculdade de Direito da UFRGS, v. 20, Outubro/2001 
a 1903 liga-se ao positivismo. Em 1903 licenciando-se para ser deputado federal pelo PRR não mais retorna da capital federal, Rio de Janeiro, onde estabelece-se como advogado. Antes de reger a disciplina de filosofia do direito fora promotor público, onde se destacara como "orador brilhante".

Saindo James Darcy em 1903, entra Alcides Freitas Cruz, jornalista, promotor público que elaborou o programa da disciplina, "afinado com Lamarck e Darwin". Lucas Graffé, ingressa em 1906 na cátedra, trabalhando na "perspectiva kantiana." Graffé vai insurgir-se contra o "positivismo" que dominava as "mentes filosóficas" e políticas do Estado:

"No prefácio de seu lúcido ensaio publicado em 1909, afirma o professor riograndense: $O$ culpado dessa incúria pelas coisas filosóficas é o espírito sectário do positivismo que no berço do nosso republicanismo oficial procurou imprimir o seu cunho a todas as nossas instituições não the escapando como de direito, o ensino (In "A Faculdade de Direito de Porto Alegre e a vocação política, Salgado Martins, Correio do Povo, 25/07/1970).

Em 1907 assume o desembargador Melchisedeck Mathusalen Cardoso, natural de Sergipe e que percorreu toda a carreira de magistrado no Rio Grande do Sul, sendo pai de Maurício Cardoso. Francisco Rodolfo Simch, filho de engenheiro, sucede Cardoso em 19091911. Em 1911 é suprimida a disciplina e substituída por teoria geral do direito. Quando é novamente restabelecida a filosofia do direito, é regida por Fernando Antunes colega de turma e "fraternal amigo" de Maurício Cardoso, sendo seu chefe de gabinete quando este exerceu o Ministério da Justiça. Este filiava-se também ao "positivismo comteano".

Importa ainda, para este período uma referência à Plínio Casado que foi lente de direito constitucional entre 1900 e 1924 . Casa- do vai opor-se ao "pensamento positivista", devido a sua postura de oposição ao governo de Júlio de Castilhos e sua proximidade com o liberalismo, defendendo um Estado moderno de "corte democrático-representantivo"

Nota-se para este período do início do século, até a década de 30 , que variavam as posições "doutrinárias" dos professores de direito constitucional e filosofia do direito, em função da sua inserção político-partidária, sendo o debate propriamente filosófico, uma extensão das lutas políticas. Como a maioria dos lentes que ministraram aulas na Faculdade até a década de 30 filiava-se ao positivismo e as tredes opolíticas que tinham por centro as vinculações ao PRR, este debate não assumia maiores proporções. Esta situação só vai se modificar com a ascensão de Armando Câmara à cátedra de filosofia do direito, representando a chegada de toda uma geração de católicos que passarão daí em diante a ter forte influência nas definições do ensino jurídico.

Armando Câmara é oriundo de família tradicional, neto paterno do Visconde de Pelotas, $1^{\circ}$ Governador do Estado no Regime republicano e bisneto do Visconde de São Leopoldo, primeiro Presidente da Província de São Pedro do Rio Grande do Sul no período imperial. Segundo Azevedo(1975), "pelo seu pai, general Alfredo Pinheiro Corrêa da Câmara descendida também o tronco secular de João Carneiro da Fontoura e sua mãe de outro tronco secular, o dos Barreto Pereira Pinto".

Sua formação intelectual compreende a passagem pelo Colégio militar após adolescência vivida no interior, em Bagé, transferindo-se para o Colégio Anchieta por "falta de inclinação para a carreira militar" (Azevedo, op cit). Lá teve a influência decisiva do padre Werner. Azevedo (op. cit) caracteriza Câmara dentro da tradição de "oralidade" do pensamento jurídico gaúcho:

"Homem de pensamento, orador excep- cional, a ponto e fascinar horas a fio, auditórios compostos quer de estudantes, quer de intelectuais de primeira grandeza, não era homem de muito escrever. Felizmente, nos últimos anos, alunos e admiradores decidiram preservar para o futuro os frutos da sua atividade intelectual, registrando-a em gravações. É o que restará materialmente, do muito que criou em seu trabalho profícuo de tantos anos" (Azevedo, 1975)

Câmara notabilizou-se como um "pensador católico". Característica que foi imputada por sua atuação como fundador da "Re vista Estudos" e pelo Jornal "O Dia", além de militante católico e, principalmente, pela fundação da Associação dos Professores Católicos. As características mais marcantes de seu discurso em sala de aula estavam na contestação ao positivismo e ao pensamento marxista que progressivamente passará a ser o "inimigo" principal de todos os pensadores identificados com a "geração de católicos" da qual Armando Câmara é um dos expoentes e principal ideólogo.

Neste sentido sua atuação expande-se da atividade docente para o associativismo em torno da pregação do catolicismo. A fundação da Associação de Professores Católicos tendo por objetivo promover ciclos e debates culturais e "estudos livres", é um dos resultados desta estratégia. Segundo depoimento de Obino (1975) esta associação "por sua semeadura preparou o nosso ambiente educacional e cultural para a fundação das duas primeiras faculdades leigas de filosofia em nossa província, não esquecendo as faculdades de filosofia dos seminários católicos e luterano no interior do Rio Grande". A atuação de Câmara também imbrica-se à uma atuação política que o levará inclusive a uma eleição para o senado em 1954.

Segundo Till (2000), Câmara teve expressiva votação ao Senado "praticamente sem fazer campanha" O Rio Grande do Sul possuía 1.224.761 eleitores inscritos. Dos 837.755, que votaram, 402.438, votaram em Câmara. A votação de Câmara, é atribuída por Till (op. cit.) ao fato deste ser "um dos nomes de maior prestígio dos círculos da Igreja, estando sempre à testa de grandes realizações no campo do Catolicismo gaúcho". Tal fato demonstra que as redes de relações sociais estabelecidas por Câmara dentro dos meios católicos eram diretamente acionadas e reconvertidas em capital político, sendo que o fato de ter atuado na Faculdade de Direito, núcleo de formação política, demonstrava o total imbricamento entre as esferas política-jurídica/acadêmica e religiosa.

A extensão da influência de Câmara e do grupo dos católicos tem como espaço privilegiado o investimento no ensino secundário e superior. É este grupo que vai fundar o curso de Direito da Pontifícia Universidade CatólicaPUC, Universidade da qual também Câmara vai ser reitor. O grupo de fundadores do curso de Direito da PUC em 1947 se constituía de "juristas católicos", praticamente todos formados em direito na Faculdade de Porto Alegre e identificados aos movimentos do catolicismo. Este grupo era integrado por Adroaldo Mesquita da Costa formado em 1918, Armando Dias de Azevedo formado em 1918, Balthazar Gama Barbosa formado em 1930, Camilo Martins Costa, formado em 1918, Darcy Azambuja formado em 1927, Elpídio Ferreira Paes, formado em 1929, Eloy José da Rocha, formado em 1929, Francisco Juruena, Ney Wiedmann formado em 1916, Ruy Cirne Lima formado em 1929 e Walter Becker formado em 1926.

A característica social fundamental deste grupo de "católicos" é a passagem pelo Colégio Anchieta ou pelo Colégio Nossa Senhora da Conceição de São Leopoldo. O ensino secundário nestes colégios funcionava como instância de homogeneização intelectual. Além de serem contemporâneos e colegas na Faculdade de Direito, muitos desta geração já haviam passado, no âmbito dos estudos pré-uni- 
versitários por uma formação que reforçava disposições para a apreensão e uso das "doutrinas jurídicas e políticas" que os levaria a uma militância política e católica no âmbito dos estudos universitários.

As relações pessoais, intelectuais e políticas que estabeleciam os membros da geração entre si, afirmavam-se como indistintas. Uma passagem que ilustra, é a constante no livro de depoimentos de Armando Câmara produzido por seu discípulo, que foi assistente e, posteriormente, regente da disciplina de filosofia do direito substituindo-o na Faculdade. Trata-se de Jacy de Souza Mendonça que se referindo ao concurso em que este foi admitido, após lecionar como convidado de Câmara, assinala:

"A nota curiosa, e também reveladora de sua personalidade(refere-se à Câmara), ficou por conta do veemente protesto que dirigiu a um dos examinadores do concurso, porque, numa das quatro notas que devia atribuir-me, deu grau nove e não dez, como o fizeram todos os demais examinadores, em todas as quatro notas... Armando Câmara tomou o fato como se tratasse de uma crítica às idéias que eu defendia (no fundo eram as dele) ou de uma ofensa pessoal dirigida ele, pois eu era quem ele escolhera"...(p. 45, Mendonça, 1999) (grifo meu)

Além dos laços de solidariedade pessoal e origens escolares e políticas comuns, a atuação em defesa da moralidade católica num sentido conservador é também um indicador forte que une este grupo e permite afirmar estar-se diante de uma "geração de católicos". Um dos exemplos é retratado no artigo de Trindade (1982) que envolveu a crítica produzida por Padre Fritzen no ano em 1943 contra o romance publicado por Érico Veríssimo "O resto é silêncio". Tal polêmica acabaria por desencadear um processo judicial de Érico contra o padre que viria a tomar uma dimensão pública com a publicação de manifesto de solidariedade ao padre assinado por praticamente todos os ex- poentes da "geração católica", da mesma, forma geraria um manifesto de apoio à Érico que era produzido por um grupo que não pode, segundo Trindade (op. cit), ser caracterizado ideologicamente, mas que reunia comunistas, liberais e intelectuais, unidos em torno de uma "indiferença religiosa e filosófica".

Segundo Trindade, a compreensão desta polêmica remete ao ano de 1935 quando Armando Câmara publica o primeiro documento conhecido do seu pensamento político, "Manifesto de Programa da Ação Brasileira de Renovação Social". De outro lado um Manifesto "anti-fascista" assinado por Érico Veríssimo também foi seu primeiro posicionamento político. Muitos integrantes da "geração dos católicos" encontravam-se próximos aos ideais do integralismo, como a defesa "ordem", e o "anticomunismo", tendo algumas lideranças católicas atuado na Ação Integralista Brasileira, como Ernani Fiori.

Segundo Brandalise (1992), Fiori vai ser um dos principais líderes da dissidência dos católicos no movimento integralista, por não aceitar a idéia da pluralidade religiosa no seio do movimento integralista. Fiori vai ser professor de filosofia do direito por um ano na Faculdade de Direito de março de 1955 a abril de 1956 tendo sido professor catedrático na Faculdade de Filosofia da UFRGS. Entretanto sua influência estende-se pois após sua dissidência do integralismo será um dos inspiradores de uma tendência de "católicos de esquerda" .

Além da filosofia do direito, a influência do catolicismo estende-se ao aparecimento da disciplina de direito do trabalho que aparece no currículo do curso de direito da Faculdade de Porto Alegre na década de 30 . O primeiro professor a reger a disciplina foi Eloy José da Rocha que também, segundo seu sucessor, João Antonio Pereira Leite, "pouco escreveu". Entretanto, teria construído: "com o poder da palavra falada, uma verdadeira escola de direito do trabalho, cujos princípios e fundamentos ao longo de quatro décadas, têm norteado o estudo da disciplina que, de certo modo, ele ajudou a criar no Brasil"13.

Também ressalta Pereira Leite, as virtudes de Eloy José da Rocha como advogado, político, magistrado da justiça comum, não mencionando, entretanto, sua ligação com a prática profissional do direito do trabalho especificamente. "Estranho aos quadros da Justiça do Trabalho e a experiência diária das relações de trabalho, forjou, não obstante, o mais perfeito curso de direito do trabalho existente em nosso país (...)" posteriormente lhe sucederiam discípulos que publicaram obras como Carlos Alberto Barata e Silva e José Luiz Ferreira Prunes, além do próprio João Antonio G. Pereira Leite.

No âmbito do "direito do trabalho" e do "direito econômico" destaca-se também a figura de Dário de Bitencourt. Tendo passado pelo Colégio Nossa Senhora da Conceição, posteriormente, migrado para o Colégio Anchieta, em virtude da extinção do primeiro em 1911, teve uma relação de proximidade com os integrantes da "geração dos católicos", Dario vai ser colega no Anchieta de Adroaldo Mesquita da Costa e, segundo o trabalho de Barreras(1998), vai se afastar do catolicismo, ingressando na maçonaria em 1927 e aproximando-se do integralismo.

Segundo Barreras (op. cit.), seu ingresso na cátedra de legislação social e do trabalho na Faculdade em 1939 "coincide" com a "volta à Igreja como membro ativo da Ação Católica" que será feita através do convite para reingresso à fé por um "importante vulto da Ação Católica Brasileira, Armando Câmara." (op. cit, p. 77). Segundo o autor:

"A catolicização das faculdades permite o ingresso de Bittencourt como catedrático, sem problemas. Nessa época, final dos anos 30 e início do anos 40 , os rejeitados pela instituição são indivíduos identificados com o positivismo - os ex-integralistas, em Porto Alegre, são aceitos sem problemas - o que, referindo-se a Dario, é uma grande ironia!" (op. cit, p. 78)

A "reflexão jurídica" de Bittencourt quanto à legislação social estará simultaneamente afinada com os preceitos corporativistas do integralismo e com a doutrina social da igreja que floresce com a pregação do Papa Leão XXIII.

Esta ampla catolicização do espaço intelectual no Rio Grande do Sul que atinge a Faculdade de Filosofia e a Faculdade de Direito notadamente a partir da década de 40 tem sua expressão mais visível, no caso da última na ocupação dos postos de direção por parte de agentes que podem se agrupados como pertencentes a "geração dos católicos" a partir de seus percursos sociais como se depreende da análise de algumas características sociais dos agentes que ocuparam a direção da Faculdade de Direito no intervalo de 1948 a 1973, José Salgado Martins (1949/1952,1954/61, 1971/73), Eloy José da Rocha (1952/1953), José Salgado Martins (1953/1961), Galeno Vellinho de Lacerda (1961/1967), Ruy Cirne Lima (1967/1971) ${ }^{14}$, expostas no quadro que segue:
${ }^{13}$ Caderno de Sábado, 80 anos(p. 13) 'O Professor de Direito do Trabalho e sua escola

${ }^{14}$ Fonte: Livro do Centenário da Faculdade de Direito da UFRGS publicado em outubro de 2000. 


\begin{tabular}{|c|c|}
\hline \multicolumn{2}{|c|}{ Características sociais comparadas dos Diretores da Faculdade de Direito (1948-173) } \\
\hline $\begin{array}{l}\text { Nome do Diretor: } \\
\text { JOSÉ SALGADO MARTINS } \\
\text { - Filho e Floduado Cunha Martins e de } \\
\text { Georgiana Salgado Martins. } \\
\text { * Porto Alegre - 14/12/1908 +20/11/1973 } \\
\text { Profissão do pai: General } \\
\text { Estudos pré-universitários: } \\
\text { - Curso primário no Colégio Anchieta } \\
\text { - Cursou Colégio Militar, volta para o } \\
\text { Anchieta para os preparatórios, fazendo uma } \\
\text { matéria no Instituto Júlio de Castilhos } \\
\text { Formatura em Direito, Faculdade de } \\
\text { Porto Alegre 02/07/1932 } \\
\text { Atuação na Faculdade de Direito: } \\
\text { - } 31 / 12 / 1943 \text { Catedrático deDireito Penal } \\
\text { - 18/03/1949 a28/06/1949/52 Diretor da } \\
\text { Faculdade } \\
\text { - 1950 membro de bancas examinado- } \\
\text { para concurso de docência } \\
\text { - 1952 Nomeado Reitor da UFRS, não } \\
\text { ras } \\
\text { aceitou nomeação } \\
\text { - 1954/1961 } 2 \text { vez diretor } \\
\text { - 14/09/1967-30/12/1971 Vice-Diretor } \\
\text { - 1971/1973 3 a vez diretor } \\
\text { - 10/05/1962 Eleito Diretor do Instituo } \\
\text { ?ireito }\end{array}$ & $\begin{array}{l}\text { Posições políticas e jurídicas ocupadas: } \\
\text { - 10/12/1929 Ainda estudante Nomeado Promo- } \\
\text { tor público em José Bonifácio (atual Erexim) } \\
\text { - 24/07/1930Removido para São Vicente } \\
\text { - 13/06/1931 São João Montenegro } \\
\text {-27/11/1931 Juiz Distrital na mesma comarca } \\
\text {-27/11/1932/1943 Promotor Militar de São } \\
\text { Gabriel } \\
\text { - 08/08/1944 Membro do Conselho } \\
\text { Penitenciário do Estado } \\
\text { - Indicado duas vezes para o 5 constitu- } \\
\text { cional para o Tribunal de Justiça } \\
\text { - "político militante" Vice-Presidente da } \\
\text { UDN } \\
\text { - 1954 - Suplente de Senador } \\
\text { Outras atividades exercidas, títulos, e trunfos } \\
\text { possuídos: } \\
\text { - 23/07/1946 Designado para reger disci- } \\
\text { plina de Literatura brasileira na Faculdade de } \\
\text { Filosofia da URGS } \\
\text { - 13/01/1947 Catedrático de Direito Penal } \\
\text { da PUC } \\
\text { - 1947 Representou a Faculdade de Direi- } \\
\text { to da UPA da 1ª Conferência Pan Americana } \\
\text { de Criminologia realizada em São Paulo e Rio e } \\
\text { Janeiro } \\
\text { - Presidente da Federação das Associa- } \\
\text { ções Rurais do RGS } \\
\text { - Membro da Comissão Revisora o Projeto } \\
\text { de Código de Processo Penal } \\
\text { - 1972 Membro da Comissão de Direitos } \\
\text { Humanos } \\
\text { - Membro da ONU da comissão de estu- } \\
\text { dos para o combate à delinquência } \\
\text { - "Falece gloriosamente no exercício da cá- } \\
\text { tedra durante exame de livre docência em di- } \\
\text { reito penal } \\
\text { - publicações em Literatura, Direitoe Filosofia }\end{array}$ \\
\hline
\end{tabular}

Revista da Faculdade de Direito da UFRGS, v. 20, Outubro/2001

\begin{tabular}{|c|c|}
\hline $\begin{array}{l}\text { Nome do Diretor: } \\
\text { ELOY JOSÉDA ROCHA } \\
\text { - Filho de Dogello José da Rocha e de } \\
\text { Olga Tereze Kruze da Rocha } \\
\text { *São Leopoldo, 03/06/1907 } \\
\text { Profissão do pai:? } \\
\text { Estudos pré-universitários: } \\
\text { Ginásio N. S. Rosário, preparatórios } \\
\text { com o prof. Emílio Meyer } \\
\text { Frequentou curso de filosofia do padre } \\
\text { Werner, no Colégio Anchieta } \\
\text { Formatura em direito, 1929 } \\
\text { Atuação na Faculdade de Direito: } \\
\text {-1939 - Catedrático de Direito do Traba- } \\
\text { lho } \\
\text { - 1942-Regeu interinamente Direito Co- } \\
\text { mercial } \\
\text { - 1952/53 Diretor da Faculdade de Direito } \\
\text { - Posto a disposição da Universidade de } \\
\text { Brasília, aposentou-se em } 26 / 12 / 1969 \\
\text { Posições políticas e jurídicas ocupadas: } \\
\text {-Até o } 4^{\circ} \text { ano de direito foi funcionário da } \\
\text { repartição dos correios } \\
\text { - 07/02/1928/30 Juiz municipal de Taquara } \\
\text { (quando ainda cursava o } 5^{\circ} \text { ano de direito) } \\
\text { - 22/11/1961 Diretor do Instituto e Direito } \\
\text { do Trabalho de Reforma Social } \\
\text { - 1970/72 Presidente do STE } \\
\text { - 02/12/1945 Deputado à Assembléia } \\
\text { Constituinte Nacional } \\
\text { - 1947 - Secretário de Estado da Educa- } \\
\text { ção e Cultura } \\
\text { - } 1950 \text { - Candidatonte do STF a Deputado estadual } \\
\text { - 30/04/1953 Desembargador do Tribunal } \\
\text { de Justiça nomeado como representante classista } \\
\text { pelo 5o constitucional (nunca advogou) } \\
\end{array}$ & $\begin{array}{l}\text { Outras atividades exercidas, títulos, e trun- } \\
\text { fospossuídos: } \\
\text { - } \quad \text { Professor catedrático do Instituto Superi- } \\
\text { or do Comércio pois transformado em Fa- } \\
\text { culdade de Economia da URGS, lecionou } \\
\text { direito civil, comercial e direito industrial e } \\
\text { operário } \\
\text { - } \quad \text { Diretor da Faculdade de Ciências Políti- } \\
\text { cas e Econômicas de Porto Alegre(PUC) } \\
\text { - } 1940 \text {-Fundou a Faculdade de Educação, } \\
\text { Ciências e Letras da PUC onde foi diretor } \\
\text { e catedrático de história da filosofia do } \\
\text { curso de pedagogia } \\
\text { - Publicou sua tese de concurso a cátedra } \\
\text { sobre a extinção do contrato de trabalho. }\end{array}$ \\
\hline
\end{tabular}

Revista da Faculdade de Direito da UFRGS, v. 20, Outubro/2001 


\section{Nome do Diretor: \\ RUY CIRNELIMA \\ - filho de Elias Cirne Lima e de Judith \\ Masson Cirne Lima}

*Porto Alegre, 23/12/1908

Profissão do pai: ?

Advogado

\section{Estudos pré-universitários:}

Primeiras letras no Ginásio Sevigné, depois passou para o Ginásio Anchieta, concluindo preparatórios com o professor Emílio Meyer Formatura em Direito, Faculdade de Porto Alegre, 1929

\section{Atuação na Faculdade de Direito:}

- 31/10/1929 Livre-docente de Direito Internacional Privado

- 24/08/1932 Redesignado para reger direito administrativo

- 28/08/193 Catedrático de Direito Administrativo

- 25/06/1935 Catedrático de Direito Administrativo

- 1938 Designado, regeu Direito Romano

- 1941- Posto em disponibilidade

- 1946 Readmitido

- 1935, 1938, 1939, 1945-Membro da comissão examinadora, como Presidente do concurso para docente

- 10/05/1962 Eleito Diretor do Instituto de Direito Público

- 10/03/1964 Vice-Diretor da Faculdade de Direito

07/08/1967/71 Diretor da Faculdade de Direito - 06/07/1972 Aposentou-se

$-27 / 02 / 1934$

-28/08/1933 Catedrático de Direito Administrativo
Posições políticas e jurídicas ocupadas:

"Advogado militante desde a formatura" "um dos maiores jurisconsultos do país" - 01/02 a 22/03 de 1930 Promotor Público subs. $\mathrm{Da} 2^{\mathrm{a}}$ promotoria da capital

- 1931 Advogado m Santa Catarina

- 01/05/1938-01/05/1940 Advogado da Companhia de Seguros "Previdência do Sul" quando foi eleito seu diretor exercendo este cargo por 30 anos

- Consultor Jurídico do Banco Industrial e Comercial do Sul S/A

- 1964/1965 Secretário da Fazenda do Rio Grande do Sul

\section{Outras atividades exercidas, títulos, e trunfos} possuídos:

- 1946-1947 Presidente do IARGS

- 13/01/1947 Professor titular de Direito Administrativo da Faculdade de Direito da PUC, desde sua fundação.

- Provedor da Santa Casa de Misericórdia

- Títulos honoríficos:

Doutor m Medicina "honoris causa" da Faculdade Católica de Medicina de Porto Alegre

- Comenda do IAGRS "Jurista emérito"

1967-Prêmio Teixeira de Freitas, concedido pelo IARGS

"Admirável articulista da $4^{\text {a }}$ Coluna o "Correio do Povo"

- "Pertenceu ao movimento literário modernista da década de 20 "

- Publicou obras literárias e jurídicas

\section{Nome do Diretor: Maria Vellinho de Lacerda \\ *26/11/1921- Caxias do Sul \\ Profissão do pai: \\ Engenheiro}

GALENOVELLINHOELACERDA

- filho de Norberto Barros de Lacerda e de

Estudos pré-universitários:

Anchieta e Colégio Universitário

Formado em Direito Faculdade de Porto alegre, 1943

\section{Atuação na Faculdade de Direito:}

1947-Assistente de Dir. judiciário

1956-Catedrático de Dir. Judiciário Civil

1961-1967 Diretor da Faculdade de Direito
Posições políticas e jurídicas ocupadas:

-1946-Assessor do Conselho Adm. do Estado

- 1946-1947-Consultor Jurídico do Conselho do Estado

1947-1954-Auditor do Tribunal e Contas do Estado

1959-1961-Juiz do TRE

1952-1963- Diretor da Navegação Riograndense

Outras atividades exercidas, títulos, e trunfos possuídos:

1951-1962-professor de dir. judiciário e fil. do direito PUC

- Membro do conselho superior do IARGS

1975- Comenda - Professor insigne o IARGS

1974 - Comenda "Osvaldo Vergara" do conselho da OAB

Publicações em revistas especializadas em direito

Fontes primárias: pastas funcionais e curriculum vitae encontrados no Arquivo da Faculdade de Direito / Fontes secundárias: Santos (2000), Nequete (1974), Felix (1999)

\section{Considerações finais}

Os dados expostos resumidamente acerca dos padrões de recrutamento e formação intelectual que estruturam o espaço jurídico nas décadas de 40 e 70 , podem contribuir para a formulação de hipóteses para novas investigações visando a compreensão do "estado atual" das lutas simbólicas que envolvem as formas legítimas de pensar juridicamente. A expansão quantitativa do ensino jurídico no Rio Grande do Sul, e a diversificação das origens sociais dos acadêmicos das Faculdades de Direito mais tradicionais é uma variável importante para a compreensão dos movimentos de "contestação" da tradição dóxica de reprodução (ensino) e intelecção (pesquisa) que resulta das oposições entre as gerações anteriores, onde o "positivismo" e o "catolicismo" se afirmaram como grandes referências.
Pode-se, inclusive, tomar como hipótese que as bases desta "contestação", apresentam-se, antes como uma segmentação ou reelaboração da tradição que pretendem negar. Um dos exemplos é a tradição marxista que se firma nos meios intelectuais nas décadas de 60 e 70 no âmbito da Faculdade de Filosofia e que pode ser lida como uma segmentação de um certo "catolicismo de esquerda". A expressão tardia da "politização das faculdades" pode ser visualizada no "direito alternativo" da década de 90. As hipóteses aqui enunciadas a partir do material empírico coletado, entretanto, tem que ser testadas em uma investigação mais detalhada tendo por base estes "novos" movimentos e posicionamentos intelectuais no âmbito do espaço jurídico. 


\section{Bibliografia Consultada}

ADORNO, Sérgio. "Os Aprendizes do Poder: $O$ Bacharelismo Liberal na Política Brasileira." Rio de Janeiro, Paz e Terra, 1988

BANCAUD, A "Une constance mobile: la haute magistrature". In Actes du la Recherche en sciences sociales $\mathrm{n}$. 76-77-mars. 1989.

BARMAN, R \& BARMAN, J . "The Role of Law Graduate in the Political Elite of Imperial Brazil In "Journal of interamerican Studies and World Affairs, nov 1976. 18 (4) 423-50"

BOIGEOL, A. "La Formation des magistrats: De l'aprentissage sur le tas a l'école professionelle: In: Actes du le Rcherche en Sciences Sociales. $\mathrm{n}$ 76/77, mars. 1989.

BOEIRA, N. "O Rio Grande de Augusto Comte". IN DACANAL, J. H. e GONZAGA, S. (org) RS: $\mathrm{Cul}$ tura e Ideologia. Porto Alegre, Mercado Aberto, 1980.

BONI, Luis Alberto de Armando Câmara. Obrasescolhidas. Coleção pensadores gaúchos -1 . Porto Alegre, 1999. EDPUCRS.

BARRERAS, M. J. L. "Dario de Bitencourt (1901. 1974): Uma incursão pela cultura política autoritária gaúcha" Porto Alegre, EDIPUCRS, 1998.

BRANDALISE, C. "O Fascismo na Periferia Latino Americana: o paradoxo da implantação do integralismo no Rio Grande do Sul"'(dişa do de mestrado CPGCP-UFRGS), Porto Alegre, 1992. (mimeo)

COELHO, E. C. A profissões imperiais: Medicina, Engenharia e Advocacia no Rio de Janeiro(1822. 1930). Rio de Janeiro: Record, 1999

ENGELMANN, F. "A Formação da Elite jurídica no Rio Grande do Sul: Notas para uma pesquisa. IN Revista da Faculdade de Direito da Universidade Federal do Rio Grande do Sul, vol. 17, 1999

ENGELMANN, F. “A Formação da Elite jurídica no Rio Grande do Sul.(dissertação de mestrado) Porto Alegre, PPGCP-UFRGS, março 2001(mimeo)

FÉLIX, L.O. \& GRIJÓ, L. "Histórias de Vida: Entrevistase Depoimentos de Magistrados Gaúchos. Porto Alegre: Tribunal de Justiça do Estado do Rio Grande do Sul. Projeto Memória do Judiciário Gaúcho, 1999.

GRIJÓ, L. A "Origens sociais, estratégias de ascensão e recursos dos componentes da chamada 'geração de 1907'. (dissertação de mestrado). Porto Alegre, PPGCP-UFRGS, setembro de 1998
INSTITUTO DOS ADVOGADOS BRASILEIROS, História dos 150 anos do Instituto dos Advogados Brasileiros, ed Destaque-Rio de Janeiro, 1993

INSTITUTO DOS ADVOGADOS DO RIO GRANDE DO SUL; sessenta anos de existência, org. Antônio Paulo Cachapuz e Medeiros. Porto Alegre, IARGS, 1986.

LOVE, J. O regionalismo gaúcho, Perspectiva, 1975 MARCON, I.(org.) Poetas do Ministério Público Porto Alegre: AGE, 1996.

MARTINS, José Salgado. O Direito no Rio Grande do Sul. Porto Alegre, URGS, 1961

MELlo, Abdon de. "Ministério Público Riograndense"(subsídios para sua história), s/ed,

MENDONÇA, J. S. "Diálogos no solar dos Câmara" Coleção Pensadores gaúchos, EDIPUCRS Porto Alegre, 1999

NEQUETE, Lenine(org) $O$ Poder Judiciário no Rio Grande do Sul. Livro comemorativo do centenario do Tribunal da Relaça de Porto Alegre e Tri-

PINTO, C.R. "Positivismo - Um projeto político allernativo"(1889-1930)" Porto Alegre, LPM, 1986.

SANTOS, J. P. S. “A Faculdade de Direito de Porto Alegre" Porto Alegre: Síntese, 2000

SOARES, M. P. O positivismo no Brasil: 200 anos de Augusto Comte. Porto Alegre: AGE: Editora da Universidade, 1998

PANG, Eul Soo. \& SECHIRINGER, R. L "The Mandarins of Imperial Brazil" In: Comparative studies in society and history. University of Carolina - Press, mar 1972. 14(2):215-44

TILL, Rodrigues. História da Faculdade de Direito 1900-2000. Porto Alegre: Martins Livreiro, 2000

TRINDADE, F. C. "Uma contribuição à história da Faculdade de Filosofia da UFRGS. Revista do Instituto de Filosofia e Ciências Humanas, Porto Alegre, a X., p. 39-53, 1982

TRINDADE, F. C. "A Polêmica entre Érico Veríssimo e o Padre Leonardo Fritzen, S.J. Revista do Instituto de Filosofia e Ciências Humanas, Porto Alegre, 1984

\title{
A Aproximação das Legislações: o Caminho do Mercosul
}

\author{
Florisbal de Souza Del'Olmo \\ Professor convidado do Curso "O Novo Direito Internacional", \\ da Faculdade de Direito da UFRGS
}

\section{Introdução}

1 presente monografia busca realizar uma reflexão sobre a aproximação das legislações no âmbito do Mercado Comum do Su (MERCOSUL). É seu objetivo a identificação dessa aproximação e a apresentação de propostas que possam contribuir para uma integração mais efetiva no âmbito do bloco econômico regional.

A abordagem é efetuada a partir de noções de integração, blocos econômicos regionais e Direito Comunitário, detendo-se, por fim, na aproximação dos textos constitucionais do Estados-membros do Mercosul, capazes de propiciar a evolução do processo.

A investigação utiliza o método indutivo, comparativo e histórico, a contribuição do Direito Comunitário e a experiência da União Européia. Inúmeras obras, tanto nacionais quanto oriundas de outros países, constituem a bibliografia de que se serviu o pesquisador. As referências citadas ao longo do trabalho têm suas traduções para o vernáculo de responsabilidade do autor.

Compõe-se o ensaio de quatro capítulos: no primeiro se abordam os Movimentos de Integração, no que se entende indispensável para a compreensão do tema proposto, ocupando-se da União Européia, em cujo proces- so de constituição se buscam subsídios e reflexões no sentido de alcançar a aproximação das legislações nacionais dos Estados-partes do Mercosul. No segundo, é estudada a Integração no Cone Sul da América, reportando-se ao histórico e tratativas que redundaram na instituição do bloco. O terceiro capítulo se ocupa do Direito Comunitário e sua importância na consolidação do bloco econômico regional sulamericano, detendo-se ainda na instituição do futuro Tribunal de Justiça do Mercosul. O último capítulo estuda a Aproximação das Legislações dos Estados-partes.

Essa é a ênfase da investigação propriamente dita. Uma busca incessante com vistas ao encontro do conhecimento projetado, na expectativa de alcançá-lo. Sem dúvida, o ponto de partida é a integração, paradigma de um novo modo de viver democrático e harmônico entre Estados, objetivo dos povos do Mercosul.

Centra-se a monografia, por fim, no estudo da aproximação das legislações sobre a supranacionalidade nos quatro Estados do bloco regional do Cone Sul, buscando-se delinear a instituição, como proposta, de organismos comunitários capazes de completar o processo de integração e o desenvolvimento e a consolidação do Mercosul.

Revista da Faculdade de Direito da UFRGS, v. 20, Outubro/2001 
I. Os Movimentos de Integração

\subsection{Conceito de Integração}

Sem procurar definir o que seja integração, pensa-se buscar algumas luzes sobre esse fenômeno, que ocupa as atenções dos estudiosos dos mais importantes movimentos que envolvem o ser humano no dealbar do século XXI.

A integração é mais recente do que a própria globalização e se as pode entender ambas, mais como antagônicas do que como complementares. Admitindo-se que o mundo se venha a organizar em diversos blocos regionais, e que esses se transformem em comunidades, pode-se admitir em futuro não distante que a integração se constitua mesmo em uma parcela da globalização.

FERREIRA e OLIVEIRA definiram integração com rara propriedade: "É um processo de mudança social voluntária, mediante o qual, a partir da existência de problemas, interesses e objetivos comuns, as nações se associam e adotam estratégias de ação conjunta para melhorar seu status, o de suas respectivas comunidades, e sua inserção no sistema estratificado internacional"'.

Convém lembrar que para haver integração impõe-se que persistam diferenças entre os Estados engajados, cada um deles procurando na formação do bloco soluções para as suas deficiências.

\subsection{Pródromos dos Movimentos de Integração}

A idéia de um Estado global, no qual a população gozasse de direitos básicos e igualmente distribuídos entre todos, tem sido um sonho ao longo dos tempos. Mesmo os movi- mentos mais antagônicos, e aí poderiam ser citados o marxismo e o capitalismo, buscaram a unificação dos cidadãos sob um mesmo poder. Em essência, pregavam o domínio das pessoas por alguém, prometendo-lhes bem-estar e mehores condições de vida. Pecaram seus formuladores sempre, contudo, porque só os dominadores, de que são exemplo os mais férreos ditadores, como Stalin e Hitler, bem como os líderes do capitalismo, consideram-se em condições de ditar o paradigma de felicidade para seus subalternos. Günter GRASS, Prêmio Nobel de Literatura, observou: "O mundo capitalista somente está interessado em ganhar muito dinheiro da forma mais rápida possível. Assim como o comunismo, está destruindo seu próprio sistema porque acredita nas mentiras de sua própria propaganda"2.

O Império Romano no seu apogeu, a Idade Média sob Carlos Magno, a Grande França de Napoleão, o Reich Milenar de Hitler e o Planeta Soviético de Stalin, nos quais a voz de versal, foram, paradoxalmente, movimentos de integração.

Entretanto, é imperioso ressaltar que ditos movimentos não podem ser tidos como tal, na acepção contemporânea da palavra, na medida em que não foram, precipuamente, fruto da voluntariedade e do espírito democrático que hoje funcionam como o norte de qualquer espécie de integração entre Estados soberanos. Resultaram, em verdade, da imposição de determinados governantes, deturpando em alguns desses casos, manifestações oriundas da vontade popular. Deve-se enfatizar, com a devida clareza, que o significado atual do termo integração não comporta analogia com os movimentos referidos, ainda que, por linhas antagônicas, todos eles conduzam as populações chefes megalomaníacos era a suprema lei uni-

' FERREIRA, Maria Carmen e OLIVERA, Julio Ramos. Las relaciones laborales en el Mercosur, p. 10. ${ }^{2}$ GRASS, Günter. Não amor, mas tolerância, p. 4.

Revista da Faculdade de Direito da UFRGS, v. 20, Outubro/2001 envolvidas a um processo de aproximação e vivência sob um governo comum. A integração hoje provém de uma conscientização coletiva.

Impõe-se, ainda, reconhecer que tais tentativas aconteceram pela força e se alicerçavam na ambição e na vaidade desmesurada de conquistadores, interessados na subjugação das populações de todos os continentes, mas especialmente as européias, diversas em suas origens, culturas e idiomas, mas avançadas em seu desenvolvimento e habitando territórios com enormes potencialidades econômicas.

O princípio das nacionalidades de Mancini, pregado passionalmente em meados do século XIX, a partir de Turim, serviu de emblema e ponto de partida para as unificações italiana e alemã, que trouxeram no seu âmago o germe dos totalitarismos fascista e nazista, com funestas conseqüências no século seguinte.

Todos os movimentos enfocados, como se vê, tinham no horizonte o desejado domínio da população mundial por determinado segmento, pretendendo organizar o mundo em torno dos que tinham o privilégio de fazer parte do povo mais forte.

Até porque o vencido permanece na expectativa de uma desforra, todos esses processos chegaram ao seu ocaso, não deixando saudades, no conjunto da sociedade mundial, presentes os estigmas dessas experiências.

Cabe mencionar, ainda, o Cristianismo, que buscou a união, idealizando um mundo de pessoas irmanadas na vida em comunidade utopia de difícil compreensão ainda hoje. Todavia, o próprio Cristianismo foi enormemente influenciado pelos sonhos temporais de seus condutores, tendo muitos Papas se engajado na procura de conquistas territoriais e os Estados Pontifícios se envolvido em inúmeras guerras e na perseguição aos discordantes de sua linha ideológica, de que é triste exemplo o negro período da Inquisição.

\subsection{O Exemplo da União Européia}

A partir de meados do século XX, com destaque nas últimas décadas do milênio, integração entre Estados ou regiões se torna uma necessidade, em virtude dos avanços da tecnologia e das comunicações. O fenômeno se consolida gradativamente. Em um primeiro momento, isso ocorre sob o aspecto econômi$\mathrm{co}$, notadamente quanto às relações comerciais, mas com a expectativa de evoluir e atingir o social e o político, com evidentes vantagens para as populações envolvidas.

É impōssível falar-se na formação de blocos econômicos regionais sem analisar o mais arrojado modelo de integração, de unificação entre Estados soberanos, que é a União Européia, embora o mesmo ainda não esteja plenamente concluído.

Dedicado internacionalista, HUSEK enfatizou que "a civilização européia, berço do mundo moderno, é o resultado das instituições jurídicas e sociais romanas, do espólio helênico e do ideário judaico-cristão"3, exemplificado no seu individualismo radical ateniense, na impregnação da alma aristocrática romana nas leis, nas instituições e na paixão cristã pela justiça social.

Os meados da década de cinqüenta do século $\mathrm{XX}$ vão propiciar à humanidade assistir ao surgimento de um movimento de integração dos países europeus, após duas sangrentas guerras que envolveram, direta ou indiretamente, quase todos os povos do globo. E essa extraordinária busca de compreensão e entendimento começa com o engajamento das populações mais sacrificadas durante os dois conflitos mundiais: a francesa e a alemã.

São precisamente Alemanha e França, cada uma com cerca de dois milhões de morto na guerra de 1914-1918, derrotada e conquistada em seis semanas a segunda e literalmente aniquilada a primeira ao final da Segunda Guerra Mundial, que acordam a instituição da Comunidade Européia do Carvão e do Aço 
$(\mathrm{CECA})^{4}$. Enfatize-se que esses dois países possuíam estratégicas reservas carboníferas e de aço, mormente na região do Ruhr, na Alemanha, e da Lorena, na França. A aludida convenção, datada de 18 de abril de 1951 , e que passaria à História como o Tratado de Paris, teve como signatários, além dos países referidos, Itália, Bélgica, Holanda e Luxemburgo, esses três últimos já integrados entre si no bloco conhecido por BENELUX, criado em $1^{\circ}$ de janeiro de 1948.

Com objetividade, ROQUE observa que esses seis Estados haviam concluído que as duas grandes guerras tiveram como motivos primordiais "a produção, em excesso, de produtos siderúrgicos e a dificuldade de colocação desses produtos no mercado internacional, gerando litígios contínuos, até o desencadear da guerra"s.

Seria, contudo, uma trilogia de convenções que daria origem e consistência à magna tentativa de integração continental européia: Tratado Institutivo da Comunidade Econômica Européia (CEE), que passaria à História como o Tratado de Roma, assinado em 25 de março de 1957, na capital do antigo Império Romano, e o Tratado Institutivo da Comunidade Européia de Energia Atômica (CEEA), também acordado na mesma ocasião e tendo como signatários os Estados participantes já mencionados na Comu- nidade do Carvão e do Aço.

A moderna idéia de integração européia tem dois mentores, que devem ser citados: Jean Monnet, Chefe do Planejamento de Reconstrução e Modernização da França e Robert Schuman, Ministro das Relações Exteriores do mesmo país, nos últimos anos da década de 40 . Jean Monnet foi o idealizador da Comunidade em torno do tratamento em conjunto a ser dado às políticas do carvão e do aço, pois defendeu uma igualdade de direitos aos alemães, impensável até então, já que a Alemanha, dividida e ocupada, não dispunha de soberania plena. Robert Schuman, ao adotar o ideário de Jean Monnet, vai exercer extraordinário papel no futuro europeu, com sua ontológica declaração de 9 de maio de 1950, em Paris, transcrita em muitos estudos, inclusive por $S O D E R^{6}$

O movimento pela unificação do continente europeu teve sua culminância no Tratado de Maastricht, assinado em 1992, nessa cidade holandesa, perto da fronteira com a Bélgica, o qual transformou a Comunidade Econômica Européia em Comunidade Européia (CE), e as três Comunidades (do Carvão e do Aço, Econômica Européia e Européia de Energia Atômica) em União Européia, a qual se constitui, como acentuou VIANA SANTOS, na experiência "mais antiga, mais sofisticada e mais amadurecida que se conhece" .
${ }^{3}$ HUSEK, Carlos Roberto. Curso de direito internacional público, p. 134. Segundo esse autor, o Tratado de Roma, que foi assinado em 1957, é "talvez um dos fatos jurídicos mais importantes deste século e vem demonstrar que o Direito Internacional, como sistema, é possível desde que a cooperação supere o conceito de soberania”. Idem, p. 135.

${ }^{4}$ Joana Stelzer identificou a CECA como a "primeira resposta positiva de integração européia e pedra fundamental de todo o edifício comunitário". STELZER, Joana. Integração européia: dimensão supranacional, p. 71.

${ }^{5}$ ROQUE, Sebastião José. Direito internacional público, p. 111-112. O autor destaca que a própria produção seria explorada em comum, devendo cada país produzir apenas o suficiente para suprir o mercado comum, evitando concorrência desnecessária entre si.

${ }^{6}$ SODER, José. A União Européia, p. 29. Para esse autor, a declaração de Robert Schuman é tida como a certidão de nascimento da Comunidade Européia.

7 VIANA SANTOS, Antônio Carlos. Tribunal de justiça supranacional do Mercosul, p. 26.

Revista da Faculdade de Direito da UFRGS, v. 20, Outubro/2001
Por fim, em 2 de outubro de 1997 é assinado o Tratado de Amsterdã, pelo qual se modificam substanciais postulados em diversos artigos dos Tratados da década de 50 , instituidores das três anteriores Comunidades. Palmilha-se, assim, o caminho natural que a integração vai ensejando, adaptando-o às novas circunstâncias e preparando-o para as necessidades e desafios futuros do poderoso bloco europeu.

\section{A Integração chega ao Cone Sul da América}

\subsection{Sonho Antigo}

Caso se busquem as origens da história de aproximações e desencontros dos povos que formam o Mercado Comum do Sul, Mercosul, remontar-se-á à última década do século $\mathrm{XV}$ quando, em 1493 e 1494, com a Bula Inter Coetera, do Papa Alexandre VI, e com o Tratado de Tordesilhas, firmados por portugueses e espanhóis, foram divididas as terras do continente americano, cabendo a Portugal as que ficassem cem (no primeiro desses documentos) e trezentas e setenta léguas (no último), a leste das Ilhas do Cabo Verde. As situadas a oeste dessa linha imaginária seriam espanholas.

Foram tratados concertados entre as duas maiores potências da época, que delinearam os domínios de povos europeus sobre as pouco habitadas terras americanas, nas quais 0 estágio de vida das populações e seus limitados recursos bélicos não habilitavam seus nativos a fazerem frente à colonização que se en cetaria, às expensas de trágicos sofrimentos da destruição de culturas, constituindo-se em um dos mais nefandos genocídios da história humana.

Há que referir também as diferentes for- mas e princípios de colonização utilizados nos dois hemisférios do continente americano: os ingleses, no Norte, com a vinda, desde o início do processo de ocupação das terras, de pessoas interessadas em se fixar e realizar um plano de vida no novo mundo, explorando a terra em benefício próprio; e os espanhóis e portugueses, no Sul, com expedições essencialmente exploradoras, que buscavam ouro e outras riquezas minerais, que acabariam por fazer a opulência de templos e palácios europeus, em detrimento da terra e dos seus naturais.

O triste saldo da destruição das culturas inca, no Peru, e asteca, no México, são consectários dessa postura espanhola, essencialmente realizada, no início, por aventureiros, unicamente interessados no bem-estar e enriquecimento pessoais e no de seus senhores: os monarcas europeus e suas insaciáveis cortes.

\subsection{A Integração a Partir do Século XIX}

Dois homens nascidos na América, que viveram no século XIX, Simão Bolívar e José de San Martin, dedicaram suas existências à busca da unificação dos povos latino-americanos. Tratados, projetos de união e sonhos de confederação por eles intentados conseguem legar à posteridade tão somente as sementes de uma integração que só floresceria século e meio depois.

Antecedentes do Mercosul, já no século XX, foram a Associação Latino-Americana de Livre Comércio (ALALC) e a Associação Latino-Americana de Integração (ALADI), criadas ambas por Tratados assinados em Montevidéu, respectivamente em 1960 e 1980 , sendo a segunda uma sucessora da primeira, que não atingira os objetivos almejados, como refere FARRANDO $O^{8}$ e como têm sido lembrados pela maioria dos autores que abordam os pródromos 
do bloco regional do Cone Sul da América ${ }^{9}$.

\subsection{Brasil e Argentina: Mais Perto do Merca- do Comum}

Atendo-se mais especificamente à concepção e à institucionalização do Mercosul, impõe-se referir o relacionamento entre os dois maiores países sul-americanos: Brasil e Argentina. É que, se a União Européia foi concebida a partir do concerto franco-alemão, o Mercosul só começou a se tornar realidade graças ao entendimento brasileiro-argentino.

Já observou RECKZIEGEL que a característica principal desse relacionamento, "mesmo que intercalado por momentos de amizade, ou até mesmo de certa indiferença, foi o constante estado de rivalidade. Muitas vezes não oficialmente declarado, o antagonismo permeou essas ligações na medida em que suscitou desconfianças e prevenções mútuas" 10 . Segundo a autora, "esse contexto de rivalidade foi animado, antes de qualquer coisa, pela pretensão de ambos de liderarem as nações do bloco sulamericano, ou seja, pelo desejo de hegemonia regional." "11

Se as divergências entre os dois gigantes do Cone Sul da América datam de mais de

- Ver: ALMEDA. ElzahethAcciov Pinto

9 Ver: ALMEIDA, Elizabeth Accioly Pinto de. Mercosul \& União Européia: estrutura jurídico-institucional, p.19. ALMEIDA, Paulo Roberto de. O Mercosul no contexto regional e internacional, p. 64-68. BASALDÚA,
Ricardo Xavier. Mercosur y derecho de integración, p. 65-74. DEL'OLMO, Florisbal de Souza. Direito internacional privado: abordagens fundamentais, legislą̧ãa, jurisprudência, p. 149-166. ESTRELLA FARIA Ângelo. O Mercosul: princípios, finalidade e alcance do Tratado de Assuncão, p. xv. HUSEK C FARIA, Jose 129-130. MIDÓN, Mario A. R. Derecho de la integración, p. 283-296. ROQUE, S. JUSEK, C. R. Op. cit., p. Roberto Lui Direito comunitário da de la integración, p. 283-296. ROQUE, S. J. Op. cit., p. 173. SILVA Roberto Luiz. Direito comunitário e da integração, p. 111-115. SOARES, Esther Bueno. Mercosul: desenvolvi-
mento histórico, p. 19-22.

${ }^{10}$ RECKZIEGEL, Ana Luiza Gobbi Setti. O pacto ABC: as relações Brasil-Argentina na década de 50, p. 30 Esse trabalho é o resultado de pesquisa, como dissertação de mestrado, aprovada na PUC de Porto Alegre, RS. O pacto $\mathrm{ABC}$ - de Argentina, Brasil e Chile - "a despeito de sua fachada integracionista, evidenciou a histórica disputa pela liderança do bloco sul-americano entre as duas nações", conclui a mestra da Universidade de Passo Fundo. Idem, p. 167.

${ }^{11}$ Idem, ibidem.

${ }^{12}$ BASALDÚA, R. X. Op. cit., p. 65.

Revista da Faculdade de Direito da UFRGS, v. 20, Outubro/2001
As dificuldades enfrentadas por Brasil e Argentina nas últimas três décadas, tanto no plano interno - em que abundavam problemas distintos, inclusive longos períodos de gover nos ditatoriais -, quanto no contexto internacional, com graves conseqüências para seus povos, serviram, paradoxalmente, para convencêlos da necessidade de aproximação, de enten dimento, e, em última análise, de integração.

Sobre a transcendental importância da aproximação entre os dois maiores Estados sulamericanos, observou ALMEIDA, com propriedade,: "A opção política fundamental - propriamente geopolítica, no bom sentido da palavra - feita pelas lideranças políticas de ambos os países, no sentido de encerrar décadas de egoísmos nacionais estreitamente mesquinhos erivalidades hegemonistas de origem supostamente castrense, para inaugurar uma nova era de concórdia e de orientação política e econômica no relacionamento bilateral, constitui provavelmente o elemento mais significativo da história da região neste último meio século"13 .

E o resultado foi o surgimento do Mercosul. Emblematicamente, o primeiro passo efetivo na consecução desse objetivo ocorreu na mesma região de Itaipu, com a Declaração de Iguaçu, assinada em 30 de novembro de 1985 pelos presidentes da Argentina e do Brasil, expressando a determinação de se aproximarem política e comercialmente os dois países, superando antigas e, lamentavelmente, tradicionais rivalidades.

Tal fato ocorreu quando se inaugurava a Ponte Presidente Tancredo Neves, unindo Puerto Iguazu, na Argentina, a Foz do Iguaçu, no Brasil. Um elo físico-geográfico sobre um grande rio, tão caro este a ambos os países,

\section{${ }^{13}$ ALMEIDA, P. R. Op. cit., p. 72.}

${ }^{14}$ OLIVEIRA, Odete Maria de. Integração nuclear Brasil-Argentina: uma estratégia compartilhada. Ver também: OLIVEIRA, Odete Maria de. A integração bilateral Brasil-Argentina: tecnologia nuclear e Mercosul, p. 523. serviu de campo para estreitar os vínculos histórico-espirituais entre os dois povos, até então separados por um imenso caudal de desencontros, ambigüidades e desconfianças entre seus governantes, mas atavicamente unidos pela origem latina e ibérica comum.

Também aí se firmou a Declaração Conjunta sobre Política Nuclear, início da camiA busca da harmonização na política argentino-brasileira sobre energia nuclear tem merecido acurados estudos de $O L I V E I R A^{14}$, vindo a lume trabalhos que permitem amplo conhecimento do tema e de suas benfazejas conseqüências para ambos os países e para a tranqüilidade de seus povos.

\subsection{Nasce o Mercosul: Tratado de Assunção}

Os pactos mencionados têm sequiência em 1986, com a Ata para a Integração BrasilArgentina e, em 1988, com o Tratado de Integração, Cooperação e Desenvolvimento, nesse já se estabelecendo uma área econômica comum e definindo-se, inclusive, um horizonte temporal: dez anos. Por fim, em julho de 1990 assina-se a Ata de Buenos Aires, pela qual os presidentes dos dois países decidiram instituir um mercado comum bilateral até o final de 1994. Nunca é demais enfatizar: tudo isso ocorreu sul-americanos.

Todas essas meritórias tratativas tiveram ampla repercussão na imprensa continental e foram percebidas pelos demais países da região, o que levou o Uruguai, inicialmente, e logo após o Paraguai a manifestarem a intenção de se integrar ao nascente organismo, cujo esnhada de cooperação nesse delicado terreno. envolvendo apenas os dois maiores Estados 
boço tomava corpo. Estava preparado o terreno para o surgimento daquele que se vai tornando promissor modelo de integração econômica de países da América do Sul, lastreado pela experiência registrada na União Européia.

O Mercado Comum do Sul (Mercosul), constituído formalmente pelo Tratado de Assunção, assinado na capital guarani no dia 26 de março de 1991, tem como seus componentes originários o Brasil, a Argentina, o Uruguai e o Paraguai, mas registrando-se o interesse manifestado por outros países da região na futura integração. Entre esses devem ser destacados o Chile e a Bolívia, já participando do bloco regional desde 1996, na condição de associados.

Enfatiza MIDÓN que uma observação retrospectiva sobre a busca de integração empreendida pelos diversos países americanos leva o estudioso a concluir que as experiências havidas, a par de terem sido inicialmente políticas e econômicas, transformaram os processos de integração, tal como hoje vêm sendo concebidos, não mais em projeto político de determinado governo, mas em política de Estado, reafirmada de modo regular e periódico, e agindo como instrumento de desenvolvimento dos respectivos povos, verificando-se acentuada interdependência entre os partidários de cada processo, o que conduz ao entendimento de que o caminho para levar adiante o empreendimento é o do regionalismo aberto ${ }^{15}$.

O Tratado de Assunção representa o nascimento do Mercosul na esfera do Direito Internacional: a partir desse histórico documento um novo bloco econômico regional passa a se constituir como uma célula expressiva da Sociedade Universal. Esse acordo emblemático coloca a emergente associação de Estados no contexto do Direito das Gentes, ainda que um tratado posterior, o Protocolo de Ouro Preto, de

17 de dezembro de 1994, seja o marco formal da instauração do bloco no mundo das ciências jurídicas, uma vez que foi a partir de então, segundo o art. 34 desse Protocolo, que o Mercosul passaria a ter personalidade jurídica.

Embora seja um acordo de caráter eminentemente econômico, o Tratado de Assunção não pode a esse aspecto ser reduzido, devendo, a serem seguidos os seus preceitos, buscar-se incessantemente a melhora da proteção social e do nível de vida dos cidadãos e estabelecidas suas liberdades, até porque, no seu artigo primeiro, está preconizada a livre circulação de bens, de serviços e de fatores produtivos entre os países.

\section{O Direito Comunitário e o Mercosul}

\subsection{Considerações Iniciais}

O sucesso da integração de Estados soberanos, muito bem representado pela União Européia, ensejou, com a pertinente consolidação do espírito de comunidade, o desenvolvimento do Direito Comunitário. Trata-se de disciplina jurídica própria, distinta da ordem jurídica interna e da internacional.

VIGNALI, renomado Professor de Direito e Doutor em Diplomacia uruguaio, entende o Direito Comunitário como "o conjunto de normas jurídicas e princípios que as hierarquizam e coordenam coerentemente, que regula as relações entre Estados soberanos e Organizações Internacionais que participam de um processo de integração amplo e profundo, quando atuam (as normas e princípios) nos limites de uma comunidade internacional inserida em uma sociedade maior, com o propósito de cooperar com os Estados-membros, sob a coordenação da
Organização que os agrupa, para obter maio segurança e bem-estar e fortalecer suas posições ao atuarem (essas organizações) em conjunto frente aos demais Estados."16

A rigor, essa ordem jurídica só exercerá seu importante papel no contexto dos povo mediante cedência de parcela da soberania dos Estados, o que tem ocorrido através dos Tratados entre os países engajados no processo. E imprescindível que se entenda que é justamente a soberania (que não se perde) que viabilizará uma projetada integração: a soberania atribui ao Estado o poder de decidir se irá ou não participar de um bloco regional.

É pressuposto do Direito Comunitário a adoção, pelos países engajados no processo de integração, do instituto da supranacionalidade. Deve ser desprezado o entendimento equivocado de que soberania supranacionalidade são incompatíveis, mito que necessita ser afastado, uma vez que a integração plena pode e deve ocorrer sem que os Estados abram mão de sua soberania.

Quanto ao direito interno, difere ele da ordem jurídica comunitária por disporem os tribunais comunitários de competências específicas, embora o objeto substancial desse direito sejam atos e fatos que têm seu curso no território dos Estados-membros.

Na expressão de RULLI JUNIOR, “o direito comunitário não se opõe ao direito nacional, porque não o derroga expressa ou tacitamente, não havendo hierarquia entre eles, apenas prevalência da regra comunitária." ${ }^{17}$ Embora se entenda que hierarquia e prevalência são

\footnotetext{
${ }^{16}$ VIGNALI, Heber Arbuet. Soberanía e integración, p. 102-103.
}

${ }^{17}$ RULLI JUNIOR, Antonio. Mercosul: o direito comunitário e a garantia de investimentos e cidadania, p. 63 64.

${ }^{18}$ LOBO, Maria Teresa Cárcomo. Ordenamento jurídico comunitário: União Européia-Mercosul, p. 43. ${ }^{19}$ FERREIRA, M. C. e OLIVERA, J. R. Op. cit., p. 103.

Revista da Faculdade de Direito da UFRGS, v. 20, Outubro/2001 sinônimos, a observação desse autor identifica algo que deve restar claro: a norma comunitária prevalece quando oposta à interna.

Observou $\angle O B O$ : "A autonomia do direito comunitário não o impede de estar integrado nas ordens jurídicas internas, uma vez que as suas diferentes regras tomam lugar no seio dos ordenamentos nacionais, aí se aplicando diretamente e prevalecendo sobre as regras nacionais contrárias." 18

A doutrina tem apresentado como características do Direito Comunitário a aplicabilidade imediata (suas normas adquiro), a aplicabilidade direta (cria direitos e obrigações por si mesmo) e a prevalência (a norma dos países integrantes da Comunidade) ${ }^{19}$.

\subsection{O Direito Comunitário e o Direito Inter-} nacional

A diferença essencial entre o ordenamento comunitário e o internacional consiste em que este não se impõe à ordem jurídica dos Estados, não existindo, como se sabe, uma ascendência jurídica dos tribunais internacionais sobre as cortes nacionais, até porque não existe um órgão institucionalizado com essa competência, o que seria, diga-se, uma hipotética Suprema Corte Planetária. Já em relação ao cão sui generis, uma subordinação das ordens jurídicas internas ao Tribunal Comunitário Supranacional, quando este vier a existir.

${ }^{15}$ MIDÓN, M. A. R. Op. cit., p. 33

Revista da Faculdade de Direito da UFRGS, v. 20, Outubro/2001 
$\mathrm{Na}$ esteira da observação de $W O L K M E R^{20}$ de que existe forte legalismo de cunho nacional-monista e histórica tradição do Estado como fonte privilegiada de produção legislativa nos países latino-americanos, capazes de dificultar o Direito Comunitário na região, pode-se enfatizar que é indiscutível a prevalência do direito interno sobre a norma jurídica internacional nos Estados-membros do Mercosul. É peremptório que o ordenamento jurídico de cada um desses países é monista com primazia do direito nacional.

Sem querer abordar em profundidade as teorias que estudam as relações entre os ramos do Direito, monista e dualista, não seria demasiado observar que a implantação do Direito Comunitário nesses países poderia ocasionar uma despropositada terceira teoria nas relaçõe entre os campos das ciências jurídicas, triadicalismo, consistente em uma ordem jurídica que comportaria três sistemas paralelos: 0 direito interno, o internacional e o comunitário, com presumível predomínio do direito nacional, o que dificultaria a aplicação eficaz da legislação emanante da Comunidade.

O Direito Comunitário está sincronizado com o espírito da nova ótica da integração do Direito Internacional. Caminha-se hoje em direção a um mundo integrado, ou um mundo globalizado, no qual o ser humano está irreversivelmente se engajando, de uma forma ou de outra, a um modo de vida universal.

\subsection{O Direito Comunitário no Mercosul: Uma Necessidade}

No âmbito da União Européia a primazia

do Direito Comunitário se verifica, e não poderia ser diferente, mesmo sobre as próprias normas constitucionais dos países da Comunida$\mathrm{de}^{21}$. Assim, se o juiz, no curso de um processo, se defronta com uma contradição entre a norma jurídica interna e a norma do Direito Comunitário, deverá optar pela aplicação dessa última. Fruto da jurisprudência comunitária, a prevalência sobre o direito interno vem sendo reiteradamente aplicada na União Européia, constituindo em paradigma para o futuro Direito Comunitário no Cone Sul da América.

Trazendo para o Mercosul o exemplo europeu, no que for adequado, são relevantes as considerações de BERTOLOTTI - após lembrar que longo ainda é o caminho que deve ser percorrido pelo bloco regional sul-americano no terreno jurídico e institucional - quando afirma: "Esse fenômeno não é só produto da história, mas também criação do direito. Um direito que deu vida e que deve permitir agora seu desenvolvimento e seu crescimento, pois - tal como sucedeu na Comunidade Européia - é um efetivo fator integrador, capaz de fazer do Mercosul uma verdadeira "comunidade de direito."22

No caso do Mercosul, o Direito Comunitário originário se encontra no Tratado de Assunção e no Protocolo de Ouro Preto, que poderiam, na esteira do entendimento de José Soder, antes mencionado, serem considerados como a Constituição escrita do Mercosul.

Verifica-se, por outro lado, que o Direito Comunitário derivado emana de órgãos constitutivos dos blocos econômicos regionais, como o Conselho, o Grupo e a Comissão de Comércio, no caso do bloco econômico regional do Cone Sul. Esses organismos foram cria-

${ }^{20}$ WOLKMER, Antônio Carlos. Integração e direito comunitário latino-americano, p. 48.

${ }^{21}$ Charles Vallée, ao recordar que as Constituições da maioria dos Estados que formam a União Européia préexistiam às Comunidades, enfatiza que algumas delas sofreram revisões a fim de se adaptarem ao ordenamento jurídico comunitário. VALLEE, Charles. $O$ direito das comunidades européias, p. 105.

${ }^{22}$ BERTOLOTTI, Silvina Barón Knoll de. Administración y gobierno del Mercosur, p. 175.

Revista da Faculdade de Direito da UFRGS, v. 20, Outubro/2001 dos nos Tratados instituidores das Comunidades, e entre suas atividades está previsto o estabelecimento dessas normas.

O artigo 42 do Protocolo de Ouro Preto estabelece que as normas emanadas dos órgãos do Mercosul, previstos no seu artigo $2^{\circ}$, quais sejam o Conselho do Mercado Comum, o Grupo Mercado Comum e a Comissão de Comércio do Mercosul, terão caráter obrigatório e deverão ser incorporadas aos ordenamentos jurídicos nacionais dos Estados-membros quando necessário, mediante procedimentos previstos na legislação de cada um deles.

Há que ressaltar que, pelo artigo 38 do mesmo Protocolo, os países do bloco regional mercosulista ficam comprometidos a adotar as medidas necessárias para assegurar o cumprimento, no território respectivo, das normas provenientes dos órgãos do Mercosul, normas as quais estão previstas no mencionado artigo $2^{\circ}$ do documento de Ouro Preto. E para garantir a vigência simultânea de tais normas nos Estados-membros deverão ser adotadas as medidas necessárias à sua incorporação ao ordenamento jurídico nacional, comunicadas Secretaria Administrativa do Mercosul.

Por ora, a consolidação de um Direito Comunitário no bloco econômico regional do Cone Sul está longe de se tornar uma realidade. Afirmuu BAHIA que "o direito comunitário do Mercosul, quanto à aplicabilidade direta, possui uma característica invulgar, por merecer distinto apreço por parte dos Estados-partes do acordo. Para uns, pode tratar-se de autêntico direito comunitário (supranacional). Para outros, não passaria de direito internacional puro e simples"23.

Torna-se imperiosa, para a consolidação do Mercosul e a consecução dos seus objetivos, a implantação, em seu âmbito, do Direito

${ }^{23}$ BAHIA, Saulo José Casali. A supranacionalidade no Mercosul, p. 195

${ }^{24}$ BERTOLOTTI, S. B. K. Op. cit., p. 145-152.

Revista da Faculdade de Direito da UFRGS, v. 20, Outubro/2001
Comunitário. E ela só ocorrerá quando os Estados participantes, cônscios da magnitude do momento que atravessam, adotarem como instituição do grupo a supranacionalidade. Será o abandono da integração intergovernamental, que depende da unanimidade, sempre mais difícil ante assuntos muitas vezes polêmicos, até porque os interesses regionais podem ser divergentes ou antagônicos, em favor da decisão partida da comunidade, que é soberana na sua determinação e procede de um consenso.

\subsection{O Futuro Tribunal de Justiça do Mercosul}

Ao analisar a estrutura institucional do Mercosul-depois de referidas as experiências comunitárias para o bloco regional sul-americano, representadas pela União Européia BERTOLOTTI assinala, entre outros, os seguintes importantes aspectos: 1) natureza intergovernamental de todos os órgãos instituídos, ausente, portanto, a supranacionalidade; 2) a inexistência, na atual estrutura do Mercosul, de um órgão que represente exclusivamente os te a respeito dos Estados-partes; 3) a falta de uma clara distinção de funções entre os órgãos atuais, embora o avanço trazido, nesse sentido, pelo Protocolo de Ouro Preto; 4) a inexistência de uma instituição que represente os povos dos Estados, permitindo-lhes participar no processo de elaboração normativa, qual fosse um Congresso, um Parlamento ou uma Assembléia; 5) ausência de um Tribunal de Justiça do Mercosul, o que impossibilita a uniformidade de interpretação e aplicação dos termos do Tratado de Assunção e do direito dele derivado; e 6) o estado de indefesa no procedimento previsto para as reclamações dos particulares, já que ausente norma que dirima a aplicação de medida de efeito restritivo ou discriminatório ${ }^{24}$. interesses comunitários, que seja independen- 
ALMEIDA enfatiza: "Um dos grandes problemas da evolução política futura do Mercosul é, precisamente, o 'salto' para a adoção integral de instituições comunitárias de tipo supranacional, transição que ocorrerá, mais cedo ou mais tarde, nos países-membros, considerando-se que o Mercosul constitui, efetivamente, o embrião de etapas superiores de integração" 25 .

Para STELZER, "a origem da supranacionalidade encontra-se na transferência de parcelas soberanas por parte dos Estados-nacionais em benefício de um organismo que, ao fusionar as partes recebidas, avoca-se desse poder e opera por cima das unidades que o compõem, na qualidade de titular absoluto." 26 Já COSTA entende que a supranacionalidade está "ligada à legitimidade regional e apenas tem sentido quando é instrumento das demandas sociais, notadamente a de integração. A opção por órgãos e direitos supranacionais não é, assim, uma questão de mera vontade, mas principalmente de finalidades e possibilidades sociais. Deve, portanto, estar balizada por uma análise profunda da sociedade e da economia, mas nunca pode lançar suas bases sobre modelos formais, cujo transplante apenas pode resultar em rejeição."27

A importância fundamental da implantação do Direito Comunitário no bloco regional do Cone Sul da América é uma imposição realçada por RULLI JUNIOR, que acrescenta dever ele ser construído "com a participação e

o compromisso da sociedade civil da região, seus governos e estruturas governamentais e políticas, aplicado por uma Corte de Justiça, também regional e independente, que possibilitará a construção e a conseqüente manutenção de regras jurídicas claras, e com efetividade social compatível com as necessidades"28

Ainda sobre a institucionalização de um Tribunal de Justiça em uma comunidade de Estados, acompanhe-se ALMEIDA: "A existência de um Tribunal da Justiça é um elemento essencial num processo de integração. $O$ sistema de repartição das competências que ele comporta supõe a garantia para os Estados de que o seu respeito será assegurado tanto por parte das instituições como dos seus membros. A subordinação a regras comuns implica que a uniformidade da sua aplicação será mantida, pois, se numa comunidade de Estados as normas comunitárias estivessem sob o controle dos tribunais nacionais, elas seriam interpretadas $\mathrm{e}$ aplicadas diferentemente em cada um deles. A aplicação uniforme do Direito Comunitário seria, por conseqüência, posta em causa." ${ }^{29}$

CAIROLIMARTINEZ enfatiza sua convicção de que a criação de um tribunal de justiça "será suficiente garantia da segurança jurídica que deve emanar da jurisprudência, o que contribuirá para a segurança de toda a população dos países que integram a comunidade." ${ }^{30}$ Para ele, somente o futuro Tribunal de Justiça do Mercosul garantirá a aplicação uniforme do Direito Comunitário.

${ }^{25}$ ALMEIDA, Paulo Roberto. O Mercosul no contexto global, p. 127

${ }^{26}$ STELZER, J. Op. cit., p. 65.

${ }^{27}$ COSTA, José Augusto Fontoura. Multiplicidade jurídica e integração regional, p. 268

${ }^{28}$ RULLI JUNIOR, A. Op. cit., p. 74. O autor conclui: "A institucionalização do Mercosul passa necessariamente pela criação de um Parlamento e de um Tribunal de Justiça Supranacional que representam a segurança de investimentos na região e o desenvolvimento de uma cidadania capaz de formar um espaço de integração democratizado".

${ }^{29}$ ALMEIDA, E. A. P. de. Op. cit., p. 100.

${ }^{30}$ CAIROLI MARTINEZ, Milton. El papel de la justicia en el Mercosur, p. 226.

Revista da Faculdade de Direito da UFRGS, v. 20, Outubro/2001
Por fim, KLAES observa: "O aprimoramento do atual Sistema de Solução de Controvérsias, com a criação de um órgão judicial, se torna obrigatoriamente necessário para acompanhar e promover o crescimento do mercado interno e o aprimoramento da ordem jurídica do Mercosul. A instalação de um Tribuna Supranacional pode não ser o próximo passo, em razão do alto grau de maturidade política que uma instituição desse porte demanda, mas certamente será o passo seguinte. A experiência da CE é, nesse aspecto, uma oportunidade de aprendizado de valor inestimável, mas cabe aos Estados- Partes o condão de transformá-la em vantagem efetiva." ${ }^{11}$

Depreende-se que o Mercosul se apresenta como um modelo de integração intergovernamental, no qual uma decisão que implique nova postura do bloco deve ter o ne varietur de todos os governos. Sua estrutura atual requer a unanimidade dos Estados, com o que se torna mais difícil o avanço e o desenvolvimento normal do processo, uma vez que a ausência de consenso ocasiona o abandono, por algum tempo pelo menos, das metas encetadas. A União Européia, ao contrário, porta um paradigma de integração supranacional, em que as decisões emanam do órgão comunitário, que se encontra além e acima das competências estatais. Daí a importância do modelo europeu, cujo sucesso deve constituir-se em fator determinante para um processo de conscientização, não só dos Estados que compõem o bloco regional do Cone Sul, como também de toda a população mercosulista.

No paralelo entre essas duas formas de integração - a intergovernamental, no

${ }^{31}$ KLAES, Marianna Izabel Medeiros. Mercosul e tribunal supranacional: um dos pressupostos essenciais à efetiva integração, p. 368-369.

${ }^{32}$ URIARTE, Oscar Ermida. Mercosur y derecho laboral, p. 19.

${ }^{33}$ Idem, ibidem
Mercosul, e a supranacional, em adiantada fase na União Européia -, com evidente vantagem do modelo do Velho Mundo, devem ser buscados subsídios que permitam a aceleração do processo sul-americano. E esse caminho passa obrigatoriamente pela criação de um tribunal supranacional, o Tribunal de Justiça do é difícil a consolidação de uma comunidade sem seu órgão jurídico, de outro este organismo só ção comunitária, da qual é peça fundamental.

\section{A Aproximação das Legis- lações no Mercosul}

\subsection{A Aproximação nas Legislações}

Recorda URIARTE que "toda vez que se apresenta a questão da integração econômica regional surge, de maneira quase automática, a demanda de ou a pergunta sobre a harmonização ou a aproximação das legislações nacionais." 32

O mesmo autor uruguaio complementa: "Além das precisões das diversas técnicas a respeito (unificação, harmonização, aproximação), das vantagens e dos inconvenientes da convergência e de suas inevitáveis limitações em atenção às tendências provavelmente divergentes das negociações coletivas e as jurisprudências nacionais, o estado da opinião a respeito no Mercosul pareceria ser nem tanto nem tão pouco." 33

Ao abordar o tema da aproximação das legislações laborais no Mercosul, FERREIRA e Mercosul. Pode-se enfatizar que, se de um lado se justifica e fortalece no seio de uma institui- 
OLIVERA observam: "O nível mais profundo seria o da unificação e da uniformização das legislações. Este objetivo é de difícil aplicação prática, porque requer impor uma legislação coincidente para todos os países da área, o que só é possível lograr partindo-se de uma plataforma comum muito similar, hipótese que dificilmente ocorre"34.

Ainda na esteira das formas de convergência da legislação, reporte-se ao estudo de $B A B A C E$, para quem a uniformização "depende da profundidade com que se logre aproximar as legislações. Em um sentido, uniformizar é sinônimo da ação de convergir, e, em outro, é gênero de várias espécies." ${ }^{35} \mathrm{E}$ entre essas espécies, o mesmo autor refere a unificação, harmonização, aproximação e coordenação.

Entende-se que a unificação presume a uniformização completa das legislações, o que é viável em determinados institutos jurídicos, mas impensável em um segmento maior ou, menos ainda, em todo o ordenamento jurídico. ${ }^{36}$ Isso só seria possível quando a sociedade universal estivesse submetida a um só governo, ao mesmo poder de competência.

A harmonização seria a instituição de legislações em que houvesse um mínimo de divergências significativas entre seus postulados e as convergências fossem as mais amplas, facilitando a solução de lides que envolvessem esses ordenamentos jurídicos. ${ }^{37}$

Aproximação, por sua vez, deve ser entendida como a convergência de legislações em

${ }^{34}$ FERREIRA, Maria Carmen e OLIVERA, Julio Ramos. Mercosur: enfoque laboral, p. 37.

${ }^{35} \mathrm{BABACE}$, Héctor. Introducción al estudio de las relaciones laborales en los procesos de integración, p. 92.

${ }^{36}$ Idem, ibidem.

${ }^{37}$ Idem, ibidem.

${ }^{38}$ Idem, ibidem.

${ }^{39}$ Idem, ibidem

${ }^{40}$ PABST, Haroldo. Mercosul: direito da integração, p. 109.

${ }^{41}$ Idem, p. 34

Revista da Faculdade de Direito da UFRGS, v. 20, Outubro/2001 que ocorre uma busca de proximidade entre suas normas, limitada a determinado instituto ou a alguns deles. ${ }^{38}$

A coordenação, ainda na ótica de BABACE, seria "uma modalidade de convermedidas adotadas pelos Estados a nível interno, com base em políticas previamente coordenadas em instâncias regionais." 39

Na observação de PABST, "a transformação do mundo, em que nossos vizinhos não são mais os habitantes de uma cidade próxima mas os de cidades de países próximos, e em que a distância geográfica perde sentido, exige uma conformação de regras jurídicas básicas para estruturar os negócios inter-regionais, para dar segurança jurídica aos contratantes e para proteger a parte fraca da relação jurídica." ${ }^{40}$

Complementando essas assertivas, afirma o mesmo autor que a harmonização jurídica é o instrumento ideal para azeitar todo o processo de integração no próprio momento em que o mesmo ocorre.

Nesse sentido, PABST acentua que "o trabalho de colaboração internacional na busca da uniformização não deve limitar-se ao momento da adoção de uma norma única, mas deve ser permanente, com vistas principalmente à sua preservação"41

É ainda do mesmo autor esta observação: “A complementação de uniformização, através de um esforço harmonizador na área do digência pela qual as ações a promover implicam reito internacional privado, exatamente para aquelas relações jurídicas que, por razões culturais ou outras, não puderam ser objeto do processo de integração, é idéia que encontra corroboração em Ulmer (1992)." ${ }^{\text {42 }}$

Uma aproximação da legislação nos quatro países do Mercosul é uma imposição da fase que vive o movimento de integração regional encetado. Só ela será capaz de conduzir à formação de uma comunidade, aspiração maior vontade emblemática nesta quadra da história da integração. Sequer se poderá dizer que é uma utopia, por ser plenamente exeqüível entre povos já decididos a não mais viver estanques ou submetidos a situações de animosidades ou oposições.

Para VIANA SANTOS, significativamente: "É verdade que a construção de um Direito Comunitário para o Mercosul, entendido como o conjunto de normas vinculantes para instituições comunitárias e seus Estados-Membros, formando 'corpus harmônico', ainda passa por longo e laborioso caminho, cujo passo concreto inicial e a etapa ainda não vencida, prevista no Tratado de Assunção, de harmonização das legislações nacionais nas matérias pertinentes, encontra-se em curso" ${ }^{43}$.

Lembra JUCÁ que a possibilidade de um Direito Comunitário está condicionada à harmonização da legislação pertinente e lamenta que o processo para tal não está ocorrendo em qualquer dos Estados-membros do Mercosul, pelo menos com a dinâmica compatível e ante os interesses em jogo. ${ }^{44}$
A harmonização das legislações possibilitaria a pessoas que vivem sob bandeiras diferentes caminharem na mesma direção, encetando passos que sejam na direção comum, e que esses passos sejam imitados. Assim, esse movimento logo redundará na consolidação de um bloco econômico integrado, o Mercosul. Esse é, por certo, o futuro desejável por todos os que vivem e trabalham na futura comunidade do Cone Sul da América.

O artigo $1^{\circ}$ do Tratado de Assunção, em sua parte final, preconiza "o compromisso dos Estados-Partes de harmonizar suas legislações, nas áreas pertinentes, para lograr o fortalecimento do processo de integração". Lembra $R O Q U E$, entretanto, que "a resistência às mudanças já é uma tradição de nossas arcaicas estruturas jurídicas" ${ }^{45}$, manifestando uma antevisão dos obstáculos a serem vencidos na caminhada da aproximação das legislações no Mercosul em qualquer área da normatização jurídica, o que vai exigir redobrada atenção e empenho das populações interessadas, quai sejam, as pessoas dos quatro Estados-membros do bloco econômico regional do Cone Sul.

\subsection{A Aproximação nos Textos Constitucio-} nais

Por acreditar que a instituição de um sistema jurisdicional semelhante ao europeu pode ser o instrumento válido para a consolidação efetiva do Mercosul, lamenta KEMELMAJER $D E C A R L U C C I$ que "esta convicção não che-

${ }^{42}$ Idem, p. 42

${ }^{43}$ VIANA SANTOS, Antônio Carlos. Mercosul: espaços de integração e jurisdição, soberania e jurisdição supranacional, p. 25

${ }^{44}$ JUCÁ, J. F. Op. cit., 85. Indica esse autor desconhecer informações concretas sobre os trabalhos de harmonização e a existência de linhas de pesquisa sistemática em Universidades a respeito desse conhecimento do Direito Positivo em qualquer dos Estados do bloco regional.

${ }^{45}$ ROQUE, S. J. Op. cit., p. 177 
gou aos que detêm a decisão política de levar adiante a integração latino-americana." ${ }^{\prime 4}$

Recordando que independência integração são hoje termos necessariamente conciliáveis, ausente qualquer antinomia do passado, afirma GROS ESPIELL: "Um país é mais independente e mais soberano quando tem uma economia sadia em processo de expansão e crescimento. Um povo é mais livre quando sua vida se embasa em uma situação social que abre perspectivas de uma vida melhor." 47

OLIVAR JIMÉNEZ, por sua vez, ao estudar as particularidades do processo de integração no Mercosul, recorda que "para a doutrina integracionista, tanto européia como latino-americana, o elemento essencial que diferencia um processo integracionista da simples cooperação entre Estados é supranacionalidade." 48

Adverte SEITENFUS que, "sendo o Mercosul uma organização de natureza intergovernamental, a vigência das regras resultantes do funcionamento das instituições com poder decisório depende da internalização dessas decisões pelas ordens jurídicas internas dos Estados-partes." 49

Feitas tão oportunas e pertinentes alusões a estudiosos do fenômeno da integração e do próprio bloco econômico regional do Cone

Sul, engajados todos eles em trazer contribuições e luzes à nascente comunidade, é o momento de referir as grandes dificuldades geradas pela postura constitucional dominante nos países integrantes do Mercosul. Poder-se-ia afirmar que o empecilho maior provém da vontade dos constituintes de todos eles.

A rigor, a Constituição paraguaia, de 20 de junho de 1992, é a única, entre as Cartas Magnas dos Estados do Mercosul, que admite uma ordem jurídica supranacional, como se inscreve no artigo 145: "A República do Paraguai, em condições de igualdade com outros Estados, admite uma ordem jurídica supranacional que garanta a vigência dos direitos humanos, da paz, da justiça, da cooperação e do desenvolvimento político, econômico, social e cultural". Essa postura da Lex Legum paraguaia abre caminho para a inserção no ordenamento jurídico do País de norma emanada por um eventual legislador de Comunidade da qual o Paragua faça parte, como o Mercosul.

Exige a Norma Ápice paraguaia, é verdade, a aprovação dessa ordem supranacional pela maioria absoluta de cada uma das casas do Congresso.

Outrossim, a Constituição argentina, de $1^{\circ}$ de maio de $1853^{50}$, no artigo 75 , que trata das atribuições do Congresso Nacional, estabelece

${ }^{46}$ KEMELMAJER DE CARLUCCI, Aída. Integración y jurisdición, p. 202.

${ }^{47}$ GROS ESPIELL, Héctor. Naturaleza juridica del Tratado de Asunción y de sus protocolos, p. 244 ${ }^{48}$ OLIVAR JIMÉNEZ, Martha Lucía. La compreensión del concepto de derecho comunitario para una verdader integración en el cono sur, p. 128.

${ }^{49}$ SEITENFUS, Ricardo. Manual das organizaçōes internacionais, p. 221.

${ }^{50}$ A Argentina é o único dos países do Mercosul que teve ao longo de sua História apenas uma Constituição federal, sofrido substanciais reformas, sempre através de Cia $1^{\circ}$ de maio de 1853, que continua vigente, embora tenha 1994. ZAVALÍA, Ricardo de. Conpre através de Convenções Constituintes, em 1860, 1866, 1898, 1949, 1957 e A. Ramella, identificam a Carta Magna dén de la Nación Argentina, p. 5. Alguns autores argentinos, como Pablo A. Ramella, identificam a Carta Magna de seu país, como Constituição de 1853-1860, pela importância que vêem na primeira das grandes reformas. RAMELLA, P. A. Nacionalidad y ciudadania, p. 21.

Revista da Faculdade de Direito da UFRGS, v. 20, Outubro/2001 no inciso 24 que cabe ao mesmo "aprovar tratados de integração que deleguem competência e jurisdição a organizações supra-estatais em condições de reciprocidade e igualdade e que respeitem a ordem democrática e os direitos humanos".

Já as Cartas Magnas brasileira e uruguaia não fazem referência à instituição de uma ordem jurídica supranacional. Dão guarida, é verdade, aos movimentos de integração regional, prescrevendo a Constituição publicada em 1 de fevereiro de 1967 que a República Orienta do Uruguai "procurará a integração social e econômica dos Estados Latino-Americanos, especialmente no que se refere à defesa comum de seus produtos e matérias-primas" (art. $6^{\circ}$ ). A Constituição de 5 de outubro de 1988, no pará grafo único do artigo $4^{\circ}$, prescreve, por sua vez que "a República Federativa do Brasil buscará a integração econômica, política, social e cultural dos povos da América Latina, visando à formação de uma comunidade latino-americana de nações".

Em diligente trabalho sobre a supranacionalidade nas legislações constituci onais do Mercosul, KERBER recorda que o Brasil e o Uruguai não avançaram, desde a assinatura do Tratado de Assunção, no sentido de colocarem suas leis maiores nos patamares das da Argentina e Paraguai, no que se refere "à adoção do instituto da supranacionalidade, que demonstra as dificuldades que tal instituto apresenta ao bloco do Cone Sul." 51 E complementa, com propriedade, o mestre gaúcho: "Para essa etapa será necessário que as Constituições admitam expressamente a existência de um órgão judicial supranacional, que predomine sobre a estrutura dos respectivos poderes judiciários nacionais. Esses desafios a vencer encontram-se na ordem das preocupações dos meios jurídicos, políticos e diplomáti-

${ }^{51}$ KERBER, Gilberto. Mercosul e supranacionalidade: um estudo à luz das legislações constitucionais, p. 90. ${ }^{52}$ Idem, ibidem cos dos países envolvidos com a criação do Mercosul, para a adoção do instituto da supranacionalidade, que deve ser enfrentada com a revisão constitucional." 52

Depreende-se, pois, que os primeiros obstáculos a serem vencidos na busca da implantação de uma comunidade jurídica no Mercosul passam por um novo posicionamento constitucional dos Estados-membros do bloco, consubstanciada na cedência de parcela de soberania em favor de uma ordem jurídica que se estenda sobre todos eles. E essa postura a ser adotada, em especial, pelas leis maiores brasileira e uruguaia, é pressuposto para a consecução da almejada integração, a menos que se pretenda manter uma grande margem de discricionariedade nas condutas dos paísesmembros, o que pode redundar em um comprometimento do futuro do bloco.

\subsection{Todos Crescendo com a Integração}

A História é a mestra inexorável da razão. Também o é dos povos. Nela se encontram postulados e motivações para um encontro com o fim maior do ser humano: a felicidade. Sim, porque outro objetivo não tem o homem, em qualquer época ou lugar, senão a identificação com aquela situação de empatia consigo mesmo e harmonia com o meio, com o seu semelhante e com os outros seres que o cercam, vivos ou inanimados.

A infindável sucessão de desencontros entre os povos, de que é o mais pungente exemplo a guerra, nada mais reflete do que um anseio de ser feliz. Nessas situações se entende que a busca da felicidade redundou em um domínio do vencedor, que o comemorou sobre ruínas, com a destruição daquilo que também lhe seria necessário e útil. 
São bem atuais as observações, feitas em 1984, por SILVA: "É indubitável que na sociedade internacional do século $\mathrm{XX}$ a idéia do isolamento dos Estados é utópica e irrealizável. O processo tecnológico derivado da Revolução Industrial, a dinâmica e mobilidade social, progresso individual e o desenvolvimento dos povos impõem a necessidade de integração e complementação sobre bases políticas, culturais e econômico-sociais." ${ }^{53}$

Busque-se o entendimento de JUCÁ para quem o modo de produção imposto no interregno entre a Modernidade e a PósModernidade "com a cultura da velocidade de obsolescência e as idéias de instantaneidade descartabilidade, que inclui o processo produtivo e o sistema econômico, ensejam enorme exclusão humana, e legiões inteiras, em todo os países e sistemas são colhidas pelo desemprego, subemprego, falta de condições de sobrevivência, gerando massas de excluídos, de desassistidos lançados à própria sorte, os quais os Estados nacionais são incapazes de atender. com os mecanismos disponíveis e pela falta de recursos." ${ }^{54}$

No âmago do processo da globalização em marcha e o contraponto da instituição de blocos de integração econômica regional, em que se vive, somadas a tantas outras mudanças, assim observa OLIVEIRA: "Nosso planeta, antes circundado por grandes e desconhecidas distâncias, parece que agora encolheu, tornou-se virtual, face a uma rede instantânea de fácil comunicação de massa somada ao avanço acelerado da revolução tecnológica. Na rea-

lidade, não há atividades que possam escapar dos efeitos da globalização do capitalismo, pois o mundo, atualmente, se apresenta sem fronteiras, com sua economia e cultura mundializadas e onde as corporações transnacionais, cosmopolitas, descentralizadas e independentes dos Estados, operam sem nacionalidades, sob o comando do poderoso processo global: nova divisão internacional do trabalho, mudança total nos fluxos comerciais internos e externos sob diferente dinâmica de regulação financeira, reprodução ampliada do capital em escala global, maximização da produtividade e de seu lucro, competitividade entre as empresas transnacionais na acirrada arena da guerra comercial frente à disputa do controle dos principais mercados do mundo." 55

Os tempos presentes são também de interdependências, de um lado, e de privatização, liberalização, competitividade e desregulamentação, de outro, o que COVAS chamou de regime da ditadura globalitária. ${ }^{56}$ Afirma o mestre português: "Os territórios regionais politicamente constituídos reagem acaloradamente a esta mercantilização do seu território sobrecarregando os poderes centrais com reivindicações sucessivas de compensação e transferência de recursos." 57 Isso coloca em tensão permanente o regime democrático nos planos internacional, supranacional e nacional.

Não se cogita ignorar as pontes invisíveis, mas concretas, que tentam aproximar os indivíduos em todas as dimensões geográficas. O homem, em qualquer Continente, mesmo no mais afastado recôndito do planeta, está, de uma

${ }^{53}$ SILVA, Hector Ramon. La comunidad internacional, p. 108.

${ }^{54}$ JUCÁ, Francisco Pedro. Possibilidades de um parlamento latino-americano vinculado ao Mercosul, p. 49 Enfatiza ainda esse autor: "O desafio da contemporaneidade é enfrentar, adequada e eficientemente, o p. 49. entre incluídos e excluídos, partícipes do processo e marginalizados, o tue requada e eficientemente, o abismo Ibidem.

${ }^{55}$ OLIVEIRA, Odete Maria de. União Européia: processos de integração e mutação, p. 23

${ }^{56}$ COVAS, A. Op. cit., p. 7

${ }^{57}$ Idem, p. 7-8.

Revista da Faculdade de Direito da UFRGS, v. 20, Outubro/200I maneira ou de outra, preso ao seu semelhante, ainda que dele afastado por milhares de quilômetros, por um liame de interdependência. Se a vinculação humana, psicológica, emocional ou moral não conseguiu aproximá-lo, no passado, às injunções do presente - sejam de que ordem forem - hoje o une e o torna convivente com a assimetria imposta pelas injunções do mercado econômico mundializado.

O Mercosul tem ensejado a busca incessante da integração desejada pelos povos dos Estados-membros, o que permite antever avanços no seu porvir. ALMEIDA lembra que a prática diplomática tem levado a consultas políticas entre os quatro Estados, sobretudo entre Brasil e Argentina, incluindo os setores militares. Já ocorreram encontros dos EstadosMaiores das Forças Armadas nacionais brasileiras e argentinas, reduzindo ao mínimo, a proporções insignificantes, os riscos de uma instabilidade político-militar nas relações entre os dois países. Com isso, a possibilidade de guerra entre Brasil e Argentina, no passado uma hipótese previsível, é cada vez mais remota quase impossível. ${ }^{58}$ Trata-se, enfatize-se, de algo inimaginável, há apenas uma década, e que já permite vislumbrar uma política de segurança comum para o bloco regional.

O próprio ALMEIDA destaca, entretanto, que o processo de integração, por si só, não vai resolver todos os dilemas do desenvolvimento. Ele é simplesmente "uma poderosa alavanca e um indutor do aperfeiçoamento das estruturas produtivas no âmbito empresarial, das condições de concorrência em nível macroeconômico e do grau de bem-estar do consumidor final." 59

${ }^{58}$ ALMEIDA, P. R. O Mercosul no contexto global, p. 131.

${ }^{59}$ Idem, p. 116

${ }^{60}$ GENRO, Tarso. O mundo globalizado e o estado necessário, p. 33

${ }^{61}$ Idem, p. 36. Para esse autor, tal processo não é impossível ou utópico, bastando integrar-se politicamente as sociedades, através de diferentes formas de Conselhos, que envolvam inclusive cidades e regiões fronteiriças e com afirmações de suas personalidades culturais.

Revista da Faculdade de Direito da UFRGS, v. 20, Outubro/2001

As reformas trazidas pela globalização econômica, que tanto têm diminuído o tamanho do Estado, deveriam oferecer a compensação de torná-lo mais democrático, como asseverou GENRO, desde que "o mesmo seja controlado por uma sociedade civil exigente, dotada de instituições políticas e meios tecnológicos para tal." ${ }^{60}$ Para o mesmo autor, a integração regional e seus consectários requerem "a emergência de uma nova concepção de cidadania, ou seja, a emergência de uma cidadania transnacional, onde o local, o regional e o nacional integrem-se em diferentes formas de convívio econômico e cultural: para que, assim, a internacionalização da economia seja amparada no reconhecimento das identidades e, ao mesmo tempo, pelo enriquecimento recíproco das culturas participantes." 61

A realidade está indicando que o caminho buscado, o da integração dos povos do Mercosul em um mercado comum, tem-se mostrado exequível, superada, em sua maior parte, livre comércio, e encetada a fase de união aduaneira.

Só o futuro responderá questionamentos que se levantam sobre o bloco regional do Cone Sul, com o que perdurarão os sonhos que povoam as consciências das populações engajadas no processo. Todas as pessoas que aí vivem ou trabalham, como já referido, alme"a constituição de um bloco econômico único, com o surgimento de políticas comuns em setores como a atividade agrícola, industri, de transportes' e de comunicações. E mesmo uma política de proteção ao consumidor e ao 
meio-ambiente, tão necessárias para a fraternal convivência entre os povos." 62

Verifica-se uma salutar preocupação com o social no Mercosul, especialmente na área da legislação trabalhista - o direito laboral, termo muito em voga, pelos autores hispano-americanos -, envolvendo a organização sindical, as relações individuais e coletivas de trabalho, os planos de seguridade social, a previdência social, as negociações coletivas e a livre circulação de trabalhadores. ${ }^{63}$

Como é facilmente compreensível, a abor dagem da circulação de pessoas entre os países do bloco regional do Cone Sul, aí incluído os trabalhadores, tem uma correlação muito próxima com a adoção do espírito comunitário. $O$ obreiro que chega de seu país não se dirigiu um Estado estrangeiro, mas foi de uma parte de um bloco econômico regional a outra, na qual deve encontrar a mesma norma jurídica de seu país de origem.

Os blocos regionais que estão buscando a integração de Estados têm sua gênese no fator econômico e comercial. Seguem, normalmente, um modelo que começa com uma zona de livre comércio e chega à etapa do chamado mercado comum. Exceção feita ao paradigma d União Européia, que pretende atingir a fase completa de União Política.

Não se pode imaginar que o Mercosul tenha limites na sua caminhada de busca da integração de todas as gentes dos países engajados. Exsurge a necessidade de uma adaptação e convergência na lei fundamental de cada um dos Estados componentes do bloco, permitindo que o espírito de comunidade, o sentimento de que sua população é uma só, com objetivos, sonhos e aspirações comuns, passe

${ }^{62}$ DEL'OLMO, F. S. Op. cit., p. 161.

${ }^{63}$ Sobre o tema, é por demais oportuna a leitura da excelente obra de Augusto Jaeger Junior, Mercosul e a livre circulação de pessoas, resultado de bem elaborada dissertação de Mestrado na UFSC, em 1999.

Revista da Faculdade de Direito da UFRGS, v. 20, Outubro/2001 ção de todas as lides jurídicas que provenham de uma norma do Direito interno quando em conflito com a prescrição emanada do legislador comunitário.

Os complexos desafios que se antepõem na caminhada do Mercosul não devem ser vistos como obstáculos intransponíveis, mas como estágios inerentes aos movimentos integracionistas. A longa jornada em que se constituem essas iniciativas comporta etapas que necessitam de muita vontade política dos Estados e engajamento das populações envolvidas no processo. Se esses dois pressupostos se fizerem presentes não se deve duvidar que brasileiros, argentinos, paraguaios e uruguaios - assim como chilenos, bolivianos e venezuelanos, na complementação projetada do Mercosul - gozarão em tempos vindouros da saudável prerrogativa de viver em uma comunidade que será para eles a grande pátria de todos.

\section{Considerações finais}

Vive o Mercosul uma situação de primeira fase de um processo de integração, a zona de livre comércio, quase implementada. O segundo estágio - o da união aduaneira - desenvolve-se em ritmo lento, apesar de já estabelecida a tarifa externa comum entre Brasil, Argentina, Uruguai e Paraguai, preparando-se, de certa forma e em alguns aspectos, as perspectivas para a fase de mercado comum, a rigor o objetivo-título da instituição do bloco.

Na busca da integração do Cone Sul, palco de movimentos de aproximação no passado, quais sejam a Associação Latino-Americana de Livre Comércio (ALALC) e a Associa- a falar mais alto no encaminhamento da solu- ção Latino-Americana de Integração (ALADI), entre outros, o Mercosul palmilha caminho mai entro, reavivando esperanças e criando expectativas favoráveis à integração que se propectativa.

Deve-se lembrar que a ALALC e a ALADI se sucederam no pequeno interregno de duas décadas, sem apresentar resultados palpáveis. E se considere que a primeira delas portava, modestamente, no próprio título designativo, a condição de associação de livre comércio, contentando-se, assim, com a primeicomércio, contentando-se, de qualquer processo de integração.

Resultado de pretensões seculares de próceres sul-americanos, o Mercosul atinge seus primeiros objetivos e busca conquistar seu espaço, aproximar os governantes de países tradicionalmente divergentes e portadores de dificuldades geradas por incompreensões que, em bão se perdendo no tempo, tentando trazer reais benefícios para as populações.

Os desafios de seus problemas e dificuldades são enormes. A superação vem sendo buscada e a cada dia se evidencia mais próxima. Sente-se, no desenho do Mercosul, um clima de obstinado desejo de integração dos povos da América Latina, seguindo o exemplo invocado da União Européia.

Urge passar-se ousadamente do Mercosul real para o Mercosul ideal. O que existe é ainda um simulacro do que sempre pretenderam os empreendedores e seus povos. Não cabe lamentar tempo perdido, oportunidades desperdiçadas, tarefas não cumpridas, etapas relegadas. Há que se criar o espírito mercosulista no seio das massas populares. Formar na população de toda a área a empatia da integração, o anseio de aproximação e de busca da união, sem questionar dificuldades. O mundo está repleto de exemplos de povos que buscaram nas vicissitudes e nas intempéries da História a chama que os unificou na persecução de ideais capazes de torná-los mais cônscios de suas potencialidades, mais ricos, mais felizes e mais orgulhosos de seu destino.

Deve brotar no seio de cada rincão do Mercosul, de fala portuguesa ou espanhola, a cobrança para que os legisladores apressem a adaptação dos textos constitucionais e legais, tornando possível a almejada comunidade mercosulista. Essa não se tornará realidade enquanto um excessivo ranço de soberania estiver arraigado entre as pessoas e entre seus representantes. Um novo paradigma deve ressaltar-se, olvidando o absolutismo da soberania medieval, na qual o Estado se confundia com o monarca.

O presente ensaio propõe o engajamento na busca dessa aproximação legislativa. Considera-se que ela é viável, a par de ser desejável pelas pessoas que vivem e trabalham nos quatro Estados-membros do bloco econômico regional do Cone Sul.

Há que se partir para a sua efetiva implantação. Não há melindres que devam ser evitados, nem ressentimentos ou animosidades que tornem os indivíduos distantes apenas por viver em outro Estado de um mesmo bloco.

Não se deve imaginar que o fim do segundo milênio - fase da História de que se está tendo o privilégio de vivenciar e participar seja apenas o suceder de um ciclo da longa cruzada dos povos pelo mundo, mas um período que pode e deve ser marcado por conquistas grandiosas, a maior das quais, com certeza, seria entendimento e a compreensão entre as pessoas de um bloco, de um megabloco, do mundo globalizado por fim, no sentido de tornar possível o seu sonho mais elevado e acalentado em todas as épocas, a celebração do franco entendimento entre todas as pessoas.

Como se observou no estudo, não se trata de utopia impraticável a convergência nas legislacões sobre a supranacionalidade e a instituição de uma só comunidade nos Estados que formam o bloco econômico regional do ConeSul. 
Impõe-se apenas que cada Estado-membro adapte a sua Constituição, inserindo no supremo texto legislativo a possibilidade de integração do país em um organismo supra-estatal, a exemplo da atual Carta Magna do Paraguai. Como se viu, o caminho se encontra nos próprios textos maiores analisados, nos quais há um vislumbre de aceitação da integração, ainda limitado, mas que necessita ser ampliado com a admissão da plena inserção do país no organismo comunitário, privilegiando as normas supranacionais sobre as de seu direito interno.

\section{Bibliografia}

ALMEIDA, Elizabeth Accioly Pinto de. Mercosul \& União Européia: estruturajurídico-institucional. Curitiba: Juruá, 1996. 160 p

ALMEIDA, Paulo Roberto de. O Mercosul no contex-

to regional e internacional. São Paulo: Aduane ras, 1993. $204 \mathrm{p}$.

TOS O Mercosul no contexto global. In: BASTOS, Celso Ribeiro e FINKELSTEIN, Cláudio (Coordenadores). Mercosul: liçóes do período de transitoriedade. São Paulo: Instituto Brasileiro de Direito Constitucional, 1998. p. 109-135.

reito Constitucional, 1998. p. 109-135.
ARAÚJO, Luis Ivani de Amorim. Direito internacional público. 9. ed. Rio de Janeiro: Forense, 1995. $364 \mathrm{p}$.

BABACE, Héctor. Introducción al estudio de las relaciones laborales en los procesos de integración. Montevidéu: Fundação de Cultura Universitária, 1998. $169 \mathrm{p}$.

BAHIA, Saulo José Casali. A supranacionalidade no Mercosul. In: BASTOS, Celso Ribeiro e FINKELSTEIN, Cláudio (Coordenadores) Mercosul: lições do periodo de transitoriedade. São Paulo: Instituto Brasileiro de Direito Constitucional, 1998. p. 193-208.

BASALDÚA, Ricardo Xavier. Mercosur y derecho de integación. Buenos Aires: Abeledo-Perrot, 1999. $910 \mathrm{p}$.

BERTOLOTTI, Silvina Barón Knoll de. Administración y gobierno del Mercosur. Buenos Aires: Depalma, 1997. $201 \mathrm{p}$.

BORCHARDT, Klaus Dieter. Oabc do direito comunitário. 3. ed. Luxemburgo: Serviço das Publicações Oficiais das Comunidades Europeias, $1991.50 \mathrm{p}$.
CAIROLI MARTINEZ, Milton. El papel de la justicia en el Mercosur. In: Revista da Faculdade de Direito das Faculdades Metropolitaculdade de DiPaulo, a. X. n. 16, jul/dez 1996. p. 217-226. Säo

CAVARZERE, Thelma Thais. Direito internacional pessoa humana: a circulaceito internacional da pessoa humana: a circulação internacional de pessoas. Rio de Janeiro: Renovar, 1995. 275 p.

CHIARELLI, Carlos Alberto Gomes. (Coordenador). Temas de integração com enfoques no Mercosul. v. I. São Paulo: LTr, 1997.

CONSTITUIÇÃO da República Federativa do Brasil. 21. ed. São Paulo: Saraiva, 1999. 267p.

CONSTITUCIÓN de la Nación Argentina. Buenos Aires: Editorial Universidad, 1985. 257p.

CONSTITUCIÓN de la República del Paraguay. Asunción: Fides, 1993. 98 p.

COSTA, José Augusto Fontoura. Multiplicidade jurídica e integração regional. In: PIMENTEL, Luiz Otávio (Organizador). Mercosul no cenário internacional: direito e sociedade. v. I. Curitiba: Juruá 1998. p. 263-270.

COVAS, Antônio. A União Européia. Oeiras: Celta, 1997. $142 \mathrm{p}$.

DELGADO, Maria Isabel Lirola. Libre circulación de personas y Unión Europea. Madrid: Fundación Universidad-Empresa, 1994. $318 \mathrm{p}$.

DEL'OLMO, Florisbal de Souza. Direito internacional privado: abordagens fundamentais, le gislação, jurisprudência. Rio de Janeiro: Forense, 1999. 259 p.

luz do O Mercosul e a nacionalidade: estudo à luz do direito internacional. Rio de Janeiro: Forense, 2001. $226 \mathrm{p}$.

ESTRELLA FARIA, José Ângelo. O Mercosul: princípios, finalidade e alcance do Tratado de Assunção. Brasília: MRE/SGIE/NAT, 1993. 193 p.

RREIRA, Maria Carmen e OLIVEIRA, Julio Ramos. Las relaciones laborales en el Mercosur. Montevidéu: Fundação de Cultura Universitária, 1997. 254 p.

. Mercosur: enfoque laboral. Montevidéu: Fundação de Cultura Universitária, 1994. 123 p. GENRO, Tarso. O mundo globalizado e o estado necessário. In: Revista da Faculdade de Direito de Cruz Alta: Lato Sensu. Cruz Alta: Unicruz, Departamento de Ciências Jurídicas, v. 1, a. 3, dez. 1997. p. 31-40.

GRASS, Gunter. Não amor, mas tolerância. In: Zero Hora: Cultura. Porto Alegre: 24.06 .2000 , p. $4-5$.

ROS ESPIELL, Héctor. Naturaleza jurídica del Tratado de Asunción y de sus protocolos. In: CHIARELLI, Carlos Alberto Gomes (Coordenador). Temas de integração com enfoques Mercosul. v. I. São Paulo: LTr, 1997. p. 240-267.
HUSEK, Carlos Roberto. Elementos de direito intemacional público. São Paulo: Malheiros, 1995. $203 \mathrm{p}$

JAEGER JUNIOR, Augusto. Mercosul e a livre circulação de pessoas. São Paulo: LTr, 2000. $190 \mathrm{p}$.

JUCÁ, Francisco Pedro. Possibilidades de um parlamento latino-americano vinculado ao Mercosul. In: Revista da Faculdade de Direito das Faculdades Metropolitanas Unidas. São Paulo, a. X, n. 16 , jul/dez 1996. p. 39-92.

KEMELMAJER DE CARLUCCI, Aída. Integración y jurisdición. In: Revista da Faculdade de Direito das Faculdades Metropolitanas Unidas. São Paulo, a. X, n. 16, jul/dez 1996. p. 195-202.

KERBER, Gilberto. Mercosul e supranacionalidade um estudo à luz das legislações constitucionais. Florianópolis: Dissertação de Mestrado em Direito UFSC, 2000. 123p.

KLAES, Marianna Izabel Medeiros. Mercosul e tribunal supranacional: um dos pressupostos essenciais à efetiva integração. In: PIMENTEL, Luiz Otávio (Organizador). Mercosul no cenário internacional: direito e sociedade. v. I. Curitiba: Juruá, 1998 p. $359-370$.

LA NUEVA Constitución Nacional. Assunção: Noticias El Diario rpc, 1992. $58 \mathrm{p}$

LOBO, Maria Teresa Cárcomo. Ordenamento jurídico comunitário. Belo Horizonte: Del Rey, 1997. 358 p.

LORENTZ, Adriane Cláudia Melo. Supranacionalidade no Mercosul. Curitiba: Juruá, 2001. 126 p.

LOURO FIGUERAS, José Geraldo. Constitución de la República Oriental del Uruguay. Montevidéu: Comunidad del Sur, 1967.221 p.

MATHIEU, Jean-Luc. L'Union Européenne. 2. ed. Paris: Presses Universitaires de France, 1996. 128 p.

MIDÓN, Mario A. R. Derecho de la integración. Bueno Aires: Rubinzal-Culzoni, $1998.463 \mathrm{p}$

OLIVAR JIMÉNEZ, Martha Lucía. La compreensión del concepto de derecho comunitario para una in da Faculdade de Direito das Faculdades Metropolitanas Unidas. São Paulo, a. X, n. 16, jul/dez politanas Unidas.

OLIVEIRA, Odete Maria de. A integração bilatera Brasil-Argentina: tecnologia nuclear e Mercosul. In: Revista Brasileira de Política Internacional. Brasília, v. 41, n. 1, 1998. p. 5-23.

.Integração nuclear Brasil-Argentina: uma estratégia compartilhada. Florianópolis: UFSC 1996.

Relações internacionais: breves apontamento e contextualização. In OLIVEIRA, Odete Maria de. (Coordenadora). Relações internacionais a globalização. Ijuí: Editora Unijuí, 1998. p. 15-65.
União Européia: processos de integração e mutação. Curitiba: Juruá, $1999.486 \mathrm{p}$

PABST, Haroldo. Mercosul: direito da integração. Rio de Janeiro: Forense, 1998. 278 p.

APPALARDOZALDÍVAR, Conrado. (Recopilación). Paraguay: itinerário constitucional. 6. ed. Assunção: Intercontinental, $1997.317 \mathrm{p}$.

PELLEGRINI, Miguel A. Ortiz Pellegrini e al. (Organizadores). Constitución de la Nación-República Argentina. Cordoba: Marcos Erner, 1994. $185 \mathrm{p}$.

PÉREZ PÉREZ, Alberto. Constitución de 1967 de la República Oriental del Uruguay Actualizada (1997). 3. ed. Montevidéu: Fundação de Cultura Universitária, 1998. 180p.

- Constitución de 1967 de la República Oriental del Uruguay concordada y anotada. v. I. 2 . ed. Montevidéu: Fundação de Cultura Universitária, 1994. $463 \mathrm{p}$.

PIMENTEL, Luiz Otávio (Organizador). Mercosul no cenário internacional: direito e sociedade. v. I. Curitiba: Juruá, 1998. 527 p.

RAMELlA, Pablo A. Nacionalidad y ciudadanía. Buenos Aires: Depalma, 1978. 117p.

RECKZIEGEL, Ana Luiza Gobbi Setti. O pacto ABC: as relações Brasil-Argentina na década de 50. Passo Fundo: Ediupf, 1996. 181 p.

REY PAZ, Vânia Beatriz. Mercosul: legislações sindicais (im)possibilidade de harmonização. Curitiba: Juruá, 1999.

ROQUE, Sebastião José. Direito internacional público. São Paulo: Hemus, 1997. 272p.

ROVAN, Joseph. Como tornar-se cidadão da Europa: primeiro os deveres, depois os direitos. Trad. J. Freitas e Silva. Lisboa: Publicações Dom Quixote, 1993. $217 \mathrm{p}$.

RULLI JUNIOR, Antonio. MERCOSUL: o direito comunitário e a garantia de investimentos e cidadania In: Revista da culdades Metropolitanas Unidas. São Paulo, a. XII, n. 20 , 1998. p. $60-78$.

SABSAY, Daniel Alberto e ONAINDIA, José Miguel. La constitución de los argentinos. 4.ed. Buenos Aires: Errepar, 1998. 445 p.

SANTOS, Ricardo Soares Stersi. Mercosul e arbitragem internacional comercial: aspectos relevantes e algumas possibilidades. Belo Horizonte: Del Rey, 1998

SARMIENTO GARCÍA, Jorge H. e FARRANDO, Ismael. "rocesos de integración y Mercosur. Buenos Aires: Depalma, 1993. 120 p.

SEITENFUS, Ricardo. Manual das organizações internacionais. Porto Alegre: Livraria do Advogado, $1997.352 \mathrm{p}$ 
SILVA, Hector R. La comunidad internacional. Buenos Aires: Depalma, 1984. $189 \mathrm{p}$

SILVA ALONSO, Ramón. Derecho internacional privado. 5. ed. Assunção: Intercontinental, 1999. 518 p.

SILVA, Roberto Luiz. Direito comunitário e da integração. Porto Alegre: Síntese, 1999. $192 \mathrm{p}$.

SOARES, Esther Bueno. Mercosul: desenvolvime to histórico. São Paulo: Oliveira Mendes, 1997. $137 \mathrm{p}$.

SOARES, Orlando. Comentários à Constituição da República Federativa do Brasil. 9. ed. Rio de Janeiro: Forense, 1998. $896 \mathrm{p}$

ODER, José. A União Européia São Leopoldo: Unisinos, $1995.183 \mathrm{p}$.

STELZER, Joana. Integração européia: dimensão supranacional. Florianópolis: Dissertação de Mestrado em Direito UFSC, 1998. 212

RATADO de Amsterdam. Luxemburgo: Serviço das Publicações Oficiais da Comunidades Europeias, 1997. $144 \mathrm{p}$

URIARTE, Oscar Ermida. Mercosur y derecho laboral. Montevidéu: Fundação de Cultura Universitária, 1996. $89 \mathrm{p}$

VALLEEE, Charles. O direito das comunidades européias. Trad. Eduardo Saló. Lisboa: Editorial Nottcias, $1983.119 \mathrm{p}$.
VERSÃO compilada do tratado da União Européia Luxemburgo: Serviço das Publicações Oficiais da Com

de inANTos, Antônio Carlos. Mercosul: espaço de integração e jurisdição, soberania e jurisdiçãa supranacional. In. Revista da Faculdade de Dire to das Faculdades Metropolitanas Unidas. São Paulo, a. X, n. 17, jul/dez 1996. p. 19-32.

Mecos Tribunal de justiça supranacional do Mercosul. In: Revista da Faculdade de Direito das Faculdades Metropolitanas Unidas. São Paulo, a. X, n. 16, jul/dez 1996. p. 23-37.

IGNALI, Heber Arbuet. Soberanía e integración. In: CHIARELLI, Carlos Alberto Gomes (Coordenador). Temas de integração com enfoques no Mercosul. v. I. São Paulo: LTr, 1997, p. 84-104.

WOLKMER, Antônio Carlos. Integração e direito comunitário latino-americano. In: PIMENTEL, Luiz Otávio (Organizador). Mercosul no cenário internacional: direito e sociedade. v. I. Curitiba: Juruá, 1998. p. 43-54.

ZAVALÍA, Ricardo de. Constitución de la Nación Argentina. Buenos Aires: Zavalía S. A., 1998. 519 p.

\title{
Construcción social del derecho: aproximaciones al debate del siglo XXI
}

\author{
Graciela Lovece
}

\section{Introducción}

(ר) ada estructura social tiene caracterísiticas distintivas, cada una de ellas posee una realidad; y esta realidad; es construída socialmente.

El afuera de cualquier observador, in vestigador, legislador juez es objetivo respecto de ese sujeto como individuo atomizado, pero no como ser humano ya que lo objetivo no existe como tal; pues la supuesta realidad es Construída por otros. y cada sociedad adopt una realidad diferenciada. ${ }^{1}$

Las claves son entonces realidad y su conocimiento; pudiendo definirse la realidad como una cualidad propia de los fenómenos que reconocemos como independientes de nuestra volición y los que no podemos impedir que existan.

Por otro lado el conocimiento es la certidumbre de que estos fenómenos son reales y que poseen características específicas y que pueden ser aprehendidos. ${ }^{2}$

Asi por ejemplo un hombre común de la calle cree que posee libre albedrío y que en virtud de esa libertad es responsable de sus actos, ahora bien también conoce que los menores no gozan de esa libertad reconociendo para estos una realidad diferente.

Este mismo fenómeno de la realidad si es analizado por un filósofo se preguntará que es la libertad? Que es la responsabilidad? Cuales son sus límites? etc.

Un sociólogo en cambio indagará por qué la noción de libertad ha llegado a darse por establecida en algunas sociedades y en otras no?; cömo alguna de estas sociedades conservan esta realidad? y lo que resulta más interesante aún es saber como esa realidad puede desaparecer para un individuo o para una colectividad entera. $?^{3}$

Esa construcción de la realidad resulta de la existencia de formas organizativas y/o institucionales diversas vrg. empresas,

${ }^{1}$ Bordieu, Pierre: "Los usos sociales de la Ciencia” pág. 109. Ed INRA Bs. As 2000

2 Berger. Peter, Luckmann, Thomas: “La Construcción Social de la Realidad” pág. 13 Ed Amorrortu Avellaneda 1999.

${ }^{3}$ Berger, Peter; Luckmana, Thomas: "La Construcción Social de la Realidad” pág 14 Ed Amorrortu Avellaneda 1999. 
legislatura, partidos políticos, organismos internacionales, magisrados, etc., que ante intereses contrapuestos en un ámbito de disputa ideológica van encontrando soluciones diferentes

El interés científico estará entonces centrado en el hecho de que la realidad y e conocimiento poseeen relatividad social la realidad que percirbe un individuo africano no es la misma que la de un hombre de Buenos Aires se desprende entonces que las acumulaciones particulares (formales y no formales) de realidad y conocimiento pertenecen a contextos sociales específicos. ${ }^{4}$

Dentro de este análisis podemos establecer que en la sociedad humana existen variaciones empíricas de conocimiento y procesos por los cuales cualquier cuerpo de conocimiento llega a quedar establecido socialmente como realidad.

El derecho por ej como cuerpo de conocimiento, determina una realidad social específica a partir del cual se construye un modelo social, si bien no es el único elemento determinante; pues existen otros como la economía etc.debe tenerse presente que es el fundante pues toda la estructura social tanto institucional como individual se desarrolla a partir de él.

\section{La Constitución Nacional y los Derechos Individuales y Sociales}

El derecho es el producto de una disputa de intereses contrapuestos; y cualquie norma que se dicte habrá de favorecer alguno

${ }^{4}$ García, Pablo Sebastián: "Intenionalidad Causalidad y Conocimiento Perceptivo. Tres estudios sobre filosofía de la percepción en el pensamiento contemporáneo." Pág 14"Como ya señalamos cuando nos ocupamos del tema de la pecepción, vemos la pecepción, vemos que es a través d ella que tomamos onciencia del mundo que nos rodea. Así si bien mis campos perceptivos son limitados, su mutua complementación en el espacio y $\mathrm{n}$ el tiempo me permite onstruir un conocimiento del mundo considerablemente extenso y detallado. "Ed. Oficina del Libro Internacional Bs. As. 1996.

Revista da Faculdade de Direito da UFRGS, v. 20, Outubro/2001

Crea también una dicotomía al aumen-

hecho el art. $17^{5}$ protege a ultranza la propiedad privada, derecho que posteriormente se encuentra enfatizado en el art. $2513^{6}$ del Código Civil.(dominio absoluto)

Al producirse el acceso al gobierno de un proyecto popular de redistribución como es el caso de Hirigoyen primero y Perón posteriormente se modifica la Constitución Nacional en el año 1949 dando comienzo a una etapa en 1 que se construye un derecho diferente con mayor contenido social; que posteriormente con el auge del constitucionalismo socia produce la modificadión de la Carta Magna en el año 1957 con la inclusión del art. 14 bis ${ }^{7}$.

Finalmente la reforma constitucional del año 1994 construye un nuevo modelo social de Sociedad de Consumo y ambientalistà y marca las pautas para la construcción de un nuevo derecho. tar la protección del ser humano en todos sus aspectos (consumidor, habeas data etc.) dando muestra de un hábil manejo del doble discurso posmoderno pues la reañidad nos muestra la prevalencia del mercado.

\section{La Distribución del Poder y la adjudicación de Roles}

La Cosntitución Nacional ha dispuesto un esquema básico de división de poderes con la finalidad de lograr un equilibrio y de esta forma compensar el ejercicio de roles diferenciados.

Estableciendo un rol y funciones básicas e indelegables a cada uno de los tres poderes, la no intromisión, su autonomía funciona

${ }^{5}$ Constitución Nacional art. 17." La propiedad es inviolable, y ningún habitante de la Nación puede ser privado de ella, sino en virtud de sentencia fundada en ley. La expropiación por causa de utilidad pública debe ser calificada por ley y previamente indemnizada. Solo el Congreso impone las contribuciones que se expresan en el art. 4. Ningún servicio personal es exigible, sino en virtud de ley o de sentencia fundada en ley.odo autor o inventor es propietari exclusivo de su obra, invento o descubrimiento, por el término que le acuerde la ley. La confiscación de biens queda borrada para siempre del Códgo Penal Argentino. Ningún cuerpo armado pueda hacer requisaciones ni exiir auxilios de ninguna especie."

6 Art. 2513(Derogado por Ley 17.711) "Es inherente a la propiedad, el derecho de poseer la cosa, de disponer 0 de servirse de ella, de usarla y gozarla según la voluntad del propietario. El puede desnaturalizarla, degradarla 0 destruirla; tiene el derecho de accesión, de reivindicación, de cosntituir sobre ella derechos reales, de percibir todos sus frutos, prohibir que otro se sirva de ella, o perciba sus frutos y de disponer de ella por actos entre vivos."

H 14 bis $\mathrm{CN}$ : $\mathrm{El}$ tabajo en sus disersas formas gozará de la protección de las leyes, las que asegurarán trabajador condicones dignas y equitativas de labor, jornada limitada, descanso y vaciones pagados, retribución justa; salario mínimo vital móil; igual remuneración por igual tarea, participación de las ganacias en las empresas, con control de la producción y colaboraión en la dirección; protección contra el despido arbitrario; estabilidad de empleo público, organización sindical libre y democrática, reconocida por la simple inscripción en el registro especial.

Quecia arbitraje, el derecho de huelga. Los representantes gremiales gozarán de las garantías necesarias para el cumplimiento de su gestión sindical y las relacionadas con la estabilidad de su empleo.

El Estado otorgará los beneficios de la seguridad social, que tendrá carácter de integral e irrenunciable. En especia la ley establecerá; el seguro social obligatorio, que estrá a cargo de entidades nacionales o provinciales con autonomía financiera y económica administrada poor los interesados con participación del Estado , sin que pueda existir superposición de aportes, jubilaciones y pensiones móviles, la protección integral de la familia, la defensa

del bien de familia, la compensación económica familiar y el acceso a una vivineda digna."

Revista da Faculdade de Direito da UFRGS, v. 20, Outubro/2001 
etc, construyéndose a partir de ella un sistema institucional al cual legitimtima y le otorg validez garantizando de este modo su gobernabilidad (como sistema).

La división de poderes resulta entonces la base fundamental para la reproducción del sitstema institucional marcando un nivel horizontal de integración

Esta construcción de la sociedad a partir de la Constitución Nacional resulta una decisión política de la cual por ejemplo el Poder Judicial se encontró ajeno en tanto su conformación se efectúa con posterioridad a su sanción.

Y si bien no establece su independencia en forma expresa; est independencia surge implícitamente al regularlo como un poder con un rol específico: el control constitucional.

Ahora bien a que independencia nos estamos refiriendo?

Pareciera ser que la idea es deslindar al Poder Judicial de los vaivenes políticos y económicos a los cuales se enuentran sometidos tanto el Poder Ejecutivo como el Poder Legislativo de hecho no solo rermarca claramente su autonomía funcional y financiera , sino que fundamentalmente se predica que los jueces y funcionarios no deben participar en organizaciones o actividades políticas como $\mathrm{s}$ se tratara de entes a-históricos y a-ideológicos y no de personas con una conflictiva particular y un contexto socio-histórico específico.

Si bien es cierto que el efecto simbólico del lenguaje jurídico utilizado pareciera da una imagen de independencia en la realidad esta se encuentra limitada por diferentes razones:

En primer término ¿quienes nombran los jueces? Es evidente que el poder político y la creación a nivel nacional del Consejo de la Magistratura no ha logrado en principio destrabar esta situación en la que los partidos mayoritarios intercambian postulantes.
El hecho de incorporar un concurso de antecedentes y oposición no resultó hasta el momento óbice para colocar en el cargos a quienes resulten más conveniente a los intereses políticos partidarios.

El deterioro a que se encuentra sometido la prestación del servicio de justicia tiene básicamente relación con la falta de presupuesto que es determinado no por las necesidades del PoderJudicial como reza la Constitución Nacional sino por la capacidad presupuestaria cada vez más limitada por el Poder Legislativo a instancia de lo dispuesto por el Poder Ejecutivo y los Organismos Internacionales le asigna, volviendo a interferir el Poder Político sobre el Poder Judicial.

Puede hablarse de una independencia de la justicia federal? La que resultó en la última década, un caso paradigmático de implicancia política con nombramiento de jueces inidóneos y por tanto facilmente manipulables? En muchos casos con una foja de servicios impresentable y con un cuantioso patrimonio desarrollado a partir de su nombramiento.

Si en la Constitución Nacional se establece como requisito para ser miembro del máximo tribunal no solo tener capacidad o aptitud técnica sino también capacidad económica exactamente igual que para ser senador y esto no fue modificado en ninguna de las sucesivas reformas; uno podría preguntarse si tal requisito no plantea una suerte de discriminación o que en realidad lo que se busca es la protección jurídica de los intereses de un determinado estrato social al cual estos pertenecen.

Los acontecimientos que se produjeron en los últimos tiempos en el país han demostrado que tal división de poder en la práctica real no existe el sistema establecido por la Constitución Naional ha sido disfuncional atentanto contra las bases mismas del sistema democrático y republicano.
El Poder Legislativo por dos veces intentó a través del Proyecto de Unificación Civil y Comercial del año 1987 y de la Ley de Defensa del Consumidor imponer una legislación más progresista en lo referente a la responsabilidad civil, regulando la responsabilidad objetiva y solidaria de toda la cadena de producción, distribución y comercialización de bienes y servicios; y en las dos oportunidades el Poder Ejecutivo los vetó actuando como colegislador al igual que con los decretos de necesidad y urgencia permitiendo esta falta de equilbrio instituciona que el poder económico imponga su criterio. ${ }^{8}$

Así por ejemplo el Poder Judicial sorprendió a la comunidad jurídica con dos fallos de trascendencia Pepsi-Cola y Duna y en este último se remarca la necesidad de pertenencia del damnificado a un estrato social alto para pòder gozar del derecho a la seguridad.

A partir de estos ejemplos podemos en principio establecer que la construcción del derecho no solo es practicada por el Poder derecho no solo es practicada por el Poder que es el ámbito en el que se dearrollar la discusión política.

Sino que también interviene en su construcción el Poder Ejecutivo cuando excede el rol constitucionalmente asignado de reglamentar las normas y lo hace mediante la forma de veto impropio o de decreto de necesidad y urgencia, etc.
Finalmente también el Poder Judicial a través de la interpretación de intereses y aplicación que realiza de las normas en el caso concreto pudiendo en algunos casos modificar su finalidad teleológica construyendo una norma especial, conforme a una ideología coyuntural

\section{La interacción del Sistema y sus Estructuras}

El sistema social se encuentra integrado por distintas estructuras, que constituyen en sí mismas subsistemas, así el subsistema jurídico, el económico, el político etc y el comportamiento de cada uno de ellos depende de cómo se relacionan sus estructuras internas y de cómo se relacionan con las estructuras de los otros subsistemas.

El sistema jurídico puede construírse de dos formas:

a) como un sistema autopoiético cerrado sin permitir que el entorno lo consustancie en una forma piramidal teniendocomo principiofundamental como sostiene Kelsen la eliminación de todos los elementos que le son extraños ${ }^{9}$ al estilo del derecho construído en la alemania nazi, el comunista, o el liberal de Velez Sarsfield, (arts. $1137^{10} .1197^{11}$ en los que pone en una situación de igualdad abstracta a los sujetos contratantes) $)^{12}$

${ }^{8}$ Ghersi, Carlos y otros:’Teoría General de la Reparación de Daños" 2 ${ }^{\circ}$ Edición pág 45 Ed Astrea Bs. As. 1999.

"Ghersi, Cartos y omo teoría "pura" indica que 9 Kelsen Hans: "Teoría Pura del Derecho" $9^{\circ}$ edición pág. 15 "Al calficar entiende construir una ciencia que tenga por único objeto al derecho e ignora todo lo que no responda estrictamente a su definición" Ed. EUDEBA Bs. As. 1970

${ }^{10}$ Art 1137 Código Civil "Hay contrato cuando varias personas se ponen de acuerdo sobre una declaración de voluntad común destinada a reglar sus derechos"

${ }^{11}$ Art. 1197 del Código Civil: "Las convenciones hechas en los contratos forman para las partes una regla a la cual deben sometrse como a la ley misma."

${ }^{12}$ Guerra Filho Willisis. "Autopoiese do Direito no Sociedade Pos-Moderna Introducao a uma Teoría Social Sistèmica" pág 57 Ed Do Avogado Porto Alegre 1997.

Revista da Faculdade de Direito da UFRGS, v. 20, Outubro/2001 
b) como un sistema abierto de normas jurídicas que se construyen recibiendo las influencias del entorno que conforman una normación contextuada esto en base a la existencia de principios generales tal es el caso de Borda en la Reforma de 1968 (buena fe, equidad, abuso del derecho)

El derecho según la tradicional dogmática jurídica es un sistema de normas más o menos homogéneo debiendo carecer de contradicciones ${ }^{13}$ para lo cual la interpretación que se haga de cada una de las estructuras que lo componen debe básicamente derivarse de la premisa. (kibertad e igualdad).

De lo contrario, se sostiene, se transforma en un sistema inconsistente frente a la existencia de dos normas que pueden demostrar su validez dentro del mismo (igualdad y libertad frente a la presunción del ignorante del desconocimiento del derecho)

Sin embargo, la teoría del derecho contamporáneo se caracteriza fundamentalmente por el cuestionamiento de estas premisas en tanto la pregunta si el sistema jurídico es internametne coherente o incoherente apuntando a la existencia o inexistencia de lagunas jurídicas, o contradicciones, o indeterminaciones, etc.

\section{Las Sentencias como producto ideológico y su valor social}

El segundo gran interrogante se refiere

a la aplicación de las normas particularmente a través de las desiciones judiciales; si la interpretación de las normas para el caso concreto tiene un carácter "objetivo" esto es una aplicación técnica y neutra por lo cual el juez es solo un apéndice funcional del sistema jurídico?

O si por el contrario; su interpretación se encuentra teñida de "subjetividad "y de ser así cual es el punto de intersección entre el prejuicio inherente al hombre, lo jurídico y lo político dado que el tradicional límite o contrabalanceo entre los Poderes del Estado es diferenciando roles?

Quienes se enrolan en una postura constructivista objetivista y de coherencia del sistema jurídico tienden a sostener la neutralidad de los jueces en la aplicación de las normas, apoyados en una abstracción en la cual el sistema permanece cerrado ( autopoiético) a cualquier interferencia proveniente del entorno social. (dogmática jurídica) ${ }^{14}$

Por el contrario cuando se entiende al sistema jurídico como un sistema abierto, compuesto de normas en constante tensión spues protejen intereses antagónicos, la función del juez lejos de ser neutra tiende a una interpretación favorable a aquella postura que considera más justa según su propia escala valorativa y su propio sistema de referencia ${ }^{15}$ o bien por que comparte ideológicamente la normación establecida por el poder político y asume el rol de coherencia ideológica (con todo lo que ello significa)

\footnotetext{
${ }^{13}$ Caracciolo, Ricardo: "La Noción de Sistema en la Teoría del Derecho" pág. 11Ed. Fontamara México 1994. ${ }^{14}$ Teran Oscar: "Positivismo y Nación en la Argentina" pág 11 Ed Puntosur Bs. As. 1987.

${ }^{15}$ Weber, Max: "Sobre la Teoría de las Ciencias Sociales" pág. 36 "No existe ningún análisis científico "objetivo" de la vida cultural o bien de los "fenómenos sociales" que fuese independiente de unas perspectivas especíales y "parciales" que de forma expresa o tácita consiente o inconsiente, las eligiese, analizase y articulase plásticamente. La razón se debe al carácter particular del fin del conocimiento de todo trabajo de las ciencias sociales que quiera más allá de un estudio formal de las normas -legales o convencionales- de la convivencia social." Ed Planeta Bs. As. 1993.
}

Revista da Faculdade de Direito da UFRGS, v. 20, Outubro/2001
Cual de estas posturas defiende la Constitución Nacional como rol del Poder Judicial? ¿la que aplica la ley corroborando la defensa de los derechos que subjetivamente considera justos constitucionalmente? o ¿la de cumplimiento de la Constitución sin indagar sobre la justicia de la norma porque asume que el Poder Político es quien ya analizó la coherencia constitucional? ${ }^{16}$

El adoptar cualquiera de las dos posturas implica adoptar una posición ideológica y asumir la construcción de un derecho diferente.

Siguiendo esta línea de razonamiento, las decisiones judiciales entonces no son únicamente la aplicación lisa y llana de la norma vigente para un caso concreto, sino por el contraro son el resultado de la interpretación y preferencia del juez en una sociedad y en un momento histórico determinado.

En toda sentencia entonces no hay neutralidad valorativa como sostenía el positivismo jurídico que era racional, científico e independiente, sino como sostienen en cambio las escuelas socioeconómicas y jurídicas alemanas Lhumann ${ }^{17}$ o Habermas ${ }^{18}$ y las americanas Robertson o Duncan Kennedy; que el proceso de producción de la sentencia es de contenido ideológico y estas pueden ser dictadas desde la ética individual de cada juez, y social a partir de distrbuir moral como valor social.

Insistir entonces con una clara diferenciación entre la construcción del derecho que es una tarea legislativa y su aplicación que

${ }^{16}$ Bobbio, Norberto, Bovero, Michelangelo. "Origen y Fundamento del Poder Político" Ed Grijalbo ${ }^{17}$ Consult. Luhmann, Niklas; "Hacia una Teoría Científica de la Sociedad." Ed. Anthropos Barcelona 1997.

${ }^{18}$ Consult. Habermas, Jurgen : “Más allá del Estado Nacional” Ed Trotta Valladolid 1997.

${ }^{19}$ Consult. Arrighi, Giovanni y otros :New Left Review No 10 "Pensamiento crítico contra la dominación" Ed Axal Madrid 2000. es una función privativa del juez; pareciera anánica, pues inciden en ambas instancias argumentos de conveniencia, ideológicos, políticos, económicos, la presión de la opinión pública incentivada por los medios masivos de difusión no carentes de intereses etc.

Existiendo por tanto una delicada línea de distinción entre lo político y lo jurídico en tanto el derecho y su aplicación son esencialmente la reproducción de las tensiones de la dinámica social y todas se estructuran ideológicamente

El Magistrado al resolver va enconrando soluciones abriendo el espacio en el ámbito jurídico para la construcción del derecho

Esta construción puede ser desde lo individual, por ejemplo desde la ética, que como pauta subjetiva va construyendo derechos, as una sentencia puede ser ética pero a pesar de

En cambio la costrucción social de derecho nace a partir de la procupación por el otro tiene que ver entonces con la moral que implica un valor que el conjunto de la sociedad reconoce para ella en un momento histórico determinado por el valor justicia. ${ }^{19}$

Pero la justicia es un molde que puede adaptarse a distintas concepciones, lo justo para un liberal no es lo mismo que para un marxista

Desde la construcción social del derecho la justicia significa acercar las asimetrías reales empresas-consumidores, incluídos -excluídos es decir construir a partir de cada senello puede ser antisocial 
tencia un orden más justo para el caso concreto y en lo general tratar de provocar la reacción de los otros para el futuro como ejercicio anticipatorio entonces la sentencia tiene un doble valor como justicia para el caso específico y como construcción social del derecho para el resto de la comunidad. (los modelos proyectados)

\section{El derecho y la escuela episte- mológica como herramienta de la construcción social del derecho}

La adopción de una estructura jurídica basada en el sistema francés a través de la sanción de un Código Civil inspirado en el Código de Napoleón con una tradición formalista en el cual prevalece una interpretación exegética de la norma y en la insistencia de una aplicación apolítica por parte de los jueces. Es real o un mera ficción que sirve como cortina de humo para la consolidación del poder político o económico o el que sea?

Se manejará acaso igual que en la Revolución Francesa el doble discurso "la revolución fue la liberación del pueblo o simplemente la consolidación de los derechos de la burguesía "?

Acaso el Juez es la verdadera voz del pueblo y defensor a ultranza de sus derechos o solo forma parte el doble discurso que consolida el poder de turno?

$\mathrm{Si}$ en los Códigos existe una prevalencia en la protección de la propiedad privada a ultranza (art. 2513 en su versión original) la aplicación lisa y llana de la norma contribuye a la reproducción de las desigualdades sociales en el caso concreto delineando el marco ideológico imperante?

El estudio del derecho enmarcado en una concepción formalista mediante el estudio exclusivo de las normas positivas sin efectuar un análisis contextuado de cada una de ellas contribuye a la idea de abstracción del derecho de la realidad social?

Pues pensemos que de practicarse un análisis histórico y socieconómico de las normas (epistemológico) la jursiprudencia puede demostrar que los grupos de interés, las clases sociales altas y las instituciones económicas arraigadas en forma contínua se han visto favorecidas? Y decretar su inconstitucionalidad real?

Finalmente desde siempre ha existido un impedimento para el cuestionamiento de las normas y de su aplicación que puede entenderse basado en la confianza en la racionalidad interna del sistema jurídico; en la carencia de un proyecto social alternativo que elimine las desigualdades, o bien en la necesidad del mantenimiento del status quo imperante.convenciendo a la sociedad de que el sistema jurídico y social es inevitable y esencial y que lo justo.solo lo es en la medida de lo posible ${ }^{20}$

Así por ejemplo el Derecho Privado puede ser cosntruído desde dos ópticas

a) desde el individualismo y el liberalismo a ultranza sustentado por Velez en donde la autonomía de la voluntad es el principio fundamental

b) desde una óptica con criterio social que en nuestro caso se encuentra reflejado en la Reforma Borda defendiendo obligaciones jurídicas con fundamento en la solidaridad social en el cual por ejemplo se limita el

${ }^{20}$ Alburquenque, Mario: “O Orgao Jurisdicional E A Sua Funçao estudio sobre Ideología, Aspectos Críticos e o Controle do Poder Judiciario" pág. 110 Ed. Malheiros Sao Paulo 1997.

Revista da Faculdade de Direito da UFRGS, v. 20, Outubro/2001

derecho de dominio (art. 2513 reformado) ${ }^{21}$

Existe un cambio cambio ideológico? No fue acaso el resultado la postura ideológica de la jurisprudencia de la década de 1950 y 1960 en la Argentina?

Si uno analiza la jurisprudencia esencialmente de la Cámara Civil Nacional y de la Cámara de la Provincia de Buenos Aires ambas de gran influencia en la reforma legislativa; se ve con claridad que "construyeron la reforma social" del nuevo art. 2513 del Código Civil pero ello ocurrió porque se dio lugar a las distintintas interpretaciones y formulaciones del derecho de propiedad y esto resultaba importante para los cambios sociales que se habían producido entre las décadas de 1930 y 1950 y los que le siguieron entre 1950 y 1960.

Es importante la ubicación social del pensamiento del juez que no puede abstraerse de su propia naturaleza ni de la influencia de grupo de pertenencia como sostiene Merton. Nadie puede colocarse en el lugar de aquel que corta una ruta cuando tiene trabajo y un estandart de vida asegurado

En síntesis bajo el manto de la coherencia del derecho y del carácte aideológico de la judicatura; se legitima el funcionamiento de un sistema que tiende a favorecer los intereses de los grupos que cuentan con mayor información sobre las normas y con mayor poder económico para defender sus intereses ya que se enarbola la retórica de la igualdad jurídica cuando existe una desigualdad real entre los individuos y los grupos sociales.?22
Frente a estas desigualdades reales el derecho. debe satisfacer dos líneas fundamentales uno garantizar la libertad del individuo y dentro del sistema económico receptado por la Constitución Nacional el resguardo del ejercicio de esa libertad sobre los bienes que son de su propiedad; pero al mismo tiempo debe establecer reglas precisas para el intercambio representados fundamentalemente en normas que regulen la formación y ejecución de los contratos y sobre la base de la desigualdad real, para lo cual el Magistrado debe colocarse del lado débil para reequilibrar haciendo uso por ejemplo de los Principios Generales del Derecho de los arts. 954; 1071 o 1198 del Código.Civil. o los Principios Generales establecidos en la Ley de Defensa del Consumidor art. 4 información , 5 seguridad art. 37 cláusulas abusivas etc. 23

En el campo de la responsabilidad civil la lógica individualista inspira la institución de la responsabilidad subjetiva debiendo responder únicamente quien ocaciona un daño con culpa o dolo centrándose en la conducta de agente dañador independientemente del daño ocasionado a la víctima. Recepta una de las nociones más caras del individualismo

Frente a esta lógica individualista surgen nociones que enfatizan el valor de la solidariad en las relaciones sociales permitinedo que el derecho cumpla con su función de cohesión social estableciendo deberes recíprocos entre los individuos protegiendo a la parte más débil de la sociedad. La responsabilidad objetiva es un ejemplo en la cual el que causa un daño debe responder independientemente de su conducta (riesgo empresario)

${ }^{21}$ Art. 2513 ley 17.711: "Es inherente a la propiedad el dereho de poseer la cosa, disponer o servirse de ella usarla y gozarla conforme a un ejercicio regular."

${ }^{22}$ Consult. Lautmann Rüdger:: "Sociología y Jurisprudencia" $2^{\circ}$ Edición ed Fontamara México 1993.

${ }^{23}$ Wiearker, Franz: "El Principio General de la Buena Fe" pág. 28/29 Ed. Civitas S.A. Madrid 1986 
VII. Conslusión: La trascendencia social del Magistrado y su sentencia

La formación ideológica del juez incide en la desición judicial?

Duncan Kennedy Profesor de Jurisprudencia de la Escuela de Derecho de la Universidad de Harvard sostiene:que lo político en las sentencias surge a través de la ideología en la aplicación judicial del derecho.

Si la ideología ${ }^{24}$ es un discurso elaborado en defensa de determinados sectores sociales a los que se pretende representar, la estrategia es articular el discurso en términos universales de manera de ocultar el vínculo con el grupo repersentado.

Sin embargo el discurso judiicial se cubre bajo la abstracción de la estricta aplicación de la norma. y la ideología política surge a través de la permanente argumentación respecto de la conveniencia pública en los fallos judiciales.

Los jueces son un símbolo social de imparcialidad y de autoridad creando con sus decisiones la convicción pública de que esa posición es la correcta dirimiendo una confrontación ideológica en un caso concreto y generando pautas de conducta a futuro. ${ }^{25}$

La desiiones judiciales tienen un efecto social determinante pero estas esconden bajo la semántica de un discurso neutral y de estricta aplicación de la norma las reales motivaciones del fallo, que solo pueden desentrañarse si se realiza una lectura por debajo de la superficie como dijera Foucoult.

\footnotetext{
${ }^{24}$ Eagleton, Terry. "Ideología” pág. 19 Ed. Paidós barcelona 1997.
}

${ }^{25}$ Kennedy, Duncan: "Libertad y Restricción en la Decisión Judicial" pág. 68 Ed. Siglo del Hombre Editores. Bogotá 1999.

${ }^{26}$ Kennedy, Duncan: "Libertad y Restricción en la Decisión Judicial” pág. 63 Ed. Siglo del Hombre Editores. Bogotá 199.

Revista da Faculdade de Direito da UFRGS, v. 20, Outubro/2001
Entonces incluso aquel Magistrado que se empeña en guardar la retórica de la neutralidad en tanto desarrolla una solución y luego la justifica jurídicamente a través de la utilización de argumentos no deductivos invirtiendo el modelo silogístico está actuando movilizado por su propia ideología? ${ }^{26}$

Si toda desición judicial es permeable las motivaciones ideológicas porque razón se sigue manteniendo la ficción de la neutralidad judicial cuando vemos a diario el contenido socio-económico y cultural de las sentencias?

Una respuesta puede ser que tanto la comuidad jurídica como la sociedad en general quiere conservar la imagen del juez neutral, en tanto esta es el símbolo social por exelencia de la imparcialidad.

Se intenta preservar una instancia sim bólica siendo la imagen paradigmática de la coherencia que compense las incoherencia existentes en la realidad social.

La retórica de la neutralidad se mantine porque la sociedad necesita creer que es cierta.

Sin embargo llegar a una verdadera justicia y a una real democracia requiere por parte de los Magistrados un debate interno y objetivo en la desición judicial y ser concientes de que la neutralidad no existe como tal; por que el juez es un hombre y todos los condicionantes que lo afectan como individuo influyen en su decisión y turo con la cual puede modificar o no la realidad social existente. 
reito Internacional Privado ${ }^{4}$, já possuindo algumas das suas Convenções incorporadas e em vigor nos seus ordenamentos.

Ademais, é uma organização composta, hoje, por 54 países dos cinco Continentes ${ }^{5}$ e que se relaciona, em condições de igualdade, com uma série de outras organizações internacionais, seja no plano da cooperação, a exemplo das relações com a ONU ou com a International Law Assocation, seja na delimitação dos âmbitos de atuação, como na hipóteses do acordo firmado com o Conselho da Europa, com sede em Strasbourg ${ }^{6}$.

Frente a isso, este trabalho se propõe a fazer uma análise da Conferência sob o ponto de vista de sua estrutura, identificando-a como entidade intergovernamental, autônoma em relação aos Estados que a integram e, por isso mesmo, com vida institucional própria e configurada para atingir os objetivos estabelecidos pelo seu Estatuto.

Propõe-se também a analisá-la sob a ótica de sua finalidade, isto é, como uma organização estruturada para o alcance dos objetivos que levaram à sua própria criação e que explicam a sua razão de ser e forma de atuar.
Para melhor compreensão da estrutura e do funcionamento da Conferência da Haia, interessante retomar aqui alguns elementos da teoria geral das organizações internacionais, que se revelaram como mais um exemplo expressivo do fenômeno associativo internacional do Pós-Guerra.

Temos que as organizações internacionais, tais como hoje se apresentam, encontram fenômeno associativo, existente em todos os momentos da história das civilizações e caracterizado pela "necessidade comum a todo $e$ qualquer corpo social, qualquer que seja a sua dimensão ou composição"?

Reforça este entendimento a afirmação do internacionalista Charles DUPUIS, pronunciada na Academia de Direito Internacional de Haia, de que "desde o Império romano até nossos dias, a Europa, primeiramente, e, depois, o mundo oscilaram entre a organização internacional e a anarquia da soberanias".

Este fenômeno associativo deve ser entendido, segundo BOBBIO, "como fato sóciopolítico", e, sob esta perspectiva, "a história das relações internacionais tem registrado, sua origem e fundamento no sempre presente

${ }^{4}$ A Argentina tornou-se membro da Conferência em 28.04.72. O Uruguai, em 27.07.83 e, mais tarde o Chile, em 25.04.86.

${ }^{5}$ Alemanha, Argentina, Austrália, Áustria, Bielorússia, Bélgica, Bósnia-Herzegovina, Brasil, Bulgária, Canadá, Chile, China, Chipre, República da Coréia, Croácia, Dinamarca, Egito, Espanha, Estônia, EUA, Ex-República Iugoslávia da Macedônia, Finlândia, França, Geórgia, Grécia, Hungria, Irlanda, Israel, Itália, Jap̃õo Joûn Letônia, Luxemburgo, Malta, Marrocos, México, Mônaco, Noruega, Países Baixos, Peru, Polônia, Jordânia Romênia, Reino Unido da República Tchéca, Turquia, Uruguai, Venezuela, Iugoslávia.

${ }^{6} \mathrm{O}$ Conselho da Europa (composto por 43 países, inclusive os 15 países membros da UE e outros mais), criado em 1949, ou seja, antes dos Tratados constitutivos das Comunidades Européia, não deve ser confundido como o Conselho Europeu, que é ́́rgão composto pelos Chefes de Estados Membros da União Européia, cuja sede normalmente é em Bruxelas. Como a presidência da UE muda a cada seis meses, o Conselho Europeu pode sered em lugares diferentes.

${ }^{7}$ BOBBIO, Norberto. Dicionário de política, 9 ed., Brasília: Editora Universidade de Brasília, 1997, p. 885. ${ }^{8}$ Apud ACCIOLY, Hildebrando. Organizações internacionais - Conferência pronunciada em Madrid, na "Escola de Funcionários Internacionais", em abril de 1956. In Boletim da Sociedade Brasileira de Direito Internacional, $\mathrm{n}^{\circ} 23 / 24,1956$, p. 12

Revista da Faculdade de Direito da UFRGS, v. 20, Outubro/2001 nos últimos vinte anos, o surgir e rápido multiplicar-se de associações e Estados que, de simples uniões, foram progressivamente evoluindo até às mais recentes comunidades supranacionais". 9

Na verdade, o sentimento da existência de uma comunidade internacional é muito antigo, como afirmou o Professor DUPUIS, e baseia-se numa manifestação constante do gênero humano. ${ }^{10}$

Neste processo evolutivo, onde o alcance das relações deixa de ser apenas limitado às simples uniões para hoje receber contornos de comunidades integradas sob uma ótica supranacional, pode-se identificar duas fases pelas quais a organização da sociedade internacional se desenvolveu. ${ }^{11}$
A primeira fase foi fundada no direito internacional que, ao codificar costumes e estabelecer regras e princípios à convivência entre os Estados, respondia aos interesses específicos dos Estados contratantes. ${ }^{12}$

Como esta fase traz consigo as primeiras bases da organização da sociedade internacional, ela pode ser caracterizada como de relações bilaterais, estabelecendo a reciprocidade como condição nos acordos firmados. ${ }^{13}$

Já a segunda fase deste processo deuse a partir da união de três ou mais Estados para a consecução de determinados fins comuns, caracterizando a passagem do bilateralismo para o multilateralismo do comportamento organizacional contemporâneo. ${ }^{14}$

${ }^{9}$ BOBBIO. Dicionário, p. 855.

${ }^{10}$ ACCIOLY. Ob. cit., p. 13. Aqui o autor traz o pensamento romântico de SUAREZ que, em seu Tractatus de Legibus ac Deo Legislatore, "deu como razão de ser do direito das gentes o fato de que o gênero humano, embora dividido em nações e reinos diferentes, tem certa unidade, não só específica, mas também política e moral, resultante do preceito natural do amor e da caridade mútuas, que se devem estender a todos, mesmo aos estrangeiros, seja qual for a nação a que pertençam."

${ }^{11}$ Celso D. de Albuquerque Mello, em seu Curso de direito internacional público, $1^{\circ}$ volume, $10^{a}$ edição, Rio de Janeiro: Renovar, 1994, p. 44 e 45, analisa a distinção entre a denominação do meio social onde se desenvolve o DIP, que não tem sido dada de maneira uniforme pelos doutrinadores. A sociedade internacional é histórica, baseada no voluntarismo refletido dos Estados, regida pelo contrato, que se manifesta através dos tratados, enquanto que a comunidade internacional, seria regida pelo naturalismo involuntário, criação de cooperação enquanto que a comunidade internacional, seria regida pelo naturalismo involuntário, criação de cooperação
natural anterior à uma escolha consciente de seus membros. Sereni e Balladore Pallieri utilizam a denominação comunidade internacional, enquanto que Aguilar Navarro e Truyol y Serra preferem a denominação sociedade internacional. Segundo Celso Mello, a análise dos argumentos apresentados pela doutrina leva a concluir que existe uma sociedade internacional e não uma comunidade internacional.

SEITENFUS, Ricardo. Manual das organizações internacionais, Porto Alegre: Livraria do Advogado, 1997, p. 23, por seu vez anota que "a denominação de sociedade internacional não reflete com exatidão o que pretendemos descrever. Trata-se do meio internacional ou sistema internacional. Todavia, optando por outra designação, utilizada com freqüência pela literatura, qual seja a expressão comunidade internacional, estariamos nos distanciando mais ainda das características objetivas que marcam as relações internacionais. Com efeito, a expressão comunidade implica na existência de uma comunhão de interesses e a vontade de forma congraçada. Ora, as relaçōes internacionais demonstram, que o congraçamento não consiste no maior de seus traços. Portanto, adotamos a expressão sociedade internacional no seu sentido sociológico, a demonstrar a existência de um mínimo de vontade de convivência."

${ }^{12}$ SEITENFUS. Ob. cit., p. 23.

${ }^{13}$ Ibidem, p. 23.

${ }^{14}$ Ibidem, p. 23 
Este momento ocorre, segundo FIORATI, quando, assinado o Tratado de Viena, em 1815, criou-se a Santa Aliança, cujo objetivo era estruturar a sociedade internacional naquele tempo, e abriu-se a possibilidade de celebração de "Tratados Multilaterais Abertos". ${ }^{15}$

O grau de evolução atingido, a partir de então, pelo processo associativo demonstra necessidade de se definir o que seja uma organização internacional, a fim de que possamos extrair seus elementos conceituais e suas principais características.

BOBBIO a define como sendo uma "as sociação entre sujeitos de direito internacional, instituida e disciplinada segundo normas do mesmo direito, caracterizada numa entida de de caráter estável e dotada de um ordenamento jurídico peculiar, bem como de órgãos e meios próprios para cumprir os fin de interesse comum para que foi criada" ${ }^{16}$

Mais sintética, porém, é a definição de SEITENFUS, para quem "trata-se de uma sociedade entre Estados, constituída através de um tratado, com a finalidade de buscar inte- resses comuns através de uma permanente cooperação entre seus membros". ${ }^{17}$

Das definições acima, extraímos os seguintes elementos constitutivos de uma organização internacional:

a) união intergovernamental: uma organização é internacional porque constituída por Estados soberanos, com personalidade jurídica internacional. Desta forma, exclui-se conceitualmente as ONGS do âmbito das organizações internacionais;

b) acordo internacional: é a forma pela qual se constitui juridicamente uma organização internacional e onde estão estabelecidos os principais direitos, obrigações, poderes, fa culdades e encargos inerentes a ela e aos Estados signatários; ${ }^{18}$

c) ordenamento jurídico próprio: por ser uma entidade autônoma em relação aos Estado membros, possui a organização um ordenamento interno próprio, destinado a regular a sua estrutura e a forma de realização dos seus fins: ${ }^{19}$

d) órgão permanente: necessário porque, se- gundo doutrina dominante, a entidade internacional não surge a partir do momento em que passa a vigorar o acordo que lhe deu origem, mas do momento em que a entidade começa a funcionar por meio dos seus próprios órgãos; ${ }^{20}$

e) interesse comum: já que a constituição, bem como o motivo da permanência da organização internacional no cenário das relações internacionais, pressupõem a existência de in teresses comuns entre os Estados membros; $\mathrm{e}$

f) cooperação estável: é o modo pelo qual os Estados membros devem atuar, no âmbito da organização, para atingir os objetivos estabelecidos no acordo que a criou.

SEITENFUS enumera a liberdade de associação como um dos elementos presentes n configuração de uma organização internacional. ${ }^{21}$ Posição da qual discordamos, porque mais apropriado entendê-la como um princípio informador deste fato sócio-político - próprio das relações internacionais, do que necessariamente como um elemento que participe de sua constituição. $^{22}$
Em razão dos próprios elementos conceituais, as organizações internacionais apresentam um caráter multilateral, permanente e institucional. ${ }^{23}$

A multilateralidade é expressa pela quantidade de Estados membros que a integram, o que faz com que tenha um caráter universal ou regional, dependendo exclusivamente da composição dos sócios.

O caráter permanente da entidade, por sua vez, é expresso no próprio ato institucional de sua criação, ao não prever termo final para as suas atividades. Com efeito, este caráter também se expressa na existência de um secretariado que, dentre todos os órgãos que possam subsistir em seu seio é o mais apto a efetivar o objetivo de durar indefinidamente, dados os seus aspectos político e funcional (burocrático).

O caráter institucional da organização internacional se manifesta pela previsibilidade de situações, ao prever fatos e condutas que tendem a materializar-se, atribuindo-lhes conseqüências jurídicas e políticas por meio de sanções. Manifesta-se, de igual forma, pela sobe-
${ }^{15}$ FIORATI, Jete Jane. As inovações no direito internacional privado brasileiro presentes no Projeto de lei de aplicação das normas jurídicas. In Revistas dos Tribunais - Caderno de Direito Tributário e Finanças Públicas, no 17 , p. 18 et seq.

${ }^{16}$ BOBBIO. Ob. cit., p. 856.

${ }^{17}$ SEITENFUS. Ob. cit., p. $26 / 27$

${ }^{18}$ BOBBIO (Ob. cit., p.856) observa que "o ato institucional da Organização Internacional não se considera portanto, apenas como ato formal pertencente à categoria jurídica dos acordos, mas também como ato diretamente ligado à nova entidade a que da vida e cuja constituição representa. Na verdade, ele não possui a caracteristicas normais de um acordo internacional, destinado a esgotar seus efeitos com a consecução dos objetivos previstos, mas de um ato destinado a perdurar e a desenvolver-se no tempo, bem como a representar o núcleo jurídico-estrutural da nova organização."

${ }^{19}$ Relativamente a este elemento, assim entende Norberto BOBBIO: "Considerada, de fato, sob o aspecto normativo, toda Organização Internacional constitui ordenamento jurídico, já que possui uma estrutura própria, seus órgãos, seus meios de ação e normas jurídicas peculiares. Este ordenamento, embora se mova, em sentido lato, na órbita do ordenamento internacional gral, de que se distingue e freqüentemente se afasta em virtude da própria autonomia, possui um caráter particular, quer em relação aos Estados e ao ato que lhe deu origem, quer porque visa a disciplinar, não já toda a vida dos membros, mas apenas algumas de suas atividades." In Dicionário, p. 856.

Revista da Faculdade de Direito da UFRGS, v. 20, Outubro/2001

Ob. cit., p.27.

${ }^{21}$ Neste momento, o autor brasileiro elenca a existência de órgãos permanentes também como elemento constitutivo das organizações internacionais. No entanto, quando discorre sobre a personalidade jurídica destas entidades, SEITENFUS afirma que o surgimento das mesmas dá-se como "consequiência" de um acordo multilateral, ou seja, pela simples formalidade, não importando, em princípio, a existência e atuação ou não dos órgãos permanentes da entidade. SEITENFUS. Manual, p. 54 e s.

${ }^{22}$ SEITENFUS. Ob. cit., p. 28

${ }^{23}$ SEITENFUS (Manual, p. 23/25.) enumera estas características partindo da própria evolução institucional das organizações internacionais, considerando que as primeiras conferências até tinham objeto definido, mas não apresentavam qualquer preocupação com a regularidade de suas realizações. Posteriormente, devido ao contexto em que as relações internacionais se desenvolviam, as conferências tornaram-se cada vez mais freqüentes, fazendo surgir um embrião de institucionalização, em função mesmo desta maior periodicidade imposta às suas realizações. Por consequiência, a necessidade de se preparar uma agenda e infra-estrutura à realização dos encontros, bem como a de manter o registro das discussões e suas decisões fez com que surgissem os secretariados, com sede fixa e dotados de personalidade jurídica internacional.

Revista da Faculdade de Direito da UFRGS, v. 20, Outubro/200 
rania, ao adquirir competências que antes pertenciam ao absoluto domínio nacional, e pela voluntariedade da adesão do Estado à organização, o que faz com que o decidido pela entidade tenha que ser por ele acatado, desde que tenha participado do processo decisório. ${ }^{24}$

BOBBIO, no entanto, destaca como características das organizações internacionais a voluntariedade de sua constituição, expressa no acordo que lhe dá origem; a paridade de seus membros; e a sua pluralidade. ${ }^{25}$

Discordamos, no entanto, do fato de a voluntariedade e a paridade serem tratadas como características das organizações internacionais, porque tanto uma como outra funcionam como princípios no âmbito deste fenômeno associativo contemporâneo. Além do mais, a voluntariedade e a paridade dos seus membros são condições para a existência e para o alcance dos objetivos propostos pela organização internacional, não se sustentando, de forma alguma, que qualquer privilégio a uma nação advenha da representação de caráter desigual e preferencial de qualquer um de seus membros.

Todavia, como observa BOBBIO, este princípio não impede que algumas organizações introduzam no ordenamento interno, por razões de ordem estrutural e funcional, corretivos que derrogam o princípio da paridade dos seus mem-

De qualquer maneira, esta é uma exceção à regra que só poderá existir com o consentimento dos Estados que integram a organização, principalmente por aqueles atingidos diretamente pela "limitação", expressado na forma prevista no ordenamento da entidade, garantindo-se, neste momento, todas as prerrogativas da igualdade e proteção aos interesses dos Estados mais "fracos".

No que diz respeito à personalidade jurídica das organizações internacionais, SEITENFUS ${ }^{27}$ a defende com furor, ponderando que os Estados, por manifesta vontade, criam as organizações que representam, em última análise, o encontro de interesses e aspirações da comunidade que a compõem. A partir daí, sob o ponto de vista jurídico e político, a organização então criada torna-se algo externo e distinto, estabelecida no cenário internacional com personalidade jurídica própria, distinguindo-se das demais entidades manifestamente intergovernamentais ou de caráter privado, delineando-se como sujeito de direito internacional, possuidora de direitos e deveres, condição exclusiva, até então, dos Estados soberanos.

Quanto à estrutura, as organizações internacionais não sofrem interferência do Direibros, a exemplo do voto ponderado. 26

${ }^{24}$ SEITENFUS. Ob. cit., p. 25/26.

${ }^{25}$ BOBBIO. Ob. cit., p. 856

${ }^{26}$ Ibidem, p.856.

${ }^{27}$ SEITENFUS. Ob. cit., p. 51 a 53. Aqui, o autor faz referência à história das organizações internacionais, evidenciando que, no início do fenômeno associativo contemporâneo, os tratados constitutivos das organizações não tinham a preocupação sobre sua eventual personalidade jurídica. Assim, em consulta à Corte Internacional de Justiça "sobre sua eventual capacidade de demandar junto aos Estados, e portanto, sobre o caráter de sua personalidade jurídica no Direito Internacional", a ONU, em 11 de abril de 1949, recebe o parecer que informa sua personalidade jurídica internacional pois constitui "o tipo mais elevado de organização Internacional, e não poderia corresponder às intenções de seus fundadores caso ela fosse desprovida da personalidade jurídica (....). A Corte julga que cinqüenta Estados, representando uma muito larga maioria dos membros da Comunidade Internacional têm o poder, conforme o Direito Internaci dade reconhecida somente pelos Estados membros".

Revista da Faculdade de Direito da UFRGS, v. 20, Outubro/2001 to Internacional ${ }^{28}$, prevalecendo o princípio da liberdade de organização.

A regra é que se estabeleça uma pluralidade de órgãos, vinculando-os, evidentemente, às necessidades e interesses diversos, próprios à realização dos objetivos e funções da organização.

A estrutura mais freqüente é a ternária, que consiste em uma assembléia, um órgão executivo e um órgão burocrático.

A assembléia é um órgão colegiado com periodicidade de reuniões, onde se manifestam as representações dos Estados em condição de paridade, e competente para analisar e deliberar sobre todas as atividades da organização.

Por ser um órgão de vital importânicia, pode-se dizer presente em todas as organizações, prevendo muitas vezes em sua estrutura interna a existência de comissões, como parte complementar à sua atividade, cuja competência em determinadas matérias se assemelha à dos parlamentos nacionais. ${ }^{29}$

O órgão executivo, por seu turno, é o responsável pela execução das diretrizes estabelecidas pela assembléia, realizando-as de forma a atingir os objetivos da organização.

Por isso mesmo, não existem regras uniformes quanto a forma de sua constituição, composição e modus agendi, uma vez que estes órgãos têm que estar aptos e capacitados para exercerem suas atividades que, por serem peculiares às singularidades das organizações às quais estão vinculados, não podem estar limitadas a formalismo uniformizado completamente desnecessário.

O órgão burocrático é aquele responsável pela atividade funcional da organização, dando continuidade à ação da entidade, sobretudo, a administrativa.

Salienta-se que a estrutura básica das organizações internacionais, embora ternária comporta a existência de outros órgãos, caso a necessidade para o desenvolvimento de suas atividades assim o exija. ${ }^{30}$

Relativamente às funções desempenhadas pelas organizações internacionais, tanto quantos forem os fins para os quais ela se destina tantas quantas serão as suas funções, posto que a variedade de uma reflete diretamente na variedade da outra.

Com efeito, a importância institucional de uma organização internacional faz com suas funções tenham características próprias e, por conseguinte, diversas das dos Estados membros. ${ }^{31}$

As funções, via de regra, são: normativa - que é a de maior relevo; executiva - um tanto mais limitada, porém de suma importância; mili-

${ }^{28}$ BOBBIO. Dicionário, p. 858

${ }^{29}$ Ibidem, p. 858.

${ }^{30}$ Segundo BOBBIO (Ob. cit., p. 859), "Os atos de instituição das organizações internacionais limitam-se a prever a constituição dos órgãos principais, como os já descritos, órgãos que exercem os poderes e atribuições essenciais para a vida das organizações internacionais, cujos objetivos se estendem e multiplicam progressivamente, carece de uma adaptação constante que se reflete em sua própria estrutura interna. Tal necessidade é inerente a toda a organização que participe da vida e da evolução da sociedade internacional. Não raro, os próprios Estados promotores, prevendo o fenômeno, atribuem explicitamente à organização o poder de instituir prõos Es

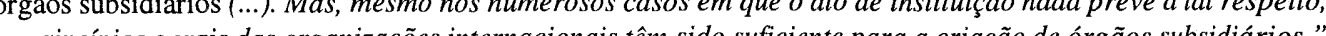
os princípios gerais das organizações internacionais têm sido suficiente para a criação de órgãos subsidiários." ${ }^{31}$ BOBBIO, Dicionário, p. 860.

Revista da Faculdade de Direito da UFRGS, v. 20, Outubro/2001 
tar - embora de caráter mais excepcional; jurisdicional - mais recente; e a de assistência técnica - sendo expressivo o número de organizações que apresentam esta função.

No que diz respeito à classificação das organizações internacionais, que é importante pela amplitude do fenômeno associativo moderno e pelo seu contínuo multiplicar-se, adotaremos os critérios de classificação quanto ao seu ato constitutivo e quanto às suas atividades específicas.

Quanto ao ato constitutivo, as organizações internacionais podem ser abertas ou fechadas, segundo disponha o ato institucional sobre a admissão de novos membros distintos dos originários; temporárias ou não, presumindo-se constituídas por tempo indeterminado caso haja silêncio no ato institucional; e universais ou regionais (particulares), caso a possibilidade de participação nestas organizações esteja vinculada à condição de o Estado pertencer a uma determinada área geográfica comum aos outros Estados contratantes ou não.

Consideradas as atividades específicas, as organizações internacionais podem ser econômicas, baseadas na cooperação entre os Estados com o fim de alcançar um desenvolvimento econômico satisfatório; técnicas, tendo como atividade principal a cooperação técnica; técnico-científicas, onde se verifica a conjugação de esforços para o desenvolvimento de uma determinada área do conhecimento e da produção científica, cuja incumbência não teria como ser suportada isoladamente pelos Estados membros; sociais, cuja essência da cooperação é a de estabelecer e buscar padrões mínimos de qualidade de vida no seio de suas comunida-

des; militares, que têm como ambição a manutenção da paz e a solução pacífica dos conflitos; e de comunicações, na busca de desenvolver, setorialmente, as diversas formas de comunicação entre os povos.

Analisados os pontos centrais da Teoria Geral das organizações internacionais, examinaremos a Conferência da Haia de Direito Internacional Privado.

\section{A Conferência e sua Estru- tura}

Nesta parte, analisaremos a Conferência da Haia de Direito Internacional Privado em dois momentos bastante distintos de sua história, classicamente definidos ${ }^{32}:$ a Conferência antes e após 1951, que foi o ano de sua institucionalização.

\subsection{A Conferência antes de 1951}

A história da Conferência da Haia de Direito Internacional Privado começa no ano de 1893, quando, por iniciativa do Governo dos Países Baixos, foi realizada a sua primeira sessão ${ }^{33}$, cujos esforços iniciais para a sua concepção são dignos de referência.

A Conferência encontra suas raízes no movimento uniformizador do século XIX. Segundo seus adeptos, o conflito de leis e a divergência normativa entre os Estados eram de fato um problema, e que, uma vez assim entendidos, deveriam ser solucionados pela comunidade de Estados por meio de Tratados e Convenções. ${ }^{34}$

\footnotetext{
${ }^{32}$ Ver DROZ, Georges A. L. . La Conférence de la Haye de Droit Internationale Privé en 1980: Évolution et perspectives. In Recueil des Cours 168 (180 - III), p.135.

${ }^{33}$ DROZ. Ob. cit., p. 135.

${ }^{34}$ FIORATI. Ob. cit., p. 20.
}

Revista da Faculdade de Direito da UFRGS, v. 20, Outubro/2001
Este movimento propugnava pela unificação das normas substantivas, adotando um direito global uniforme (Weltrecht), "com regras idênticas para o direito de família, contratos e sucessões, que pudesse vigorar indistintamente em qualquer lugar do mundo (...)" ${ }^{\prime 35}$. Destacam-se como seus maiores expoentes Pascale Mancini e Zittelmann ${ }^{36}$, sendo aquele o principal impulsionador deste movimento. $^{37}$

Em 1861, Mancini propôs ao Governo italiano que examinasse como diminuir ou afastar as controvérsias a que davam lugar os conflitos de leis quando aplicados às pessoas, aos bens e aos atos jurídicos. Em 1866, propunha à Câmara de Deputados uma revisão geral dos Tratados assinados pelo Governo da Itália, particularmente aqueles que se referiam à garantia dos direitos civis dos nacionais no estrangeiro. $^{38}$

Por insistência, o Governo italiano tornou-o responsável pelo contato com outros Estados, notadamente a França, a Alemanha e a Bélgica, no sentido de tornar possível a fixação de regras comuns no que diz respeito à condição dos estrangeiros e às prerrogativas que a envolvem, à capacidade, à propriedade, às sucessões e aos atos jurídicos. ${ }^{39}$

No entanto, a instabilidade política do Continente, causada pela Guerra francoprussiana, impediu que Mancini levasse a cabo

${ }^{35}$ FIORATI. Ob. cit., p. 21.

${ }^{36}$ FIORATI Ob. cit., p. 20.

${ }^{37}$ RAMOS, Rui Manuel Gens de Moura. Das relações privadas internacionais - Estudos de Direito Internacional Privado. Coimbra: Coimbra Editora, 1995, p. 251.

${ }^{38}$ RAMOS. Ob. cit., p. 251.

${ }^{39}$ RAMOS. Ob. cit., p. 252.

${ }^{40}$ PASSOS, Maria da Luz Lapa de. Conferência de direito internacional privado. In Documentação e Direito Comparado - Boletim do Ministério da Justiça, ${ }^{\circ} 10,1982$, p. 215.

${ }^{41}$ RAMOS. Ob cit., p. 252.

${ }^{42}$ RAMOS. Ob. cit., p. 252 aquela tarefa ${ }^{40}$, fazendo com que, em 1873 , viesse a propor ao Instituto de Direito Internacional que se tornasse obrigatório a todos os Estados, por meio de Tratados, certas regras uniformes capazes de assegurar também decisões uniformes em matéria de conflito de leis. Esta iniciativa fez com que o Instituto criasse, imediatamente, uma comissão especial para a análise da proposta e conseqüente formulação de princípios que pudessem servir de base para uma futura codificação do Direito Internacional Privado. ${ }^{41}$

Os resultados auferidos pela Comissão do Instituto, apresentados em 1874, na sessão de Genebra, reforçavam a proposta de Pascale Mancini e Tobias Michael Carl Asser e propunham que o método a ser seguido para esta codificação se assentasse em projetos elaborados pelo Instituto de Direito Internacional e discutidos, posteriormente, em conferências diplomáticas. ${ }^{42}$ Estes resultados, no entanto, não geraram os frutos esperados.

Também em 1877, o Governo italiano, com iniciativa congênere, não foi feliz.

Como derradeiro esforço, em 1881, Mancini, já como Ministro dos Estrangeiros do Governo italiano, tentou realizar uma conferência de Direito Internacional Privado em torno da problemática da execução de sentenças estrangeiras, sem que isso implicasse, necessariamente, no abandono dos objetivos gerais do 
movimento uniformizador. Esta conferência, todavia, não veio a acontecer por razões técnicas. $^{43}$ logra êxito ao propor ao Governo holandês o encargo de convocar uma conferência internacional sobre a codificação do Direito Internacional Privado, que assim o fez, realizando, em 1893, a primeira das conferências da Haia de Direito Internacional Privado, depois de ampla negociação diplomática ${ }^{44}$, com a participação de delegações de 13 Estados europeus.

A Primeira Sessão da Conferência da Haia teve como Presidente o seu proponente, o advogado, diplomata e jurisconsulto Tobias Michael Carl Asser, que foi escolhido pelas delegações dos trezes Estados presentes à Conferência, em reconhecimento ao seu esforço e à sua autoridade no assunto, demonstrada pelos vinte anos de propagação e realização da codificação internacional do Direito Internacional Privado. ${ }^{45}$

Com efeito, esta primeira fase da Conferência é caracterizada pela sua não institucionalização e é marcada pela predominância de países europeus, com exceção ao Japão, membro desde 1904. ${ }^{46}$

Nesta fase, realizaram-se seis sessões da Conferência, estando sempre a cargo do Governo holandês a iniciativa de sua convocação, organização e realização. gunda Sessão da Conferência, o Governo holandês instituiu uma Comissão, presidida por
Não obstante, em 1891, Tobias Asser

Diante desta incumbência, após a Se-

Asser, para auxiliá-lo na prossecução dos trabalhos já iniciados e possibilitar, por seu turno, a convocação da Terceira Sessão Conferência que se realizou no ano de $1900 .{ }^{47}$

Esta Comissão ficou, desde então, responsável pela revisão das conclusões das sessões anteriores da Conferência que apresentassem uma certa possibilidade de serem aprovadas, em definitivo, pelos Governos até então interessados, e pelo auxílio nas próximas atividades exigidas pela Conferência.

Ao final da Terceira Sessão da Conferência, havia quatro projetos de Convenção serem assinados e, ao final da Quarta, cinco projetos.

No que diz respeito à estrutura da Conferência nesta fase, a iniciativa da realização das sessões cabia ao Governo holandês, auxiliado pela Comissão por ele instituída, situação que perdurou até 1951, ano de sua institucionalização.

E é desta forma que o Governo holandês conduzia os trabalhos de unificação das normas de Direito Internacional Privado: por meio de Convenções aprovadas no seio da Conferência, cujas sessões realizavam-se sem uma periodicidade regular, devido mesmo à falta de uma estrutura institucional que lhes desse suporte. Este fato dificultará sobremaneira o desenvolvimento dos trabalhos nos períodos bélicos, notadamente no período entre Guerras, onde se verificou grande dificuldade na convocação da Quinta Sessão da Conferência. ${ }^{48}$

${ }^{43}$ RAMOS. Ob. cit., p. 252 e s.

${ }^{44}$ RAMOS. Ob. cit., p. 253

${ }^{45}$ STEENHOF, G.J.W.. Asser et la fondation de la Conférence de La Haye de droit internacional privé. In Revue Critique de Droit International Privé. 83 (2), 1994, p. 298

${ }^{46}$ GROZ. Ob. cit., p. 135.

${ }^{47}$ RAMOS. Ob. cit., p. 254.

${ }^{48}$ RAMOS. Ob. cit., p. 258 et seq.

Revista da Faculdade de Direito da UFRGS, v. 20, Outubro/200/
Governo holandês, no entanto, insistiu em dar continuidade aos trabalhos da Conferência e, em 1921, remetendo aos Estados questionários sobre os diversos temas já agendados (sucessões e competência em matéria sucessória; efeitos do divórcio e separação; efeitos do casamento sobre a pessoa do filho; falência; execução de sentenças estrangeiras e processo civil), o que resultou na condução dos Estados à conclusão de dois Protocolos adicionais às Convenções de 1902 e 1905 (Protocolos de 28 de novembro de 1924 e de 04 de julho de 1925), transformando estes instrumentos em verdadeiras Convenções abertas, a serem ratificadas por qualquer Estado. ${ }^{49}$

Assim, diante deste esforço em manter viva a idéia de unificação das normas de Direito Internacional Privado, mesmo nưm ambiente político sensível, onde as relações internacionais estavam abaladas pelo primeiro conflito mundial, é que o Governo holandês convocou a Quinta Sessão da Conferência, realizada no ano de 1925 , cujos trabalhos estiveram adstritos à análise de dois projetos de convenção: um sobre falências e o outro sobre reconhecimento e execução civil das decisões judiciais, os quais a Sexta Conferência, em 1928, veio a rechaçar completamente. ${ }^{50}$

Nesta fase, portanto, compreendida entre 1893 e 1928, foi o Governo holandês o grande responsável por toda a atividade funcional da Conferência que, por meio da Comissão especial presidida por Asser, manteve vivo o mo- vimento uniformizador iniciado por Pascale Mancini e Zittelmann e evitou que se tivessem tornado inúteis todos os esforços até então dispensados na busca da unificação do Direito Internacional Privado.

\subsection{A Conferência após 1951}

Em 1951, ao se realizar a Sétima Sessão, os Estados membros ${ }^{51}$, considerando o caráter permanente da Conferência e desejando acentuar esse caráter, dotaram-na de um Estatuto e estabeleceram-na como uma organização internacional, de vida institucional própria.

Este Estatuto entrou em vigor a 15 de julho de 1955, determinando que as Sessões ordinárias ocorressem de quatro em quatro anos, não obstante a possibilidade de chamadas extraordinárias.

A partir daí, a Conferência passou a contar uma estrutura organizacional própria, intimamente associada à realização do seu objetivo, cujas linhas mestras serão aqui apresentadas.

Assim é que, pela leitura do art. $1^{\circ}$ do Estatuto $^{52}$, pode-se, de pronto, classificar a Conferência como uma organização internacional de função normativa, cuja atividade específica é a de criação de normas jurídicas.

Por outro lado, conforme o permissivo do art. $2^{\circ}$ do Estatuto, podemos classificar a

${ }^{49}$ RAMOS. Ob. cit., p. 259

${ }^{50}$ Ibidem, p. 259.

${ }^{51}$ Que, à época, eram os seguintes os: República Federal da Alemanha, Áustria, Bélgica, Dinamarca, Espanha, Finlândia, França, Itália, Japão, Luxemburgo, Noruega, Países Baixos, Portugal, Reino Unido da Grã-Bretanha e Irlanda do Norte, Suécia e Suiça.

52 "Artigo $1^{\circ}$ - A Conferência da Haia tem como objetivo trabalhar para a unificação progressiva das regras de direito internacional privado." 
Conferência como uma organização de caráter universal e aberta. ${ }^{53}$

A estrutura institucional da Conferência é quaternária, composta por uma sessão plenária, um órgão de direção, um secretariado e um conselho de representantes diplomáticos.

A Sessão Plenária é composta pelos representantes diplomáticos dos Estados membros e realizada ordinariamente, de quatro em quatro anos, e extraordinariamente, se necessário.

Sua função precípua é discutir e aprovar os projetos de Convenção preparados pela pelas comissões especiais instituídas para este fim, bem como estabelecer regras de procedure das sessões plenárias, tendo cada Estado membro direito a um voto, admitindo-se, não obstante, a participação de Estados não membros na condição de membros ad hoc.

Por tradição, desde a Primeira Sessão, quando Asser foi eleito seu presidente, os Estados membros sempre elegem o representante da Delegação holandesa como presidente da Sessão.

Por fim, é competente a Seção Plenária para decidir, em primeira ou última instância, quaisquer assuntos que envolvam a vida institucional da Conferência.

O órgão de direção da Conferência está previsto no art. $3^{\circ}$ do Estatuto e é representado pela Comissão dos Países Baixos, instituída por Real Decreto em 1897, para promover a codificação do direito internacional privado. ${ }^{54}$

Esta Comissão teve como seu primeiro presidente Tobias Asser e tornou-se respeitada, como já visto, pelo expressivo trabalho de auxílio ao Governo holandês no desenvolvimento das atividades da Conferência durante a sua primeira fase.

Ela é responsável pelo funcionamento da Conferência, valendo-se, para isso, de uma Repartição Permanente (Bureau Permanent), do qual nos ocuparemos adiante.

Como principal atividade, fixa as datas e a ordem do dia das Sessões Plenárias. Mas, no curso deste ofício, permite que as representações diplomáticas exerçam certa influência sobre as decisões concernentes à ordem do dia aos assuntos gerais e à política da Conferência

É responsável, ainda, segundo o disposto no art. $7^{\circ}$ do Estatuto, pela criação de Comissões especiais para elaborar, durante o intervalo das Sessões, projetos de convenção ou estudar quaisquer outras questões de direito internacional privado compreendidas no objeto da Conferência.

53 "Artigo $2^{\circ}$ - São Membros da Conferência da Haia de Direito Internacional Privado os Estados que participaram de uma ou várias das sessões da Conferência e que aceitem o presente Estatuto. Poderão tornare Membros quaisquer outros Estados cuja participação tenha importância jurídica para os trabalhos da Conferência. A admissão de novos Membros será decidida pelos Governos dos Estados participantes, por propostas de um ou vários dentre eles, por maioria dos votos expressos, num prazo de seis meses contados da data em que essa proposta for submetida aos Governos. A admissão tornar-se-á definitiva pela aceitacĩo do presente Estatuto pelo Estado interessado."

54 "Artigo $3^{\circ}$ - A Comissão de Estado Neerlandesa, instituída pelo Decreto Real de 20 de fevereiro de 1897 para promover a codificação do direito internacional privado, ficará encarregada do funcionamento da Conferênia. A Comissão assegurará tal funcionamento por intermédio de uma Repartição Permanente, cujas atividades dirigirá. Ela examinará todas as propostas destinadas a serem incluidas na agenda da Conferência. Ela poder determinar livremente as medidas a serem tomadas em relação a essas propostas. A Comissão de Es Ela poder após consulta aos Membros da Conferência a data e a agenda da Conferência. Ela se dirigirá ao Governo dos Paises Baixos para a convocação dos Membros. As sessões ordinárias da Conferência serão realizado dos princípio, cada quatro anos. Em caso de necessidade, a Comissão de Estado podera, apos aprovacas en Membros, solicitar ao Governo dos Paises Bairos a con a Comissăo de Estado podera, apos aprovação do Membros, solicitar ao Governo dos Paises Baixos a convocação da Conferência em sessão extraordinária." Revista da Faculdade de Direito da UFRGS, v. 20, Outubro/2001
O secretariado, ou Bureau Permanent, é responsável, por delegação estatutária, em assegurar o funcionamento da Conferência, sob a direção da Comissão dos Países Baixos.

Este Bureau é composto por um Secretário Geral, assistido por outros três juristas (um Primeiro Secretário, um Secretário Geral Adjunto e um Secretário), de distintas nacionalidades, nomeados pelo Governo do Países Baixos e possuidores de conhecimentos jurídicos e experiências práticas apropriados. De qualquer forma, o número de Secretários pode ser aumentado, mediante decisão da Sessão Plenária. ${ }^{55}$

As atividades sob a responsabilidade do Secretário estão elencadas no art. $5^{\circ}$ do Estatuto e compreendem: a) a preparação e a organização das Sessões da Conferência, bem como das reuniões das Comissões especiais; b) o trabalho de secretaria das Sessões e das reuniões previstas; e c) todas as tarefas incluídas nas atividades de uma secretaria. ${ }^{56}$

Além das atividades elencadas no art. $5^{\circ}$, compete, ainda, ao Bureau Permanent a ela-

boração da regulamentação do Estatuto e a sua submissão à Sessão Plenária para aprovação, conforme norma estatutária. ${ }^{57}$

O último dos órgãos, o Conselho dos Representantes Diplomáticos, tem a função de aprovar o orçamento apresentado pelo Secretário Geral para cobrir as despesas com o Bureau Permanent e com as Comissões especiais. É igualmente responsável pela fixação das cotas pelas quais os Estados membros deverão responder.

Contudo, os gastos com o traslado e a estada dos Delegados das Comissões especiais correram por conta dos Governos representados, de acordo com o art. $8^{\circ}$ do Estatuto. ${ }^{58}$

Ressalta-se que os gastos que se originem das Sessões da Conferência serão suportados pelo Governo dos Países Baixos, sendo que os oriundos das Sessões extraordinárias serão repartidos entre os Estados membros da Conferência representados na Sessão. ${ }^{59}$ Já a matéria relativa ao orçamento da Conferência encontra-se regulada no art. $9^{\circ}$ do Estatuto. ${ }^{60}$

${ }^{55}$ No Estatuo, está prevista a existência de um Secretário Geral e dois outros Secretários Adjuntos - art. $4^{\circ}$, sendo que o aumento no número inicial, hoje verificado, deu-se em razão do permissivo da terceira parte do mesmo artigo.

${ }^{56}$ PASSOS. Ob. cit., p.221: "Com vista à preparação dos tratados, tem um papel preponderante na realização de pesquisas, elaboração de relatórios preliminares e preparação de questionários para o que mantém estreito contato com órgãos nacionais existentes em cada Estado membro, com os Delegados às sessões da Conferência e com outras organizações internacionais."

57 "Artigo 13 - As disposições do presente Estatuto serão complementadas por um regulamento, o qual deverá assegurar sua execução. O regulamento será adotado pela Repartição Permanente e submetido à aprovação dos Governos dos Membros."

${ }_{58}$ "Artigo $8^{a}$ - As despesas de funcionamento e manutenção da Repartição Permanente e das Comissões especiais serão rateadas entre os Membros da Conferência, com exceção das despesas de viagem e de permanência dos Delegados nas comissões especiais, despesas essas que ficarão a cargo dos Governos representados."

59 "Artigo $10^{\circ}$ - As despesas que resultarem das sessões ordinárias da Conferência serão custeadas pelo Governo dos Países Baixos. No caso de sessão extraordinária, as despesas serão rateadas entre os Membros da Conferência representados na sessão. Em todos os casos as despesas de viagem e de permanência dos Delegados deverão cia representados na sessão. Em todos os casos as

60 "Artigo $9^{\circ}$ - O orçamento da Repartição Permanente e das comissões especiais será submetido, cada ano, à aprovação dos representantes diplomáticos dos Membros na Haia. Esses representantes deverão igualmente ratear entre os Membros as despesas a estes atribuidas pelo orcamento. Os representantes diplomáticos reunirse-ão, para tal finalidade, sob a presidência do Ministro dos Assuntos Estrangeiros dos Países Baixos."

Revista da Faculdade de Direito da UFRGS, v. 20, Outubro/2001 
A estrutura institucional da Conferência tem o seu funcionamento totalmente voltado para o objetivo central da entidade. ${ }^{61} \mathrm{Em}$ função disso, a Conferência desenvolveu técnicas e processos de elaboração de convenções, que se desenvolvem por um período quadrienal, os quais, em linhas gerais, delinearemos aqui. ${ }^{62}$

A primeira fase de elaboração das convenções, chamada de período de seleção, consiste em toda a atividade que precede à tomada de posição ulterior, de caráter definitivo. Nesse período, escolhe-se o tema por sugestão dos Delegados do Bureau ou ainda de outras organizações internacionais. Após, discute-se o tema proposto no âmbito da Comissão especial, apurando sua exeqüibilidade pelo Secretariado. Apoiada nas discussões e estudos feitos pela Comissão especial, a Sessão Plenária, caso adotado o tema proposto, elabora recomendações à Comissão dos Países Baixos para decisão final.

Acolhido o tema pela Comissão dos Países Baixos, o Bureau assume a atividade de pesquisa, dada a sua responsabilidade em enviar um relatório, com natureza de estudo-pesquisa, e um questionário aos governos dos Estados membros ${ }^{63}$.

Isso feito, o terceiro período é o da discussão, que consiste em uma reunião de vários especialistas que analisam e debatem o relatório, o questionário, as respostas dos Estados e, se houver, a síntese destas respostas preparadas pelo Bureau.

Das conclusões dos especialistas, elaboram-se os projetos preliminar e principal de convenção. O primeiro, no âmbito da Comissão especial, com assistência do Bureau; o segundo, no âmbito da Sessão Plenária, já com o texto na forma de uma convenção.

Após este ciclo de quatro anos, vem o período de consolidação, onde se abre o tratado à assinatura, realiza-se a distribuição do correspondente relatório, procede-se à revisão do Projeto pelo Bureau Permanent, que poderá sugerir alterações e, por último, procede-se à publicação do conjunto das matérias relativas à preparação da Convenção, nomeadamente dos processos verbais das Sessões e de sua bibliografia na série "Actes et documents de la Conférence de la Haye de droit international Privé".

Vê-se, portanto, que a Conferência da Haia, na busca de realização dos interesses que levaram à sua existência, desenvolveu uma estrutura institucional simples, básica, porém funcional, que lhe possibilita alcançar o objetivo traçado pelos seus idealizadores e claramente definido no seu Estatuto.

\section{A Conferência e sua Fina- lidade}

Nesta parte, analisaremos a Conferência da Haia de Direito Internacional Privado sob a ótica de sua finalidade, e, ao fim, para demonstrar o alcance dos seus objetivos, traremos ao

${ }^{61}$ Curioso e valioso o que, a propósito do funcionamento da Conferência, dispõe o Artigo 11 do Estatuto: "As práticas adotadas pela Conferência continuarão a ser mantidas em relação a tudo que não for contrário ao presente Estatuto ao Regulamento."

${ }^{62}$ Ver PASSOS. Ob. cit., p. 223 et seq.

${ }^{63}$ Segundo a regra do art. $6^{\circ}$ do estatuto, o Governo de cada Estado membro deverá designar um órgão nacional com o objetivo de facilitar as comunicações entre os Membros da Conferência e a Repartição Permanente (Bureau). No Brasil, este órgão é Prof. João Grandino Rodas, da Faculdade de Direito da Universidade de São Paulo - USP.

Revista da Faculdade de Direito da UFRGS, v. 20, Outubro/2001 conhecimento as Convenções por ela aprovadas e os trabalhos atualmente desenvolvidos.

\subsection{Sua Razão de Ser - Finalidade}

Pelo seu Estatuto, a Conferência da Haia tem como objetivo trabalhar para a unificação progressiva das normas de Direito Internacional Privado. Sua finalidade é, portanto, alcançada na medida em que aprova e vê em vigor, no maior número de países possíveis, as Convenções preparadas pelas suas Comissões especiais.

O objetivo estabelecido pelo Estatuto é fruto de uma longa trajetória histórica do desenvolvimento das idéias que levaram, por fim à criação própria da Conferência. Esta trajetória está associada ao desenvolvimento políticoeconômico ocorrido na Europa a partir dos séculos XII e XIII, como também intimamente ligada ao próprio desenvolvimento do Direito Internacional Privado.

É no movimento uniformizador do DIP no Século XIX ${ }^{64}$ que surge o embrião da Conferência da Haia de Direito Internacional Privado, cujas idéias parecem estar perfeitamente abrigadas no objetivo estabelecido pela entidade.

$\mathrm{Na}$ busca desse objetivo, tem a Conferência percorrido largo caminho, principalmente após 1951, onde suas atividades levaram à produção de vultosa obra de autêntico significado. ${ }^{65}$

Fruto deste trabalho são as mais de quarenta Convenções aprovadas pela Conferência nas dezenove Sessões Ordinárias e nas duas

\footnotetext{
${ }^{64}$ Vide nesta exposição o item 2.1. A Conferência antes de 1951

${ }^{65}$ PASSOS. Ob. cit., p. 225.

${ }^{66}$ RAMOS. Ob cit., p. 264.

${ }^{67}$ RAMOS, ob. cit. p. 261.
}

Extraordinárias já realizadas.

Não se pode negar que, como fruto das relações internacionais, muitas decisões em relação à aprovação desta ou daquela Convenção envolve um forte "jogo" diplomático, evidenciado principalmente quando o tema da Convenção atinge diretamente os interesses de ordem interna de cada Estado membro.

Tal foi a hipótese da Convenção sobre a lei aplicável ao trust e ao seu reconhecimento, onde se afiguravam posicionamentos diferentes sobre a matéria, embora hoje já se encontre em vigor. ${ }^{66}$

Ressalta-se que, após 1951, a Conferência, na busca da unificação do direito internacional privado, não hesitou em se aventurar em temas que anteriormente não havia sido objeto de discussão. Como exemplo, podemos citar os de domínio do processo civil, onde seu êxito deve ser assinalado. ${ }^{67}$

Apontam-se ainda como exemplos as Convenções que apresentaram o maior número de ratificações: a Convenção de 1954, relativa ao processo civil; as Convenções de 1961 sobre o conflito de leis em matéria de forma das disposições testamentárias e supressão da exigência da legalização dos atos públicos estrangeiros; a Convenção de 1965, relativa à citação e à notificação no estrangeiro dos atos judiciais e extrajudiciais em matéria civil e comercial, a Convenção de 1970, que dispõe sobre a obtenção de provas no estrangeiro em matéria civil e comercial; e, ainda, as Convenções de 1980 e 1993, que dispõem sobre aspectos civis de sequiestro internacional de crianças e sobre a adoção internacional, respectivamente, cujo 
teor tem despertado relevado interesses dos cia. Estados membros e não membros da Conferên-

Imperioso ainda destacar que a finalidade expressa no Estatuto da Conferência tem sido alcançada, não só sob o ponto de vista do volume de trabalho que vem apresentando desde sua institucionalização, mas também, e principalmente, pela qualidade destes trabalhos, que desperta cada vez mais a atenção dos Estados não pertencentes ao seu corpo institucional.

\subsection{As Convenções da Conferência}

Em 1893, conforme anota DOLINGER, os idealizadores da Conferência aspiraram a elaboração de uma convenção ampla, que abrangesse todas as questões atinentes ao Direito Internacional Privado. Todavia, essa idéia foi abandonada por demais ambiciosa, optando a Conferência por elaborar convenções sobre matérias específicas no campo do conflito de leis, conflito das jurisdições e cooperação judiciária internacional. ${ }^{68}$

Tais convenções, como dito, são oriundas de um razoável período de análise e discussão, e aprovadas pelos membros da Conferência a cada Sessão Plenária quadrienal. ${ }^{69}$

Em geral, uma Convenção entra em vigor três meses após o depósito terceiro instrumento de ratificação, de aceitação ou de aprovação (ver, por exemplo, o art. 46 (1) da Convenção de 1993 sobre adoção internacional). ${ }^{70}$
Por conseguinte, para cada Estado que ratifica, aceita ou aprova uma Convenção já em vigor, a mesma passa a vigorar para ele três meses após o depósito do instrumento de sua ratificação, aceitação, aprovação ou adesão (ver, por exemplo, o art. 46 (2a) da Convenção de 1993 sobre adoção internacional).

Todavia, deve-se verificar atentamente a regra de vigência estabelecida ao final de cada Convenção, porque pode haver exceções à regra acima, que não se aplica per si.

As Convenções podem ser assinadas, ratificadas ou serem objetos de adesão. Ao as sinar uma Convenção, um Estado exprime, em princípio, sua intenção de tornar-se parte na Convenção. A assinatura, no entanto, não prejudica de maneira alguma eventual medida do Estado, que poderá ratificá-la ou não.

A ratificação envolve a assunção de uma obrigação jurídica para o Estado ratificante de aplicar a Convenção. $\mathrm{Na}$ terminologia da Conferência, a ratificação é, em geral, reservada aos seus Estados membros, com exceção da Convenção de 22 dezembro de 1986 sobre lei aplicável aos contratos de compra e venda internacional de mercadorias que é aberta à assinatura e à ratificação de todos os Estados, sem distinção, e da Convenção de 29 maio de 1993 sobre a proteção de menores e a cooperação em matéria de adoção internacional que também está aberta à assinatura e à ratificação de todos os Estados que participaram da Décima Sétima Sessão.
Os Estados que desejam tornar-se parte numa Convenção podem a ela aderir. Para isso, a Convenção deve estar em vigor, segundo as em certos casos, ser aceita pelos Estados já partes na Convenção. Esse sistema de aceitação varia de uma Convenção para outra: certas Convenções prevêem um sistema de aceitação

As Convenções aprovadas no âmbito da Conferência da Haia de Direito Internaciona Privado podem ser agrupadas pela matéria:

\begin{tabular}{|c|c|}
\hline \multicolumn{2}{|l|}{ Convenções anteriores a 1951 . } \\
\hline Título e número & Aprovada em \\
\hline a. Convenção para regular os conflitos de lei em matéria de matrimônio - (a); & 12.06 .1902 \\
\hline $\begin{array}{l}\text { b. Protocolo concernente à adesão à Convenção para regular os conflitos de lei } \\
\text { em matéria de matrimônio; }\end{array}$ & 28.11.1923 \\
\hline $\begin{array}{l}\text { c. Convenção para regular os conflitos de lei e de jurisdição em matéria de } \\
\text { divórcio e separação de corpos - (b); e }\end{array}$ & 12.06 .1902 \\
\hline d. Convenção para regular a tutela de menores - (c); & 12.06.1902 \\
\hline e. Convenção relativa ao processo civil - (d); & 17.07.1902 \\
\hline $\begin{array}{l}\text { f. Convenção concernente aos conflitos de leis relativos aos efeitos dos } \\
\text { matrimônios sobre os direitos e os deveres do casal em suas relações pessoais } \\
\text { e sobre os bens do casal - (e); e }\end{array}$ & 17.07.1905 \\
\hline g. Convenção concernente à interdição e os meios de proteção análogos - (f). & 17.07.1905 \\
\hline
\end{tabular}

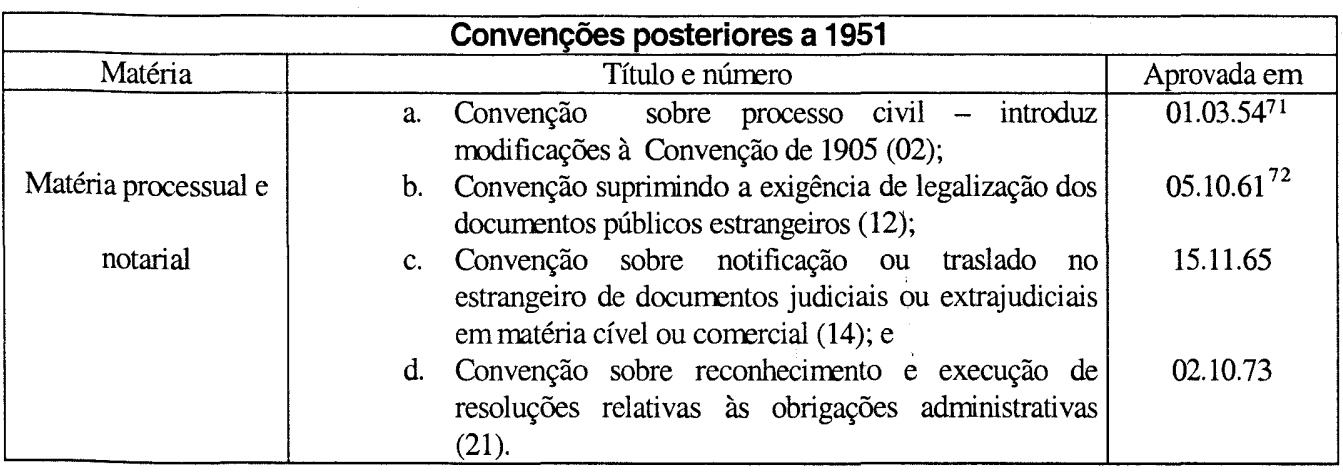

${ }^{71}$ Vigente para a Argentina desde 09.07.1988.

(âcita (à falta de oposiça de qualquer dos Estados partes, a exemplo do art. 58 (3) da Convenção de 1996 sobre a proteção de menores) que outras exigem uma aceitação exEstados partes da Convenção, exemplo do art. 38 (4) da Convenção de 1980 sobre os aspectos civis do seqüestro internaci onal de menores. regras antes evidenciadas. Essa adesão deve,

72 Vigente para a Argentina desde 08.02.1988.

${ }^{68}$ DOLINGER. Ob. cit., p. 77

${ }^{69} \mathrm{Nem}$ todas as Convenções concluídas na Haia são oriundas da Conferência da Haia de Direito Internaciona Privado, como, por exemplo, as Convenções da Haia de 1964 que são leis uniformes sobre a formação dos contratos de compra e venda internacional de mercadorias (LUFC) e a lei uniforme sobre a compra e vend internacional de mercadorias (LUVI).

${ }^{70}$ No início, era necessário que seis países aceitassem a Convenção para que ela entrasse em vigor

Revista da Faculdade de Direito da UFRGS, v. 20, Outubro/200 


\begin{tabular}{|c|c|c|}
\hline $\begin{array}{l}\text { Competência } \\
\text { internacional }\end{array}$ & $\begin{array}{l}\text { a. Convenção sobre a competência de foro contratual em } \\
\text { caso de venda de caráter internacional de objetos } \\
\text { móveis corpóreos (05); } \\
\text { b. Convenção para regular os conflitos entre a lei } \\
\text { nacional e a lei do domicílio (06); } \\
\text { c. Convenção sobre os acordos de eleição de foro (15); } \\
\text { d. Convença sobre reconhecimento e execução de } \\
\text { sentenças estrangeiras em matéria civil e comercial } \\
(16) ; \\
\text { e. Protocolo adicional à Convenção sobre } \\
\text { reconhecimento e execução de sentenças estrangeiras } \\
\text { em matéria civil e comecial (17); e } \\
\text { f. Convenção para facilitar o acesso internacional à } \\
\text { justiça (29). }\end{array}$ & $\begin{array}{l}15.06 .55 \\
25.11 .65 \\
01.02 .71 \\
01.02 .71 \\
\\
25.10 .80\end{array}$ \\
\hline $\begin{array}{l}\text { Matéria civil } \\
\text { e } \\
\text { Comercial }\end{array}$ & $\begin{array}{l}\text { A. Convenção sobre o reconhecimento da personalidade jurídica } \\
\text { de sociedades, associações e fundações estrangeiras (07); } \\
\text { B. Convenção sobre lei aplicável em matéria de acidentes } \\
\text { de circulação por rodovia (19); } \\
\text { C. Convenção sobre a obtenção de provas no estrangeiro } \\
\text { em matéria civil e comercial (20); } \\
\text { D. Convenção sobre a lei aplicável aos contratos de } \\
\text { intermediários e à representação (27) } \\
\text { E. Convenção sobre os aspectos civis do seqüestro } \\
\text { internacional de menores (28) } \\
\text { F. Convenção sobre a lei aplicável ao trust e ao seu } \\
\text { reconhecimento (30); e } \\
\text { G. Convenção sobre a proteção internacional dos adultos (35). }\end{array}$ & $\begin{array}{l}01.07 .56 \\
04.05 .71 \\
18.03 .70^{73} \\
14.03 .78^{74} \\
25.10 .80^{75} \\
01.07 .85 \\
13.01 .00 \\
\end{array}$ \\
\hline
\end{tabular}

\begin{tabular}{|c|c|c|c|}
\hline Direito de família & $\begin{array}{l}\text { a. } \\
\text { b. } \\
\text { c. } \\
\text { d. } \\
\text { e. } \\
\text { f. } \\
\text { g. } \\
\text { h. } \\
\text { i. }\end{array}$ & $\begin{array}{l}\text { Convenção sobre a lei aplicável às obrigações } \\
\text { alimentícias relativamente à menores (08); } \\
\text { Convenção sobre o reconhecimento e execução } \\
\text { de decisões em matéria de obrigações } \\
\text { alimentícias (09); } \\
\text { Convenção sobre competência de autoridades e } \\
\text { lei aplicável em matéria de proteção de menores } \\
\text { (10); } \\
\text { Convenção sobre competência de autoridades, } \\
\text { lei aplicável e reconhecimento de decisões em } \\
\text { matéria de adoção (13); } \\
\text { Convenção sobre o reconhecimento de divórcios } \\
\text { e separações de corpos (18); } \\
\text { Convenção sobre lei aplicável às obrigações } \\
\text { alimentíias (24); } \\
\text { Convenção sobre lei aplicável aos regimes } \\
\text { matrimoniais (25); } \\
\text { Convenção relativa à celebração e ao } \\
\text { reconhecimento do matrimônio (26); } \\
\text { Convenção sobre cooperação internacional e à } \\
\text { proteção da criança em matéria de adoção } \\
\text { internacional (33); } \\
\text { Convenção sobre a competência, a lei aplicável, } \\
\text { a reconhecimento, a execução e a cooperação } \\
\text { em matéria de responsabilidade parental e de } \\
\text { meios de proteção de menores (34). }\end{array}$ & $\begin{array}{l}24.10 .56 \\
15.04 .58 \\
05.10 .61 \\
15.11 .65 \\
01.07 .70 \\
02.10 .73 \\
14.03 .78 \\
14.03 .78 \\
29.05 .93^{76} \\
19.10 .96\end{array}$ \\
\hline Direito das sucessões & a. & $\begin{array}{l}\text { Convenção sobre os conflitos de leis em matéria } \\
\text { de forma das disposições testamentárias (11); } \\
\text { Convenção sobre a administração internacional } \\
\text { das sucessões (21); e } \\
\text { Convenção sobre a lei aplicável às sucessões por } \\
\text { causa mortis (32) }\end{array}$ & $\begin{array}{c}5.10 .61 \\
2.10 .73 \\
01.08 .89^{77}\end{array}$ \\
\hline $\begin{array}{l}\text { Compra e Venda } \\
\text { Internacional }\end{array}$ & a. & $\begin{array}{l}\text { Convenção sobre a lei aplicável às vendas de caráter } \\
\text { internacional de objetos móveis corpóreos (04); } \\
\text { Convenção sobre a lei aplicável à transferência da } \\
\text { propriedade em caso venda de caráter internacional de } \\
\text { objetos móveis corpóreos (05); e } \\
\text { Convenção sobre a lei aplicável aos contratos de } \\
\text { compra e venda internacional de mercadorias (31). }\end{array}$ & $\begin{array}{l}15.06 .55 \\
15.06 .55\end{array}$ \\
\hline $\begin{array}{c}\text { Respons. Contratual e } \\
\text { extracontratual }\end{array}$ & \multicolumn{2}{|c|}{$\begin{array}{l}\text { A. Convenção sobre lei aplicável à responsabilidade por produtos } \\
(22) \text {. }\end{array}$} & 02.10 .73 \\
\hline
\end{tabular}

${ }^{73}$ Vigente para a Argentina desde 07.07.1977.

${ }^{74}$ Vigente para a Argentina desde 01.05.1992.

${ }^{75}$ Vigente para a Argentina desde 01.06.1991, para o Brasil desde 01.01.2000, para o Chile, desde 01.05.1994, para o Uruguai desde 01.02.200, e para o Paraguai desde 01.10.1989, embora como Estado não membro da Conferência.

${ }^{76}$ Vigente para o Brasil desde 01.07.1999, para o Chile desde 01.11.1999, e para o Paraguai desde 01.09.1998. O Uruguai e a Bolívia somente a assinaram e a Argentina ainda não aderiu a ela.

${ }^{77}$ Embora assinada pela Argentina, ainda não foi por ela ratificada. De qualquer forma, é Convenção que ainda não entrou em vigor.

${ }^{78}$ Ratificada pela Argentina em 04.10.1991, mas ainda não em vigor para ela. 
Das Convenções acima nomeadas, o Brasil ratificou a que trata da cooperação internacional e da proteção da criança em matéria de adoção internacional, concluída em 29 de maio $1993^{79}$, informando à Conferência que as adoções de crianças cuja residência habitual estiver situada em seu território somente poderão ocorrer se as funções conferidas às Autoridades Centrais forem exercidas de acordo com o parágrafo $1^{\circ}$ do art. 22 , isto é, por autoridades públicas ou por organismos credenciados de conformidade com o capítulo III da Convenção, e sempre na forma prevista pela lei de seu Estado.

Aderiu o Brasil ainda à Convenção sobre os aspectos civis do seqüestro internacional de menores, concluída em 25 de outubro de $1980^{80}$, apondo uma reserva ao art. 24 desta Convenção ${ }^{81}$, conforme permissão do art. 42. Todavia, a reserva aposta foi além dos limites estabelecidos pelo dispositivo, provocando a manifestação do Governo Finlandês quanto à validade da declaração brasileira, o que não impediu que País tivesse sua adesão aceita pe-

los demais Estados partes e pela própria Finlândia que, no entanto, resguardou-se no direito de desconsiderar a reserva do Brasil nos termos em que ela foi feita, mas somente naquilo em que for incompatível com a Convenção..$^{82} 83$

Por fim, outros trabalhos vêm sendo desenvolvidos pela Conferência da Haia de Direito Internacional Privado. Em Comunicado à Imprensa lançado no início do mês de julho a Conferência noticiou a reunião diplomática (19 sessão, primeira parte) ocorrida no período de 6 a 22 de junho de 2001, no Palácio da Paz, em Haia, para fins de continuar as negociações sobre uma nova Convenção sobre a competência e os efeitos dos julgamentos estrangeiros em matéria civil e comercial. As delegações confirmaram, em unanimidade, estar de acordo com este projeto sobre os julgamentos, mas que a segunda parte da reunião não poderia ocorrer antes do final do ano de 2002, e deveria ser preparada por uma nova reunião da Comission sur les Affaires générales et la politique de la Conférence no início de 2002.

Conforme François DIESSE ${ }^{84}$, os auto-

79 Promulgada pelo Dec. 3.087, de 21.06.1999.

${ }^{80}$ Promulgada pelo Dec. 3.413, de 14.04.2000.

${ }^{81}$ "Art. 24 - Os pedidos, comunicações e outros documentos serão enviados na língua original à Autoridade Central do Estado requerido e acompanhados de uma tradução na língua oficial, ou numa das línguas oficiais, desse Estado, ou, quando tal tradução for dificilmente realizável, de uma tradução em francês ou inglês. No entanto, um Estado Contratante poderá, fazendo a reserva prevista no Artigo 42, opor-se à utilização seja do

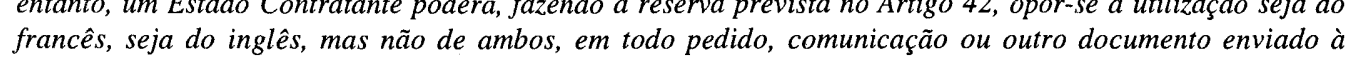
francês, seja do inglês, mas não
respectiva Autoridade Central."

${ }^{82}$ O Brasil, nos termos dos arts. 24 e 42 daquela Convenção, apôs uma reserva no sentido de que os pedidos, comunicações e outros documentos enviados na língua original à Autoridade Central do País deverão vir acompanhados de uma tradução na língua portuguesa, não aceitando, na hipótese de a tradução ser dificilmente realizável, uma tradução em francês ou inglês dos documentos, conforme autoriza o dispositivo comentado. Todavia, a Finlândia apontou que o Brasil não poderia apor essa reserva porque em desacordo com a segunda parte do dispositivo que autoriza o Estado Contratante opor-se à utilização seja do francês, seja do inglês, mas não de ambos, em todo pedido, comunicação ou outro documento enviado à respectiva Autoridade Central.

${ }^{83}$ Os conteúdos da reserva feita pelo Brasil e da manifestação do Governo da Finlândia estão disponíveis na Internet, no Site da Conferência, acessado pelo endereço www.hcch.net.

${ }^{84}$ DIESSE, François. Travaux des organizations internationales (Droit du commerce international). In Revue de Droit des Affaires Internationales, $\mathrm{n}^{\circ} 2,2.000$, p. 263.

Revista da Faculdade de Direito da UFRGS, v. 20, Outubro/2001 res desse projeto pretendem um trabalho adaptado às evoluções técnicas, econômicas, sociológicas e jurídicas do próximo século, com redação programática e disposições eficazes, simples, susceptíveis de serem compreendidas e aplicadas pelos operadores do Direito. Pretendem ainda que a Convenção alcance os objetivos de previsibilidade e de certeza das soluções; deve ter vocação universal no sentido de levar em conta todos os sistemas jurídicos e judiciários, bem como o respeito pelo equilíbrio entre as partes.

Outros pontos discutidos nesta $19^{\mathrm{a}}$ reunião-primeira parte, além do Projeto preliminar de Convenção elaborado em outubro de 1999. foram os resultados de reuniões de experts sobre o comércio eletrônico e a propriedade intelectual, que aconteceram em Otawa e em Genebra, e ainda os resultados das reuniões informais sobre este tema, que aconteceram em Washington, Otawa, Bâle e Edimbourg. Os delegados identificaram os pontos de acordo e decidiram que intensas consultas deveriam, a partir daí, ser iniciadas, a fim de preparar a próxima reunião da Comission sur les Affaires générales et la politique. Esta Comissão poderia examinar em detalhes se as condições são presentes para um resultado positivo destas negociações - notadamente um acordo suficiente sobre a maneira de abordar estes pontos-chaves sobre os quais um consenso não foi ainda encontrado, um método de negociação centralizado sobre os resultados e um calendário das eventuais futuras negociações.

A $19^{a}$ reunião- primeira parte - decidiu igualmente continuar a se lançar sobre o processo de negociação sobre um tema importante para os mercados financeiros modernos: uma convenção mundial sobre a lei aplicável aos títulos negociáveis em Bolsa, por agentes autorizados. Uma Comissão especial reunir-se-á em janeiro 2002 para elaborar um ante-projeto de Convenção, tendo em vista a adoção de texto final da Convenção durante 2002.
A $19^{a}$ reunião decidiu enfim incluir em suas prioridades para a $20^{\mathrm{a}}$ sessão diplomática uma Convenção mundial sobre o pagamento de pensões alimentares.

\section{Conclusão}

Esta breve análise sobre a Conferência de Haia não pode de forma alguma desejar-se completa. Tem, no entanto, o propósito de indicar que a Conferência da Haia Direito Internacional Privado continuará sendo oforum universal por excelência da codificação internacional deste ramo do direito, mesmo diante das novas contingências que a sociedade internacional impõe às relações internacionais, tais como os processos de integração regional, cuja unificação necessária ao processo atinge também a unificação do Direito Internacional Privado.

Segundo os termos do Secretariado, a Conferência da Haia de Direito Internacional Privado é a principal organização intergovernamental para a unificação e a cooperação no domínio do Direito Internacional Privado. Contando atualmente com 54 Estados membros, a organização é reputada pelas suas convenções em matéria de processo civil, de supressão das exigências de legalização, de direito comercial, de direito de família, principalmente em matéria de sequiestro de crianças e de adoção internacional, além de convenções sobre matéria testamentária e trust.

Apesar de ter caminhado por um terreno árido ao longo de mais de cem anos de sua existência, a Conferência consolida uma importante prática em elaboração e negociação de convenções de direito privado, que envolve não apenas o tato político necessário à discussão e aprovação de tratados e convenções, mas um grande esforço de conhecimento e harmonização de vários sistemas jurídicos nacionais, nem sempre pertencentes à mesma família. Esta lon- 
ga experiência possibilita a superação de contingências que surgem e autoriza à Conferência traçar com firmeza o seu caminhar na progressiva solidificação da "comunidade jurídica do gênero humano", propugnada por Jitta.

Esta breve exposição tem ainda o propósito de fomentar a curiosidade e o estudo deste complexo fenômeno associativo contemporâneo - o das organizações internacionais que se destinam à criação de normas jurídicas, como também o de aguçar o interesse dos juristas nacionais para esta área extremamente complexa do Direito, que evidencia extraordinária relevância nas relações jurídicas da atualidade e que compõem o universo normativo dos sistemas jurídicos nacionais, além do legislador ordinário.
Por fim, entendemos ter sido providencial a adesão do Brasil ao Estatuto da Conferência da Haia, pois, ao tornar-se membro efetivo desta importante organização internacional, repara o equívoco de ter, no passado, denunciado aquele instrumento.

Com a sua volta à Conferência da Haia, o Brasil cria um espaço no cenário internacional para contribuições riquíssimas que as nossa experiências internas e internacionais podem oferecer, a exemplo do que ocorreu no processo de elaboração e aprovação da Convenção sobre cooperação internacional e à proteção da criança em matéria de adoção internacional, de 29 de maio 1993, onde, ao lado das delegações dos tradicionais países membros da Conferência, atuou de maneira decisiva. ${ }^{85}$

${ }^{85}$ Quanto ao tema específico desta Convenção, que trata da cooperação internacional em matéria de adoção de menores, ver valioso Artigo da Professora Cláudia Lima Marques: "Notícia sobre a Convenção de Haia sobre Adoção internacional: Perspectivas de cooperação internacional e proteção dos direitos das crianças", publicado na Revista Igualdade - Ministério Público do Paraná, Curitiba, ano IV, n. ${ }^{\circ} \mathrm{XI}$, abr/jun 1996, p. 1 a 15.

\section{Pressupostos e Diferenças de um Direito Dogmaticamente Organizado}

\author{
Prof. Dr. Goão Mauricio Adeodato
}

Professor Titular de Introdução ao Estudo do Direito (Graduação) e de Filosofia do Direito (Mestrado e Doutorado) na Universidade Federal de Pernambuco.

\section{Introdução: objetivos e co- locação metodológica}

1 ste texto pretende apresentar parte de uma teoria sobre o direito moderno, não uma teoria universal para todo e qualquer direito, completando trabalho anteriormente publica$\mathrm{do}^{1}$. Sequer aspira a uma teoria geral do direito na modernidade, pela grande diversidade que isso comportaria. O texto procura fixar mais precisamente um conceito específico de direito (dogmático) dentro de um conceito específico de modernidade. Como objetivo corolário, tenta colocar uma teoria do direito moderno que considere e ajude a compreender algumas diferenças entre as formas de organização do direito postas pelas sociedades e Estados ditos desenvolvidos e aquelas características das periferias subdesenvolvidas de um mundo aparentemente globalizado em torno de capital tecnologia.

Diante dessas metas, as questões propriamente filosóficas só interessam aqui à guisa de introdução ao tema, indispensáveis porém subsidiárias. Indispensáveis enquanto fornecem as bases da metodologia de tratamento do problema do conhecimento e esclarecem- lhes os pressupostos, ao mesmo tempo em que estabelecer alguns pontos de partida, buscando facilitar a compreensão do texto, ainda que o leitor venha a entender por bem discordar do seu conteúdo. Assim, tomam-se aqui duas direções quanto aos pressupostos filosóficos, tentando controlar a ambigüidade e a vagueza quando se fala de um conceito de direito: redução do abismo gnoseológico e do abismo axiológico, que serão esclarecidos a seguir.

Antes de tudo, porém, uma colocação va de que o direito é uma forma de organização inerente às sociedades humanas, a aceitação do conhecido dito latino ubi societas ibi jus, isto é, "onde sociedade, aí direito", onde existe sociedade existe direito, preenchendo a elipse verbal. Esta aceitação aqui é instrumental, sem pretensões de verdade ou validade absolutas. Note-se que importantes filósofos e mesmo juristas a questionaram, tais como Karl Marx, para quem o direito seria uma doença ou pelo menos um remédio contra uma doença da sociedade, um instrumento para servir à dominação do homem pelo homem, tendente a desaparecer em uma sociedade plenamente desenvolvida são, por definição, infinitas. Por isso é preciso metodológica: este trabalho parte da perspecti-

${ }^{1}$ Adeodato, João Maurício: "Modernidade e direito". Revista Ciências Sociais, vol. 3, n ${ }^{\circ}$. Rio de Janeiro: Universidade Gama Filho, 1997, p. 264-279.

Revista da Faculdade de Direito da UFRGS, v. 20, Outubro/2001 
(comunista), sem luta de classes ${ }^{2}$, ou o jusfilósofo anticoercitivista polonês León Petrazycki, que entende a sanção jurídica como substitutivo do amor, pois a civilização é sempre uma progressiva realização do amor entre as pessoas, forma particular de razão emotiva do ser humano ${ }^{3}$.

Com todo o respeito que merecem os autores citados, mantém-se aqui a tese de que é o direito um dos fatores fundamentais para transformação de um mero agrupamento de seres humanos em uma sociedade, de que o termo expressa uma forma de comunicação social que organiza minimamente os contornos indispensáveis à constituição de uma sociedade, daí $u b i$ societas ibi jus.

Corroborando esta base metodológica, muito embora vários autores afirmem a possibilidade de sociedade sem direito, como dito, não parece haver ninguém que defenda a existência de direito em isolamento; para aqueles que vêem algum sentido na palavra "direito", certamente a sociabilidade humana, levando ao agrupamento dos seres humanos em comunidades, parece ser uma conditio sine qua non para o aparecimento de relações jurídicas, pois direito é interação. Portanto, mesmo havendo sociedade sem direito, posição marcadamente minoritária entre os juristas, não se afirma a possibilidade de direito sem "sociedade", esta palavra compreendida no sentido básico de mais de uma pessoa convivendo em algum mesmo lugar simultaneamente, segundo determinadas regras. Um conceito acompanha o outro.

Finalmente, cabe mencionar que existe a dificuldade lógica, ainda que não impossibilidade, de tentar fazer uma ciência ou teoria do direito entendendo-o como algo fadado a o passível de desaparecimento, ou mesmo algo circunstancial, contingente. A mutabilidade de seu objeto sempre foi um problema para os juristas preocupados com a cientificidade de suas pesquisa. Pior do que a mutabilidade parece ser a contingência ${ }^{4}$. Se o direito não é permanente na sociabilidade humana, pode não se justificar uma ciência ou uma filosofia do direito como setor específico do conhecimento.

Fixados esses pontos de partida, podese ir ao que aqui significam os dois abismos que dificultam o conhecimento, com os quais tem de se haver toda filosofia.

\section{Pressupostos filosóficos: o abismo gnoseológico e o abis- mo axiológico}

Uma teoria do direito precisa enfrentar, portanto, o abismo gnoseológico, que dificulta o conhecimento do mundo, e o abismo axiológico, que dificulta a avaliação do mundo. Aí estão os fundamentos da epistemologia e da ética jurídicas.

Pode-se explicar o que aqui se compreende por abismo gnoseológico através de três problemas que o compõem e que precisam ser transpostos ou ao menos tratados pela teoria ${ }^{2}$ Marx, Karl: Das Kapital - Kritik der politischen Ökonomie, Band 1. Marx Engels Werke, Band 23. Berlin: Dietz
Verlag, 1988, p. 99 e 789, ou Marx, Karl e Engels, Friedrich: Manifest der kommunistischen Partei. Berlin: Dietz Verlag, 1989, passim.

${ }^{3}$ Gurvitch, Georges: "Une philosophie intuitionniste du droit: Léon Petrazycki". Archives de Philosophie du Droit et de Sociologie Juridique, cahier duble n. 3-4. Paris: Sirey, 1931, p. 403-420. E Rooney, John: "Polish Legal Theory". Indian Socio-Legal Journal, vol. XVIII No. 1 \& 2. Jaipur: Indian Institute of Comparative Law, 1992 p. 107-114.

${ }^{4}$ Kirchmann, Julius Hermann von: Die Wertlosigkeit der Jurisprudenz als Wissenschaft - Vortrag gehalten in der Juristischen Gesellschaft zur Berlin (1848). Darmstadt: Wissenschaftliche Buchgesellschaft, 1966.

Revista da Faculdade de Direito da UFRGS, v. 20, Outubro/2001 do conhecimento: são as incompatibilidades recíprocas entre: a) evento real; b) idéia (ou "conceito", "pensamento"); e c) expressão lingüística (ou "simbólica"). Estas são as três unidades componentes do conhecimento humano, as quais não podem ser reduzidas uma à outra. Como são todos termos ambiguamente empregados na linguagem filosófica, necessário tentar melhor precisá-los.

Por evento real entende-se aqui o acontecimento único e irrepetível que, aparentemente de maneira independente do sujeito cognoscente, coloca-se presente em sua experiência ${ }^{5}$. Esta experiência, seja sensível, intelectual, de qualquer tipo, parece ser também única e irrepetível. A experiência real, mesmo que a partir de objetos não-reais, como na intelecção, é particularizada, individual, única, irrepetível, e é aqui considerada incognoscível ${ }^{6}$. Todo o individual é, em certo sentido, irracional para o ser humano, pois a individualidade, que é uma das características do mundo real, não se adapta ao aparato cognoscitivo do ser humano, que não consegue proceder sem generalizações. $\mathrm{O}$ individual é irracional por ser irredutivelmente contingente. Há uma novidade radical em tudo o que é real e, por isso, qualquer regra geral estabelecida pela razão seleciona alguns aspectos em detrimento de outros. Seguindo uma forte tradição na cultura filosófica do Ocidente, une-se aqui razão a generalização. Além de qualitativamente ilimitada, pois o individual nunca se repete, a irracionalidade individual é também quantitativamente infinita, pois todo indivíduo pode ser mais e mais decomposto em elementos menos complexos: moléculas, átomos, prótons, quarks, a física enfrenta dificuldades na busca pela unidade da matéria.

O leitor atento deve observar que, mesmo diante de uma experiência intelectual, como a intelecção, o objeto será geral, como o triângulo escaleno ou o teorema de Pitágoras, conseqüentemente irreal e ideal, mas a experiência psíquica diante dele é um evento real na consciência, logo único e irrepetível. Quer dizer, a idéia é sempre geral, mas a experiência de cada idéia ou pensamento por parte deste ou daquele indivíduo não deixa de ser um acontecimento real, passível de observação empírica desde que disponíveis os meios adequados.

Um outro aspecto é diferençar claramente o ideal e o irreal: todo ideal é irreal, no sentido de que não é parte da realidade; mas nem todo irreal é ideal. Dividem a característica da irrealidade, mas não se confundem: ideais são a relação de igualdade e a circunferência perfeitas, são objetos que existem idealmente; irreais são o centauro e a quimera, o imaginário, o fictício, existem apenas no sujeito enquanto fenômeno psíquico. Por isso prefere-se aqui o termo "idéia" para designar o que existe idealmente e o termo "pensamento" para compreender os objetos irreais em sua totalidade.

Assim, por idéia entende-se o estímulo que se completa no sujeito no ambiente de seu defrontar-se com os eventos. Ocorre em uma espécie de síntese, uma generalização ideal combinada com os eventos reais. Uma generalização irreal, portanto, posto que tudo o que é real é particular, mas não imaginária. São essas generalizações que permitem à mente humana pensar conjuntamente eventos, fazer sentido. Alguns outros animais parecem ser capazes de proceder a semelhante operação. A idéia é o resultado de um processo que tenta abstrair os aspectos particulares dos eventos e detectar

${ }^{5}$ Weinberg, Steven: "Os limites da explicação científica". Folha de São Paulo (Caderno Mais). São Paulo domingo, 24 de junho de 2001, p. 8.

${ }^{6}$ Para essa perspectiva gnoseológica cf. Hartmann, Nicolai: Grundzüge einer Metaphysik der Erkenntnis. Berlin: Walter de Gruyter, 1946, p. 302-306. Adeodato, João Maurício: Filosofia do direito. Uma crítica à verdade na ética e na ciência (através de um exame da ontologia de Nicolai Hartmann). São Paulo: Saraiva, 1996, p. 104. 
neles algo de comum que permita reuni-los em "classes", em "setores" ou coisa que o valha, em suma, classificá-los. Assim é que, mesmo sem ter visto todas as cadeiras que existem na realidade, o ser humano é capaz de, através de operação complexa e ainda não satisfatoriamente explicada, diante de uma cadeira com que nunca teve contato, pensar nela e defini-la como uma cadeira.

Essas idéias, ou como quer que seja denominado o fenômeno, e suas relações com os eventos são por vezes consideradas pelos filósofos ontologicamente, existentes em si mesmas, como no caso das idéias de Platão ${ }^{7}$, ou meras palavras, flatus vocis, como na Escolástica nominalista ${ }^{8}$, ou como resultado de um determinado desenvolvimento cultural que poderia não ter ocorrido, como sugerem Richard Rorty ou Hans Blumenberg, detectando uma atividade seletiva e relativamente arbitrária na escolha dos caracteres principais dos objetos ${ }^{9}$. Tomando a tese de Husserl como exemplo ${ }^{10}$, a redução fenomenológica transcendental consiste em retirar mentalmente do objeto as características acidentais que apresenta para chegar a sua essência enquanto fenômeno colocado diante da consciência cognoscitiva do ser humano. Retirando os aspectos contingentes e individualizadores de todas as cadeiras, acredi-

ta Husserl, chega-se à essência mesma de "cadeira". Todo sujeito procede a operação semelhante quando nomeia e observa os objetos, quaisquer que sejam, ainda que tal atitude não pareça ter o caráter ontológico que Husserl lhe quis imprimir.

Mesmo sendo a idéia geral, ou generalizante, ela ainda é única em relação ao sujeito que a produz, pois cada um seleciona alguns aspectos em detrimento de outros dentre os infinitos atributos que o evento apresenta. Em sua plenitude a idéia é incomunicável, pois o processo de concebê-la e transmiti-la outrem passa por sua vez pela linguagem, a qual já passa a ser um evento da realidade, e submete-a aos critérios relativos do receptor da mensagem, do ambiente e contexto da comunicação, etc.

O termo "conceito" é ambiguamente em pregado, a depender do filósofo, com três sentidos básicos: como o que aqui se denomina "idéia", o que está "por trás" da expressão lingưística, o "primeiro" nível de generalização, se se partir do evento real como referência do ato gnoseológico; ou como essa própria expressão lingüística da idéia, o "segundo" nível de generalização; e ainda observa-se uma sinonímia dominante na linguagem comum, entre "conceito" e "definição", quando, a rigor, definição

7 Platão: Parmenides, in The Dialogues of Plato, translated by Benjamin Jowett, Great Books of the Western World, vol. 6. Chicago: Encyclopaedia Britannica, 1990, p. 486-511. Para Platão os universais existem antes do objetos, diferentemente de Aristóteles, para quem os universais estão nos próprios objetos (teses depois denominadas universalia ante rem e universalia in re, respectivamente).

${ }^{8}$ Russell, Bertrand: History of Western Philosophy - and its Connection with Political and Social Circumstances from the Earliest Times to the Present Day. London: Routledge, 1993, p. 175 s. e 430.

${ }^{9}$ Dentre outros trechos Rorty, Richard: A filosofia e o espelho da natureza, trad. de Antônio Trânsito. Rio de Janeiro: Relume-Dumará, 1994, p. 51 s. Blumenberg, Hans: Die Lesbarkeit der Welt. Frankfurt a. M.: Suhrkamp, 1993 , p. 373 s.

${ }^{10}$ Husserl, Edmund: Ideen zu einer Reiner Phänomenologie und Phänomenologischen Philosophie, Gesammelte Werke, Band III. W. Biemel (Hrsg.). Haag: Martinus Nijhoff, 1956, p. 23-24, e os caps. III (Noesis und Noema) e IV (Zur Problematik der noetisch-noematischen Strukturen), parte III, e § 97, p. 242 s. Também sobre o caráte ôntico da noemática, Husserl, Edmund: Meditaciones Cartesianas, trad. Mario Presas. Madrid: ed. Paulinas, 1979 $\S 43$, p. 152 s. Criticamente Sukale, Michael:Denken, Sprechen und Wissen. Logische Untersuchungen zu Husserl und Quine. Tübingen: J.C.B. Mohr, 1988, p. 272 s.

Revista da Faculdade de Direito da UFRGS, v. 20, Outubro/2001 seria uma tentativa de explicitação analítica dos elementos do conceito a ser definido, lançando mão, por sua vez, de outros conceitos. Aqui vai-se tomar o primeiro sentido, de "idéia", sempre que aparecer o termo "conceito", tentando evitar a imprecisão desse termo. Vai-se também deixar de lado a análise da "filtragem biológica" e da "filtragem ideológica", anteriores a qualquer tratamento linguiístico, as quais parecem ocorrer entre a percepção dos eventos reais e a formação noemática das idéias, tema importante na semiótica contemporânea ${ }^{11}$.

A expressão simbólica comunica a idéia, reintroduzindo-a no mundo real, sempre de maneira incompleta e ainda mais generalizada do que aquela, pois a idéia é ainda individual em relação ao sujeito, enquanto a expressão tem pretensões de comunicabilidade genérica para um determinado universo de receptores dentro de uma linguagem. Não há uma correspondência completa entre a idéia e a realidade, é certo, mas parece haver alguma compatibilidade; um indício neste sentido é que se os cálculos forem assado e não assim, a ponte planejada pelo engenheiro cai. Este um dos grandes problemas que preocupou Kant: como é possível que haja uma correspondência entre fenômenos cerebrais, como cálculos matemáticos, e o mundo rea ${ }^{12}$. A expressão lingüística, por seu turno, parece ser ainda mais distante da realidade individualizada, posto que busca representar e comunicar a idéia, constituindo o segundo nível de generalização mencionado. "Assim, o recurso ao universal não é uma força do pensamento, mas uma enfermidade do discurso. $O$ drama é que o homem fala sempre em geral enquanto as coisas são singulares." ${ }^{\prime 13}$

Ao ser expressada a idéia, ela penetra novamente no mundo sensível e constitui-se por sua vez em evento real, como dito. Então é reiniciado esse processo de conhecimento do mundo. Ciências ideais como as matemáticas puras, por exemplo, têm de se haver apenas com os fatores da idéia e de sua expressão simbólica, posto que não trabalham com eventos reais; já ciências empíricas como a geografia física deparam-se com os três fatores. O direito e outros campos do conhecimento, porém, ainda se deparam com um quarto elemento complicador, trazido pela valoração que os envolve, as perspectivas emocionais diferentes e por vezes antagônicas que as pessoas têm sobre o mundo.

Este outro problema é o abismo axiológico, também decorrente da individualidade humana e de sua criatividade reativa e ativa diante do ambiente, das enormes diferenças entre as pessoas, que são entes reais e cujas atitudes constituem eventos reais. A cultura, em que o direito tem papel fundamental, precisa lidar com essas diferenças e tentar reduzi-las, organizá-las. Um problema gnoseológico apresenta-se, por exemplo, quando se afirma que só a mulher pode ser vítima do crime de estupro, como no atual texto do código penal brasileiro, e é preciso definir se determinada pessoa que sofreu violência sexual no caso concreto é ou não uma mulher, o que pode ser problemático diante dos progressos da medicina. Um problema axiológico surge quando se questiona por que uma pessoa do sexo masculino violentada não deve ser encarada como vítima do crime de estupro, tipificando-se retoricamente o crime como atentado violento ao pudor ou lesão corporal.

${ }^{11}$ Bizzocchi, Aldo: "Cognição - como pensamos o mundo". Ciência Hoje, vol. 30, n 175. Rio de Janeiro: Sociedade Brasileira para o Progresso da Ciência (SBPC), p. 34-40.

${ }^{12}$ Kant, Immanuel: Kritik der Reinen Vernunft,. Werkausgabe - in zwölf Bände, Bd. III, W. Weischedel (Hrsg.) Frankfurt a.M. 1977, S. 76 (A 28, B 44) und 82 (A 35, 36; B 52).

${ }^{13}$ Eco, Umberto: Kant e o ornitorrinco, trad. Ana Thereza Vieira. Rio de Janeiro - São Paulo: Record, 1998, p. 28 
Do ponto de vista do conhecimento, assumido aqui, tentativa de solução é assumir uma perspectiva científica, entendida com um mínimo de partidarismo e a partir de uma atitude na medida do possível neutra e objetiva. Pode-se denominar essa concepção "positivista", excluídas as conotações reducionistas da expressão no campo jurídico.

Nas origens históricas da cultura ocidental, no que concerne ao direito, o abismo axiológico tem sido enfrentado através da no. ção de legitimidade. Da procura, desde a Grécia antiga, por uma instância que separasse o poder efetivo da legitimidade, à distinção romana entre auctoritas e potestas, herdada e transmitida pela grande síntese da Igreja Católica, a cultura ocidental tem sempre procurado uma base que fundamente a legitimidade ${ }^{14}$. Só na modernidade a prática e a teoria do direito passam a reconhecer e afirmar a auto-determinação do direito positivo, evitando como extra-jurídico o problema da legitimidade. A legitimidade não só se confunde com a legalidade enquanto princípio básico mas também com a própria validade das normas jurídicas. $O$ direito passa a ser identificado com aquilo que é produzido de acordo com as regras do sistema, por autoridade declarada competente para tanto e seguindo rito de elaboração específico, estando o sentido das normas inferiores subordinado ao sentido das normas superiores independentemente de seu conteúdo "ideológico", "axiológico", "material". Observe-se o conceito de constitucionalidade material e formal, base de legitimidade, de legalidade, de validade do sistema ${ }^{15}$.

O abismo axiológico reflete-se também na dicotomia entre jusnaturalismo $e$ juspositivismo colocada pela modernidade. $\mathrm{O}$ jovem estudioso espanta-se como podem ser quase todos os pensadores dos últimos duzentos anos positivistas, se todos eram jusnaturalistas nos três mil anos que antecederam esse período. É que o direito mudou muito. Mesmo os mais ferrenhos antipositivistas têm de se haver com o fenômeno da dogmatização do direito e seus corolários. E daí vem a grande questão: se o direito é fruto da vontade do poder empiricamente estabelecido, autodeterminado e autolimitado, ou se há direito acima ou independentemente do poder efetivo. A questão atual da universalidade dos chamados direitos humanos é ilustrativa a respeito ${ }^{16}$.

Pode-se afirmar a existência de direito ou direitos em si mesmos válidos, fora do sistema positivo, direitos que seriam inerentes à própria condição humana; esta ideologia encontra problemas ao se defrontar com a grande diversidade cultural que vem caracterizando as comunidades humanas segundo seu desenvolvimento histórico no tempo e no espaço. Do outro lado, ao afirmar a total subordinação das normas jurídicas às contingências históricas $e$ à luta pelo poder, a ideologia positivista vê-se diante do problema de admitir como jurídico todo e qualquer conteúdo normativo, tal como negar direito à vida a segmentos humanos assemelhados. É o problema do poder constituinte originário incondicionado e da norma fundamental independente de conteúdo axiológico de Kelsen.

${ }^{14}$ Adeodato, João Maurício: O problema da legitimidade - no rastro do pensamento de Hannah Arendt. Rio de Janeiro: Forense-Universitária, 1989, p. 29-52.

${ }^{15}$ Dentre muitos outros v. Silva, José Afonso da: Curso de direito constitucional positivo. São Paulo: Malheiros, 1992, p. 48.

${ }^{16}$ Para uma visão contemporânea da questão, aliada aos direitos naturais, Rabenhorst, Eduardo Ramalho: "Dever e obrigação", in Felipe, Sônia (org.): Justiça como eqüidade - fundamentação e interlocuçôes polêmicas (Kant, Rawls, Habermas). Florianópolis: Insular, 1998, p. 291-300, e Noleto, Mauro de Almeida: Subjetividade jurídica. A titularidade dos direitos em perspectiva emancipatória. Porto Alegre: Fabris, 1998, p. 85-127.

Revista da Faculdade de Direito da UFRGS, v. 20, Outubro/2001
A dogmatização do direito que vem ocorrendo na modernidade parece vir em apoio a esta segunda ideologia. Basta que se observe o conceito de justiça advindo dos tribunais modernos, que são de fato responsáveis pela realização, no sentido literal e filosófico de "torna real", do direito e da norma jurídica. "Justa" é a decisão que toma por base as regras do sistema dogmático positivado pelo poder, seja pelo Talibã, seja pelas cortes de Amsterdã. "Injustiça" permanece, em termos jurídicos, um conceito interno ao próprio direito positivo.

Algumas estratégias podem ajudar a tratar os problemas provocados pelo abismo gnoseológico, as quais serão brevemente sugeridas a seguir.

Uma delas é entender os conceitos descritivos da realidade, claro que incluindo o que é dito aqui, em termos dos Idealtypen de Max Weber. Esses tipos ideais constituem generalizações que, através de abstrações controladas, pretendem reunir unidades reais, em si mesmas incognoscíveis, em conceitos ideais aproximativos. Exatamente porque uma separação precisa não é possível na realidade, os conceitos claros e precisos são mais necessários ainda. Com efeito, o método weberiano imuniza contra a ingenuidade da concepção ontológica, "realista", da língua e ajuda a reduzir pretensões de verdade e a enfrentar com mais segurança o abismo gnoseológico. Só assim a casuística sociológica é possível ${ }^{17}$. É daí que, embora não seja possível encontrar uma sociedade efetivamente legitimada pela via legal-racional weberiana, pode-se dizer que quanto mais institucionalizada a legalidade, mais racional o procedimento legitimador. Da mesma forma,

pode-se enunciar que uma sociedade estará tanto mais em condições de dogmatizar o seu direito quanto mais seus subsistemas estejam reciprocamente imunizados contra as interferências mútuas, mesmo sabendo que, no mundo real, tal imunização jamais ocorre de forma completa.

Em segundo lugar, além de encarar os conceitos como tipos ideais, não se procura aqui definir "o direito" em si, se é que é viável tal tipo de definição, mas simplesmente descrever algumas características de um fenômeno social a que parece se referir esse conceito. Procura-se evitar deste modo a armadilha das definições pretensamente totalizadoras, as quais ou deixam de lado aspectos fundamentais do fenômeno jurídico ou são tão genéricas que, apesar de corretas, em nada auxiliam na compreensão do objeto definido. Definir o direito como "ordenação heterônoma e coercível da conduta humana", "realidade que se refere ao valor do justo", "generalização congruente de expectativas" ou "conjunto de normas coercitivas que possibilita a convivência social", além de atribuir-lhe uma pluralidade de significações definidas, como fazem tradicionalmente os livros de teoria geral do direito ${ }^{18}$, pode até corresponder ao objeto definido, mas pouco ajuda a compreender cientificamente o fenômeno jurídico ou a argumentar dogmaticamente.

Conta-se na Faculdade de Direito do Recife de um exame oral, nos idos da década de vinte, no qual o professor Andrade Bezerra, catedrático de direito civil, teria solicitado de um aluno uma definição do direito. $O$ aluno não teve dúvidas: "é um círculo dentro do qual obramos, mestre". A esta frase teria retorquido o professor: "ora, meu filho, esta é a definição de

${ }^{17}$ Weber, Max: Wirtschaft und Gesellschaft - Grundriss der verstehenden Soziologie. Tübingen: J.C.B. Mohr (Paul Siebeck), 1985, p. 9-10 (I, I, 11).

${ }^{18}$ Reale, Miguel: Lições preliminares de direito. São Paulo: Saraiva, 1994, p. 49; Batalha, Wilson de Souza Campos: Introdução ao estudo do direito. Rio de Janeiro: Forense, 1986, p. 9; Montoro, André Franco: Introdução à ciência do direito, $20^{\mathrm{a}}$ edição refundida com a colaboração de Luiz Antonio Nunes. São Paulo: Introdução à ciéncia do direito, 20 s.
Revista dos Tribunais, $1991, \mathrm{p} .29 \mathrm{~s}$. 
urinol!"'19 . Esta anedota ilustra bem como uma definição omnicompreensiva, ainda que correta, pode induzir em erro e designar idéias inteiramente diferentes. De outro lado, expressões conceituais homônimas podem ser esclarecidos pela definição, a qual as detalha lingüisticamente e permite a diferenciação.

Depois, em terceiro lugar, procura-se privilegiar aqui uma sociologia compreensiva d perspectiva etnometodológica. Etnometodologia entendida como uma perspectiva da sociologia do conhecimento que se interessa pelas obviedades que, por isso mesmo, passam despercebidas, aquelas significações $\mathrm{e}$ pontos de acordo localizados que ficam subentendidos no relacionamento social. O casuísmo da perspectiva etnometodológica procura responder aos novos tempos, nos quais as verdades longa e tradicionalmente aceitas passam a ser questionadas, levando a problemas de "falta de orientação, desorganização e anomia" e tornando fundamental a construção de um novo entendimento sobre temas que pareciam resolvidos, a construção de uma nova realidade e de uma aproximação científica adequada, pois "A confiança naquilo que 'todos sabem' ou 'ninguém faz' começa a desaparecer" 20

Segundo a perspectiva etnometodológica, a realidade deve ser entendida sobretudo como realidade empírica, aquela que se dá no "mundo exterior" e é apreendida pelos órgão dos sentidos e demais portas da percepção. Isto porque os objetos desse mundo exterior, um dos quais é o corpo humano, oferecem resistência e diminuem as possibilidades da livre ação, isso quando não simplesmente as eliminam. A observação de tal realidade não deve se concentrar, de um ponto de vista filosófico, em aspectos materiais da conduta, em conteúdos específicos, pois esses são infinitamente variáveis no tempo e no espaço, necessita procurar abstrair, "idealizar" padrões e expectativas de normalidade e racionalidade. Alguns desses padrões e expectativas parecem, inclusive, ancorados geneticamente em um desenvolvimento das capacidades cognitivas da espécie humana, como, por exemplo, a convicção de que o mundo real independe da opinião pessoal sobre os eventos ocorridos. Outros parecem ter maior interferência do ambiente cultural, por exemplo, a expectativa de que percepções e condutas passadas venham a se repeti em contextos semelhantes ${ }^{21}$. Um estudo mais aprofundado dessa perspectiva ficará para outra oportunidade.

Da outra parte, para tentar tratar dos problemas provocados pelo abismo axiológico mister abstrair de qualquer valoração prévia a questão da modernidade ou da atual pós-modernização globalizada do direito. A modernidade simplesmente trouxe ao direito, fenômeno inerente à sociabilidade humana, como visto, formas próprias de organização. Ser "moderno" não significa ser melhor ou mesmo "mais eficiente" no sentido de efetivamente dirimir conflitos. O direito moderno parece ser o mais eficiente para a sociedade que o produz, apenas isto, esta mesma sociedade que perspectivas jusnaturalistas não conseguem explicar satisfatoriamente. Não se pode dizer que ele torna as pessoas mais ou menos felizes, que ele enseja ou não um desenvolvimento moral ou intelectual mais pleno do ser humano ou da sociedade.
${ }^{19}$ Veiga, Gláucio: História das idéias da Faculdade de Direito do Recife, vol. IX. Recife (no prelo).

${ }^{20}$ Patzelt, Werner: Grundlagen der Ethnomethodologie. Theorie, Empirie und politikwissenschaftlicher Nutzen einer Soziologie des Alltags. München: Wilhelm Fink, 1987, p. 9-14 e 25.

${ }^{21}$ Patzelt, Werner: Grundlagen der Ethnomethodologie. Theorie, Empirie und politikwissenschaftlicher Nutzen einer Soziologie des Alltags. München: Wilhelm Fink, 1987, p. 57.

Revista da Faculdade de Direito da UFRGS, v. 20, Outubro/200
Quando utilizada a expressão "modernidade", então, não há qualquer conotação elogiosa, que a palavra tem adquirido na arrogância da sociedade que se diz moderna, ou pejorativa, como costumam referir os saudosistas de tempos idos.

\section{Pressupostos semânticos paraum conceito instrumental de modernidade}

Relacionando o conceito ao objeto que ele pretende designar, assumem-se aqui dois pontos de partida para tentar definir a modernidade.

Em primeiro lugar, o conceito de modernidade é qualitativo, relativo a um estado inusitado que o direito apresenta enquanto forma de organização social. Em outras palavras, 0 conceito de modernidade não é meramente resultado do fluxo histórico do tempo. Para se "moderna", não é suficiente uma sociedade pertencer aos séculos XIX ou XX, ela precis apresentar certas características específicas em sua estrutura organizacional. Sistemas fundamentalistas contemporâneos, fazendo o direito e a religião inseparáveis, ou Estados embasados em nepotismo e relações de parentesco ou amizade, não são modernos no senti- do aqui empregado, assim como não é pós-moderno isto ou aquilo que acontece na "era da globalização", pois as características da modernidade não dependem de prazos, pontos determinados no tempo. O direito dogmaticamente organizado é o direito moderno por excelência, não por estar onipresente, mas sim pelo seu caráter historicamente inusitado, inexistente na pré-modernidade. $\mathrm{O}$ direito dogmático é moderno mas nem todo direito contemporâneo é dogmático. modernidade não é escatológico. "Escatologia" tem dois sentidos etimologicamente diversos: do grego skór, atós, ou seja, excremento ou caráter relativo a excremento, que obviamente não é o significado aqui; e do grego éscathos, último, isto é, uma "doutrina sobre a consumação do tempo e da história", um "tratado sobre os fins últimos do homem"'22. A atitude de recusar teorias escatológicas parte da compreensão de que a história é imprevisível, nada promete para o futuro, que o futuro enquanto tal não existe, constituindo mero artifício verbal. Não se entende aqui que os parâmetros de organização do direito definidos como modernos constituem um caminho pelo qual evoluirão todos os povos e a sociedade globalizada. Muitos dos sistemas jurídicos alopoiéticos contemporâneos apresentam outras formas também altamente complexas e estáveis, estrategicamente bemsucedidas, de positivação do direito ${ }^{23}$, como
Em segundo lugar, o conceito de

${ }^{22}$ Ferreira Aurélio Buarque de Holanda: Novo Dicionário da Língua Portuguesa. Rio de Janeiro: Nova Fronteira 1986, p. 686, e Meyers Konverstions-Lexicon, fünfter Band. Leipzig/Wien: 1897, p. 996. Para uma ligação do pensamento escatológico ao pensamento teológico, v. Blumenberg, Hans: Die Legitimität der Neuzeit. Frankfurt a. M.: Suhrkamp, 1999, p. 47. Sobre as conexões entre o pensamento metodológico moderno e suas origen teológicas cf. Saldanha, Nelson: Da teologia à metodologia - secularização e crise no pensamento jurídico. Belo Horizonte: Del Rey, 1993, p. 95 s.

${ }^{23}$ Observe-se que o conceito de positivação aqui colocado é mais amplo do que o sentido que lhe parece dar Luhmann, não aparecendo, entre outras diferenças, como corolário do Estado democrático, legitimado procedimentalmente através de constitucionalização, legalização reflexiva do direito ou controle politicamente

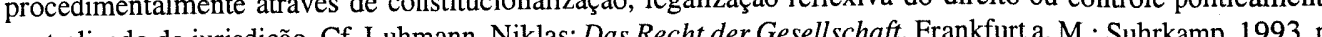
centralizado da jurisdição. Cr. Luhmann, Niklas. Das Rech der Gesellschaf. Frankura. M.: Suhkamp, 1993, p. 38 s., 145-146, 277-278 e 410. Ou anteriormente em Luhmann, Niklas: Legitimation durch Verfahren. Frankfur a. M.: Suhrkamp, 1983 , p. 151 s. 
visto em artigos anteriores ${ }^{24}$.

Além do fato de que não se pode detectar um "caminho histórico" em direção à modernização, poucas formas de organização jurídica existente hoje em dia são modernas no sentido em que o termo é empregado aqui.

Este segundo pressuposto semântico pode ser exemplificado por oposição a concepções holísticas, pretensiosamente dirigidas a explicações não apenas totalizadoras mas ao mesmo tempo previsoras do que está por vir, em uma transposição ingênua e mais do que indevida de categorias (no sentido de "vícios do pensamento") fisio-químico-biológicas a realidades mais complexas e imprevisíveis. São resquícios do intrincado relacionamento entre o pensamento escatológico antigo e os "sucessos" de formas científicas modernas, "dominadoras da natureza", o qual gerou concepções da história tão diferentes entre si como as do cristianismo, com sua concepção de juízo final, justiça aos bons que sofrem nesta vida $e$ aos maus que têm saúde, amigos, poder, aind que a observação empírica não lhes dê respaldo; do liberalismo, com uma escatologia otimista de progresso comandado pelo "mercado", entidade metafísica no mais intrincado sentido do termo, guia da história e da "evolução" da humanidade; do marxismo, prevendo a espiral histórica do feudalismo ao comunismo, passando pelo capitalismo e pelo socialismo; do darwinismo, detectando uma linha evolutiva determinada pela adaptação do ser vivo ao meio ambiente. E ainda outros.
Mais procedente parece conceber a história da humanidade conforme ilustrada pelo mito grego de Sísifo. Este rei de Corinto fo condenado por Zeus a ficar eternamente no Hades, arrastando montanha acima uma rocha que sempre the escapava e rolava montanh abaixo antes de atingir o topo. O motivo do castigo seria ter revelado o rapto de Egina a seu pai, o deus-rio Asopo, sendo Zeus o raptor segundo outros relatos, Sísifo teria enganado e aprisionado Hades, o próprio deus da morte, fazendo com que, durante certo tempo, ninguém morresse ${ }^{25}$. A pedra representa a história, repleta de altos e baixos, avanços e recuos; Sísifo é a humanidade; a montanha é o mundo.

Perguntar-se-á, então, por que estudar a modernidade jurídica, dogmatizada nessas características que serão aqui adiante expostas, se ela existe de fato em apenas alguns países e se nada garante será efetivada nos demais. Dentre outras, cabe ressaltar três motivações principais.

A um, os Estados que dogmatizaram seu direito parecem deter a supremacia militar, ideológica e política do mundo atual. A dogmatização do direito constituiu-se em um instrumento importante para a eficiência do padrão europeu. Parece ser um dos fatores importantes para o domínio relativamente recente da cultura branca européia sobre o mundo, ao lado da resistência a doenças, do desenvolvimento da ciência e dos meios de violência que ela proporcionou, o desenvolvimento da dogmática jurídica. Da mesma forma que se tem notícia de
${ }^{24}$ Adeodato, João Maurício: "Para uma conceituação do direito alternativo". Revista de Direito Alternativo, $\mathrm{n}^{\circ} 1$ São Paulo: Acadêmica, 1992, p. 157-174; "Uma teoria (emancipatória) da legitimação para países subdesenvolvidos". Anuário do Mestrado em Direito, $\mathrm{n}^{\circ}$ 5. Recife: Universitária da UFPE, 1992, p. 207-242; "Unbeständigkeitsstrategien in Rechtssystemen der Peripherie: eine Form alternativen Rechts". Verfassung und Recht in Ubersee, 32. Jahrgang, 3 Quartal 1999. Baden-Baden: Nomos Verlagsgesellschaft, 1999, p. 335-346. ${ }^{25}$ Hamilton, Edith: Mitologia, trad. de Jefferson Camargo. São Paulo: Martins Fontes, 1995, p. 460, e Pinsent, John: Mitos e lendas da Grécia antiga, trad. de Octavio Casado. São Paulo: EDUSP/Melhoramentos, 1978, p. 49 50 .

Revista da Faculdade de Direito da UFRGS, v. 20, Outubro/2001 jovens japoneses, para dar um exemplo, pertencentes a uma cultura milenar e muito mais antiga do que a européia, submetendo-se a operações plásticas para arredondarem os olhos e se parecerem com Elvis Presley, vêm-se sistemas jurídicos asiáticos adotarem o habeas corpus ou as ações de inconstitucionalidade como estratégias importantes.

A dois, um número de Estados muito maior do que aqueles que realmente modernizaram seu direito apresentam-se como se de fato o tivessem dogmatizado. Portanto, a mera aparência de dogmatização e sua adoção enquanto discurso parecem ser funcionais política e juridicamente falando. Se a efetiva dogmatização do direito tem se mostrado um poderoso instrumento estratégico, também é eficiente o șimples apresentar-se dogmático o sistema.

A três, a chamada globalização vem tendo como uma de suas vias a imposição desse padrões de modernização jurídica a todos os Estados participantes, restando a marginalização da comunidade internacional àqueles que não o fizerem. $O$ direito dogmático passa a ser um elemento importante de inclusão/exclusão no mundo globalizado, no padrão de aferição do grau de civilização de uma sociedade, servindo com pré-condição inclusive para o comércio e a atração de investimentos. Aí interrelacionam-se questões econômicas temas éticos como o respeito aos direitos humanos. Compreender esses padrões de pensamento jurídico é útil inclusive para países cujo direito não é dogmático, sejam porque pretendem dogmatizá-lo, como parece ser o caso do Brasil, seja porque pretendem manter-se afastados disto, como parece ser o caso de países fundamentalistas.

${ }^{26}$ Merkel, Adolf Julius: Grundlagen des Rechts, vol. I dos Gesammetten Schriften, (Dorohea Mayer-Maly, Herbert Schambeck e Wolf-Dietrich Grussman - Hrsg.). Berlin: 1993, p. 437 s. ("Prolegomena einer Theorie de rechtlichen Stufenbaues"); Kelsen, Hans: Reine Rechtslehre, 2. Auflage, Wien 2000, p. 228 s. (V, 35, "De (techeral das normas, trad. de José Florentino Duarte. Porto Alegre: Fabris, 1986, p. 323 s. (59, I).
Pode-se supor, por outro lado, que o Estado nacional enfraquece-se contemporaneamente e que a globalização do direito virá a eliminar essas formas de organização social sob as quais vivemos, dentre as quais sobressai-se, conforme visto, a dogmática jurídica. Mas também é possível supor que, ao contrário, a globalização econômica virá a exigir cada vez mais uma globalização jurídica e que esta partirá, certamente, dos padrões da dogmática estabelecida nos países dominantes política e economicamente. Por tudo isso é importante estudar e conhecer a dogmática jurídica.

\section{Pressupostos sociológicos para dogmatização do direito na modernidade}

Procuram-se agora determinar algumas características básicas que uma sociedade precisa apresentar para que possa vir a dogmatizar eu direito. É necessário enfatizar que falar em pressupostos sociológicos não contradiz de modo algum o que foi afirmado acima contra uma concepção escatológica. Não se está aqui a dizer que uma sociedade que apresente tais pressupostos necessariamente modernizará o seu direito mas sim que terá tal possibilidade; $\mathrm{e}$ que sem sua realização prévia, o direito não poderá modernizar-se.

Inicialmente, a organização dogmática do direito pressupõe uma estrutura piramidal, as normas superiores fundamentando as inferiores, na imagem de Adolf Merkel adotada por Kelsen ${ }^{26}$. Para tanto, surge a necessidade de um centro produtor de normas, de um sistema

Revista da Faculdade de Direito da UFRGS, v. 20, Outubro/200 
para trato com certo tipo de relações previamente determinadas, que decida em última instância sobre questões relacionadas com o próprio sistema, monopolizando a definição do direito. Este centro produtor de normas constitui o Estado, o Estado moderno, caso se queira aplicar o conceito de Estado a formas de organização jurídica anteriores à modernidade.

Este fenômeno vem acompanhado de uma filosofia e de uma convicção relativamente generalizada que procuram separar o direito das demais "ordens normativas" enquanto objeto de uma ciência e de um método próprios, assim como de toda uma teoria altamente complexa, a chamada teoria dogmática do direito ou teoria do direito dogmático, que inclui uma hierarquização das fontes do direito, com o privilégio das fontes estatais, a lei e a jurisprudência. A concepção de mundo que subjaz a essas filosofia e teoria geral do direito é o positivismo jurídico estatalista, entendida como aquela perspectiva segundo a qual o único direito existente não é apenas aquele efetivamente empírico, perceptível pelos órgãos dos sentidos, mas sobretudo aquele tutelado pelo Estado.

Ao mesmo tempo em que o Estado responde pelo funcionamento do sistema, é também necessário que seu campo de ação, o direito, esteja relativamente separado, no mundo dos eventos, das demais formas e dicotomias de organização social, ou seja, o segundo pressuposto sociológico para dogmatização é a eman-

cipação, a imunização do direito em relação aos demais agrupamentos de normas.

Daí o segundo pressuposto sociológico importante: uma sociedade só estará potencialmente apta a dogmatizar seu direito se houver uma relativa emancipação do sistema jurídico em relação às demais ordens normativas e aos demais subsistemas sociais, tais como a técnica, a religião, a moral, a etiqueta e os usos sociais, a magia, a posse de bens e riquezas, amizade. Tal faceta de sociedades modernas tem sido descrita como um tipo especial de autonomia do sistema jurídico ou autopoiesis autopoiese ${ }^{27}$. A crer em Luhmann, a inovação do conceito de autopoiese, em relação às teorias anteriores que tomam por base a idéia de auto-organização, é dizer que certos sistemas são capazes não apenas de criar uma ordem autônoma mas também de criar seus próprios elementos.

Não se pretende aqui intervir na discussão sobre se a perspectiva utilizada pela teoria dos sistemas sociais seria ou não fruto de uma adequada transposição de con ceitos biológicos para a teoria do direito ou se essa estratégia das ciências humanas e sociais em geral ajuda ou prejudica sua seriedade e especificidade. Nada obstante, resta evidente que a utilização do conceito de autopoiese aqui indica opção pela aproveitabilidade tanto do conceito específico quanto da estratégia genérica ${ }^{28}$.

${ }^{27}$ Acentuando a distinção entre auto-organização, auto-observação e autopoiese (auto-referência básica), cf. Luhmann, Niklas: Soziale Systeme. Grundriß einer allgemeinen Theorie. Frankfurt a.M.: Suhrkamp, 1984, p. 60 167, 296 e passim. Mais recentemente em sua obra, Luhmann, Niklas: Das Recht der Gesellschaft. Frankfurt M. Suhrkamp, 1995, p 45 s; na p. 62 o autor chama atencão para o sentido confuso da expressão autont M.: Suhrkamp, 1995, p 45 s; Suhrkamp, 1998, p. 810

${ }^{28}$ Sobre o conceito específico de autopoiese, além das referências de Luhmann já feitas, cf. Maturana, Humberto R. e Varela, Francisco J.: Autopoiesis and cognition - The realization of the living. Dordrecht: D. Reidel, 1972, p. $73 \mathrm{~s}$. Sobre a estratégia em geral de aproveitamento de conceitos de um setor do conhecimento por outro cf. criticamente Sokal, Alan \& Bricmont Jean. Imposturas intelectuais - o abuso da ciência pelos filósofos pósmodernos, trad. Max Altman. Rio de Janeiro e São Paulo: Record, 1999, passim, sobretudo o "Prefácio à edição brasileira".

Revista da Faculdade de Direito da UFRGS, v. 20, Outubro/2001
Ainda que toda sociedade possa ser chamada de autopoiética em um primeiro nível, a partir do momento em que a construção do sentido na comunicação vai separando as interações sociais dos indivíduos concretos, refere-se aqui a uma autopoiese de segundo nível, uma "diferenciação funcional". Exemplificando, uma sociedade fundamentalista, por mais indiferenciados que estejam seus subsistemas religioso, moral, jurídico, é autopoiética na medida em que constitui-se a partir da evolução de um sentido consciente para um sentido comunicativo, pois se a consciência é a base da autopoiese dos sistemas psíquicos, a comunicação é a base da autopoiese dos subsistemas sociais. Mas seu direito não o é, por não ser operacionalmente diferenciado de outros códigos comunicativos, como a religião. Uma sociedade como a brasileira, por seu turno, é autopoiética em relação ao ambiente circundante, "natural", mas seu direito também sofre distúrbios alopoiéticos, ou corrupção de códigos quando, por exemplo, subsistema econômico interfere no jurídico, colocando apenas pobres na prisão. Neste sentido, a modernização pode ser compreendida sem prejuízo de outros paradigmas, segundo o modelo da indiferenciação à diferenciação, de uma menor a uma maior complexidade social. Uma sociedade será tanto mais moderna quanto mais diferenciada funcionalmente ${ }^{29}$. Daí, conseqüentemente, mais apta a dogmatizar seu direito.

Não se pense, contudo, que tal fechamento operacional implique um isolamento do direito autopoieticamente organizado em relação aos subsistemas morais ou religiosos ou outros circundantes, mas sim que os critérios para admissão das influências desses outros subsistemas sociais são fixados pelo próprio direito positivo, através de seus procedimentos de modificação e adaptação, tais como novas legislações, jurisdição constitucional e concretizações jurisprudenciais em geral. Quando essa interação acontece sem que haja a corrupção de códigos e a adaptação é funcionalmente bem sucedida, fala-se em acoplamento estrutura ${ }^{30}$. O acoplamento estrutural viabiliza a abertura cognitiva do sistema jurídico, mantendo-o permeável, sensível às influências de novas perspectivas religiosas ou morais, por exemplo, e também influenciando-as, como ocorreu no Brasil em relação à proteção à concubina e aos vínculos homossexuais. Mas essa permeabilidade precisa efetivar-se segundo critérios e procedimentos controlados pelas próprias regras internas do sistema jurídico, tornando necessária uma internalização das novas perspectivas morais, para ficar no exemplo, através de vias dogmáticas como a edição de novas leis ou concretizações jurisprudenciais, configurando o fechamento normativo ${ }^{31}$.

Em outro contexto gnoseológico, podese dizer que "O isolamento de um subsistema (o econômico, o político, o religioso, o jurídico - para somente indicar os principais) é temático. Resulta de uma abstração simplificadora, com fins metodológicos e gnosiológicos." Mas há também “... um automovimento, relativamente independente de agentes externos, como sistema fechado" 32

Este processo de diferenciação, de uma

${ }^{29}$ Luhmann, Niklas e De Giorgi, Raffaele: Teoria della società. Milano: FrancoAngeli, 1995, p. 302 s.

${ }^{30}$ Maturana, Humberto; Magro, Cristina; Graciano, Miriam e Vaz, Nelson (orgs.): A ontologia da realidade. Belo Horizonte: Ed. UFMG, 1997, p. 86-87 (inclui texto com Jorge Mpodozis). Luhmann também utiliza destacadamente o concito: Luhmann, Niklas: Das Recht der Gesellschaft. Frankfurt a. M.: Suhrkamp, 1995, p. 440 s.

${ }^{31}$ Luhmann, Niklas: "The unity of the legal system", in Teubner, Gunther (ed.): Autopoietic law: a new approach to law and society. Berlin / New York: Walter de Gruyter, 1988, p. 12-35.

${ }^{32}$ Vilanova, Lourival: Causalidade e relação no direito. São Paulo: Revista dos Tribunais, 2000, p. 34 e 36.

Revista da Faculdade de Direito da UFRGS, v. 20, Outubro/2001 
perspectiva histórica, pode ser rastreado por diversas vias. Talvez a primeira delas, em termos de nossa cultura ocidental, seja justamente a separação entre técnica e ética. Observe-se que a distinção não é clara para os gregos, ainda que Aristóteles procure estabelecê-la ${ }^{33}$. Para nós, modernos, é clara a diferença entre a maldade (ética) e a incompetência (técnica), o que na teoria geral do direito, reflete na distinção importante entre dolo e culpa, por exemplo. Se a incompetência que causa danos merece se punida, a maldade merece sê-lo com mais rigor Ainda que, mais recentemente, a distinção jurídica tenha sido esmaecida por teorias como do dolo eventual, que aproxima o desvio ético do desvio de competência, ela permanece como um dos postulados do sistema dogmático. Ja em Paulo de Tarso encontra-se nítida a diferença ${ }^{34}$.

Também são os primeiros cristãos os responsáveis pela diferenciação entre religião direito, apontada pelos evangelhos católico através de célebres frases atribuídas a Jesu Cristo, para quem a distinção já parecia pioneiramente clara: "o meu reino não é deste mundo" 35 ou "a César o que é de César, a Deus o que é de Deus" 36 .

Com a expansão do cristianismo, a Igreja assume a guarda da auctoritas, fonte da legitimidade, deixando aos poderes seculares potestas. Etimologicamente, inclusive, não há

distinção entre legalidade e legitimidade, pois legitimus-a-um parece exatamente ter significado "de acordo com a lei" 37 , ainda que só na modernidade isso se explicite com os sistemas dogmáticos, conforme mencionado acima. Os reis bárbaros europeus freqüentemente se viam envolvidos em disputas e guerras dinásticas, fazendo importantes as regras e a intervenção da Igreja. O poder temporal da Igreja Católica, contudo, internacional e coercitivo nos tribunais do Santo Ofício, retarda de alguma maneira a diferenciação entre religião e direito.

É justamente esta posição acima do poder efetivo que se constitui em um entrave à ascensão do Estado moderno, quando tornase mais aguda a necessidade de separação e os primeiros juristas da modernidade esforçam-se por distinguir com nitidez a fronteira entre a esfera de ação da Igreja e a esfera de ação do Estado emergente, soberano e leigo. O protestantismo já surge dividido em termos nacionais e sua convivência com os Estados soberanos, para não dizer subordinação, jáémais pacífica. Mesmo assim, na França católica, observe-se que é de Napoleão I, em tempo relativamente recente e já na era moderna, 2 de dezembro de 1804 , o gesto emblemático de demonstrar publicamente que dispensava a auctoritas e a legitimação da Igreja, ao retirar no último instante a coroa de imperador das mãos do papa Pio VII e coroar-se a si próprio na catedral de Notre Dame ${ }^{38}$.

${ }^{33}$ Entre outros trechos, Aristóteles: Nicomachean ethics, VI, 4, 1140a, trad. de W. D. Ross, in The Works of Aristotle, coleção Great Books of the Western World, vol. 8. Chicago: Encyclopaedia Britannica, 1990, p. 333-436, Aristotle, coleç

${ }^{34}$ Adeodato, João Maurício: "Ética, jusnaturalismo e positivismo no direito". Anuário dos Cursos de PósGraduação em Direito, $\mathrm{n}^{\circ}$ 7. Recife: Universitária da UFPE, 1995, p. 119-216.

${ }^{35}$ Evangelho de João 18 (36-37) e 19 (11). A edição consultada é a Bíblia Sagrada, trad. Pe. Antonio Pereira de Figueiredo. Rio de Janeiro: Encyclopaedia Britannica, 1987.

${ }^{36}$ Evangelhos de Marcos 12 (17) e Lucas 20 (25).

${ }^{37}$ Ritter, Joachim e Gründer, Karlfried (Hrsg.): Historisches Wörterbuch der Philosophie, Band V. Basel / Stuttgart: Schwabe \& Co. AG, 1980, p. 160-166 (verbete: Legalität, Legitimität). E Lafer, Celso: "Prefácio" a Faria, José Eduardo: Poder e legitimidade - Uma introdução à politica do direito. São Paulo: Perspectiva, 1978, 9-13, p. 9. ${ }^{38}$ Săo muitas as obras históricas que podem ser consultadas. Sugere-se a The New Encyclopaedia Britannica, Macropaedia, vol. 24, Chicago: The University of Chicago, 1989, p. 745.

Revista da Faculdade de Direito da UFRGS, v. 20, Outubro/2001
As próximas distinções, no que concerne às ordens normativas, dão-se entre religião e moral, de um lado, e direito e etiqueta, de outro. $\mathrm{O}$ ateísmo ou a pertinência a outras religiões vai deixando de constituir uma imoralidade, aparecendo pessoas que defendem coerência e rigidez morais sem apelo a qualquer divindade. O ateu deixa de ser necessariamente antiético uma moral laicizada vai se tornando possível.

Da mesma forma, depois de uma preoobjetivando-as em compilações e buscando divulgá-las ${ }^{39}$, aparecem tentativas de estudálas cientificamente e, o que mais aqui interess ressaltar aqui, de separá-las das normas de direito. Isso se torna mais necessário, também, devido às tentativas modernas de emancipar cientificamente o direito, identificando seu objeto específico, posto que os critérios tradicionalmente utilizados diante da religião e da moral (exterioridade, heteronomia, alteridade) não funcionavam diante das normas de uso social, de etiqueta, de bom-tom, exigindo conceitos mais sofisticados como os de coercitividade e bilateralidade para separá-las das normas jurídicas. Assim, no início do século XX já estão mais claras as diferenças entre uso, costume, convenção, direito, dentro do conceito mais amplo de ação social ${ }^{40}$. cupação crescente com as normas de etiqueta,

\section{Diferenças de um direito dogmaticamente organizado}

O direito dogmaticamente organizado apresenta as mais diversas facetas e seu alto grau de diversidade não permite falar de uma evolução homogênea em qualquer direção. Inobstante, dentre suas inúmeras características, cujo grau de importância também varia, cinco serão agora destacadas, apenas de um ponto de vista da retórica analítica e visando sobretudo efeitos didáticos ${ }^{41}$, pois essas condições ou constrangimentos aparecem indissociadamente na realidade jurídica. Eles constituem a visão interna do sistema dogmático ${ }^{42}$.

São eles: em primeiro lugar, fixar textos normativos; em segundo, dizer o que significam os termos que os compõem; em terceiro, argumentar com referência a eles; em quarto, decidir com base neles; em quinto, fundamentá-los, justificando as decisões concretas.

Pode-se, como outros autores, utilizar a expressão direito positivo para designar essa forma estatal moderna de organi-

${ }^{39}$ Roquette, José Inácio: Código do bom-tom ou Regras da civilidade e de bem viver no século XIX (org. Lilia Schwarcz). São Paulo: Companhia das Letras, 1997.

${ }^{40}$ Max Weber: Wirtschaft und Gesellschaft -Grundriss der verstehenden Soziologie. Tübingen: J.C.B. Mohr (Paul Siebeck), 1985, p. 11-15 (I, II, \& $1^{\circ}-4^{\circ}$ ).

${ }^{41}$ Tomam-se por base Ballweg, Ottmar: "Analytische Rhetorik als juristische Grundlagenforschung", in Robert Alexy, Ralf Dreier, Ulfrid Neumann (Hrsg.): Archiv für Rechts- und Sozialphilosophie, Beiheft 44. Sttutgart: Steiner, 1991, p. 45-54, dentre outros trabalhos, o qual ressalta quatro constrangimentos ou Zwänge (Entscheidungszwang, Bregründungszwang, Deutungszwang e Normsetzungszwang); Ferraz Junior, Tercio: Função Social da Dogmática Jurídica São Paulo: Revista dos Tribunais, 1980; e sobretudo a obra de Viehweg, Theodor muito embora esses autores não sejam sequer co-responsáveis pelas presentes colocações.

${ }^{42}$ Repita-se que esses constrangimentos não são suficientes para definição de um estado democrático de direito, cujos elementos (constitutivos, nomocráticos, relacionais) exigem condições mais complexas e específicas, formando uma estrutura organizacional que, se pressupõe a dogmatização, vai muito além dela. Cf. Sobota, Katharina: Das Prinzip Rechtstaat. Verfassungs- und verwaltungsrechtliche Aspekte. Tübingen: Mohr Siebeck, 1997, p. 518.

Revista da Faculdade de Direito da UFRGS, v. 20, Outubro/2001 
zação jurídica ${ }^{43}$ ou, como escolhido aqui, direito dogmático. Isto porque a expressão positividade e seus derivados têm levado a equívocos na literatura jurídica, sendo empregada em sentidos diversos, tais como os de validade, vigência, eficácia, efetividade ${ }^{44}$. Entendese aqui o direito dogmático como uma das formas que pode assumir o direito positivo; direito dogmático é o direito posto pelo Estado moderno segundo tais e tais características, mas o direito pode ser posto por outras instâncias nãoestatais, pode ser atual ou histórico, em suma, exibir múltiplas e diferentes características.

Assim, como primeiro constrangimento, coloca-se a obrigatoriedade de estabelecer textos normativos, fixar previamente os pontos de partida para as regras do jogo. Daí a expressão dogmática jurídica, pois são precisamente esses textos os dogmas que procuram fixar os limites que, apesar de elásticos, não devem ser explicitamente negados. Nos sistemas jurídicos democráticos, informados pela separação dos poderes, tal função fica mais a cargo do poder legislativo e, cada vez mais no mundo moderno, mais ainda nos países subdesenvolvidos, a cargo do poder executivo. Isto porque o poder executivo, além de estabelecer textos genéricos tal e qual o legislativo, como nas medidas provisórias no Brasil, ainda cuida de reduzir o grau de generalidade, no caminho da concretização, da especificação realizadora da norma, através de decretos regulamentadores que, em certas áreas, também são de sua competência constitucional. Isto sem contar quando decide mes- mo, especificando o texto, criando a norma em sua concretude, aí já no constrangimento a decidir. Este primeiro constrangimento, assim, não consiste exatamente em fixar as normas e sim apenas seu texto, seus pontos de partida lingüísticos.

Em segundo lugar, a obrigatoriedade de dizer o que o texto da norma significa efetivamente, pois ele não é "portador" da norma mas sim um meio para interpretações diversas e concorrentes entre $\mathrm{si}^{45}$. O sistema jurídico precisa determinar o sentido real do texto normativo previamente fixado e agora alegado diante do caso concreto, colocando em que medida concreta ele deverá pautar as condutas e os conflitos a respeito dos quais os textos são mencionados. É a obrigatoriedade de interpretar os textos normativos. Esses textos apresentam-se com diferentes graus de generalidade e é difícil dizer exatamente quando se concretizam, o que não invalida o constrangimento dogmático. A disparidade entre as interpretações possíveis leva muitas vezes o ambiente social a uma perplexidade que pode até prejudicar a necessidade de fundamentação, a legitimação da decisão. Mas, de qualquer modo, toda decisão diante do caso concreto provém de determinada interpretação.

Note-se, sobretudo mas não unicamente nos países periféricos, que muitas vezes os próprios juízes e demais agentes jurídicodogmáticos são limitados intelectualmente para esta difícil tarefa concretizadora e prendem-se a

${ }^{43}$ Luhmann, Niklas: "Positivität des Rechts als Voraussetzung einer modernen Gesellschaft", in Luhmann, Niklas: Ausdifferenzierung des Rechts - Beiträge zur Rechtssoziologie und Rechtstheorie. Frankfurt a.M.: Suhrkamp, 1981, pp. 113-154; mais recentemente, já com o conceito autopoiético de "fechamento operativo do sistema jurídico", Luhmann, Niklas: Das Recht der Gesellschaft. Frankfurt a. M.: Suhrkamp, 1995, p. 38 s.

${ }^{44}$ Alexy, Robert: Begriff und Geltung des Rechts. Freiburg / München: Alber, 1992, p. 31 s. divide os positivistas em duas grandes vertentes: aquela primariamente orientada para a efetividade (Wirksamkeit) e a primariamente orientada para o estabelecimento (Setzung), a validade da norma. Sobre a ambigüidade do conceito de positividade, cf. Silva, José Afonso da: Aplicabilidade das normas constitucionais. São Paulo: Malheiros, $3^{\mathrm{a}}$ ed., s/d, p. 63-66. ${ }^{45}$ Müller, Friedrich, Christensen, Ralph e Sokolowski, Michael: Rechtstext und Textarbeit. Berlin: Duncker \& Humblot, 1997, p. 19 s.

Revista da Faculdade de Direito da UFRGS, v. 20, Outubro/2001

um formalismo silogístico que, já inadaptado a um regime ditatorial subdesenvolvido como aqueles que aqui e ali têm pontificado na América Latina, mostra-se inteiramente incapaz de responder às demandas sociais do direito dogmático que caracteriza as democracias modernas ${ }^{46}$.

Em terceiro lugar, a obrigatoriedade de só argumentar tomando por base ealegando expressamente esses textos normativos pré-fixados. A validade dogmática de um argumento não está previamente condicionada a critérios externos como justiça, verdade científica, racionalidade ou mesmo a fatos concretos, daí a independência da "verdade" jurídica em relação à "realidade", exemplificada pelo brocardo "o que não está nos autos não está no mundo". Essa autonomia ou fechamento do sistema dogmático leva a procedimentos absurdamente formalistas aos olhos do leigo, que não aceita a idéia de seu direito ser negado por perda de prazo, incompetência ou outros defeitos no processo.

Em quarto lugar, o constrangimento a decidir todo e qualquer conflito considerado juridicamente relevante pelo sistema, a também chamada proibição do non liquet $t^{47}$. A atitude de Pilatos, lavando as mãos ${ }^{48}$, não é opção admissível para um juiz dogmático, dentro de sua esfera de competência. O juiz moderno não deve poder dizer jus non liquet ("o direito não está claro"), não está entre suas possibilidade dizer "não sei." Uma das diferenças básicas entre os textos dogmáticos e os demais é precisamente essa necessidade de decidir todo qualquer problema juridicamente relevante. Não se devem confundir textos jurídicos dogmáticos, que precisam responder (dokein) decisivamente a pro-

${ }^{46}$ Krell, Andreas: "10 Jahre brasilianische Bundesverfassung: Rechtdogmatische und rechtssoziologische Aspekte der Entwicklung des Grundrechtsschutzes". Verfassung und Recht in Übersee, 32. Jahrgang, 1. Quartal. BadenBaden: Nomos, 1999, p. 7-30, p. 15

${ }^{47}$ No direito positivo brasileiro, cf. Lei ${ }^{\circ} 5.869$, de 11 de janeiro de 1973 (Código de Processo Civil), art. 126. São Paulo: Saraiva, 1997, e o art. $5^{\circ}, \mathrm{XXXV}$, da Constituição Federal de 1988 (atualizada até a Emenda Constitucional 30/2001). São Paulo: Juarez de Oliveira, 2001.

${ }^{48}$ Evangelho de Mateus 27 (24). Mateus é o único dos evangelistas que se refere à ablução quando Jesus 6 levado a Pilatos. Observem-se os Evangelhos de João 19 (1-16), Lucas 23 (1-25) e Marcos 15 (1-15).

${ }^{49}$ Ballweg, Ottmar: "Analytische Rhetorik als juristische Grundlagenforschung", in Alexy, Robert, Dreier, Ralf e Neumann, Ulfrid (Hrsg.): Archiv für Rechts- und Sozialphilosophie, Beiheft 44. Sttutgart: Steiner, 1991, p. 50. Revista da Faculdade de Direito da UFRGS, v. 20, Outubro/2001 

constitucionais $^{50}$. Esses textos apenas sugerem sigquestão. O sistema jurídico-dogmático da mentação mais ou menos definidas, comoquer Alexy, ou se se trata de uma neutralização que institucionaliza o dissenso por meio de um procedimento autopoieticamente organizado, como quer Luhmann, essa é uma discussão que não cabe travar aqui. Isso sem contar as análises combinatórias conceituais levadas a efeito por autores menores. Agora basta fixar que o plexo normativo dogmático leva esta fundamentação a efeito ampliando cada vez mais a vagueza e a ambigüidade dos textos fundantes, culminando nas referências aos princípios expressos nos textos nificados, a partir de estruturas lingüísticas entimemáticas, as quais vêm a ser concretamente preenchidas segundo as peculiaridades do caso em modernidade é constrangido a isso justamente em função de sua relativa emancipação dos demais subsistemas normativos sociais, afastando o problema dos conteúdos éticos específicos. Ao perder suas bases éticas comuns em uma ambiente socia grandemente diferenciado, no qual as pessoas e os grupos humanos não concordam sobre questões vitais para a vida em comum, as normas jurídicas precisam de um alto grau de maleabilidade interpretativa.

O problema da fundamentação está relacionado com o abismo axiológico de que foi falado acima, constituindo-se no mais hetero-referente do constrangimentos dogmáticos, a ponto de positivistas considerarem a questão da fundamentação uma questão extra-dogmática. Mas esta é uma simplificação indevida, ainda que a questão da legitimidade constitua-se em um dos pontos cruciais de abertura e comunicação entre o sistema dogmáticoe o sistema político, dentre outros. De toda forma, a dogmática, como procedimento jurídico de solução de conflitos, o positivismo, enquanto perspectiva teórica e filosófica, e ademocracia, comoregime po-

lítico, parecem estar umbilicalmente ligados na organização e compreensão do direito na modernidade, sem esquecer as formas pré-modernas existentes hoje. Mas o problema da legitimidade, escamoteado e descartado pelo positivismo ortodoxo, na medida em que é equacionado em termos de legalidade e mera validade intra-sistêmica, vem se constituindo em problema crucial para o direito da pósmodernidade, cada vez mais complexo. Isso não deve aqui significar uma visão negativa e desiludida dos tempos futuros, nem a uma visão otimista iluminada ${ }^{51}$.

Ainda assimnote-se que, mesmo nos Estados democráticos do centro desenvolvido, a dogmatização do direito constitui um tipo ideal, uma ficção, uma estratégia retórica de controle social que se tem mostrado funcional $e$ eficiente nos mais diversos contextos. Mas daí a crer que é real e verdadeira, construindo uma teoria social ou jurídica omnicompreensiva a partir dela, vai uma grande distância. O mesmo vale para os demais tipos ideais discutidos aqui, incluindo o Estado democrático de direito.

Mais ainda, se a dogmática jurídica e o Estado moderno têm seus dias contados na pós-modernidade ou se haverá uma adaptação crescente aos novos desafios, com uma maior abertura do direito em função de um acoplamento estrutural mais abrangente, por exemplo, através de uma jurisdição constitucional cada vez mais embasada em princípios ou de procedimentos alternativos de solução de conflitos, só o futuro dirá. Mesmo deixando de lado as escatologias, pode-se dizer que a organização dogmática do direito incorporase definitivamente ao patrimônio cultural desses tempos modernos.

${ }^{50}$ Para uma posição mais confiante na "força normativa" dos princípios, Streck, Lenio Luiz: Hermenêutica jurídica e $(m)$ crise. Uma exploração hermenêutica da construção do direito. Porto Alegre: Livraria do Advogado, 2000, p. 224-239.

${ }^{51}$ Para referências no sentido de uma conceituação da "pós-modernidade", cf. Apostolova, Bistra Stepanova: Poder judiciário: do moderno ao contemporâneo. Porto Alegre: Fabris, 1998, p. 25-37.

Revista da Faculdade de Direito da UFRGS, v. 20, Outubro/2001

\section{O Novo Código Civil Brasileiro: em busca da "Ética da Situação"}

\author{
Gudith Martins-Costa
}

"A 'ética da situação' inspira e governa a estrutura do Projeto, obedecendo à exigência atual do 'Direito como concreção', ou, como prefiro dizer, do 'Direito como experiência', inexistencial". (Miguel Reale)

\section{Introdução}

O velho "Código de Beviláqua", o ainda vigente Civil Brasileiro ${ }^{2}$, tido por Pontes de Miranda ${ }^{3}$ como "o antepenúltimo código oitocentista" - muito embora tendo entrado em vigor em 1916 - por seu espírito individualista, liberal em matéria econômica, conservador ao extremo nas relações familiares, está prestes a se transformar numa referência histórica. Acaba de ser finalmente votado pelo Congres-

so Nacional o Projeto de Lei $\mathrm{n}^{\circ}$ 635-/75, que institui o novo Código Civil Brasileiro.

O novo Código, contendo 2.046 artigos, resulta de Anteprojeto elaborado por Comissão de Juristas presidida por Miguel Reale. Para compreendê-lo, mister um olhar sobre as suas origens, que recuam, no tempo, à década de 60 , quando se fez mais forte a compreensão da necompativel com disposições que levam em conta relações formais, com olvido de seu conteúdo

${ }^{1} O$ presente estudo foi originalmente elaborado para integrar volume acerca da codificação nas Américas, a ser publicado na Revista Jurídica de la Universidad Interamericana de Puerto Rico, tendo sido também publicado na Revista Jurídica vol. 282, Porto Alegre, 2001. Em razão da recente aprovação do texto proposto e consolidado pelo Relator Geral, Deputado Ricardo Fiúza, pela Câmara dos Deputados em 15 de agosto de 2001, foram agora atualizados o título e as referências já ao "novo Código", remodelada, em parte, a estrutura do trabalho e acrescidas considerações. Agradeço o auxílio de Laura Beck Varela na revisão das notas.

2 O vigente Código Civil resultou do trabalho de Clóvis BEVILÁQUA. Convidado em 1899 pelo Governo Brasileiro para a sua elaboração, deveria aproveitar o quanto possível dos Projetos anteriores, desde a ConsoBrasileiro para de NABUCO DE ARAÚJO (1872), FelKCOO dOS SANTOS (1881) C COELO elaborou a sua obra em poucos meses. Submetido a duas revisôes, o Projeto fol enviado em 1900 ao Congresso Nacional, lá tramitando por 15 anos, até que em 26 de dezembro de 1915 foi aprovado, sendo sancionado em $1^{\circ}$ de janeiro de 1916 e entrando em vigor um ano após.

${ }^{3}$ PONTES DE MIRANDA, F.C, Fontes e Evolução do Direito Civil Brasileiro, Rio de Janeiro, Forense, 1981 , p. 85 . 
cessidade de ultrapassagem do antigo Código Civil.

Foi ao aproximar-se o cinqüentenário do Código de Beviláqua que começaram a ser ouvidas, no Brasil, as vozes defensoras de sua revisão. De um lado, os reclamos eram tributários de um movimento que então apenas se esboçava na Europa, a saber o movimento d descodificação civil, sintetizado, uma década mais tarde, no paradigmático texto de Natalino Irti,. "L'età della decodificazione"4 . De outro lado, não mais era compatível com o ethos da sociedade brasileira o individualismo dominante no Código de Beviláqua: "individualismo possessivo" revelador da "lógica proprietária"s em matéria de direitos patrimoniais, ao qual corresponde a mais absoluta avareza no tratamento dos valores existenciais ligados à vida civil $^{6}$. A excelência técnica do velho Código, unanimemente reconhecida, não mais se mostrava suficiente para justificar a sua permanência.

É bem verdade que já em 1941 houvera uma tentativa de mudança - entretanto infrutífera - ao imaginar-se o desmembramento do Direito das Obrigações do corpus codificado, segundo o modelo do Código Suíço das Obrigações ${ }^{7}$. Porém, em 1961 Caio Mário da Silva Pereira, um dos mais conhecidos civilistas brasileiros, expressando o pensamento então dominante afirmava, em obra didática, que "hoje em dia, os juristas brasileiros estão convencidos da necessidade de ser revisto e atualizado o Código Civil"s.

Dando efetividade ao consenso dos juristas, o Governo Federal, naquele mesmo ano, convidou o Professor Orlando Gomes - um dos mais renomados juristas brasileiros, conhecido por suas preocupações sociais - a redigir um Anteprojeto de Código Civil, o que tomou corpo em 1963 com o contrato firmado, convertido o texto apresentado em 1964 em Projeto enviado à Câmara dos Deputados.

$\mathrm{Na}$ época, o pensamento governamental encontrava-se ainda preso à idéia de fratura o Direito Civil, cindindo o Direito das Obrigações do corpo codificado. Tanto assim que paralelamente ao Projeto Orlando Gomes, destinado a regular as relações de família, propriedade e sucessões, foi contratado, em 1963, Professor Caio Mário da Silva Pereira, o qual em 1964, apresentou o Anteprojeto de Código das Obrigações que elaborara juntamente com os juristas Sylvio Marcondes e Theóphilo de Azeredo Santos.

O Projeto de Código Civil de 1963, que teve como Relator Orlando Gomes ${ }^{9}$, inspirado em subsídios oferecidos pelos Códigos Civis da Suíça, Itália, Grécia, do México e Peru, propunha modificações radicais na própria estru-
${ }_{5}^{4}$ IRTI, Natalino, L'età della decodificazione ( $1^{\mathrm{a}}$ edição , 1979), que li na $3^{\mathrm{a}}$ edição, Milão, Giuffrè, 1989. 5 A expressão é de Davide MESSINETTI, "Personalitá" (Diritti della), verbete, in Enciclopedia Giuridica, Giuffrè, Milão, 1984, p. 356 .

${ }^{6}$ Assinala neste sentido Luiz Edson FACHIN: “O Código Civil Brasileiro, a par de ser patrimonial-imobiliário, portanto um sistema enucleado em torno de uma noção patrimonial fundamental, de patrimônio imobiliário como prevalente, é coerente com a feição dos códigos do século XIX e foi fundamentalmente feito no século passado. Outro é o horizonte contemporâneo" (Teoria Crítica do Direito Civil, Rio de Janeiro, Renovar, 2000, p. 25)

'Trata-se do Anteprojeto de Código das Obrigações, elaborado pelos Professores Orosimbo NONATO, Philadelpho AZEVEDO e Hahnemann GUIMARÃES.

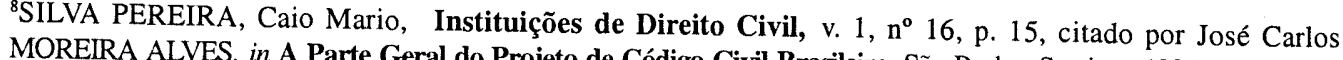
MOREIRA ALVES, in A Parte Geral do Projeto de Código Civil Brasileiro, São Paulo, Saraiva, 1986, p. 7 ${ }^{9}$ Constituíam a Comissão Revisora também os professores Orosimbo NONATO e Caio Mário da SILVA PEREIRA.

Revista da Faculdade de Direito da UFRGS, v. 20, Outubro/2001 tura do Código, não mais acolhendo a divisão em Parte Geral e Parte Especial. Promovia aind mudanças no Direito de Família que não foram bem aceitas pela comunidade jurídica, refletindo o estágio conservador então dominante na sociedade brasileira, na época antidivorcista. Assim é que, já modificado o Governo - e iniGovernos Militares, que prosseguiu até 1985 -, foi esse Projeto ${ }^{10}$ retirado do Congresso Nacional pelo próprio Governo, para que se procedesse à sua revisão, já afastada a idéia de codificar separadamente o Direito das Obrigações.

Por esta razão, concomitantemente ao insucesso do Projeto de Código Civil de Orlando Gomes, também a tentativa de codificar-se apartadamente o Direito das Obrigações acabou frustrada. No ano de 1969, nomeou o Governo uma nova Comissão para rever e reelaborar ambos os Projetos.

Esta foi a Comissão que, presidida por Miguel Reale ${ }^{12}$ e integrada por José Carlos Moreira Alves ${ }^{13}$ (Parte Geral), Agostinho ciado, em março de 1964, o longo período dos

Alvim ${ }^{14}$ (Direito das Obrigações), Sylvio Marcondes ${ }^{15}$ (Direito da Empresa), Ebert Chamoun ${ }^{16}$ (Direito das Coisas), Clóvis do Couto e Silva ${ }^{17}$ (Direito de Família) e Torquato Castro $^{18}$ (Direito das Sucessões), acabou por redigir o Anteprojeto, hoje em vias de se transformar no novo Código Civil Brasileiro. Deixemos Miguel Reale explicitar o perfil da Comissão que presidiu:

"Quando fui convidado para desempenhar tão alta missão, respondi a Gama e Sil$v a^{19}$ que não a poderia aceitar sozinho, por considerar o mundo contemporâneo incompativel com a vaidade de legisladores solitários, tentando repetir a façanha de Sólon, para Atenas, e de Licurgo, para Esparta. Assente a idéia de constituir-se uma Comissão Especial, procurei atender a diversos requisitos, não só de alta competência doutrinária, mas também de afinidade intelectual, sem a qual seria impossivel levar a bom termo um trabalho que, mais do que qualquer outro, exige harmonia das partes no todo, numa unidade sistemática. Além disto, para prevenir acusações de bairrismo, julguei necessário convidar juris-

${ }^{10}$ Esse, na Câmara dos Deputados, tomou o n 3.263 , de 1965.

"O Anteprojeto acolhia divisão tripartida, a primeira (Negócio Jurídico, Parte Geral, Contratos e outros títulos de ordem geral) tendo como relator o próprio professor Caio Mário da SILVA PEREIRA, a segunda (Títulos de Crédito) sendo relatada por Theóphilo de AZEREDO SANTOS e a terceira (Empresários e Sociedades) de autoria do professor Sylvio MARCONDES

12 Jurista, professor catedrático de Filosofia do Direito na Faculdade de Direito da Universidade de São Paulo, advogado.

advogado. Supremo Tribunal Federal.

${ }^{14}$ Professor catedrático de Direito Civil na Faculdade de Direito da Pontifícia Universidade Católica de São Paulo e advogado, já falecido.

${ }^{15}$ Professor catedrático de Direito Comercial na Faculdade de Direito da Universidade de São Paulo e advogado, já falecido.

${ }^{16}$ Desembargador do Tribunal de Justiça do Rio de Janeiro, professor catedrático de Direito Civil na Faculdade de Direito da Universidade Nacional do Rio de Janeiro.

${ }^{17}$ Professor catedrático de Direito Civil na Faculdade de Direito da Universidade Federal do Rio Grande do Sul, advogado, já falecido.

${ }^{18}$ Professor catedrático de Direito Civil da Faculdade de Direito Universidade Federal de Pernambuco e advogado, já falecido.

já falecido.

${ }^{19}$ Então Ministro da Justiça, portador do convite.

Revista da Faculdade de Direito da UFRGS, v. 20, Outubro/2001 
tas de vários pontos do País, entrelaçados por vínculos de compreensão e amizade"20.

Configurando uma verdadeira "escola de pensamento", formada por professores por tadores de solidíssima cultura dogmática, à qua se aliava a vivência na praxis das lides forenses, sendo todos ou advogados ou juízes, os membros da Comissão Revisora e Elaboradora do Código Civil apresentaram um primeiro texto, o qual foi revisto e sistematizado por Migue Reale em 1972. Conquanto nascida para revisa o Projeto Orlando Gomes, na verdade a Comissão apresentou um novo texto, que englobou, certo, como subsídios, as anteriores tentativas, afirmando Miguel Reale que o Projeto Orlando Gomes refletiu-se no espírito anti-idividualista, na diretriz da socialidade que acabou por impregnar o novo trabalho ${ }^{21}$. Este novo texto a par de superar a idéia da fratura do Código Civil, reintroduzindo no seu corpus o Direito Obrigacional, promoveu a própria unidade do Direito das Obrigações civis e comerciais, "ver dadeira vocação da experiência jurídica bra sileira", no dizer de Reale ${ }^{22}$, pois, antes de copiar a legislação civil italiana de 1942 , mais propriamente retoma idéia do grande jurisconsulto Teixeira de Freitas que acabara não acolhida por Beviláqua $^{23}$.

Do Anteprojeto é lícito afirmar desde logo que, ao cuidado com os aspectos teóricos e metodológicos, próprios dos professores, aliou-se a preocupação com os aspectos pragmáticos, atinentes à operabilidade do Direito, expressa no que Miguel Reale denominou de "diretriz da operabilidade" e sintetizada na frase de Von Jhering: "O Direito é feito para ser operado". Assim é que a Comissão, a par de propor determinada idéia de Código — - que oportunamente examinarei - cuidou de melhor sistematizar institutos que, no vigente Código, vêm confundidos (como os da prescrição e da decadência), de ordenar de modo lógico os direitos e deveres (como procedeu ao distinguir, no Direito de Família, entre o direito pessoal e o patrimonial), atentando, por igual, para a simplificação de regras e para a rejeição do formalismo antiquado e estéril, ao acolher inovações tecnológicas em matéria de documentação, registros e provas. Endossando expressamente o princípio da atipicidade (art. 425) adotou, por exemplo, em relação aos títulos de crédito, uma disciplina ampla, entendendo que a disciplina da letra de câmbio, da nota promissória e dos demais títulos que a prática vem constantemente configurando, deve ser objeto de "leis aditivas"24, "por tratar-se de matéria em cujo âmbito são previsiveis alterações a curto prazo, em função de alterações econômicas ainda em processo" 25 . Bem assim, ofereceu a criação de uma categoria intermediária de do-
${ }^{20}$ REALE, Miguel, Memórias - vol. 2 - a Balança e a Espada, São Paulo, Saraiva, 1987, p. 221.

${ }^{21}$ Conforme afirmou Miguel REALE em entrevista à autora, em junho de 1998.

${ }^{22}$ REALE, Miguel, na "Exposição de Motivos do Projeto de Código Civil", ora em O Projeto de Código Civil - Situação atual e seus problemas fundamentais, São Paulo, Saraiva, 1986, p. 71 e ss.

${ }^{23}$ Ao projetar a Consolidac̃a FREITAS, mais de três décaçá das Leis Civis, aprovada pelo Governo Imperial em 1858 TEIXEIRA DE FREITAS, mais de três décadas antes da promulgação do Código Civil Alemão, já assentara a imprescindibilidade da divisão entre Parte Geral e Parte Especial para implementar a noção de sistema. Neste sentido o meu " $O$ sistema na Codificação Civil Brasileira - de Leibniz a Teixeira de Freitas", Revista da Faculdade de Direito da UFRGS vol. 17, Porto Alegre, 1999, p. 189.

${ }^{24} \mathrm{~A}$ expressão é de Miguel Reale e diz respeito à própria metodologia empregada pelo novo Código, que, não pretendendo tudo enrijecer em seu texto, supõe a emissão, no correr do tempo, de leis que o complementem, com maior flexibilidade inclusive no tocante ao processo legislativo, naqueles campos de vida mais suscetívis alteraçôes constantes. (in Código Civil - Anteprojetos, vol. 5, Tomo 1 Senado Federal, Subsecretaria de Edições Técnicas, Brasília, 1989, p. 23).

${ }^{25}$ REALE, Miguel, in Código Civil-Anteprojetos, cit., p. 23).

Revista da Faculdade de Direito da UFRGS, v. 20, Outubro/2001 cumentação de direitos creditícios, a meio caminho entre os chamados "créditos de direitos não-cambiários", oriundos de negócios jurídicos celebrados por instrumento particular ou público, e os títulos de crédito típicos ${ }^{26}$ (art. 889).

Com essas e outras inovações foi o Anteprojeto apresentado no mesmo ano de 1972 à comunidade jurídica e à sociedade, sendo, em 18 de junho de 1974, republicado e encaminhado ao Congresso Nacional ${ }^{27}$. Dez anos tramitou o Projeto na Câmara dos Deputados, sendo, a final, aprovado em 9 de maio de 1984, rumando então ao Senado da República, uma vez que o sistema bicameral vigente no Brasil impõe a aprovação legislativa em ambas as $\mathrm{Ca}$ sas do Congresso Nacional ${ }^{28}$.

No Senado o Projeto permaneceu por treze anos, até novembro de 1997, submergido que esteve o Brasil, desde 1985, no processo de redemocratização que implicou uma nova Constituição em 1988 e, em seguida, a edição de numerosas leis complementares à Constituição. Na legislatura de 1994, contudo, foram os trabalhos retomados, tendo o Projeto merecido notável atualização por parte da Comissão Especial que

o examinou, sendo Relator-Geral o Senador e Professor de Direito Josaphat Marinho ${ }^{29}$, com o auxílio de Miguel Reale e José Carlos Moreira Alves, os dois únicos membros da Comissão Elaboradora ainda em plena atividade, e de outros juristas e entidades ${ }^{30}$.

Retornando à Câmara dos Deputados em 1998, o texto recebeu ainda outras alterações, notadamente no Direito de Família, para adequá-lo às novas realidades normativa e sociológica - pois a instituição familiar certamente é, dentre os tradicionais pilares do Direito Civil, a que mais fortemente sente o impacto da realidade e das mudanças de mentalidade que levam à própria positivação, compreensão e operacionalização das normas jurídicas. Em meio a fortes críticas nos meios acadêmicos, sucessivos encontros nos quais tem sido objeto de debates acirrados entre os que enfatizam os seus méritos e os partidários da descodificação, e a oposição formal da Ordem dos Advogados do Brasil, o Projeto, agora finalmente aprovado, fala por si: tentando ouvir a sua voz, examinarei a sua estrutura e a noção de sistema que acolhe (Primeira Parte), e, após, as diretrizes expressivas do que há de inovador em seu conteúdo (Segunda Parte).

${ }^{26}$ Sobre este último ponto veja-se a análise de Mauro RODRIGUES PENTEADO, na "Exposição Justificativa da Proposta de Modificação do Título VIII, Livro I, Parte Especial, do Projeto de Código Civil (PLC n ${ }^{\circ} 118 / 84$ ) que dispõe sobre os Títulos de Crédito", in O Projeto de Código Civil no Senado, Tomo II, Brasília, Senado Federal, 1998, p. 277.

${ }^{27}$ Mensagem presidencial $n^{\circ} 160$, de 10.6.1975.

${ }^{28} \mathrm{Em}$ virtude das alterações procedidas pelo Senado no texto apreciado pela Câmara dos Deputados, o Projeto retornou a essa Casa Legislativa, onde, como já se esclareceu, foi Relator-Geral o Deputado Ricardo FIÚZA.

${ }^{29}$ A Comissão era Presidida pelo Senador Ronaldo CUNHA LIMA, sendo Vice-Presidente o Senador José Ignácio FERREIRA e Relator-Geral o Senador Josaphat MARINHO.

${ }^{30}$ Veja-se as contribuições de Fábio KONDER COMPARATO, Luis Edson FACHIN e Álvaro VILLAÇA AZEVEDO, MAURO BRANDÃO LOPES, entre outros juristas, in O Projeto de Código Civil no Senado, Tomo II, Brasília, Senado Federal, 1998.

Revista da Faculdade de Direito da UFRGS, v. 20, Outubro/2001 


\section{Estrutura e Sistema no novo Código}

A estrutura de um código não reflete uma opção puramente técnica, muito menos derivando do acaso ou de uma escolha arbitrária. Antes indica uma tomada de posição metodológica reveladora de uma filosofia (A). Também assim a idéia de sistema passível de ser retirada de um Códigoé claramente indicativa do seu modelo (B).

\section{A. A divisão em Parte Geral e Parte Especial}

Seguindo tradição que, no Direito brasileiro remonta à obra de Teixeira de Freitas, anterior, portanto, ao próprio Código Civil alemão, sendo acolhida por Beviláqua e vigorando no atual Código Civil, também o novo Código procede à estruturação bipartida em Parte Geral Parte Especial. Distingue-se, assim, da divisão clássica tripartite, o chamado "plano franeês", no qual a regulação das matérias civis é antecedida por um Livro ou Título Preliminar sintético, com normas de sobredireito. Adota o que se convencionou chamar de "plano germânico"31 , seguindo-se à Parte Geral a Parte Especial, composta por cinco Livros. Nesta se articulam o Livro I, concernente ao Direito das Obrigações, o Livro II, que versa o Direito de Empresa, o Livro III, tratando do Direito das Coisas (Direitos Reais), o Livro IV, contendo o Direito de Família, e o Livro V, com o Direito das Sucessões.

Revela esta estrutura uma opção política em tudo e por tudo diversa da existente no Código de 1.916, típico de uma sociedade patriarcal e centrada na propriedade fundiária, por isto seguindo à Parte Geral o Direito de Família, após o Direito das Coisas, o Direito das Obrigações e por fim o Direito Sucessório. Diferentemente, o novo Código inicia com a enunciação dos direitos da pessoa e da sua personalidade. trata das obrigações civis e comerciais, unificando-as mediante o conceito de empresa que merece um Livro próprio - só então passando aos direitos reais, ao direito das relações familiares e ao direito sucessório.

A Parte Geral é operacionalmente necessária para interligar todas as partes que compõem a estrutura codificada. Como afirmou com razão Octavian Ionescu ${ }^{32}$, o fato de a parte introdutória dos códigos civis ser estruturada ou sob a forma sintética de um "título preliminar", ou sob a forma desenvolvida de uma "parte geral" não é questão de mera técnica legislativa, comportando, ao revés, implicações de ordem científica e ideológica e, conseqüentemente, problemas de ordem teórica e prática que se refletem na noção de sistema. A ausência de uma parte geral significa a recusa à idéia de sistema enquanto encadeamento lógico-dedutivo, identificando-se, então, o termo sistema, apenas com um método de organização das matérias componentes do Direito Privado.

Diversamente, a presença de uma Parte

${ }^{31}$ A estruturação em uma Parte Geral e uma Parte Especial é devida aos pandectistas alemães do séc. XIX. Segundo informa MOREIRA ALVES, primeiramente ela se encontra na segunda edição (1796) da obra System der gesamten heutigen Civilrechts, de DABELOW, de onde foi a idéia retirada por Gustav HUGO e, após, por Georg Arnold HEISE, que dela se utiliza em 1807 em sua obra Grundriss eines Systems des gemeinen Zivilrechts, acabando por ganhar corpo no Código da Saxônia, de 1863, e, ao final do século, no BGB (vide A Parte Geral do Projeto de Código Civil Brasileiro, cit., pp. 14 e 21).

${ }^{32}$ IONESCU, Octavian, "Le problème de la partie introductive du code civil", Revue International de Droit Comparé, 1967, n.3, p. 579.

Revista da Faculdade de Direito da UFRGS, v. 20, Outubro/2001
Geral significa a ausência de "paredes internas", de modo que muito mais facilmente permite operar o que a doutrina alemã chama de "sistema móvel", isto é, aquele em que a solução prevista para determinado setor pode ser utilizada, se assim parecer útil e conveniente, para regular outro instituto, para o qual originalmente não havia sido pensada ${ }^{33}$. A importância da Parte Geral está, pois, em que assegura a unidade do Código, permitindo que o direito seja construído de forma centralizada, mediante a dedução lógica entre os conceitos de maior grau de generalidade, ali postos e os institutos (casos ou espécies) versados na Parte Especial, o que não implica dizer que o sistema seja necessariamente lógico-formal, ou que a lógica formal represente o único meio possível para este fim: o conteúdo material da Parte Geral poderá conduzir a outras acepções de sistema ${ }^{34}$, não se devendo confundir a "idéia de Código" carac- terística do século XIX com cada concreto e do elaborados nesta nossa "era da recodificação" 35 .

Na Parte Geral do novo Código Civil brasileiro (arts. $1^{\circ}$ a 232 ) estão, pois, as disposições gerais aplicáveis às pessoas, aos valores essenciais da personalidade humana, ao regramento das pessoas jurídicas, aos bens e aos fatos jurídicos, iniciando com a norma fundamental da capacidade jurídica de todo ser humano $^{36}$ e a regra relativa à personalização civil, iniciada do nascimento com vida, protegendo-se os direitos do nascituro desde a concepção $0^{37}$.

Diversamente do ainda vigente Código, no qual são ausentes as regras a respeito dos direitos de personalidade - no mais das vezes efetivo código civil, mormente os que vêm sen-

${ }^{33}$ Vide CANARIS, Claus Wilhem, Pensamento Sistemático e Conceito de Sistema na Ciência do Direito, trad. MENEZES CORDEIRO, Lisboa, Gulbenkian, 1989, pp. 130 e ss.

${ }^{34}$ As observações de CANARIS acerca do sistema como ordem axiológica ou teleológica estão em Pensamento Sistemático e Conceito de Sistema na Ciência do Direito, cit., pp. 66 e ss. Uma estrutura lógico-formal, desde que contenha, materialmente, princípios de valor e cláusulas gerais que permitam a ligação intersistemática (por exemplo, com a Constituição) conduzirá a delineamento do sistema como uma ordem teleológica ou (por exemplo, com a Constituição) conduzirá ao delineamento do sistema como uma ordem teleológica ou axiológica.

${ }^{35} \mathrm{~A}$ expressão remete tanto ao paradigmático texto de N. IRTI, já antes citado (L'età della decodificazione) quanto ao seu recente Codice Civile $\mathrm{e}$ Società Politiche, Roma, LATERZA,1999, no qual, com a humildade que é própria aos grandes juristas, revisa o seu entendimento, afirmando que, mudado o contexto que o levara a situar a unidade do sistema, como tábua de valores coletivos, sob a garantia da Constituição, esta unidade encontrase, agora, novamente sob a responsabilidade do Código (ver, em especial, o ensaio Códice Civile e Plusvalore Político, pp.5 a 18)

${ }^{36 " A r t .} 1^{\circ}$ : "Toda pessoa é capaz de direitos e obrigações na ordem civil", substituindo-se, por pressões eministas o termo "homem", constante do Anteprojeto, pela expressão "ser humano" e, finalmente, após Glima voção ma Camara dos Deputados, empregando-se o termo "pesso", restando a questão de saber se perceberam os Deputados (ou perceberão, daí para diante, os operadores jurídicos), a existência, ou não de sinonímia entre os termos "pessoa" " "ser humano", aproximando, assim, o conceito normativo ("pessoa") do conceito naturalista ("ser humano").

${ }^{37}$ Art. $2^{\circ}$ "A personalidade civil da pessoa começa do nascimento com vida; mas a lei põe a salvo, desde a concepção, os direitos do nascituro".

Revista da Faculdade de Direito da UFRGS, v. 20, Outubro/2001 
confundida com a capacidade ${ }^{38}$ - o Código recém aprovado dedica o Capítulo II do Livro I da Parte Geral ao seu regramento ${ }^{39}$.Em boa hora os codificadores renunciaram tanto à tentativa de conceituar os direitos de personalidade quanto a promover a sua indicação pontual e a sua taxinomia. Esta é tarefa própria à atividade doutrinária, sabendo-se que desde que Von Gierke dedicou-se pioneiramente ao tema, a doutrina e a jurisprudência não cessam de reconhecer novas espécies de direitos que derivam do mero fato de existirmos e possuirmos, por isso, especial dignidade ${ }^{40}$.

Por esta razão, a técnica utilizada foi a das cláusulas gerais ${ }^{41}$, que permitem tanto a ligação intra-sistemática (entre as normas do próprio Código) quanto a conexão inter-sistemática (por exemplo, entre o Código e a Constituição) e mesmo extra-sistemática (remetendo o intérprete para fora do sistema jurídico, a fim de concretizar determinado valor ou diretiva).

Já no art. 11, determina serem intransmissíveis e irrenunciáveis os direitos de personalidade, não podendo o seu exercício sofrer limitação voluntária, salvo nos casos pre-

${ }^{38}$ Como já tive ocasião de observar, "vivíamos, até há pouco, dominados pela idéia de pessoa modulada pela era codificatória, assim entendida a que seguiu-se às grandes codificações oitocentistas correspondentes à ascensão do individualismo burguês e do capitalismo. Aí foi desenhada a idéia de pessoa como "sujeito" e como "indivíduo". No discurso pandectista do século XIX, a palavra "sujeito" depreendeu-se das subjetividades que mais tarde a psicanálise viria revelar e conotou-se a uma idéia externa, objetivada, por assim vidades que mais tarde a psicanálise viria revelar e conotou-se a uma idéa externa, objetivada, por assim
dizer, a idéia de um "sujeito" que é visto tão só como "termo" ou "elemento" da relação jurídica, como dizer, a ideia de um "sujeito" que é visto tão só como "termo" ou "elemento" da relação jurídica, como
aquele que pode (é capaz de) ser titular de direitos, atuando na ordem jurídica. Sujeito que é privilegiadamente o "indivíduo", porque não mais definido pela pertença a um grupo, casta, classe, família, status, porque apartado (dividido) de um todo, de uma comunidade que o ultrapassa, significações reveladoras da "lógica proprietária" que revestiu a própria idéia de pessoa humana. Submergida a idéia de "pessoa" na de "indivíduo" (ao senso "egoísta" do termo) e não-visualizada a de "personalidade" pela preeminência do conceito técnico de "capacidade", traçaram-se as tramas semânticas que acabaram por fundir o "ser pessoa" com o "ser capaz de adquirir direitos e contrair obrigações". Em outras palavras, instrumentalizou - se a personalidade humana reproduziu-se, na sua conceituacão a lógica do mercado, o que conduziu

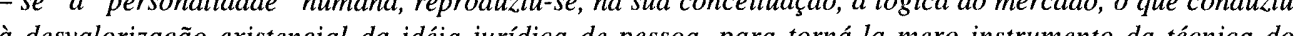
à desvalorização existencial da idéta juridica de pessoa, para tornála mero instrumento da técnica do Direito" (In "Os Danos à Pessoa e a Natureza de sua Reparação", Revista da Faculdade de Direito da Universidade Federal do Rio Grande do Sul vol. 19, Porto Alegre, março 2001)

${ }^{39}$ Acerca dos direitos de personalidade no Projeto, veja-se MARINHO, Josaphat, "Os Direitos de Personalidade no Projeto do Código Civil", Boletim da Faculdade de Direito da Universidade de Coimbra, col. Stvdia Juridica, 40, Coimbra, 2000.

${ }^{40} \mathrm{~A}$ expressão "direitos de personalidade" parece ter sido utilizada pioneiramente por Georg Carl NEUER, em 1866, embora a época ainda fosse fortemente marcada pela concepção savignyana do primado da relação sobre a pessoa o que conduziu ao obscurecimento da idéia de personalidade pela noção de capacidade. Na verdade foi VON GIERKE, em 1895, no seu Deutsches Privatrecht quem primirecte direitos subjetivos que nascem do fato de "ser pessoa", influ suiço de 1907, que expressamente os previu. Para um exame veja-se HATTENHAUER, Hans, Conceptos Fundamentales del Derecho Civil, Barcelona, Ariel, 1987, e, na doutrina brasileira mais recente, Fachin, Luis Edson, Teoria Critica do Direito Civil, Rio de Janeiro, Renovar, 2000; LUDWIG, Marcos de Campos, "O direito ao livre desenvolvimento da personalidade na Alemanha e possibilidades de sua aplicação no Direito privado brasileiro" e CUNHA, Alexandre dos Santos, "Dignidade da Pessoa Humana: conceito fundamental do Direito Civil", ambos in A Reconstrução do Direito Privado - reflexos dos princípios constitucionais e dos direitos fundamentais no Direito Privado, MARTINS-COSTA, Judith(org.), no prelo e ainda o meu "Bioética e dignidade da Pessoa Humana: Rumo à Construção do Biodireito", Revista da Faculdade de Direito da Universidade Federal do Rio Grande do Sul vol. 18, Porto Alegre, 2000.

${ }_{41}$ A propósito da metodologia no emprego das cláusulas gerais, observe-se, infra.

Revista da Faculdade de Direito da UFRGS, v. 20, Outubro/2001 vistos em lei. $O$ art. 12 determina poder-se exigir que cesse a ameaça, ou a lesão, a direito de personalidade, e reclamar perdas e danos, sem prejuízo de outras sanções previstas em lei, estatuindo o art. 21 a tutela da vida privada, nos seguintes termos: "A vida privada da pessoa natural é inviolável, e o juiz, a requeri mento do interessado, adotará as providências necessárias para impedir ou fazer cessar ato contrário a esta norma". Em outras palavras, o juiz tem o dever ${ }^{42}$ de determinar a providência que, à vista das circunstâncias, entenda mais adequada à otimização do conteúdo das normas protetivas do art. $12 \mathrm{e} 21$, podendo esta consistir na adoção de medida cautelar, antecipatória da tutela definitiva, na imposição de astreintes, de obrigação de não-fazer, de perdas e danos, etc.

O art 13 regula os atos de disposição de próprio corpo, permitindo-se os transplantes (parágrafo único) e a disposição gratuita do próprio corpo, post mortem (art. 14), tutelandose expressamente o direito ao nome e o pseudônimo (arts. 16 a 19), a propriedade intelectual, a honra, a imagem, a boa fama e a respeitabilidade da pessoa (art. 20).

Manteve a Parte Geral, outrossim, as normas comuns aplicáveis às pessoas jurídicas de direito público e de direito privado (arts. $40 \mathrm{a}$ 69 e 75), prevendo expressamente a desconsideração da personalidade jurídica em caso de abuso, desvio de finalidade ou confusão patrimonial (art. 50). Na origem desta regra está sugestão do Professor Fábio Konder

${ }^{42}$ Assinalo o emprego do modo imperativo no verbo "adotar, no art. 21."

${ }^{43}$ COMPARATO, Fábio Konder, Correspondência dirigida ao Senador Josaphat Marinho em 3.9.97, in O Projeto de Código Civil no Senado, Tomo II, Brasília, Senado Federal, 1998.

${ }^{44}$ Idem.

${ }^{45}$ COUTO E SILVA, Clóvis, "Observações à Parte Geral do Anteprojeto de Código Civil", dirigidas ao Relator José Carlos MOREIRA ALVES em março de 1970, reproduzidas nas notas de rodapé da "Análise das Observações José Carlos MOREIRA ALVES em r şo de 197, reprólas nivil", in A Parte Geral do Projeto de Código do Prof. Couto e Silva à Parte Geral do Anteprojetode Código Civil", in A Parte Geral do Projeto de Cóngo
Civil, cit., pp. 39 a 42 .

Revista da Faculdade de Direito da UFRGS, v. 20, Outubro/2001
Comparato, da Universidade de São Paulo, que assim se pronunciou: "É preciso distinguir entre despersonalização esconsideração da personalidade jurídica. suprime a autonomia subjetiva da pessoa jurídica, como ente distinto da pessoa de seus só(

A causa da desconsideração, isto é, o abuso, deve ser buscada no desvio dos fins estabelecidos no contrato social ou nos atos so, como alerta Comparato, "na confusão entre o patrimônio social e o dos sócios ou admividade prevista, estatutária ou contratualmen$e{ }^{\prime 4}$. as pertenças (que não são partes integrantes) no art. 93, determinando no art. 94 que os negócios jurídicos que dizem respeito ao bem princitrírio resultar da lei, da manifestação de vontade ou das circunstâncias do caso. Como explica Clóvis do Couto e Silva ${ }^{45}$, no que toca aos bens, os códigos italiano e português estabelecram a distinção entre parte integrante essenassim consideradas as coisas destinadas permanentemente ao serviço ou ao ornamento de outra coisa cuja característica é - diversamente dos bens acessórios, sujeitos ao "princípio cios ou administradores, mas afasta-a tão só nistradores, ainda que mantida a mesma ati- 
da gravitação jurídica" — suportar relação jurídica própria ${ }^{46}$.

A distinção tem importância porque, de modo geral, nas codificações latino-americanas, incluso o vigente Código Civil brasileiro, vigora o axioma de que o vendedor, na dúvida, tem que entregar ao comprador a coisa com as pertenças. Contudo, podem existir, e efetivamente existem, diversos graus de vinculação entre as coisas. Adotando-se uma perspectiva escalonada do ordenamento jurídico, observase que uma vinculação mais íntima dará lugar à noção de parte integrante essencial, como a que liga uma edificação ao terreno no qual construída. Uma vinculação não tão íntima dará lugar à categoria das partes integrantes nãoessenciais, como a que vincula uma fábrica ao seu maquinário. Num grau mais distante estarão as pertenças, configurando-se o grau do liame pela concreta natureza da relação, pelas circunstâncias, pelos usos, pela lei ou pelo exercício da autonomia privada ${ }^{47}$.

Já o Livro III trata dos Fatos Jurídicos. Aqui se contêm as maiores inovações respeitantemente à disciplina do Código Civil vigente, a iniciar pela denominação - "Do Negócio Jurídico" - constante de seu Título I especificando-os e recortando-os da categoria geral dos Atos Jurídicos, o que tem evidentes reflexos práticos, não se tratando de mero nominalismo. Aos atos jurídicos lícitos stricto sensu e aos atos-fatos (ou "atos reais", na terminologia portuguesa, denominação derivada da doutrina alemã) aplica-se, apenas no que couber, a disciplina reservada aos negócios (art. 185), assim seguindo a metodologia adotada no

Código Civil português de 1967, como esclarece José Carlos Moreira Alves, o Relator da Parte $\mathrm{Geral}^{48}$.

O Livro III inicia, pois, com a regulação dos Negócios Jurídicos (Título III), cujas disposições gerais abarcam as regras de sua validade (art. 104), da impossibilidade do objeto quando de sua celebração (art. 106), determinando que esta não invalida o negócio, se relativa; ou, se absoluta, só quando cessar antes de realizada a condição a que estiver subordinada. Contém, por igual, regra acerca do silêncio (art. 111), que importa anuência quando as circunstâncias ou os usos o autorizarem, dispondo, no art. 113, acerca da interpretação ("Os negócios jurídicos devem ser interpretados conforme a boa-fé e os usos do lugar de sua celebração"), o que conduzirá - oportunamente o veremos - à eticidade como uma das marcas do novo Código.

Superando a linguagem oitocentista que tratava dos "vícios do consentimento", o Código recém aprovado, mais adequadamente versa, no Capítulo IV do Livro III da Parte Geral, sobre os Defeitos do Negócio Jurídico - o erro ou ignorância (arts. 138 a 144), o dolo (art. 145 a 150 ), a coação (art. 151 e 155), o estado de perigo (art. 156) e a lesão (art. 157). Acerca destes dois últimos cabe breve consideração, pois o primeiro introduz, e o segundo reintroduz, no Direito brasileiro, expressivas alterações.

O "estado de perigo" configura-se "quando alguém, premido da necessidade de salvar-se, ou a pessoa de sua família, de grave dano conhecido pela outra parte, assume obri-

${ }^{46}$ Sobre as pertenças veja-se PONTES DE MIRANDA, Tratado de Direito Privado, Tomo II, Rio de Janeiro, Borsói, 154, parágrafos 127 e 138, e FRADERA, Vera Maria JACOB de, "Pertenças", Revista Jurídica 1.26, Porto Alegre, 1988

${ }^{47}$ Para estas observações veja-se COUTO E SILVA, in MOREIRA ALVES, op. cit., nota 5, pp. 39240. ${ }^{48}$ MOREIRA ALVES, José Carlos, op. cit.,p. 98.

Revista da Faculdade de Direito da UFRGS, v. 20, Outubro/2001 gação excessivamente onerosa', estendendose a regra inclusive para pessoa não integrante da família do declarante, hipótese em que o juiz decidirá "segundo as circunstâncias". Tratase de hipótese em que alguém se obriga a dar ou a fazer (prestação) por uma contraprestação sempre de fazer, como esclareceu Moreira Alves ao dar parecer opinativo da rejeição à emenda senatorial que visava simplesmente a suprimir o art. 156, sob o argumento de que o mesmo "com grande prejuízo para os interesses e a validade dos contratos em geral"49.

Preceito similar constava do Projeto de Beviláqua, tendo sido suprimido pela Comissão Revisora 'sem que se saibam os motivos que a isto conduziram"so. Uma hipótese que avento para a supressão, há quase cem anos, e para os protestos que ainda hoje gera esta re$\mathrm{gra}^{51}$ é a sua imensa potencialidade social, que, como é sabido, incomoda ao pensamento conservador. Com efeito, no seu substrato não esta a ficção da igualdade das partes, de modo que a regra terá relevância na tutela do contratante fraco: figure-se a hipótese de, numa internação hospitalar de urgência, a entidade obrigar doente, ou os seus familiares, a assumirem peestaria confundido com o instituto da lesão sada obrigação financeira, sob pena de, assim ou não se fazerem exames que seriam devidos, ou não ministrar o dispendioso medicamento! Do mesmo modo que o "estado de perigo", a invalidade (anulabilidade) por lesão (art. 157) constitui novidade em relação ao Código vigente, muito embora o instituto da lesão, com origens romanas, mas elaborado pelo ius commune, seja figura antiquíssima em nosso Direito: previsto em Portugal desde o séc. XIII ${ }^{52}$, mantido nas Ordenações Filipinas (Livro IV, Titulo XIII) foi expressamente acolhido por Teixeira de Freitas na Consolidação das Leis Civis (art. 359), aí estatuindo o que Ruy Rosado de Aguiar Júnior qualificou de "lesão pura, onde não havia vício de vontade, mas rescindibilidade entre as prestações, objetivamente verificada ${ }^{53}$.

A reintrodução destes instituto é também reveladora da "ética da situação" que marca o novo Código. Bevilácqua era frontalmente contrário, em nome do "princípio da autonomia da vontade", posicionando-se antagonicamente, pois, ao intervencionismo estatal representado pelo poder dado ao juiz de apreciar a lenão procedendo, não se realizar o tratamento, fundada na simples quebra de equivalência

${ }^{49}$ Emenda ${ }^{\circ}$ 20, de autoria do Senador Gabriel HERMES, in O Projeto de Código Civil no Senado, Tomo I, Brasília, Senado Federal, 1998.

${ }^{50}$ MOREIRA ALVES, José Carlos, A Parte Geral..., cit., p.108.

${ }^{51}$ Assim editorial no conservador jornal O ESTADO DE S. PAULO de 6 de janeiro de 2001.

${ }^{52}$ Segundo Antonio HESPANHA, a lesão ingressa na Idade Média através de uma Decretal do papa Gregório IX (1234) que, por sua vez, se baseava na teoria escolástica do "justo preço"(ver, do autor, a "Nota do Tradutor", à 741 du po 741 dabra I como 0 ar 170 no ano de 1170 , relativa a venda de un bosque pela metade do valor, e a outra de Inocencio III, do ano de 1208 que trata também da venda de um imóvel pela metade do valor (MOISSET DE ESPANES, Luis, La lesión los Actos Juridicos, Cordoba, Victor P. De Zavalia Editor, 1979, p. 56 e 57.Em Portugal, especificamente, a lesão foi recebida nos finais do séc. XIII, sendo consagrada nas Ordenações Afonsinas (IV, 45) Manuelinas (IV, 30) e Filipinas (Liv. IV, T.13): aí se declarava que o contrato de compra e venda de bens móveis ou imóveis (bens de raiz) embora "perfeito", poderia ser desfeito se uma das partes tivesse sido enganada além da metade do justo preço, distinguindo-se entre a lesão "enorme" e a "enormíssima" de forma tarifária.

${ }_{53}$ AGUIAR JÚNIOR, Ruy Rosado. "Cláusulas Abusivas no Código do Consumidor", in A Protecão do Con-

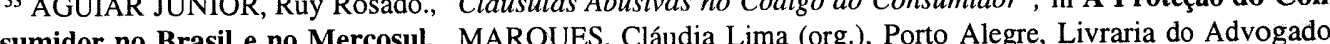

1994, p. 16.

Revista da Faculdade de Direito da UFRGS, v. 20, Outubro/2001 
são. Para tanto, argumentava, como base no Direito Comparado, que "as legislações mai modernas" haviam abolido o instituto, invocando também razões de ordem sociológica: desse ponto de vista, escreveu, só se admite a rescisão por lesão "nas épocas em que o Estado necessita exercer uma tutela mais direta e contínua sobre a vida privada dos indivíduos, porque esses não se sentem assaz fortes contra a prepotência e contra a cobiça, e porque, entre as classes sociais, há um verdadeiro contraste ${ }^{54}$ ".

Ressurgirá a lesão, apenas sob a forma da usura, no campo penal, no final da década de $30^{55}$, sendo fixada como crime contra a economia popular na Lei ${ }^{\circ} 1.521 / 51$. Porém, até recentemente, no campo civil, era totalmente afastada. Dos raros acórdãos indexados na jurisprudência eletrônica do Supremo Tribuna Federal está o que afirma a "impossibilidade" da anulabilidade de contrato por lesão, pois "desde que o Código Civil regulou a matéria relativa aos atos jurídicos e especificou os ví cios do consentimento, excluindo a lesão, é evidente que esta não constitui mais motivo de anulação dos contratos" $" 56$.

Como defeito do negócio jurídico que leva à sua rescisão, a lesão reingressa apena

${ }^{54}$ BEVILÁQUA, Clóvis, Projeto de Código Civil Brasileiro, Trabalhos da Comissão Especial da Câmara do Deputados, VI, p. 8, citado por SILVA PEREIRA, Caio Mario, Lesão nos Contratos, Rio de Janeiro, Forense,

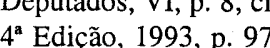

${ }_{55} \mathrm{Em} 1938$, Decreto-Lei ${ }^{\circ}$ 869, definiu como crime contra a economia popular a usura pecuniária, ou real e definiu o crime:"obter ou estipular, em qualquer contrato, abusando da premente necessidade, inexperiência ou leviandade da outra parte, lucro patrimonial que exceda o quinto do valor corrente ou justo da prestação feita ou prometida. O elemento subjetivo estava justamente na causa, ou seja, abusar da necessidade inexperiência ou leviandade da outra parte, para obter vantagem patrimonial, residindo o elemento objetivo na ruptura da igualdade das prestações, exigido que se observasse uma "igualdade parcial" (garantindo o lucro), o qual não poderia exceder de $20 \%$ o justo valor. No Estado Novo, Carta Constitucional de 1937, determinou, no art. 142: "A usura será punida". E, finalmente, a Lei $\mathrm{n}^{\circ} 1521$, de 26 de dezembro de 1951, ao definir os crimes contra a economia popular, preceituou igualmente o crime.

RE 82971/RS, Rel. Min. Cunha Peixoto, $1^{\text {a }}$ T. j. 26.10.76, p. em DJ de 31. 12.76 e in RTJ vol. 84 p. 218), ${ }^{57}$ ROSADO DE AGUIAR, Ruy, "Aspectos do Código de Defesa do Consumidor" Revista Ajuris, vol. 52. Vejase do mesmo autor "Cláusulas Abusivas no Código do Consumidor", citado, p. 16."

Revista da Faculdade de Direito da UFRGS, v. 20, Outubro/2001
O reingresso da lesão em nosso ordenamento civil não foi tranqüilo: no Senado atual art 157 sofreu emendas, uma proposta pelo Senador Jutahy Magalhães, que queria nova redação, para subordinar a lesão ao dolo, outra proposta pelo Senador Gabriel Hermes ${ }^{58}$ que queria eliminar a expressão "por inexperiência do agente" como causa de invalidação do negócio jurídico, restringindo-a apenas à "premente necessidade" do lesado.

Mas, felizmente, as emendas foram rejeitadas, seguindo-se a opinião de Moreira Alves, segundo o qual a lesão ocorre quando há a "usura real", não sendo necessário que a outra parte saiba da necessidade ou da inexperiência, pois "ao contrário do que ocorre com o estado de perigo em que o beneficiắrio tem que conhecê-lo, na lesão o próprio conhe cimento é indiferente para que ela se configu$r e, 59$, o que significa dizer que em nosso Direito mantém-se a tradição salutar de considerar a lesão objetivamente.

Também seguindo a tradição que vem do ius commune, expressa nas Ordenações e na Consolidação de Teixeira de Freitas, o negócio pode convalescer, se for oferecido suplemento, determinando o Código que a desproporção se apure segundo os valores vigentes ao tempo do ato (art. $157, \S 1^{\circ}$ ), o que indica se francês, mas também do sistema alemão e do

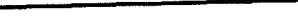

58 Assim pronunciou-se MOREIRA ALVES ao dar parecer sobre a emenda supressiva do Senador Gabriel Hermes: "A lesão ocorre quando há a usura real. Não há, na lesão, ao contrário do que ocorre com o estado de perigo, que vicie a simples oferta. Ademais, na lesão não é preciso que a outra parte saiba da necessidade ou da inexperiência: a lesão é objetiva. Já no estado de perigo é preciso que a parte beneficiada saiba que a obrigação foi assumida pela parte contrária para que esta se salve de grave dano (levando-se em conta, pois, elemento subjetivo"). In O Projeto de Código Civil no Senado, Tomo II, Brasília, Senado Federal, 1998, p. 015.

${ }^{59}$ MOREIRA ALVES, Idem, ibidem.

${ }^{60}$ MOREIRA ALVES, Idem, ibidem.

${ }^{61}$ SILVA PEREIRA, Caio Mario,Lesão nos Contratos, cit., p. 199.

${ }^{62}$ Art. 186: “Aquele que, por ação ou omissão voluntária, negligência ou imprudência, violar

direito e causar dano a outrem, ainda que exclusivamente moral, comete ato ilícito". Revista da Faculdade de Direito da UFRGS, v. 20, Outubro/2001 

como sinônimas ${ }^{63}$. trina e da jurisprudência brasileiras ao situar o da não para o gênero, mas para uma das espécies de dano extrapatrimonial, é corrente na doutrina e jurisprudência brasileiras como designativa do gênero, podendo-se afirmar que, muito embora as distinções feitas pela doutrina mais rigorosa, no Brasil, as expressões "dano moral" e "dano não-patrimonial" são utilizadas

Juntamente a esta cláusula geral de ilicitude, fundada na culpa, o novo Texto reserva, no art. 187, cláusula geral de ilicitude, de índole objetiva ${ }^{64}$. Esta norma constitui, na abalizada opinião de Ruy Rosado de Aguiar Júnior, "regra quase perfeita, que servirá para iluminar todo o Direito Obrigacional no Brasil ${ }^{65}$ ". A sua importância está em que deixa claro o injustificável equívoco de grande parte da dou-

abuso apenas quando há a intenção de prejudicar (o que efetivamente não se retira da literalidade do art. 160, I do Código vigente), indo além, por reunir, num mesmo dispositivo, referência a quatro princípios fundamentais do ordenamento: o abuso de direito, o fim social, a

No que concerne ao regramento da prescrição e da decadência - tema tormentoso no Código Civil vigente, que mistura ambas as espécies - o novo Código adotou interessante solução metodológica: trata sistematicamente apenas da prescrição (art. 189 a 196), enumerando as hipóteses na Parte Geral (art. 206) e acoplando as regras relativas à decadência em cada preceito onde cabível, salvo a regulação genérica dos arts. 207 a 211. Sabe-se que a prescrição é o encobrimento dos direitos análogos

${ }^{63}$ A legislação brasileira utiliza a expressão "dano moral" para referir-se a todas as espécies de danos nãopatrimoniais, assim constando do art. $5^{\circ}$, incisos $\mathrm{V} \mathrm{e} \mathrm{X} \mathrm{da} \mathrm{Constituição} \mathrm{Federal,} \mathrm{e} \mathrm{da} \mathrm{legislação} \mathrm{especial.} \mathrm{A} \mathrm{mesma}$ denominação é seguida por grande parte da doutrina e da jurisprudência, encontrando-se a distinção seja entre danos morais subjetivos e objetivos, seja entre danos morais diretos ou indiretos para especificar aqueles que dizem respeito diretamente à esfera da mais direta subjetividade e os que atinem à repercussão social da esfera da

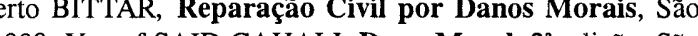
Paulo, Revista dos Tribunais, $3^{\mathrm{a}}$ edição, $2^{\mathrm{a}}$ tiragem, 1999; Yussef SAID CAHALI, Dano Moral, $2^{\mathrm{a}}$ edição, São Paulo, Revista dos Tribunais, 1998; Arnoldo MEDEIROS DA FONSECA, Dano Moral, verbete in Repertório Enciclopédico Brasileiro, vol. 14, 241). Raros são os textos, doutrinários ou jurisprudenciais, que utilizam a expressão "danos à pessoa" para indicar a vasta categoria dos atentados à personalidade, como o faz Clóvis do Couto e Silva, o qual, todavia, realiza a sinonímia entre dano moral e dano extrapatrimonial que já havia sido contestada nos anos 60, com integral pertinência, por Pontes de Miranda (Vide Clóvis DO COUTO E SILVA, " $O$ conceito de dano no Direito brasileiro e comparado", in O Direito Privado Brasileiro na visão de Clóvis do Couto e Silva", 20 cuidado de FRADERA, Vera Maria Jacob, Porto Alegre, Livraria do Advogado, 1997, 217). Diversamente, PONTE "para graves confuszes", explicando. "As vezes, os escritores e juizes dissertadores empregam a expressão "dano moral" em sentido amplíssimo (dano à normalidade da vida de relação, dano moral estrito, que é o dano à reputação, o dano por depressão ou exaltação psíquica ou nêurica, dano que não é qualquer dos anteriores mas também não ofende o patrimônio, como a dor sofrida, o de destruição de bem sem qualquer valor moral o dano à normalidade da vida de relação, o dano que faz baixar o moral da pessoa e o dano à reputação. Finalmente, há o senso estrito de dano moral: o dano à reputação"(PONTES DE MIRANDA, Tratado de Direito Privado, T. 26, Ed. Borsói, Rio de Janeiro, 1959, parágrafo 3.108, 31, grifos do autor).

${ }^{64}$ Art. 187: "Comete ato ilícito o titular de um direito que, ao exercê-lo, excede manifestamente os limites impostos pelo seu fim econômico-social, pela boa-fé ou pelos bons costumes". Justiça Federal v.9, Brasília, 1999, p. 31, também disponivel em http://www. cjf.gov.br/Publicacoes/Publicacoes.asp. Revista da Faculdade de Direito da UFRGS, v. 20, Outubro/2001 boa-fé e os bons costumes. "As vezes, os escciores e juzes dissertadores expo patrimonial ou de valor patrimonial infimo. Aí, dano moral seria dano não patrimonial. Outros têm como dano

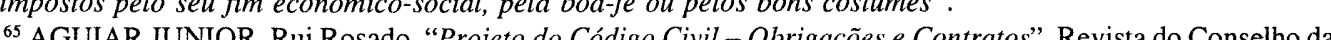

à pretensão, enquanto a decadência trata da extinção dos direitos potestativos, de modo que a solução adotada é extremamente operativa, motivo pelo qual Reale com ela exemplifica a diretriz da operacionalidade que dominou, entre outros, os trabalhos codificatórios ${ }^{66}$.

A Parte Geral encerra com as regras relativas à prova dos fatos jurídicos (art. $212 \mathrm{e} \mathrm{ss),}$ regulamentando a confissão (arts. 213 e 214), e admitindo no art. 225, quaisquer reproduções fotográficas, fonográficas, cinematográficas e, em geral, quaisquer reproduções mecânicas ou eletrônicas de fatos ou coisas, salvo impugnação da parte contrária.

Se a Parte Geral corresponde - para usar antigo clichê - "ao que, na matemática, vem antes do parêntese", definindo, assim, a possibilidade de um sistema interno inconfundível com a mera ordenação extrínseca das matérias é porque, da estrutura calcada numa Parte Geral e numa Especial decorre certa unidade lógica e conceitual, o que Miguel Reale denominou de diretriz sistemática ${ }^{67}$.

Porém, não se confunda a diretriz sistemática com a "idéia de sistema" construída, desde o Jusracionalismo, como um abstrato modelo geométrico. A diretriz, aqui, diz mais de perto com a noção de unidade. Como afirma Irti, hoje em dia o Código Civil reassume uma decisiva posição histórica, pois, acolhendo princípios, custodiando técnicas de disciplina e categorias ordenatórias, tem novamente "la responsabilità dell'unità", suprindo a Consti-

tuição, que não pode tudo prever e está mais fortemente sujeita aos azares da política, desenvolvendo então o Código a função de garantia e protegendo a continuidade da vida ci$\mathrm{vil}^{68}$.

Bem por isto, no novo Código Civil a estrutura sistemática, não estática e fechada, mas aberta e móvel, uma vez centrar-se em numerosas cláusulas gerais, é completada pela obra de implementação da unidade do Direito das Obrigações, que, na verdade, é uma realidade independentemente da previsão codicista: nosso Código Comercial de 1850, por demais vetusto e totalmente recortado por leis especiais de há muito tem, para a prática jurídica brasileira, valor meramente residual .Como assinala Reale, 'na realidade o Direito das Obrigações, na matéria civil, é hoje tábua reguladora também das obrigações de natureza empresarial. de natureza mercantil ou industrial" ${ }^{\prime \prime}$.

A unidade do Direito Obrigacional é assegurada pela disciplina jurídica da Empresa (Livro II da Parte Especial). Partiram os codificadores do pensamento de que o modelo jurídico da empresa não é uma criação do Direito, a ele antecedendo a sua existência como realidade econômica, constatação relevante por gem uma constante resposta do Direito ${ }^{70}$. Forte nesta premissa o Código ora aprovado recusa-se a conceituar a empresa, disciplinando-a, todavia, sistematicamente, a partir da noção do empresário como aquele que "exerce profissionalmente atividade econômica organizada salientar a existência de forças sociais que exi-

${ }^{66}$ REALE, Miguel, O Projeto de Código Civil - situação atual e seus problemas fundamentais, São Paulo, Saraiva, 1986, pp. 11 e 12 .

${ }^{67}$ REALE, Miguel, O Projeto de Código Civil - situação atual e seus problemas fundamentais, São Paulo, Saraiva, 1986, pp. 5 a 7.

68 IRTI, N. Diritto Civile e Società Política, cit., p.15.

${ }^{68}$ IRTI, N. Diritt
${ }^{69}$ Idem, p. 6.

70 Veja COUTO E SILVA, Clóvis, "O Conceito de Empresa no Direito Brasileiro", Revista Ajuris vol. 37 , p. 42 e ss. 
para a produção ou a circulação de bens ou de serviços" (art. 966 ${ }^{71}$ ).

Muito embora a unificação do Direito Obrigacional proposta no novo Código Civil brasileiro não constitua cópia das legislações suíça e italiana, que também a asseguram pois, como visto, uma tal estrutura já havia sido imaginada no século XIX pelo grande Teixeira de Freitas- é bem verdade que algumas das regras relativas à disciplina da empresa têm inspiração italiana ${ }^{72}$. Assim, o próprio conceito de empresário (art. 966), que corresponde ao disposto no art. 2.082 do Codice Civile, o que foi aceito pela Comissão Elaboradora "porque as notas da definição reproduzem, em grande medida, o conceito econômico de empresa" 73 .

A empresa pode ser exercida por uma pessoa isoladamente, o empresário, pessoa física, ou por uma sociedade, hipótese em que se configurará a sociedade empresária (art. 982) A nova Lei Civil divide as sociedades em não personificadas (Livro II, Título II, Subtítulo I,) e personificadas (Subtítulo II), não admitindo, porém, as sociedades unipessoais.

A sistematização em termos amplos, com um sentido muito mais de "ordenação da prática social" do que propriamente uma intervenção de tipo "regulativo", pode também ser observada no que concerne às sociedades. O novo Código distingue as pessoas jurídicas de direito privado sem fins lucrativos (associações) das com fins econômicos (sociedades), tratando das primeiras no Título II do Livro I da Parte Geral. As sociedades encontram-se divididas em sociedades empresárias e sociedades simples, sendo as primeiras as que têm por objeto o exercício da atividade própria de empresário, sujeito a registro, assim consideradas, independentemente de seu objeto, as sociedades por ações, e, simples, as cooperativas ${ }^{74}$.

O grande valor de nosso novo Código, mormente se comparado com o seu congênere italiano está, nessa matéria, na adstrição à diretriz sistemática: não regulando o Direito do Trabalho, que no Brasil tem diploma próprio ${ }^{75}$, o novo Código promove a sistematização da disciplina da empresa sem cindir as suas regras das demais normas de direito privado nem confundi-las com as especificidades da disciplina das relações de emprego.

À disciplina da Empresa segue-se o Direito das Coisas (Livro III), do Direito de Família (Livro IV) e o Direito Sucessório (Livro V). Destes, o Direito de Família - justamente o que menor unidade apresenta, em razão das múltiplas e às vezes antinômicas emendas que o Projeto sofreu, para adequá-lo às novas realidades normativas e sociológicas - é o que contém, no que concerne à estrutura no qual assentado, a mais peculiar e elaborada forma de ordenação.

É que a regulação tradicional do Direito de Família, tal como aparece no ainda vigente Código, não contém a divisão entre direito de
${ }^{71}$ O parágrafo único do art. 966 exclui da noção de empresário "quem exerce profissão intelectual, de natureza cientifica, literária ou artística, ainda com o concurso de auxiliares ou colaboradores, salvo se o exercício da profissão constituir elemento da empresa".

${ }^{2}$ Veja-se, a propósito, o estudo de MAC-DONALD, Norberto da Costa Caruso, O Projeto de Código Civil e o Direito Comercial, Revista da Faculdade de Direito da UFRGS, vol. 16, Porto Alegre, 1999, p. 139.

${ }^{73}$ Assim, COUTO E SILVA, Clóvis, "O Conceito de Empresa no Direito Brasileiro", cit., p. 51. Anote-se que o Senado, mediante a Emenda ${ }^{\circ} 68$, ainda mais aproximado o modelo do novo Código do modelo italiano.

${ }^{74}$ Neste sentido MAC-DONALD, Norberto da Costa Caruso, O Projeto de Código Civil e o Direito Comercial, cit., p. 153.

${ }^{75}$ A Consolidação das Leis do Trabalho, Decreto- Lei $n^{\circ} 5.452$, de $1^{\circ}$ de maio de 1943.

Revista da Faculdade de Direito da UFRGS, v. 20, Outubro/2001 família pessoal e patrimonial, limitando-se a seguir, passo a passo, a ordem de certos institutos. Agora, diversamente, o método de classificação, proposto por Clóvis do Couto e Silva, atendeu à análise interna, e não meramente a classificação extrínseca, das relações jurídicas de Direito de Família, atentando-se aí à concepção do "Direito como experiência', isto é, como "concretitude de valoração do Direito", como "realidade histórico cultural"(...) atual e concretamente presente à consciência em geral, tanto em seus aspectos teoréticos como práti$\cos ^{\prime \prime 6}$, com o que afasta-se a concepção do Direito seja como objeto de contemplação ou descrição, ou, ainda, como "pura seqüência de esquemas lógicos"77.

Ora, se a experiência jurídica constitui a compreensão do Direito in actu, percebe-se que o Direito de Família - visualizado como totalidade e como complexo de valorações e comportamentos aos quais são atribuídos significados suscetíveis de valoração jurídica ${ }^{78}$ segundo certos valores morais e finalidades práticas - compõe-se de elementos que " $n a \tilde{o}$ re cebem $e$ nem poderiam receber do ordenamento jurídico a mesma disciplina do seus efeitos"79. Percebe-se quase que intuitivamente que a sua normação, sobretudo no campo dos direitos pessoais, "é fortemente impreg nada de princípios éticos, de tal modo que os próprios direitos lesados não se submetem aos mesmos cânones dos outros ramos do direito

como, por exemplo, o das obrigações" $" 80$. Diversamente, o Direito Patrimonial de Família está informado pelos princípios gerais do Código, assumindo, por vezes, a estrutura de uma obrigação, submetendo-se, em outras, a regras que integram o Direito das Coisas ${ }^{81}$.

Por esta razão, e forte nestas concepções, alinhou-se, numa parte (Direito Pessoal) os aspectos mais propriamente existenciais, atinentes à dimensão do afeto, aí estando as regras relativas ao casamento, da dissolução da sociedade conjugal, da proteção à pessoa dos filhos, das relações de parentesco, da adoção e do poder familiar, expressão que, significativamente, substitui o "pátrio poder". Noutro Título está o Direito Patrimonial, englobando os direitos e deveres dos cônjuges, o regime de bens, a administração dos bens dos filhos, os interditos, o patrimônio familiar e as sociedades, provindo esta distinção do fato de "o ordenamento não poder deixar de valorizar as relações dos partícipes da família levando em conta os seus atributos de pessoalidade e patrimonialidade já existentes na dimensão social" 82 .

Por intermédio desta metodologia, esclarece ainda Couto e Silva ${ }^{83}$, a revelação da existência de um duplo sistema de relações jurídicas no Direito de Família, permite que a diversidade material que está na sua base conduza à adoção de normas e de tutela jurídica valorativa

${ }^{76}$ As expressões grifadas são de REALE, Miguel, O Direito como Experiểncia, São Paulo, Saraiva, 1968, p. 31. ${ }^{77}$ Idem, ibidem.

78. Neste sentido REALE, Miguel, op. por último citada, p. 31.

${ }^{78}$. Neste sentido REALE, Miguel, op. por último citada, p. 31 .
${ }^{9}$ COUTO e SILVA, Clóvis, Exposição de Motivos para a Reforma do Direito de Família, in Anteprojeto

${ }^{79}$ COUTO e SILVA, Clóvis, Exposição de Motivos para a Reforma do Direito de Famínia,
do Código civil, Arquivos do Ministério da Justiça, vol. 155, Rio de Janeiro, 1975, p. 153.

${ }^{80} \mathrm{Idem}$, ibidem.

${ }^{81} \mathrm{Idem}$, ibidem.

${ }^{82}$ COUTO e SILVA, Clóvis, Direito Patrimonial de Família no Projeto de Código Civil Brasileiro e no Direito Português, São Paulo, RT 520, 1979, p. 14.

${ }^{83}$ COUTO e SILVA, Clóvis, Direito Patrimonial de Família no Projeto de Código Civil Brasileiro e no Direito Português, cit., p. 15. 

embora com menor apuro técnico, no Título III, e finalisticamente inconfundíveis, umas centradas na dimensão afetiva, pessoal, outra na dimensão propriamente patrimonial decorrente da sociedade familiar. Porém, como 'nem sempre uma relação jurídica aparece de modo puro, pessoal ou patrimonial", estando ambos os setores dialeticamente co-implicados, $\mathrm{o}$ critério há de ser o da prevalência de um ou outro destes elementos, conforme a situação concretamente apreciada.

Assim, conquanto não rígida a classificação - como também não é rígida, no plano pré-jurídico, a distinção — o modelo adotado "torna mais compreensivel o Direito de Famí lia, porque lhe dá transparência, o que nem sempre sucede quando se aglutinam numa só figura as mais diversas regras, submetidas, por força desta diversidade, a regimes jurídicos próprios" ${ }^{84}$. Viabiliza, outrossim, compreender a diversidade de papéis que podem ser assumidos, no interior da estrutura familiar, pelos seus diversos figurantes, "conforme o seu círculo de atividades se insira no Direito Pessoal ou patrimonial".

A mesma estrutura pode ser observada, relativo à União Estável, inserido pelo Congresso Nacional uma vez que a matéria constitui inovação proposta pela Constituição Federal de 1988, posterior, portanto, à elaboração do Anteprojeto. Mesmo sendo este Título III enxertado posteriormente - e talvez sem a clara consciência dos pressupostos filosóficos e culturais que conduziram à classificação contida nos Títulos I e II, observa-se, nos arts. 1.723 a 1.724 o regramento das relações pessoais entre os companheiros, sujeitas, portanto, à principiologia ali contida e também à cláusula

geral da comunhão plena de vida, uma vez estar o casamento equiparado à união estável, por força constitucional. Já no art. 1725, estão as indicações relativas às relações patrimoniais, aqui mais fortemente sujeitas ao princípio da autonomia privada e à disciplina do Direito das Obrigações.

Completando a estrutura - que define o aspecto externo do sistema - é à linguagem empregada pelo novo Código que deveremos agora atentar, pois esta indicará os aspectos internos do sistema, o seu modelo, se aberto ou fechado.Tenho a convicção de aí residir a maior inovação da nova Lei, não se devendo buscar as "novidades" apenas em uma ou outra regra punctualmente arroladas, mas nos aspectos metodológicos, que poderão, se bem compreendidos e adequadamente utilizados, causar mudança realmente notável em relação ao Código de Beviláqua. Cabe, pois, pelo viés da linguagem, examinar a noção de sistema que está em seu substrato.

\section{A noção de sistema que aco- lhe: o Código como "eixo cen- tral" do sistema de direito pri- vado $^{85}$}

Sabe-se que os grandes Códigos oitocentistas de que é paradigma o Code francês, foram construídos como sistemas fechados, isto é, o mais possível impermeáveis à in tervenção da realidade e do poder criador da jurisprudência. Acreditava-se que a perfeição da construção conceitual e o encadeamento lógico-dedutivo dos conceitos bastaria para a total apreensão da realidade nos lindes do

${ }^{84}$ Idem, ibidem Construção: As Cláusulas Gerais no Projeto do Código Civil”, citado, agregando algumas novas considerações.

Revista da Faculdade de Direito da UFRGS, v. 20, Outubro/2001
${ }^{85}$ Para as seguintes observações sintetizei reflexões que expendi em "O Direito Privado como corpus codificado. Em outras palavras, o modelo de Código oitocentista traduzia determinado modelo de sistema, constituindo, como já tive a ocasião de assinalar, verdadeiramente 0 "espelho e metáfora do sistema fechado"86 aquele que, tributário das concepções iluministas, era dominado pela pretensão de plenitude lógica e completude legislativa. Surgiram assim, como um fenômeno típico da modernidade oitocentista, os Códigos totais, totalizadores e totalitários, aqueles que, pela interligação sistemática de regras casuísticas, tiveram a pretensão de cobrir a plenitude dos atos possíveis vada, prevendo soluções às variadas questões da vida civil em um mesmo e único corpus legislativo, harmônico e perfeito em sua abștrata arquitetura.

A posição histórica do Código não tem, porém, caráter absoluto e imutável ${ }^{87}$, não podendo ser reduzida a uma noção, ou empobrecida pela rigidez de uma fórmula $\mathrm{a}^{88} \mathrm{a}$ Codificação é um fenômeno histórico, é certo, por si fixa e congelada no tempo. É correto pois, discernir entre o significado histórico da Codificação oitocentista - como fenômeno de ruptura que foi, como manifestação de uma determinada operação política, como instrumento de uma nova racionalidade, a do capitalismo, construído sobre a hegemonia de uma única classe social, a burguesia - e o significado que podem adquirir, na aurora do século XXI os novos Códigos civis concretamente considerados, pois, de modo geral, nestes é diverso o relacionamento com as demais instâncias do todo social e com os diversos loci nos quais se manifesta o fenômeno jurídico, sendo, em consequiência, também diverso o modelo de sistema que espelham

${ }^{86}$ No nosso A Boa-Fé no Direito Privado, cit., p. 169.

${ }^{87}$ Assim IRTI, Natalino, Códice Civile e Società Política, cit., p. 12

${ }^{88}$ Idem, p. 18. e dos comportamentos devidos na esfera primas a historicidade das formas jurídicas não é
Os "Códigos totais", construídos ao modelo oitocentista, são marcados notadamente por sua linguagem, o mais "precisa" possível. Diz-se que expressam um sistema fechado justamente porque, empregando a técnica da casuística, centrada em modelos cerrados, com a perfeita definição da fattispecie e de suas conseqüências, sua linguagem dificilmente permite comunicação com a realidade que está em seu entorno, notadamente com os chamados "elementos metajurídicos", tais como valores éticos, dados econômicos, científicos, tecnológicos, elementos de ordem social etc. Por esta razão, para a regulação dos novos problemas, faz-se necessária a constante intervenção legislativa.

Não é este, contudo, o modelo de sistediversos pressupostos metodológicos, atuando por intermédio de duas soluções técnicas: a primeira dela consiste num chamado à responsabilidade da jurisprudência, pelo emprego de numerosas cláusulas gerais; já a segunda diz respeito à tarefa do legislador, encarregado, para o futuro, de editar "leis aditivas" ao Código, naqueles campos, como o Direito de Empresa e o Direito de Família, sujeitos à maior econômica, embora estejam estas futuras leis vinculadas ao Código, "eixo central", pela ligação ao valores e aos conceitos genéricos ali postos com a função de assegurar a unidade (relativa) do sistema.

\subsection{Pressupostos metodológicos}

O Código Civil é polarizado, é certo, pela diretriz sistemática, que assegura a sua unidade lógica e conceitual, o que visa assegurar um ma subjacente ao novo Código Civil, que adota mutabilidade dos imperativos de ordem social e 
minimum de segurança jurídica pela regulação coordenada dos comportamentos sociais desenvolvidos na esfera privada. Porém, do ponto de vista da técnica legislativa, o sistema caracteriza-se como um "eixo central" 89 " e como um sistema aberto em virtude da linguagem que emprega, permitindo a constante incorporação —e solução — de novos problemas ${ }^{90}$, seja por via da construção jurisprudencial, seja por ter a humildade de deixar ao legislador, no futuro, a tarefa de progressivamente complementá-lo.

Por isto é que sua inspiração por vezes aproxima-se estrutura constitucional, que requer leis complementares, bem como da sua linguagem, farta em modelos jurídicos abertos. Como já tive oportunidade de escrever, um Código não-totalitário tem janelas abertas para a mobilidade da vida, pontes que o ligam a outros corpos normativos - mesmo os extrajurídicos e avenidas, bem trilhadas, que o vinculam, dialeticamente, aos princípios e regras constitucionais ${ }^{91}$.

Estas “janelas", bem denominadas por Irti de "concetti di collegamento" com a realidade social ${ }^{92}$ são constituídas pelas cláusulas gerais, técnica legislativa que conforma o meio hábil para permitir o ingresso, no ordenamento jurídico codificado, de princípios valorativos ainda não expressos legislativamente, de

standards, arquétipos exemplares de comportamento, de deveres de conduta não previstos legislativamente (e, por vezes, nos casos concretos, também não advindos da autonomia privada), de direitos e deveres configurados segundo os usos do tráfego jurídico, de diretivas econômicas, sociais e políticas, de normas, enfim, constantes de universos metajurídicos, viabilizando a sua sistematização e permanente ressistematização no ordenamento positivo.

Nas cláusulas gerais a formulação da hipótese legal é procedida mediante o emprego de conceitos cujos termos têm significados intencionalmente vagos e abertos, os chamados "conceitos jurídicos indeterminados". Por vezes - e aí encontraremos as cláusulas gerais propriamente ditas - o seu enunciado, ao in vés de traçar punctualmente a hipótese e as suas conseqüências, é desenhado como uma vaga moldura, permitindo, pela vagueza semântica que caracteriza os seus termos, a incorporação de princípios e máximas de conduta originalmente estrangeiros ao corpus codificado, do que resulta, mediante a atividade de concreção destes princípios, diretrizes e máximas de conduta, a constante formulação de novas normas. Têm, assim, a vantagem da mobilidade proporcionada pela intencional imprecisão dos termos da fattispecie que contém, pelo que é afastado o risco do imobilismo porquanto é utilizado em

${ }^{89}$ A expressão é de Clóvis do Couto e Silva, para indicar justamente o aspecto "não totalitário" do Código, ma a sua função de centro do sistema das relações civis, necessariamente ligado ao que está às suas margens, isto é, tanto as "leis aditivas" quanto à realidade social, econômica e cultural. Por evidente, no centro do ordenamento está a Constituição, sabendo-se que a palavra "ordenamento" designa, como aponta Miguel REALE, uma espécie de "ecossistema" que abrange uma ampla variedade de sistemas e subsistemas normativos ( ver, de COUTO e SILVA, $O$ Direito Civil Brasileiro em Perspectiva Histórica e Visão de Futuro, Porto Alegre, Revista Ajuris, v. 40, e de REALE, Fontes e Modelos do Direito - para um novo paradigma hermenêutico, São Paulo, Saraiva, 1994, p. 95).

${ }^{90}$ A propósito da perspectiva dicotômica entre "sistema" e "problema", observa REALE: “ $O$ direito todo estaria em causa, se pudesse prevalecer essa antinomia abstrata entre o "problemático" e o 'sistemático", só admissivel com base em um rigido e equivoco conceito de sistema". (In O Direito como Experiência, cit., p. 4). Por esta razão vem a doutrina atentando ao "novo pensamento sistemático", como aludi in A Boa-Fé no Direito Privado, cit., p. 364

${ }_{92}^{91}$ IRTI o meu "O Direito Privado como Construção: As Cláusulas Gerais no Projeto do Código Civil”, citado. 92 IRTI, Natalino, Diritto Civile e Società Política, cit,, p. 35.

Revista da Faculdade de Direito da UFRGS, v. 20, Outubro/2001 grau mínimo o princípio da tipicidade ${ }^{93}$.

Dotadas que são de grande abertura semântica, não pretendem as cláusulas gerais dar, previamente, resposta a todos os problemas da realidade, uma vez que essas respostas são progressivamente construídas pela jurisprudência. Na verdade, por nada regulamentarem de modo completo e exaustivo, atuam tecnicamente como metanormas, cujo objetivo é remeter o juiz a critérios aplicativos determináveis ou em outros espaços do sistema ou mediante variáveis tipologias sociais, dos usos e costumes objetivamente vigorantes em determinada ambiência social. Em razão destas características essa técnica permite capturar, em uma mesma hipótese, uma ampla variedade de casos cujas notas específicas serão formadas por via jurisprudencial, e não legal.

Desta constatação decorre que o juiz tem o dever, e a responsabilidade ${ }^{94}$, de formular, a cada caso, a estatuição, para o que deve percorrer o ciclo do reenvio, buscando em outras normas do sistema ou em valores e padrões ex- tra-sistemáticos os elementos que, motivando a decisã $0^{95}$, possam preencher e especificar a moldura vagamente desenhada na cláusula geral. Conquanto tenha a cláusula geral a vantagem de criar aberturas do direito legislado à dinamicidade da vida social, tem, em contrapartida, a desvantagem de provocar até que consolidada a jurisprudência - certa incerteza acerca da efetiva dimensão dos seus contornos. O problema da cláusula geral situase sempre no estabelecimento dos seus limites $^{96}$. É por isto evidente que nenhum Código pode ser formulado apenas e tão somente com base em cláusulas gerais, porque, assim, o grau de certeza jurídica seria mínimo. Verifica-se, pois, com freqüência, a combinação entre os métodos de regulamentação casuística e por cláusulas gerais, técnicas cuja distinção por vezes inclusive resta extremamente relativizada, podendo ocorrer, numa mesma disposição, variados "graus" de casuísmo e de vagueza.

Assim acontece no novo Código Civil brasileiro, sobre o qual seu Relator no Senado. Federal, Senador Josaphat Marinho, já nas pri-
${ }^{93}$ A tipicidade, pode ser compreendida como "a qualidade de uma pessoa, coisa ou conceito pela qual suas características resultam conformes as de um tipo predeterminado", entendendo-se por "tipo" "o modelo ideal que reúne as características essenciais de todos os entes de igual natureza" (conforme Noemi Nidia Nicolau, " $L a$ autonomia de la voluntad como factor de resistencia a la tipicidad en el sistema de derecho privado argentino", Porto Alegre, nov. 1994, datilog.).

${ }^{94} \mathrm{~A}$ voz do juiz não é, todavia, arbitrária, mas vinculada. Como já se viu, as cláusulas gerais promovem o reenvio do intérprete/aplicador do direito a certas pautas de valoração do caso concreto. Estas estão, ou já indicadas em outras disposições normativas integrantes do sistema (caso tradicional de reenvio), ou são objetivamente vigentes no ambiente social em que o juiz opera (caso de direcionamento). A distinção deriva da circunstância de, em paralelo ao primeiro e tradicional papel, estar sendo hoje em dia sublinhado o fato de as cláusulas gerais também configurarem normas de diretiva, assim concebidas aquelas que não se exaurem na indicação de um fim a perseguir, indicando certa medida de comportamento que o juiz deve concretizar em forma generalizante, isto é, com a função de uma tipologia social. Aí está posta, pois, uma das funções das cláusulas gerais, que é a de permitir a mobilidade externa do sistema.

${ }^{95} \mathrm{Na}$ concreção das cláusulas gerais cresce extraordinariamente o dever de fundamentar a decisão, devendo o juiz deixar claro não só a concreta razão de fato ensejadora da invocação ao princípio, máxima de conduta ou diretriz contidos na cláusula geral, como da conexão entre ambas, a razão de fato e a razão jurídico-valorativa. Por isto, é imenso, nesta operação intelectiva, opeso dos precedentes judiciais, que expressam uma espécie de "razão comum" de decidir para os casos análogos ou similares.

${ }^{96}$ Nesse sentido a observação de Sérgio José Porto in A Responsabilidade Civil por Difamação no Direito Inglês, Ed. Sergio Fabris, Porto Alegre, 1995, p. 15. 
meiras linhas do Parecer pela aprovação assinalava: (...) o Projeto de Código Civil em elaboração no ocaso de um para o nascer de outro século, deve traduzir-se emfórmulas genéricas e flexiveis, em condições de resistir ao embate de novas idéias" $"$.

Do mesmo modo, ao encaminhar o Anteprojeto à apreciação governamental, em 1975 , sublinhava Miguel Reale a necessidade de a codificação do direito privado, nos dias atuais, apresentar-se metodologicamente, mediante modelos abertos, expressos mediante uma "estrutura normativa concreta (...), destituida de qualquer apego a meros valores formais abstratos", o que seria alcançado se plasmadas, no Código, "soluções que deixam margem ao juiz e à doutrina, com freqüente apelo a conceitos integradores da compreensão ética, tais como os de boa-fé, eqüidade, probidade, finalidade social do direito, equivalência de prestações, etc. "98.

Por igual, outros integrantes da aludida Comissão, nomeadamente, José Carlos Moreira Alves e Clóvis do Couto e Silva, verberaram, em trabalhos acerca da proposta da nova lei civil, o caráter estruturalmente inovador de certas normas. Assim, Couto e Silva expressamente se manifestou:

"O pensamento que norteou a Comis são que elaborou o projeto do Código Civil

brasileiro foi o de realizar um Código central, no sentido que lhe deu Arthur Steinwenter, sem leis em vigor no País (...). O Código Civil, como Código central, é mais amplo que os códigos civis tradicionais. E que a linguagem é outra e nela se contém "cláusulas gerais", um convite para uma atividade judicial mais criadora, destinada a complementar o corpus juris vigente com novos princípios e normas". 99

José Carlos Moreira Alves, por sua vez, há mais de uma década, alertava para o fato de a inserção das cláusulas gerais promover a mudança da concepção filosófica do novo Código por meio de alterações formalmente diminutas, exemplificando com a concepção de propriedade, de tal maneira que, "com dois artigos apenas passou-se da propriedade individualista para a propriedade com função social"'lo . Sendo este o pensamento dos autores do Anteprojeto, bem como o do Relator do Projeto no Senado, nada mais natural que o texto venha a público pleno de cláusulas gerais. Estas situam o novo Código no plano da concretude, que constitui uma das dimensões da diretriz da operabilidade que norteou a sua redação.

A concretitude, ou concreção jurídica, significa "a correspondência adequada dos fatos às normas segundo o valor que se quer realizar"101. Em outras palavras constitui " $a$ obrigação que tem o legislador de não legis-

${ }^{97}$ Parecer Final ao Projeto do Código Civil, in O Projeto de Código Civil no Senado Federal, Vol. I, cit., p. 302.

${ }^{98}$ Exposição de Motivos do Projeto de Código Civil”, 1975, in O Projeto de Código Civil - Situação atual e seus problemas fundamentais, cit., p. 84, grifos meus. No mesmo trabalho, averbou ainda conter o Código projetado preceitos "que, à primeira vista, podem parecer de mero valor ético, mas que, tendo como destinatário primordial o juiz, consubstanciam exigências de equidade, de amparo aos economicamente mais fracos, ou de preservação às forças criadoras do trabalho".

${ }^{99}$ COUTO E SILVA, Clóvis, "O Direito Civil Brasileiro em Perspectiva Histórica e Visão de Futuro" in Revista Ajuris no 40, Porto Alegre, 1987, p. 128. O texto reproduzido está às páginas 148 e 149.

${ }^{100}$ MOREIRA ALVES, José Carlos, A Parte Geral do Projeto do Código Civil Brasileiro, cit., p. 27

${ }^{101}$ Assim REALE, Miguel, O Projeto de Código Civil - Situação atual e seus problemas fundamentais, cit., p. 9.

Revista da Faculdade de Direito da UFRGS, v. 20, Outubro/2001 lar em abstrato, para um indivíduo perdido na estratosfera, mas, quanto possivel, legislar para o indivíduo situado" 102 . É dimensão da operabilidade porque, viabilizando a "ética da situação" 103 pela concreção dos modelos abertos, logra-se a constante alteração do significado e do conteúdo de uma disposição codificada sem alterar a sua letra, evitando, assim, os males da inflação legislativa e da rigidez que, marcando o modelo dos Códigos oitocentistas, ensejaram o seu distanciamento do "direito vivente".

Sabemos não ser uniforme o tecido das relações sociais, não se apresentando a sociedade como uma harmônica sinfonia de vozes promanadas por um abstrato sujeito de direito: hoje, à metáfora da sinfonia, substitui-se a da polifonia, por vezes mesmo a da cacofonia. Se na Codificação oitocentista a ficção da igualdade era o suporte ideológico dos próprios atributos das regras codificadas, quais sejam, a sua generalidade e abstração - a primeira designando "o caráter anônimo dos destinatários", a segunda "o caráter hipotético da ação dis ciplinada ${ }^{104}$, hoje em dia esta ficção não mais remanesce nas normas agora codificadas, polarizadas que estão pela diretriz da concretude, "ética da situação".

Esta expressão rica em significados indica, primariamente, que a noção de sujeito de direito deve ser percebida em sua essencial pluralidade, englobando tanto o rico quanto $o$ pobre, o empresário e o desempregado, a grande corporação econômica e os menores de rua o contratante forte e o contratante débil, o latifundiário e o sem-terra, o consumidor e o forne-

cedor, enfim, o ser humano e(m) suas circunstâncias, sempre urgentes e concretas. Deve-se considerar, ainda mais, que um mesmo sujeito pode desempenhar e desempenha, concomitantemente, vários papéis sociais. Por isso o apelo, tantas vezes feito na nova Lei $\mathrm{Ci}$ vil, aos "usos do lugar" às "circunstâncias do caso", à "natureza da situação"105, para permitir ao aplicador do Direito descer do plano das abstrações ao terreno por vezes áspero do concreto.

Os modelos abertos não estão uniformemente dispersos no novo Texto, e nem poderiam estar, pois é da natureza do Direito Civil conter campos que requerem maior ou menor ductilidade. A Parte Geral, destinando-se a " $f i$ xar os parâmetros de todo o sistema" - como afirmou José Carlos Moreira Alves - vem marcada pelo propósito "de máximo rigor conceitual" 106 . Abriga, mesmo assim, ponderável número de normas abertas ou semanticamente vagas, inclusive fazendo remissão a princípios ou direcionando o juiz à pesquisa de elementos culturais, econômicos e sociais, sendo aí potencialmente forte $o$ impacto do princípio constitucional da dignidade da pessoa humana.

Ainda assim, e no que concerne especilmente ao Direitos de Personalidade, tratados na Parte Geral, penso que o novo Código poderia ainda ter avançado nesta matéria, talvez pelo emprego de uma cláusula geral do Direito de Personalidade, a exemplo do que procedeu relativamente a um dos seus aspectos, qual seja, o direito ao resguardo da vida privada. Criaria assim, mais diretamente, uma ponte entre o prin-

${ }^{102}$ Idem, p. 13.

${ }^{103}$ REALE, Miguel, O Projeto do Novo Código Civil - situação após a aprovação pelo Senado Federal, São Paulo, Saraiva, 2000, p. 42.

${ }_{104}$ As expressões em itálico são de IRTI, Natalino, Diritto Civile e Società Política, cit., p. 25.

105 V

106 MOREIRA ALVES, José Carlos, A Parte Geral do Projeto do Código Civil Brasileiro, cit., p. 7.

Revista da Faculdade de Direito da UFRGS, v. 20, Outubro/2001 
Esta tutela preventiva não resta, porém cípio constitucional da dignidade da pessoa e os direitos constitucionais sociais, também atinentes à múltipla dimensão da personalidade, sendo indiscutível que a atual ênfase numa esfera de valores existenciais da pessoa devese, entre outros fatores, à compreensão do papel desempenhado pelos princípios constitucionais no Direito Civil. Estes, para além de constituírem normas jurídicas atuantes nas relações de Direito Público, têm incidência especial em todo o ordenamento e, nesta perspectiva, também no Direito Civil, disciplina das relações jurídicas travadas entre os particulares entre $\mathrm{si}^{107}$. Todavia, pelo viés da tutela dos danos à pessoa, como examinarei em seguida ${ }^{108}$, esta ligação resta marcada, viabilizando alargado campo de tutela, inclusive preventiva. suficientemente clara no que diz com a indevida utilização da imagem (art. 20), objeto de proteção indenizatória. É certo que, para além da tutela indenizatória, uma tutela preventiva da imagem é absolutamente necessária num tempo em que a indústria do marketing conduz à derisão os valores do pudor pessoal e da intimidade,

em que o totalitarismo das empresas de comunicação tudo transforma em matéria de sua ganância. Assim, uma cláusula geral de proteção à imagem, juntamente com a norma dos arts. 12 e 21, antes aludidas, e outra relativa ao Direito Geral da Personalidade, certamente ensejariam maior facilidade no trânsito, às relações civis, dos valores constitucionais fundamentais ${ }^{109}$, notadamente os que têm por objeto a tutela do que Miguel Reale, desde aos anos 40, tem denominado de "valor-fonte" do ordenamento a pessoa humana - considerada em sua própria fundamental dignidade ${ }^{110}$, alcançando mais facilmente o desenvolvimento jurisprudencial de novas hipóteses.

Contudo, mesmo não explicitando o Código esta previsão, é possível chegar, por via jurisprudencial, à construção de um de um "Direito Geral da Personalidade" que não se esgota no reconhecimento dos tradicionais atributos, tais como a honra, o nome, a imagem, a intimidade e a vida privada, mas que tem alargada possibilidade de contínua expansão. É que aqui, o "progresso" do Direito, para reconhecer continuamente 'novos direitos de per-

${ }^{107}$ Como referência a esta a questão, consulte-se Pietro PERLINGIERI, Il Diritto Civile nella legalità costituzionale", Nápoles, Edizione Scientifiche Italiane, 1991, Joaquin ARCE Y FLORES-VALDEZ, El Derecho Civil Constitucional, Madrid, Civitas, 1986; Konrad HESSE, Derecho Constitucional y Derecho Privado, Madrid, Civitas, 1985. Na literatura brasileira Maria Celina BODIN DE MORAES, "A caminho do Direito CivilConstitucional", Revis Direito, Esto e Sociedude, PUC, Rio de Janeiro, 1991 " p. 59, Teresa NECREIROS, Consincione", Revista Direito, Esta e Sociede, Fundamentos para uma interpretação constitucional do princípio da boa-fé, Rio de Janeiro, Renovar, Direito da UFRGS , vol. 16, Porto Alegre, 1999, p.111 e Luiz Edson FACHIN, Teoria Crítica do Direito Civil, cit.

${ }^{108}$ Vide item b. 2 - um caso exemplar de "abertura e mobilidade"do sistema: os danos à pessoa.

${ }^{109}$ A Constituição Brasileira insere, no inciso III do art. $1^{\circ}$, a dignidade da pessoa humana entre os valores fundamentais da República, tratando, no art. $5^{\circ}$, dos direitos fundamentais individuais, entre os quais estão a proteção da vida, da saúde, da honra, da imagem, da vida privada e da intimidade das pessoas.

${ }^{110}$ Como anotei em outro ensaio - "Direito e Cultura - Entre as Veredas da Existência e da História "- o valor da pessoa humana como "valor fonte de todos os valores" ou "valor fonte do ordenamento" tem sido objeto da atenção de REALE desde os seus primeiros escritos filosóficos, ainda na década de 40 , sendo versado já em Fundamentos do Direito ( primeira edição, 1940, terceira edição, São Paulo, Revista dos Tribunais, 1998). Fundamentos do Direito ( primeira edição, 1940, terceira edição, São Paulo, Revista dos Tribunais, 1998).
Porém, é em Pluralismo e Liberdade (Rio de Janeiro, Expressão e Cultura, 1998 (2a edição, $1^{\mathrm{a}}$ edição 1963) que assentará com todas as letras que o "problema central da axiologia jurídica, vista em função da experiência histórica, é o relativo ao valor da pessoa humana", ali produzindo, notadamente no Capítulo V, notáveis ensaios. Revista da Faculdade de Direito da UFRGS, v. 20, Outubro/2001 1998, Luis Afonso HECK, "Direitos Fundamentais e sua influência no Direito Civil", in Revista da Faculdade de sonalidade", é tarefa que resulta da concreção, no campo das relações interprivadas, do já alupessoa humana por intermédio de sua ligação gras do Código, competindo, pois, à jurisprudência, construir a sua dogmática, com bases nestes fundamentos axiológicos e normativos, e de acordo às necessidades práticas que se apresentarão no decurso do tempo.

Como exemplo da possibilidade de reconstrução sistemática ensejada pelo novo Código tomo o caso dos danos à pessoa, espécie do gênero danos extrapatrimoniais, pois aí é nítida a conexão intersistemática (entre diversos sistemas ou subsistemas integrantes de um mesmo ordenamento) e intrassistemática (entre normas integrantes de um mesmo sistema, ou subsistema).

\subsection{Um caso exemplar de "abertura e} mobilidade"do sistema: os danos à pessoa

O modelo paradigmático de ligação intersistemática é o que ocorre entre a Constituição e o Código Civil, avultando aí em importância especial para o Direito Privado o princípio constitucional da dignidade da pessoa humana. dido princípio constitucional da dignidade da intersistemática com os demais princípios e re-
Vazado em termos amplíssimo e incidente em todo o ordenamento, espraiando-se por todos os "ramos' do Direito, o princípio da dig nidade da pessoa humana deve ser densificado, tornando-se concreto e operativo em particulapessoa é exemplar, pela excelência do tratamento dado pelo novo Código ao instituto da restuto ao princípio constitucional às cláusulas gerais e regras objeto do novo Código, e ainda dole processual, poderá ser viabilizada a permanente e crescente reconstrução do modelo jurídico ${ }^{111}$ da responsabilidade civil por danos à pessoa, ou danos aos direitos de personalidade.

Para tanto, é necessário estabelecer conexão entre as normas do art. $5^{\circ}$, incisos $\mathrm{V} \mathrm{e} \mathrm{X}$ constitucional, as cláusulas gerais dos arts.12, 21,187 e as regras dos arts 927 e seu parágrafo único e 944 do novo Código Civil e ainda, se for o caso, das regras dos artigos 287, 644 e 645 do Código de Processo Civil ${ }^{112}$ ou, havendo relação de consumo, do art. 84, caput, do Código de Defesa do Consumidor.

Como já se viu, consoante o art. 12, pode-se "exigir que cesse a ameaça ou a lesão a direito de personalidade, e reclamar previstas em lei ${ }^{113}$ ", sendo de observar que no suporte fático desta norma está não apenas o res domínios de casos. O campo dos danos à ponsabilidade civil. Conectando-se este instioperando-se a ligação com instrumentos de ínsão a direito de personalidade, e reclamar ${ }^{111}$ Acerca da acepção pela qual tomo a expressão "modelo jurídico", REALE, Miguel, Fontes e Modelos..., cit.,
meu ensaio acerca da "Boa-Fé como Modelo", in Diretrizes Teóricas do Novo Código Civil, MARTINSmeu ensaio acerca da "Boa-Fé como
COSTA, J. e BRANCO, G., no prelo.

COSTA, J. e BRANCO, G., no prelo. ${ }_{112}$ Como alerta Araken de ASSIS em comentário ao art. 644 do CPC, hoje em dia, "desaparecido o rito especial da vetusta ação cominatória, há nova sistemática na aplicação do preceito (ordem, monitório, mandado). A pressão psicológica sobre o devedor, derivada da astreinte, doravante ocorre após o provimento judicial (sentença ou decisão liminar, ex vi do art. $461, \S 3^{\circ}$.) e o esgotamento do prazo de cumprimento assinado na forma do art. 632". Muito embora a aplicação da pena deva constar do pedido (art. 287), "ao juiz se mostrara lícito, no caso de omissão, impor multa independentemente do pedido (art. $461, \S 4^{\circ}$ )". Em suma, "a cominação licito, no caso de omis dos poderes do juiz, que não se vincula, neste assunto, à iniciativa da parte". (Comentários ao Código de Processo Civil, vol IV, arts. 566 a 645, Rio de Janeiro, Forense, $1^{a}$ edição, $4^{a}$ tiragem, 2001, p. Código

424).

${ }^{113}$ Grifos meus 
dano já consumado, mas também a ameaça de dano a direito da personalidade, o que introduz, no instituto da responsabilidade civil, um nítido caráter preventivo. Isto porque, para impedir o dano, a continuidade dos seus efeitos ou mesmo a sua mera possibilidade, a norma oferece, diante da ameaça, tanto a solução $e x$ post, qual seja, o pagamento de perdas e danos, como recursos de ordem preventiva, tais como, por exemplo, a imposição de obrigação de não-fazer ao autor da ameaça, podendo o determinar, se descumprida a obrigação, o pagamento de astreintes.

Se o atentado for a um específico direito de personalidade, qual seja, a vida privada, é chamada a operar a cláusula geral do art. 21. Aqui também se está a indicar que o juiz tem o dever de determinar a providência que, à vista das circunstâncias, entenda mais adequada à otimização do conteúdo da norma protetiva, desde que a busque no quadro das soluções técnicas oferecidas pelo ordenamento.

Por evidente, estas cláusulas gerais constitucionais e civis, de proteção à pesso estão ligadas ao novo regime dos atos ilícitos seja ao disposto no art. 186 - cláusula gera de responsabilidade, patrimonial ou extrapatrimonial, por culpa - seja à cláusula geral de ilicitude do art. 187, que é, como ante assinalei, de índole objetiva, pois não reque ato culposo para situar no plano da ilicitude ato praticado abusivamente, ou desviado de seu fim econômico ou social, ou excedente dos limites traçados pela boa-fé e pelos bons costumes $^{114}$

Maior será o alcance se o princípio cons-

titucional e ambas cláusulas gerais acima indicadas forem ligadas às normas que defluem do art. 927, que estabelece a obrigação de indenizar o dano causado por ato ilícito.

No seu parágrafo único, o Código institui espécie de cláusula geral de responsabilidade objetiva , ao determinar o nascimento do dever de indenizar, independentemente de culpa, não apenas nos casos especificados em lei, mas também "quando a atividade normalmente desenvolvida pelo autor do dano implicar por sua natureza, risco para os direitos de outrem". No substrato desta norma está a noção de estrutura social, tão cara à Miguel Reale, entendendo-se por esta noção "um todo de valorações, determinado pela polarização de uma valoração-matriz", incompreensível "em rermos de mera causalidade, ou de puras relações formais" 115 .

Assim é que, transposta ao plano da dogmática da responsabilidade civil, esta noção permite afirmar: "Se aquele que atua na vida jurídica desencadeia uma estrutura social que, por sua própria natureza, é capaz de por em riscos os interesses e os direitos alheios, a sua responsabilidade passa a ser objetiva e não mais apenas subjetiva" 116 . Em outras palavras, é a noção metajurídica de "atividade normalmente exercida pelo autor do dano, que implique risco", a ser necessariamente concretizada pelo intérprete, que definirá qual o regime aplicável à responsabilidade, constituindo esta norma ao meu ver, a projeção, neste domínio, da diretriz da solidariedade social.

Por evidente, e no que toca à indenização, as normas do art. 927 e seu parágrafo de-

${ }^{114}$ Art. 187: "Comete ato ilícito o titular de um direito que, ao exercê-lo, excede manifestamente os limites impostos pelo seu fim econômico-social, pela boa-fé ou pelos bons costumes".

${ }_{115}$ REALE, Miguel, O Direito como Experiência, cit., p. 156.

${ }^{116}$ REALE, Miguel, O Projeto de Código Civil - Situação Atual e seus Problemas Fundamentais, cit., p. 10 .

Revista da Faculdade de Direito da UFRGS, v. 20, Outubro/2001 vem ser ainda conjugadas com a do art. 944 segundo o qual a indenização mede-se pela extensão do dano, cabendo ao juiz, no caso de desproporção entre a gravidade da culpa e o dano, reduzir "equiitativamente" a indenização: trata-se aí da concreção, no campo da responsabilidade civil, do princípio da proporcionalidade que domina o ordenamento jurídico em sua integralidade, apresentando-se mais propriamente como dever de proporcionalidade $^{117}$

Por esta razão estou convencida de que Poder Judiciário, utilizando responsavelmente $^{118}$ as cláusulas gerais dos artigos 186 e 187 poderá promover alargada construção do direito dos danos, cujas consequiências estão previstas na Parte Especial (art.389 e seguintes, art.402 e seguintes, art. 927 a 954). Poderá, ainda, se combinar adequadamente estas previsões abertas com outras contidas na Parte Geral (v.g., a da tutela à vida privada) ou em outras leis (por exemplo, o Código de Processo Civil, ao prever formas de tutela inibitória), proceder ao progresso do Direito à vista de situações ainda não previstas pelo legislador, sem a necessidade de recorrer à pontual intervenção do legislador, amenizando, assim, os males da inflação legislativa.

Já por este exemplo fácil é perceber no que consiste a "abertura e a mobilidade" de um

117 Veja-se, a propósito, o excelente estudo de AVILA, Humberto Bergmann, A Distinção entre Principios e Regras e a Redefiniçâ do Devéte USP, 1, 1999, Porto Alegre, Sintese, 19 "estabelece uma estrutura formal de aplicação dos princípio ou uma norma-principio (...). Este, na verdade, "estabelece uma estrutura formal de aplicação dos princípios envolvidos: o meio escolhido deve ser adequado, necessáno e nao-excessivo. (...) Por isto, "consiste num postulado normativo-aplicativo", "consiste numa condição non Direito para a sua devida aplicação". (pp. 46 a 49, grifos do autor).

${ }_{118}$ Acerca da utilização, pelo Judiciário, das cláusulas gerais, seus limites e responsabilidades, veja-se AGUIAR JÚNIOR, Ruy Rosado, "O Poder Judiciário e a concretização das cláusulas gerais: limites e responsabilidades" Revista da Faculdade de Direito da UFRGS, vol. 18, Porto Alegre, 2000, p.221.

${ }_{119}$ Revista da Faculdade Dirito cosperiência, cit., p. 157, grifos do autor.

120 Art $2^{\circ}$ "A personalidade civil da pessoa começa do nascimento com vida; mas a lei põe a salvo, desde a concepção, os direitos do nascituro".

Revista da Faculdade de Direito da UFRGS, v. 20, Outubro/200I tem que levar em conta o ser humano concreto, concreto, as circunstâncias concretas ameaça de prejuízo, tudo permeado pelo valor fundamental da tutela à pessoa. Percebe-se art. 927 "é inseparável de sua compreensão ou compreensivo (...)"119 que está na raiz do

Outro exemplo da incidência, ao novo , disposiçoes principiológicas consParte Geral (arts. $1^{\circ}$ a 232 ), entre as disposiessenciais da personalidade humana, do regramento das pessoas jurídicas, dos bens e va à personalização civil, iniciada do nascimencom vida, protegendo-se os direitos do a numa perspectiva não patrimonialista, mas garantidora da perspectiva existencial da vida do art. $5^{\circ} \mathrm{da}$ Constituição, que protege o direito à vida, alcançando-se, assim, a proteção idial ao nascituro, não mais limitanque está na base do aludido parágrafo único do 
vamente patrimoniais, consoante já acenou pioneira jurisprudência do Tribunal de Alçada do Rio Grande do Sul ${ }^{121}$.

A "'abertura e mobilidade"do sistema caracteriza-se, pois, pela conjugação que o Código viabiliza entre cláusulas gerais e regras específicas, ocorrendo setores, como exemplificativamente, o Direito da Empresa, em que ocorre uma normativa genérica, assecuratória de uma certa unidade conceitual e valorativa, a ser completada, contudo, por leis aditivas, especificantes, em matérias sujeitas ao mais intenso dinamismo econômico-social, de determinados regulamentos particulares.

É nos Livros concernentes ao Direito de Família, ao Direito das Obrigações e aos Direitos Reais que encontraremos, em paralelo às normas marcadas pela estrita casuística, a maior parte das cláusulas gerais, as quais todavia permeiam, ainda que mais escassamente, os demais Livros. O seu exame proporcionará uma visão do conteúdo do novo Código e de suas diretrizes fundamentais.

\section{O conteúdo do novo Có- digo em suas diretrizes funda- mentais}

Consoante adverte Miguel Reale, a afirmação corrente de que uma lei não deve ser interpretada segundo a sua letra mas consoante o seu espírito leva a considerar o conjunto de diretrizes que norteou a obra codificadora "constituindo o seu travamento lógico e técnico, bem como a base de sua fundamentação ética"122. Arrola, assim, quatro diretrizes, a sa-

ber: a da sistematicidade, a da operabilidade, a da eticidade e a da socialidade. Já examinadas, na apresentação da estrutura e do sistema, as duas primeiras, analisarei as diretrizes da eticidade (A) e da socialidade (B) que poderão dar uma ampla visão do conteúdo do novel Código Civil.

Ambas, eticidade e socialidade, constituem perspectivas reversamente conexas, pois as regras dotadas de alto conteúdo social são fundamentalmente éticas, assim como as normas éticas têm afinidade com a socialidade. A distinção ora procedida, de cunho meramente pedagógico, não faz mais do que assinalar ênfases, ora pendendo para o fundamento axiológico das normas, ora inclinando-se às suas características numa sociedade que tenta ultrapassar o individualismo, não significando, de modo algum, que uma regra ética não se ponha, também, na dimensão da socialidade, e viceversa.

\section{A) A eticidade como fundamento das normas} civis

As regras jurídicas jamais são um "dado", antes constituindo um "construído" por realizarem-se sempre na História, consubstanciando, assim, uma das privilegiadas dimensões da cultura. Se esta afirmação é correta para o Direito em sua integralidade, sua adequação ressalta particularmente no Direito Civil, que é o Direito das pessoas que vivem na cive, traçando as regras aplicáveis às pessoas enquanto pessoas, dos "homens enquanto homens" 123 os quais relacionam-se, no entanto, em necessária comunidade. Bem por isso hoje o Direito Privado reapresenta-se como "direito sim dos particulares, mas dos particulares uti cives; di-

${ }^{122}$ Ap. Civ. no $195080585,5^{a}$ C. Civ., 26.10.95, Rel. Des. Rui PORTANOVA, in RTARGS 97/298

${ }^{123}$ Assime, Miguel, O Projeto de Código Civil - Situação atual e seus problemas fundamentais, cit., p. 3. ${ }^{123}$ Assim a proposição de HOBBES em De Cive (Do Cidadão). Tradução de Renato Janine Ribeiro. São Paulo,
Martins Fontes, p.10.

Revista da Faculdade de Direito da UFRGS, v. 20, Outubro/2001 reito dos particulares como portadores da sua própria singularidade, mas também da necessidade de comunicá-la aos outros; da necessidade de isolar-se (que é algo a ser respeitado) mas também de associar-se; da necessidade de defender a própria personalidade, mas também de desenvolvê-la na comunidade que a enriquece e não a comprime", como afirmou, magnificamente, Giorgio Oppo ${ }^{124}$. Direito dos particulares, do que é, pois de interesse particular na tríplice dimensão do ser (direitos da personalidade, direito pessoal de família) do ter (direito de propriedade) e do agir (direito das obrigações, dos contratos e da empresa), mas que nem por isso se contrapõe ao que é interesse público, pois direito dos particulares que vivem na ordem civil.

O conteúdo do Direito Privado, bem por isto, está muito proximamente ligado ao valor que historicamente é dado à pessoa e às suas relações com os demais bens da vida, patrimoniais ou existenciais, com as esferas do ser, do ter e do agir. Se o mais relevante for a relação entre a pessoa e os bens patrimoniais, economicamente avaliáveis, crescem em importância as regras jurídicas atinentes à tutela do patrimônio. As normas do Direito Privado restam aí reduzidas a meios de tutela dos bens patrimoniais, obscurecendo-se a civilidade, dimensão social da existência, e a própria dimensão social do "ser civil" no individualismo egoísta.

Contudo, se em primeiro plano está a pessoa humana valorada por si só, pelo exclusivo fato de ser pessoa - isto é, a pessoa em sua irredutível subjetividade e dignidade, dotada de personalidade singular e por isto mesmo titular de atributos e de interesses não mensuráveis economicamente - passa o Direito a construir princípios e regras que visam

${ }^{124}$ OPPO, Giorgio, “Diritto Privato e Interessi Pubblici”, in Rivista di Diritto Civile, 1994, 1, p.26, traduzi. ${ }^{125}$ REALE, Miguel, O Projeto de Código Civil - Situação atual e seus problemas fundamentais, cit, p.8. tutelar essa dimensão existencial, na qual, mais do que tudo, ressalta a dimensão ética das normas jurídicas. Então o Direito Civil reassume a sua direção etimológica e, do direito dos indivíduos, passa a ser considerado o direito dos civis, dos que portam em si os valores da civilidade.

Ora, sendo o Coordenador da Comissão Elaboradora do Projeto um filósofo e humanista do porte de Miguel Reale, é natural que o seu texto encontre-se permeado por regras nas quais é funda a exigência de eticidade que deve pautar as relações extrapatrimoniais e patrimoniais entre as pessoas, portadoras que são da espeção Federal lhes reconhece. Por isso, afirma Reale, o novo Código, diferentemente do Código de 1916, "muito avaro ao referir-se à equidade, à boa-fé, à probidade", é, "ao con trário, pródigo em inserir, nos mais diversos aspectos das relações civis, a exigência da eticidade nas condutas, como um verdadeiro dever jurídico positivo." 125

Em vários artigos pode-se observar como uma das mais salientes características do novo Texto Civil, a valorização dos pressupostos éticos na ação dos sujeitos de direito, seja como consequêência da proteção da confiança que deve existir como condição sine qua non da vida civil, seja como mandamento de eqüidade;seja, ainda, comodever de proporcionalidade.

O princípio da confiança vem especificado, no interior das relações que nascem do tráfego jurídico, notadamente (mas não exclusivamente) o tráfego negocial, pelos correlatos conexos princípios da lealdade e da boa-fé objetiva, ambos constituindo a dupla face da confiança. Estes princípios têm a característica de constituir normas de conduta que impõem a quantos entram em contacto social relevante cial dignidade que, agora, a própria Constitui- 
juridicamente deveres de conduta, entre os quais os de informação e os de proteção aos legítimos interesses do alter.

A correlação entre a lealdade e a boa-fé está em que esta última, na acepção objetiva caracteriza arquétipo ou standard jurídico, segundo o qual cada pessoa deve ajustar a própria conduta a esse arquétipo, obrando como obraria um homem reto: com honestidade, lealdade, probidade, qualificando, por isto, uma norma de comportamento leal ${ }^{126}$. A boa-fé objetiva vem posta como princípio cardeal do moderno Direito das Obrigações, sejam estas civis ou comerciais, como emanação da confiança que deve presidir o tráfico jurídico, entendendo Mário Júlio de Almeida Costa que

"As exigências pragmáticas do tráfico jurídico e uma legítima aspiração a um direito objectivamente justo postulam que não se atenda apenas à intenção ou vontade do declarante, mas também à sua conduta e à confiança do destinatário"127.

Para além de designar, em sua acepção objetiva, uma norma de conduta que impõe ao participantes da relação obrigacional um agi pautado pela lealdade, pela colaboração intersubjetiva no tráfico negocial, pela consideração dos interesses da contraparte, o princípio da boa-fé indica, outrossim, um critério de interpretação dos negócios jurídicos e uma norma impositiva de limites ao exercício de direito subjetivos, em certas hipóteses. Como emanação da confiança no domínio das obrigações, a grande relevância dos deveres que decorrem

da lealdade e da boa-fé objetiva está em que, como norma de conduta, operam defensiva ativamente ${ }^{128}$, isto é, impedindo o exercício de pretensões e criando deveres específicos ${ }^{129}$ que decorrem do dever geral de colaboração que domina todo o Direito das Obrigações.

O novo Código, pródigo nas referências ao princípio, seja nas sua acepção objetiva como regra de conduta, seja na versão subjetiva, designativa de uma crença na aparência de ilicitude ou da convicção de não se estar a lesar direito alheio, engloba uma verdadeira exigência de comportamento correto, probo e leal na vida de relações sociais. Nesse sentido os já aludidos arts. 113, impositivo do standard da boa-fé na interpretação dos negócios jurídicos, 128, elusivo da eficácia de condição resolutiva sobre atos já praticados, em negócios de execução continuada ou periódica, se conformes estes à boa-fé objetiva, e 187, atributivo de ilicitude ao ato se exercitado o direito em desconformidade à conduta segundo a boa-fé

Não aí se esgotam, contudo, as referências à boa-fé: é no campo do Direito Obrigacional que encontraremos as mais vigorosas referências a esta norma impositiva de conduta leal, geradora de um dever geral de correção que domina o tráfego negocial.

Desde logo, a boa-fé vem posta como princípio fundamental e cláusula geral do contratos (art. 422), seja na fase de sua conclusão (abrangendo, por óbvio, a fase das tratativas, pois se deve considerar a noção

126 Assim o nosso Da Boa-Fé no Direito Privado, São Paulo, Revista dos Tribunais, 1999, p. 411.

${ }^{127}$ ALMEIDA COSTA, Mario Júlio Responsabilidade civil pela ruptura das negociações preparatórias de um contrato, Coimbra, Coimbra Ed., 1984, p 48, grifei.

${ }^{128}$ COUTO E SILVA, Clóvis, "O princípio da boa-fé no Direito brasileiro e português", in Estudos de Direito Civil Brasileiro e Português, São Paulo, 1986, p. 55.

${ }_{129}$ No mesmo sentido, o meu A Boa-Fé no Direito Privado, cit., pp. 427 e ss.

Revista da Faculdade de Direito da UFRGS, v. 20, Outubro/2001 da obrigação como um processo ${ }^{130}$ ), seja na sua execução. Nas relações contratuais, o que se exige é uma atitude positiva de cooperação, e, assim sendo, o princípio é a fonte normativa de deveres de comportamento pautado por um específico standard ou arquétipo, qual seja a conduta segundo a boa-fé que reveste todo o iter contratual.

Assim, conquanto não esteja expresso na litttera do Código o dever de ser observada a conduta segundo a boa-fé também na fase das tratativas negociais, e, quando for o caso, no período pós-contratual, há de ser compreendida a sua extensão também a esses períodos, em razão da própria natureza de cláusula geral que reveste o art. $422 \mathrm{e}$ ao cunho eminentemente prospectivo que está no cerne desta técnica legislativa.

Constituindo cláusula geral, o art. 422 também acolhe, em outro exemplo, o princípio que veda venire contra factum proprium. Este incide, por certo, na fase da execução contratual, e também no âmbito do contrato preliminar, que passa agora a ser regulado no próprio Código (arts 462 a 466), mas que adquire particular relevância no período pré-contratual, no qual se desenvolvem as chamadas "negociações preliminares". Os variados contratos que disciplinam, sempre mais freqüentemente, vastos projetos nas áreas financeira, comercial ou industrial, têm necessidade, pela complexidade que lhes é ínsita, de longas atividades preparatórias, tendo a praxe negocial, ainda antes da ela-

boração teórica, criado um "sistema de retoma, atualizando-os, os antigos conceitos de minuta e punctação, inserindo-os na chamada formação progressiva do acordo. As letters of intent, os heads of agreement, as instructions to proceed, os "acordos de base", os memorandos de entendimento e todas as restantes declarações de intenção de contratar - práticas que não apresentam descrição homogênea, e são, por vezes, de difícil qualificação jurídica - constituem os produtos desta realidade, atestando a importância que tem crescentemente revestido a fase antecedente do contrato.

Ora, nesta fase em que estão as partes ainda não formalmente vinculadas a obrigações propriamente contratuais, o princípio que veda "venire contra factum proprium ${ }^{131}$ " se apresenta com particular relevância porque, traduz justamente o princípio geral que tem como injurídico o aproveitamento de situações prejudiciais ao alter para a caracterização das quais tenha agido, positiva ou negativamente, o titular do direito ou faculdade ${ }^{132}$

Em modo genérico se pode afirmar que recai proibição do venire quem, tendo estabelecido determinados critérios, ou agido segundo determinada direção, modifica de critério, ou altera a direção seguida, em prejuízo alheio. Indica a expressãovenire contra factum proprium, por igual, um freio erguido à pretensão de quem reclama algo em aberta contradição com o que havia anteriormente aceitado, como explica Moisset de Espanés ${ }^{133}$, podendo ainda ser

${ }^{130} \mathrm{~A}$ idéia da obrigação como um processo que liga os seus partícipes e se dirige à sua finalidade, que é o A adimpleme desen um ex SILVA, encontrando-se expressa na própria estrutura do Direito por um dos codic

Obrigacional no Prót $3^{131}$ Veja-se, a propósito, BORDÃo atualizada e ampliada, 2000 , p. 13

3. edição atualizada e ampliada, 2000, p. 13 .

${ }_{133}^{132}$ Assim o meu Da Boa-fé no Direito Privado DE ESPANËS, Luis, La Teoria de los Propios Actos y la Doctrina y la Jurisprudencia ${ }^{133}$ MOISSET DE ESPANËS, Luis, La Teora
Nacionales, apud BORDA, op. cit., p. 26.

Revista da Faculdade de Direito da UFRGS, v. 20, Outubro/2001 
caracterizada por uma omissão, quando tinha o agente, para manter comportamento coerente com sua ação anterior, o dever de agir. Entre tantos exemplos que aqui poderiam ser indicados está a omissão em adotar providências tendentes a garantir o adequado adimplemento do pactuado, ou do combinado na fase précontratual ou, ainda, a omissão de informar ao parceiro contratual, ou pré-contratual, acerca de certo requisito de forma, para, após, requerer, por este motivo, a resolução ou nulidade do pactuado, ou assim justificar o seu recesso das tratativas negociais. Abarca ainda o venire casos nos quais verifica-se a omissão, por parte de um parceiro contratual ou pré-contratual, em informar adequadamente a contraparte acerca de pontos que seriam essências à perfeita formação do consentimento, para vir o autor do ato ${ }^{134}$ posteriormente, buscar esquivar-se à realização do combinado, "justificando" o eventual pedido anulatório, ou resolutório, ou a sua retirada das negociações, justamente pela ausência de providências que teriam sido adotadas pela contraparte, se devidamente informada.

Está a boa-fé, seja em sua feição subjetiva, seja objetiva, ainda prevista em expressiva referências tópicas na disciplina das espécies contratuais (v.g, o art. 518, a contrario, em matéria de preempção, na compra e venda; art. 523 , na venda com reserva de domínio; arts. 686 689 , no contrato de mandato), sendo ainda expressamente aludida em matéria de atos unilaterais, como a promessa de recompensa (art. 856 , $\S$ único) e no que diz com as regras relativas ao pagamento (arts. 879 e $\S$ único)

A boa-fé também está aludida nos arts. 765,766, a contrario, concernentes ao seguro. Neste campo a boa-fé é verdadeiramente

multidimensional, pois atua subjetivamente como "crença", impõe o dever de veracidade às partes, como decorrência da lealdade, e o deve de consideração, pelo segurado, aos interesses da contraparte, no art. 768 , vedando-lhe a prática de atos que agravem intencionalmente o risco objeto do contrato. Porém, as normas dos arts $769, \S \S 1^{\circ}$ e $2^{\circ}$, e do art. 770 , segund parte, constituem um evidente retrocesso no que diz com a proteção que vem sendo, legal e jurisdicionalmente, conferida ao segurado, implicando verdadeiramente numa contradição com os deveres que decorrem da cláusula gera do art. 422. Por esta razão, entendo devam aqui prevalecer as regras do Código de Defesa do Consumidor, inclusive por força da proteção constitucional que é assegurada ao seguradoconsumidor e da regra de reenvio constante do art. 777, evitando-se assim, por força de interpretação intra e intersistemática, a injusta consequiência resolutória, prevista nas citadas re gras.

O princípio da confiança também domina o Direito de Empresa, impondo aos administradores deveres de tutela e de consideração aos legítimos interesses dos sócios e da sociedade. É preciso considerar que o termo "empresa" significa, no Código recém aprovado, atividade econômica organizada no sentido da produção e da circulação da riqueza, de modo que "toda vez que o negócio jurídico, disciplinado na parte do Direito das Obrigações, adquire uma estrutura própria adequada à realização do fato econômico, surge a empresa" 135 Assim, incidem à atividade empresarial os princípios que regem o Direito das Obrigações em sua integralidade.

Esses deveres de tutela e consideração manifestam-se de forma escalonada, consoan-

${ }^{134}$ Isto é, do pedido anulatório, ou resolutório, ou ainda do ato de retirada das tratativas negociais.

${ }^{135}$ REALE, Miguel, O Projeto de Código Civil - Situação atual e seus problemas fundamentais, cit., p. 48

Revista da Faculdade de Direito da UFRGS, v. 20, Outubro/2001 te a natureza do vínculo, explicando Clóvis do Couto e Silva que nos negócios bilaterais $v g$, os contratos de intercâmbio - o interesse, conferido a cada participante da relação jurídica (mea res agitur) "encontra a sua fronteira nos interesses do outro figurante, dignos de serem protegidos" (de modo que) "o princípio da boa-fé opera, aqui, significativamente, como mandamento de consideração ${ }^{136}$ ". Diversa e maior é a intensidade dos deveres decorrentes da boa-fé quando os interesses em jogo não são contrapostos, como acontece nos contratos bilaterais, mas quando verifica-se uma atividade em proveito alheio: nos acordos de gestão, nos negócios fiduciários em geral " dever de levar em conta o interesse da outra parte (tua res agitur) é o conteúdo do dever do gestor ou do fiduciário".

Porém, é nas relações obrigacionai marcadas pela comunhão de escopo, como as relações de sociedade, que a cooperação se manifesta em sua plenitude (nostra res agitur). Aqui "cuida-se de algo mais do que a mera consideração, pois existe dever de aplicação à tarefa supra-pessoal, e exige-se disposição ao trabalho conjunto e a sacrificios relacionados com ofim comum" ${ }^{\prime 137}$.

Observa-se, assim, que os deveres decorrentes da lealdade e da boa-fé, ordenado em graus de intensidade conforme a categoria dos atos jurídicos a que se ligam, encontram sua máxima intensidade nas relações societárias que, tal como as relações de família, envolvem interesses suprapessoais.

Por esta razão impõe o novo Código expressiva carga de responsabilidade aos administradores e sócios, seja determinando conduta consoante o standard da pessoa "ativa $e$ proba" (art. 1.011), seja impondo responsabili-

dade solidária perante a sociedade e aos terceiprejudicados por culpa no desempenho de suas funções (art. 1.016), seja determinando a não-isenção de responsabilidade do sócio que se retirou, ou foi excluído, ou dos herdeiros de sócio falecido, pelas obrigações sociais, por certo tempo (art. 1.032).

Há de se convir, no entanto, que o Direito da Empresa constitui o setor, no novo Código, em que mais escassas são as cláusulas gerais. É certo que, como já observei, atingem este campo os princípios do Direito Obrigacional como um todo e ainda as normas da Parte Geral, como um todo e ainda as normas da Parte Gera da personalidade jurídica) e 187 (ilicitude, por abuso de direito e desvio de finalidade). Porém, considerando-se o estreito legalismo que ainda domina, como marca cultural, boa parte da doutrina e jurisprudência brasileiras, mais oportuno pareceria aqui repetir os preceitos ético-jurídicos tão amplamente postos anteriormente. A exigência de rigor técnico não deveria obstar nesta matéria, a imposição de modelos que reenviam a idéias éticas e que podem proporcionar o controle, pelo Poder Judiciário, de domínio onde se travam relações econômicas essen ciais à comunidade.

É ainda a exigência de eticidade, já aî como mandamento de eqüidade, que está no substrato da regra do art. 396 , segundo a qual não havendo omissão imputável ao devedor não incorre este em mora; do art. 413 que atribui ao juiz o dever de reduzir "eqüitativamente" a cláusula penal se a obrigação principal tiver sido cumprida em parte, ou se o montante da penalidade for manifestamente excessivo, "tendo-se em vista a natureza e a finalidade do negóio", da excessiva onerosidade, de clara inspiração em Emilio Betti: não é équo o locupletamento

${ }^{136}$ COUTO e SILVA, CLÓVIS, A Obrigação como Processo, São Paulo, José Bushatsky , 1976, p. 30 ${ }^{137}$ COUTO E SILVA, cit., p. 31 , grifamos.

Revista da Faculdade de Direito da UFRGS, v. 20, Outubro/200 
na relação contratual, que é relação de colaboração $0^{138}$.

A regra é completada pelo disposto no art. 479 , possibilitando evitar a resolução se o réu modificar "eqüitativamente" as condições do contrato, e no art. 480 , alusivo aos contratos unilaterais, assim entendidos aqueles em que a carga de onerosidade recai apenas sobre uma das partes.

Reflexo da eticidade é também o preceito do art. 317, atinente à excessiva desproporção entre prestação e contraprestação no momento do pagamento, que apanhará inúmeros casos de enriquecimento injustificado, aliás previsto nos artigos 884 a 886 . Bem assim é a eqüidade que informa a regra do parágrafo único do art. 738, possibilitando ao juiz reduzir "eqüita tivamente" a indenização devida por prejuízo sofrido em razão de contrato de transporte, quando a vítima houver concorrido para a ocorrência do dano. A mesma diretriz fundamenta a norma, já aludida, referente à desconsideração da personalidade jurídica (art. 50): não é équo que alguém se utilize de um instituto jurídico (a personificação jurídica), para fugir de suas responsabilidades.

É também por exigência ética que o casamento é fundado no princípio da "comunhão plena de vida" (art. 1.511). Não seria admissíve que um projeto existencial da dimensão do estabelecido pela união conjugal não fosse eticamente pautado pela comunhão de vida, pelo compartilhamento de sucessos e de infortúnios, de esperanças e de realizações e também de

${ }^{138} \mathrm{O}$ Projeto tem recebido expressivas críticas, neste ponto, por não ter acolhido a doutrina da base objetiva do negócio, formulada na Alemanha por K. LARENZ, a qual, como é sabido, exige apenas a excessiva desproporção entre prestação e contraprestação, não imputável aos contratantes, e causada por circunstâncias supervenientes que desequilibrem o contrato. Veja-se, neste sentido, AGUIAR JÚNIOR, Ruy Rosado, "O Projeto de Código Civil: Obrigações e Contratos", Revista do Conselho da Justiça federal, cit.

${ }^{139}$ COUTO e SILVA, Clóvis, Princípios para a Reforma do Direito de Família, cit., p. 159.

${ }^{140} \mathrm{Idem}$, ibidem.

${ }^{141}$ LAFER, Celso, A reconstrução dos Direitos Humanos: um diálogo com o pensamento de Hannah Arendt. São Paulo, Companhia das Letras, $19911^{2}$ reimpressão, pp. 267 e 268.

Revista da Faculdade de Direito da UFRGS, v. 20, Outubro/2001 denominou de princípio da exclusividade: para a tutela da dignidade humana exige-se, além da luz da esfera pública, "a proteção das sombra que permitem a transparência dos sentimentos da vida intima" ${ }^{142}$, a exclusividade regendo aquela especial esfera da vida privada em relação à qual é defesa a interferência alheia pois é olocus, material e espiritual, no qual "es colhemos aqueles com os quais desejamos passar nossas vidas, amigos pessoais e aqueles que amamos", não sendo nossa escolha "guiada, de fato, por nenhum padrão objetivo ou normas, mas, inexplicável e infalivelmente, afetada pelo impacto de uma pessoa em sua singularidade, sua diferença em relação a todas pessoas que conhecemos" 143

Limite à interferência da esfera pública no duplo sentido de Poder Público e opinião pública), o princípio da exclusividade mantém na decisão da família a sua intimidade, o seu "modo de ser" particular. É do casal, por exemplo, a decisão quanto ao planejamento familiar (art. 1.565, $\S 2^{\circ}$ ) determinando explicitamente o novo Código ser defeso a qualquer pessoa, de direito público ou privado, "interferir na comunhão de vida instituída pela família" (art. 1.513), o que, evidentemente, não impede a tutela estatal aos filhos quando necessário (arts. 1.584 a 1.589 e art. $1567, \S$ único), pois o princípio da exclusividade incide em tudo o quanto não envolva direitos de terceiros ${ }^{144}$. Em relação aos filhos, os pais, que estão em relação de igualdade (art. 1.511) exercem dever-poder denominado "poder familiar" 145 devendo dirigir a sociedade conjugal "em colaboração" e "sempre no interesse do casal e dos filhos" (art. 1.567).
A igualdade entre homem e mulher, no casamento, também decorrente de uma nova ética nas relações entre os sexos, reflete-se na modificação no regime de bens - o regime da comunhão parcial, com comunhão de aqüestos (art. 1.640) será o regime normal, extensível aos companheiros, salvo convenção em contrário (art. 1725) - e, no Direito Sucessório, na mudança da regra pela qual o cônjuge supérstite não concorria com descendentes e ascendentes. $\mathrm{O}$ art. 1.845 dispõe: "São herdeiros necessários os descendentes, os ascendentes e o cônjuge". São herdeiros necessários, portanto, os que se ligam ao falecido por relações de afeto, mantida, é certo, a regra da relativa liberdade de $\operatorname{testar}^{146}$.

Regra por todos os motivos criticável, porém, é a do inciso II do art. 1.641, que impõe aos maiores de 60 anos o regime da separação de bens no casamento. Como já demonstrou em paradigmática decisão o Tribunal de Justiça de São Paulo ${ }^{147}$, é claramente atentatória à dignidade da pessoa considerar que o fato da idade - hoje em dia, não provecta - de 60 anos, retira da pessoa o poder de autodeterminação, impedindo-lhe o exercício da autonomia privada em tema tão essencialmente ligado ao princípio da exclusividade quanto é o da organização dos interesses econômicos do casal.

Relacionam-se ainda com o princípio da eticidade as regras relativas ao "estado de perigo" (art. 156) e à lesão (art. 157), já referidas, e o princípio fixado no art. 944, que, como se viu, acolhe expressamente o dever de razoabilidade.

142 LAFER, Celso, A reconstrução dos Direitos Humanos, cit., p. 267.

142 LAFER, Celso, A reconstrução dos Direitos Humanos,
${ }_{143}$ ARENDT, Hannah, apud LAFER, op. cit., pp. 267 e 268.

${ }^{143}$ ARENDT, Hannah, apud
${ }^{144}$ LAFER, op. cit., p. 268.

${ }_{145}^{144}$ LAFER, op. cit., p. 268.

${ }^{145}$ Expressão utilizada em substituição ao antigo "pátrio poder" no Capítulo V, do Livro IV, arts. 1.630 a 1.638. ${ }^{146}$ No Direito brasileiro assegura-se aos herdeiros
legítima, regra posta no novoCódigo no art. 1.789 .

${ }_{147}$ TJSP, ap. cív. 007.512-4/2-00, $2^{\mathrm{a}}$.Câmara, j. 18.08.98, Rel. Des. César Peluso. Vide o substancioso comentário de RIBEIRO LOPES, Maurício, in Revista dos Tribunais 758/106-117. 
É justamente o dever de razoabilidade, exigência ética fundamental, que inspira o art 571, relativo à hipótese de, em contrato de locação por tempo determinado, o locatário devolver o imóvel antes do termo, quando deverá pagar multa. Neste caso, determina o art. 572 "se a obrigação de pagar o aluguel, pelo tempo que faltar, constituir indenização excessiva, será facultado ao juiz em bases razoáveis".

Observa-se, pois, que no novo Código Civil brasileiro a equidade tradicionalmente associada ao Direito Natural torna-se, de modo incontroverso, direito positivo, devendo a jurisprudência - fonte formal de produção jurídica - ainda ampliar o seu conteúdo pela concreção dos variados modelos abertos contidos em seu texto.

Certas regras são de difícil classificação entre a eticidade e a socialidade. Assim, em tem de direitos reais, as vedações aos atos emulativos, desviados de sua função, no direito de propriedade, parecem ligar-se tanto a um dever geral de correção, decorrente da boa-fé, quanto ao princípio da função social. É o que agora examinarei.

\section{B) A socialidade como característica do Direi-} to Civil contemporâneo

Se a eticidade está no fundamento das regras civis, dúvidas não há de que o Direito Civil em nossos dias é também marcado pela ${ }_{\text {socialidad em la teoria de loja-se CALERA, Nicolas López, Hay derechos colectivos? Individualidad y }}^{148}$ socialidad em la teoria de los Derechos, Barcelona, Ariel Derecho, 2000.

${ }^{149} \mathrm{Na}$ Constituição brasileira o princípio da função social vem expresso nos arts. $5^{\circ}$, inciso XXIII, e 170. Acerca do tema escrevi em Mercado e solidariedade social entre cosmos e taxis: a boa-fé nas relaçóes de consumo, ensaio integrante do livro A Reconstrução do Direito Privado - reflexos dos princípios e garantias fundamentais no Direito Privado, MARTINS-COSTA, Judith (org)., no prelo.

${ }^{150}$ Neste sentido REALE, Miguel, O Projeto de Código Civil - Situação atual e seus problemas fundamentais cit., p. 9.

${ }^{151}$ Constituição Federal, art. $3^{\circ}$, inciso III.

${ }^{152}$ RODOTÀ, Stefano, Il terribile diritto, Bologna, Il Mulino, 1981, que li na tradução espanhola, El terrible derecho- Estudios sobre la propiedad privada, Madri, Civitas, 1986.

Revista da Faculdade de Direito da UFRGS, v. 20, Outubro/200I
Rodotà̀ ${ }^{152}$ e que está, no novo Código, claramente informada pela função social. Aqui - e também na posse - o princípio da função social, para além de relativizar ou temperar o individualismo que marcou o tratamento do direito da propriedade na codificação oitocentista " não está, de forma alguma, confinado a mero apêndice do direito de propriedade, a simples elemento configurador de seu conteúdo 153 ", sendo muito mais que isso: "Por função social da propriedade", afirma Teori Zavascki,

"há de se entender o princípio que diz respeito à utilização dos bens, e não à sua titularidade jurídica, a significar que sua força normativa ocorre independentemente da específica consideração de quem detenha o título jurídico de proprietário. Os bens, no seu sentido mais amplo, as propriedades, genericamente consideradas, é que estão submetidas a uma destinação social, e não o direito de propriedade em si mesmo" ${ }^{154}$.

A atribuição de uma função social à propriedade está inserida no movimento da funcionalização dos direitos subjetivos que, desde o final do século XIX vem promovendo a reconstrução de institutos centrais do Direito moderno, tais quais a propriedade e o contrato,

como uma tentativa de "buscar um novo equilíbrio entre os interesses dos particulares e as necessidades da coletividade ${ }^{155}$. Com efeito, cláusula da "função social" exerce papel central na superação do modelo proprietário oferecido no século XIX pelo Code Napóleon e pela Pandectística, possibilitando, nas palavras de Stefano Rodotà, as bases para a "reconstrução do instituto da propriedade" 156

Sendo a determinação do conceito de função social - sua autonomia científica - condição necessária para que não se o reduza ao plano das motivações morais, políticas e ideológicas ${ }^{157}$, cabe mencionar, ainda que de passagem, as suas raízes e a significação que tem recebido da doutrina.

Como é por todos sabido, a noção de função social da propriedade começa a sua história com base nas formulações acerca da figura do abuso de direito, pela qual foi a jurisprudência francesa gradativamente impondo certos limites ao poder absoluto do proprietário ${ }^{158}$. A abordagem, contudo, ainda ocorria no plano dos "limites", fatores externos à estrutura mesma do direito subjetivo, que restava inatingido, tendo-se a propriedade como um "droit absolu et sacré", excepcionalmente restringido nas hipóteses de abu-

${ }^{153}$ Assim ZAVASCKI, Teori, "A tutela da posse na Constituição e no Projeto do novo Código Civil", in A Reconstrução do Direito Privado - reflexos dos princípios e garantias fundamentais no Direito Privado, MARTINS-COSTA, Judith (org)., no prelo, grifei.

${ }^{154} \mathrm{Idem}$. Isto porque, prossegue o autor, "bens, propriedades, são fenômenós da realidade. Direito - $e$, portanto direito da propriedade - é fenômeno do mundo dos pensamentos. Utilizar bens, ou não utilizá-los, dar-lhes ou não uma destinação que atenda aos interesses sociais, representa atuar no plano real, e não no campo puramente jurídico

${ }^{155}$ Neste sentido, Francesco GALGANO,Il Diritto Privato fra Codice e Costituzione, Bolonha, Zanichelli, $2^{\mathrm{a}}$ edição, 1983, p. 152.

${ }_{156}$ RODOTÀ, S. Proprietà (diritto vigente), in Novissimo Digesto Italiano, vol.XIV, 1967, p.134. Também RODOTÀ, em El terrible derecho- Estudios sobre la propiedad privada, Trad. Española, Madri, Civitas, 1986, p. 81

1986, p. 81.

${ }^{157}$ RODOTÀ, S. El terrible derecho - Estudios sobre la propiedad privada,cit. p. 212.

${ }^{158}$ Assim sentença do Tribunal de Colmar, de maio de 1885, que se tornou célebre por impor como limite ao direito de propriedade o seu exercício em prol de um interesse sério e legítimo - um marco na construção da doutrina do abuso de direito (DUGUIT, Léon, La responsabilidad del propietario y la jurisprudencia francesa, apend. in: Las transformaciones del Derecho (público y privado), trad. De Carlos POSADA, Buenos Aires, Editorial Heliasta, 1975, pp. 259 e ss.)

Revista da Faculdade de Direito da UFRGS, v. 20, Outubro/200 
Este entendimento inicial sofreu forte ruptura nos finais do século XIX pela pena de Leon Duguit ${ }^{159}$ que promoveu uma crítica radical à noção mesma de direito subjetivo, propondo substituí-lo pela "noção realista de função social", daí assentando, em célebre dito, que a propriedade é uma função social ${ }^{160}$ (pois esta lhe é inerente), e não tem, meramente, uma função social. É bem verdade que a idéia dả "propriété-fonction" já havia sido anteriormente expressa por Proudhon ${ }^{161}$, mas é Duguit quem aprofunda, em termos jurídicos, a polêmica, centrando sua atenção no rechaço à idéia de um sistema de direito privado orientado pelo conceito de direito subjetivo, enquanto poder reconhecido a uma pessoa de impor a sua vontade às demais.

Seguindo essa orientação, afirma, ainda no início do século XX, Georges Ripert:

“(...) os direitos não são outorgados ao homem senão para lhe permitir que preencha sua função na sociedade, não há qualquer razão para lhe conceder direitos que lhe permitiriam subtrair, da utilização comum, bens

O intenso debate doutrinário que seguiu-se a estas asserções acabou por refletirse nas legislações do início do século XX, da qual é expoente a Constituição de Weimar a qual, no célebre artigo 153 estabeleceu:" $A$ Constituição garante a propriedade. O seu conteúdo e os seus limites resultam de lei. (...) A propriedade obriga e o seu uso e exercício devem ao mesmo tempo representar uma função no interesse social." 163

Desde então, e progressivamente, as Constituições da segunda metade do Século XX passaram a aderir à fórmula, pela qual admite-se que os poderes do titular de um direito subjetivo estão condicionados pela respectiva função, indicando a funcionalização justamente a atribuição de um poder tendo em vista certa finalidade ou a atribuição de um poder que se desdobra como dever, posto concedido para a satisfação de interesses não meramente próprios ou individuais, podendo atingir também a esfera dos interesses alheios.

Isto não significa dizer que o direito de propriedade tenha deixado o campo da

${ }^{159}$ DUGUIT, L., El derecho subjetivo y la función social, in Las transformaciones del Derecho (público y privado), cit., p.178.

${ }^{160}$ DUGUIT, L. La propiedad función social in Las transor cit., p.241; e El derecho subjetivo y la función social", na mesma obra, p.179.

${ }^{162}$ Apud PACHECO BARROS, Wellington, A propriedade agrária e Paris, Gallimard, 1967, p. 111.

${ }^{162}$ Apud PACHECO BARROS, Wellington, A propriedade agrária e seu novo conceito jurídico constitu cional, Porto Alegre, Revista Ajuris, $\mathrm{n}^{\circ} 32$

${ }^{163}$ In Textos Históricos do Direito Constitucional, org. e tradução de Jorge MIRANDA, Lisboa, Imprensa Nacional - Casa da Moeda, 1980.

${ }^{164}$ Assim, em posição em nosso ver equivocada, o mestre Celso Antônio BANDEIRA DE MELLO. É o que afirma em artigo inúmeras vezes citado na bibliografia brasileira sobre o tema:" $O$ direito de propriedade - 0 u seja reconhecimento de que a organização jurídica da Sociedade (Estado) dispensa aos poderes de alguém sobre coisas - encarta-se, ao nosso ver, no Direito Público e não no Direito Privado. É evidente que tal Direito comporta relações tanto de Direito Público quanto de Direito Privado. Entretanto o direito de propritu como aliás sempre sustentou o prof. Osvaldo Aranha Bandeira de Mello é, essencialmente, um direito conde, rado no Direito Público e - desde logo - no Direito Constitucional" (Novos aspectos da direito configupropriedade no direito público, São Paulo, Revista de Direito Público vol. 84, out-dez 1987,p̧a social da temente, averba GRAU, pressuposto fundo, Revista de Direito Público, vol. 84, out-dez. 1987,p.39. DiferenA Ordem Econômica na Constituicão de 1988, São Pauo social a propriedade privada". (GRAU, Eros Roberto Ardem Econômica na Constituição de 1988, São Paulo, Malheiros, $5^{a}$ edição, 2000, p. 253).

Revista da Faculdade de Direito da UFRGS, v. 20, Outubro/2001 regulação privada, passando a integrar o domínio do Direito Público ${ }^{164}$. É que a atribuição de função social aos bens enseja, em nossa mente antropocêntrica, centrada e concentrada na idéia de "direito subjetivo", um verdadeiro giro epistemológico, para que passemos a considerar o tema a partir do bem, da res, e de suas efetivas utilidades: em outras palavras, a função social exige a compreensão da propriedade privada já não como o verdadeiro monólito passível de dedução nos códigos oitocentistas, mas como uma pluralidade complexa de situações jurídicas reais, que englobam, concomitantemente, um complexo de situações jurídicas subjetivas ${ }^{165}$, sobre as quais incidem, escalonadamente, graus de publicismo e de privatismo, consoante o bem objeto da concreta situação jurídica.

A perspectiva de um escalonamento em graus de publicismo e privatismo a incidir nos institutos componentes do Direito Privado foi traçada em meados do século XX por Ludwig Raiser que, atento ao complexo e plurifacetado painel da vida social contemporânea que esfacelava o rígido muro divisório erigido entre o Direito Público e o Privado desde a Codificação, propôs visualizar o ordenamento como uma elipse estruturada em dois núcleos ou pólos, um centrado na autonomia privada, na autodeterminação e na idéia de responsabilidade social, outro no interesse público e na heterodeterminação, os quais constituiriam, res-

${ }^{165} \mathrm{~A}$ função social da propriedade designa um complexo de obrigações, de encargos, de limitações, de estímulos e de ameaças que formam parte da regulamentação do direito de propriedade. A função social da propriedade não se

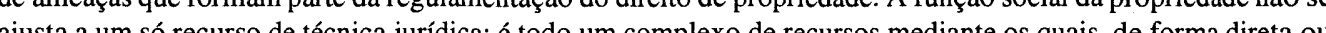
ajusta a so recta direta ou indireta, o propretáro levado ao canpo da função social. (Neste sentido, A. BALLARIN MARCIAL, Evolução do principio jurídico do direito de propriedade rural, Revista de Dire Dilo Agránio, n.12, ano 10, 1994, p.28). ${ }^{166}$ RAISER, Ludwig, "Il futuro del Diritto Privato", in: Il Compito del Diritto Privato, trad. Italiana de Marta Graziadei, Milão, Giuffrè, 1990

${ }^{167}$ RAISER, ob. cit., p. 232.

${ }^{168} \mathrm{GRAU}$, Eros Roberto, A Ordem Econômica na Constituição de 1988, cit., p. 257.

${ }^{169}$ Para o exame das "propriedades" no Direito Medieval veja-se GROSSI, Paolo, Proprietà - diritto intermedio, verbete in: Enciclopedia del Diritto, vol. XXXVII, 1988 e L'Ordine Giuridico Medievale, Laterza, RomaBari, 1995, p.72 e ss. pectivamente, pólos de irradiação de graus de do teria, assim, uma estrutura escalonada, consoante o grau de relevância pública ${ }^{167}$ de cada situação social concretamente regulada. Em exemplo, a propriedade, ou o contrato - peria chamado a desempenhar diferentes funções, ora sendo marcado por um grau elevado de publicismo ( o que conduziria, no caso da propor graus de privatismo, sendo então ensejado

Embora adotando diversa perspectiva, entre nós também reconhece Eros Roberto Grau tuição única mas o conjunto de várias instituições, "relacionadas a diversos tipos de bens"168, o que, de resto, não constitui uma trado Paolo Grossi que a propriedade, no Medievo, era medida pelo critério do que levava à sua concepção plural. Sem recair em anti-histórico anacronismo, pode-se dizer que hoje em dia perspectiva-se, na base da própria plexo de situações, deveres, obrigações, ônus jurídicos, a par de direitos subjetivos e poderes formativos, que se põem em perspectiva escalonada. Neste sentido inclina-se Perlingiere, segundo o qual,",em realidade, a propriedade

Revista da Faculdade de Direito da UFRGS, v. 20, Outubro/2001 
privada não se configura como direito subjetivo, individualistamente compreendido, mas como situação unitária e complexa composta por poderes, mas também por obrigações, de veres, ônus, a qual, diferentemente da propriedade pública, não é função, mas tem função social" ${ }^{170}$

Isso porque " a propriedade não tem uma estrutura natural e originária ${ }^{171}$, ante decorrendo os seus efetivos contornos "segun do a normativa vigente, a evolução das relações patrimoniais, em sentido lato, e o pape que estas historicamente adquiriram no mai amplo sistema das relações sociais e politicas" 172 , de sorte que, conquanto atinente imediatamente aos bens, objeto do direito, a função social, "uma vez configurar conotação essencial ao estatuto proprietário, não pode não contribuir para desenhar a estrutura da rela tiva situação subjetiva"173.

Em outras palavras, $\mathrm{o}$ atributo da função social não é meramente "externo" ao direito: constituindo, em caráter imediato, função social do bem (objeto do direito), reflete-se no conjunto de situações jurídicas incidentes sobre o bem, e assim, de forma mediata, ela, a função social, acaba por integrar o complexo de direitos e deveres subsumidos no conceito de "direito de propriedade", modificando-se a idéia construída pelo Jusracionalismo que o perspectivara como "poder da vontade", como direito natural do homem sobre as coisas, em

cujo conteúdo não cabem deveres e limitações É o que, também afirma Eros Roberto Grau, segundo o qual o princípio "passa a integrar o conceito jurídico-positivo de propriedade, (...) de modo a determinar profundas alterações estruturais na sua interioridade"174.

A concepção complexa e escalonada da função social da propriedade teve o mérito de superar os entendimentos dualistas, pelo qual a função social estaria atada à "natureza" de certos tipos de propriedade (por exemplo, a propriedade dos bens de produção). Não sendo mais considerado monoliticamente o direito, nem apenas visualizado externamente, a questão é de saber como se estrutura, em diferentes graus, a função social, conforme a função que o direito é chamado a operar e às efetivas utilidades da res para a sociedade, sendo certo que nem a Constituição brasileira nem o novo Código Civil traduzem a distinção, determinando apenas que 'a propriedade (isto é, qualquer propriedade) atenderá à sua função social".

E se toda e qualquer propriedade "atenderá à sua função social", assim não apenas a propriedade do solo ou a dos bens de produção, mas também a propriedade imaterial e a propriedade da empresa, por exemplo. Como conseqüência

'O uso do direito é correto se, para além de respeitar as proibições e os limites expressamente predispostos pelo legislador, se

${ }^{170}$ PERLINGIERE, Pietro, II Diritto Civile nella Legalità Costituzionale, Nápoles, ESI, $2^{\mathrm{a}}$ edição, 1991 p. 452 , traduzi. No original: "In realtà la proprietà privata non si configura come diritto soggetivo,

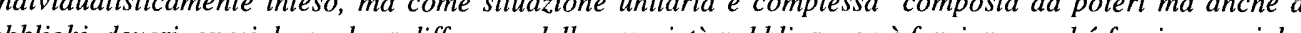
obblighi, doveri, oneri, la quale, a differenza della proprietà pubblica, non è funzione, ma há funzione sociale". ${ }^{17}$ Idem, ibidem.

${ }^{172}$ Idem, ibidem, traduzi, no original: "secondo la normativa vigente, l"evoluzione dei rapporti in senso lato patrimoniali ed il ruolo che questi hanno storicamente acquisto nel più ampio sistema dei rapporti sociali politici".

${ }^{173}$ Idem, ibidem, traduzi.No original: "la funzione sociale, una volta configurata connotazione essenziale allo statuto proprietario, non può non contribuere a disegnare la struttura della relativa situazione soggetiva".

${ }^{174} \mathrm{GRAU}$, Eros Roberto, A Ordem Econômica..., . cit., p. 260.

Revista da Faculdade de Direito da UFRGS, v. 20, Outubro/2001 substancia em um comportamento conforme à função social, que pode consistir seja em omissões seja em adimplemento de deveres positivos, atuativos dos interesses individuais e gerais" ${ }^{175}$

Iss está a indicar que a função socia em funçoes negativas e positivas, não constituindo apenas na imposição de limites, mas, por igual, conduzindo ao nascimento de devere jurídicos positivos. Com efeito, equívoco devido a uma literatura hoje já ultrapassada, vigorante nos primeiros decênios do século XX, percebia-se a cláusula da função social tão somente em sua dimensão negativa, como proibição do exercício de determinados comportamentos No Estado Social contemporâneo, todavia, que procura "a harmonia entre, num lado, idéias liberais de uma economia livre e, no outro, a igualdade de chances e a distribuição de riquezas" 176 , a função social predeterminada à propriedade privada não concerne exclusivamente à questão dos seus limites, assumindo, ao contrário, "um papel de tipo promocional, no sentido que a disciplina das formas proprietárias e a sua interpretação devem ser "atuadas"para garantir e para promover os valores nos quais se funda o ordenamento" 177 .

Assim ocorre entre nós por força do art. 170 incisos II e III que encerram princípios constitucionais impositivos, uma vez cumprirem a dupla função de instrumental e de objetivo es-

pecífico a ser alcançado, justificando não só a eivindicação de políticas públicas comprometidas com a sua concretização ${ }^{178}$ quanto interpretação produtiva, que não lhe restrinja a eficácia.

Reconhecendo esta perspectiva, deixan do antever que a idéia de propriedade é uma idéia plural, e, regendo-as mediante a cláusula geral do $\S 1^{\circ}$ do art. 1.228 , que põe em relevância justamente a utilidade dos bens - isto é, as finalidade econômicas e sociais dos bens objeto do direito de propriedade - , o novo Texto Civil trata escalonadamente do exercício deste direito, conforme a intensidade dos graus de publicismo e de privatismo incidentes em cada situação concreta.

A leitura complessiva dos dispositivos da Parte Geral, notadamente a cláusula geral da ilicitude do art. 187, e a introdução do conceito de pertença, no art. 93 , bem como das regras da Parte Especial levam, inelutavelmente a esta conclusão, sendo de exponencial importância a compreensão do tratamento dado à posse, em si mesma considerada e em sua relação com a propriedade, e a leitura do art. 1228 e de seus parágrafos.

No art. 1.228 determina-se que "o proprietário tem a faculdade de usar, gozar e dispor da coisa e o direito de reavê-la do poder de quem quer que injustamente a possua ou

175 PERLINGIERE, op. cit., p. 449, traduzi. No original: ' $L$ 'uso del diritto è corretto se, oltre a realizzare il rispetto dei divieti e dei limiti espressamente predisposti dal legislatore, si sustanzia in un comportamento conforme alla funzione sociale, che può consistere sai in omissioni sai in adempimenti di obblighi positivi attuativi di interessi individuali e generali"

${ }_{176}$ Assim KREL a da ordento constituição Concretizada Básicos na Base dos Direitos Fundamentais Sociais, tado 2000 , p. 37

org., SARLET, Ingo Wolfgang, Poro Alegre, Lita PERLINGIERE, P., op. cit., p. 445, traduzi, no original. "Un ruolo di tipo promozionate, nel senso che la disciplina delle forme proprietarie e le loro interpretazione dovranno essere attuate per garantire e per promuover $i$ valori sui quali se fonda $l$ ordinamento".

${ }^{178}$ Eros Grau, in A Ordem Econômica na Constituição de 1988. São Paulo, ed. RT, 1991, $2^{\mathrm{a}}$ ed., p. 244.

Revista da Faculdade de Direito da UFRGS, v. 20, Outubro/200 
detenha", preceituando o seu $\$ 1^{\circ}$ que "o direito de propriedade deve ser exercido em consonância com as suas finalidades econômicas sociais, e de modo que sejam preservados, $d$ conformidade com o estabelecido em lei especial, a flora, a fauna, as belezas naturais, o equilíbrio ecológico e o patrimônio histórico e artístico, bem como evitada a poluição do ar e das águas".

Completam esta regra a diç̧ão do $\S 2^{\circ}$ pela qual proíbe-se ao proprietário "os atos que não trazem ao proprietário qualquer comodidade, ou utilidade, e sejam animados pela intenção de prejudicar outrem" e do art. 1.277 relativa aos direitos de vizinhança, que sanciona o "uso anormal" da propriedade, sendo essencial à compreensão do conjunto normativo da propriedade também as normas que instituem o direito de superfície (arts. 1.369 a 1.377), as que regulam o condomínio (arts. 1.331 a 1.358) o exercício das servidões (arts. 1.378 a 1.389) da usucapião (arts.1238 e ss.).

Por outro lado, por decorrerem do princípio da função social funções positivas e negativas, o novo Código impõe o dever de usar o direito de propriedade em conformidade com as finalidades econômicas e sociais, na qual se incluem os fatores ecológicos e ambientais e os relativos à preservação do patrimônio histórico e artístico, de inegável interesse coletivo, transindividual. Há, pois, na norma, um claro direcionamento promocional.

Já do ponto de vista das funções negativas, o proprietário não pode exercer "anormalmente" o seu direito, assim entendido, a meu juízo, o exercício abusivo ou desviado das finalidades arroladas no citado $\S 1^{\circ}$ - não podendo, por igual, furtar-se ao alargamento da servidão quando as necessidades "da cultura ou da indústria, do prédio dominante" assim de terminarem, ainda que mediante indenização (art. $\left.1.385, \S^{\circ}\right)$

Contudo, não se esgota aí operatividade do princípio, o qual projeta a sua incidência por todo o corpus codificado e ainda para além, mesmo para as leis especiais que têm a propriedade como objeto de regulação. É porque o $\S 1^{\circ}$ do art. 1.228 constitui cláusula geral na matéria, regendo não apenas o exercício do direito de propriedade regulado pelo Código quanto as demais formas, as "propriedades"179 justifica-se, pela extrema relevância pública que pode revestir determinados bens, a regra do parágrafo $4^{\circ}$ do art. 1.228 que institui uma peculiar forma de desapropriação por ato judicial, fundada na utilidade social da posse na destinação do bem expropriado.

Essa regra é digna de nota por variados motivos, entre eles a sua oportunidade num país como o Brasil, onde o problema fundiário permanece intocado e irresoluto através dos séculos. Aí se revela, para além da função social da propriedade, a função social da posse que, no Código agora aprovado, não se prende apenas à concepção

${ }^{179}$ Acerca das "propiedades", em análise histórica, ceja-se de Paolo GROSSI, além das obras já citadas, La propiedad y las propiedades, un analisis histórico, trad. LÓPEZ Y LÓPEZ, Angel, Madrid, Civitas, 1992 propiedad y las propiedades, un analisis historico, trad. LOPEZ Y LOPEZ, Angel, Madrin, Civitas, 1992. No preâmbulo desta obra, observa com a agudeza habitual López y López, dissolvido o mito oitocentista do conceito unitário de propriedade, atualmente não se deve mais falar em propriedade. Pelo contrário, fale-se "nas propriedades", o que significa, "cambiar absolutamente de ángulo visual; significa contemplar el fenómeno de la apropiación privada desde la perspectiva de la relevancia económico-social de los bienes, no desde aquella outra que pivota sobre la abstracta consideración de éstos, y en consecuencia se resuelve en la simplicidad unidad y homogeneidad del poder atribuido a un sujeto, siempre identico a si mismo y, por ende tambiém abstracto (LOPEZ Y LOPEZ, Angel, "Prólogo para Civilistas", in GROSSI, Paolo, La propiedad y las propiedades, un analisis histórico, cit.,p. 11).

Revista da Faculdade de Direito da UFRGS, v. 20, Outubro/2001 abstrata de Von Jhering, refletida no art. 485 do vigente Código, mas engloba, também, a noção autônoma da posse ${ }^{180}$. Por isso, parailelamente ao regramento da posse como mera ocupação do bem, o conceito de "possetrabalho", aquela posse que "vem acompanhada de um ato criador do trabalho humano" 181 e que, bem por isso, deve ter uma proteção maior do que a outra.

Preceitua o parágrafo $4^{\circ}$ do art. 1.228: “O proprietário também pode ser privado da coisa se o imóvel reivindicado consistir em extensa área, na posse ininterrupta $e$ de boa-fé, por mais de cinco anos, de considerável número de pessoas e estas nela houverem realizado, em conjunto ou separadamente, obras e serviços considerados pelo juiz de interesse social e econômico relevante". Completa a norma o $\$ 5^{\circ}$, pelo qual "no caso do parágrafo antecedente, o juiz fixará a justa indenização devida ao proprietário; pago o preço, valerá a sentença como título para a transcrição do imóvel em nome dos possuidores".

Esta regra recebeu inúmeros ataques havendo quem contestasse a sua constitucionalidade, por atentatória ao direito de propriedade ${ }^{182}$. Nos subsídios ofertados quando do exame das Emendas, Luiz Edson Fachin acertadamente opinou que "o mecanismo, disposto no parágrafo que deve ser mantido, é de uma inovação elogiável, coerente com o sentido de função social da propriedade" 183 , assim logrando-se afastar a emenda supressora. Segundo Reale ${ }^{184}$, trata-se de "inovação do mais alto alcance, inspirada no sentido social do direito de propriedade, implicando não só novo conceito desta, mas também novo conceito de posse, que se poderia qualificar como sendo posse-trabalho (...). Defende o Coordenador da Comissão Codificadora a idéia de que a lei deve outorgar especial proteção à posse "que se traduz em trabalho criador, quer este se corporifique na construção de uma residência, quer se concretize em investimentos de caráter produtivo ou cultural", o que justificaria o discrimine, na própria regulação normativa, entre a "posse simples", aquela que é "simples poder manifestado sobre uma coisa, 'como se' fora atividade do proprietário" e aquela que chama de "posse qualificada' pois "enriquecida pelos valores do trabalho". A "posse trabalho", está na base da peculiar forma expropriatória contida nos mencionados $\S \S 4^{\circ}$ e $5^{\circ}$. Aliás, como salienta Zavascki, o instituto desafiará, dogmaticamente, a argúcia da doutrina e, sobretudo, dos juízes, pois "fundado em diversos conceitos abertos ("extensa área", "considerável número de pessoas", "obras e serviços de interesse econômico e social relevante", "justa indenização")

180 Acerca do tema escreveu VARELA, Laura Beck, "A Tutela da Posse entre abstração e autonomia: uma bordagem histórica" in A Reconstrução do Direito Privado - reflexos dos princípios e garantias fundamentais no Direito Privado, MARTINS-COSTA, Judith (org)., no prelo.

${ }_{181}$ Assim REALE cit, p. 54.

cit, p. 54.
182 Assim a Emenda 135, do Senador Gabriel HERMES, rejeitada.

${ }_{183}$ "Primeiros subsídios para exame das emendas apresentadas perante a Comissão Especial ao Projeto de Lei 183 "Primeiros subsídios para exame das emendas apresentadas perante a Comissão Especial ao Projeto de Lei
da Câmara $n^{\circ} 118$, de 1984, que institui o Código Civil - Livro III, Direito das Coisas", in O Projeto de Código Civil no Senado - Tomo II, cit., p. 311

184 REALE, Miguel, O Projeto do Novo Código Civil, cit., p. 82. 
haverá de ter sua finalidade social bem portuguesa enfrenta o tema Mario Júlio de de contratar existe, pelo menos quando se tra compreendida para que possa ser adapta do às variantes circunstanciais do cada caso concreto"185.

\section{b.2) A função social do contrato}

Assim como reveste e modifica o estatuto proprietário, a função social também recobre a disciplina das obrigações e dos contratos, até porque entre os deveres positivos que decorrem da função social da propriedade está, por vezes, o dever de contratar. $\mathrm{Na}$ literatura Almeida Costa para assegurar que, independenemente dos casos expressos na lei, "o dever te de uma situação de monopólio de direito ou de fato e de bens ou serviços de importância vital para os particulares ${ }^{186}$, podendo verificar-se também em situações em que "baste que se esteja diante de bens ou serviços de importância vital, mesmo não se verificando uma situação monopolista ${ }^{187}$.

É que, como tem reiteradamente acentu-

ado Miguel Reale, o princípio da função socia do contrato é mero corolário dos imperativo constitucionais relativos à função social da propriedade e à justiça que deve presidir à ordem econômica ${ }^{188}$.

Deixando bem marcada esta perspectiva, o Código exprime, com todas as letras, no art. 421, a função social dos contratos. Com efeito, no Direito dos Contratos ${ }^{189}$ concomitantemente à boa-fé e à probidade vigora o princípio: "A liberdade de contratar será exercida em razão e nos limites da função social do contrato". Essa norma, posta no art. 421 constitui a projeção do valor constitucional expresso como garantia fundamental dos indivíduos e da coletividade que está no art. $5^{\circ}$, XXIII da Constituição Federal, uma vez que o contrato tem, entre outras funções, a de instrumentalizar a aquisição da propriedade. Se a esta não é mais reconhecido o caráter absoluto e sagrado, a condição de direito natural e inviolável do indivíduo, correlatamente, também inflete ao contrato o cometimento - ou o reconhecimento - de desempenhar função que traspassa a esfera dos meros interesses individu-

${ }^{185}$ ZAVASCKI, Teori, "A tutela da posse na Constituição e no Projeto do novo Código Civil”" "A desapropriação é ato de natureza administrativa e, no caso, o ato do juiz é tipicama forma da usucapião: simplesmente resolve um conflito de interesses entre particulares, ato do juiz é tipicamente jurisdicional: ele estejam atendidos ou não os pressupostos legais. O juiz não poderá "desapropriar" sentido ou em outro, segundo peçam expressamente, até porque eles é que sofrerão os ônus corré "desapropriar" sem que os interessados o não o Poder Público, que adquirirão é que sofrerão os ônus correspondentes, de pagar o preço e serão eles, $e$ órgão jurisdicional Se fôssemos comparar com algum insto sequer é parte no processo, atuando nele como haveríamos de fazê-lo fỗo comos comparar com algum instituto já formado e sedimentado em nosso sistema, haveriamos de fazê-lo, não com o da desapropriação, mas com o da usucapião. Pelos seus requisitos ("posse ininterrupta e de boa-fé, por mais de cinco anos") assemelha-se à usucapião, com a única diferença de que, para adquirir a propriedade, os possuidores-usucapientes ficam sujeitos a pagar um preço. Ou seja:é espécie de usucapião onerosa. Todavia, comparações à parte, o que o novo instituto faculta ao juiz nâo é desapropriar o bem, mas sim converter a prestação devida pelos réus, que de específica (de restituir a coisa vindicada) passa a ser alternativa (de indenizá-la em dinheiro). Nosso sistema processual prevê várias hipóteses dessada), passa

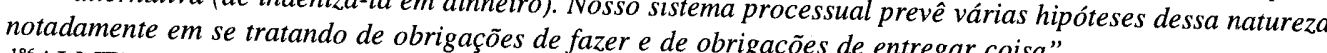
${ }^{136}$ ALMEIDA COSTA, Mario Júlio, Direito das Or e obrigaçōes de entregar coisa".

${ }^{187} \mathrm{Idem}$, ibidem, grifamos. ${ }^{188}$ REALE, Miguel, $O$ Proje

Paulo, Saraiva, 1986, p. 32 .

Privado como Construç̃ão: as $C$ acuerca da função social do contrato sintetizam o que escrevi em "O Direito Reviado como Construção: as Cláusulas Gerais no Projeto do Código Civil", cit.

Revista da Faculdade de Direito da UFRGS, v. 20, Outubro/2001 porém o autor que não se trata de uma forma de expropriação, antes assemelhando-se a umo Civil", cit. Entende metidas também funções positivas e negativas. Assim como ocorre com a função social da propriedade,a atribuição de uma função social ao contrato insere-se no movimento da funcionalização dos direitos subjetivos: atualmente admite-se que os poderes do titular de um direito subjetivo estão condicionados pela respectiva função ${ }^{190}$, e a categoria do direito subjetivo, posto que histórica e contingente como todas as categorias jurídicas, não vem mais revestida pelo "mito jusnaturalista" 191 que a recobrira na codificação oitocentista, na qual fora elevada ao status de realidade ontológica, esfera jurídica de soberania do indivíduo ${ }^{192}$. Portanto, o direito subjetivo de contratar e a forma de seu exercício também são afetados pela funcionalização, que indica a atribuição de um poder tendo em vista certa finalidade ou a atribuição de um poder que se desdobra como dever, posto concedido para a satisfação de interesses não meramente próprios ou individuais, podendo atingir também a esfera dos interesses alheios.

Frase dita e repetida indica que " $o$ contrato é a veste jurídica das operações econômicas", de modo que constitui sua função primordial instrumentalizar a circulação da riqueza, a transferência da riqueza, atual ou potenci- ais e, ao exercício do poder negocial estão co- al, de um patrimônio para outro ${ }^{193}$. A constituição econômica de uma sociedade, todos o sabemos, não é matéria de interesse individual, ou particular, mas atinge - e interessa - a todos. O contrato, veste jurídica das operações de circulação de riqueza, tem, inegavelmente, função social, assim como a disciplina das Obrigações, pois não devemos esquecer, no exame das projeções da diretriz da socialidade, a estrutura sistemática do Código.

Coerentemente a estas percepções, o citado art. 421 afirma dever o contrato, expressão privilegiada da autonomia privada, ou poder negocial ${ }^{194}$ não mais ser perspectivado apenas como a expressão, no campo negocial, daquela autonomia ou poder, mas como o instrumento que, principalmente nas economias de mercado, mas não apenas nelas ${ }^{195}$, instrumentaliza a circulação da riqueza da sociedade.

Colocada no pórtico da disciplina contratual, formando "quase que um preâmbulo de todo o direito contratual"196 a cláusula geral da função social do contrato desempenha um duplo papel. A função social é, evidentemente, e na literal dicção do art. 421, uma condicionante posta ao princípio da liberdade contratual, o qual, reafirmado, está na base da
${ }^{190}$ Ver ALMEIDA COSTA, Mario Júlio, Direito das Obrigações, Ed. Almedina, Coimbra, $8^{\mathrm{a}}$ edição, pp. 60 e ss. ${ }^{191}$ A expressão é de Vitorio FROSINI, "Le transformazioni sociali e il diritto soggetivo", Riv. Inter. di Filosofia del Diritto, 1968, I, Milão, pág.114.

${ }^{192}$ Idem, ibidem.

${ }^{193}$ Ver ROPPO, Enzo, O Contrato, trad., de Ana Coimbra e M. Januário Gomes, Ed. Almedina, Coimbra, 1988, pp. 10 e ss.

${ }^{194}$ A expressão "poder negocial", de Miguel REALE, remete à concepção kelseniana do poder normativo derivado da autonomia privada. Na concepção de REALE, aqui adotada, o poder negocial, que dá origem às cláusulas do contrato, é correlato à fonte negocial de produção de normas jurídicas. Ver O Projeto de Código Civil-Situação atual e seus problemas fundamentais, cit., p. 9. ${ }^{195}$ A propósito das funções do contrato na economia socialista, ver TALLON, Denis, "L'évolution des idées en matière de contrat: survol comparatif", in Droits, 12, 1990, p. 81 e ss.

${ }^{196}$ Miguel Reale, O Projeto de Código Civil-Situação atual e seus problemas fundamentais, cit., p. 10 
disciplina contratual e constitui o pressuposto mesmo da função (social) que é cometida ao contrato. Ao termo condição pode corresponder uma conotação adjetiva, de limitação da liberdade contratual, podendo e devendo a consideração da função social restringir o exercício da autonomia privada quando esta se mostrar incompatível com as exigências da socialidade. Na sua concreção o juiz poderá, avaliadas e sopesadas as circunstâncias do caso, determinar, por exemplo, a nulificação de cláusulas contratuais abusivas, inclusive para o efeito de formar, progressivamente, catálogos de casos de abusividade.

Contudo, considerar a norma do art. 421 apenas uma restrição à liberdade contratual seria acreditar que esta constitui um princípio absoluto, o que constitui uma falácia há muito desmentida. Por isso entendo estar cometida àquela norma também uma conotação substantiva, vale dizer, de elemento integrante do conceito de contrato. É por ser este dotado de função social que a liberdade contratual encontra limites. É pelo mesmo motivo que esta é regularmente exercida.

Integrando o próprio conceito de contrato, a função social tem um peso específico, que é o de entender-se a eventual restrição à liberdade contratual não mais como uma "exceção" a um direito absoluto, mas como expressão da função metaindividual que integra aquele direito. Há, portanto, um valor operativo, regulador da disciplina contratual, que deve ser utilizado não apenas na interpretação dos contratos, mas, por igual, na integração e $n$ concretização das normas contratuais particu-

larmente consideradas. Em outras palavras, a concreção especificativa da norma, em vez de já estar pré-constituída, preposta pelo legislador, há de ser construída pelo julgador, a cada novo julgamento, cabendo relevantíssimo papel aos casos precedentes, que auxiliam a fixação da hipótese, e à doutrina, no apontar de exemplos.

A doutrina - sua argúcia e sensibilidade - bem como o sentido de responsabilidade da jurisprudência , não só nesta passagem serão convocadas a atuar complementando, atualizando e desenvolvendo a letra do Códigos. Doutrina e juris prudência constituem a matéria da qual um Código é feito. Se é certo que nenhuma lei nasce no vazio, também é certo que nenhuma lei opera no vazio, portanto, a visão prospectiva dos modelos jurídicos e a consciência do caráter dinâmico e processual da construção da normatividade que animaram a Comissão Elaboradora do Projeto do Código Civil brasileiro ${ }^{197}$ deverão agora tornar-se concreta realidade por obra dos destinatários da nova lei.

Para tanto, porém, é preciso ter presente a nova racionalidade do Código, que não mais pretendendo tudo regular, reque as contribuições da doutrina e da jurisprudência para continuar e completar a sua força normativa, postulando por igual a consciência de todos os cidadãos, destinatários do Código - os reais construtores de sua normatividade - de que "não existe a plenitude do Direito escrito, mas sim a plenitude ético-jurídica do ordenamento" ${ }^{198}$.

${ }^{197}$ Neste sentido o meu "Direito e Cultura: entre as veredas da existência e da história", Revista do Advogado $n^{\circ}$ 61, São Paulo, 2000, p. 72

${ }^{198}$ REALE, Miguel, O Projeto do Novo Código Civil, cit., p. 178

Revista da Faculdade de Direito da UFRGS, v. 20, Outubro/2001

\section{Bibliografia}

AGUIAR DIAS, José Da responsabilidade Civil, Rio de Janeiro, Forense, Tomo II, 1994.

AGUIAR JUNIOR, Rui Rosado, "Projeto do Código Civil - Obrigações e Contratos", Revista do Conselho da Justiça Federal v.9, Brasilia, 1999.

AGUIAR JÚNIOR, Ruy Rosado, "O Poder Judiciário e a concretização das cláusulas gerais: limites e responsabilidades" , $\mathrm{Re}$ vista da Faculdade de Direito da UFRGS, vol. 18, Porto Alegre, 2000.

ALMEIDA COSTA, Mario Júlio Responsabilidade civil pela ruptura das negociações preparatórias de um contrato, Coimbra, 1984.

ALMEIDA COSTA, Mario Júlio, Direito das Obrigações, Ed. Almedina, Coimbra, $8^{a}$ edição, 2000.

ARCEYFLORES-VALDEZ, Joaquin, EIDerecho Civil Constitucional, Madrid, Civitas, 1986.

ASSIS, Araken, Comentários ao Código de Processo Civil, vol IV, arts. 566 a 645, Rio de Janeiro, Forense, $1^{\mathrm{a}}$ edição, $4^{\mathrm{a}}$ tiragem, 2001.

AVILA, Humberto Bergmann, A Distinção en tre Princípios e Regras e a Redefinição do Dever de Proporcionalidade, Revista da Pós-Graduação da Faculdade de Direito da USP, 1, 1999, Porto Alegre, Síntese, 1999,p. 27.

BALLARIN MARCIAL, A. Evolução do princípio jurídico do direito de propriedade rural, Revista de Direito Agrário, n.12, ano 10, 1994,p.28.

BANDEIRA DE MELLO, Celso Antônio. Novos aspectos da função social da propriedade no direito público, São Paulo, Revista de Direito Público, vol. 84, out-dez. 1987.

BITTAR, Carlos Alberto, Reparação Civil por Danos Morais, São Paulo, Revista dos Tri bunais, $3^{a}$ edição, $2^{a}$ tiragem, 1999.
BODIN DE MORAES, Maria Celina "A caminho do Direito Civil-Constitucional", Revista Direito, Estado e Sociedade, PUC, Rio de Janeiro, 1991, p. 59.

BORDA, Alejandro, La Teoria de los Actos Proprios, Buenos Aires, Abeledo-Perrot, 3 edição atualizada e ampliada, 2000.

CAHALI, Yussef Said Dano Moral, $2^{\mathrm{a}}$ edição, São Paulo, Revista dos Tribunais, 1998.

CALERA, Nicolas López, Hay derechos colectivos? Individualidad y socialidad em la teoria de los Derechos, Barcelona, Ariel Derecho, 2000.

CANARIS, Claus Wilhem, Pensamento Sistemático e Conceito de Sistema na Ciência do Direito, trad. MENEZES CORDEIRO, Lisboa, Gulbenkian, 1989.

COMPARATO, Fábio Konder, Correspondência dirigida ao Senador Josaphat Marinho em 3.9.97, in O Projeto de Código Civil no Senado, Tomo II, Brasília, Senado Federal 1998

COUTO E SILVA, Clóvis, "O princípio da boafé no Direito brasileiro e português", in Estudos de Direito Civil Brasileiro e Português, São Paulo, 1986

COUTOE SILVA, A Obrigação como Processo, São Paulo, José Bushatsky , 1976.

COUTO E SILVA, Clóvis, "Observações à Parte Geral do Anteprojeto de Código Civil", dirigidas ao Relator José Carlos MOREIRA ALVES em março de 1970, reproduzidas nas notas de rodapé da "Análise das Observaçóes do Prof. Couto e Silva à Parte Geral do Anteprojetode Código Civil", in MOREIRA ALVES, José Carlos, A Parte Geral do Projeto de Código Civil,

COUTO E SILVA, Clóvis, "O Conceito de Empresa no Direito Brasileiro", Revista Ajuris vol. 37, Porto Alegre. 
COUTO E SILVA, "O conceito de dano no Direito brasileiro e comparado", in O Direito Privado Brasileiro na visão de Clóvis do Couto e Silva", ao cuidado de FRADERA, Vera Maria Jacob, Porto Alegre, Livraria do Advogado, 1997.

COUTO E SILVA, Clóvis, “O Direito Civil Brasileiro em Perspectiva Histórica e Visão de Futuro" in Revista Ajuris no 40, Porto Alegre, 1987.

COUTO SILVA, Clóvis, Exposição de Motivos para a Reforma do Direito de Família, in Anteprojeto do Código civil, Arquivos do Ministério da Justiça, vol. 155, Rio de Janeiro, 1975.

COUTO e SILVA, Clóvis, Direito Patrimonia de Família no Projeto de Código Civil Brasileiro e no Direito Português, São Paulo RT 520, 1979, p. 14

CUNHA, Alexandre dos Santos, "Dignidade da Pessoa Humana: conceito fundamental do Direito Civil", in ", in MARTINS-COSTA, Judith, A Reconstrução do Direito Privado - reflexos dos princípios constitucionais e dos direitos fundamentais no Direito Privado, São Paulo, Revista dos Tribunais, no prelo.

DUGUIT, Léon, La responsabilidad del propietario y la jurisprudencia francesa, apend. in: Las transformaciones delDerecho (público y privado), trad. De Carlos POSADA, Buenos Aires, Editorial Heliasta, 1975.

DUGUTT,L.,Elderechosubjetivoy lafunciónsocial in in:Las transformaciones delDerecho (público y privado), trad. De Carlos POSADA, Bueno Aires, Editorial Heliasta, 1975.

DUGUIT, L. La propiedad función social in in Las transformaciones del Derecho (público y privado), trad. De Carlos POSADA, Buenos Aires, Editorial Heliasta, 1975.

FACHIN, Luis Edson Teoria Crítica do Direito Civil, Rio de Janeiro, Renovar, 2000
FRADERA, Vera Maria JACOB de, "Pertenças", Revista Jurídica 126, Porto Alegre, 1988

FROSINI, Vitório, "Le transformazioni social e il diritto soggetivo", Riv. Inter. di Filosofia del Diritto, 1968, I, Milão, pág.114.

GILISSEN, John, Introdução Histórica ao Direito,. Lisboa, Gulbenkian, 1988.

GROSSI, Paolo, La propiedad y las propiedades, un analisis histórico, trad. LÓPEZ Y LÓPEZ, Angel, Madrid, Civitas, 1992.

GROSSI, Paolo,Proprietà - diritto intermedio verbete in: Enciclopedia del Diritto, vol. XXXVII, 1988

GROSSI, Paolo, L'Ordine Giuridico Medievale, Laterza, Roma-Bari, 1995.

HATTENHAUER, Hans, ConceptosFundamentales delDerecho Civil,Barcelona, Ariel, 1987.

HECK, Luis Afonso ,"Direitos Fundamentais e sua influência no Direito Civil", in Revista da Faculdade de Direito da UFRGS , vol. 16, Porto Alegre, 1999

HESSE, Konrad ,Derecho Constitucional Derecho Privado, Madrid, Civitas, 1985

HOBBES,Thomas, De Cive (Do Cidadão). Tradução de Renato Janine Ribeiro. São Paulo, Martins Fontes.

IONESCU, Octavian, "Le problème de la partie introductive du code civil", Revue Internation de Droit Comparé, 1967, n.3, p. 579.

IRTI, Natalino, L'età della decodificazione Milão, Giuffrè, 1989.

IRTI, Natalino, Codice Civile e Società Politiche, Roma, LATERZA,1999.

KRELL, Andreas, Controle Judicial dos Servicos Públicos Básicos na Base dos Direitos Fundamentais Sociais, in A Constituição Concretizada, org., SARLET, Ingo Wolfgang, Porto Alegre, Livraria do Advogado, 2000.

LAFER, Celso, A reconstrução dos Direitos Humanos: um diálogo com o pensamento de Hannah Arendt. São Paulo, Companhi das Letras, $19911^{\text {a }}$ reimpressão.
LUDWIG, Marcos de Campos, " $O$ direito ao livre desenvolvimento da personalidade na Alemanha e possibilidades de sua aplicaça no Direito privado brasileiro", in MARTINS-COSTA, Judith, A Reconstrução do Direito Privado - reflexos dos princípios constitucionais e dos direitos fundamentais no Direito Privado, São Paulo, Revista dos Tribunais, no prelo.

MAC-DONALD, Norberto da Costa Caruso, $\mathbf{O}$ Projeto de Código Civil e o Direito Comercial, Revista da Faculdade de Direito da UFRGS, vol. 16, Porto Alegre, 1999.

MARINHO, Josaphat, "Os Direitos de Personalidade no Projeto do Código Civil", Boletim da Faculdade de Direito da Universidade de Coimbra, col. Stvdia Juridica, 40, Coimbra, 2000

MARINHO, Josaphat, Parecer Final ao Projeto do Código Civil, in O Projeto de Código Civil no Senado Federal, Vol. I, Brasília

MARTINS-COSTA Da Boa-Fé no Direito Privado, São Paulo, Revista dos Tribunais, 1999.

MARTINS-COSTA, Judith $O$ sistema na Codificação Civil Brasileira - de Leibniz a Teixeira de Freitas", Revista da Faculdade de Direito da UFRGS vol. 17, Porto Alegre, 1999.

MARTINS-COSTA, Judith, "Os Danos à Pessoa e a Natureza de sua Reparação", Revista da Faculdade de Direito da Universidade Federal do Rio Grande do Sul vol. 19 Porto Alegre, 2000.

MARTINS-COSTA, Judith, Bioética e dignidade da Pessoa Humana: Rumo à Cons trução do Biodireito", Revista da Faculdade de Direito da Universidade Federal do Rio Grande do Sul vol. 18, Porto Alegre, 2000.

MARTINS-COSTA, Judith, "O Direito Privado como Construção: as Cláusulas Gerai no Projeto do Código Civil Brasileiro" Revista de Informação Legislativa vol. 139 Brasília, 1998
MARTINS-COSTA, Judith, Direito e Cultura entre as veredas da existência e da história", Revista do Advogado, n 61, São Paulo, 2000, p. 72.

MARTINS-COSTA, Judith, Mercado e solidariedade social entrecosmos e taxis: a boafé nas relações de consumo, , in A Reconstrução do Direito Privado - reflexos dos princípios constitucionais e dos direitos fundamentais no Direito Privado, São Paulo, Revista dos Tribunais, no prelo.

MENEZES CORDEIRO, António Manuel, Da Boa-Fé no Direito Civil, Coimbra, Almendina, 1989.

MEDEIROS DA FONSECA, Arnoldo. Dano Moral, verbete in Repertório Enciclopédico Brasileiro.

MESSINETTI, Davide, "Personalitá" (Diritti della), verbete, in Enciclopedia Giuridica, Giuffrè, Milão, 1984

MIRANDA, Jorge (org.). Textos Históricos do Direito Constitucional, Lisboa, Imprensa Nacional - Casa da Moeda, 1980.

MOREIRA ALVES, José Carlos, A Parte Geral do Projeto de Código Civil Brasileiro, São Paulo, Saraiva, 1986, p. 7.

MOISSET DE ESPANES, Luis, La lesión los Actos Juridicos, Cordoba, Victor P. De Zavalia Editor, 1979

MOREIRA ALVES, parecer in O Projeto de Código Civil no Senado, Tomo II, Brasília, Senado Federal, 1998

NICOLAU, Noemi Nidia, "La autonomia de la voluntad como factor de resistencia a la tipicidad en el sistema de derecho privado argentino", Porto Alegre, nov. 1994, datilog.

NEGREIROS, Teresa, Fundamentos para uma interpretacão constitucional do princípio da boa-fé, Rio de Janeiro, Renovar, 1998.

OPPO, Giorgio, "Diritto Privato e Interess Pubblicl’, inRivista di DirittoCivile, 1994,1,p.26. 
PACHECOBARROS, Wellington, A propriedade agrária e seunovo conceito jurídico constitucional,Porto Alegre, RevistaAjuris, $n^{\circ} 32$

PENTEADO, Mauro Rodrigues, "Exposição Justificativa da Proposta de Modificação do Título VIII, Livro I, Parte Especial, do Projeto de Código Civil (PLC no 118/84) que dispõe sobre os Títulos de Crédito", in O Projeto de Código Civil no Senado, Tomo II, Brasília, Senado Federal, 1998.

PERLINGIERI, Pietro,II Diritto Civile nella legalità costituzionale", Nápoles, Edizione Scientifiche Italiane, 1991

PONTES DE MIRANDA, F.C, Fontes e Evolução do Direito Civil Brasileiro, Rio de Janeiro, Forense, 1981

PONTES DE MIRANDA, Tratado de Direito Privado, Tomo II, Rio de Janeiro, Borsói,

PONTESDEMIRANDATratadode Direito Privado, T.26, Ed. Borsói, Riode Janeiro, 1959.

PORTO, Sérgio José A Responsabilidade Civil por Difamação no Direito Inglês, Ed. Sergio Fabris, Porto Alegre, 1995.

PROUDHON. Qu'est-ce que la propriété, in Oeuvres Choisies. Paris, Gallimard, 1967.

RAISER, Ludwig, "Il futuro del Diritto Privato", in: Il Compito del Diritto Privato, trad. Italiana de Marta Graziadei, Milão, Giuffrè, 1990.

REALE, Miguel, Memórias - vol. 2 -a Balança e a Espada, São Paulo, Saraiva, 1987, p. 221

REALE, Miguel, O Projeto de Código Civil Situação atual e seus problemas fundamentais, São Paulo, Saraiva, 1986.

REALE, Miguel, O Projeto do Novo Código Civil-situação após a aprovação pelo Senado Federal, São Paulo, Saraiva, 2000.

REALE Fundamentos do Direito, São Paulo, Revista dos Tribunais, 3a. edição, 1998.

REALE, Miguel, Pluralismo e Liberdade ,Rio de Janeiro, Expressão e Cultura, $2^{a}$ edição, 1998.
REALE, Miguel, Código Civil-Anteprojetos, vol. 5, Tomo 1, Senado Federal, Subsecretaria de Edições Técnicas, Brasília, 1989.

REALE, Miguel, O Direito como Experiência, São Paulo, Saraiva, 1968.

REALE, Miguel, Fontes e Modelos do Direitopara um novo paradigma hermenêutico,São Paulo, Saraiva, 1994.

RIBEIRO LOPES, Maurício, Dignidade da Pes soa Humana, in Revista dos Tribunais 758 106-117.

RODOTÀ, Stefano, El terrible derechoEstudios sobre la propiedad privada, Madri, Civitas, 1986.

ROPPO, Enzo, O Contrato, trad., de Ana Coimbra e M. Januário Gomes, Ed. Almedina, Coimbra, 1988

SENADOFEDERAL, O Projeto de Código Civil no Senado, Tomo II, Brasília, Senado Federal, 1998.

SILVA PEREIRA, Caio Mario, Instituições de Direito Civil, v. $1, \mathrm{n}^{\circ} 16$

SILVA PEREIRA, Caio Mario, Lesão nos Contratos, Rio de Janeiro, Forense, $4^{\text {a }}$ Edição, 1993.

TALLON, Denis, "L'évolution des idées en matière de contrat: survol comparatif", in Droits, 12, 1990.

VARELA, Laura Beck, "A Tutela da Posse entre abstração e autonomia: uma abordagem histórica," in A Reconstrução do Direito Privado - reflexos dos princípios e garan tias fundamentais no Direito Privado, MARTINS-COSTA, Judith (org)., no prelo.

ZAVASKI, Teori, "A tutela da posse na Constituição e no Projeto do novo Código Civil", in MARTINS-COSTA, Judith, A Reconstrução do Direito Privado - reflexos dos princípios e garantias fundamentais no $\mathrm{Di}$ reito Privado, no prelo.

\section{Repudiando Montesquieu? A Expansão e a Legitimidade da "Justiça Constitucional" *}

\author{
Mauro Capelletti \\ (Tradução de Fernando Sá - advogado em Porto Alegre)**
}

se ela existe ou não, em algum ponto final, em alguma abrangente permanência, um Absoluto que proporcione uma trégua, sentido e luz a todo este comovente, batalhado e fugaz fenômeno que é a vida humana.

Tenho a honra de estar hoje com vocês, que "a justiça humana" pode fazer é olucionar, ou tentar solucionar, problemas concretos da vida individual e social: promulgar e impor normas, criar instituições, traçar processos, tudo com um objetivo em mente dirimir problemas reais. Mas os problemas humanos mudam continuamente, assim como as normas, os processos e as instituições. A justiça humana está mudando a idéia de Justiça, em um tributo de respeito e gratidão ao Papa João XXIII. Sua visão de fé no Absoluto não diminuiu seu profundo compromisso e ardor pela mudança. A justiça humana nunca cessou de ser a sua preocupação. Suas duas principais Encíclicas, Mater et Magistra (1961) e Pacem in Terris $(1963)^{1}$ representam um formidáve esforço na tentativa de traçar as linhas básicas

* Nota do tradutor: esta tradução resulta de um repto a mim lançado pelo amigo e professor Carlos Alberto Alvaro de Oliveira em suas aulas no mestrado da Faculdade de Direito da UFRGS. Aceito o desafio, teve ainda o mestre a dedicação [no que pese a tremenda carga de trabalho que enfrenta, como Magistrado consciente responsável, no Tribunal de Justiça do Estado do Rio Grande do Sul] de revisar e conformar à linguagem técnica do texto certos conceitos do autor.

* Copyright Mauro Capelletti. Esta é uma versão brevemente revista de um artigo originariamente publicado em 35 Catholic University Law Review 10001-1032 (1985). É um texto anotado da 20 Conferência Anual do Papa João XXIII proferida no dia 25 de abril de 1985 na Universidade Católica Americana em Washington, D.C. Fo João XXII pronstion

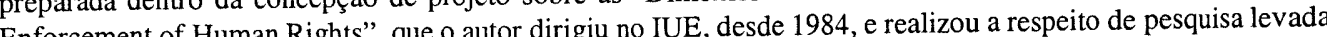
Enforcement of miro pelo autor, denominado "Access to Justice Project" a efeito no IEU em dois projes prosts. I-IV, Milão \& Alphen (1976-79) (resultados publicados in M. Castice and the Welfare aan den Rijn, Giuffre \& Sijhoff \& Nordhoff, 1978-79) e M. Cappelltion State, Alphen aan den Rijn \& Bruxelles, Stihhoff \& Bruylant, in Light of the American Federal Experience" (1979-85) (resultados publicados in M. Cappelletti, M. Seccombe \& J. Weiler, gen., eds., Integration Through Law: Europe and the American Federal Exper VI, Berlin \& New York, Walter de Cruyter, 1985-...

${ }^{1}$ A versão inglesa comentada pode ser encontrada in The Encyclicas and Other Messages of John XXIII, editada por Staff of the Pope Speaks Magazine, Washington, D.C., TPS Press, 1964 
para a solução do que seja talvez o mais desafiador dos problemas da vida em nossa época: o desafio da opressão, da pobreza e da guerra; os problemas da liberdade e da dignidade humanas, da justiça social e da coexistência pacífica dos indivíduos e dos povos; problemas cuja solução deveriam unir, como ele afirmou, todos os homens de boa vontade, pouco importando a raça, a nacionalidade e a fé. Ele nos deu, assim, a base para esboçar uma filosofia de vida para os indivíduos e as nações de nossa época.

Em suas raízes pode-se dizer que sua doutrina era relevante para todos os tempos, pois cada época sofre opressão, injustiça social, violência e guerra. Mas, num sentido mais profundo, a sua doutrina tinha o significado de uma filosofia essencialmente do e para nosso tempo. Essa foi a lição tirada dos tremendos desafios do nosso século, o qual, embora alardeando os mais nobres ideais de liberdade individual e de dignidade humana, caracterizouse justamente como sendo a época dos mais terríveis sistemas de opressão dos indivíduos, grupos e povos, como o foram o holocausto e o tentado genocídio de populações e de nações inteiras. Este nosso século, embora tenha testemunhado o mais impressionante crescimento de riqueza material e de genuína possibilidade de criar novas riquezas e bem estar, foi e vem sendo flagelado pela miséria nascente e pela fome maciça. O mundo, reduzindo-se no seu tamanho, pede, e até mesmo clama, por união e paz. Todavia, esta tem sido a era das mais terríveis guerras mundiais e de uma impendente ameaça de um terceiro e derradeiro conflito; o dilúvio universal; o fim, possivelmente, da humanidade.

É tempo, para todos nós, de nos preocuparmos com o fundamental. Se alguns episódios, relativamente limitados, como, por exemplo, o escândalo de Watergate, têm feito advogados e professores americanos de Direito lembrar que existe um problema de moralidade no Direito, na profissão e na formação jurídica, e se o Vietnam, assim como também o Iraque e o Chile e o Afeganistão, e muitos outros, fizeram com que homens e mulheres lembrassem ainda mais - felizmente atrás da cortina de ferro também - que existe um problema de moralidade na política e no modo em que nosso mundo em perigo é conduzido, é tempo, então, para todos nós, de nos preocuparmos em encontrar solução adequada para as mais importante questões que nos assolam - os problemas de sobrevivência em nossa época. Os problemas de buscar a liberdade, a justiça e a paz são novos, pela forma como assumiram afinal uma dimensão sem precedentes em nosso tempo: uma dimensão que, se as soluções adequadas não forem encontradas, pode eventualmente significar o fim do milênio da civilização.

Seja-me permitido, então, usar este privilegiado forum, para fazer um breve interrogatório em busca da resposta específica que a nossa época tem tentado dar àqueles problemas maiores da sobrevivência especialmente para um deles - o problema da opressão política. Em um nível pessoal, gostaria de acrescentar que me é particularmente gratificante falar a respeito deste tópico, hoje 25 de abril, dia da liberação da Itália, o quadragésimo aniversário da libertação de minha pátria, de um terrível sistema de opressão política que levou à mais trágica de todas as guerras. Minha busca focar-se-á, na Europa mas não se limitará a ela; e, obviamente, será a indagação de um advogado, uma vez que procurarei ordenar algumas das mais significativas normas legais, instituições e processos que proporcionam, em minha opinião, respostas objetivas ou potenciais ao mais dramático desafio de nosso tempo. Outros, naturalmente, podem propor diferentes respostas para este desafio - ou, como preferiria pensar, diferentes facetas à mesma resposta - oferecendo, por exemplo, visualizações econômicas, mais do que legais, como estou eu, aqui e agora, mais diretamente preocupado.

\section{O Significado de "Justiça Constitucional"}

A principal resposta em termos de justiça legal, ao problema da opressão, pode ser expressa por uma formula largamente usada hoje em dia na Europa: Justiça Constitucional. É comum dizer-se que o poder governamental encontra-se limitado por uma norm constitucional, e que os procedimentos tenhan sido concebidos e as instituições criadas para implementar tal limitação.

Na verdade, as formas de opressão que caracterizam nossa época são várias e muito complexas. Por exemplo, o poder não governamental - como o poder de grupo organizados, as corporações econômicas, os sindicatos, as associações, e os partidos políticos - ocasionalmente provou não se menos perigoso e opressivo, não menos invaso da privacidade e da liberdade dos indivíduos, do que o poder oficial do Estado. Mesmo os fantásticos e esplêndidos desenvolvimentos tecnológicos constituem-se numa ameaça potencial, pois os instrumentos de intromissão tornaram-se cada vez mais disponíveis para uso opressivo imediato. E, na verdade, nunca talvez tão agudamente quanto nos dias de hoje o indivíduo sentiu a opressão da "solidão dentro da multidão"; o sentimento de que nossa voz como a paráfrase bíblica, clamans in deserto; sentimento de alienação, que constitui uma das mais básicas doenças psicológicas do homem moderno.

Ademais, o perigo que provou ser o mais temido de nosso século é, sem dúvida, o poder organizado - o Estado e a sua multiplicidade de órgãos e agências, sua proliferação central e local. Os casos, para mencionar apenas os mais clamorosos, da Alemanha Nazista, da Itália fascista e da Rússia de Stalin, nunca passarão sem nos terem ensinado a mais importante lição: quando o poder político não sofre controle, mesmo os instrumentos da nova tecnologia, da comunicação de massa, da assim chamada "educação popular", tudo pode perverter-se numa grande máquina corruptora. A corrupção das mentes é obtida através da desinformação maciça e da proibição de toda crítica. Lembro uma das mais infames leis, discutidas alguns anos atrás pelos professores Hart e Fuller ${ }^{2}$, num dos mais citados debates sobre o direito e a moral. A lei alemã, de 1944, permitia que um homem, denunciado por sua mulher, fosse condenado à pena capital, pelo "crime" de criticar Hitler ${ }^{3}$, quando em licença militar, em sua casa. O que pode emergir de um governo sem controle, como a triste história recente nos revela, é uma distorção, até mesmo para o mais prosaico sentido de justiça. Daí, a intolerância e o fanatismo e, eventualmente, a aceitação, e até mesmo o chamamento à violência e à guerra A justiça constitucional, acredito, é na verdade uma das mais importantes e promissoras respostas que um crescente número de nações tem procurado dar a esse problema da opressão governamental. Como já mencionado, o que está implícito na justiça constitucional é a noção de um novo 4 tipo de normas constitucionais,

${ }^{2} \mathrm{H}$. L A HART "Positivism and Fidelity to Law - A Reply to Professor Hart". Ibidem, 630-672.

${ }^{2} \mathrm{H}$. L. A HART, "Positivism and Fidelity to Law - A Repl

3 HART, ob., cit., 618-619; FULLER, ob. cit., 654-655.
${ }^{4}$ Para alguns precedentes históricos, entretanto, vide, v.g., M. CAPPELLETTI e J. C. ADAMS, "Judicial Review ${ }^{4}$ Para alguns precedentes históricos, entretanto, vide, v.g., M. CAPPELLETT1 e J. 24 (1966); M. CAPPELLETTI, of Legislation: European Antecedents and Adaptations",79 Harv. L. Rev. 1207-1224 (1966); M. CAPPELLial Review in the Contemporary World, Indianapolis, Bobbs-Merrill, 1971, 24-43 [doravante citada como Judicial Review]. 
instituições e processos, numa tentativa de limitar e controlar o poder político. Existe, naturalmente, uma variedade de meios que ajudam a alcançar este desiderato. Esses meios incluem o regionalismo, que traz à tona a descentralização, pelo menos de parte do poder político, uma forma de "divisão vertical" do mesmo. Aqui, todavia, eu pretendo centrar minha discussão a respeito da revisão judicial da constitucionalidade do ato administrativo e particularmente, da legislação. Trata-se de uma evolução que, num sentido mais real, mudou a estrutura governamental na maior parte da Europa continental, nos últimos 40 anos mais ou menos, com expansões em outras partes do mundo, incluindo, por exemplo, o Japão.

\section{O Surgimento e o Cresci- mento da Justiça Constitucional na Era Posterior à II Guerra Mundial}

A Áustria desde 1945, o Japão desde 1947, a Itália desde 1948, a Alemanha desde 1949: emergindo do pesadelo da tirania e da guerra, todos esses países percorreram um caminho semelhante em seus esforços de construção duma nova forma de governo civil e democrático. Cada um deles adotou uma Constituição escrita, aceita como obrigatória por todos os órgãos do governo. Introduziram severas limitações ao processo de emenda à Constituição, protegendo assim o novo direito fundamental, dos caprichos de maiorias passageiras. Incluíram direitos fundamentais na
Constituição, estendendo, assim, a proteção constitucional aos indivíduos em face do poder governamental; e, last but not least, reforçaram a atuação da Constituição e de seus direitos fundamentais, em relação a novos ou reestruturados tribunais judiciais, dotados de importantes garantias de independência face a órgãos políticos. 5

Isso, naturalmente, pode parecer um pouco banal para os americanos. Permitam-me advertir, todavia, que mesmo neste país, o papel da decisão constitucional adquiriu sua importância atual somente depois da II Guerra Mundial, quando se tornou o mais importante instrumento para a garantia de certos direitos civis básicos dos cidadãos e de grupos minoritários contra maiorias resistentes nos Estados e da inação de órgãos políticos no plano federal. Quanto ao resto do mundo, notase que em muitos outros países a justiça constitucional, em todos os sentidos até agora mencionados, representou um inovação fundamental. Realmente, foi uma verdadeira revolução, ao menos na Europa continental e, talvez, no Japão.

Constituições e direitos fundamentais, é claro, existiram na França, na Alemanha e em outros lugares, por muitos anos. Até a época que se seguiu à II Guerra Mundial, todavia, seus significados tendiam a ser compreendidos mais como meras declarações político-filosóficas do que como atos legalmente obrigatórios. $\mathrm{E}$ isso porque, com poucas e esporádicas exceções de curta duração (mais marcadamente as da Áustria em 1920 e início de 1930$)^{6}$, nenhum órgão independente tinha a prerrogativa de
${ }^{5}$ Sobre estes desdobramentos vide Judicial Review, supra nota 4, especialmente cap. 3. A principal característica dos sistemas europeus de revisão é sua natureza "centralizada", vale dizer, que a autoridade para declarar uma lei inconstitucional, logo (em princípio) nula e ineficaz, está restrita à revisão da recém criada Corte Constitucional. Se confrontada com a questão da inconstitucionalidade da lei relevante no caso em espécie, as outras cortes não decidirão mas sim suspenderão o feito e reverterão a decisão de constitucionalidade à Corte constitucional cuja decisões têm efeito erga omnes. Os sistemas europeus são contrastantes com o sistema americano "desceujas zado" em que as cortes têm o poder revisional. Vide Judicial Review supra nota 4 , caps, 3-5. ${ }^{6}$ Vide $i d .$, p. 46-47 et passim.

Revista da Faculdade de Direito da UFRGS, v. 20, Outubro/2001 supervisionar suas reais aplicações. A revolução constitucional - e eu realmente entendo o que estas palavras significam somente ocorreu na Europa com o doloroso entendimento de que a Constituição e os direitos fundamentais constitucionais necessitam de uma máquina judiciária para se tornarem efetivos. Os Estados Unidos certamente concorreram com um influente precedente. Mas a mais marcante lição veio da experiência doméstica, da experiência de tirania e de opressão por um poder político sem freios, por uma máquina ao mesmo tempo acessivel às vítimas do abuso governamental e capaz de restringir tal abuso.

A lição foi eventualmente apreendida. Cortes constitucionais foram criadas e processos constitucionais esboçados para fazê-las funcionar. Menciono apenas um desse processos, porque parece ser o mais indicativo de uma filosofia permeando essa revolução constitucional de direitos civis. Na Alemanha, em 1951, a legislação ordinária concedeu qualquer cidadão o direito de demandar perante a recém criada Corte Constitucional, contra qualquer ato do Estado, legislativo, administrativo ou judicial, que violasse direito constitucionalmente protegidos ${ }^{7}$. Em 1969 este extraordinário remédio, chamado "Verfassungsbeschwerde", ou queix constitucional, foi introduzido na Constituição

alemã, e na Áustria, especialmente desde 1975 , foi adotado um processo similar ${ }^{8}$. Através desse e de outros mecanismos a constitucionalidade de milhares de atos legislativos e de outros administrativos foi controlada e os direitos fundamentais do povo protegidos por Cortes independentes, na Alemanha, na Áustria, na Itália e em outros lugares.

O sucesso da "justiça constitucional", como instrumento para a proteção dos direitos humanos, e seu profundo impacto na forma de liberdade democrática de governo, tem sido geralmente reconhecido em todos esses países, muito embora, como é natural, a dissensão muitas vezes diga respeito ao conteúdo das decisões constitucionais particulares ou mesmo acerca de algumas tendências generalizantes no caso do direito constitucional. Talvez a mais conclusiva evidência, do sucesso deste fenomenal desenvolvimento conceitual seja dada por sua tremenda força de expansão. Refiro alguns episódios: Chipre em 1960, Turquia em 1961, e Malta em 1964, todos introduziram formas de jurisdição constitucional largamente inspirados nos modelos da Alemanha, Áustria, e Itália ${ }^{9}$. Realmente, parece que nenhum país da Europa, emergindo de alguma forma de regime não democrático ou de sérios conflitos domésticos, poderia achar uma melhor resposta à exigência de reagir contra pecados passados,

${ }^{7}$ Vide id., p. 22-23. Para prevenir o abuso deste processo, é necessário ocorrer a exaustão dos remédios normais, mas mesmo este pré-requisito não é necessário no caso de uma queixa refletindo um "interesse geral" ou quando a demora poderia ocasionar importante prejuízo à parte interessada. Vide, v.g., K. SCHLAICH, "Procédures et techniques de protection des droits fondamentaux. Tribunal Constitutionnel Fédéral Allemand," in Louis FAVOREU (sob a direção de), Cours constitutionnelles européennes et fondamentaux, Paris, Econômica, 1982, p. 128-129 [doravante citada como Cours constitutionnels].

${ }^{8}$ Vide o relatório de L. Favoreu sobre a Europa Ocidental, §§ 8-10, apresentado na Conferência da Associação Internacional de Ciência Legal, realizada em junho de 1984, em Uppsala, Suécia, no "Judicial Review at Legislation and its Legitimate - Recent Developments" Os relatórios regionais, tanto quanto o relatório geral de CAPPELLETTI form publicas em forma de volume sob a edich

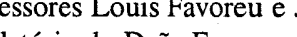
publicada in Revue du droit public et de la science politique en France et à l'étranger, 1984, 1147-1201).

${ }_{9}^{9}$ Constituições de Chipre (1960), Turquia (1961) e Malta (1964), Vide Judicial Review, supra nota 4, p. 50-51. 
e, possivelmente prevenindo uma recaída, do que introduzindo a justiça constitucional em seu novo sistema de governo. Foi o caso da Grécia em 1975, depois da queda do regime dos coronéis, ${ }^{10}$ de Portugal em 1976, depois da queda do regime de Salazar ${ }^{11}$; e da Espanha, depois da queda de Franco ${ }^{12}$. Significativamente, também a Iugoslávia, na procura de uma autonomia política e ideológica vis-à-vis da União Soviética, promulgou uma constituição em 1963 que introduziu um sistema de revisão judicial ${ }^{13}$. A Iugoslávia foi o primeiro e, até agora, o único país de regime comunista a fazer isso; mas é bastante significativo que a Tchecoslováquia em 1968 - o ano das paixões e esperanças da "Primavera de Praga" - tenha tentado logo a seguir ${ }^{14}$ uma experiência semelhante, e que assim o tenha feito a Polônia, em 1982, antes de o "Solidariedade" e todo o resto terem sido condenados ao silêncio ${ }^{15}$ Diferentemente da Iugoslávia, entretanto, as emendas constitucionais da Tchecoslováquia e da Polônia permaneceram letra morta, esmagadas pela ressurgência de seus regimes autocráticos. Realmente, se uma boa lição claramente emerge da análise comparativa desses acontecimentos mais recentes, uma lição que muitos críticos da legitimidade democrática da revisão judicial parecem negligenciar, é a de que nenhum sistema efetivo de controle judicial é compatível ou tolerado por regimes antilibertários e autocráticos, quer se coloquem à esquerda ou à direita dum espectro político. $\mathrm{O}$ fato de que a revisão judicial se constitui em um anátema à tirania, é confirmado pelo seu desenvolvimento em vários continentes, e mais freqüentemente na América Latina e África ${ }^{16}$. Uma ilustração peculiar oferece a África do Sul,

${ }^{10}$ Constituição Grega de 1975. Vide E.SPILIOTOPOULOS, "Judicial Review of Legislative Acts in Greece", 56 Temple Law Quartely 463 (1983); J. ILIOPOULOS-STRANGAS, "Grundrechtsschutz in Griechenland”, Jarhbuch des oeffentlichen Rechts, 1983, 396; V. Perifanaki ROTOLO, "La Corte Suprema Speciale nella Costituzione Greca del 1975", 29 Rivista trim. di diritto pubblico 183 (1979); L. FAVOREU, supra nota 8, §§ 27-31. Sob o sistema grego, todas as cortes têm o poder de negar aplicação de leis inconstitucionais (assim o chamado sistema de revisão "descentralizado", vide nota 5 supra), mas uma recém instituída "Suprema Corte Especial" tem a palavra final no caso de opiniões conflitantes entre as altas cortes.

${ }^{11}$ Constituição Portuguesa de 1976. Especialmente após a reforma constitucional de 1982, Portugal adotou um sistema de revisão judicial similar àquele prevalecente na maioria das nações européias mencionadas no texto, confiando a função de controle a uma recém criada Corte constitucional. Vide L. FAVOREU, supra nota 8 , §§ 22 26; H. FIX-ZAMUDIO, La protección jurídica y procesal de los derechos humanos ante las jurisdicciones nacionales, Madrid, Civitas, 1982, 203-207.

${ }_{12}$ Constituição da Espanha de 1978, seguida pela criação em 1980 de um tribunal constitucional bastante ativo. Vide E. GARCIA DE ENTERRIA, La constitución como norma y tribunal constitucional, Madrid, Civitas, $2^{\mathrm{a}}$ ed., 1982; J. GONZÁLEZ PÉREZ, Derecho procesal constitucional, Madrid, Civitas, 1980; M. ARAGÓN REYES, "El control de constitucionalidad en la Constitución española de 1978", 7 Revista de Estudios Politicos 171 (1979); H. FIX. ZAMUDIO, supra nota 11, 197-202; FAVOREU, supra nota 8, §§ 13-14.

${ }^{13} \mathrm{O}$ sistema foi reafirmado na Constituição da Iugoslávia de 1974. Vide o relatório de Uppsala por Pavle NIKOLIC sobre as nações socialistas, supra nota 8, \&\$ I. 1, III. 2. A et passim; vide também H. F. FIX-ZAMUDIO supra nota 11, 208-212; Judicial Review, supra nota 4, 51-52.

${ }^{14}$ Vide relatório Uppsala por P. NICKLIC, supra nota 13, § III. 2. B.; relatório geral de Uppsala por M. CAPPELLETTI, supra nota $8, \S 2$.

${ }^{15}$ Vide A GWIZDZ, "The Constitutional Review of Laws in Poland", relatório polonês do $1^{\circ}$ Congresso da Associação Internacional de Direito Constitucional realizado em Belgrado, setembro de 1983 (não publicado) relatório de Uppsala por P. NIKOLIC supra nota 13, § III. 2. C; relatório geral de Uppsala por M. CAPPELLETTI, supra nota $8, \S 2$.

${ }^{16}$ Vide os iluminados relatórios de Uppsala por J. CARPIZO \& H. FIX-ZAMUDIO sobre a América Latina e por B. O NWABUEZE sobre a África, supra nota 8.

Revista da Faculdade de Direito da UFRGS, v. 20, Outubro/2001 onde uma "crise constitucional" desenvolvida em 1950 irrompeu no momento em que o Judiciário deciarou inconstitucionais certas promulgações do Parlamento Sul Africano. A crise culminou com a adoção da Constituição Sul Africana de 1961, que efetivamente negava ao Judiciário qualquer autoridade para revisar a validade dos atos legislativos. ${ }^{17}$
IV. A França Repudiou Montesquieu?

Não sou um especialista em assuntos japoneses. Sei, todavia, que, mesmo naquela nação, a justiça constitucional, inicialmente vista por muitos como um elemento alienígena

A história Sul-Africana de luta de uma corte contra alguns excessos de um regime não liberal é muito sugestiva merece ser relembrada com certos detalhes. A "crise constitucional" daquele país pode ser remontada à decisão da Suprema Corte da África do Sul no ano de 1952 no caso de Harris e outros v. Ministro do Interior, 1952 (2) A 428 (A.D.), também conhecido como o caso do Voto. Na decisão, a Corte manto e fundamental de desqualificar Representação Separada do Ato dos Elet orte decidiu que isto violava algumas seções "enraizadas" na Constituiçãa Sul-Africana (Ato da Arica do Sul de 1909), particularmente a seção 35 que dispunha que "nenhuma lei...desqualificará qualquer pessoa ...que é ou possa vir a ser capaz de se registrar como votante...somente em razão de sua raça, a não ser que [aprovada por maioria de dois terços do Senado e da Câmara dos Deputados em sessão conjunta]. Naquele tempo, a autoridade de revisão juridicial da Suprema Corte com respeito às seções "enraizadas" era motivo de grande debate e a decisão do Presidente da Suprema Corte, A. van de Sant Centives (que foi declarada pelo menos por um comentarista - o então Deão da Escola de Direito de Harvard, Ervin Griswold - Ombrear com as melhore decisões sobre direito constitur Harv. L. R. 1361 [1953]), criou uma enorme conpetente para determinar se um Ato do Parlamento havia sido Corte Centlivres declarou que a corte era competente significaria dizer que as cortes de justiça não teriam poder vara proteger os direitos dos indivíduos que estavam especialmente protegidos pela constituição deste país." O para proteger os 479 . O governo da África do Sul não ficou satisfeito com a decisão sobre o Voto e mais tarde, em 1952, cada uma das casas do Parlamento por maioria simples de votos promulgou o Ato da Alta Corte do Parlamento, 35 de 1952, que criou a "Alta Corte" da qual cada membro do Parlamento seria membro. A "Alta Corte" foi declarada como sendo uma corte de direito com poder de revisão de qualquer decisão da Suprema Corte que declarasse atos do Parlamento como inválidos. A "Alta Corte" procedeu então a revisão dram mais aplicáveis. derrogou sob a alegação de que as seçôes "enaizadas cas Cola Suprema Corte como inválido, concordando os O Ato da Alta Corte, todavia, j69 (A. D.) Finalmente, em 1955, em outra tentativa de passar por cima de um Judiciário "pouco amigável", . das duas casas do Congresso o Governo teria uma maioria de dois terços de todos os membros das duas Casas. O Ato do Senado, 53, de 1955. No ano seguinte, o Ato de Emenda Sul-Africana, 9 de 1956, foi aprovado por uma sessão conjunta. Essa emenda constitucional alterou consideravelmente as cláusulas pétreas da Constituição e particularmente derrogou a seção 35 relativa aos direitos de desquallficaça do voto. A emenda constitucional tambem considerou a revisão judicial. A seção 2 estabelecia em para investigar ou pronunciar-se sobre a validade de lei aprovada pelo Paráamentótreas foram consideravelmente seções "enraizadas"]. E claro, como previamente notado, que as seçôes pétreas foram coram ameaçados mas enfraquecidas pela envia. retirar os poderes de voto dos negros do Cabo tal como originariamente tentado em 1951. A indignação causada por esses desdobramentos foi finalmente acalmada em 1961, quando a Africa do Sul formalmente tornou-se uma República. A constituição Sul-Africana de 1961 refletia inteiramente as enfraquecidas secções pétreas e o significado da emenda de 1956. Essa ausência de revisáo judicial foi mantida na da $\mathrm{A}$ (n) do Su de implica $\mathrm{Am}$ um Constituição, todavia, incorporou uma terminologia de direitos politicos em seu preâmbulo e pode implicar em úm papel constitucional mais auante do Sul é algo que permanece em dúvida. Para maiores discussões da "crise constitucional da Africa do Sul em vide H.J.MAY, The South African Constitution, 3 ed., Capetown 7 (1958). Para maiores discussões sobre a revisão Audicial System and its backgrounded, Cape Town, Juta \& Co., 1968, 53-63; L. A. ROSE INNES, Judicial Review of Administrative Tribunals in South Africa, Capetown, Juta \& Co., 1963, 1-20. Para discussão da Constituição da África do Sul de 1983 e melhor bibliografia vide L. J. BOULLE, Conntitutional Reform and Apartheid, New York, St. Martin's Press, 1984.

Revista da Faculdade de Direito da UFRGS, v. 20, Outubro/2001 
no sistema de governo japonês, gradualmente construiu para si uma relevante função e uma significação genuína dentro do sistema, mesmo que nem tão importante e significativa quanto a da Europa Continental. ${ }^{18}$

Retornando à Europa, meu relato seria um tanto quanto incompleto caso não dissesse algo a respeito de outras duas grandes nações: a França e a Inglaterra. Esses países têm sido muito mais relutantes do que a maior parte da Europa em participar da "revolução constitucional". Neles, a supremacia parlamentar se enraizou de há muito como um credo político - de tal forma que o Parlamento nacional, como incorporação da vontade democrática, tem-se mostrado imune ao controle judicial. Essa tem sido a tradição e o mito; na Inglaterra desde a "Revolução Gloriosa" de 1688, e na França desde sua Revolução um século depois; mito de que não compartilha a Revolução Americana. ${ }^{19}$

Para dizer a verdade, cada uma dessas duas nações européias tem uma história diferente acerca da supremacia parlamentar $\mathrm{Na}$ França, é mister voltar-se ao passado para nele encontrar um profundo sentimento de repulsa popular contra o abuso da função jurisdicional exercido pelas as altas cortes de justiça no tempo do ancien régime. Esses tribunais, ironicamente denominados de Parlaments, tinham competência para rever atos do soberano, recusando-se a aplicar os considerados incompatíveis com "as leis fundamentais do reino". ${ }^{20}$ Os pronunciamentos - na maior parte não escritos - acerca dessas leis fundamentais, entretanto, induziram as cortes a afirmar a "heureuse impuissance" do legislador até mesmo introduzindo pequenas reformas liberais. Os juizes estavam de tal maneira identificados com o regime feudal que consideravam inaceitável qualquer inovação liberal. Os cargos eram hereditários, podendo ser comprados e vendidos. ${ }^{21} \mathrm{O}$ trabalho dos juízes devia ser pago pelos litigantes como se a administração da justiça ${ }^{22}$ fosse um privilégio dos magistrados e não uma obrigação. Status, educação, família e interesses pessoais de classe se combinavam para motivar comportamentos extremamente conservadores, fato que, eventualmente, contribuiu para a

${ }^{18}$ Vide relatório Uppsala por Y. Taniguchi sobre o Japão, supra nota 8.

${ }^{19}$ Talvez a razão histórica para esta diferença básica, que se reflete na profunda diferença entre as versões francesas e americanas de "separação de poderes" (vide texto acompanhando e seguindo nota 33, infra), encontra-se no fato de que a americana independe do Parlamento Britânico. Isto pode explicar por que, como diz o Professor HENKIN, os constituintes da Constituição Americana "não estavam contentes com a democracia, nem mesmo com o governo representativo, pois tinham apreendido que o Parlamento também poderia ser despótico". Louis BENKIN, The Rights of Man Today, Boulder, Colorado, Westview Press, 1978 p. 10, repetindo The Federalist n. ${ }^{\circ} 4$ (James MADISON): "A acumulação de todos os poderes, legislativo, executivo e judiciário nas mesmas mãos, se em uma, algumas, ou muitas, e se hereditária, autonomeada, ou eletiva, pode ser justamente declarada como a exata definição da tirania."

${ }^{20} \mathrm{O}$ desenvolvimento gradual e as conseqüências políticas do "poder dos Parlements de vetarem a legislação real" $1968,362-371$. O poder de veto foi exercido por ambos, face à recusa de registrar as proclamações reais nos registros do Parlement e pelo protesto público (remonstrance) contra um ato real de que o Parlement desaprovava. ${ }^{21}$ Vide, v.g., J. P. DAWSON, supra nota 20, p. 350-362

${ }^{22} \mathrm{O}$ assim denominado "princípio da venalidade da justiça" foi abolido na França pela Revolução através da lei de agosto 16-24, 1790, tit. II, art. 1 Vide M. CAPPELLETTI \& J. GORDLEY, "Legal Aid: Modern Themes and Variations", 24 Stanford Law Rev. 347, 355 (1972).

Revista da Faculdade de Direito da UFRGS, v. 20, Outubro/2001 deflagração da explosão revolucionária ${ }^{23}$. O ressentimento popular contra os Parlements era justificado ${ }^{24}$ e refletiu-se,
por vezes em forma velada, na celebrada obra, De L'Esprit des Lois, publicada pela primeira vez, em 1748 , por quem, ao falar dos juizes de seu tempo e país, sabia muito bem o que estava dizendo. Charles-Louis de Secondat, o primogênito duma antiga família de juizes "parlamentares", contando 27 anos de idade, em 1716, já se tinha tornado "Président à mortier" no "Parlement" de Bordeaux. Herdara o alto cargo judiciário, assim como o nome de Montesquieu, de seu falecido tio ${ }^{25}$ Perfeitamente compreensível, dado o tipo de juízes daquele tempo, pregasse um iluminado Montesquieu que os juízes não deveriam ser investidos de nenhum poder político:

Não há liberdade .....se o poder de julgar não está separado do poder legislativo e do executivo ${ }^{26}$.

"Mesmo que a lei", diz ele, "embora clarividente e cega" 27 , parecesse em certos casos cruel, ainda assim não seria dado aos juízes interferirem; pois esta tarefa é da competência exclusiva dos legisladores. Aos juizes incumbe o dever de aplicar a le cegamente, uma vez que os juizes não são nada mais do que a boca que pronuncia as palavras da lei; são seres inanimados que

23 "Por volta de 1750 os Parlements tinham emergido como uma bem articulada e determinada oposição, ${ }^{23}$ "Por resistindo a todos os fireitos fundamentais do reino $\mathrm{e}$ tos fundamentavam suas demandes privilégios da alegavam estar resguardando suas liberdades... A conistra ." . P. DAWSON, supra nota 20, p. 369.

nobreza e da resistência a todas as mudanças na admistraça " "Juando se considera a selvageria do ressentimento ${ }^{24} \mathrm{~A}$ Revolução prontame isto largamente deveu-se ao fato de muitos se terem exilado." J. P. DAWSON, supra nota 20, p. 370. "A mais alta isto largamente deveu-se ao fato de mutamentaires de Toulouse ( 55 executados, i.e., 50 porcento). Bordeaux for taxa de mortalidade recaiu sobre os parlamentaires de $370, \mathrm{n}^{\circ} 22$.

$370, \mathrm{n}^{\circ} 22$.
${ }^{25}$ Vide Robert DERATHÉ, in MONTESQUIEU, De L'Esprit des Lois", Tomo I, Paris, Editions Garnier Frères, 1973, p. LXVII-LXVIII.

${ }^{26}$ De L'Esprit des Lois, livro XI, cap. VI (traduções desse artigo, senão diferentemente indicado, são de M. CAPPELLETTI).

${ }^{27}$ Ibidem.

Revista da Faculdade de Direito da UFRGS, v. 20, Outubro/200/ 
não podem moderar quer a força quer o rigor da lei ${ }^{28}$.
Embora Montesquieu, diferentemente de Locke, tenha apresentado o ${ }^{28}$ Ibidem. A teoria de Montesquieu tem, nada obstante, várias ambiguidades. Contrariamente a J. J. ROUSSEAU,
que era a favor de um governo "republicano" - i. e., de um governo "guiado pela vontade geral, que é a lei" (Jeanque era a favor de um governo "republicano" - i. e., de um governo "guiado pela vontade geral, que é a lei" (Jean
Jacques ROUSSEAU, Du Contrat Social ou Principes du Droit Politique, livro II, cap. VI, nota 1 et passim) ou, na definição de Montesquieu, de um governo no qual "o povo...tem o poder soberano" (MONTESQUIEU, ob. cit., livro II, cap. 1) - Monstequieu advogava uma monarquia moderada, não absoluta, ou, como nós a chamamos hoje uma monarquia constitucional (livro II, cap. IV e livro V, cap. XI), enquanto condenava a forma despótica de governo (livro II, cap. V e livro V, cap. XIV). A monarquia de Montesquieu era por ele caracterizada como un sistema em que "somente uma pessoa governa, mas com base em leis fixas e estabelecidas" (livro II, cap. 1)
contrastava com o regime despótico em que "uma pessoa decide tudo, sem leis nem regras, meramente baseada em sua vontade e caprichos" (ibidem). Ele enfatizou, repetidamente, que o monarca não despótico estará obrigado por "direitos fundamentais" (livro II, cap. IV; livro V, cap. XI) e não deverá concentrar em si a função judicia (livro VI, cap. V). Assim agindo, todavia, Montesquieu parecia apoiar exatamente o que os Parlements tinhan tentado fazer por um longo tempo - impor, mesmo contra o monarca, a superioridade de certas leis não escritas "leges generales" ou direitos fundamentais, "fixes et immuables", que, no entanto, devido a sua essencialmente doutrina da superioridade "dos direitos fundamentais do reino" leva os Parlements a exercerem aquilo que redundava ser uma revisão judicial da legislação. Vide Judicial Review, supra nota 4, 32-36; e vide o texto e nota 20, supra. Há no mínimo duas passagens no L'Esprit des Lois, nas quais Montesquieu parece apoiar essa função jurisdicional dos Parlements: no livro III, cap. X, onde ele lamenta que nos regimes despóticos, o "príncipe" requer obediência absoluta a seus desejos e nenhuma "remonstrance" é permitida; e no livro V, cap. X, onde ele pessoa, mais eficiente e prontamente do que no governo "republicano", tal eficiência não degenera em descaso porque a ação estatal é constrangida ao respeito às leis. Teria então Montesquieu "repudiado" - ou de fato contraditado a si mesmo? Onde estará o "verdadeiro" Montesquieu? Como poderiam tais passagens ser reconciliadas com o contínuo apelo no sentido de que as decisôes não deveriam ser "arbitrárias" (ivro XI, cap. VI); que nas boas monarquias a virtude do juiz encontra-se na "la médiocrité" (livro XX, cap. XIII); que os juízes estão obrigados a aplicar rigorosamente "la loi" ("onde necessário, o juiz simplesmente a segue; onde não, ele procur
seu espírito") (livro VI.., cap. III; que o julgamento não refletirá as opiniôes pessoais do juiz (livro XI, cap. VI); que nenhuma liberdade existe quando o juiz é também o legislador (livro XI, cap. VI); em suma, que o juiz deve ser somente a "inanimada" boca da lei (ibidem)? Uma explicação, naturalmente, poderia ser a influência das teorias do direito natural dominante em toda a Europa nos séculos XVII-XVIII com os quais Montesquieu compactuo (vide, v.g., livro I, cap. II, para uma estudada interpretação vide R. SHACKLETON, "Montesquieu em 1948", Estudos Franceses $299,303-323$ (1949)). Tais teorias afirmam a existência de certos direitos, enraizados na natureza ou na razão humanas, imutáveis e universais e superiores ao direito positivo de um dado tempo e lugar
Essas teorias também eram dificilmente compatíveis com um papel puramente mecânico do juiz. No entanto, afora a obediência e a aplicacão do direito natural, eram para serem relegadas à exclusiva preocupação do soberano, como na concep̧̧ão de Hobbes, que fol severamente condenado por Montesquieu (vide R. SHACKELTON, "Montesquieu em 1948", 3 Estudos Franceses 299, p. 310-311 (1949). Uma outra explicação pode ser a de que Montesqueu não atribuía afinal de contas uma importância muito grande aos "direitos naturais" na determinação do papel dos juízes. Deve-se notar que, muito embora mesmo os reis de França admitindo a existência de tais regulava a sucessão à coroa (Lei Sálica) e o direito que estabelecia a inalterabilidade do domínio real" (assim R. DERATHE, supra nota 25 , p. 430). Isso, naturalmente, era muito pouco, para representar a fundamentação de um sistema de revisão judicial da legislaçâo monárquica. Uma terceira explicação, que parece mais plausível é a da visăo de Montesquieu em defesa de uma "monarquia moderada" em que os poderes do monarca estavam mai limitados pelos "poderes intermediários" (vide v.g., De Lesprit des Lois, livro II, cap. IV) e mais particularmente não parece convincente: mesmo o assim chamado "eloge de l'état de la robe" por Montesquieu no livro XX, cap. XXIl está longe de significar o que DERATHÉ parece sugerir. Porque, conforme o já mencionado, mesmo Montesquieu magnificava a "médiocrite" e a "suffisance" do juiz "parlamantaire", embora pagasse um tributo à "gloire" do "corps" como tal; a glória, a qualquer custo, que e imediatamente declarada bastante inferior àquela da desta recomenda $\tilde{a}^{\circ}$, não muitas décadas depois a Franca e no despertar da França, grande parte do o espírito europeu, acabou por introduzir a carreira judiciária, preenchida por servidores públicos - a glória real da médiocrité Como tentei demonstrar em outra ocasião (vide Judicial Review, supra nota 4, p. 60-66 e "The Doctrine of Stare Decisis and the Civil Law", in Festschrift für Konrad Zweigert, H. Berstein, U. Drobing \& H. Kötz eds., Tübingen Mohr, 1981, 381, 387-393), esta "mediocridade " social e profissional dos juizes ordinarios continentais ("Civis") tornar-se-ia uma das razões por que eles se tornariam inadequados para o desafiador papel da revisão judicial dos precisaram ser criadas no século XIX e especialmente as cortes constitucionais em nosso século para preencherem aquele papel. Hoje, os juizes administrativos e até mesmo os constitucionais na Europa assemelham-se muito mais aos juízes federais americanos do que aos simples juizes de carreira.

Revista da Faculdade de Direito da UFRGS, v. 20, Outubro/2001 judiciário como um dos "três poderes", seguindo-se ao legislativo e ao executivo" deixou claro, contudo, que este terceiro ramo, na realidade, não é um "poder"

Dos três poderes de que falamos, judiciário é, em certo sentido, nulo. ${ }^{30}$

Qualquer que tenha sido a real influência de Montesquieu na Revolução Francesa, essa idéia deveria tornar-se a parte central de sua ideologia. A Revolução proclamou, como um de seus primeiros princípios, a absoluta supremacia do direito escrito; do direito originado do corps législatif por representantes do povo, enquanto reduzia o judiciário a desempenhar uma tarefa puramente mecânica de aplicação da lei aos casos concretos. Naturalmente, também a fé roussoniana na "infallibilité" da "loi", como expressão da "volonté générale", encontrou sua maior expressão neste desdobramento revolucionário. ${ }^{31}$

Na realidade, a estrita separação, "French style", dos poderes governamentais", se de inspiração realmente 32 "montesquiana" ou não, estava a milhas de distância do tipo da

${ }^{29}$ De L'Esprit des Lois, livro XI, cap. VI.

${ }^{30}$ Ibidem.

${ }^{31}$ Ibidem. ${ }^{32}$ A influência dos "ditames da lógica de Montesquieu nanãąa judicial francesa" é afirmada por J. P. DAWSON mentais que permaneceuco

supra nota 20, p. 376. ${ }^{33} \mathrm{~A}$ freqüente afirmação feita de que "a Constituição dos Estados Unidos compre. Dictionary of the History of Montesquieu)" da separação dos poderes - como se pode ler, .g., in P. P. Wímo, de justificação duvidosa. O fato Ideas, II, New York, Charles Scribe's Sons, 1973, 251 - e, para dizr o man é que a "séparation des pouvoirs", do modelo francês, é algo muito diferente do que sua Tradition. $2^{2}$ ed., Stanford, descrita como "de pesos e contrapesos". Vide, v.g., J. H. MERRYMAN, The Civil Law Tradici, 2 ed., Stanford Cal. Stanford University Press, 1985, 15-16; Sir Otto KAHN-FREUND, Common Law and Civil Law in Imaginary and Real Obstacles to Assimilation", in M. CAPPELLETT1, ed., New Perspectives for a Common Law of Europe, and Real Obstas Leyden \& Bruxelles, Sijhó \& BIX e da justice constitutionnelle em nosso tempo, sobre a qual vide infra nesta Justice administrative no século XIX él se a afirmação acima fosse correta.

seção, seria totalmente incomprens. Vide, vg. Alf Ross, sobre Direito e justiça, Berkeley, University of California Press, ${ }^{34}$ Até os positivistas legais concordam. Vide, v.g., Alf Ross, sobca Dão da lei"); H. L. A. HART, supra nota 2, p. 629 ("a lei 1959, 284 ("nenhuma situação concreta permite una e não sobre a escolha propriamente dita").

$\frac{\text { existente impõe limites somente em nossa escolha e não sobre a escolha propriamente dita })}{\text { Revista da Faculdade de Direito da UFRGS, v. 20, Outubro/2001 }}$ separação dos poderes praticamente adotada A separação dos poderes na América é melhor caracterizada como "pesos e contrapesos" função extremamente importante de rever atos do legislativo e da administração. "Séparation mplicava que o judiciário deveria a qualquer preço assumir um papel totalmente a atividade dos órgãos políticos. Essa problemas e dificuldades não menos sérias do que as que tentava solucionar. A história legal é a ilustração contínua de tais problemas, tanto quanto de enormes esforços para os mesmos problemas. Com isso reduziu-se a máquina caça-níqueis de aplicação das leis a casos individuais, indiferente à realidade, isto poderiam ser tão claros e completos senão para permitir uma única e "correta" interpretação $0^{34}$. 
De modo ainda mais importante, modelo montesquiano (e roussoniano), tal como introduzido pela legislação Revolucionária Francesa - enquanto tentativa de proteção contra a tirania -, deixou as portas abertas às tiranias do legislativo e do executivo. A famosa loi revolucionária de 16-24 Agosto de 1790 da "organization judiciaire" - cujos princípios dever-se-iam tornar os pilares do sistema judicial francês e de outros sistemas continentais, influenciados pela França estabeleceu que não seria permitido nenhum controle pelo judiciário de atos legislativos ou administrativos:

Título II, Art. 10: Os tribunais judiciários não tomarão parte, direta ou indiretamente, n exercício do poder legislativo, nem impedirão ou suspenderão a execução de decisões do poder legislativo...

Título II, Art. 12: (Os tribunais judiciários) reportar-se-ão ao corpo legislativo sempre que assim considerarem necessário, fim de interpretar ou editar uma nova lei.

Título II, Art. 12: As funções judiciárias são distintas e sempre permanecerão separada das funções administrativas. Sob pena de perda de seus cargos, os juizes de nenhuma maneir interferirão com a administração pública, nem convocarão os administradores à prestação de contas com respeito ao exercício de suas funções. ${ }^{35}$

Isso significa dizer que tanto os legisladores quanto os administradore

públicos estavam isentos de qualquer controle por parte de um terceiro órgão, independente, apolítico ou, de alguma forma, menos político Os controles internos, naturalmente, poderiam ser e de fato foram estabelecidos. Mas a história não raro neste ponto de forma infeliz, provou que, para serem efetivos, os controles dos órgãos políticos dificilmente podem se controlados de dentro. Um poder executivo eficiente é hierarquizado. Não permite, em seu mais alto nível, um fácil controle interno independente, e isto não é menos verdadeiro para o poder legislativo, que se afirma como supremo. Deve se admitir, sem surpresa portanto, que todos os sistemas passados e presentes de controle político e não judicial, como os experimentados na França com as Constituições de 1799,1852 e 1946, e os correntemente adotados por muitos países comunistas, revelaram-se extremamente ineficientes ${ }^{36}$. O controle efetivo dos órgãos políticos necessita ser realizado de fora: precisa ser confiado a pessoas e as agências suficientemente independentes em relação aos órgãos controlados. E disso, de fato, os franceses gradualmente se deram conta, pelo menos no tocante ao ato administrativo. O Conseil d' État, gloriosa instituição. gradualmente evoluiu, de mero departamento interno da administração, como inicialmente havia sido no século XIX, até tornar-se uma agência judicial independente, por todos reconhecida como uma alta corte da França. Seu papel é o de controlar a legitimidade do ato administrativo. Quanto mais importante e aceito

${ }^{35} \mathrm{O}$ texto completo da loi pode ser encontrada em J.B. DUVERGIER, Collection Complète des Lois, etc., I, Paris, Guyot et Scribe, 1834, 310-333.

${ }^{36}$ Para os precedentes franceses vide Judicial Review supra nota 4, p. 33 e as referências na nota 30 ibidem. A maioria das constituições européias orientais e outras dos países socialistas confiam o papel de controlar a constitucionalidade da legislação ao "Soviet Supremo" ou à "Assembléia Popular" e/ou aos "praesidiums". O constitucionalidade da legislação ao "Soviet Supremo" ou à "Assembléia Popular" e/ou aos "praesidiums". O
constitucionalista iugoslavo Pavle Nikolic em seu relatório de Uppsala sobre os países socialistas, supra nota 13 informa-nos que este "autocontrole, i.e., o controle da constitucionalidade da legislação confiada ao próprio corpo legislativo, provou ser ineficiente. Esta mesma ineficiência foi a maior razão que levou a Yugoslávia a adotar, e a Tchecoslováquia e a Polônia tentaram adotar, um sistema de revisão judicial no lugar de uma revisão política. Vide o relatório de NIKOLIC, §§ II. 2. I, III. 2. A B-C; e vide o texto e as notas 13-15 supra.

Revista da Faculdade de Direito da UFRGS, v. 20, Outubro/2001 se torna o papel do Conseil, tanto mais independente ele se apresenta vis-à-vis do órgãos políticos. E com sua independência, a natureza judicial do processo também fica cad vez mais acentuada e reconhecida, com todas as conseqüências de tal entendimento incluindo a adoção das salvaguardas mais características do processo judicial: imparcialidade do magistrado, o direito das partes de serem ouvidas e de todos os vários corolários dessas regras básicas da "justiça natural" ${ }^{37}$.

A França, naturalmente, foi o início, no velho continente, dessa evolução histórica: estabelecimento da justice administrative ou da revisão judicial dos atos administrativos. Cedo ou tarde, entretanto, outras nações continentais seguiram seu exemplo, e, assim, sistema de justice administrative francês tornou-se modelo do desenvolvimento de órgãos análogos, tais como a Verwaltungsgerichtsbarkeit, na Alemanha, e a giustizia amministrativa, na Itália, etc. ${ }^{38}$

Nosso século, todavia, haveria de ensinar uma outra lição: a de que a idéi roussoniana da infalibilidade da lei parlamentar não passava de outra ilusão ${ }^{39}$, pois até legislativo, e não apenas o executivo, pode abusar do poder. A experiência mostrou, além disso, que a possibilidade do abuso legislativo cresceu enormemente com o crescimento legiferante do estado moderno ${ }^{40}$, e, também que as tiranias legislativas e majoritárias podem ser tão opressivas quanto a tirania do executivo. É suficiente lembrar a legislação fascista, que

privou os judeus e outras minorias de seus direitos mais fundamentais. Essa é a razão por que a Áustria, a Itália e a Alemanha, emergindo do descalabro moral e material, da perversão política, da ditadura e da derrota, logo se voltaram para a justiça constitucional, como antes se aludiu, para criar um novo tipo de controle a ser acrescentado à justice administrative. Assim fazendo, tentavam limitar e controlar o poder do legislativo e da maioria legislativa, dentro do esquema da nova norma constitucional, tornada atuante pela decisão constitucional. A influência histórica das idéias francesas, entretanto, pode também ajudar a compreender porque essas nações sentiram a necessidade de seguir um caminho similar àquele da justice administrative: todas elas controlam os órgãos judiciais de controle do ato administrativo ${ }^{41}$ - criado que foi um novo tipo de órgão controlador, quase como um pendant do Conseil d' Etat do século XIX e de seus similares alemães e italianos.

A França, por outro lado, estava de algum modo menos envolvida nesse novo curso de ação. Os abusos do régime de Vichy durante a II Guerra Mundial foram talvez menos excessivos, e certamente menos duráveis do que em outros países. Isso pode explicar porque a França, muito embora a líder no século XIX no desenvolvimento da justice administrative, não desempenhou o mesmo papel no desenvolvimento da "constitutional justice" no mundo que se seguiu à II Guerra Mundial.

Todavia, isso não foi ainda o fim da atuação francesa. A França, embora não tenha

${ }^{37}$ Para uma breve idéia sobre o desenvolvimento da justice administrative na França vide L. N. BROWN \& J. F. GARNER, French Administrative Law, $3^{\mathrm{a}}$ ed., London, Butterworth, 1983, 28-31.

GARNER, French Administrative Law, $3^{a}$ ed., London, Butterworth, 1983, 28-31.
${ }_{38}$ A influência do sistema francês de justiça administrativa fora da França é discutida in id., 162-171. ${ }^{38}$ A influência do sistema francês de justiça administrativa fora da França é discutida in id., 162-171.

Constitutionnel et les Libertés, Paris, Economia, 1984, 166.

${ }^{40}$ Vide M. CAPPELLETTI, "Nécessité et Légitimité de la Justice Constitutionnelle", in Cursos Constitucionais, supra nota 7, 464-471 [doravante citada como "Nécessité et Légitimé"].

${ }^{41}$ Vide nota 5, supra. 
liderado o processo, envolveu-se ultimamente de maneira profunda num fato mais recente: $\mathrm{o}$ da revolução da revisão constitucional e judicial $^{42}$. Tal tornou-se patente especialmente a partir de 1971, quando o órgão criado pela Constituição de De Gaulle, de 1958, denominado Conseil Constitutionnel, corajosamente transformou seu papel, transmudando-o radicalmente. Originariamente, visto como mero vigia dos ampliados poderes do executivo sob o regime do Général, o Conseil Constitutionnel assentou-se pela primeira vez, em julho de 1971 , como um órgão independente, quase judicial, cujo papel era o de rever a constitucionalidade da legislação parlamentar, violadora de direitos fundamentais. Uma emenda constitucional de 1974, emitida durante o governo do Presidente Giscard d'Estaing, reforçou esse desenvolvimento, garantindo às minorias parlamentares de oposição o direito de questionarem a legislação perante o Conseil Constitutionnel. Hoje, muitos juristas concordam com nosso colega francês, o Deão Louis Favoreu, que manteve a opinião de que o sistema de revisão judicial da constitucionalidade da legislação, desenvolvido pela França durante os últimos quinze anos, é tão efetivo como o das nações continentais vizinhas ${ }^{43}$. No entanto, ao menos duas sérias limitações do sistema francês não devem ser desconsideradas ${ }^{44}$. Primeiro, na França não há possibilidade de os indivíduos, cujos direitos fundamentais tenham sido violados, levarem sua inconformidade ao Conseil Constitutionnel, uma vez que a legislação parlamentar somente pode ser atacada por pelo menos 60 membros de cada Casa do Congresso, ou por autoridades políticas que tenham representatividade individual para assim agirem no interesse geral. Segundo, a legislação só pode ser atacada durante o curto período entre sua aprovação pelo congresso e o de sua promulgação, porquanto, uma vez promulgada, nenhum juiz na França pode afastar uma loi, declarando-a conflitante com a Constituição. De mais a mais, mesmo nesses estreitos limites, a revisão judicial da legislação na França só se tornou expressiva há bem constitucionais das minorias e dos cidadãos encontraram nesse sistema revisional um formidável escudo contra o que era havido por muitos como um abuso da maioria. Assim, a Constituição francesa, e muito particularmente seus direitos fundamentais que, incluem a Déclaration des droits de l'homme et du citoyen, de 1789, tornou-se pela primeira vez, em toda a sua extensão $0^{45}$, legalmente obrigatória e judicialmente impositiva.

A Inglaterra, naturalmente, apresenta uma história muito diferente. Por um lado, contrariamente ao ancien régime da França, lá não houve nenhum profundo sentimento pouco tempo. Em muitos casos, os direitos

\section{A "Grundnorm" inglesa: A Absoluta Supremacia do Parlamento}

${ }^{42}$ Os desdobramentos na França são descritos por M. CAPPELLETTI, "The 'Mighty Problem' of Judicial Review and the Contribution of Comparative Analyses", 53 Southern California Law Rev. 409, 412-421 (1980) [doravante citada como “The Mighty Problem”]; vide também o relatório Uppsala por Favoreu, supra nota 8, §§ $15-20$.

${ }^{15}$-20.
${ }^{3}$ Relatório Uppsala por L. Favoreu, supra nota $8, \S 38$ et passim.

${ }^{43}$ Relatório Uppsala por L. Favoreu, supra nota 8, § 38 et passim.
${ }^{44}$ Sobre as "infirmações" do sistema francês vide "Nécessité et Légitimité", supra nota 40, 499-501.

${ }^{44}$ Sobre as "infirmações" do sistema francês vide "Nécessité et Légitimité", supra nota 40, 499-501.
${ }^{45}$ Algumas das decisões mais marcantes do Conseil Constitutionnel são traduzidas in M. CAPPELLETTI \& W. COHEN, Comparative Constitutional Law, Indianapolis, Bobbs-Merril, 1979, cap. 3. C e cap. 5.C. [doravante citado como Coparative Const. Law]. Vide L. FAVOREU \& L. PHILIP, Les Grandes Décisions du Conseil Constitutionnel, $3^{\mathrm{a}}$ ed., Paris, 1984.

Revista da Faculdade de Direito da UFRGS, v. 20, Outubro/2001 popular contra o judiciário, cujo histórico papel de proteção das liberdades individuais geralmente gozou de largo espectro ${ }^{46}$. Isso pode explicar porque, diferentemente da França, na Grã-Bretanha a revisão judicial do ato administrative nunca encontrou sérios obstáculos. A doutrina da separação dos poderes jamais foi inteiramente adotada na Inglaterra, em sua "versão francesa", isto é, na versão que implica a proibição de qualquer "interferência" dos tribunais nos órgãos da administração, e não somente no legislativo. Por outro lado, a Revolução Inglesa de 1688 afirmou, muito enfaticamente, a absoluta supremacia do Parlamento que, como diz o provérbio, "pode fazer tudo, menos transformar um homem em mulher ou uma mulher em homem"47. Rejeitando esses precedentes judiciais como a famosa decisão do Lord Coke no caso Dr. Bonham, em $1610{ }^{48}$ a supremacia parlamentar teve como corolário a irrevisibilidade da legislação parlamentar - a "onipotência" do controlar a "validade" da lei..$^{49}$

Se o modelo francês de impotência do judiciário encontra em Montesquieu seu mais autorizado teórico, embora não sem ambigüidades, John Locke é visto como tendo desempenhado papel similar na Inglaterra. direito (lei) positivo e a impotência judicial para

${ }^{46}$ Vide Judicial Review, supra nota 4, 36; J. H. MERRYMAN, supra nota 33, 16.

${ }^{47}$ A frase citada no texto tem uma literatura própria, discutindo a quem se deve a paternidade (De Lolme, Bagehot?). Vide, v.g. W. HOLDSWORTH, 12 A History of English Law, London, Methuen, 1938, reedição 1966, p. 344 n. 5; H. J. ABRAHAM, The Judicial Press, $2^{\mathrm{a}}$ ed., 1968, p. 295

${ }^{48}$ A decisão Bonham, como é muito conhecida, afirmava o poder que o judiciário tem de controlar a validade da legislação: "porque, quando um ato do parlamento é contra o direito e a razão comum, ou incompatível, ou impossível de ser aplicada, o direito consuetudinário o controlará e o considerarão um ato nulo." 8 relatórios Coge 118; 77 Eng. Rep. 652. Para um comentário muito utilizado vide T. F. T. PLUCKNETT, "O caso Bonham e Revisão Judicial” 40 Harvard Law Rev. 30-70 (1926). Vide também Judicial Review, supra nota 4, 36-41.

${ }^{49} \mathrm{Em}$ uma passagem muito criticada por John Austin. Blackstone afirmava que o direito natural, sendo "superior em obrigação" ao direito positivo, "é obrigatório sobre todo o mundo, em todas as nações, e em todos os tempos: nebuma lei human as as as aças neste original", de forma que "[somos] obrigados a e toda sua auid " Vommentaries of the Laws transgredir a lei hon "Of in England, Introduçao, seç̧ão Segunda 'Or the 41,43); John AUSTIN, The Povince of Jurisprudence Detán Nicolson, 1954, p. 184-186). Todavia, Blackstone tamberm afirmou que o poder do Parlamento é "tão transcendental e absoluto, que ele não pode ser confinado...dentro de quaisquer fronteiras...ele tem autoridade soberana e incontrolável para fazer, confirmar, aumentar, restringir, abrogar, anular, repristinar e interpretar as leis concernentes a matérias de qualquer natureza eclesiásticas ou temporais, civis, militares, marítimas ou criminais: este sendo a sede em que esse poder absoluto e despótico, que há de residir em qualquer governo, é posto pelas constituições deste reino...Pode, em suma, fazer tudo quanto não seja naturalmente impossível; e por isso alguns não têm escrúpulos em exercer este poder, através de uma imagem excessivamente ousada como e a onipotência do parlamento. Na verdade, o que o Parlamento faz, nenhuma força no mundo pode desfazer Consequentemente, enquanto a Constituição inglesa subsistir, ousaremos afirmar que o poder do parladefaze. messibilidade de os juízes a Inroduça, seça 3" " afastarem as leis do " "qu "posa "têm liberdade para rejeitá-las", conheço poder", diz ele, "que "possa obstar "tais leis, e sustentar que os jưzes "thm liojo colocaria o poder judicial acima da legislatura, o que seria a subversáo de qualquer goveno. Como Pound observou acertadamente, quando Blackstone "aplica [esta teoria do direito natural] à legislaçăo, ele se retra". "Common Law and Legislation", 21 Harv. L.Rev. 338, p. 392 (1908)

Revista da Faculdade de Direito da UFRGS, v. 20, Outubro/2001 
Embora esteja freqüentemente associado com a histórica doutrina da separação dos poderes, Locke de fato não via o judiciário como um "ramo" ou "poder" separado. Em sua tricotomia, os dois poderes "derivados" ou "inferiores" eram o "executivo 50 " e o "federativo" 51 , enquanto o poder "supremo", o "legislativo, ${ }^{52}$ é magnificado como o "a alma que dá Forma, Vida, e Unidade à Commonwealth" ${ }^{53}$. Ainda que o "legislativo" de Locke estivesse constrangido a "revelar" e a "executar" as "eternas e imutáveis leis da natureza", descobertas mas não criadas pela razão $0^{54}$, ele não via o judiciário como o aplicador competente e privilegiado desses naturais limites legais da vontade legislativa ${ }^{55}$. A doutrina de Locke repercutiria e far-se-ia mais explícita através de Blackstone, quando o grande comentador rudemente rejeitou a revisão judicial, considerando-a como eqüivalendo a colocar "o poder judiciário acima do legislativo, o que seria a subversão de todo o governo". ${ }^{56}$

Diferentemente do que ocorre na França, não se trata de história passada para a Inglaterra. A supremacia parlamentar ainda é ali afirmada como um princípio básico: a Grundnorm ${ }^{57}$ da constituição não escrita daquele país. Nos últimos anos, porém, significativas brechas foram abertas nos sólidos princípios das tricentenárias muralhas. Mencionarei apenas

duas que se aplicam ao Reino Unido, e ao mesmo tempo a várias das demais nações da Europa Ocidental. Elas nos revelaram uma nova e única dimensão do extraordinário desenvolvimento e crescimento da revisão judicial na Europa, vale dizer, sua dimensão transnacional.

\section{Estaria a Inglaterra Abandonando Sua Grundnorm Lockeniana? A Lei Comum "Não poderia Ser Detida"}

A primeira "brecha na muralha" foi aberta pela Comunidade Européia. Como se sabe desde 1973 o Reino Unido tornou-se membro pleno da Comunidade Européia - o assim chamado Mercado Comum, de que ora participam dez países da Europa, mas que em breve tornar-se-ão treze, com uma população de cerca de 300 milhões de pessoas. Uma das características básicas da Comunidade é a de que ela se auto-outorgou poderes legislativos, em um largo espectro de áreas, especialmente na econômica, mas também no plano social. $\mathrm{O}$ direito comunitário, na sua maior parte promulgado pelo Conselho de Ministros da Comunidade Européia, com alguma participação da Comissão Comunitária e do Parlamento Europeu, provou ser um ordenamento de

so John LOCKE, The Second Treatise of Government, cap. XII, §§ 145, 149 et passim.

${ }^{51}$ The Second Treatise, cap. XII, §§ 145-148 et passim.

${ }^{52}$ The Second Treatise, 52, cap. XI, § 134, cap., 149, et passim.

${ }^{53}$ The Second Treatise, cap. XIX, § 212. Pode ser verdade, no entanto, que em razão do poder legislativo e mais geralmente, do "poder de governar", ter sido considerado por Locke como "a promulgação e a sanção de uma lei,

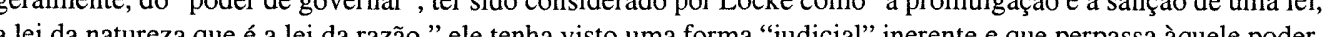
. in University Press, 1960, 96, 107; vide, v.g., The Second Treatise, cap. VII, \$§ 88-89, cap. XI, § 136.

${ }_{55}^{5}$ Vide, v.g., The Second treatise, cap. IX, \& 124.

${ }_{55}$ Vide v.g., The Second Treatise, cap. XI, \& 135 .

${ }^{56}$ Vide nota 49, supra.

${ }^{57}$ Vide v.g., G. WINTERTORN, "The British Grundnorm: Parlamentary Supremacy Re-examined" Law Quartely Review, 1976, 591-617.

Revista da Faculdade de Direito da UFRGS, v. 20, Outubro/2001 legislação transnacional em expansão, consistindo por enquanto, basicamente em milhares de "regulamentos" e "diretivas". 58

$\mathrm{Na}$ expressiva frase de Lord Denning, este corpo legislativo da comunidade penetrou no sistema legal britânico e no sistema dos outros nove Estados membros "como uma maré crescente, [que] corre pelos estuários e rios adentro [e que] não pode retroceder." ${ }^{59}$ A razão pela qual ele não pode ser contido decorre do princípio básico do direito comunitário que assegura a "aplicação direta" da lei da comunidade, como sendo automaticamente the law of the land de cada um dos Estados membros ${ }^{60}$. Nas palavras ainda de Lord Denning: "o Parlamento decretou que (a lei da Comunidade) é....parte de nosso direito."

Tal conseqüência é da própria natureza do direito Comunitário, porquanto, pelo menos como regra geral, ele deverá ser uniformemente aplicado em todos os Estados membros. Isso explica porque, desde 1964, consistente corrente jurisprudencial da Corte de Justiça
Européia - a Corte da Comunidade, com sede em Luxemburgo - estabeleceu que o direito da Comunidade não é somente o direito de todos os Estados membros, a ser diretamente aplicado por todas os tribunais nacionais, como também, e sobretudo, é a mais alta lei dos Estados membros, prevalecendo sobre a legislação nacional conflitante ${ }^{62}$. A legislação nacional, independente da data de sua promulgação, há de ser afastada pelos tribunais nacionais dos dez países, se considerada contrária à legislação da Comunidade ${ }^{63}$, e os problemas de interpretação se resolvem, em última instância e com efeito final, para todos os Estados membros, pela Corte Européia de Justiça. $^{64}$

Podemos verificar, assim, que uma nova e importante forma de revisão judicial da legislação penetrou nos "estuários e nos rios" da Inglaterra e também nos outros nove sistemas jurídicos europeus. É uma forma de revisão muito similar à decisão executiva americana da supremacia da legislação federal

58 Vide v.g. C. Sasse \& H. C. YOUROW \& E. STEIN, eds., COURTS AND FACE MARKETS, I, Oxford, 88 Vide v. C. Clarendon Press, 1982, Law and Institutions in Perspective, Indianapolis, Bobto, Luxemburgo, Office for Official Publications of the COMMUNITIES, 30 anos da

European Communities, 1983.

59 Vide
1226.

${ }^{\circ} \mathrm{O}$ princípio foi afirmado pela primeira vez na histórica decisão da Corte de Justiça Européia (CJE), van Gend en Loos v. Nederlandse Administrative Belastingen, Case 26/62 (1963) ECR 1. Vide v.g., L. N. BROWN N. F. G. JACOBS, The Court of Justice of the European Communities, $2^{a}$ ed., London, Sweet \& Maxwell, 1983, p. 162. ${ }_{61}$ Vide Comparative Const. Law, supra nota 45, p. 137. Vide também M. P. FURMSTON, R. KERRIDGE \& B. SUFRIN, eds. The Effect on English Domestic Law of Membership of the European Communities and of Ratification of the European Convention on Human Rights, The Hague, Nijhoff, 1983, 1-246.

${ }_{62}$ A primeira afirmação da preeminência da doutrina pode ser encontrada em outra histórica decisão da CJE, 22 A primeira afirnaça da pres) ECR 585. Sobre a gradual aceitação pela maioria da cortes nacionais da doutrina Costa v. ENEL, Caso 64 (19) "The Mighty Problem", supra nota 42, p. 424-426; R. KOVER, da suprenaia do dieto da Comuide Community Law, Luxembourg, 1982, 109 .

${ }^{63}$ Vide a decisão da CJE in Simmenthal, Case 106/77, (1978) ECR 629

${ }^{64}$ Vide v.g., L. N. BROWN \& F. G. JACOBS, supra nota 60, p. 281-285; decisão da CJE Da Costa en Schaake, Casos 18-30/62 (1963) ECR 31. Geralmente no papel da Corte de Justiça Européia vide M. CAPPELLETTI, M. SECCOMBE N J. WEILER, eds. Integration Through Law. Europe and the American Federal Experience, Vol. 1, Livro 2, Berlin \& New York, de Gruyter, 1986, publicação inédita.

Revista da Faculdade de Direito da UFRGS, v. 20, Outubro/2001 
sobre as leis estaduais conflitantes. Na verdade, não se trata de um controle de constitucionalidade da legislação, embora seja pelo menos um primeiro passo para o reconhecimento, mesmo na Inglaterra, de que o princípio histórico da absoluta supremacia da lei Parlamentar não mais prevalece inteiramente.

\section{VII.A 'Justiça Transnacional"da Corte Européia dos Direitos Humanos}

Um segundo desenvolvimento dessas idéias diz mais respeito a nossa preocupação inicial, ou seja, à revisão da constitucionalidade da legislação e mais especialmente à revisão judicial, como instrumento de proteção dos direitos humanos. Realmente, há poucos anos, o desenvolvimento do que eu discutirei agora motivou o ilustre constitucionalista americano Charles Black - um anterior "conselheiro", segundo me foi dito, "do Papa João XXIII" - a sustentar que a Inglaterra, ao contrário da opinião geralmente aceita, realmente já tinha direitos fundamentais escritos e obrigatórios..$^{65}$ Esse segundo episódio, materializou-se especialmente quando o Reino Unido, membro

signatário da Convenção dos Direitos Humanos desde 1951, aceitou em 1966 a cláusula opcional do artigo 25 desta Convenção. ${ }^{66}$ Esta cláusula estabelece uma forma de Verfassungsbeschwerde transnacional, que estende a todos os cidadãos, após esgotados os remédios nacionais, o direito de apresentarem suas reivindicações perante $o$ aparelho judiciário da Convenção em Strasbourg contra qualquer sorte de ato administrativo, incluindo legislação, violador de seus direitos protegidos pela Convenção. Relembro que a Convenção é um abrangente bill of rights transnacional, ao qual aderiram, com a única exceção da Finlândia, todos os países da Europa Ocidental - vinte e uma nações, perfazendo uma população de mais de 350 milhões de pessoas. ${ }^{67}$

Dessa forma, um bill of rights transnacional tornou-se obrigatório para a Inglaterra, entre outras nações, e é imposto por um magistrado transnacional a quem os cidadãos britânicos têm acesso. Nesse contexto, basta um pequeno passo para aceitarse a idéia de que a Convenção faz parte do direito da Inglaterra, impondo-se de forma obrigatória para o Parlamento Britânico, e que os tribunais ingleses devem aplicá-lo, salvo se quiserem que seus julgamentos sejam submetidos à apreciação dos julgadores transnacionais em

${ }_{65}^{65}$ C. L. BLACK Jr. "Is There Already a British Bill of Rights?", 89 Law Quaterly Rev. 173 (1973). ${ }^{66} \mathrm{~A}$ aceitação, primeiro limitada a um período 3 anos, foi desde então regularmente renovada; a última ocorreu em 1981 por um período de cinco anos. Vide geralmente A. Z. DRZEMCZEWSKI, European Human Rights Convention in Domestic Law, Oxford, Clarendon Press, 1983, 177-187, 362-363. ${ }^{67}$ Para breves pesquisas vide v.g., Rosalyn HIGGINS, "The European Convention on Human Rights", in T.
MERON, ed. Human Rights in Internationa Law, II, Oxford, Clarendon Press, 1984, 495-549; A H. ROBERTSON, Human Rights in the World, $2^{\mathrm{a}}$ ed. New York St. Martin's Press. 1982, 80-117. A convenção foi ratificada pelo seguintes países (em parênteses está, primeiro, o ano da ratificação, e, segundo, o ano ininterrupta da cláusula opcional do art. 25: Áustria $(1958,1958)$; Bélggndo, 0 ano da aceitação, desde então Islândia (1953, 1955); Irlanda (1953, 1953); Itália (1955, 1973); Liemana $(1952,1955)$; Grécia $(1974,1985)$; (1953, 1958); Malta (1967); Holanda (1954, 1960); Noruega (1952, 1955); Portugal (1978, 1978); Espanh (1978, 1981); Suécia $(1952,1952)$; Suíça $(1974,1974)$; Turquia $(1954)$ e Inglaterra $(1951,1966)$. Desses países somente três - Chipre, Malta e Turquia - ainda não aceitaram a cláusula opcional do art. 25. Para maiores nformaçoes relativamente também às ratificações do Protocolo da Convenção vide A. Z. Drzemczewski, supra nota 66, p. 362.

Revista da Faculdade de Direito da UFRGS, v. 20, Outubro/2001 marca (1953,1963); França (1974, 1981): República Fina (1953, 1958); Malta (1967);
Strasbourg ${ }^{68}$. Se os britânicos estão prontos para dar esse passo à frente e adotar assim um amplo e definido sistema de revisão judicial não é questão a ser discutir agora. Basta dizer que ações bem sucedidas têm sido submetidas à Convenção, por indivíduos, com bastante frequiência nos últimos anos, contra a legislação inglesa e outros atos administrativos ingleses, e em não poucos casos as condenações pela Comissão Européia e pela Corte da Direitos Humanos provocaram ressentimentos no Reino Unido, por terem atingido queridas tradições. Todavia, as autoridades inglesas, inclusive o Parlamento, geralmente demonstraram a determinação de se conformarem com as decisões finais da Corte Européia de Direitos Humanos. Assim sendo, de facto, a supremacia da constituição transnacional tem sido largamente confirmada na Europa Ocidental ${ }^{69}$.

A Grã-Bretanha em particular, embora

ostensivamente mantendo suas tradições de rejeitar a revisão judicial da legislação, percorreu própria tradição - uma lockeniana e blackstoniana tradição, somos tentados a dizer - da doutrina da incontrolabilidade judicial da vontade legislativa ${ }^{70}$.

\section{Sobre o "Tormentoso Problema" da Legitimidade Democrática da Justiça Constitucional}

Vimos como a revisão judicial foi recentemente introduzida, ou teve seu papel grandemente expandido, num grande número de países. Realmente, nossa lista para ser um longo caminho para finalmente repudiar sua

${ }^{68}$ A respeito do impacto da Convenção Européia no Reino Unido vide A. Z. DRZEMCZEWSKI, supra nota 66, 177-187, com referência a um número de casos; M. P. FURMSTON, R. KERRIDGE \& B. E. SUFRIN, supra nota 61, 247-428.

${ }_{69}^{6}$ A respeito da autoridade e adequação com as decisões dos órgãos decisórios da Convenção Européia dos Direitos ${ }^{69}$ A respeito da autoridade e adequação com as decisões dos órgãos decisoorios da Convenção Européia dos Direitos
Humanos nos vários estados membros vide A. Z. DRZEMCZEWSKI, supra nota 66, p. 260-325. Com especial Humanos nos vários estados membros vide A. Z. DRZEMCZEWSKI, supra nota 66, p. 260-325. Com especial
atenção ao Reino Unido, vide os recentes comentários do Presidente do Law Commission of the European for atenção ao Reino Unido, vide os recentes comentários do Presidente do Law Commission of the European for
England and Wales, The Honourable Mr. Justice GIBSON, "Legal Procedure: Acess to Justice, 1883 to 1983", in 9 Dalhousie Law Journal" 3, $27-28$ (1984): O Reino Unido foi intimado por estar em falta com suas obrigações perante a Convenção Européia em inúmeros casos. O governo sem dúvida considerou esses acontecimentos surpreendentes e embaraçosos. Uma brecha foi estabelecida em um caso sobre o trabalho em loja que teve suas atividades encerradas numa de nossas estradas de ferro nacionalizadas, na qual os danos... e os custos...foram assegurados a três reclamantes. Houve casos...sobre imigração. Brechas também foram estabelecidas em petições individuais em outros contextos, como o uso de punição física numa escola sem o consentimento dos pais; a censura de cartas pelas autoridades carcerárias e a recusa de permissão de apenados procurarem aconselhamento legal, e o direito consuetudinário de desacato contra The Sunday Times Newspaper em suas investigaçose repor (a) For alga que as auso de vários métodos de interrogatório como permanecer em pe contra a parede, submissão a ruídos, privação do sono. A corte (Européia) sustentou que as técnicas não chegavam a ser torturas, mas eram desumanas e degradantes, conflitantes com o artigo III. A resposta do governo a estas e outras decisões foi a de suspender tais práticas ofensivas, muitas vezes antes da decisão da corte, e, quando necessário, de mudar a lei pertinente, como as regras da prisão. Não houve a intenção de desafiar a decisão da corte, embora nem todos concordem com a interpretação da Convenção pelas várias maiorias na Corte de Strasbourg. O Reino Unido poderia denunciar a Convenção dentro de seis meses conforme o artigo LXV...Não o fez e esta medida é bastante improvável.

${ }^{70}$ Vide "The Mighty Problem", supra nota 42, p. 424-430. 
completa deveria ser estendida a muitos outros países, incluindo a Suécia desde $1980^{71}$ e o Canadá especialmente desde sua nova "Carta de Direitos e Liberdades" constitucionais de $1982^{72}$. Deveria ter mencionado, além disso, que, mesmo em sua mais impressionante e historicamente sem precedente dimensão - a dimensão transnacional - o precedente europeu não se encontra mais só. A Convenção Americana sobre os Direitos Humanos, assinada em São José da Costa Rica, em 1969 tornou-se obrigatória para vários países desde 1978. Largamente modelada pela Convenção Européia, essa constituição transnacional levou à criação, em 1979, de uma Corte Inter-americana de Direitos Humanos, com sede em São José, abrindo-se talvez para futuros desdobramentos similares

aos já sensacionais de sua antecedente européia. ${ }^{73}$

Mas meu tempo está acabando, e desejo ainda discutir, posto que brevemente, a questão básica a respeito do significado e legitimidade da revisão constitucional à luz de seu tremendo desenvolvimento no mundo contemporâneo. ${ }^{74}$

Para muitas nações, como vimos, esse significado primeiramente foi o de uma reação contra passados abusos governamentais. Isso ficou sobretudo evidente em vários dos países mencionados e outros poderiam ser adicionados, da África, da Ásia e da América Latina. Inclusive nesses continentes particularmente na América Latina, onde alguns

${ }^{71}$ Vide o relatório Uppsala por Eivind Smith sobre os países escandinavos, supra nota 8; vide também, v.g., A BAYEFSKY, "Parliamentary Sovereignity and human Rights in Canada: The Promise of the Canadian Charter of Rights and Freedoms", Estudos Políticos, 1983, 239; J. B. D'ONORIO, "Le répatriement de la Constitution Canadienne", Revista internacional de direito comparado, 1983, 69 (especialmente p. 100-101 sobre as sérias 72 Vide

72 Vide o relatório Uppsala por John D. White sobre países da Common Law, supra nota 8; vide também, v.g., A BAYESKY, "The Parlamentary Sovereignty and Human Rights in Canada: The Promise of the Canadian Charter of Rights and Freedoms", Estudos Políticos, 1983, 229; J. B. D'ONORIO, "Le repatriement de la Constituition Canadienne", Revue internationale de droit comparé, 1983, 69 (esp., p. 100-101 sobre as sérias consequîncition "notwithstanding clause" da secção 33 da Carta).

${ }^{73} \mathrm{Um}$ sinal encorajador é a importante decisão tomada pela Corte Inter-Americana, sustentando, unanimemente, que uma lei da Costa Rica que requeria uma licença compulsória para jornalistas, viova e de expressão garantida pelo art. 13 da Convenção Americana dos Direitos Humb vave opinião (Corte Inter-Americana de Direitos Humanos, julgamento de 14 de BUERGENTHAL, R. NORRIS \& D. SHELTON, Protecting Humante, T. Publ., 1982; T. BUERGENTHAL "The Inter-Americas Syst supra nota 67, II, 439-493. Id. "The anerign Differences", 30 A3-493; Id., "The american and Europian Conventions on Human Rights: Similarities and States (OAS)", in K Vican Univ. Law Rev.155 (1981); H. GROSS ESPIELL, "The Organization of American States (OAS)", in K. Vasak, ed., The International Dimensions of Human Rights, II, Westport,Connecticut, Greenwood Press, 1982, 543-565; P. SIEGHART, The International Law of Human Rights, Ofxord, Clarendon Press, 1983, 401-414. Vide também Inter-American Commission on Human Rights, Ten Years of Activities 1971-1981, General Secretariat Organization of American States, Washington, D. C., 1982 (p. 11-13 discutindo a recente criação da Corte Inter-Americana de Direitos Humanos); Organization of american States. InterAmerican Court on Human Rights, Annual Report of the Inter-American Court of Human Rights, 1984, Washington, D. C., General Secretariat OAS, 1984 (um triste e impressionante documento do até agot, Waencorajador caso Schmidt de 1985 discutido previamente, Inter-American Court).

Limits: A Compcussão mais elaborada reporto-me a meus estudos, "The Law-Making Power of the Judge and its citada como "Law-Making Powe", "Nonaas University Law Rev., 15, especialmente $51-58$ (1981) [doravante Diver"]; "Nécesité et Légitimite", supsa nota 40, 475-493.

Revista da Faculdade de Direito da UFRGS, v. 20, Outubro/2001 aspectos do fenômeno da revisão judicial são mais antigos do que na Europa ${ }^{75}$ - estudo comparado demonstrou que a revisão judicial da constitucionalidade da legislação e do ato administrativo têm, ao menos, a potencialidade de agir como instrumento para proteger os indivíduos e as minorias, muito embora, verdade, a eficácia da revisão judicial no mundo em desenvolvimento tenha sido freqüentemente prejudicada pela insuficiente independência judiciária e pelo uso e abuso por parte do executivo do poder de suspender as garantias constitucionais $^{76}$. Mas, em nações como a Inglaterra, onde felizmente não houve ta herança de sério abuso governamental, a revisão judicial está emergindo indiretamente como um elemento dessa nova e fascinante tendência no direito, na política e nos direitos humanos: o transnacionalismo. O compartilhamento do poder vertical e o conseqüente pluralismo das fontes legais, um típico produto do transnacionalismo, tanto quanto do federalismo, trazem inevitavelmente a possibilidade de conflitos entre os vários níveis de poder, de leis e de direitos; e a revisão judicial é o instrumento natural para dirimir tais conflitos.

Verifica-se uma percepção generalizada o menos nos países ocidentais, de que, em nossa "era de leis" - como o Deão Calabresi denominou -77 é realmente uma salvaguarda valiosa o controle por um julgador independente, de um legislador cada vez mais

onipresente, cujo papel no Estado moderno cresceu em dimensões sem precedentes, mais ainda se considerarmos que esse controle constitui a necessária "coroação" da regra da lei. Na realidade, o legislador em sociedades democráticas é o representante e o responsável do povo, conquanto pertença à própria natureza da função judicial não serem os juízes facilmente responsabilizáveis. O paradoxo - de confiar a juizes não submetidos a controle externo a função de controlar políticos responsáveis revela-se, todavia, meramente aparente. Em nossas sociedades, os juízes deixam de ser controlados externamente somente no sentido de que eles não são e não deverão ser tidos como responsáveis perante os outros órgãos do poder ou face ao povo por suas decisões e filosofias individuais. Tal irresponsabilidade, todavia, só é sustada a curto e a médio prazo. Há muitas ligações que a longo prazo tornam os juízes conectados com seu tempo e com a sociedade. Esses laços podem ser reforçados pela maneira como são nomeados os membros do judiciário, quer neste país, ${ }^{78}$ quer na Europa, pela permanência dos juizes em seus cargos que, sem dúvida, deve ser longa o suficiente para lhes dar autonomia e segurança, estando, em regra, limitada a um certo número de anos, sem possibilidade de extensão. Também devese notar que a verdadeira natureza do processo judicial é altamente participativa, uma vez que o papel dos juizes baseia-se em casos da vida real e somente podem ser exercidos sobre e dentro de limites dos interesses e da

${ }^{75}$ Vide geralmente H. FIX-ZAMUDIO, Vienticincos años de Evolución de lá Justicia Constitucional 1940-1965, México, UNAM, 1968, esp. cap. 2.

${ }_{76}$ Vide os relatórios de Uppsala por Nwabuenze, supra nota 16, p. 18-23 e CARPIZO \& FIX, supra nota 16, §§ 61-69, 91, 95, 110 et passim. Professor Henkin aponta para o "que hoje pode parecer uma forte embora feliz omissão" da Constituição dos Estados Unidos que "não prevê sua suspensão, ou governo por decreto mesmo em omissão" da Constituição dos Estados Unidos que "não prevê sua suspensão, ou governo por decreto mesmo em 13,150 n. 31

77 Guido CALABRESI, A Common Law for the Age of Statutes, Cambridge, Mass., Harvard University Press, 1982

${ }^{78}$ Vide v.g., Robert DAHL, "Decisions-Making in a Democracy. The Supreme Court as a National PolicyMaker", 6 Journal of Public Law, 279, esp. p. 284-285 (1957).

Revista da Faculdade de Direito da UFRGS, v. 20, Outubro/2001 
controvérsia das partes. Nesse sentido, constata-se uma alta potencialidade de um contínuo contato do Judiciário com os reais problemas, desejos e aspirações ${ }^{79} \mathrm{da}$ sociedade. Uma sadia conseqüência de nossa liberdade de expressão está no fato de que os também juízes, dia após dia, estão sujeitos à crítica pública ${ }^{80}$. Quando falamos hoje na separação de poderes, certamente não queremos dizer "séparation" no sentido original francês; queremos dizer, isso sim, conexões recíprocas e controles mútuos. A irresponsabilidade judicial é uma irresponsabilidade politica e legal -, com importantes limitações no caso de abusos sérios. No entanto, não se trata de uma irresponsabilidade social $^{81}$. Abusos do tipo análogo aos dos juizes do ancien régime francês seriam dificilmente concebíveis em nossas sociedades, pois aqueles eram abusos de um corpus séparé, um grupo social separado do resto da sociedade.

O "tormentoso problema" da legitimidade da revisão judicial não pode ser resolvido por meio de soluções puramente abstratas e especulativas que sejam válidas para todo o tempo e lugar. Realmente, inexistem tais soluções universais; e certamente uma página de realística análise comparativa pode ser mais valiosa do que muitos livros acerca de especulações abstratas ${ }^{82}$. Se nossos juízes atuais fossem da espécie que prevaleceu na França pré-revolucionária, então é claro que dificilmente legitimar-se-ia a revisão judicial. Mas, em nosso mundo ocidental, em que os papéis dos órgãos políticos se expandiram de uma maneira inevitável em tantas áreas da vida, a investigação de um Judiciário mais "destacado" - embora não literalmente "separado" -, pode ser mais saudável. Valores mais duráveis podem ser

79 Vide "Law-Making Power",supra nota 74, espec. p. 42-46, 54-57. Mesmo quando sua profissão ou papel possa, de algum modo isolar os juizes da sociedade, sua atividade "traz os juízes à realidade, uma vez que são chamados para decidir casos envolvendo a vida das pessoas, fatos concretos e problemas da vida real". Id. p. 57. ${ }^{80} \mathrm{~A}$ crítica, naturalmente, é facilitada pelo fato de que, em nossas sociedades, os mais importantes julgamentos e suas motivações são publicadas; é particularmente facilitada naqueles países em que a dissensão e as opiniões concorrentes são também publicadas. Vide o estudo comparativo por K. H. NADELMANN, "The Judicial Dissent: Publiation v. Secrecy", 8 Am. J. Comp. Law 415 (1959).

${ }^{81}$ Vide M. CAPPELLETTI, "Who Watches the Watchmen. A Comparative Study on Judicial Responsability", 31, Am. Journal of Comparative Law 1 (1983).

31, Am. Journal of Comparative Law 1 (1983). ${ }^{82}$ Aplicando os ensinamentos do grande historiador-filósofo Vico, "verum factum", o comparativista "especula" acerca da significação dos fatos, tendências e desenvolvimentos, não de abstrações. Giambattista VICO, Principi di Scienza Nuova (1744). Tradução inglesa de T. G. BERGIN and M. H. FISCH, The New Science of Giambattista Vico, Ithaca, N. Y., Cornell University Press, 1948. Análise comparativa, naturalmente, não é só a comparação de leis contemporâneas mas também a análise de sua evolução e tendências. A História, em outras palavras, é um componente na essencial análise comparativa.

Revista da Faculdade de Direito da UFRGS, v. 20, Outubro/2001

mais bem preservados ${ }^{83}$; pessoas e grupos que seriam de outro modo marginalizados ou oprimidos, podem ser mais bem protegidos; e, mais genericamente, a justeza e a permanente representatividade do processo político mais bem asseguradas ${ }^{84}$. O princípio democrático requer que cada cidadão tenha uma "voz" no processo político e que seja possível à minoria de hoje tornar-se a maioria de amanhã. Se os direitos fundamentais, como as liberdades de expressão, de opinião e de associação, pudessem ser limitados pela maioria ocasional, sem o devido processo, o próprio princípio democrático estaria em perigo; e isso não é menos verdade para os "novos direitos" de natureza econômica e social, porque sua rationale é a de tornar efetiva a mais básica de todas as titulações democráticas - o direito de acesso ao sistema legal e político. ${ }^{85}$ Dessa maneira, a Justiça constitucional, longe de ser inerentemente antidemocrática e antimajoritária, emerge como um instrumento central para escudar os princípios democráticos e majoritários contra o risco de corrupção. Nosso ideal democrático - deixemos o ponto firmemente vincado -, por certo não é aquele em que a vontade majoritária esteja onipresente. Além do mais, nossa filosofia de vida não é a de que tudo possa ser objeto de barganha.

\section{IX.A Revolução Contemporâ- nea dos Direitos Humanos e sua Legitimidade - Vencendo o Tradicional Conflito entre o Direito Natural e o Positivo}

Resumo agora, de modo conclusivo, as duas mais importantes teses aqui tratadas. A primeira é que, desde a II Guerra Mundial, as sociedades ocidentais têm vivido de uma maneira que não hesito em caracterizar como

${ }^{83}$ Vide v. g., Alexander M. BICKEL, The Least Dangerous Branch, Indianápolis, Bobbs-Merril, 1962, 25-27 et passim. É freqüentemente dito que a moderna jurisdição constitucional, enquanto potencialmente um poderoso instrumento para a proteção de direitos e valores políticos tradicionais, não tem potencial para também ser ou se tornar um instrumento para a protec̃a e a implantaç̃o dos "novos" direitos sociais e econômicos. Porque estes dicios, diferent direitos, dferentem judicia (a) Maiores dificuldades são encontradas e maiores restrições são recomendáveis, quando as cortes, considerando a ilegitimidade da inação governamental, determinam ao governo fazer algo com todas as implicações economicas e outra daí decorrentes, do que quando simplesmente declaram a ilegitimidade de um ato governamental. Estudos comparativos demonstram, no entanto, que há muitas maneiras para as cortes intervirem mesmo nesta área mais difícil Um recente exemplo é fornecido pela Corte de Burger, certamente uma corte não atuante na esfera dos direitos sócio- econômicos. Vide Ake v. Oklahoma, 105 S. Ct. 1087 (1985), na qual somente um juiz dissentiu e a corte manteve o ponto de vista de que os Estados devem providenciar para que os acusados indigentes disponham de assistência psicológica ao prepararem sua defesa por insanidade, caso a sanịdade do acusado, no tempo do crime, possa vir a ser um importante fator para o julgamento.

${ }^{84}$ Vide v.g., Martin SAPHIRO, Freedom of Speech: The Supreme Court and Judicial Review, Englewood Cliffs, N. J. Prentic Hall, 1966, 37 t t passim, J. H. ELY Democracy and Distrust, Cambridge, Mass. Harvard University . J. Prs, 1980. A tese centa do le Press, (a) justo e transparente para a correção de "malfuntions" deste processo que iria enfraquecer a efetiva participação das minorias.

"s Vide M. CAPPELLETTI \& B. GARTH, "Access to Justice: The Worldwide Movement to Make Right effective", in M. CAPPELLETTI \& B. GARTH, eds. Access to Justice Vol. I: A World Survey, Milan \& Alphen aan den Rijn, Giuffrè \& Sijhoff and Noordehoff, 3-124. Vide geralmente M. CAPPELLETTI, ed., Access to Justice and the Welfare State, Alphen aan den Rijn \& Bruxelles, Sijhoff \& Bruylant, 1981.

Revista da Faculdade de Direito da UFRGS, v. 20, Outubro/2001 
uma revolução constitucional de direitos humanos. Realmente, em alguns momentos houve sinais de que essa tendência iria além do mundo ocidental: menciono apenas Declaração Universal dos Direitos Humanos de 1948 e os Convênios Internacionais de 1966 em vigor desde $1976^{86}$. Mas, infelizmente, esses documentos não foram acompanhados po processos legais e por instituições fortes o bastante, para concederem o necessário grau de efetividade às regras neles incorporadas. ${ }^{87}$ $\mathrm{E}$, mesmo essas tentativas embrionárias tal como permanecem, são significativas, pois testemunham uma aspiração universal, embor ainda largamente irrealizada.

Claro que nosso ceticismo, assim como as várias e fracassadas implementações e as violações gerais da filosofia dos direitos

humanos, pode, muitas vezes, encobrir arter humanístico de nosso tempo, e, na verdade, muitos acontecimentos podem obscurecê-lo e até mesmo negá-lo ridicularizá-lo. Rejeito, todavia o ceticismo não construtivo e excessivo, assim como o seu irmão gêmeo, o nihilismo - essas duas recorrentes doenças do narcisismo intelectual. Estamos convencidos, assim como o grande filósofo do "ceticismo moderado", David Hume, de que o ceticismo excessivo não pode resistir ao teste da "ação" e da realidade da "vida comum" 88 . Essa realidade demonstra que, do mesmo modo como afirma e demonstra amplamente o professor Henkin, há uma "explosão" de direitos humanos nas "democracias libertárias" de nosso mundo contemporâneo ${ }^{89}$ Essa explosão tem sido caracterizada por uma preocupação sem

${ }^{86}$ Vide, v. g., L. HENKIN, ed., The International bill of rights. The Convenant on Civil and political rights, New York, Columbia University Press, 1981; id., supra nota 19, p. 89-101. Outro importante desenvolvimento de nosso tempo, o impulso contra o colonialismo, que trouxe à luz dezenas de novas nações nos anos após a II Guerra Mundial pode ser visto como uma expressão da tendência mencionada no texto. Como disse o Professor Henkin foi este impulso que "revelou uma quantidade de novos Estados e governos que procuraram nos direitos humanos para alcançar a "autonomia" e a eliminação do racismo." Id. supra, nota 19, p. 18. ${ }^{87}$ Cfe. id., supra nota 19, p. 101-102, 107-113; L. HENKIN, "The International Human Rights as 'Rights' in 257-280; L. B. SOHN, "Human Rights: Their Implementation and Supervision by the United Nations", in Meron, supra nota 67, II, 369-401.

${ }^{88}$ Hume, in Enquiry Concerning Human Understanding, Setor XII, Part. I (in Enquiries Concerning the Human Understanding and Concerning the Principles of Morals por DAVID HUME reimpressão da Edição Póstuma de 1777, L. A. Selby-Bigge editor, $2^{\mathrm{a}}$ ed., Ofxord Clarendon Press, 1902, reimpressão 1963, p. 149). Embora ensinando que o conhecimento humano é limitado à experiência das idéias e impressões, e excluindo a possibilidade de qualquer verificação de suas verdades, Hume condenou severamente o que foi chamado de
ceticismo "excessivo" ou "pirrônico": ceticismo "excessivo" ou "pirrônico":

Porque aqui está a principal e mais confusa objeção do ceticismo excessivo, donde nada de bom e durável pode advir....[O Ceticismo pirrônico] precisa reconhecer...que toda a vida humana deve perecer, onde seus princípios firme e universalmente prevalecem...[Todavia] a natureza, em princípio, é muito forte...[o] primeiro e mais trivial acontecimento da vida esfumaçará todas as dúvidas [pirrônicas]...Quando [um cético excessivo] acorda de seus sonhos, ele será o primeiro a juntar-se no riso de si mesmo e a confessar que todas as suas objeç̃es sã da de divertimentos e não podem ter outra tendência do que mostrar a caricata condicão humana, que precisa aros raciocinar e acreditar; embora as pessoas disso não sejam capazes, apesar de suas mais diligentes in

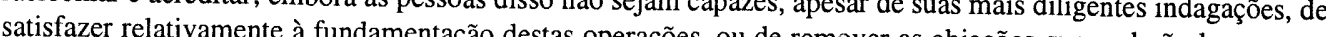
contra elas (Ibidem Setor XII, Parte II destas operaço Setor XII, Parte II, p. 158-160).

intelectul teriam quantos textos legais contemporâneos mudariam seu tema e tom e quanta energia e talento ${ }_{89}^{\text {intelectual teriam melhor uso se os ensinamentos de Hume tivessem sido assimilados. }}$

${ }^{89}$ L. HENKIN, supra nota 19, espec. p. 43-55, 156-161.

Revista da Faculdade de Direito da UFRGS, v. 20, Outubro/2001 precedentes com a criação de instrumento efetivos, nacionais e transnacionais - senão mesmo universais, para proteger os direitos básicos de pessoas e grupos - incluindo os pobres, as minorias raciais e religiosas, os jovens e os velhos, as mulheres e, mais amplamente, aqueles tradicionalmente privados de justo e igual acesso à justiça. Não reconhecer a importância histórica e o caráter desse crescente desenvolvimento implica permanecer surdo e cego à talvez mais espantosa tendência de transformação social que jamais ocorreu na história da humanidade. ${ }^{90}$

Isso está longe de ser uma rósea visão de nossa época. Em verdade, a explosão dos direitos humanos não passa de uma tentativa de dar resposta a problemas que, mais do que nunca, como disse no começo desta palestra, estão pondo em perigo a sobrevivência da civilização humana - os problemas da opressão, da pobreza e da guerra. Só o futuro dirá se esta

tentativa falhará ou terá sucesso. Mas parece claro para mim que, se for exitosa, os direitos nacionais e transnacionais e suas imposições judiciais terão uma boa parte do mérito. Torno bem clara a afirmação de que não vejo futuro para a humanidade, a não ser que uma renovada filosofia de tolerância e de mútuo respeito, num sentido real, ou seja, uma filosofia dos direitos humanos, capacite-nos a fazer uso decente do tremendo poder material que adquirimos.

A expansão sem precedentes do controle judicial dos órgãos políticos não é uma faceta secundária da revolução desses direitos humanos. Parece comprovar meu ponto de vista o próprio fato de que, até a época que se seguiu à II Guerra Mundial, a revisão judicial neste país, enquanto desempenhando um papel importante na formação de "uma mais perfeita União", não teve um papel adequado como instrumento para a perfeição dos direitos civis ${ }^{11}$. Somente em nossa época o momento é propício, para o que eu insisto em chamar de nossa revolução de

${ }^{90} \mathrm{~A}$ documentação de HENKIN focaliza os Estados Unidos sem a ele limitar-se, (para uma avaliação do desenvolvimento da Europa vide Comparative Constit. Law, supra nota 45, caps. 6-12). A "explosão dos direitos" desde a II Guerra Mundial está descrita como "impressionante":

A $14^{a}$ Emenda foi mantida por ter incorporado e tornado aplicável aos Estados as principais provisões do "Bill of Rights" - liberdade de expressão, de imprensa, de reunião, de religião, de segurança pessoal e de domicílio, Rights" - liberdade de expressão, de inim

salvaguarda para os acusados de crime...
Ainda mais impressionante foi a expansão de nossos direitos do século XVII em concep̧̧ão e conteúdo. Abrimos Ainda mais impressionante foi a expansão de nossos direitos do século XVII em concepção e conteúdo. Abrimos
nossa Constituição a cada homem e mulher, ao menor e ao pior deles. Nós a abrimos também a novos direitos e nossa Constituição a cada homem e mulher, ao menor e ao pior deles. Nós a abrimos também a novos direitos e à expansão da concep̧̧ão de velhos direitos...Nós salvaguardamos não apenas a liberdade política mas também, em princípio, a liberdade social, sexual, e outras liberdades pessoais, privacidade, autonomia, ...Todas as classificações raciais são suspeitas e prontamente verificadas... Houve uma fundamental e, creio eu, uma irresistível transformação no status da mulher...Os pobres também tiveram direitos à igual proteção, e o Estado não pode ofertar direitos importantes - um recurso criminal, um divórcio - mediante paga, sem torná-los disponíveis àqueles que não os podem pagar...Outras categorias, outrora fechadas, foram abertas: prisioneiros agora têm direitos, assim coms
funcionários militares, pacientes mentais, alunos nas escolas, e crianças independentemente de seus pais.

As cortes também descobrem novos direitos, por exemplo, o direito de viajar ao exterior bem como inter-Estados. (Elas) deschriram um área de autonomi fundamental, individu (chmada "privacide"), invaño

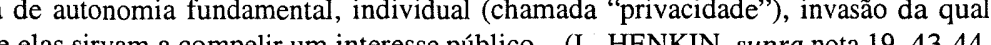
será.

${ }^{91}$ O fato inegável é que a revisão judicial na América desempenhou um papel modesto, algumas vezes até mesmo um papel negativo na proteção das liberdades civis, até poucas décadas atrás, seguidamente indigitada como evidência de um déficit da própria instituição. Vide v.g., Peter Railton, "Judicial Review, Elites, and Liberal Democracy", in Nomos XXV: Liberal Democaracy, J. R. Pennock \& J. W. Chapman eds. New York, New York University Press, 1983, 153-180, e a literatura ali mencionada.

Revista da Faculdade de Direito da UFRGS, v. 20, Outubro/2001 
direitos civis. Disse um escritor que uma das "características" das pessoas humanas é que somente o perigo e o sofrimento as fazem sensívei à justiça, aos sentimentos e à pergunta do que seja bom ou mau-em suma, aos seus valores inerentes. As tensões e os perigos de nosso tempo são tão grandes e iminentes, que este sentimento de valo de algum modo será forçado a emergir-queira Deus não apenas no ocidente. $\mathrm{E}$, em nossa sociedade ocidental, opapel privilegiado, embora não exclusivo, dos juízes nacionais e transnacionais tem sido o de interpretarem e de harmonizarem esses valores inegociáveis.

Minha segunda tese é a de que esse pape judicial mostra-se legítimo. Certamente podemos dissentir, até mesmo lutar contra certas determinações ou tendências em matéria de decisão constitucional. Mesmo, assim, um século e meio de história continental está aí para demonstrar que a solução alternativa é ainda pior. Na ausência de um controle judicial, o poder político se expõe mais facilmente ao risco da perversão. O controle judicial, certamente nãoé um remédio infalível; como proteção de nossas liberdades, muitas vezes pode provar ser incapaz de resistirà tirania, comodemonstrado pela experiênci de muitas nações. Se esse não é uma barreira invencível, talvez, possa agir, pelo menos, como um aviso e uma advertência.

Semelhante desenvolvimento marca renascimento de um novo "direito natural"? Muito afimamisso. ${ }^{93}$ Eu iria além, para dizer que o moderno constitucionalismo, com seus ingredientes básicos - uma Constituição garantidora de liberdades civis e

${ }^{92}$ Luigi PIRANDELO, Six Characters in Search of an Author, Ato III

...nunca as pessoas pensam tanto e se tornam tão introspectivas quanto em momentos de sofrimento; uma vez que estão ansiosas para entender...se é justo ou injusto o que estão sofrendo. Por outro lado, quando estão alegres pressupõem a alegria como algo evidente e não a procuram analisar, como se a alegria fosse para elas um direito natural.

${ }_{93}$ Uma ilustração típica é dada pelas contribuições no volume Natural Law and Modern Society, Cleveland \&

New York, The World Publishing Co., 1962. Vide também, v.g., L. HENKIN, supra nota 19, p. 19. Cfe. R. A. DWORKIN, "Natural Law Revisted", 34 Univ. of Florida Law Rev. 165-188 (1982).

${ }_{94}$ V ORKIN, "N3( 1033 meus estudos "Judicial Review in Comparative Perspective", 53 Califormia Law Rev. 1017, p. 1017-1020, 1032 1033 (1970); "The Significance of Judicial Review of Legislation in the Contemporary World", in Ius Privatum Gentium, Festschrift für Max Rheinstein (E. von Caemmerer, S. Mentschikoff \& K. Zewiger eds.), Tübingen, Mohr, 1969, p. 155162. Vide também HENKIN, supra nota 19, p. 5-23, 148-152, especialmente p. 19-23.

${ }^{95}$ Vide Jean RIVERO, "Rapport de synthèse", in Cours Constitucionnelles, supra nota 7, 517, p. 525-526.

Revista da Faculdade de Direito da UFRGS, v. 20, Outubro/2001

\section{Da extinção da punibilidade pela união estável da vítima com terceiro}

\author{
Mey Fayet Gúnior
}

Professor de Direito Penal - Especialista em Direito Penal (PUC/RS) Mestre em Ciências Criminais (PUC/RS) - Doutorando em Direito (UNISINOS) - Advogado.
L'

em breve resenha, discutir a ampliação das hipóteses de extinção da punibilidade ${ }^{1}$, em determinados crimes de índole sexual, a partir da união estável da vítima com terceiro. Aplica-se, neste caso, a analogia tem à censurabilidade jurídico-penal determinados episódios ilícito-típicos que, do contrário, estariam sujeitos à imposição da sanctio juris criminal.

No plano legal, inicialmente, apenas o casamento da vítima com o agente possuía o condão de extinguir a punibilidade. ${ }^{2}$ Posteriormente, também o casamento da vítima com terceiro in bonam partem, a fim de permitir que se fur-
- a partir da inovação trazida pela Lei n. ${ }^{\circ} 6.416 /$ $77^{3}$ - passou a ter o poder de eliminar a punibilidade. Isto se consolidou na Reforma do Código Penal, em 1984, com “....ligeiro acréscimo, visto que passou a contemplar o requerimento da vítima para o prosseguimento do inquérito ou da ação penal, enquanto o estatuto anterior só previa a segunda hipótese". ${ }^{4}$ Nos dias que correm, portanto, são: duas as hipóteses legalmente previstas pelas quais o casamento da vítima poderá extinguir a punibilidade nos crimes contra os costumes (Título VI, Capítulos I, II e III, do Código Penal): o casamento com o próprio agente (art. 107, VII, CP) e o casamento com terceiro (art. 107, VIII, $C P)^{5}$
${ }^{1}$ Como se tem como cetto, o Estado, “...como titular exclusivo de la potestad de castigar, puede disponer de esta, mediante 'renuncia'

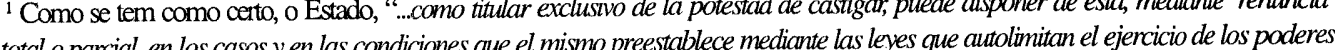
de soberaniac" (Vinenzo

${ }^{2}$ É o que nos informa Aníbal Bruno (Direito Penal: Parte geral, t. $3^{\circ}$. Rio de Janeiro : Forense, 1966, p. 229), quando ${ }^{2}$ E o que nos informa Anfibal Bruno (Direto Penal. Parte geral, t. 3 . Rio de Janeiro. Forense, 1966, p. 229), quando descreve: “...é preciso que o agente mesmo se case com a vítima, e não que esta contraia matrimônio com outrem. O que a lei exige para a extinção da punibilidade não é que a vitima se tenha refetio da desonra, mas sim que o próprio agente venha oferecer-lhe a reparação máxima do dano que causou, o que só pode fazer casando-se ele mesmo com ela." ${ }^{3}$ Como refere E. Magalhães Noronha (Direito Penal, v. 1. São Paulo : Saraiva, 1999, p. 378), “...anteriormente à vigência da Lei $n .6416$, o casamento da ofendida com terceiro não gerava efeitos, pois o Código Penal referia-se, expressamente, ao casamento do agente com aquela (art. 108, VIII, da redação primitiva). Foi acrescentado pela nova lei, entretanto, um novo inciso a este dispositivo, o IX (redação primitiva), que determina a extinção da punibilidade pelo casamento da ofendida com terceiro, nos crimes referidos no inc. VIII (redação primitiva), salvo se cometidos com violência ou grave ameaça e se ela não requerer o prosseguimento da ação penal no prazo de sessenta dias a contar da celebração. A reforma de 1984, sabiamente, manteve a inovacão introduzida pela mencionada Lei $n .6 .416$, agora pelo art. 107, VIII, fazendo um correto acréscimo: obsta também o prosseguimento de inquérito policial, enquanto a lei anterior referia-se apenas à açãa penal".

${ }_{4}$ Paúo José da Costa Júnior. Curso de Direito Penal: Parte geral, v. 1. São Paulo : Saraiva, 1991, p. 229.

${ }^{5}$ Luiz Régis Prado. Curso de Direito Penal Brasileiro: Parte geral. São Paulo : RT, 1999, p. 497. 
De outro lado, a Constituição Federal, no parágrafo terceiro, do artigo 226 ("Para efeito da proteção do Estado, é reconhecida a união estável entre o homem e a mulher como entidade familiar, devendo a lei facilitar sua conversão em casamento"), expressamente projetou à união estável a proteção jurídica que se destinava ao casamento civil. A partir disto, não se pode mais estabelecer qualquer nota distintiva entre ambos, uma vez que a Constituição Federal se lhes concede o mesmo status e a mesma proteção jurídica. Ora, se não existe mais qualquer diferença substancial entre os dois institutos, a referência, no Código Penal, restrita ao casamento (da vítima com terceiro), como fator de exclusão da punibilidade, mostra-se em contraste absoluto com o texto constitucional.

Convém destacar que, apesar de o Supremo Tribunal Federal não sufraguar a tese da inconstitucionalidade superveniente, se pode perfeitamente sustentar que o comando legal que permite a extinção da punibilidade apenas quando se verificar o casamento - se coloca, nestas condições, como uma antinomia ${ }^{6}$. De qualquer sorte, a questão comporta, ainda, a incidência da analogia in bonam partem, no sentido de recomendar que se entenda como possível a ampliação das hipóteses (previstas na Parte Geral do Código Penal ${ }^{7}$ ) de exclusão da punibilidade. Verdadeiramente, se a união estável - que se apresenta como uma realidade social e jurídica, semelhante ao casamento - é uma das formas através das quais se pode constituir uma família, não se lhe pode retirar a força de impedir a consolidação da punibilidade.

A matéria, diferentemente do que se poderia imaginar, já (e faz muitos anos) foi debatida pela jurisprudência de nosso Estado, que, em lógica decisão, muito antes de quallogia in bonam partem em casos tais:

Se o concubinato é a regra no meio social dos protagonistas, deve ele ter a mesma função do casamento, para o fim de extinguir a punibilidade. ${ }^{8}$

Em verdade, a convicção de que a sociedade de fato entre homem e mulher pode excluir o crime - uma vez que se equival, em sua concepção, ao casamento tradicional - ganha mais e mais força, na doutrina e na jurisprudência. Recentemente, Fernando Capez, com absoluto acerto, arrematou: ...em face dessa nova sistemática, o núcleo familiar estável sem casamento, após a CF/88, equipara-se ao casamento realizado para fins de extinção da punibilidade, interpretando-se analogicamente (in bonam partem) $o$ art. 107 VII, do CP.

Nesta mesma linha de intelecção, vejaquer referência legal, reconheceu a thesi da ana-

${ }^{6}$ Entende-se como antinomia “.... a falta de coerência entre normas jurídicas de mesmo ou diverso estatuto, num mesmo ou diferente grau hierárquico, causando contrariedade ou contraditoriedade", como aponta Salo de Carvalho (A política Criminal de Drogas no Brasil: do discurso oficial às razões dade", como aponta Salo de Janeiro : 1996, p. 101)

${ }^{7}$ Como anota Luiz Alberto Machado (Direito Criminal: Parte geral. São Paulo : RT, 1987, p. 58), o que está "vedado é o uso da analogia em prejuízo, in mam partem Mas ñ̃o se Panpedo a partem. Porque, com relação à parte geral dos códigos, não vige o princípio da tipicidade mas o da, in bonam (...) A explicação sistêmica é simples: ao Estado só é permitido fazer o que a lei permite, mas o da legalidade. trado pode fazer undo que a siciños. ao Estado so e permilido fazer o que a lei permite, enquanto o administrado pode fazer tudo que a lei não proíbe; portanto, ao Estado não socorre a analogia, mas ao administrado, sim. ${ }^{8}$ Apelação-crime n. ${ }^{\circ} 683028$ 633, Terceira Câmara Criminal, Des. Rel. Gilberto Niederauer Corrêa, novembro

${ }^{9}$ Fernando Capez. Curso de Direito Penal: Parte geral, v. 1. São Paulo : Saraiva, 2000, pág. 546.

Revista da Faculdade de Direito da UFRGS, v. 20, Outubro/2001 se, por exemplo, a vox de Valdir Sznick, quando aduz:

Só o casamento civil produziria esse efeito; como a Constituição equiparou o concubinato - viver junto com à vítima -, também a nosso ver extingue, pois se constitui em reparação. ${ }^{10}$

Por se tratar de matéria que encerra conceitos novos, é mister indicar a sua recepção jurisprudencial ${ }^{11}$ :

Desde que a Constituição Federal concedeu direitos à união estável sem casamento, não há porque se deixar de equiparar esse tipo de convivência conjugal ao matrimônio legalizado, para fins de extinção da punibilidade para crime contra os costumes.

O que o legislador objetivou foi sempre o interesse da vítima e de sua família, partindo-se do pressuposto de que o casamento seria uma reparação capaz de extinguir a punibilidade do sedutor, raptor ou estuprador. Ora, se atualmente a união conjugal estável, sem matrimônio civil, gera direitos, não há porque se diferenciá-lo de casamento, para fins de punibilidade_penal.(...) Correta e perfeita por isso a interpretação analógica feita na sentença apelada que, assim sendo, não comporta a modificação reclamada no recurso. A. C. MATHIAS COLTRO, VENCEDOR, com a seguinte declaração de voto: (...) A partir da Constituição federal de 1988, tem-se como

entidade familiar, a merecer proteção do Estado, a união estável entre homem e mulher, cum prindo a lei facilitar sua conversão em casamento. É o que de forma expressa consta no art. 226, \$ $3^{\circ}$.(...). O fato é que, modernamente, não se pode reconhecer que a sociedade já reconhece, sem qualquer restrição, a constituição da familia não nascida do ato civil do casamento.

Tradicionalmente, a doutrina sempre sustentou que o casamento da vítima com terceiro deveria eliminar a punibilidade do comportamento delituoso. E a ratiolegis deste comando-que permite a extinção da punibilidade pelo subsequens matrimonium traduz-se na "reparação que o agente pode conceder à ofendida"12 (que seria posta a salvo da desonra), correspondendo ao "interesse social da constituição da família"13, ou, ainda, importando no interesse do Estado na 'paz familiar'. Ora, o mesmo objetivo pode ser alcançado por meio da união estável, devendo ser emprestada a este vínculo, pois, a mesma força de extinção do jus puniendi, agasalhando-se a thesi da analogia in bonam partem.

Por outro lado, no setor específico das sanções jurídicas, a punibilidade ${ }^{14}$ desponta como conseqüência jurídico-criminal da realização de uma conduta ilícito-típica. Quer dizer, presentes os seus pressupostos condicionantes, "se perfeiciona 0 Tatbestand (no sentido da Teoria Geral do Direito) que faz entrar em jogo a consequiência jurídica (Rechtsfolge) e a sua doutrina autônoma"15 . Com

${ }^{10}$ Valdir Sznick. Crimes sexuais violentos. São Paulo : Cone, 1992, p. 229.

${ }^{11}$ Adélia Moreira Pessoa. União estável e extinção de punibilidade em crime de rapto. Revista Brasileira de Direito de Família, n. ${ }^{\circ}$ 4, jan./fev./mar, 2000, pp. 64-76.

${ }^{12}$ E. Maga ares Noro Direito Direito Penal, v. III. Campias : Milne da punição, portanto, o réu que pretende reparar o mal com o casamento, mas encontra repulsa da vítima. Não basta que o criminoso queira reparar o mal pela realização das núpcias: é necessário que o casamento se realize."

${ }^{13}$ Heleno Cláudio Fragoso. Lições de Direito Penal: Parte geral. Rio de Janeiro : Forense, 1995, p. 416.

${ }^{14}$ Como se expressa Tomaz M. Shintati (Curso de Direito Penal: Parte geral. Rio de Janeiro : Forense, 1999, p. 443), "A punibilidade é a possibilidade jurídica de imposição de sanção. Ela surge com a prática de um crime. Assim, a punibilidade não é requisito do crime, mas, sim, consequiência de sua prática."

${ }_{15}$ Jorge Figueiredo Dias. Questóes Fundamentais do Direito Penal Revisitadas. São Paulo : RT, 1999, p. 250.

Revista da Faculdade de Direito da UFRGS, v. 20, Outubro/2001 
a efetivação do crime, nasce para o Estado o direito de aplicar ao delinqüente a sanção jurídico-penal. Pode haver, entretanto, cláusulas legai (ou supralegais) que obstaculizem a aplicação da pena de índole criminal, onde "a punição acabe por não se dever efetivar por razões que já não têm a ver com a doutrina do fato, mas autonomamente com a doutrina da consequiência jurídica, com a doutrina da pena."16 De tal sorte que, nos domínios da teoria das conseqüências jurídico-penais, é absolutamente possível a existência de fatores (de índole benéfica) não previstos em qualquer comando legal. Estes fatores podem, com efeito, eliminar a punição. ${ }^{17}$

Nesta linha de intelecção, pode-se sustentar, perfeitamente, que a união estável (da ofendida com terceiro) se apresenta como exemplo de ampliação das causas de extinção do jus puniendi. Isto é admissível, pois essa união se traduz, em essência, em uma analogia in bonam partem, a recomendar que se lhe aportem as mesmas consequiências jurídicas destinadas ao casamento, na aplicação concreta na hipótese de crimes sexuais não-violentos. No universo penal, admite-se, perfeitamente, a analogia, desde que seja revestida de força benéfica. Carlos
Maximiliano, ao comentar o papel da analogia em matéria criminal, ressalta:

Estritamente se interpretam as disposi ções que restringem a liberdade humana (...) com igual reserva se aplicam os preceitos tendentes a agravar qualquer penalidade. $O$ contrário se observa relativamente às normas escritas concernentes às causas que justificam os fatos delituosos e dirimem ou atenuam criminalidade (...) em tais circunstâncias até a analogia é invocável. ${ }^{18}$

Em vista disto, conclui-se, a boas luzes que a existência da união estável é uma realidade social e jurídica. Trata-se de uma das formas de constituição da família, tal qual o casamento. Não há, portanto, como afastar a aplicação analógica do art. 107, inc. VIII, do Código Penal, ficando-lhes atribuída a mesma força de extinção da punibilidade, sob pena de darmos razão a BENTHAM quando diz que a jurisprudência é a "arte de ignorar metódicamente lo que es conocido por el mundo entero"

\section{Bibliografia:}

AMERICANO, Odin I. do Brasil. Manual de Direito Penal: Parte geral: de acordo com a Lei n. 7.209, de 11-7-84, $1^{\circ}$ v.. São Paulo : Saraiva, 1985.

BRUNO, Aníbal. Direito Penal: Parte geral, t $3^{\circ}$. Rio de Janeiro : Forense, 1966

CAPEZ, Fernando. Curso de Direito Penal: Parte geral, v. 1. São Paulo : Saraiva, 2000.

CARVAlHO, Salo de. A Política Criminal de Drogas no Brasil: do discurso oficial às razões da descriminalização. Rio de Janeiro Luam, 1996.

COSTA JÚNIOR, Paulo José da. Curso de D reito Penal: Parte geral, v. 1. São Paulo : Saraiva, 1991.

DIAS, Jorge de Figueiredo. Questões Fundamentais do Direito Penal Revisitadas. São Paulo: RT, 1999.

FERRAJOLI, Luigi. Derecho y razón: teoría del garantismopenal. Madrid:Editorial Trotta, 1997.

FRAGOSO, Heleno Cláudio. Lições de Direito Penal: Parte geral. Rio de Janeiro : Forense, 1995.
MACHADO, Luiz Alberto. Direito Criminal: Parte geral. São Paulo : RT, 1987.

MANZINI, Vincenzo.Tratado de Derecho Pe nal, t. 5. Buenos Aires : EDIAR, 1950.

MARQUES, José Frederico. Tratado de Dire to Penal. v. III. Campinas : Millennium, 1999.

MAXIMILIANO, Carlos. Hermenêutica e Aplicação do Direito. Rio de Janeiro : Forense, 1990.

NORONHA, E. Magalhães. Direito Penal, v. 1. São Paulo : Saraiva, 1999.

PESSOA Adélia Moreira. União estável e extinção de punibilidade em crime de rapto. Revista Brasileira de Direito de Família, . $^{\circ}$ 4, jan/fev/mar, 2000,p.6476.

PRADO, Luiz Régis. Curso de Direito Penal brasileiro: Parte geral. São Paulo: RT, 1999.

SHINTATI, Tomaz S..Curso de Direito Penal: Parte geral. Rio de Janeiro : Forense, 1999.

SZNICK, Valdir. Crimes Sexuais Violentos. São Paulo: Cone, 1992

\begin{abstract}
${ }^{16}$ Idem, p. 250
${ }^{17}$ Tenha-se por norte o que remarca Odin I. do Brasil Americano (Manual de Direito Penal: Parte geral: de acordo com a Lei n. 7.209, de 11-7-84, $1^{\circ}$ v.. São Paulo : Saraiva, 1985, p. 493), ao dizer: "O Código Penal, no Titulo VIII, arrola uma série de causas que extinguem a punibilidade do agente. São todas elas causas que Titulo VIII, arrola uma série de causas que extinguem a punibilidade do agente. São todas elas causas que
impedem o início da ação penal, interrompem o seu prosseguimento ou paralisam seu andamento. Os nossos impedem o inicio da ação penal, interrompem o seu prosseguimento ou paralisam seu andamento. Os nostos

autores reconhecem que a enumeração das diversas causas interruptivas ou extintivas não é taxativa".
${ }_{18}$ Carlos Maximiliano. Hermenêutica e Aplicação do Direito. Rio de Janeiro : Forense, 1990, p. 322/323. ${ }^{18}$ Carlos Maximiliano. Hermenêutica e Aplicação do Direito. Rio de Janeiro : Forense, 1990, p. 322/323.
${ }_{19}$ J. Bentham apud Luigi Ferrajoli, Derecho y razón: teoría del garantismo penal. Madrid : Editorial Trotta, 1997, p. 62.
\end{abstract}

Revista da Faculdade de Direito da UFRGS, v. 20, Outubro/2001 


\title{
La Justicia como instancia simbolica y la reconstruccion del sujeto de derecho
}

\author{
Raúl Enrique Rojot $^{\prime}$
}

\section{Introducción ${ }^{2}$}

La democracia no consiste, al decir de MONTESQUIEU (1748: 245) «en obrar de tal manera que todo el mundo gobierne o que nadie obedezca, sino en obedecer y gobernar a sus iguales». El verdadero espíritu de igualdad, afirmaba el barón de La Brède, «no persigue el fin de los señoríos, sino tener a sus iguales por señores». La Justicia debe evitar, entonces, el riesgo de la democracia extrema, aquella donde gobernando «todo el mundo», nadie obedece. Y haciéndolo va en contra del air du temps, de aquel que parece ser el sentido en que marchan las democracias: la negación del mal, la evacuación de la política (de la cual sin embargo ellas proceden), y el cuestionamiento de toda jerarquía, fruto, creemos, de un sentimiento más

profundo aún: la negativa a pagar cualquier precio. Queremos unión sin matrimonio, sexo «seguro» y sin hijos, hijos que no lloren ni crezcan, adelgazar sin dieta, escuela sin control de asistencia y sin evaluación, cárcel sin barrotes, psiquiatría sin internación ${ }^{3}$, y riqueza, en fin, sin esfuerzo, trabajo o ahorro. ¡Si hasta las naciones pretenden hacer ahora la guerra sin muertos! Nunca nos gustó ver nuestras propias filas diezmadas, claro (aunque supiésemos que "quienes iban a matar también podían morir"), pero hoy tampoco se soporta que haya bajas entre las fuerzas o la población enemigas. Se pasa, así, de la "bomba de neutrones" de la guerra fría (que se suponía que podía matar a los humanos y dejar en pie a los edificios,

${ }^{1}$ Abogado por la Universidad de Buenos Aires (UBA); Magíster en Sociología por la Pontificia Universidad Católica Argentina "Santa María de los Buenos Aires" (UCA); Doctor en Sociología por la École des Hautes Études en Sciences Sociales (EHESS, París). Ex docente de la Universidad de Buenos Aires. Director de Etudes en Sciences Sociales (EHESS, París). Ex docente de la Universidad de Buenos Aires. Director de
investigaciones del Centre de Recherches sur l'Administration de la Justice et la Société (CRAJS, París). Profesor investigaciones del Centre de Recherches sur l'Administration de la Justice et la Société (CRAJS, París). Profesor e investigador concursado de la Universidad Federal de Río Grande do Sul (UFRGS, P
Posgrado en Sociología y de Posgrado en Derecho. E-Mail: raulrojo@ vortex.ufrgs.br

${ }^{2}$ Estas reflexiones tuvieron su origen en las clases de "Temas de Sociología" dictadas por el autor en el Posgrado de Derecho de la Universidad Federal de Río Grande do Sul, durante los años lectivos de 2000 y 2001. En su actual redacción deben mucho a las observaciones y participación de los alumnos, aunque el autor debe ser tenido por el único responsable de los yerros que pueda contener el presente trabajo.

${ }^{3}$ La antipsiquiatría, movimiento que pretendía sacar los enfermos del asilo, tuvo por efecto externar un gran número de personas de entre las cuales algunas no eran capaces de vivir fuera. Y lo que afuera han encontrado no ha sido la libertad sino el encierro sin paredes, la soledad con su sufrimiento y sus síntomas. El movimiento iniciado por atendibles y humanas razones terapéuticas, ha sido continuado por razones presupuestarias, procurando ocultar la ineficiencia y el abandono de las instalaciones psiquiátricas, acabando por dejar sin ningún tratamiento a gran número de enfermos. 
puentes y fábricas) a los "bombardeos quirúrgicos" del nuevo orden internacional, donde se busca aniquilar los recursos materiales del oponente evitando matar a su gente. $O$ escamoteando, al menos, la imagen de sus muertos difundida por CNN. Al fin y al cabo, este "negarse a pagar" no es más que una manifestación de una tendencia cada vez más generalizada, que parece conducirnos hacia un brave new world, "políticamenre correcto" y soft, pasteurizado e infantilizado, de quesos asépticos, cigarrillos sin alquitrán y cerveza sin alcohol, suerte de "Disneyworld" con entrada franca y juegos "al alcance de todos los bolsillos".

En ese sentido, la Justicia parece una institución contra natura. Debe, al mismo tiempo, organizar la violencia contra la tolerancia democrática, asumir la distancia en una sociedad de proximidad, mantener las ficciones en un mundo escéptico, administrar las sanciones en colectividades anómicas, diferir el espectáculo para una platea constituida por espectadores "en directo", imponer la frustración en una sociedad de la seducción, declarar lo que es justo para un mundo desencantado y establecer referencias para un universo desorientado. Este distanciamiento interno que la Justicia impone a la democracia, es esencial, sin embargo, para cualquier tipo de reflexión. La Justicia detiene la lógica autodestructiva del individualismo para transformar al individuo en sujeto de derecho, pondera la alternativa entre el liberalismo salvaje y el dirigismo a través de la idea de personalización del derecho y morigera los ímpetus de los jueces. Hace justicia en una democracia secularizada, recuerda la norma compartida en una democracia pluralista, erige una

barrera simbólica en una democracia participativa y encarna la autoridad en una democracia representativa.

La autoridad debe mantener la distancia fundamental de la democracia a través de un trabajo que es simultáneamente de conformación y escenificación. Esta distancia es indispensable para mantener el aliento democrático. Si el poder se halla tentado constantemente de identificarse a sí mismo y emanciparse de toda referencia, si los media tienden inercialmente a una democracia directa liberándose de la mediación de las instituciones, y si la democracia individualista confunde el individuo con sus deseos y emociones, la Justicia se presenta como una instancia simbólica que se interpone entre lo real y su representación, entre el poder y sus orígenes, entre el individuo, el sujeto y el derecho. Antes que represiva o social, civil o penal, arbitral o tutelar, la Justicia, repetimos, es un instancia simbólica que debe establecer puntos de referencia colectivos ${ }^{4}$.

La Justicia es una "institución identificadora" del tipo de aquellas que Charles TAYLOR opone a las que también él denomina "instituciones servicio". "Por un lado - dice TAYLOR (1994: 93) - tenemos estructuras cuya relación con nuestras vidas es únicamente instrumental, aún cuando los servicios que nos prestan son muy importantes y, por otro, tenemos medios cuya frecuentación crea para nosotros un espacio elemental de definición de valores importantes, puntos de partida de polos posibles de identidad". La modernidad va convirtiendo las instituciones identificadoras en instituciones servicio y aquellas que conservan un fuerte valor identificatorio, como

${ }^{4}$ Ciertos criminales "de alto coturno" lo han advertido, ya, entre nosotros. Véase, sino, al sanguinario PINOCHET, que no se inmutó en su momento con la "caravana de la muerte" pero a quien desvela la posibilidad de ser prontuariado (es decir, identificado como un delincuente común, a través de los signos exteriores que la policía y la Justicia utilizan para tal fin), o nuestros delincuentes "de cuello blanco", que finalmente se entregan con la condición "de no ser esposados".

Revista da Faculdade de Direito da UFRGS, v. 20, Outubro/2001 la religión o la cultura, están en vías de privatización o individuación. Tal es el riesgo que también corre la Justicia: la idea de un "servicio público de la justicia" es la tentación constante de aquellos que se alzan contra el supuesto "gobierno de los jueces". ¿Cómo resistir a esta tendencia? ¿Qué significa concretamente, para la Justicia, asumir el papel de institución identificadora? El Palacio de Justicia (el foro), aún cuando los tribunales estén vacíos, sigue identificando el lugar donde se hace justicia. La Justicia es identificadora, tanto para la sociedad al instaurar el debate como para el individuo restaurando la parte de sujeto de derecho que le es propia.

\section{Escena y jurisdicción}

La Justicia es una instancia, decíamos, un espacio que existe por sí mismo, cuya virtud es existir y que hace de esa misma existencia una virtud. La Justicia, a su turno, es indisociable de un espacio que permite a cada actor identificarse con su papel y, consecuentemente, con una escena en la cua el grupo social interpreta constantemente su papel, esto es: su destino. El parentesco entre la escena teatral y la escena moral es profunda: jurisdicción de la escena. Es por eso que la televisión se comporta, queriéndolo o no, como instancia moral. Cuando todas las otras instituciones sociales hayan desaparecido recuerda SCHILLER - la escena continuará cumpliendo una función moral: "la jurisdicción de la escena comienza allí donde se detienen las leyes del mundo. (...) Osados criminales, que desde hace tiempo se pudren en la sombra o han sido reducidos a polvo, son convocados por el llamado todopoderoso de la poesía y vuelven a representar sus innobles papeles para la terrible edificación de la posteridad. Impotentes, cual imágenes furtivas de un espejo deformante, los horrores de cada siglo pasan ante nuestros ojos, mientras maldecimos su memoria con voluptuoso terror. Cuando no se enseñe más ninguna moral, cuando ninguna religión encuentre más fe, cuando ninguna ley tenga vigencia, Medea vendrá a aterrorizarnos, precipitándose desde las escalinatas de Palacio después de haber asesinado a sus hijos" (SCHILLER, 1784: 119-120). De allí la importancia de no desdeñar esta dimensión espectacular del oficio de juzgar que debe preocuparse de escenificar adecuadamente esta virtud. La democracia espera del legis lador que sea un buen régisseur del debate judicial, y de los jueces que sean buenos actores

\subsection{Un universo hecho de distancia}

La representación no tiene "buena prena" en este siglo XXI aún balbuciante y ya tan mante de la "autenticidad". La exigencia de "no tener pelos en la lengua" es alimentada por los medios de comunicación masiva. La democracia no se cansa de desmontar los escenarios en los que cree ver una última desigualdad que debe combatir en estos momentos en que las jerarquías sociales tienden a desaparecer. Pero todo no pasa de una trampa: los lugares del juez y del acusado nunca serán intercambiables. El espacio judicial tiene que marcar su especificidad y guardar sus distancias, so pena de frustrar a esos voyeurs en que nos hemos convertido.

Los desbordes, de los que el siglo $\mathrm{XX}$ fue muestrario "problemático y febril" (al decir de Enrique Santos DISCÉPOLO) aconsejan esta prudencia. El despotismo adoptó en este siglo dos aspectos bien diferenciados y coexistentes: el de la politización del proceso y, al mismo tiempo, el de la interiorización extrema. "Exceso de representación" y "representación insuficiente" convivieron en él. Los sistemas totalitarios se apropiaron del espacio judicial, en el que organizaron procesos políticos donde la suerte estaba echada de antemano y el decorado había sido erigido para estimular una especie de 
unanimidad ritual ${ }^{5}$. Pero ésta no fue la única perversión de la Justicia. La justicia informal, es decir la que se lleva a cabo en la soledad de un despacho, al abrigo de las miradas del pueblo (que está en el origen de la competencia y la legitimidad del juez) elude igualmente el momento solemne de la justicia. Esta forma banal de hacer justicia destiló otra forma de despotismo menos visible y mucho menos cruenta, donde la dominación se escondió detrás del paternalismo estatal, abriendo el camino del control que denunció con tanto vigor Michel FOUCAULT (1975).

El espacio del proceso articula la relación entre "personas", es decir, etimológicamente, entre "máscaras". La ceremonia desapasiona las relaciones interpersonales y las transforma en relaciones de derecho. La escena imposta los sentimientos, protege al juez de la culpabilidad de juzgar, al testigo del temor de declarar y a la víctima de la vergüenza de serlo. La Justicia no sondea los corazones, así como no pretende corregir los comportamientos: su misión es restaurar el orden simbólico del derecho y consecuentemente establecer la distancia.

El mundo judicial es un mundo frío, solemne y alejado de la vida cotidiana. En él, la comunicación, significa algo muy distinto de lo que representa en el mundo de los media. Las partes están distantes del juez y deben dirigirse a él en público y en medio de un decorado impresionante. La comunicación del proceso es frustrante: todo en él es formal y, en consecuencia, sospechosamente artificial. La comunicación judicial parece en abierta

contradicción con la ideología actual que celebra los principios de la comunicación directa y la comunión afectiva. El carácter artificial de la audiencia es, sin embargo, condición necesaria para la verdad convencional de la democracia. Las formas del proceso son indisponibles en tanto puesta en escena del Otro, de la democracia, por una parte, y de marco para el debate, por la otra.

Ese espacio sin dueño de la sala de audiencias manifiesta la distancia fundamental que en él mantienen tanto el sujeto cuanto la comunidad política. La función política del espacio judicial consiste en instaurar una distancia entre lo privado y lo público, entre lo interno y lo externo, entre el sujeto de carne y hueso y el sujeto de derecho. Esta distancia entre los diferentes protagonistas del proceso significa la imposible fusión con el otro de mi propia carne, la prohibición del incesto que es, de alguna manera, la ley de leyes. La distancia que impone el ritual judicial demuestra que el lugar de la ley está vacío, que si en su entorno se organizan los intercambios sociales, él mismo permanece inaccesible para el común de los mortales. El Palacio de Justicia representa la exterioridad de la democracia, ese espacio sin dueño que el derecho se limita a señalar.

Esta metáfora espacial ha inspirado a numerosos pensadores de la democracia. "Al indicar cual es el espacio de la ley, el poder representa su papel de instituyente simbólico del campo social - dice Marcel GAUCHET (1976: 24). Pero sólo puede señalarlo eficazmente renunciando

${ }^{5}$ A título de mero ejemplo sirvan los harto conocidos procesos que en agosto de 1936, en enero de 1937, y del 2 al 13 de marzo de 1938, se entablaron contra los más eminentes bolcheviques de la "vieja guardia", antiguos compañeros de lucha de LENIN como ZINOVIEV, KAMENEV, RADEK, SOKOLNIKOF, BUJARIN, RYKOF KRESTINSKI, YAGODA, RAKOVSKI, ROSENGOLZ, IVANOF, CHERNOF, GRINKO, etc. En estos pro KOF fueron condenados a muerte los principales acusados (algunos de los cuales acabaron sus días vivan estos procesos su verdugo). El 12 de junio de 1937 se produce la no menos famosa "purga" militar, que cuesta la vida a mALIN, TUJACHEVSKY y otros. Conf la publicación no menos famosa "purga" miltar, que cuesta la vida al mariscal antisovietique, Moscú, Commisariat du Peuple de la Justice, 1938 .

Revista da Faculdade de Direito da UFRGS, v. 20, Outubro/2001 ostensiblemente a ocuparlo". Por su parte, Claude LEFORT (1986: 27 y 29) agrega que, el carácter "revolucionario y sin precedentes" de la democracia reside en que, en ella, "el lugar del poder se convierte en un $l u$ gar vacio (...) Lo esencial es que se impide a los gobernantes apropiarse e incorporarse el poder. (...) La democracia se instituye y se mantiene en la disolución de las referencias de la certidumbre. Ella inaugura una historia en la que los hombres se hacen cargo de una indeterminación definitiva, en cuanto a los fundamentos del Poder, de la Ley y del Saber." El Estado de derecho debe renunciar constantemente a la tentación de acortar esta distancia y hacer el duelo de su omnipotencia. En este sentido, el ritual judicial podría ser mucho más auténtico que la comunicación (supuestamente espontánea) que proponen los medios de comunicación de masas, que pretenden abolir la distancia esencial a toda democracia.

Esta separación entre la escena y la sala de audiencias reproduce la distinción entre lo público y lo privado, la diferencia entre la coerción física y la libertad de conciencia. Las relaciones jurídico-procesales son exteriores y convencionales: pretender otorgarles mayor verismo puede constituir una amenaza a las libertades. Consecuentemente, cuanto más fuertes y simbólicamente consistentes sean las fronteras de este espacio, más favorecerán éstas a la representación dentro de la escena y a la libertad fuera de ella.

\subsection{Un metalenguaje evocador}

Quienquiera que entre por primera vez en un Palacio de Justicia se sorprenderá (por poco que el mismo haya sido construido en el siglo XIX o en la primera mitad del XX) con su aspecto de templo greco-romano. $\mathrm{Y}$ una vez en su interior atraerá su atención la profusión de símbolos tales como la espada y la balanza, las tablas de la ley, las inscripciones latinas y las alegorías frecuentemente pintadas en los techos abovedados o en las paredes de salas y corredores gélidos. ¿A qué se debe esta "densidad semiótica"? Todos estos símbolos son otras tantas referencias a los tiempos fundadores de nuestra civilización. Comenzando por la Biblia, en la cual se funda nuestra moral judeocristiana, siguiendo por Grecia, que liberó la razón de su ganga religiosa y acabando con Roma que creó el derecho tal como lo conocemos hoy en día. La imagen de la balanza es, por su parte, más vieja aún: se-remonta al antiguo Egipto y al pesaje de la almas. El Tribunal es también el lugar donde nos cruzamos con las efigies de los grandes legisladores: Justiniano y Cicerón, Tejedor y Dalmacio Vélez Sarsfield, Teixeira de Freitas o Clovis Bevilacqua (guardando las debidas distancias). O de reyes-magistrados como San Luis, que encontramos haciendo justicia bajo su roble legendario en la galería de la Corte de Casación del Palacio de Justicia de París.

Nuestros tribunales están también llenos de imágenes pavorosas: la Medusa, por ejemplo, con su cabellera de serpientes y llorando lágrimas de sangre. En la mitología griega, la Medusa transformaba en piedra a quienes se atrevían a mirarla. Esas figuras nos invitan a desviar la mirada. $\mathrm{O}$, mejor aún, las miradas, en verdad, se invierten: es menos lo que reparamos en estos símbolos que lo que ellos nos marcan. Los hombres deliberan bajo la mirada de los padres y los mitos fundadores que les recuerdan los juramentos iniciales.

Los edificios parlamentarios y judiciales que levantamos hasta hace poco están, entonces, llenos de bustos de grandes legistas y de imágenes atemorizantes, de emblemas nacionales y de frescos históricos que recuerdan el largo camino que hubo que transitar para establecer las libertades democráticas (como en la rotonda de la Corte Suprema de los Estados Unidos o, en un sentido diametralmente 
opuesto pero perfectamente comparable, en el Polyforum Cultural de la Ciudad de México) ${ }^{6}$. Ningún espacio colectivo es concebible sin una cultura que le brinde una expresión simbólica propia, que exprese sus valores en un lenguaje de óleo, estuco, piedra y bronce.

El edificio de nuestros foros contribuía a instituir la autoridad de los jueces, entendida como capacidad de dar forma - material, simbólica e intelectualmente - a la pública deliberación. La autoridad es la fuerza del poder instituyente. La autoridad compensa el carácter evasivo del poder. "El poder es volátil, quienes lo hacen duradero son sus fundaciones [sus cimientos]: como la acción es más frágil que la obra, el poder que deriva de ella precisa siempre ser incrementado por algo equivalente a la experiencia romana de la fundación", dice Paul RICOEUR (1993: 40). Esa es la función del ritual judicial: movilizar los símbolos de la Justicia cuantas veces se demande su intervención. La autoridad no es otra cosa que "la energía subsistente del acto fundante, la energía de los comienzos", acrecienta RICOEUR. Tal es el sentido de la repetición, propio de todo rito: repite incansablemente el momento fundador del proceso y reinicia este trabajo sin pausa de distanciamiento de la venganza privada y de la violencia ilegítima.

Estos símbolos, aparentemente obsoletos, son la clave de la modernidad: recordando nuestras tradiciones superadas por la aventura democrática, nos permiten avanzar. El marco es

lo que hace las veces de tradición para nuestros contemporáneos. La cultura compartida se vuelve evasiva a medida que nuestras sociedades se diversifican y se hacen más complejas y fragmentadas. El recurso al momento fundante es más necesario y vital cuanto más grande es el pluralismo. Un pluralismo sin referencias a una autoridad es tan ilusorio como una expansión de los derechos subjetivos carente de la contrapartida de sus obligaciones. Cuanto más una sociedad innova y se independiza de sus tradiciones, más necesidad tiene de evocar el momento fundador. La sociedad democrática substituye la tradición con una abstracción: el contrato social. Ahora bien, ¿cómo dar consistencia simbólica a esta realidad descarnada?

Los palacios de justicia actuales son mudos: nada los distingue de otros edificios públicos. Ese silencio arquitectural es peligroso. Los tribunales deberían continuar siendo, en la democracia del mañana, escenas, templos y foros. Nuestras sociedades que, según se dice, buscan denodadamente un sentido para sus actos, deben comenzar a encontrarlo en esos edificios que albergan sus deliberaciones cotidianas, es decir su perpetua gestación. A falta de tradiciones, el arquitecto moderno no sabe que oponer al vacío democrático. Para los individuos desorientados, el Palacio de Justicia debería ser una referencia, un lugar pedagógico: tendría que remitirlo tanto a un pasado inaccesible, como mostrarle el momento

${ }^{6}$ En el interior de la cúpula del Polyforum cultural de México, David Alfaro SIQUEIROS pintó una "escultopintura" de dos mil cuatrocientos metros cuadrados que tituló "La marcha de la humanidad sobre la tierra y hacia (a) el cosmos". Desde la plataforma giratoria situada bajo la cúpula, se ve, a la izquierda, la marcha de la humanidad desde los tiempos de la esclavitud y de la supersticion hasta la revolción democrátco-burguesa, a pesar de lo obstáculos que le oponen los señores, los demagogos y los militaristas. La segunda parte de la obra describe la marcha hacia la revolución futura a través de la violencia. La tercera describe la nueva vida en la que desemboca esta marcha secular: la ciencia y la técnica permiten la industrialización. Las manos de una mujer vierten, sobre esta sociedad liberada por el trabajo, las semillas de la paz y la armonía que la humanizan. En fin, en el centro de la cúpula, el hombre y la mujer, unidos en la paz y el amor, simbolizan este porvenir radiante. La obra es grandiosa y sin embargo, su mensaje pasaría desapercibido para los visitantes, si éstos no fueran advertidos del simbolismo por un oportuno folleto del que hemos extraído los párrafos precedentes.

Revista da Faculdade de Direito da UFRGS, v. 20, Outubro/200 indisponible de la vida en sociedad, allí donde se detiene la libertad individual.

1.3 La ritualización de la violencia domesticada

El paseante desprevenido puede igualmente quedar atónito con las representaciones violentas incluidas en la decoración de lo viejos tribunales: impresionantes fauces abiertas de león, armas afiladas, cuerpos humanos heridos de muerte. Este cruel simbolismo sorprende: se podría imaginar que en un lugar como ese sería mejor apaciguar a las personas, alentar la reconciliación por imágenes pacíficas o inspirar la concordia.

Es que la violencia aquí no es negada sino, por el contrario, exhibida y sublimada. Estas imágenes de las que apenas tomamos conciencia cumplen sin duda un papel compensatorio. Esas escenas vengadoras y terribles, los colmillos del león, las hachas afiladas y las aguzadas lanzas no sólo nos inspiran respeto sino que nos liberan de nuestra agresividad, para restituirnosla de forma simbólica. Estas representaciones crueles, sádicas a veces, nos dispensan de serlo a nuestro turno, descargan nuestras pulsiones ocultas ofreciendo el espectáculo, atemorizante pero liberador, de la violencia. Atestiguan el parentesco del proceso con el sacrificio. La falta de autoridad se paga con un aumento de la violencia, con la reaparición de una lógica expiatoria, como lo demuestra la evolución de la violencia en la sociedad democrática.

A diferencia de la violencia que entra todos los días en nuestras casas vehiculizada por los medios de comunicación masiva, el ritual judicial muestra al mismo tiempo el espectáculo de la transgresión y el de su reabsorción. Procura, así, un sentido para la violencia y le propone un alivio legítimo. En otras palabras, la violencia no es exhibida en estado puro, sino acompañada de un significa- do. Las reacciones que suscita esta violencia son canalizadas, diríamos, por el derecho y el procedimiento. El proceso es una suerte de domesticación de la violencia por el rito. En la audiencia el crimen no es negado sino repetido en un universo simbólico que desmonta la violencia. El crimen es reconstituido por la palabra: todos los protagonistas (testigos, peritos, policías) son convocados e invitados a exponer lo que ha ocurrido. El proceso judicial es una conmemoración del crimen a través de la palabra y el procedimiento. Anula la violencia salvaje por una violencia eufemística, que se impone al acusado. Esta violencia catártica es posible únicamente gracias al efecto de disimulación producido por el ritual. Este espectáculo de violencia mediatizado por la palabra se encuentra indisolublemente vinculado al espectáculo de reabsorción de la violencia. En los medios de comunicación, en cambio, la violencia es generalmente ofrecida en estado puro, cruel, absurda, comprendiéndose las reacciones emotivas e incontroladas que genera. Con mayor razón cuando la falta de canales de desahogo clásicos de las pasiones democráticas (como las luchas patrióticas, políticas o sindicales) no hace más que acrecentar el interés por las violencias del derecho común. A la sociedad democrática le resulta cada vez más difícil asumir sus pasiones, a medida que la emoción pública es cada vez menos simbolizable.

\subsection{La mediación institucional del debate}

El espacio de la Justicia es un lugar específico, propio (cosa que no alcanzan a comprender los media, en particular la televisión, que igualan todos niveles). La institución de un lugar de deliberación hace que éste no se confunda ni con el espacio más pequeño de la negociación o la terapia, ni con el más vasto de espacio público. El Estado debe garantizar el buen funcionamiento de la Justicia en un espacio protegido, delimitado en el interior del 
espacio público ${ }^{7}$.

Normalmente, el común de las gentes no se detiene a pensar sobre este exorcismo de la violencia colectiva, ni sobre la memoria viva de la tradición que contiene el marco ritual del proceso, pero los perciben. El marco es, en efecto, fundamentalmente percepción: su acción no es inmediatamente inteligible por los individuos. Está presente, se trata de un universo simbólico que, en sí mismo, es una representación del universo, un espacio que alberga el desenvolvimiento de la instancia. El lenguaje, en cambio, es linear: permite encadenar de manera lógica los argumentos y excluir los diferentes sentidos posibles para conducir a una solución. Contrasta, en esto, con el símbolo que es polisémico por definición. El marco, al contrario, permanece inmóvil, repetitivo: insensible a los regímenes políticos, al tiempo y a la historia. No evoluciona, es un no-suceso indispensable para que un suceso - el proceso - se produzca. El marco otorga a los argumentos una situación, los enraíza en la historia.

Así, por sus vínculos con la tradición y por su simbolización de la violencia, el marco ritual no oprime sino que libera a la razón. Permite combinar razón y tradición, lo irracional de la violencia con una elaboración racional. El intercambio regulado de argumentos no es más que la "parte viva" del proceso que necesita de un "espacio protegido". Quienes limitan la Justicia a un mero debate olvidan que los curiales no se encuentran levitando en un vacío social sino que también son sujetos de pasiones. No hay juicio - y el jurídico menos que cualquier otro - que no se produzca en situación, tributario de un lenguaje y de un marco especí ficos. El símbolo vincula el texto y el contexto. Marco simbólico y debate corren juntos, como tradición y argumentación o como autoridad y poder. El dispositivo ritual combina el espacio indisponible de autoridad y el espacio abierto de la discusión. KAFKA nos ofrece la prueba por el absurdo. En El proceso, lo sagrado omnipresente aunque impalpable - oprime e impide cualquier comunicación. Ningún hablar racional es posible, ningún intercambio. El trabajo de "distanciamiento mental a través de imágenes" es inviable. Joseph K. no llega a controlar esas imágenes que acaban por devorarlo. Sucumbe por orden de una autoridad ausente y cruel cuya ley ha sido extraviada.

La autoridad de un marco simbólico identificable, de una mediación institucional, es indispensable para el ejercicio de todo poder, comenzando por el poder argumentativo. El marco simbólico niega las relaciones de fuerza $y$ las diferencias sociales, autoriza un debate racional, expurga la violencia y celebra, más allá del conflicto, la continuidad de un destino colectivo y de la paz. El pacto democrático fundador es, de esta forma, "incrementado" por las instituciones.

\section{El sujeto de derecho}

Mientras la Justicia no fue más que el su función simbólica era poco significativa. Este papel permanece latente en una sociedad saturada de sentido como la sociedad tradicional, en la que la Justicia se limita a apaciguar los relevo del poder, la religión o las costumbres,

${ }^{7}$ La Justicia se parece a la escuela, en este aspecto como en muchos otros derivados de su carácter compartido de "instituciones identificadoras". La escuela republicana, en efecto, también debe ser un lugar cerrado (a contracorriente de quienes hoy en día la exigen "abierta a la vida"), cerrado detrás de sus muros y de sus propios reglamentos, sin los que perdería su independencia (sinónimo de laicismo) respecto de las fuerzas sociales, políticas, económicas o religiosas que se la disputan.

Revista da Faculdade de Direito da UFRGS, v. 20, Outubro/2001 conflictos. Una función de autoridad más autónoma en una democracia privada de sentido exige - y esta es una de las originalidades de la Justicia actual - que ella asuma mejor su papel de instancia simbólica. Cuando la Justicia debe asumir el papel de autoridad by default, su función simbólica es mucho más significativa. Si la sociedad democrática corre peligro de falencia simbólica, debe reactivarse ese pape identificador, tanto en lo tocante al espacio público como al sujeto de derecho.

Para comprender la noción de sujeto de derecho puede resultar interesante reinsertar misma en una perspectiva histórica. Todo sistema de justicia descansa implícitamente sobre una representación del delito o del desorden social, de la persona y de la manera de hacerle frente. Varias representaciones del sujeto de derecho se han así sucedido a lo largo de la historia.

\subsection{El modelo expiatorio}

Los cuerpos de normas de las primeras décadas del siglo $\mathrm{XX}$, como e Código Penal que todavía rige a los argentinos, por ejemplo, se representan la infracción como un mal uso del "libre arbitrio", como un cálculo que era necesario hacer no rentable (porque "el crimen no paga"). La delincuencia es percibida en ellos como un acto, sea éste la expresión de una voluntad sana que ha mostrado una falla, un desvío en el trayecto que debía haberse seguido, o bien como el resultado de una voluntad descarriada que persiste en el mal, de la misma manera que los viejos jumentos insisten en seguir el mismo camino para retornar al pesebre.

Como no conoce otra solución que la exclusión por el castigo, este primer modelo ha sido calificado de expiatorio. No se exige a la Justicia que tome en cuenta la sutileza de las relaciones afectivas o la injusticia de las situaciones sociales. La Justicia tiene aquí una función esencialmente punitiva: debe excluir al productor de desórdenes, tanto en materia penal como civil. Así el juez del divorcio expulsa del domicilio conyugal al cónyuge culpable y le retira la guarda de los hijos, el juez de menores interna en un asilo (lo más lejos posible de su hogar) al menor maltratado, y el juez penal encarcela al delincuente o lo envía a cumplir trabajos forzados en tierras lejanas. El condenado es pura y simplemente excluido: el mejor ejemplo de ello lo constituye la incapacidad relativa de derecho, es decir la supresión de los derechos políticos y civiles que acompaña a los condenados a largas penas privativas de libertad.

Se trata de un derecho sumamente "puro": sin contaminación con otros conocimientos como los de las ciencias sociales. Las categorías de este derecho son claras: el problema es civil o penal, el delincuente o es un loco o una persona absolutamente responsable. No puede haber en él graduaciones de responsabilidad, ni transición entre la libertad total y el encarcelamiento.

Se supone que todo el mundo goza de la misma capacidad social, y ahí está el problema. Este sistema formalista sólo garantizaba derechos, en verdad, a a un número limitạdo de personas: los hombres, mayores, propietarios, católicos y casados legítimamente. Los otros no estaban sino parcialmente - cuando no absolutamente privados de la capacidad propia de los sujetos de derecho. El derecho positivo necesita perentoriamente de un modelo social que haga las veces de referente. El legislador, igual que los jueces, los abogados, los psiquiatras y los asistentes sociales se referían implícitamente a este modelo decimonónico. Por eso el derrumbe simbólico de ese modelo social dominante 
perturbó todo el equilibrio del derecho. 2.2 El modelo terapéutico

Esta dialéctica del crimen y el castigo fue progresivamente sustituida por la de síntoma y el tratamiento, con arreglo a la cual el delincuente comienza a ser visto más como un enfermo que como un perverso. En este segundo modelo se impone la lógica de la curación: por eso se lo puede llama terapéutico. La delincuencia aparece no ya como una voluntad desviada sino como la manifestación de una personalidad desequilibrada.

Es a esta época que se remonta la percepción psicologizante del sujeto. La resocialización es el primer objetivo y a él se consagra la Justicia, corriendo el riesgo de abandonar la idea de responsabilidad jurídica si ella no parece corresponder a la realidad de las cosas. Para esta concepción extremadamente subjetiva del sujeto de derecho, hay que procura la responsabilidad en el propio sujeto bajo forma de culpabilidad. Durante un buen tiempo imperó, así, un concepto determinista del delincuente, que aún no hemos abandonado del todo.

\subsection{El modelo cívico}

¿A qué representación del sujeto podemos vincular nuestro naciente siglo XXI? Po cierto que ni a aquella ficción de la persona $\mathrm{ab}$ solutamente libre, social y económicamente autónoma, a ese burgués del siglo XIX, ni a ese otro individuo estructuralmente determinado desapropiado de cualquier tipo de soberaní sobre sí mismo que el siglo XX nos dejó como legado. No: a nuestra época debe corresponder un sujeto capaz. Nuestro siglo descubre que la capacidad no es un hecho que podría ser observado. Es un poder que un agente piensa poder ejercer, o que los otros le encomiendan desempeñar.
Este tercer modelo - que llamaremos $c \hat{i}$ vico - supone que el sujeto no puede se reducido ni a sus determinismos, ni a sus deseos. Procede de una distancia interior de una relación a sí mismo. La perspectiva de una sumisión a las leyes que nos hemos dado nosotros mismos supone, en efecto, 1 referencia a sí como posibilidad real y distinta a lo que hay en nosotros de súbdito (y de sumisión a un gobernante, aún benevolente) El ideal humanista de autonomía requiere en nosotros la definición de una parte de humanidad compartida, irreductible a la afirmación de nuestra mera singularidad, y a la cual nuestra singularidad debe someterse.

¿Qué es, en definitiva, un sujeto de derecho? Una persona autónoma, capaz en el sentido jurídico del término, es decir: la única habilitada para definir sus intereses $y$, consecuentemente, el exclusivo emisor de una palabra propia. No se puede limitar el sujeto a una suma de reivindicaciones unilaterales. E sujeto de derecho debe ser definido como sujeto de palabra $y$ de escucha, como autónomo $y$ dependiente, como depositario de una dignidad inalienable $y$ susceptible de ser momentáneamente enervada.

\subsection{El ciudadano como sujeto de derecho}

Nuestra época parece haber descubierto el valor rehabilitante de obligación como medio de reinsertar y, al mismo tiempo, de pagar la deuda social, de los deberes como la otra cara social de lo derechos. Todo no es posible, aquí, sino a condición de que el sujeto de derecho sea reconocido como sujeto de palabra, y es por eso que la Justicia tiene consecuencias: la intimación a explicarse, así como la facultad de asumir compromisos (de la que el juez es garante), brindan la posibilidad de modificar el curso de la institución por una palabra suficientemente trascendente.
El sujeto de derecho es indivisible, es decir que no puede perder su calidad de tal sin perder su dignidad. El sujeto de derecho es la versión judicial del ciudadano, no vinculado a una nacionalidad sino a su exclusiva condición humana.

El modelo cívico permite eludir la alternativa sujeto/no-sujeto, persona reputada acabadamente libre y sana de espíritu, al contrario, condenada a la locura y la muerte civil. Cada uno debe verse reconocida una igual e inalienable dignidad en tanto que hombre, cualquiera sea su situación social o mental. El límite de sujeto no pasa más entre ciertos sujetos para separarlos de otros ciudadanos que tendrían derechos, sino que atraviesa el interior de cada sujeto para definir un um bral infranqueable que permitirá considerar con más pragmatismo su situación concre ta. La idea de un individuo acabadamente asimilado a su deseo se fragmenta en dos: una, que da cuenta de la calidad de sujeto de derecho, depositario de una irreductible dignidad que no se puede perder jamás, y otra, que toma en consideración a un ser singular que puede estar en crisis o momentáneamente disminuido. La acción de las instituciones tendrá por material la situación, y por objetivo la dignidad. Estos dos estados del sujeto de derecho introducen una tensión en la Justicia. El reconocimiento de este límite fijado por la dignidad, más allá del cual no será posible avanzar, permite tomar en consideración situaciones concretas que el modelo expiatorio ignoraba deliberadamente, pero también sin extraviarse en ellas como en el modelo terapéutico. El regreso a la plena capacidad del sujeto de derecho proporciona a la acción social su horizonte teórico, con arreglo al cual toda crisis es considerada, en principio, como pasajera.
Se restablece, así, una distancia en el propio interior del individuo (por la introducción de dos polos: la dignidad compartida y la situación concreta) que no podía aparecer mientras se mantuviera la confusión, en una sola persona, del sujeto jurídico y del individuo psicológico. Como dice Denis SALAS (1992: 90), "el derecho penal debería decir al individuo que su personalidad no es lo mismo que su individualidad, que ella le brinda un estatus social y cívico que va más allá de su persona privada, y que se refiere a aquella parte de él mismo que es acreedora y deudora respecto de la sociedad".

\section{Conclusiones}

El juez aparece exigido por diversos imperativos contradictorios: aplicar el derecho y reparar la ofensa cometida al orden público, pero de manera inteligente $y$, sobre todo, eficaz. De allí el desafío que constituye, para una sociedad desacralizada y un individuo desorientado, la preservación de un momento de autoridad, es decir, de mantenimiento simultáneo de la violencia legítima y de la dimensión simbólica. Tal tipo de confrontación con la dimensión colectiva de la vida social es indispensable para la reconstrucción del sujeto. Reconstruir el sujeto de derecho es un objetivo político y no apenas humanista o caritativo - de la Justicia. Entre sujeto de derecho y Estado de derecho existe, en efecto, una especie de circularidad. El sujeto de derecho no es únicamente una condición de la intervención social, sino que constituye también su principal objetivo.

Ser ciudadano significa tener la posibilidad de asociarse realmente a la gestión de la vida pública; ser súbdito de un Estado de 
derecho implica simplemente poder defender sus intereses antes de que una decisión sea tomada. La diferencia entre un súbdito que tiene ciertos derechos y el ciudadano radica en que este último está en el origen del poder de sus mandatarios. Los ciudadanos, en el sentido político del término, detentan la soberanía original, lo que significa que los funcionarios (de los tres poderes) deben obtener (directa o indirectamente) de ellos su investidura y rendirles cuenta de su gestión. Los sujetos de derecho, a diferencia de los súbditos de un dés-

\section{Referências Bibliográficas}

FOUCAULT, M. 1975. Surveiller et punir naissance de la prision. París, Gallimard.

GAUCHET,M. 1976. «L'expérience totalitaire et la pensée du politique», Esprit, 7-8, pp. 3-21.

LEFORT, C. 1986. Essais sur le politique (XIX ${ }^{e}$ - XX $X^{e}$ siècles). París, Éditions du Seuil.

MONTESQUIEU (Ch. L. de Secondat, barón de La Brède y de). 1748. De l'Esprit des lois. La cita del texto, traducida por el autor del trabajo, ha sido extraída de la ed. Garnier/ Flammarion, París, 1979.

RICOEUR, P. 1993. «Le juste entre le légal et bon», in: Lectures 1, París, Éditions du Seuil.

SALAS, D. 1992. «État et droit pénal. Le droit pénal entre 'Thémis' et 'Dikè'», Droits, 15.

SCHILLER, F. von. 1784. La scène considérée comme institution morale. La cita del texto, traducida por el autor del trabajo, ha sido extraída de Justice et théâtre, París, Éditions Quintette, 1991.

TAYLOR, C. 1994. «Les institutions dans la vie nationale», Esprit, 200, pp. 90-102. pota ilustrado, son a la vez seres dotados de derechos y coautores del derecho. Tener derechos es tener, ante todo, el derecho de participar del debate sobre el derecho, de ser, uno mismo, autor (directa e indirectamente) propio derecho. Restituir al individuo (dominado, determinado, sometido a la presión de la exclusión social) su dignidad de sujeto de derecho, despertar en él la parte de soberanía que le pertenece, tal es el objetivo de la intervención judicial. Y con ese alcance la reivindicamos. 